NUREG/CR--4551-Vol + 2-ReV . 1-Pt. 2

TI91 011,55

\title{
Evaluation of Severe Accident Risks: \\ Quantification of \\ Major Input Parameters
}

Experts' Determination of Containment Loads and

Molten Core Containment Interaction Issues

Manuscript Completed: February 1991

Date Published: April 1991

\section{Prepared by}

F. T. Harper, A. C. Payne, R. J. Breeding, E. D. Gortham, T. D. Brown,

G. S. Rightley, J. J. Gregory, W. Murfin', C. N. Amos

Sandia National Laboratcries

Alouquerque, NM 87185-5800

\section{Prepared for}

Division of Systems Research

Ofice of Nuclear Regulatory Research

U.S. Nuclear Regulatory Commission

Washington, DC 20555

NRC FIN A1228

'Technadyne Engineering Consulusnts, Inc, Albuquerque, NM

2Science Applications International Corporation, Albuquerque, NM 
ABSTRACT

This report records part of the vast amount of information received during the expert judgrant elicitation process that took place in support of the NUREG-1150 effort sponsored by the U.S. Nuclear Regulatory Commisston. The results of the Containment Loads and Molten Gore/Contalnment Interaction Expert Panel elicitation are presented in this part of Volume 2 of NUREG/CR-4551. The Contalnment Loads Expert Panel considered seven issues:

1. Hydrogen Phenonena at Grand Gulf:

2. Fydrogen Burn at Vessel Breach at Sequoyah;

3. BUR Reactor Bullding Fallure Due to Hydrogen;

4. Grand Gulf Cortainment Loods at Vessel Breach;

5. Pressure Increment in the Sequoyah Containnent at Vesse? Breach;

6. Loeds at Vessel Breach: Surry;

7. Pressure Increment in the Zion iontainment at Vessel Breach.

The report begins with a brief discussion of the methods used to alicit the information fron the experts. The information for each issue is then presented in five sections: (1) a briếr definition of the issue, (2) a brfef sumary of the technical rationale supporting the distributions developed by each of the experts. (3) a brief description of the operations that the project staff performed on the raw elicitation results in order to aggregate the distrlbutions, (4) the aggregated distributions, and (5) the individual expert elicitation summaries. The individual expert elicitation sumaries were vritten soon after the elicitation and were sent to the experts for review. They represent the raw results as received directly from the experts.

The Molten Core/Cantalnuent Intezaction Panel considered three issues. The results of the following two of these lssues are presented in this document:

1. Pesch Botton Drywe1l Sheli Me1tthrough;

2. Grand Gulf Pedestal Erosion. 
cotiresta

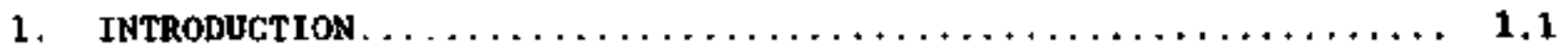

2. EXPERT CREDENTIALS $\ldots \ldots \ldots \ldots \ldots \ldots \ldots \ldots \ldots \ldots \ldots, 2.1$

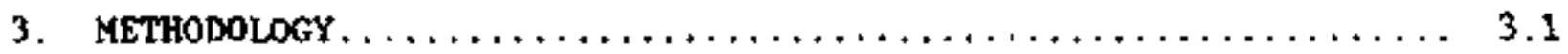

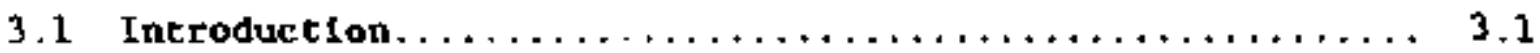

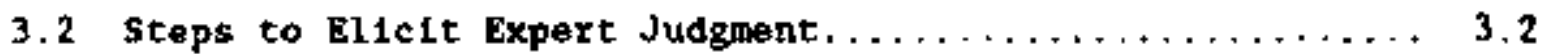

3.3 Selection of Issue $\ldots \ldots \ldots \ldots \ldots \ldots \ldots \ldots \ldots \ldots \ldots \ldots, 3.2$

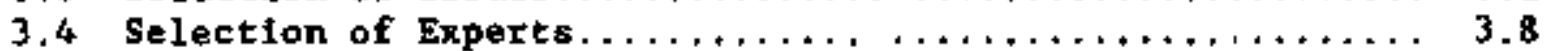

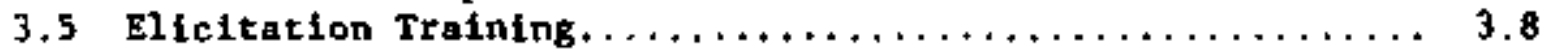

3.6 Presentation of Issues $\ldots \ldots \ldots \ldots \ldots \ldots \ldots \ldots \ldots \ldots \ldots, 3.10$

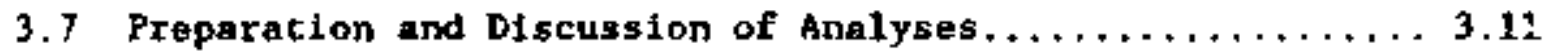

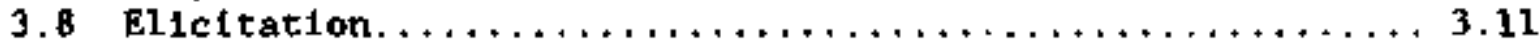

3.9 'ecomposition and Aggregation of Results, $\ldots \ldots \ldots \ldots \ldots, 3.12$

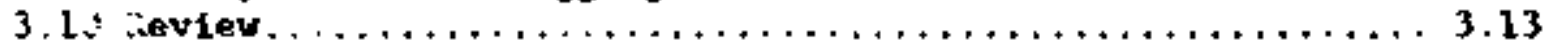

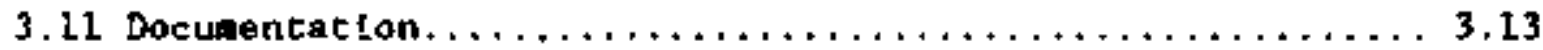

4. ELICITATION MEETINGS $\ldots \ldots \ldots \ldots \ldots \ldots \ldots \ldots \ldots \ldots \ldots \ldots \ldots \ldots, 4,1$

5. CONTAIRMENT LOADS ISSUES RESULTS--Pate $1 \ldots \ldots \ldots \ldots \ldots \ldots \ldots$. 1 -1

5.1 Cantalnment Loads Issue 1 . Hydrogen

Fhenomenon at Grand Gulf......................

5. 2 Containment Losds Issue 2, Hydrogen Burn

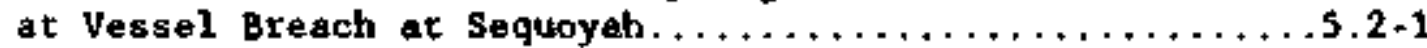

5.3 Containment Loads Issue 3. BuR Reactor

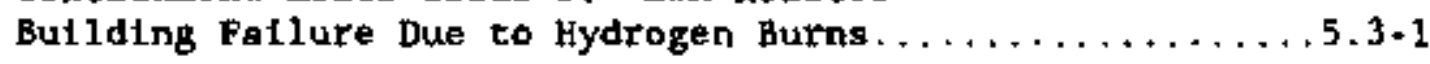

5.4 Containment Loads Issue 4 . Grand Gi:1f Contalntent Loads at vessel Breach.................5.4-1

5.5 Containment Loads Issue 5. Pressure Increnent in the Sequoyah Contafnment at Vessel breach.........5.5.1

5.6 Containment Loads Issue 6 . Loads at Vessel Breach--surry....................

5.7 Contalrment Loads Issue 7. Pressure Increment In the Zion Contafnment at Vessel Breach...........5.7.1

6. MOLTEN CORE/CONTAINMENT INTERACTION ISSUES RESULTS- -Part $2 \ldots \ldots .1 \cdot 1$

6.1 MCCI 1ssue 1: Peach Bottom Drywe11 Shell tleltthrough.....6.1.1

6.2 MCCI Issue 2: Grand Gulf Pedestal Eroston,..........6.2-1 
FICtrRES

Contalment Loads Issue 1

5-1. Ignition Before Vessel Breach; RPV at Low Presgure............................. 5, 1-8

5-2. Ignition Before Vestel Breach; RPV at

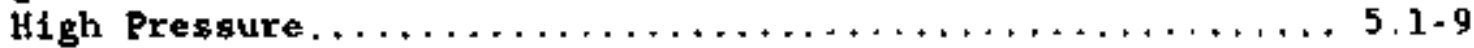

5-3. Ignition At Vessel Breach; RPV at

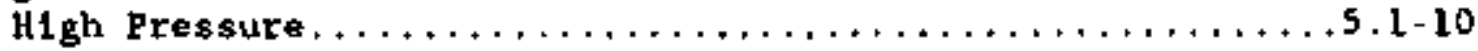

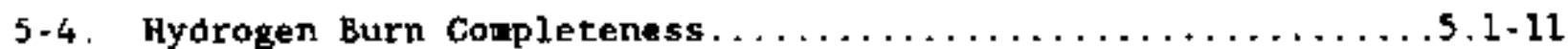

5-5. Deflagration Over Pressure; Wetwell; Low Steam.........5.1-12

5-6. Deflagration Over Pressure; Wetwell; Hfgh Steam,..........1-13

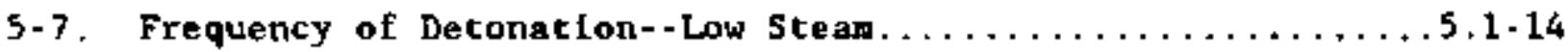

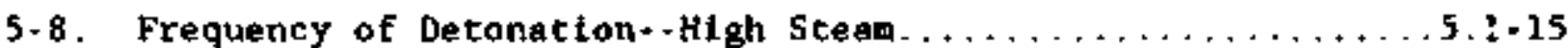

5-9. Losdg From Hydrogen Detonation In Wetwel1,..........5.1-16

A-1. Ignition Frequency Before Vessel Breach

Short-Tern Station Blackout, High Pressure for Case 1....5.1-21

A-2. Ignition Frequency Before Vessel Breach

Short-Teril Station Blackout, High Pressure for Case 2.....5.1-21

A-3 Deflagration overpressure (Wetwell)

Low steam Case............................5.1-26

A-4 Frequency of Detonation at Grand Gulf

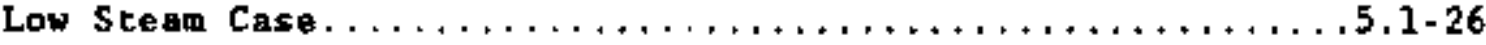

A-5 Loads Frow Hydrogen Detonation In Grand

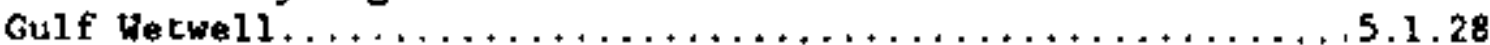

B-1 Frequency of Ignition; 8s Nole Fraction Hydrogen--

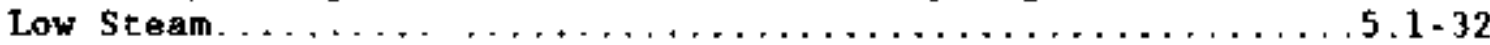

B-2 Frequency of Ignition; 12 \% Hole Fraction Hydrogen-.

Low stean $\ldots \ldots \ldots \ldots \ldots \ldots \ldots \ldots \ldots \ldots \ldots \ldots \ldots \ldots \ldots \ldots \ldots \ldots \ldots, 1-32$

B. 3 Frequency of Ignttion; 160 Mole Fraction Hydrogen--

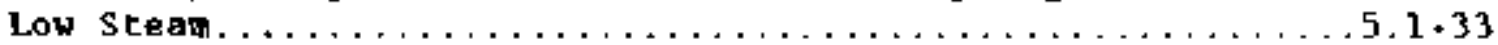

B-4 Frequency of Ignition; 20t Nole Fractinr. Hydrogen--

Low steam .............................. 


\section{FIGURES (continued)}

B-S Frequancy of I gnition at Vessel Breach

89 Mole Fraction Hydrogen - Low steam.................

B-6 Frequency of Ignition at Vessel Breach

12 hole Fraction Hydrogen--Low stean.................

8-7 Frequency of Ignttion at Vessel Breach

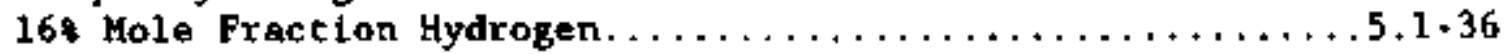

B-8 Frequency of Ignition at Vessel Breach

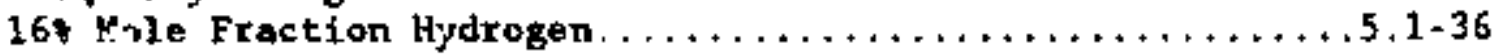

B-9 (nmpleteness of Hydrogen Burn:

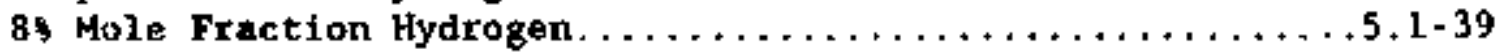

B-10 Completeness of Hydrogen Burn;

128 Mole Fraction Hydrogen. . . . . . . . . . . . . . . . . 5.1-39

B-11 Completeness of Hydrogen Burn;

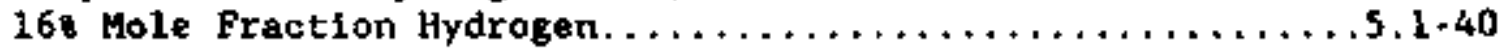

B.12 Frequency of Detonation; At Least

208 Hole Fraction Hydrogen. . . . . . . . . . . . . . . . 5.1-41

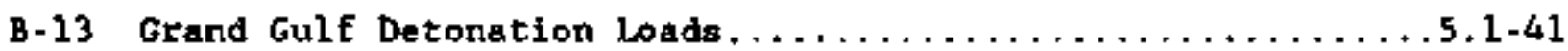

Contafneant Lods Issue 2

A-1 Expert A's Decosucsiten Tree. Beccnposition For

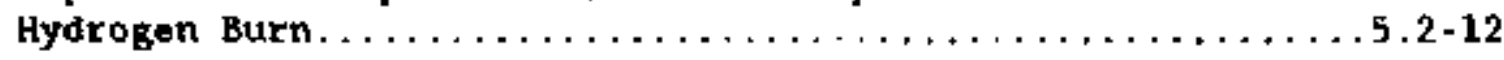

B-1 Expert B's Decompositton Iree, Perrentayes Under "Burn

Locstion" Indicate the Fract $\{$ on of Ficcontua Oxidation.....5.2-21

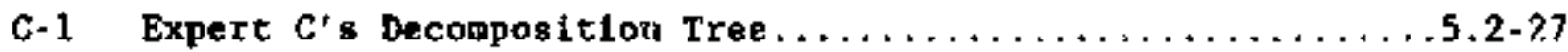

\section{Conta1nnent Loads Isave 3}

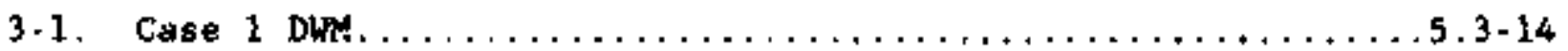

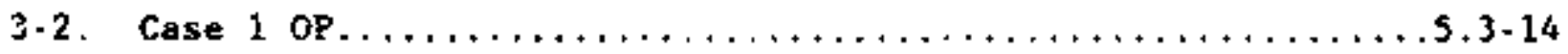

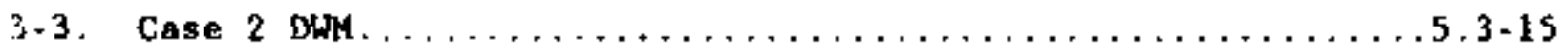

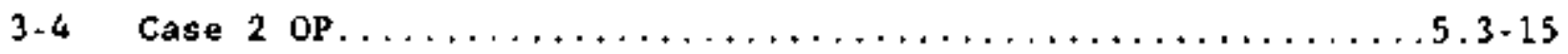

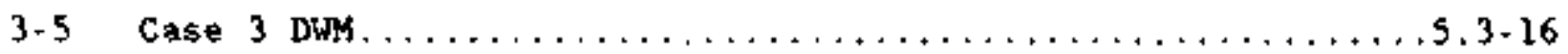

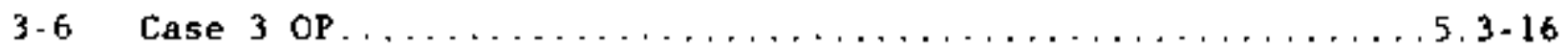




\section{EIGukes (continued)}

3-7 Caso 1: SB, High Pressure, High steam.............

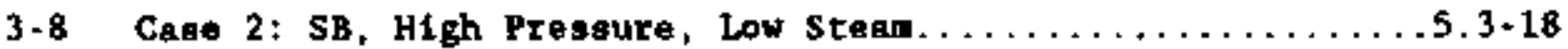

3-9 Cese 3: SB, Low Pressure, High or Low Steam............5.3-19

3-10 Case t: No SB, High Pressure, High Steas............5.3-19

3.11 Gase 5: No SB, High Presaure, Low Stean............

3-12 Case 6: No SB, Low Pressure, H1gh or Lov Stean........5.3.20

A-1 Expert A's Decomposition Tree $\ldots \ldots \ldots \ldots \ldots \ldots \ldots \ldots \ldots \ldots \ldots$ 5.3-23

A-2 Renctor Bulliling Fressux = Rise $\ldots \ldots \ldots \ldots \ldots \ldots \ldots \ldots \ldots \ldots, 3-27$

B-1 Ignition of a Hydrogen-Nitrogen Jet (Wi thout

Sodium) as a Function of Jet Tenperature.............3.31

Containment londs Istue 4

4-1 Grand Gulf Peak Dryvell/wetwell Differential Presioure at Josse1 Breach. High RPV Pressure With Wet Cavity............................

4-2. Grand Gulf Peak Drywell/Wetwell Differential Fressure at Vessel Breach. Low RPV Pressure Whth Wet Cavity............................ 5.4-10

4-3. Grand Gulf Peak Drywell/Netwell Different1al Pressure at Vessel Breach. High RPV Pressure

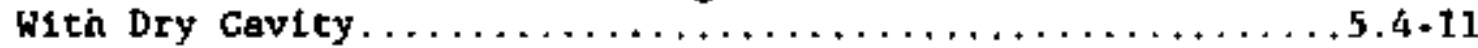

4-4. Grand Gulf Peak Contalnment Pressure at Vessel Breach. High RPV Pressure with Wet or Dry Gavity...........,5,4-12

4-5. Grand Gulf Peak Contalanent Pressure at Vessel Breach. Low RPV Pressure With Wet Cavity................5.4.13

4-6. Grand Gulf Peak Pedestal Cavity Pressure at Vessel Broach. High RPv Pressure W1th tet Cavity.......5.4-14

4-7. Grand Gulf Pesk Pedestal Cavity Pressure at Vesse1 Breach, Low RPV gressure with Wet Gavity,....., 5.4-15

4-8. Crand Gulf Peak Pedestal Cav'ty Pressure at Vessel Breach. High RPV Prespire With Dry Gavity,.......5.4.16

A.j Contaitument Pressure Rise at Vessel Breach............5.4.20 
A. 2 Peak Static Drywell/Netwell Pressure Differential;

Case 1: H1gh Pressure, Wet Pedestal...............4-22

A-3 Drywell Peak Static Presgure; Cane 3*;

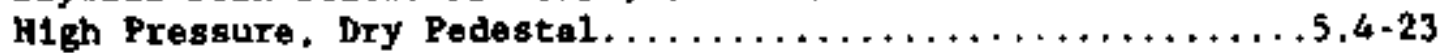

A.4 Drywell Peak Statle Pressure: Case 2*:

Low Pressure, Wet Pedestal . . . . . . . . . . . . . . . .5.4.24

A.5 Containment Pressure Rlse; Cases 1 and $3^{*}$ :

Hlgh Pressure Ejection. .....................25

A-6 Maxinun Pedestal Pressure; Case 3 :

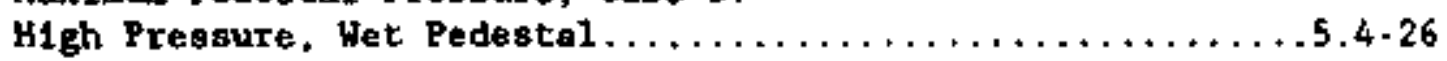

A-7 Maximun Pedestal Pressure; Case 3*:

Htgh Pressure, Dry Pedestal $\ldots \ldots \ldots \ldots \ldots \ldots \ldots \ldots \ldots \ldots \ldots \ldots \ldots, 4-27$

A-g Maximun Pedestal Pressure; Case 2*:

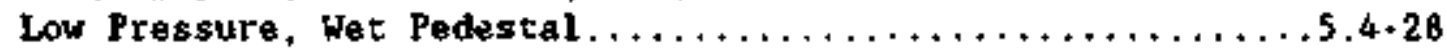

Containment Loods Issue 5

5-1. Cavity Deeply Flooded; Above the Bottouned

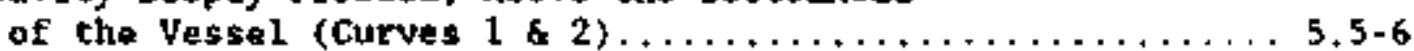

5-2. RCS Lou Ptessure; Legs Thall 200 psia

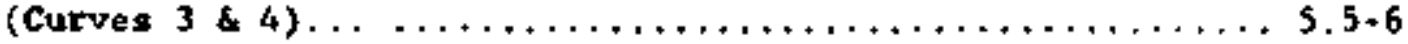

5-3. RCS Low Pressure; Less Than 200 psia

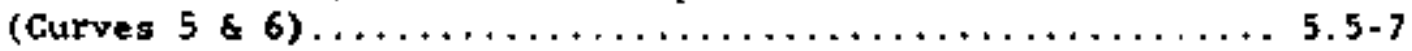

5-4 RCS Low Pressure; Less Than 200 psia

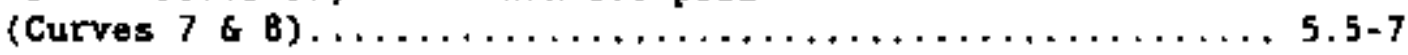

5-5 RCS Low Pressire; Less Than 200 psla

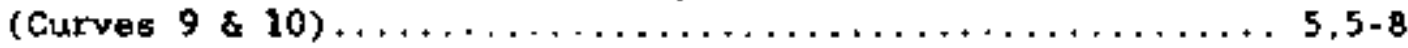

5.6 RCS Intarmedfate Pressure; 500 to 1000 psia

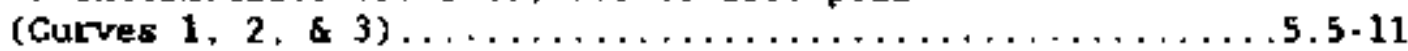

5.7 RCS Intermediate Pressure; 500 to 1000 psia

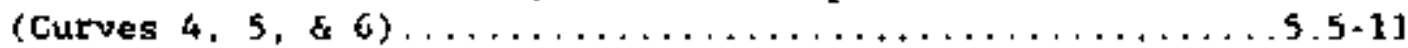

5-8 RCS Internediate Pressure; 500 to 1000 psia (Curves $7,8, \& 9$ ) $\ldots \ldots \ldots \ldots \ldots \ldots \ldots \ldots \ldots \ldots \ldots \ldots \ldots \ldots, 12$

5 -9 RCS Internediate Pressute; 500 to 1000 psia

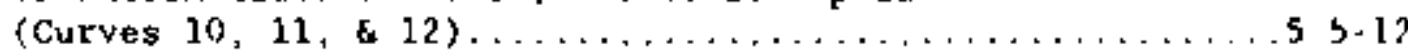


5.10 RCS Intermediate Pressure; 500 to 1000 psia

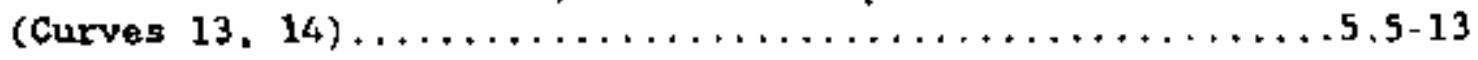

5-11 RCS Intermediate Pressure; 500 to 1000 psia

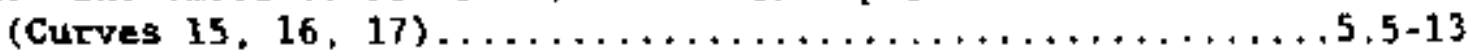

5-12 RCS Intermedinte Pressure; 500 to 1000 psia

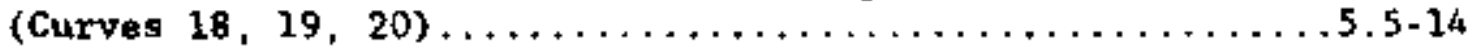

5-13 RCS Intermediate Fressure; 500 to 1000 psia

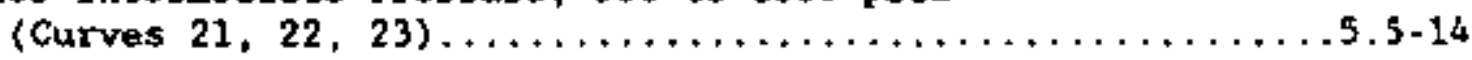

5-14 RCS Internediate Pressure: 500 to 1000 psia

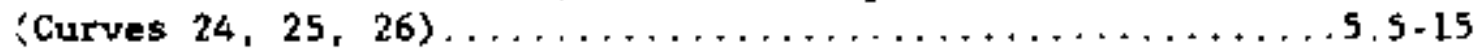

5-15 RCS Intermediate Pressure; 500 to 1000 psia

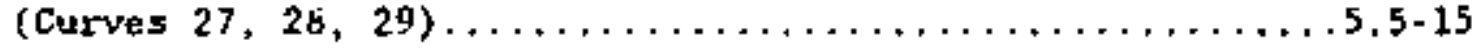

5-16 RCS Intermediate Fressure: 500 to 1000 psia

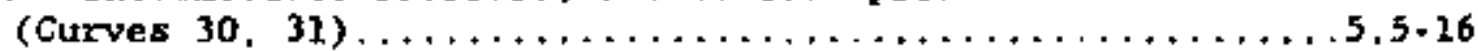

5.17 RCS High Pressure; 2000 to 2500 psia

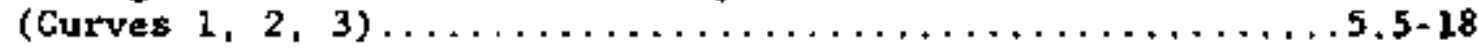

$5-18$ RCS High Pressure; 2000 to 2500 psia

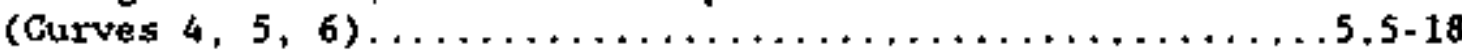

5.19 RCS High Qressure; 2000 to 2500 psia

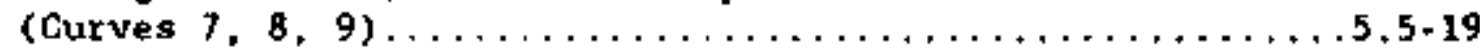

5.20 RCS High Pressure; 2000 to 2500 psia

(Curves 10, 11, 12) .........................5.5-19

\section{Conteingent Lods Issue 7}

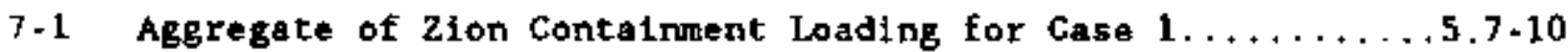

7.2 Revised Aggregate of Zion Containment Loading

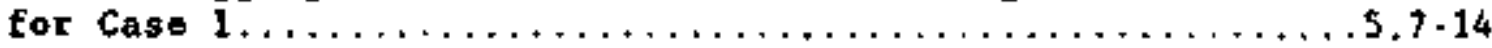

MCCI Issue 1

C-I Curmulative Fallure Probability of Drywell

vs. Time for scenario A.......................

C. 2 Cunulative Failure Probability of Orywe 11

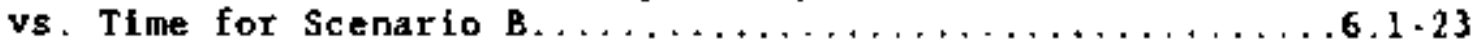

C. 3 Cumulative Tailure Probability of Drywell

vs. Tine for scenarto $C \ldots \ldots \ldots \ldots \ldots \ldots \ldots \ldots \ldots \ldots \ldots \ldots, 1-24$ 
PIGURES (cont inued)

MCGI Issue 2

6-1. Aggregation of HCCI Issue 2. Cumulative Probabllity of Different Radial Erosion Depths

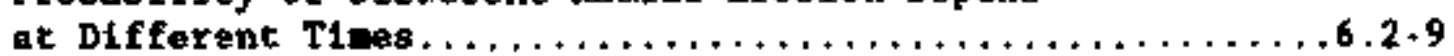

B-1 Case Structure for Grand fulf Pedestal Groston..........6.2-17

B.2 Eroded Pedestal Geonetry,...................... 2-19

\section{TABLES}

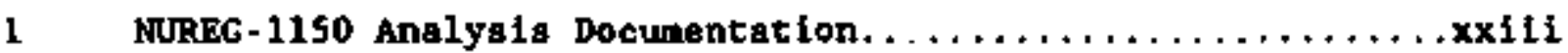

1.1 Containwent Loads Issues Considered for Bxpert Judgnent Elicitation. . . . . . . . . . . . . . . . . . . . .

1.2 Molten Core/Containent Issues Considered for Expert Judgment Elicitation. .........................

3.1 Issues Presented to the In-Vessel Panel $\ldots \ldots \ldots \ldots \ldots \ldots \ldots .4$

3.2 Issues Pregented to the Contalnwent Loads Panel ........ 3.5

3-3 Issues Presented to the Molten core Containment/ Interaction Fanel........................... 3.5

3.4 Issues Presented to the Structural Regponse Panel......., 3.6

3-5 Issues Presented to the Source Tere Panel............ 3.7 Contafinent Lods Isous 1

A-1. Hydrogen Ignition Hale-Lives $\ldots \ldots \ldots \ldots \ldots \ldots \ldots \ldots \ldots \ldots \ldots 5.1-20$

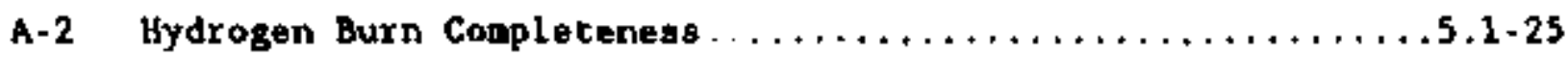

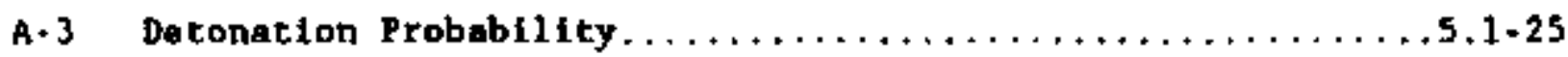

A-4 Relative Likelihood Subgequent Peaks Are Maximum Impulse.............................5,1-27

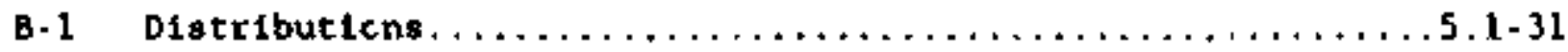

B.2 Selected Bets Distributions..................... 5.14

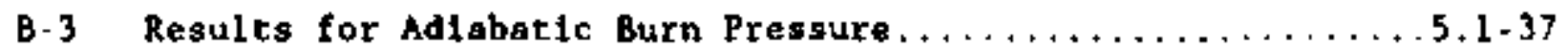

B.4 Distribution of Burn Conpleteness $\ldots \ldots \ldots \ldots \ldots \ldots \ldots \ldots \ldots \ldots .1 .38$ 
TABLes (continued)

\section{Conteinnent Load: Istue 2}

2.1 Distribution of Hydrogen in Containment;

Compartantal Fraction of Total Hydrogen Released

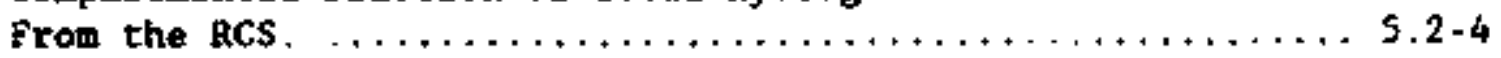

2.2 Mixing of hydrogen into the Done $\ldots \ldots \ldots \ldots \ldots \ldots \ldots \ldots \ldots, 5.2 .5$

2.3 Distribution for Ignition Frequency in the

Ice Condenser. . . . . . . . . . . .

2-4 Distribution for Ignitjon Frequency in the

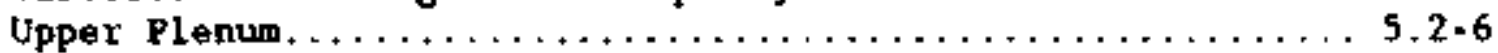

2-5 Distribution for I gntetion Frequency in the Dome........ 5.2-6

2-6 Distribution for DDT $\ldots \ldots \ldots \ldots \ldots \ldots \ldots \ldots \ldots \ldots \ldots \ldots \ldots, 2-7$

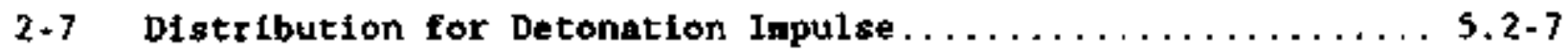

2-8 Burn Completion and Pressure Rise

Cascs $1,2,3$, and $4 \ldots \ldots \ldots \ldots \ldots \ldots \ldots \ldots \ldots \ldots \ldots, 2.8$

A-1 Distribution for Mixing of Upper Plenue

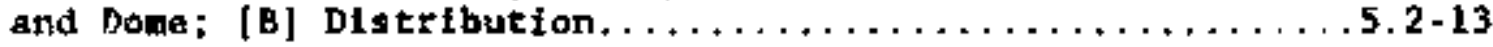

A-2 Distribution for Mole Fraction in Unisxed

Upper Pienum; [D] Distribution.......................

A.3 Distribution for Frequency of Ignition in the

Upper Plentu; $\left[E_{.00}\right],\left[E_{, 12}\right],\left[E_{.16}\right]$ D1stributions $\ldots \ldots \ldots \ldots$ 5.2-13

A-4 Distribution for Frequency of Ignition in the

Ice Condenser Relative to Frequency in

Upper Plenum (C) Distribution.

A.5 Distribution for Frequency of Detonation in the

Ice Condenser or Upper Plenun, Given Ignition;

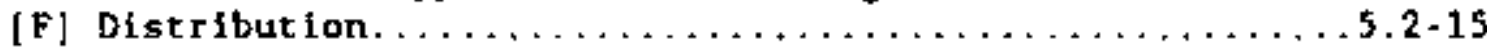

A-6 Distribution for Peak Pressure

Glven Deflagration in Ice Condenser of Upper Plenum

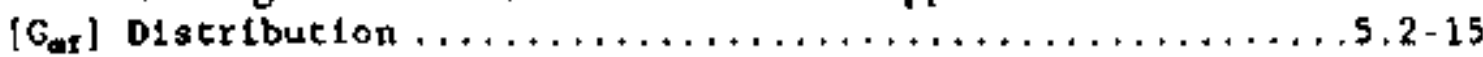

A.7 Distribution for Impulse, Given Deconation;

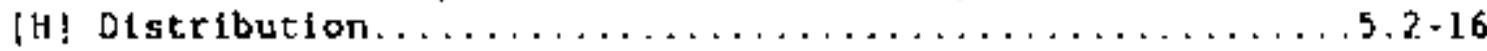

A.8 Distribution for Fraction of $\mathrm{H}_{2}$ Released

From RCS: [1] Distributfon..................... 


\section{TABLES (continued)}

A-9 Distribution for Fraction of $\mathrm{H}_{2}$ Released to Dome/ Upper Plenum; [A] Distribution. . . . . . . . . . 5.2-17

B-1 D18tribution for Existence of Ignition Source...........5.2-21

B-2 Distrtbutions for Probability of Ignition

Location $\left[\mathrm{D}_{\mathrm{D}}\right],\left[\mathrm{B}_{\mathrm{UP}}\right\}$ and $\left[\mathrm{B}_{\mathrm{IC}}\right]$ Distrfbutions $\ldots \ldots \ldots \ldots \ldots .2 .22$

B-3 Distributions for Ignition Frequency $\ldots \ldots \ldots \ldots \ldots \ldots \ldots .2-22$

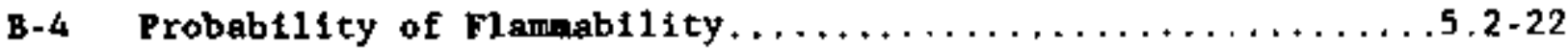

B-5 Diatribution for Detonation Impulse............... 5.2-23

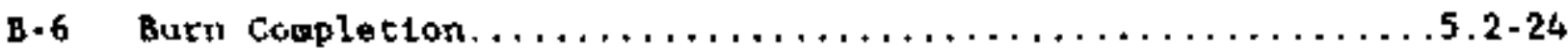

B-7 Digtributions for Fraction of Hydrogen

Releaged From RCS........................ 2-24

B.8 Distributions for Fraction of Hydrogen to

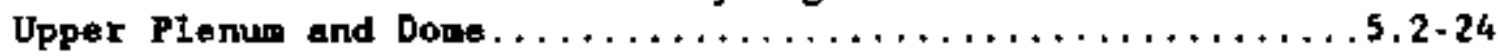

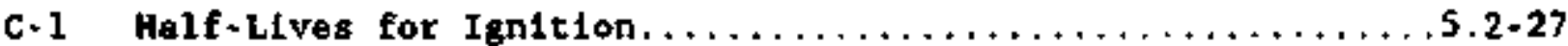

C.2 Distribution for Ignition Frequency

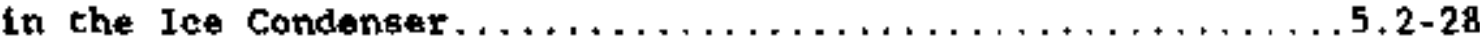

C.3 Distribution for Igndtion Frequency

1r. the Upper Plenum..........................5.2-29

C-4 Distrfbution for Ignition Frequency

In the Dome. . . . . . . . . . . . . . . . . . . . . . . . 5.2.29

C.5 Deflagration-to-Detonation Transtrion..............5.2-30

C-6 Distribution for Impulse, Given Detonation............ S.2.30

C.7 Pressure in Dome, Ice Condenser Not Bypassed

(Cases 1, 2, 3, and 4) $\ldots \ldots \ldots \ldots \ldots \ldots \ldots \ldots \ldots \ldots, \ldots, 5.30$

C-8 Pressure In Dome, tee Condenser Bypassed,............

C.9 Distribution of Hydrogen in Containent;

Compartnental Fraction of Total Hydrogen

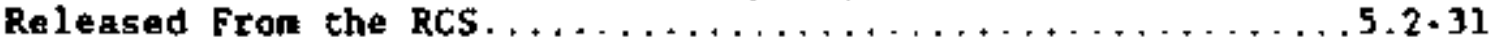

C-10 Burn Conpleteness, I ce Condenser Not Bypassed

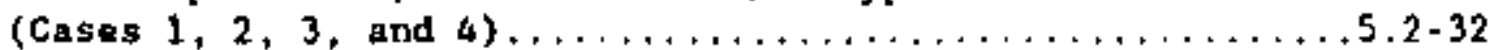

C.11 Burn Completeness, Ice Condenser Bypassed

Alternate Case 2$) \ldots \ldots \ldots \ldots \ldots \ldots \ldots \ldots \ldots \ldots \ldots \ldots \ldots, 2,32$ 


\section{Contalnant :oads Iaves 3}

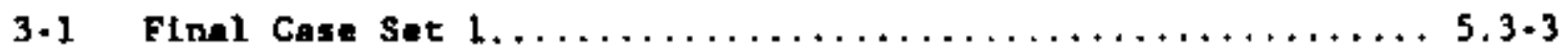

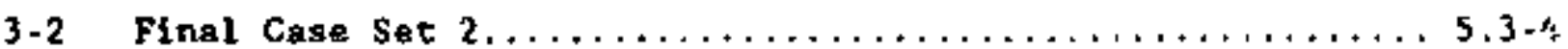

3-3 Average of Expertg' Elleltetions:

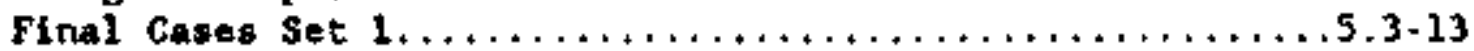

3-4 Average of Experts' Elicitations:

Final Cases Set $2 \ldots \ldots \ldots \ldots \ldots \ldots \ldots \ldots \ldots \ldots \ldots \ldots \ldots \ldots \ldots, 5.3+17$

A-1 Decompos1tion Tree Probabillties

(Case 2, Station Blackout With Drywell Meltehrough....., 5.3-25

A-2 Assessnent of Peak Reactor Building Pressure...........5.3-26

B-1 Ignition Pcababilities for a Jet. $\ldots \ldots \ldots \ldots \ldots \ldots \ldots \ldots \ldots, 5,3-32$

B-2 Ignition Probabilities for Deflagrations..............5.3-33

B-3 Pregsure Rise In Reactor Buflding Due to

a Hydrogen Burn (Atr.)........................ 5.33

-4 Reactor Bullding Hydrogen Concentration

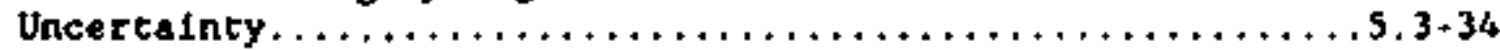

Contelreont Lad: Isaue 4

4-1 Aggregate: Drywell Pressurization, Gase $1 \ldots \ldots \ldots \ldots \ldots \ldots$ 5.4-6

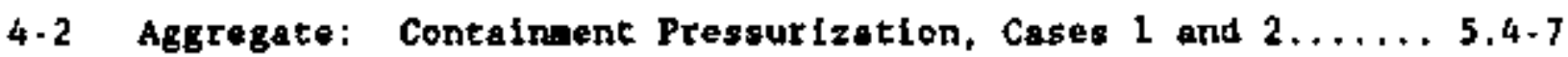

4-3 Aggregate: Contsinment Pressurizatjon, Case $3 \ldots \ldots \ldots \ldots$ 3.4-7

4-4 Aggregate: Pedestal Pressurization, Case $1 \ldots \ldots \ldots \ldots \ldots .4 .8$

4.5 Aggregate: Pedestel Pressurtzetiotı, Cave $3 \ldots \ldots \ldots \ldots \ldots \ldots 5.4 .8$

A-1 Dryvell Pressure Rlse for Case $\ldots \ldots \ldots \ldots \ldots \ldots \ldots \ldots \ldots \ldots .4 .22$

A.2 Drywell Pressuxe R1se for Case $3 \ldots \ldots \ldots \ldots \ldots \ldots \ldots \ldots \ldots .4 .23$

A-3 Dryvell Pressure Rise for Gase $2 \ldots \ldots \ldots \ldots \ldots \ldots \ldots \ldots \ldots, 4-24$

A.4 Contalnment Presgure R1se for Cages 1 and $3 \ldots \ldots \ldots \ldots \ldots, 5,4 \cdot 25$ 
TABLES (contimud)

A-5 Pedestal Pressurization for Case $1 \ldots \ldots \ldots \ldots \ldots \ldots \ldots \ldots \ldots 5.426$

A-6 Pedestal Preasurization for Case $3 \ldots \ldots \ldots \ldots \ldots \ldots \ldots \ldots .4-27$

A.7 Peciestal Pressurization for Case $2 \ldots \ldots \ldots \ldots \ldots \ldots \ldots \ldots .4 .4,28$

B-1 Pesk Drywell static Pressure (bar) $\ldots \ldots \ldots \ldots \ldots \ldots \ldots \ldots \ldots .4-32$

B-2 Peak Contalnment statlc Pressure (bar) $\ldots \ldots \ldots \ldots \ldots \ldots \ldots .4-34$

8-3 Peak Pedestal static pressure (bar) $\ldots \ldots \ldots \ldots \ldots \ldots \ldots \ldots .4 .35$

c-1 Definition of Casea......................... 5.4-39

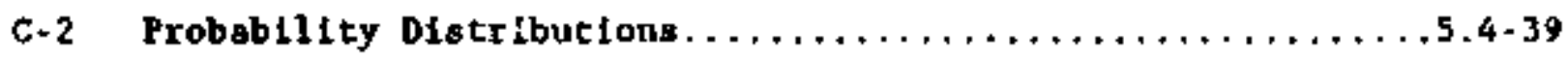
Conteinment Lasde Iasus 5

5-1 Aggregate for Low Pressure or Hon-HPHE Cases......... 5.5-5

5-2 Aggregate for Interwedlate Pressure or Non-HPHE Cages..... 5.5-9

5-3 Aggregate for High Pressure or ton-hPHE Cases .........5.17

A-1 Base Cases 1a, 2a Uith Small Vossel Failure.............5.5.30

A.2 Base Cases 1a, 2a Hich Large vessel Failure..........5.5-31

A-3 Dase Gase 3 e W1th sall vessel Fallure...............5,5-31

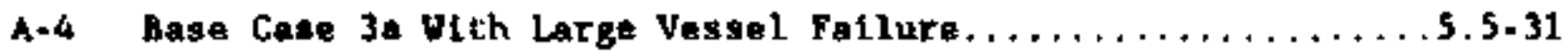

A-5 Base Cases 1 and 2 With Small vessel Faflure..........5.5.32

A.6 Base Cases 1 and 2 With Large vessel gailure..........,5.5.32

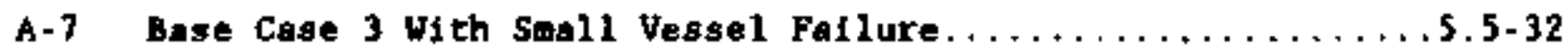

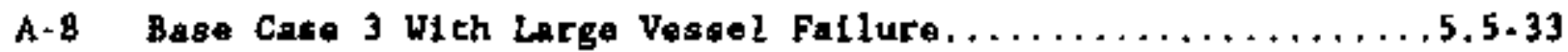

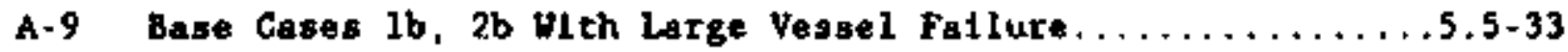

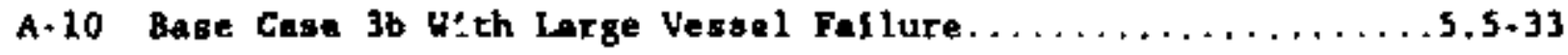

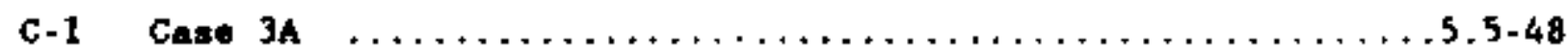

$c \cdot \hat{2}$ Case $3 \quad \ldots \ldots \ldots \ldots \ldots \ldots \ldots \ldots \ldots \ldots \ldots \ldots \ldots \ldots \ldots \ldots \ldots \ldots+5,5.48$ 
Theths (continued)

Contalmone Louda Iasue 6

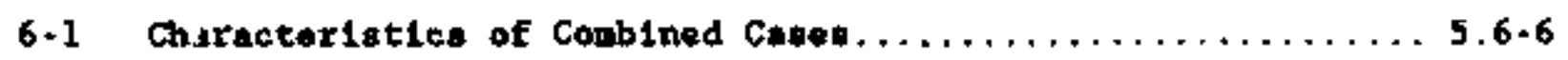

6.2 Aggregate Ragults Prosiruro R1se at Veasel

Breach for surry.......................... 5.6-7

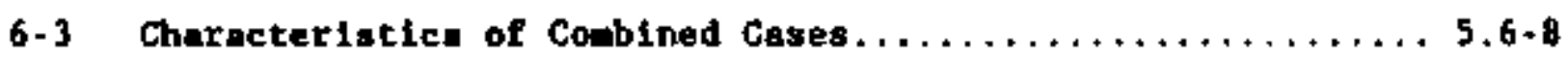

6-4 Aggregate Resulto Pressure Rise at

Vesgel Breach for surry. . . . . . . . . . . . . . . . .

6-5 Aggregate Results Frossure Ries at

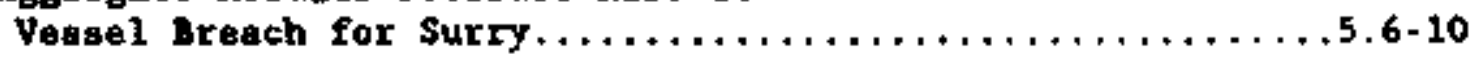

B-1 Loads at Veasel Breach at Surry for Expert B..........5.6-21

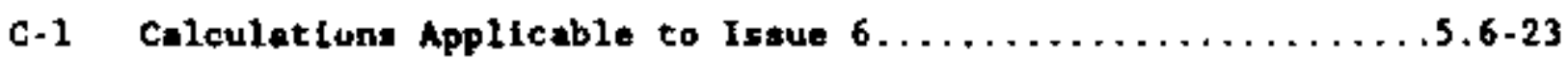

c-2 Distributions for Pressure Increnent (Bars) $\ldots \ldots \ldots \ldots \ldots .6 .64$

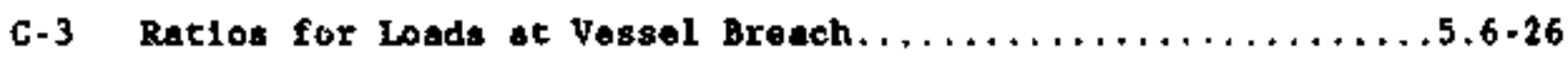

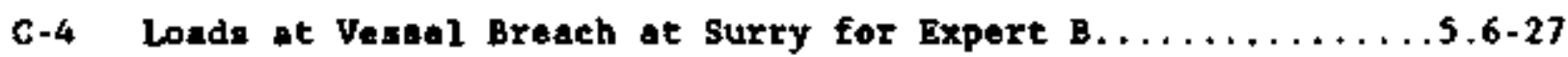

D.1 Cage 1b: High RCS Preasure and Dry Cavity;

Large Fraction....... . . . . . . . . . . . . . . . . . 5.6-35

D-2 Case 1b: H1gh RCS Pressure and Dry Cavity

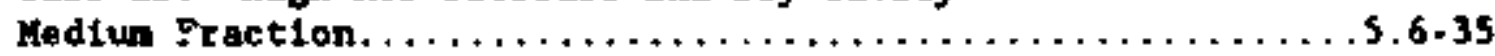

D-3 Gase lb: High RCS Presaure and Dry Cavity

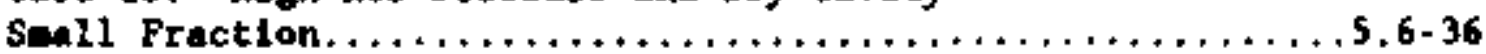

D-4 Case 1b: High RCS Pressure and Dry Cavity

Large Fraction. . . . . . . . . . . . .

D-5 Caso 1b: High RCS Pregaure and Dry Cevity

Medsu Fraction. . . .............................5.6-37

D-6 Gage Ib: High RCS Presaure and Dey Cavity

sall Fraction. . . . . . . . . . .

D.7 Cese 1: High RCS Pregrure and Uet Gavity

Large Fraction $\ldots \ldots \ldots \ldots \ldots \ldots \ldots \ldots \ldots \ldots \ldots \ldots \ldots \ldots \ldots, 6 \ldots \ldots$

D-8 Case 1: High RCS Pregsure and Wet Cavicy

Sediue Fraction. $\ldots \ldots \ldots \ldots \ldots \ldots \ldots \ldots \ldots \ldots \ldots \ldots \ldots \ldots, \ldots, 38$

D-9 Case 1: High RCS Presoure and Wet Cavity

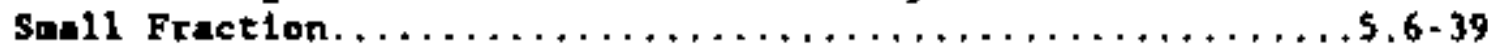

xvI 
TABLES (continued)

D-10 Case 1: High RCS Pressure and Wat Cavity

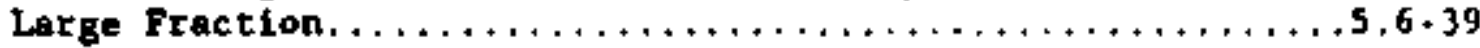

0-11 Case 1: H1gh RCS Pressure and Wet Cavity

Mediur Fraction. ...............................5.6-40

D-12 Case 1: H1gh RCS Pressure and Wet Cavity

Small Fraction. ...............................5.6-40

D.13 Gase 3b: Koderate RCS Pressure and Dry Cavicy

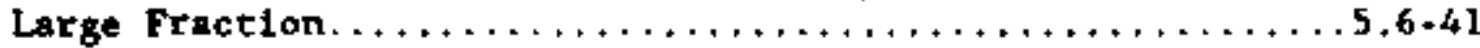

D-14 Case 3b: Moderate RCS Pressure and Dry Cavity

Mediun Fraction.................................5.6.41

D-15 Case 3b: Hoderate RCS Presgure and Dry Cavity

Snal1 Fraction..................................5.6-42

D-16 Case 3b: Moderate RCS Pressure and Dry Cavity

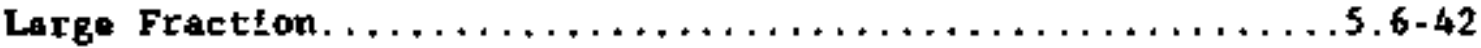

D.17 Case 3b: Moderate RCs Pressure and Dry Cavity

Large Fraction..................................5.6.43

D-18 Cage 3b: Moderate RCS Pressure and Dry Gavity

Snell Fraction. ..............................5.6-43

D.19 Case 3: Hoderate RCS Pressure and Wet Cavity

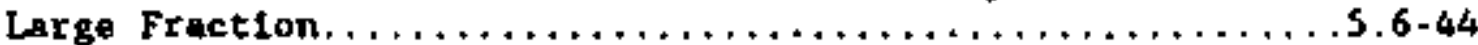

D-20 Cage 3: Moderate RCS Pressure and Wet Govity

Mediun Fraction. ..............................., 5,6-44

D.21 Case 3: Moderate RCS Pressure and Wet Cavicy

Sall Fraction. ..............................5.6.45

D-22 Case 3: Moderate RCS Pressure and Wet Cavity

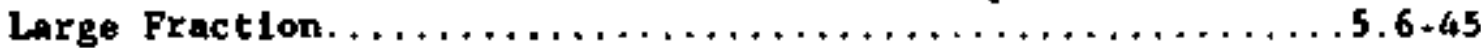

D-23 Case 3: Moderate RCS Pressure and Wet Cavity

Mediun Fraction. ..............................5.6-46

D-24 Case 3: Moderate RCS Pressure and Wet Cavity

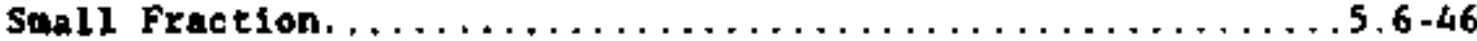

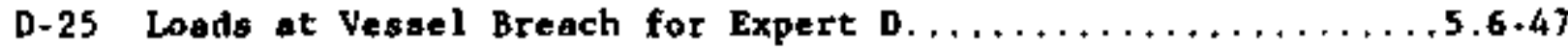


TABy IS (continuad)

Conte Innent Londa Ians 7

7-1 Characteristics of Conbined Casas ................ $5.7-8$

7.2 Aggregated Regults by Probability Averaging

Loadz at Vessel Breach at 2Ion Pressure Increments

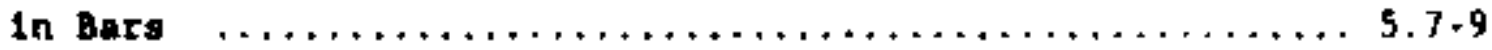

7-3 Characterintias of Conbined Cases Expanded fron

Table $7-1 \ldots \ldots \ldots \ldots \ldots \ldots \ldots \ldots \ldots \ldots \ldots \ldots \ldots \ldots \ldots \ldots \ldots \ldots 5,7-11$

7.4 Aggregated Results by Probability Averaging Losds

at Vessel Breach at $210 n$ (Pressure Increments

in Bars $) \ldots \ldots \ldots \ldots \ldots \ldots \ldots \ldots \ldots \ldots \ldots \ldots \ldots \ldots \ldots \ldots \ldots \ldots, 7 \cdot 12$

7-5 Aggregeted Results by Probability Averaging Loads

at Vessel Breach at zion (psig) $\ldots \ldots \ldots \ldots \ldots \ldots \ldots \ldots \ldots \ldots \ldots$, 7.13

B-1 Pressure Increaent in the Zlon Contafnrent

at Vessel Breach. ...........................5.7.24

B-2 Pressure Increment in the zion Containaent

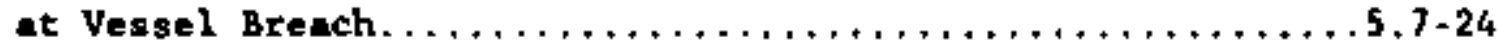

B-3 Pressure Increaent in the 21on Containment

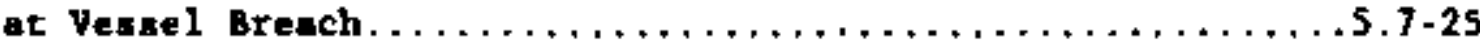

D-1 Pressure Incrament in the Zion Containnant

at Vessel Breach $\ldots \ldots \ldots \ldots, \ldots \ldots \ldots \ldots \ldots \ldots \ldots \ldots \ldots \ldots \ldots 5.7-35$

D-2 Pressure Increment in the Zlon Containsent

at Vessel Breach $\ldots \ldots \ldots \ldots \ldots \ldots \ldots \ldots \ldots \ldots \ldots \ldots \ldots \ldots \ldots \ldots 5,7-36$

D. 3 Pressure Increment in the Zion Contefrment

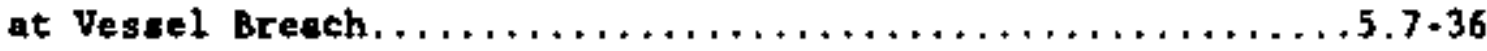

D.4 Pressure Increant in the 21on Contalment

at Vessel Dresch. $\ldots \ldots \ldots \ldots \ldots \ldots \ldots \ldots \ldots \ldots \ldots \ldots \ldots \ldots \ldots 5.7 .37$

HCCI Iseve 1

6.1 Average of 48 cases $\ldots \ldots \ldots \ldots \ldots \ldots \ldots \ldots \ldots \ldots \ldots \ldots \ldots \ldots, 6,6$

6-2 Average of Five Collapsed Cagas After ANOVA $\ldots \ldots \ldots \ldots \ldots \ldots 6.1-8$

A-l Cunulative Probability of Drywell Shell Failure.........6.1-12

B-1 Cunuletive Probabiltty of Drywell shell Fallure.........6.17 


\section{TABLES (continuad)}

\section{Iseue 2}

6-1 Compiete Set of Scenarlos for Consideration

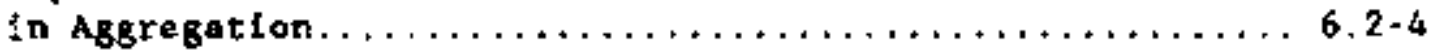

6.2 Average of 24 Cases $\ldots \ldots \ldots \ldots \ldots \ldots \ldots \ldots \ldots \ldots \ldots \ldots \ldots, 6.2-7$

$6-3$ Average of 7 Cases $\ldots \ldots \ldots \ldots \ldots \ldots \ldots \ldots \ldots \ldots \ldots \ldots, 6,2-8$

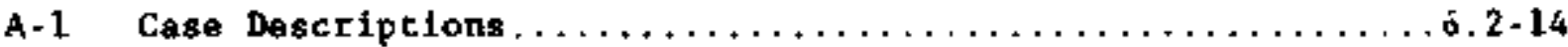

A-2 Base Distributions--Erosion Depth Probabilities

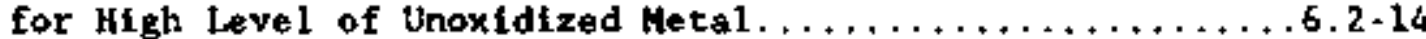

A-3 Pedestal Rartial Erosion Depths (n) ................6.2-15

B.1 Bounding Calculations for Grand Gulf Pedestal

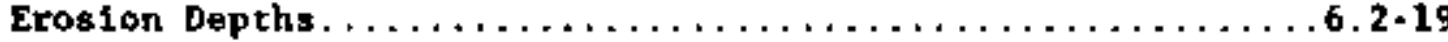

B-2 Grand Gulf Pedestal Erosion Depths for

Cases 1, 2, and $3 \ldots \ldots \ldots \ldots \ldots \ldots \ldots \ldots \ldots \ldots \ldots \ldots \ldots \ldots, 2-20$

F-1 Interpolated Values of $\mathrm{V} / \mathrm{V}_{\mathrm{ax}}$ for Cases Defined

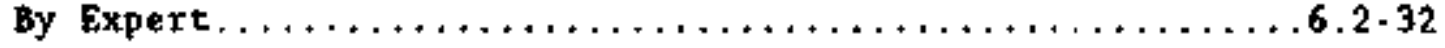




\section{FOREWORD}

This is one of many documents that constlute the technical basis for the NUREG-1250 document produced by the NRC Oifice of Nuclear Regulatory Research. This document's purpose is to present the results of the elieltations from the Contalnment Loads Expert Panel and the Molten Core/Concrete Interaction Expert Panel. The document consists of the distributions and assoctated technical rationale provided by the expert pane is for the phenomenological questions posed by the NUREC-1150 analysts.

Figure 1 identifies all the documents that present the results of the accident progression aralysis, the source tera analysis, the consequence analysis, and the overall risk Integration. Three Interfacing programs performed this work: the Accldent Sequence Evaluation Program (ASEP). the Severe Accldent Risk Reduction Program (SARRP), and the PKA Phenomenology and Risk Uncertsinty Evaluation Program (PRUEP). Table 1 is a 1ist of all of the original primary documentation (published in 1987 ) and the corresponding revised dac'mentation that supports the current version of NUREG - 1150 .

The current NUREC/CR-4551 covers the anglysis included in the ariginal NUREG/CR-4551 and NUREC/CR-4700. The accident progression event treas orfginally documented in NUREG/CR-4700 are now documented in the appendices of volunes 3 to 7 of NUREG/CR-4551.

Originally, NUREC/CR-4550 was published without the designation "Draft for Compent." Thus, the final revision of NUREC/CR-4550 is designated Revision 1. The label Reviston $l$ is used consistently on all volumes, including Volume 2 which was not part of the origlnal documentation. NUREG/CR+4551 was originally published as a "Draft for comment": the Revision 1 designator $1 \mathrm{~s}$ used to maintain consistency with NUREG -4550 documents.

There are several other reports publfshed that are closely related to NUREG/CR-4551. These are:

NUREG/CR-5380, SAND88-2988, S, J. Higgins, "A User's Manua1 for the Post Processing Program PSTEVNT, "Sandla National Laboratories, Albuquerque, NH. 1989 .

NUREG/CR-5360, SAND89-0943, H.-N. Jow, W. B, Murfin, and J, D. Johnson, "XSOR Codes User" Manual," Sandia National Laboratories, Albuquerque, NK, 1989.

NUREC/CR-4624, BMI-2139, R. S. Denning et al., "Radionuclide Releage Calculationg for Selected Severe Accident Scenarlos," Volunes $I-V$. gattelle's Columbus Division, Colunbus, OH, 1986.

NUREG/CR-5062, BHI-2160, M. T. Leonard et al., Supplemental Radionuclide Release Calculations for selected Severe Aceldent Scenarios." Battelle Columbus Division. Columbus, OH, 1988. 
NUREG/CR-5331, SAND89.0072, S. E. DIngman t al., "MELCOR Analyses for Accident Progression I sues," Sandia National Laboratories, Albuquerque, NM, 19B9.

NUREG/CR-52S3, SANDBB-2940, R, L. Iman, J, C. Helton, and J, D. Johnson, "PARTITION: A Program fir Defining the Source Term/Consequence Analysis Interfaces in the MUREG-1150 Probabllistic Risk Assessments User's Gulde," Sandia National Laboracories, Albuquerque, NM, 1989.

NUREG/CR-5382, SAND88-2695, J . C. Helton et al., "Incorporation of Conseçuence Analysis Results Into the WJREG-1150 Probabilistic Risk Assessments," Sandia National Laboratcries, Albuquerque, NK, 1989.

NUREG/CR-5174, SANO88-1.007, J. M. Griesmeyer and L. N. Smith, "A Reference Manual for the Fvent Progression Analysis Code (EVNTRE)." Sandia National Laboratorfes, Albuquexpate, NS, 1988.

NIIREG/CR-5262, SAN088-3093, R, L, tran, J, D. Johnson, and J. C. Helton. "PRAkIS: Probabllistic Risk Assessuent Model Integration Systen User's Gudie," Sandia National Laboratorfes, Albuquerque, NM, May 1990. 


\section{SUPPORT DOCUMENTS TO NUREG-1150}
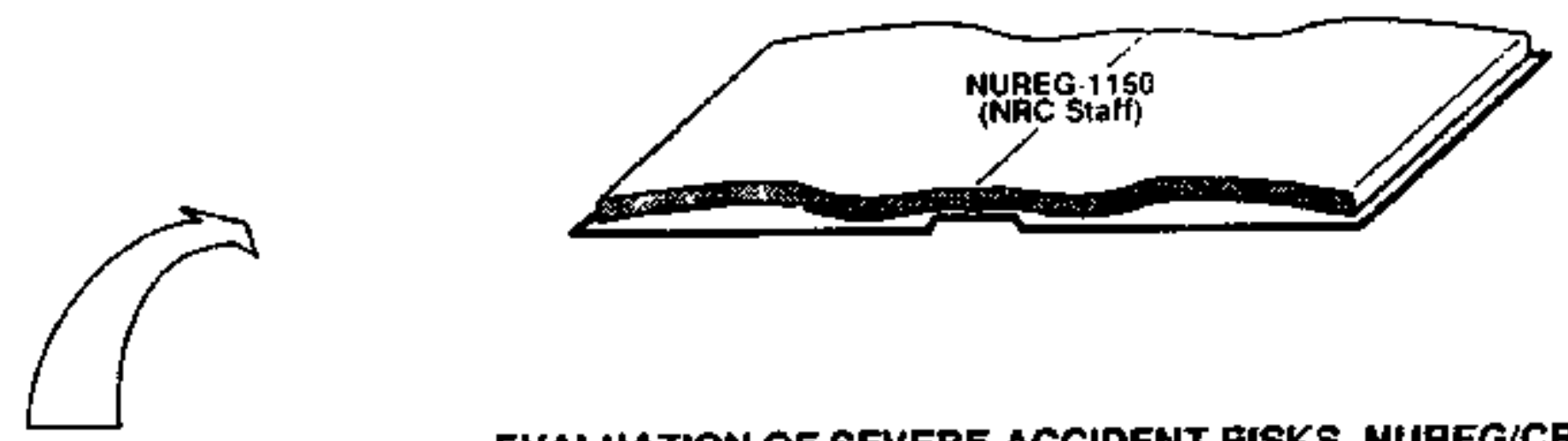

\section{NUREG/CR.4550}

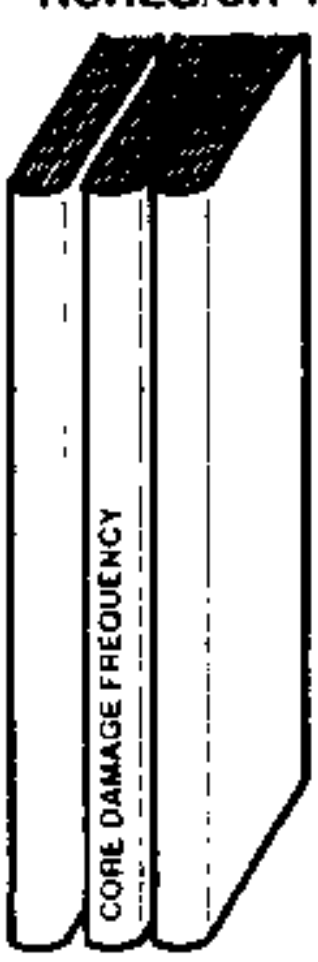

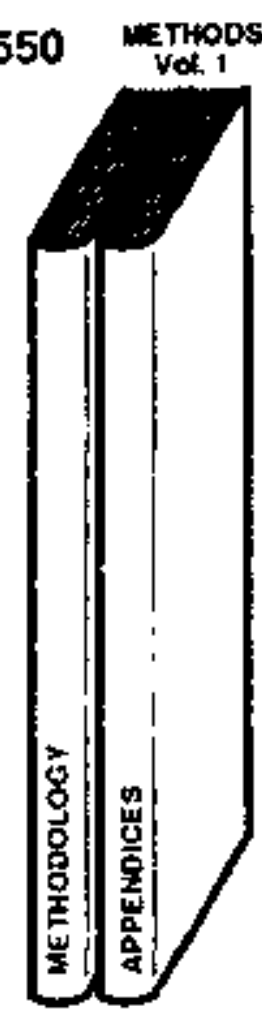
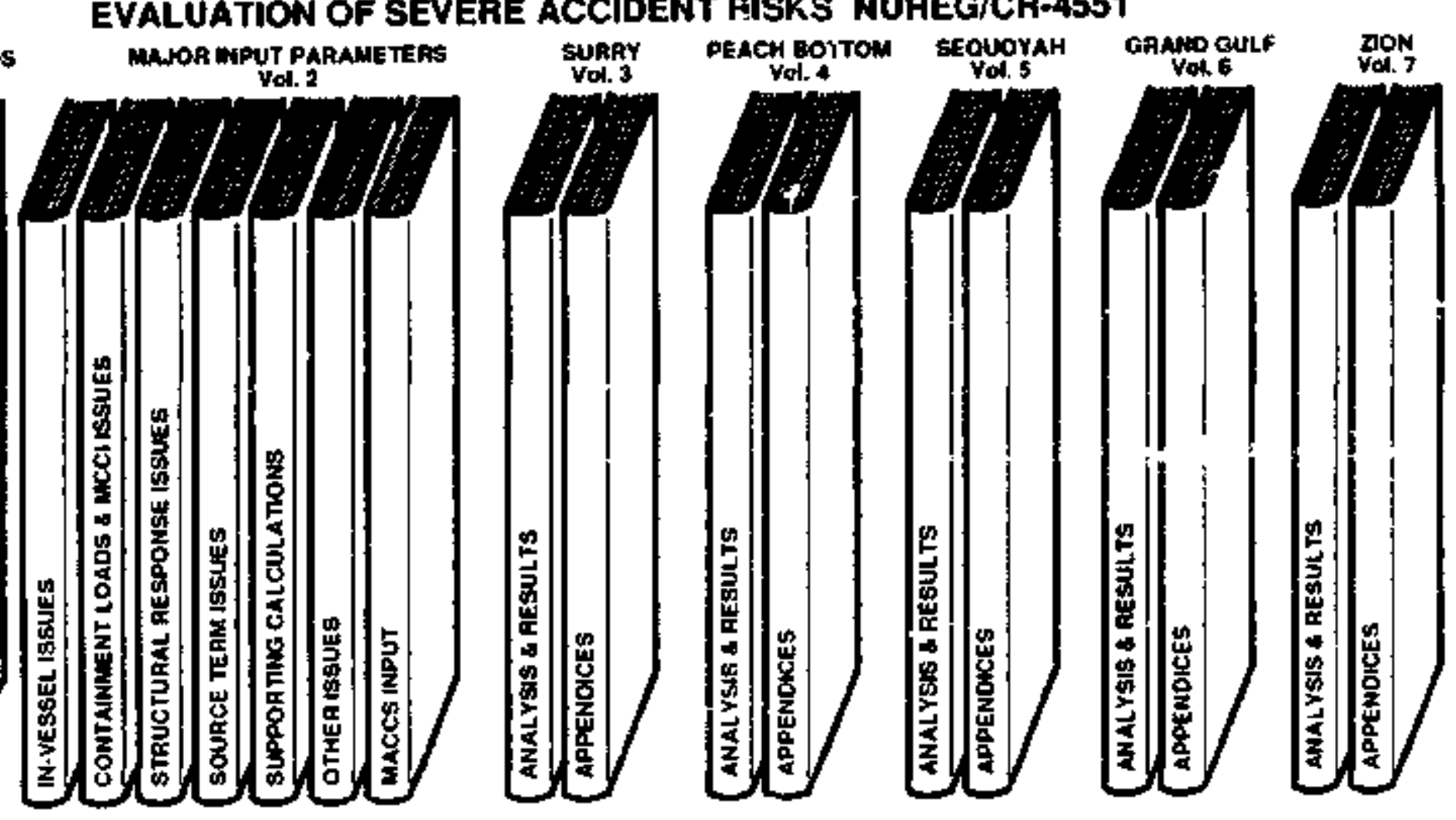

Figure 1. Back-End Documentation for NUREG-1150. 
Table 1. NUREG-1150 Analysis Documentation

Original Documentacion NUREG/CR-4550

Analysis of Core Damage Frequency From Internal Events

Vol. 1 Mechodology

2 Summary (Not Published)

3 Surry Unic 1

4 Peach Botto- Unit 2

5 Sequoyah Unit 1

6 Grand Gulf Unit 1

7 Zion Unit 1

\section{NUREG/CR - 4551}

Evaluation of Severe Accident Risks and the Potential for Risk Reduction

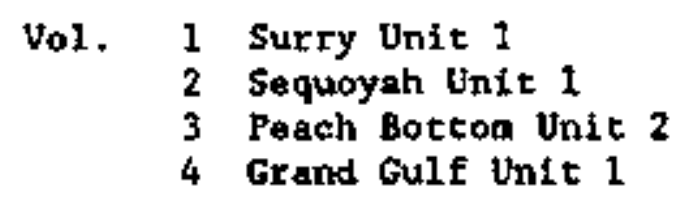

3 Peach Botton Untt 2

4 Grand Gulf Untt 1

NUREG/CR-4700

Contalment Event Anslys 18 for Potencial Severe Accidents

Revised Documencation

\section{NUREG/CR-4550, Rev. 1, Ansiysts of Core Darage Frequency}

Me thodology

Part 1 Expert Judgment Elicit. Expert Panel

Part 2 Expert Judgment Elicit. Project Staff

3 Part 1 Surry Unit 1 Internal Events

Part 2 Surcy Unle 1 Internal Events App.

Part 3 Surry External Events

4 Part 1 Peach Botton Unit 2 Internal Events

Part 2 Peach Batton Unit 2 Int. Events App.

Part 3 Peach Botton Unit 2 External Events

5 Part 1 Sequoyah Unit 1 Internal Events Part 2 Sequoyah Vnit 1 Internal Events App.

6 Part 1 Grand Gulf Unit 1 Internal Events Part 2 Grand Gulf Unic 1 Internal Events App.

7 Zion Unit 1 Internal Events
NUREG/CR-4551, Rev, 1, Eval, of Severe AccIdent Rlsks

Vol, 1 Part 1, Methodology: Part 2, Appendices

2 Part 1 In.Vessel Issues

Part 2 Containment Loads and MCCI Issues

Part 3 structural Issues

Part 4 Source Term Issues

Part 5 Supporting Calculations

Part 6 Other Issuas

Part 7 Maccs Input

3 Part I Surry Anelysis and Results Part 2 Surry Appendices

4 Part 1 Peach Bottom Analysis and Results Part 2 Peach Bottor Appendices

5 Part 1 Sequoyah Aralysis and Results Part 2 Sequoyah Appendices

6 Part 1 Grand Gulf Anstys is and Results Part 2 Grand Gulf Appendices

7 Part 1 Zion Analysis and Results Part 2 Appendices 
As authars of this report, we acknowledge the help of all of the particlpants in the expert judgment elicitation process including the expert panel; the normative experts; the substantive experts; and the utilty, industry, national laboratory and other experts who atcended the meetings. While we wrote most of the actual report, the members of the expert panels provided us with most of the technical substance. We would particularly like to thank steve Hora of the University of Hawali for his role in developing the expert judgaent elicitation methodology, Ralph Keeney of the University of Southern Calffornia for his assistance in directing the elicitation process, and the following people from Sandia National Laboratorles: Reeta Garber for assistance in preparing thls report: Ann Shiver for aggregating the results and visually presenting these in figures: and Timothy wheeler for providing not only the template for this report but also for auch of the prose in the introductory sections. We also appreclate the support of Joseph Murphy, Mark cunninghan, and p. K. Niyogi of the NRC. 


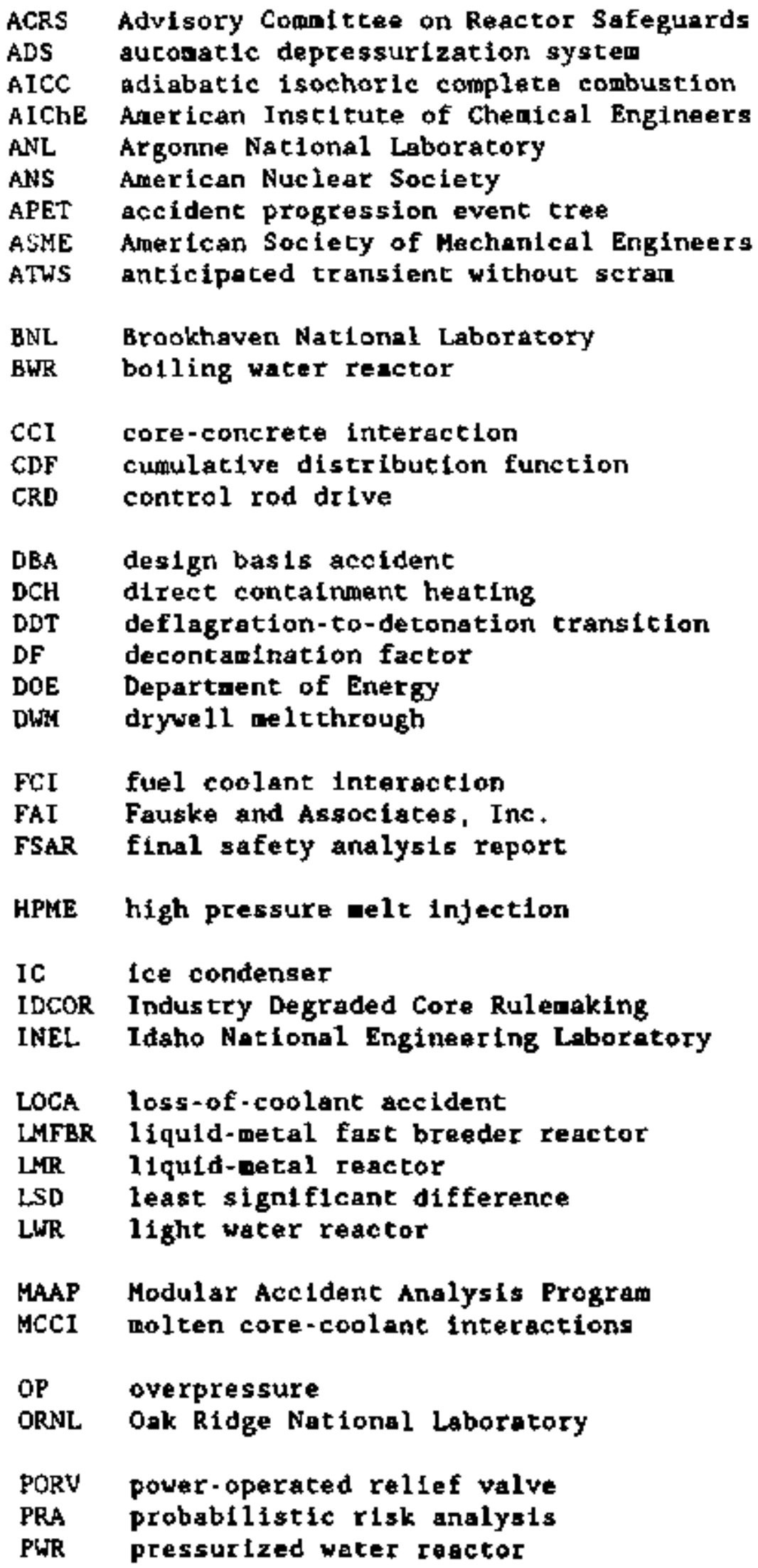




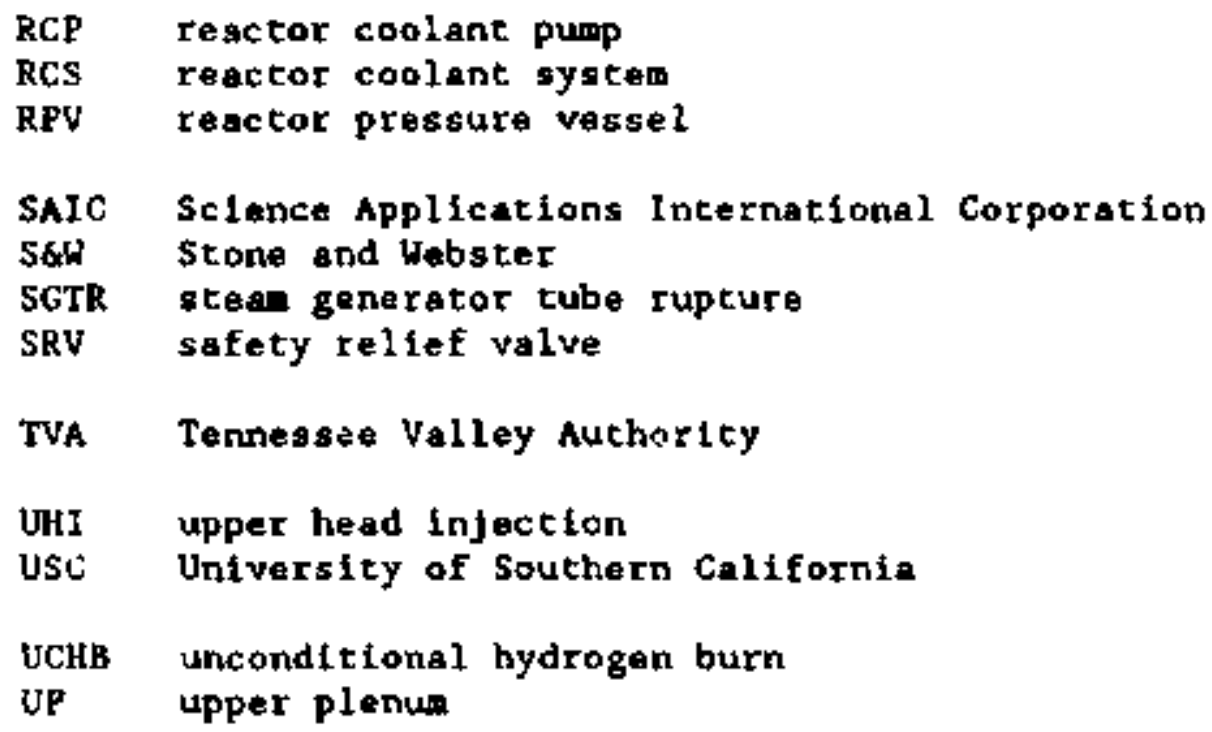




\section{INTRODUCTION}

The United States Nuclear Regulatory Compission (NRC) has prepared NUREG$1150^{1}$ to exanine the risk of accidents in a selected group of nuclear power plants. The three alin objectives of NUREG-1150 are given below.

1. Prepare a current assessment of the severe accldent $r$ isks of five nuclear power plants which will:

- Provide a "snapshot" of risks reflecting plant design and operational chsracteristics, celated failure data, and severe accident phenomenological information extant in March 1988:

- Update the estimates of NRC's 1975 risk assessment, the Reactor Safety Study;

- Include quantitative estmates of risk incertalnty, in response to a principal criticism of the Reactor Safety Study; and

- Identify plant-specific risk vulnerabilities, in context of the NRC's individual plant exemination process.

2. Sumarize the perspectives gained In performing these risk anslyses, with respect to:

- Issues significant to severe accident frequencies, consequences, and risks:

- Uncertainties for which the risk is significant and which may enrt further research;

- Comparisons with NRC's safety gosls;

- The potential benefits of a severe accident management program in reducting risk; and

- The potential benefit of other plant nodifications in reducing risk.

3. Provide a set of methods for the priaritization of potential safety issues and related reseaxch.

In support of WUREG-1150 and as part of the Accident Sequence Evaluation Program (ASEP) and the Severe Accident R1sk Reduction Program (SARRP), Sandia National laboratorles (SNL) has directed the production of Level 3 probabilistic risk assessments (PRAs) for the Surry, Sequoyah, Peach Bottom, and Grand Gulf nuclear power plants. (Level 1 PRAs contain accident sequence analyses developed to the point of core damage; Level 2 PRAs include Level 1, accident progression and source term analyses; and Level 3 PRAs include tevel 1, Level 2, and consequence analyses.) A PRA for the fifth NUREG-1150 plant. Zion, has been prepared by EGGG Idaho, Inc., of the Idaho National Engineering Laboratory (INEL) (Level 1) and 
Brookhaven National Laboratory (BNL: (Levels 2 and 3). Two of these analyses (Surry and Peach Botton) include external events.

Expert Judgment elicitation is an integral part of the methods uged to produce the PRAs in support of NUREG-1150. Expert judgment is used where applicable experimental data or complete analyses are inadequate. Such sltuations are comon in analysis of rare events and complicated severe accident phenomena. The purpose of this report is to provide the results and technical rationale obtained from the Containment Loads Expert Panel and the Molten Core/Containnent Interaction Expert Panel. The expert judgment nethodology is presented in detail in NUREG/CR-4551 Volume 1.

Expert Judgments are expressions of opinion, based on knouledge and experience, that experts make in responding to technical problems. Specifically, the judgments represent the expert's state of knowledge at the time of response to the technicsl question. Expert fudgment is not restricted to the experts' answer but includes the experts mental pracesses (definitions, assunptions, and algorithms) for arriving at answers.

Expert fudgaent is necessartly used in all technical flelds. Because these judgments are often implicit, they are sometimes not acknowledged as being expert judguents. For example, expert judgatent is frequently used implicicly, even unconsciously, when researchers make decisions about defining problens, establlshing boundary conditfors, or screening data. By contrast, expert judgnent for NUREG-1150 3.5 obtained explieltly through formal processes.

Risk assessment frequently needs expliclt expert judgant as a source of data, farticularly if one or nore of the following situations exist:

1. Wo other date (analytical or experimental) for predicting the outcome of phenomena are available;

2. High varlability characterizes the data:

3. The applicability of the data is questionable:

4. Existing date needs to be supplemented, interpreted, or incorporated with model or code caltulations:

5. Analysts need to determine the state of knowledge about what is currently known. what is not known, and what is worth learning.

The issue felection process consisted of accunulating an extensive list of potential issues by plant or across plants and then evaluating the significance of each 1ssue. Expert panel menbers participated In the lssue selec. tion by reviewing the issues selected and rejected for the expert judgant prucess and racomended the addftion, deletion, or modification of issues Erow the initial list.

There were seven contalnment loads 1 ssues and two molten core/contalnment interaction issues that were considered important enough to be the subject 
of a fortal expert judgment elicitation. Table l.1 lists the contalngent loads 1ssues and Table 1.2 lists the molten core/containnent interaction issulas. The original list of containment loads issues was slightly different than that presented in Table 1.1. The experts deleted the pressure rise at vessel breach issues for Peach Bottom and LaSalle and expanded the loads at vessel breach for pressurized water reactor (PWR) issue into three issues: loads at vessel breach for Surry, Sequoyah, and zion. (This document will not present any tesults for the LaSalle issues that were considered at the cime of the experc elicitations,)

Section 2 of this report briefly outlines the expert selection process and gives a short blographical sketch of each expert. Section 3 describes the fundamental expert judgment elleitation methodology. Section 4 11sts the metings held for the Containment Loads Expert Panel and the Molten Core/Contalument Expert Panel and the people who gave presentations at the metings. Section 5 constitutes the bulk of this report and contains a description of each 1ssue considered, a sumnary of the technical rationale applied by the experts to the issue, a description of the method use to aggregate the expert's distributions, the aggregated distributions, and written accounts of each individual response to the question. The individual expert's arrative include the distributions and the detailed rationale behind the distributions. Each account was written by the substantive expert who assisted with the elicitation. In all cases the experts were given anple opportunity to review these written accounts and approve them. In few cases, the experts did not respond and were informed that thair lack of response would be assumed to be tacit approval of the write-up. Section 6 contains conclusions and recommendations. The conclusions given in Section 6 relate to the value of the products of che study and the effectiveness of the process. 
Table 1.1

Contaimment Losds Issues Considered for Expert Judgment Blicitation

Issue

1. Hydrogen Phenomene at Grand Gulf

2. Hydrogen Burn at Vessel Breach at Sequoyeh

3. BWR Reactor Buflding Faflure Due to Fydrogen

4. Grand Gulf Containment Loads at Vessel Breach

5. Pressure Increment in the Sequoyah Contalrument at Vessel Breach

6. Loads at Vessel Breach: Surry

7. Pressure Increnent in the Zlon Contaiment at Vessel Breach

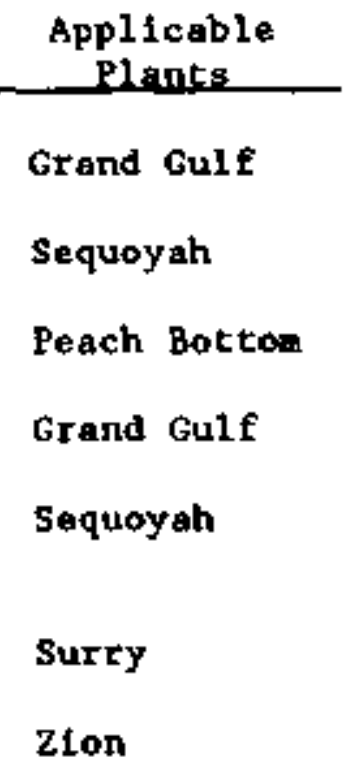

Note: lasalle Reactor Building Failure was addresged by the panel. The results will be reported in the Lasalle docunentation.

Tablo 1.2

Molten Core/Containment Issues Cons/dered

for Expert Judgent Elicitation

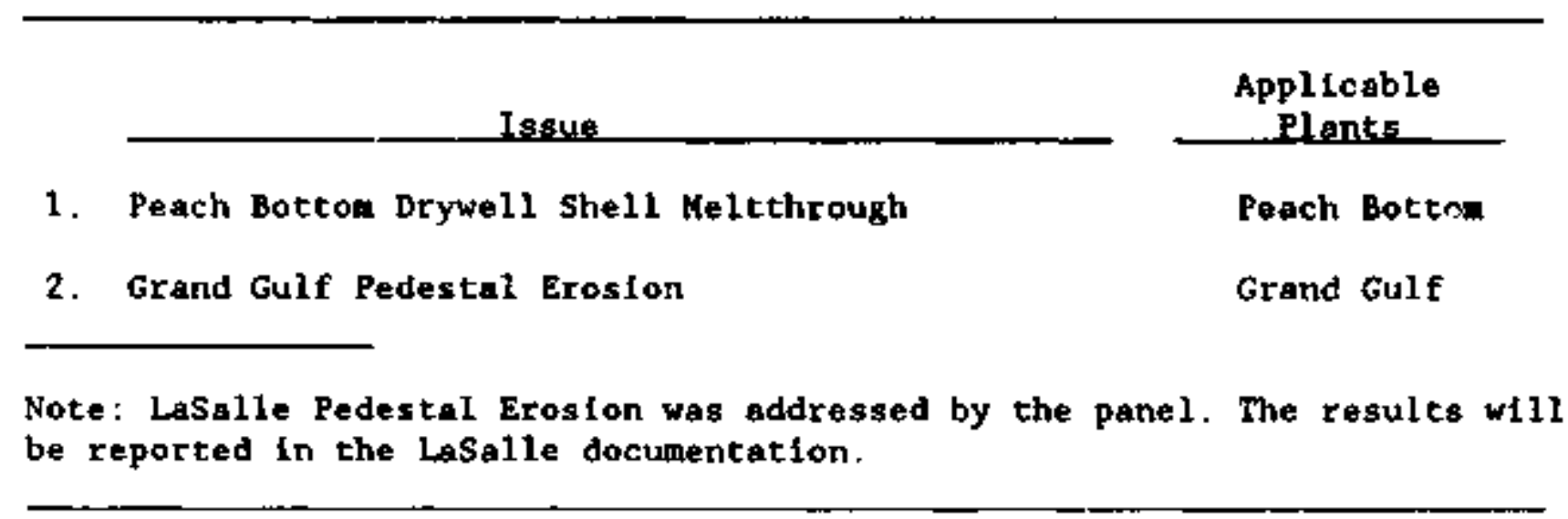

1.4 


\section{REEERENCE}

1. U. S, Nuclear Regulatory Connission, "Severe Accldent Risks: An Assessaent for Five U. $S$. Nuclear Powet Paants," Vol.1, Offlce of Nuclear Regulatory Research, Washington, D.C., 1989. 


\section{EXPERT CREDENTIALS}

The objective for selecting the panel members was to obtain experts with as wuch expertise as possible in the flelds of containment loads and molten core/contalnment interactions. The project attempted to include s wide diversity of axpertise that oncoureged alcernative points of view. The seluction of experts should preclude stakeholders in the findings of NUREG-1150 from participating as meabers of the expert panel. This led to several criteria In selecting the experts:

1. Experts should have to demonstrate experlence by authoring publfcations, handseon experience, and consulting or managing research in the ereas related to the issues;

2. Experts should have to represent a wide varfety of experfence as is obtained in universities, consulting firms, laboratories, nuclear utilities, or government agencies;

3. The experts should hava to represent as wide a perspective of the 1sauos as possible;

4. The experts should be willing to be elicited under the methodology to be used.

To ensure proper representation, letters were sent to nany organizations requesting nominations for experts to serve on the in-vessel, containment loads, molien core/contalnment interaction, structural response, and source term penels. Sone of the organizations which recelved these letters ate listed below:

Atomic Energy of Canada LTD.

Battelle Columbus Division

Bechtel Western Pover Company

Brookhaven National Laboratory

Commonwealth Edison

Electric Power Research Institute

General Electric

Idaho National Engtneering Laboratory, (EGes Idaho, Inc,)

Illinols Department of Nuclear Safety

International Technology Corporation

NHB Technical Associateg

New York Power Authority

NUMARC

Oak Ridge National Laboratory

Philadelphia Electric Co.

Sandia National Laboratories

Stone and Webster Engineering Corporation

Systens Energy Resources, Inc.

Tennessee $V_{8}$ lley Authority

U.S. Nuclear Regulatory Comnissian

Virginia Electric Power Co.

Westinghouse Electric Corp. 
It was Impossible to satisfy each criterion entirely for every expert/ issue combination. Nevertheless, we were pleased with the high quality and objectivity of the experts. The experts chosen for the containment losts (CL) and molten core/containment interaction (MCCI) issues were:

Louls Baker Jr. (CL)

Kenneth Bergeron (CL)

Theodore Ginsberg (CL)

James Metealf (CL)

Martin Plya (CL)

Martin Sherasn (CL)

Alfred Torri (CL)

Patricla Worthington (CL)

David Bradley ( $\mathrm{HCCI}$ )

Michael Corradini (MCCI)

George Greene (MCCI)

Michael J. Hazzan (MCCI)

Mujid Kazimi (MCCI)

Bal Raj Sehgal (MCCI)
Argonne National Laboratory

Sandia National Leboratorieg

Brookhaven National Laboratury

Stone and Webster Engfneering Corporation

Fauske and Associates

Sandia National laboratorles

Pickard, Lowe, and Garrick, Inc.

U.S. Nuclear Regulatory Connission

Sandia National Laboratories

University of Wisconsin

Brookhaven National Laboratory

Stone and Webster Engineering Corporation

Massachusetts Institute of Teckivlogy

Electric Power Research Insticute

Brief biographical sketchs of the experts are presented belaw:

\section{Containment Loads Export Panel}

Louis Baker. Jr, Lou Baker is a Senior Chemist at the Argonne National Laboratory (ANL). He has on undergraduate degree in Chealcal Engineerting and $\mathrm{A} \mathrm{Ph} . \mathrm{D}$. degree in Chemistry from the Illinols Institute of Technology. Before Joining ANL, ha was an aeroneutical research scientist at the Lewis Laboratory of the National Advisory Comittee for Aeronautics. At ANL, he has held a number of positions associated with reactor safety research. He was a group leader for Investigations of metal-water and metal-air reactions throughout the 1960s. Later, he was Manager of the Safety Section of the liquid-netal fast breeder reactor (IMFBR) Progran Office. Following that, he managed a research group studying postaceldent heat removal for liguld metal reactors. He also served as a progran manager in DOE's Technology Hanagement Center for Fast Reactor Safety, he managed tich concluding phase of the Electric Power Research Institute (EPRI)/Argonne Source Term Experiments Project (STEP). Currently, he is working with EPRI and Sandia National Laboratories (SNL) on the direct contalnment heating problem for light water reactors (LWRs).

Kenneth Bergeron is Supervisor of the Containment Modeling Division at SNL. This group is responsible for the development and application of the CONTAIN conputer code, which 15 the USNRC's best-estimate, mechanistic analysis cool for severe accident contalnment anslysis. Dr. Bergeron holds a Ph.D. degree In Physics from Brandels University, where hls dissertation work was in the area of theoretical non-equilibriun statistical mechantes. He has been at SNL for 14 years, where his research assignnents before his current activities in reactor safety have ranged from theoretical scudies of electrical breakdown of vacuun and insulators to systems analysis and economfes of Industrial solar energy. He has been associated with the 
Consain code for seven years, five of thea as supervisor of the group working with this code. He was a member of the Contalnment Loads Working Group, and also particlpated in the expert panel assessaents for the Draft NUREG-1150.

Thegdore Ginsbers is Group Leader of the Experimental Modeling Group in the Departwent of tuclear Energy at Brookhaven National Laboratory (BNL). He holds a Ph.D, and M.S. dogrees in Nuelear Engineering frow Pennsylvania State University and a Bachelor's degree fn Chemlcel Engineering from Pratt Institute. His current research activicies involve experimental and analytical modeling of wulti-phase transport phenowena related to LWR nuclear safoty. Sovere accldent research underway in his group currently Involves the severe accident analysis issues of direct containnent heating (DCH) and core-concrete interections (CCIs) and aerosol release. He is presently drecting reseatch and developing nodels for characterizing transpart phenomena occurring during DCH scenarlos and is leading a plant. specific DCH contairment loading analysis.

He began his career at ANL where he was Principal Investigator of a thermal-hydraulic project related to development of the LMFBR. While at ANL he also was involved in environmental studies related to thermal pollution of bodies of water by power plant condenser water outflow. He was a faculty nenber of The Technion - Israel Institute of Technology in Haifa, Israel, where his research included studies of the behavior of buoyant plumes, mathenaticel analysis of heat transfer in complex geometry and hydrodynamic wixing between connected parallel flow channels. Since 1974, his research activities have focused on many aspects of nuclear power plant safety. Related to his UFBR analytical and experimental research. his published work includea studies of multi-phase heat and mass transfer in volume-heated boiling systems, application of microwave technology for simulation of the nuclear heat source, the Impact of fluid instabllities on core disruptive accident energetics and convective solidification processes. He vas lnvolved in mathenotical analysis of specific phenomenological issues and performed integrated analyses of LHFBR systens transients using large computer codes. More recently, he has been involved in a review of the Departnent of Energy's liquid-metal reactor (IMR) concept in the areas of probabilistic risk assessment and analysis of the new tMR wetal fuels concept. His LWR research publications include experimental and analytical studies of multi-phase flow processes during the quench of packed beds of particles, aerosol generation resulting from sparging of liquid pools with gas bubbles, steam production during the quench of hot pacticulete falling through pools of water (steam spike) and condensstion-induced water hamer. He has been involved in several technology assessaents with published reports related to aspects of UWR, LMR and LMFBR phenomenology. He chalred the NRC's Stean Explosion Review Group and participated in the NRC's Containwent Lasds Working Croup.

James Metcalf. No biographical sketch available.

Martin G. Plys. Martin Plys is the Manager of Methods Development at Fauske and Associates, Inc. (FAI). He is primarily responsible for development and application of the Modular Accident Analysis Program 
(MAAP), the integrated accident analysis cool developed by FAI for the Industry Degraded Core Rulemaking (IDCOR) Progran. His career has been devoted to reactor safety analyaia, chiefly in research and model development for severe reactor accidenta. He has excensive experience in Integrated severe accldent analyaes covering all $\mathrm{U} . \mathrm{S}$. reactor types as well as several European reactors, His flelds of research and expertise include CCIs and fiosion product releage. hydrogen conbustion, containment thermalhydraulics, core melt progression, and flasion product chemistry. Before joining FAI in 1984, he recelved an Sc.D. In Nuclear Engineering fron Hassechusetes Institute of Technology (MIT), and worked for Commonwealth Edison Conpany and Northern Indiena Public Service Conpany.

Wartin Sherman. No blographical sketch avallable.

Patricis Worthington. No biographical sketch avallable.

Alfted Torr1, Since 1990, Dr. Torri has been an Independent consultant and the sole proprietor of Risk sefety Engineering. Dr. Torrt holds Ph.D. and Masters degrees in Nuclear Engineering froe MIT and a Bachelors degree in Mechanlcal Englneering frow the Swiss Foderal Institute of Technology. As an independent consultant, he was the principal investigator and technical lead for the Malne Yankee Leve' 2 PSA and the project nanaget and principal investigator for rohlebers Level 2 PSA. HIs projects also included the documentation of the Whieberg PSA Level 1 and 2 Geran wain report and the IPE Level 2 containnent event tros andysis for the Crystal River plant.

In the 1980s, while at Pickard, Lowe and Garrick. Inc. (PLC), he was a partner and the chairean of the PLG Technical oversight Connictee. He was responsible for methodalogy development end technical dizection of contalupent response analysis (Level 2) on probabilistic risk assessment (RRA) projects. In this capacity, he was project leader and principal contributor for the Sabrook and Midland Level 2 PRAs, and project manager and principal investigator for the Beznau PRA (Level 1). He also managed and was the lead author on a profect to docuent PLf PRA methodology and application, and he cestifled before the Advisory commites of Reactor Safety and the Nuclear Regulatory Cownission on reactor safety issues.

Earlier, as the nanager of the Gas-Cooled Fast Reactor Progran, Safety and Reliability Branch at General Atondc Company, he directed 6 to 12 engineers performing gas-cooled fast reactor safeey assessnents sponsored by the Departnent of Energy, At th. MIT Research Reactor, he was the Sentor Reactor Supervisor, overaeding sll apects of reactor operation, Including startup, shutdow, refueling, agintenance, and testing. Throughout his career, Dr. Torrl hod been extrenely active in professional orgenizations, such as the Anerican Nuclear Soclety and the European Nuclear Soctety.

\section{Nolten Cor $/$ Conte Inent Interection Penel}

Daytd R. Bradley. David R. Bradley to Menber of Tachnical staff at SWL. He holds a Ph.D. degreo in Huclear Englnoering from the University of Virginla, Dr, Bradley has worked prinarily on nuclear factlicy safety 
probleas and $1 s$ an expart in the fleld of core debris interactions with concrete during severe accidents. Before joining SNL, he was an assistant professor at the Univeraity of virginia where he conducted research in bubble behavior during hypothetical core disruptive eccldents in LFBRs. Since coolng to SNL, he has been involved In experianental and analytical research on the Intersctions of nolten and solidified core debris with concrete.

Wichael l. Corradint. Michael Corredint is a profegsor in the Nuclear Engineering and Engineering Physics Department at the University of Wisconsin, Madison. He also holds a iolnt appointment in the Mechanlcal Engineering Department at the University and is the Director of the Muclear Safety Research Center. He received his B.S. degree in Mechanical Engineering at Marquette University in 1975 and his M.S. and Ph.D. degrees in Nuclear Engineering at MIT 1n 1978. Before joining the university in 1981, he vas a Member of Technlcal Staff at SNL, where he worked on severe accident research, particularly vapor explosion phenomena, molten coreconcrete interactions and contaiment thermal-hydraulics. His current research activities are in the areas of nuclear reactor safety, particularly severe accldents (vapor explosions, molten core-concrete Interactions, direct heating, containment thermal-hydraulfes), radioactive waste management (transportation). Eusion reactor technology (liquid metal/water interactions and liquid metal condensation), Industrial safety (multi-phase multi-component flows) and combustion technology (spray dynamics). He is a consultant to the Advisory Compittee on Reactor Safeguards (ACRS) sub-committees on Severe Accldents and Waste Hanagement. He is also the university representative to the state Radioactive Wasce Review Board's Technical Advisory Conntetes. He is a nember of the American Nuclear Society (ANS), the Anerican Sociaty of Hechanical Engineers (ASME) and the Amertcan Institute of Chemical Engineers (AIChE).

Gegre Greene. Ho blographical sketch avaflable.

Mtchael_ J_Harzan. Michael Hazzan 1s a Principal Nuclear Technology Engineer with stone bebster (S\&W) Engineering Corporation in Cherry Hill, New Jersey. He has been a nember of S6w's Source Terw Project since 1982. He has participated in numerous severe accident thereal hydraulics and fission product transport analyses of both PWRs and BWRs, including BWR analysis in support of Baltimore Gas and Electric's EP2 Reduction request for Calvert Cliffs, and an extensive analysis of concainment bypass accidents in PWRs. He has performed these analyses with a variety of IDCOR, NRC and SSH codes. He has authored or co-authored a number of technical papers in the source tera area or in emergency planning. He has a) so managed numerous safety-related jobs involving fault tree analysis. probabilistic risk analyses (PRAs), dispersion and consequence analysis for the chenlcal process industry. Before joining Sob, Hr. Hazzan spent seven years as a nuclear-trainad naval officer.

Uujids. Karfol. Mujid $S$. Kazinl is a Professor of Nuclear Engineering at the MIT. Cambridge, Massachusetes wh a B.S. degkee from the University of 
Alexandr1a, Egypt, 1969, and a Ph.D. degree in Nuclear Engincering from MIT, 1973, Before Jolning MIT, he worked at Westinghouse Advanced Reactor Division fron 1973 to 1974 and BNL from 1974 to 1976. He has been interested in the heat transfer aspects of fission reactor design and safety, and in the Implications of safety for iusion technology developaent. He has supervised over 40 graduate theses on fission and fusion reactor engineering. He has been a consultant to industry and several national laboretories on aspects of severe accidents in LARs. He served an many Department of Energy (DOE) advisory conntthees, most recencly the Sentar Advisory Committee on Environmental, Safety and Economic Aspects of Magnetic Fuston Energy. He is a member and past chairman of the Nuclear Heat Transfer Comolttee of the AIChE and a current nember of the executive combittee of the thermal-hydraulic division of the ANS .

Bal Raj Sehgal. Dr Sehgal ts a senior scientific advisor in the Nuclear Power Division at EPRT. He has a Ph.D. degree fron the University of California at Berkeley. Before joining EPRI in 1974, he worked at BNL and ANL on problems in reactor physlcs, LWR analysis, fast reactor engineering. and safecy. He served as a visiting professor at Purdue University (1973 to 1974). MIT (1980 to 19B1), and Universfty of Calffornla, Berkeley (1982 to 1983). At EPRI, the has managed programs in advanced reactors, code development and validation and is currently directing and performing research in the degraded core and source term aress. Dr. Sehgal is a Fellow of the ANS and is the executive edicor of "Progress in Nuclear Energy", published by Pergaton Press. 


\section{METHODOLOSY}

\subsection{Introduction}

This section contains a sumary of the aethodology used to elicit expert judgenent frop the expert panels. An in-depth discussion of the methodology is contained in Volune 1 of NUREG/CR-4551.

The methodology used in the expert Judgment process for NUREG-1150 was designed to obtain subjective estimates of unknown physical quantities and frequencies in a manner that best uses the available expertise and accurately reflects the collect.. ve uncerteinty about these values. Several principles guided the developant of the sethods:

1. The assesanents should be limfted to lssues where alternative sources of inforuation such as experimentel or observational data. or validated computer models are not avallable.

2. The lssues analyzed using expert judgment should have the potential to nake a significant impact on the estimates of risk and uncertainty in risk.

3. The decomposition of complex issues into simpler assessments is made in order to improve the quality of the resulting infornation.

4. Issues should be presented to the experts without ambigulty and without the potential for preconditioning or bissing responses.

5. Experts should be trained in the practice of expressing knowledge and beliefs as probabllity distributions.

6. Discussion of issues and alternative bellefs should take place in structured and controlled meetings that encourage the exploration of alternative beliefs while inhibiting pressure to conform.

7. Elicitation of expert optaion should be conducted usirg techniques and instruments that reflect the state of the art in subjective probability assessment.

8. The aggregation of Judgments frow various experts should preserve the uncertainty that exists among alternative points of view. Equal weight should be assigned to the asseasment for each expert to represent the uncertainty completely.

NUREC-1250 does not attempt to reduce uncertainty in risk analysis, nor is It an attempt to find a best estinate. This study is an attempt to produce an unbiased picture of uncertainty in risk. The study tries to discover the range in risk inherent in the range of plausible assumptions about phenomenology and initial and boundary conditions. The risk corresponding to the most (subjectively) plausible assimptions has a higher likelihood of beling accepted by a randomly chosen expert in accldent phenomena. The risk 
corresponding to less plausible asumptons nevertheless has sowe likelihood of being accepted by any expert, and may indeed be the nost acceptable for sone experts, Experts are sowetimes vrong, and the "true" risk could lie outside the ranges found in this study.

\subsection{Steph to Ellat Fxpert Judgment}

The principles identifled above. the criticlem of the draft RUREC-1150 expert judgment efforts, and the findings of precursor studies employing expert Judgment ${ }^{2}$ provided guidence $f$ or the deaign of the MUREG-1150 expert judgment elicitation process. The process evolved into ten steps:

1. Selection of issues:

2. Selection of experts;

3. Ellcttation training:

4. Presentation and review of issues;

5. Preparation of expert analyseg by panel meabers;

6. Discussion of analyses;

7. Elicitation;

8. Reconposition and aggregation;

9. Review by the panel of experts:

10. Documentation.

The methodology was implemented in a three-weeting format, with much addl. tionsl work being acconplished between meetings. Steps 1 and 2 were accovplished before the first meeting of the expert panel. Step 3, ellcitation craining. took place in the first meeting which lasted one-half day. The presentation and review of issues, Step 4, was done during the second weeting which, in order to redtce travel costs, took place fumediately after the first aeeting. Step 5 was accomplisted betwen the sacond and third meetings (fn some cases the expert panels met for additional discussions during this tiae). Discussion and elicitation, Steps 6 and 7 , were discussed in the third meeting. which usually took place chree months after the first and second metings (the accident sequence frequency group and the structural response group two nonths after the first two aetings). The final steps, 8,9 , and 10, were accomplished after the third meating.

\subsection{Selection of Issues}

The NUREG-1150 program attenpts to show the range and distribution of risk due to uncertalnty in the inputs. Some of that uncertsinty is phenomenological, some is stochastic, and some is due to limited background of dats. There are an enormous number of input points, and all are uncertain to some extent. It was thus inpossfble to treat all questions and issues with the sane degree of thoroughness. The critecta used to select issues for detalled uncertalnty analysis were:

- Hilh impact on risk. If an issue was highly uncertain. but variation across les entire range vould not cause big change in r1sk, there wotsd be little need for a detalled treatment. The likely limpact on risk was deterwined by the outcome seen in the draft version of NUREC-1150, by smaller scale side calculations, by the opinions of the expert panels, and by examination of prevlous PRAS. 
- Interest whin the renctor gafecy conmulcy. Some issues were thought not to be major deterninants of uncertalnty in risk, but had nevertheles: been the aubject of intentse investigation and debate. The reason for Including these issuts in the analysis was to confirm th1s opinton.

- To 1.prove on the treatente in Praft N1JEG-1150, Sone issues had not appeared to be iaportant in the draft vorsion; howevor, it was recognized that the creatont there wes less than optioun. Such 1ssues were included to deteraine whether an inproved treatment would change those insights.

- The 1sgue tre uncertain. Even if an 1ssue is important for the aganitude of risk, If the outcoue 18 certain there is no impact on the uncertainty in risk.

Issues meting any of these criterla vere listed by the NUREG-1150 staff. The prelininary list of 1ssues was presented to panel of experts, along with reasons for their inclusion. A list of other issues was also presented, along with reasons for their exclusion. The expert panel was asked to review the list of 1ssues, and to add or delete 1ssues. The expert panels were the same ones that would be asked for quantification of the uncertain issues. An understanding of the linited time and resources available generally militated agalnst al unwarranted or overly generous expansion of the issues.

Those issues that vere selected for quantification by the external expert panels fell into thro broad elasses: uncertain Issues affecting the sequence frequency calculation, uncertain issues affecting the response of the containwent and Its systens, and uncertain issues affecting the radiological source terw. There vere more issues affecting containment than for the other classes, and there was a furthet breakdown into issues related to the in-vessel phenomenclogy, containment loads, structural response, and wolten core-concrete interactions. Tables 3-1 through 3-5 show the issues presented to the containment and radiological source term expert panels, along with the reasons for fncluding the issue. 
Table 3-1

Isoues Presented to the In-Vessel Panel

Is5us: No.

1

2

3

4

s

6
Tithe

Tenperature-1nduced PWR hot leg fallute

Temperature-induced PWR SGTR

In-vessel hydrogen production in BtRs

Tepperature-1nduced botton head fallure In BWRs

In-vessel hydrogen production In PWRs

Temperature-induced batton head fallures In PWRs
Reason for Inclustion

Large hot leg fallure could preclude direct contsinent heating: depressurizes RCS and precludes stean generator tube rupture ( $\mathrm{SCTR}$ )

SGTR gives direct path to onvironment, with large release of radionuclides

Hydrogen burning has potential for causing release to environment

Node of botton head fallure deteraines subsequent accident progression

Hydrogen burning has potential for causing release to environent

Mode of botton head fatiure deternines subsequent accident. progression 
Table 3.2

Issues Presented to the Contafnment Loads Panel

\begin{tabular}{|c|c|c|}
\hline Issura No. & Title & Reason for Inclusion \\
\hline 1 & $\begin{array}{l}\text { Hydrogen phenonena at } \\
\text { Grand Gulf }\end{array}$ & $\begin{array}{l}\text { Early fallure of drywell or } \\
\text { wetwell has potential for } \\
\text { causing large source term }\end{array}$ \\
\hline 2 & $\begin{array}{l}\text { Hydrogen burn at } \\
\text { vessel breach } \\
\text { at sequoyah }\end{array}$ & $\begin{array}{l}\text { Early failure of contalmont } \\
\text { or bypass of lce condenser has } \\
\text { potential for causing large source } \\
\text { term }\end{array}$ \\
\hline 3 & $\begin{array}{l}\text { But reactor building } \\
\text { fatlute due to } \\
\text { hydrogen burns }\end{array}$ & $\begin{array}{l}\text { Bypass of reactor building has } \\
\text { potential for Increasing source } \\
\text { terms }\end{array}$ \\
\hline 4 & $\begin{array}{l}\text { Loads at vessel breach } \\
\text { at Grand Gulf }\end{array}$ & $\begin{array}{l}\text { Yallure of contalnaent at vessel } \\
\text { breach has potential for causing } \\
\text { large source terms }\end{array}$ \\
\hline 5 & $\begin{array}{l}\text { Loads at vessel breach } \\
\text { at Sequoyah }\end{array}$ & Sane as Issue 4 \\
\hline 6 & $\begin{array}{l}\text { Loads at vessel breach } \\
\text { at Surry. }\end{array}$ & Same as Issue 4 \\
\hline 7 & $\begin{array}{l}\text { Loads at vessel breach } \\
\text { at } 2 \text { ion }\end{array}$ & Saseg as Issue 4 \\
\hline
\end{tabular}

Table $3 \cdot 3$

Issues Presented to the Molten Core-Containment Interaction Panel

\begin{tabular}{cc} 
Issue No & \multicolumn{1}{c}{ Tifle } \\
\cline { 2 - 3 } 2 & $\begin{array}{c}\text { Mark I drywoll melt- } \\
\text { through at Peach Botton }\end{array}$ \\
2 & $\begin{array}{c}\text { Mark I containnent } \\
\text { failure via pedestal } \\
\text { fallure at Grand Gulf }\end{array}$
\end{tabular}

Besson for_Inclustion.

Drywell weltthrough bypasses suppression pool; controversial Issue

Pedestal fallure could lead to early contairment failure; controversial issue 
Tabie 3.4

Issues Presented to the Structural Response Panel

\begin{tabular}{|c|c|c|}
\hline Igsue No. & Title & Besagn for Incluaton \\
\hline 1 & $\begin{array}{l}\text { Statfc fallure pressure } \\
\text { and mode at zion }\end{array}$ & $\begin{array}{l}\text { Containment fallure is the } \\
\text { nost inportant determinant } \\
\text { of source terms }\end{array}$ \\
\hline 2 & $\begin{array}{l}\text { Static fallure pressure } \\
\text { and mode at Surry }\end{array}$ & Sane as Issue 1 \\
\hline 3 & $\begin{array}{l}\text { Static faflure pressure } \\
\text { and wode at Peach } \\
\text { Botton }\end{array}$ & Same as Issue 1 \\
\hline 4 & $\begin{array}{l}\text { Reactor Building bypass } \\
\text { at Peach Bottom }\end{array}$ & $\begin{array}{l}\text { Bypass of Reactor Bullding } \\
\text { has potential for allowing } \\
\text { large release of radiomuclides }\end{array}$ \\
\hline 5 & $\begin{array}{l}\text { static fallure pressure } \\
\text { and mode at Sequoyah }\end{array}$ & Sarre as Issue 1 \\
\hline 6 & $\begin{array}{l}\text { Ice condenser fatlure } \\
\text { due to detonations } \\
\text { at Sequoyah }\end{array}$ & $\begin{array}{l}\text { Failure or bypass of ice condenser } \\
\text { has potential for large soutce } \\
\text { terms }\end{array}$ \\
\hline 7 & $\begin{array}{l}\text { Drywell and wetwell } \\
\text { fallure dise to } \\
\text { detonations at Grand } \\
\text { Gulf }\end{array}$ & $\begin{array}{l}\text { Fallure of dryweil bypasses } \\
\text { suppression pool. Fallure of wet- } \\
\text { well allows large release to } \\
\text { environment }\end{array}$ \\
\hline 8 & $\begin{array}{l}\text { Pedestal fallure due to } \\
\text { eroston at Grand Gulf }\end{array}$ & $\begin{array}{l}\text { Pedestal faflure is a major factor } \\
\text { in subsequent accident progression }\end{array}$ \\
\hline
\end{tabular}


Table 3-5

Issues Presented to the Source Term Panel

\begin{tabular}{|c|c|c|}
\hline Isfue No. & $T+1+1 \mathrm{e}$ & Reason for Inclusion \\
\hline 1 & $\begin{array}{l}\text { In-vessel fission product } \\
\text { release and retention }\end{array}$ & $\begin{array}{l}\text { Release and retention are major } \\
\text { determinants of source term }\end{array}$ \\
\hline 2 & $\begin{array}{l}\text { Ice condenser decon. } \\
\text { tanination factor (DF) } \\
\text { at Sequoyah }\end{array}$ & $\begin{array}{l}\text { Ice condenser is principal } \\
\text { decontamination aechanisn in } \\
\text { blackouts }\end{array}$ \\
\hline 3 & $\begin{array}{l}\text { Revolatilization from } \\
\text { RCS/RPV }\end{array}$ & $\begin{array}{l}\text { Revolatilization could negate } \\
\text { effects of high retention; highly } \\
\text { uncertain issue }\end{array}$ \\
\hline 4 & CCI release & $\begin{array}{l}\text { If in-vessel release is low, CCI } \\
\text { release could be high: uncertain } \\
\text { issue }\end{array}$ \\
\hline 5 & $\begin{array}{l}\text { Release of RCS and CCI } \\
\text { species from contain- } \\
\text { ment }\end{array}$ & $\begin{array}{l}\text { Aerosol aggloweration may be major } \\
\text { source of cleanup in blackout: } \\
\text { highly uncertain issua }\end{array}$ \\
\hline 6 & $\begin{array}{l}\text { Late sources of lodive } \\
\text { at Grand Gulf }\end{array}$ & $\begin{array}{l}\text { Appeared as 1mportant 1ssue in Draft } \\
\text { NUREG-1150 }\end{array}$ \\
\hline 7 & $\begin{array}{l}\text { Reactor Bullding DF at } \\
\text { Peach Bottom }\end{array}$ & $\begin{array}{l}\text { Natural decontanination processes } \\
\text { could reduce source term; uncertain } \\
\text { and controversial issue }\end{array}$ \\
\hline 8 & $\begin{array}{l}\text { Relesse during direct: } \\
\text { containment heating }\end{array}$ & $\begin{array}{l}\text { Uncertain and controversial issue; } \\
\text { direct heating is also assoctaced } \\
\text { with early containment faflure }\end{array}$ \\
\hline
\end{tabular}




\subsection{Selection of Experts}

Experts were chosen to ensure a balance of viewpolnts. To this end, experts from industry groups, engineering and consulting firms, the Federal Government, and the national laboratories were included in the panel. A brief sumnary of their credentials has been presented in Section 2 .

\subsection{Flugitation Training}

Training in probablifty assessment techniques is an integral part of the expert opfnion nethodology used in NUREG-1150. Each pasel of experts that participated in the expert opinton process attended a half-day trainfing session. This session constituted the first meeting of each panel. The training was given by consultants from the field of probability assessment and decision analysis. The trainer for both the Containnent Loads and Molten Core/Containnent Interaction Expert Panels was Professor Detlof von Winterfeldt of the University of Southern Californts.

The purpose of tralning in probability assessment is to facilitate the elicitation process. Experts in various flelds of science are often not trained in probability theory and the techniques of probabilicy elicitation. The expertise posses,ad by che sclentists and engineers in the panels is called substantive expertse. Expertise about probability elicitation is called nornative expertise and the participants in the expert opfnion process schaoled in probability assessment are known as normative experts. Both substantive expertise (knowledge of the probles domain being studied) and normative expertise (knouledge of techniques for encoding bollefs into probability distributions) are required for a successful expert opinion process.

During probability tralning. experts are exposed to varlous techniques for probablifty ellcitation and the difficulties that accompany probability elicitation. Once trained, experts are better able to express their knowledge in the form of probabilities and the resulting elicitations will be of a better quality. The resulting assessments are better callbrated in the sense that they accurately reflect the expert's knowledge and uncertainty. A by-product of the training is that the experts become nore comfortable th the concept of subjective probability and nore confident in expressing theit bellefs in probability distributions.

Another benefit of training is that the time spent by the experts preparing for the lssues 15 used more effectively because the experts can direct their analyses to the questlatis that must be addressed in the elfcitation sessions. Furthermore, the ellcitation sessions run smoothly since the normative and substantive experts are working with the same definitions and the same understanding of the desired product.

\section{5,1 Training Toples}

The training sessions conducted for NUREG-1150 covered several related toples. These toples included the expert opinion process itself and the need for expert opinion, the ellcttation techniques for the probabilities 
of varfous types of quantities and events or phenowena, the psychological aspects of probabllity assessments, and the decomposition of conplex Issues.

Each training eession began with an overviev of the goals of the expert opinion process and background material on the development of that process. The process was reviewed in sone detall so that the substantive experts would be aware of what would be required of them and how their elicitations wauld be used. Becouse the formalized use of expert opinion was new to many of the participants, some were Initially uneasy with the concept of expert opinion and the uses that it might be put to. Gaining the confidence of these experts through familiarization with the process whs essential to the success of the expert opinion effort.

There are many different types of assessuents that might be required of the experts. The type of assessaent depends upon the nature of the physical quanticy or phenomena under study. During the eraining sessions, the experts were introduced to assessnent instruments for continuous quantities discrete qusntities, zero-one events, and dependent ovents. At appropriate points in the training, the experts were asked to nake assessments using the methods under discussion. Using practice assessments develops confidence and ensures that the substantive experts understand the tasks that they will be required to pexform. In order to make the tratning more interesting and more relevant, examples were used that reflected nuclear power risk Issues.

Since nany of the assessnents would require the development of a probabi. lity distribution for a conclinuous quanticy, the experts were given training in both the direct agsessment techniques (assessing probabilities of given intervals of values) and bisection techriques (assessing values of the variable having given cunulative probabilities) for continuous vari. ables. Lster, in the elicitation sessions, these technlques would be used interchangeably by the nornotive experts.

A discussion of stochastic and parametric uncertainties and how they are differentiated in an uncertalnty analysis was alao provided. The concept of callbration of experts and callbration functions was also introduced. However, mothematical callbration of experts was not attempted in the NJREG-1150 expert opinion process.

Psychological aspects of probability ellcitation recelved much attention in the training because failure to recognize and deal with psychological blases can Impalt the quality of the resulting assessnents. One of the psychological aspects discussed is the tendency to give subjective probability distributions that are too narrow and chus understate the weertalncy or, conversely, overstate knowledge. This phenosena is often called "overconfidence" since the effect is that expressed probability distribution expresses greater certainty chan is warranted. Other psychological sopects of subjective probability assessment that wete discussed include: anchoring, which is the cendency to assume an intetal position and fall to give suffictent credit to other sources of information; represencativeness, which is the tendency to give too much credit to other aftuations that are simflar in some aspects but not 
others; the tendency to overestinate the probabilities of rare events; and and probleas with group behavior such as personality dominance. Whenever possible, exumples of these difficulties vere presented and the experts being trained were asked to participate in denonstrations.

At the end of the training session the partfcipants were given an assessment training quiz containing 16 assessment tasks using the direct and bisection methods of assessment. The participants were askod to complete the trafing quiz during that eventing and return the next morning to discuss the reaulte. The purpose of the training exerclse was twofold: to give the substantive experts experience with the elicitation instrumants and to provide feedback on the quality of the individual's assessments. As expected, nost particlpants found that their assersed distributions expressed overconfidence. Once astare of this tondency, it is easler for the substantive experts to correct for this blas.

Problem decomposition was the last major segment of the training session. Problen decumposition is the process of creating a model of a complex assessment that allows the experts to make a series of gimpler assessments. The sinpler assessments are nathematically recomposed through the model. The net result is that the resulting probability distribution is a better expression of the expert's knowledge than if the expert had been asked to nake an assessment of the Enitial issue without the ald of a decompostion.

Training in deconposition was conducted by presenting examples of deconpo. sitions that had been developed for the NUREG-1150 study. Several types of decomposftions were show and the process of recombining the assessmencs vas discussed. Comments from the partlcipants indicated that the use of problews frou the nuclear safety area enhanced the value of the decouposi. tion tralning.

\subsection{Prasentation of Isgueg}

During the second part of the second meeting, plant analysta preaented the issues to the expert panel. The purposes of the presentations were to ensure that there was a comon understanding of the issue being addressed; ensure that the experts would be responding to the sabe elicitation question; permit uniaportant 1ssues to be excluded and Inportant issues to be Included; allow modification or decomposition of the lasue; and provide a forus for the discussion of alternative data sources, nodels, and forms of andysis.

Each presentation include 1 a suggested decomposition of the problen. Problen decouposition ha: been used 1 n the NUREg-1150 expert judpant process as a nechanlsa to laprove the quality of the subjective assessments, Problen decomposition improves the quality of assessments by structuring the analyg's so that the expert 18 required to aoke a gerles of simpler assessuents rather than one complex assessnent. Experimental 8 tudies3. have shown that deconposition often Improves the accuracy of assesaments. Improvement occurs because the experts are responding to questions that are lesa difficult to answer. The experts must state their reasoning explfitly by being more Introspective about their aseumptions of the analysig and thus consider alternatives that they wight otherwise 
1gnore. Sone Improvenent may be due to cencellation of errors which occurs when errors of underestimation are of fset by comparable errors of overestimation. Decomposition also provides a forn of self docunentetion since the expert's thought process is mede explicit in the decomposition.

Plant analysts usually presented the suggested deconpositions without the suggested probabilities or distributions to avold preconditioning or blas. ing the experts. For many of the issues, the proposed decomposition brought about lively discussions that illuminated the altecnative approaches to analyzing the 1saue. The plant analyst also presented data sources, wodels, and reports that were televant to the issue, and provided references to other sources of information. A list of references that were provided to relevant panel is presented in Appendix I.

Capturing uncertalnty in the experts" opinions requires that the various experts be permitted to follow alternative analyses. Since the process was designed to take advantage of the diversity of approaches, experts were encouraged to seek their own decompositions or to nodify decompostitions that were suggested by the analysts. Criticlsm of the deconpositions was encouraged and the experts were assisted in producing decompasitions that betcer matched their interpretations of the Issues.

\subsection{Preparation and Discussion of analyses}

Two or three nonths were allowed between the initlal presentations of the issues and the elicitation sessions. During this period, the experts studied the 1ssues. Some experts chose to alter the proposed decomposi. tions or create now decompositions and made preliminary evaluations of the subjective probabilities represented in thelr deconpositions of the issues. The elfcitation meeting provided a forum for discussion of alternative views of the issue. Presentations from both the panel members and invited observers of the neetings were encouraged. These sessions generated a substantial amount of discussion and interchange of Information which often led the experts to make revisions of their propared analyses. In som Instances, the panel members prepared documentation that amounted to brief reports. It became apparent in the elicitation sessions that this inter. change was an 1mportant source of Information for the experts.

\subsection{Elucitation}

The discusaion of each issue was followed by elfcitacion meetings between the experts and a tean composed of one normative analyst and one substan. tive analyst. Documentation of the experts' assumptions and reasoning was produced during the ellcitation meetings. Normally, each meeting conslsted of three particlpants cone panel member, a normative expert, and a substantive expert) and lasted about two hours. However, in a few cases where there were more experts to be elicited than available normative experts, two experts were elicited 1n a single session.

The elfcitation sessions served several purposes. The first was to obtain from the experts the deconposition and assessments of the problems. The expert3 were required to explain their thinking to the assessaent tean of one noruative and one substantive expart. Durfing the discussion of the 
elfcltation process, the expert being ollctted was questioned about stated belfefs and asked to reflect on, and explain the reasoning behind, the values that he or she had provided. In many cases, the resulting decompositions and probabllity distributions differed soaewhat from the initial assessments.

The role of the noradive experts was to assist the expert in codifying the experts' beliefs and to ensure that the assessment vas complete and consistent in a probebilistic sense so that the assessmente could be reconposed at a later tiue. Normative experts have the sbility to draw from the experts the important detalls being elfctted. Their talent for becoming involved in the technical aspects of issues, which are not their baslc area of expertise, is a cruclal factor in facilitating the experts' abilities to develop logically consistent assessuents. Such individuals are necessary in any expert judgment elfctration process.

The role of the substantive analyst vas to assist the expert by answering questions related to the issue and to ensure that technical reasoning was complete and to the point. He also served as a technical advisor to the norwative expert to assist bin in questioning the expert in a direction consistent with the technical needs and constraints of the plant analysis teans.

Much of the documentation of the experts assumptions and reasoning was completad during the assessment deetings. However, some Eollow-up work was necessary after the elfcitation sessions to fill in voids in the logic provided by the experts, or to obtein values that were incomplete.

Docunentation of the elicitations is provided in Section 5 of this report. Note that whlle the experts participating for aach issue are identified, the Individual assessnents are kept anonyoous, and the experts are identifled as Experts A, B, C, etc.

\subsection{Becomposition and Aggrepation of Besultit}

Each menber of the expert panels produced a distribution for each case of each issue. For sone issues, several dependent varlables were requested, and a separate distribution was ellcited for each vartable. If all the experts had worked with ldentical case structures and if all had produced thetr results in the same form, the task of aggregation would have been simply matter of taking the numertical overage of all the distributions for each case. However, sone experts used idlosyncretic case structures, on some 1ssues, the experts expanded the case structure beyond what was tractable in the accident progression event trees or the XSOR codes. On sone 1ssues, experts gave their results in different forms.

For the purposes of aggregation it was absolutely required that the case structure be suall enough to fit into the accldent progression event tress and XSOR codes and that the case structure and degendent variables be the sane between experts. If the case structure was impractically large and complex, it was reduced if possible by an analysis of variance (ANOVNA). The ANOVA compared the variance in the dependent variable attributable to the differences between cases and the variance attributable to the 
differences among experts to the unexplained variance in the dependent variable. For many lssues it was found that the differences between cases wera not signiflcant conpared to the differences between experts, that is, that the large and complex case structure had little effect on the dependent vartable. A mathematcal procedure was then used to deteraine wh1ch of the cases could be safely combined.

If different experts used different cases, they were first encouraged to resolve their differences; if they failed to do so it was necessary to find sone common ground. The cases common to all expet is were of course retained. The renaining cases were inspected, and the most 1mportant ones were retained. If an expert did not have one of these :aneg, but did have a closely analogous case, the analog was used for the mis ing case. If the expert did not have a case closely related to the missing case, then the average of the case for all other experts vas used for his nissing case. It was recognized that this procedure would reduce the range of uncertaljty, so the substitution was used as litcle as possible. For some issues, wissing data could be filled in by interpolation or ratios of existing cases.

If the experts produced different dependent varlables, sone analysis was required to put all the outputs into the same form. Whenever this vas done the experts involved might find the final form of their data difficult to reconcile with what had been produced in the ellcitation. Therefore, analytical alteration of results vas used as little as possible, and attempts were aade to explain the reasons for and aethods of analysis to the experts.

After each of the experts* distributions vas in the same forat, they were aggregated by averaging. The experta outputs were almost always in the form of cumulative distribution functiong (CDFs), that is, curves or tables of the probability that the independent variable would be no greacer than some specific value. The aggregation was carried out by averaging all the experts probability values for ench value of the independent variable. The aggregated results were thus also CDFs.

\subsection{Reylew}

Following the reconposition of the essessments and the modification of the documentation accompanying each assessment, the written analyses of each issue vere returned to each panel expert, normativa expert, and substantive expert essocfatad with the 1ssue for review. This review process ensured that potential misunderstandings were tdentffied and resolved and that the docurentation, which is given in Section $S$ of this report, correcty reflects the fudgment of the experts involved.

\subsection{Docunentation}

Clear, corprehensive docunentation is crucial for ensuring that the expert opinion process is accepted as credible. There ust be no question as to the openness and 1mpartiality of the process. Users and reviewers of the results must be able to trace the developant of aggregated assessments from the information presented to the experts, to the rationale which 
motivates each expert to gonerato his particular assessments, and through the process of aggregating the individual assessments into 8 final result. 1ncluding any monipulation of the sssessments needed for aggregation. To chis end, the lasue discusstons vere recorded on video cassette. Such recording provides evidence of the exact conversations and presentations nade before the panel. Written noteg were taken by both the normative and substantive analysts. Each expert was encouraged to personally docunent his rationale for his elicitation indediately at the end of the session. By far the lost important docunentation 1. each expert's 1n-depth discussion of his reasoning for his assessments. The discussion should contain the technical foundation of information (experience. 1ssue presentation, existing data or analyses) from which the rationale for the assessment 18 derfved. 
1. A. Mosleh, V. M. Bier, and G. Apostolakis, "Methods for the Elicitation and Use of Expert Opinion in Riok Assessment," Pickard, Lowe \& Garrick, Inc., NUREG/CR-4962, PLG-0533, August 1987 .

2. A. Tversky and D. Kahneman, "Judgenent under Uncertainty: Heuristics and Biases," Science. 185. pp, 1124-31 (1974).

3. 3. S, Armatrong. Long-Ronge Forecasting: From Crystal Ball to Gopputer, John wiley sons, New York, 1985 .

4. J. S. Armstrong, W. B. Denniaton and M. M. Gordon, "The Use of the Decomposition Princple in Making Judgments," Organizational Behavior and Human Performance. 14, pp, 257-63, (1975). 


\section{ELICITATION MEETINGS}

The first two meetings (the elicltation tralning and the presentation and rovias of the cechnicel 1ssues) for bota the Contalnment Loads Expert Panel und the Holten Cora/Containmant Interaction (MCCI) Expert Panel were held on Decenber 15 to 17,1987 . Presentations to the Containnent Loods Panel were nade by the following people:

Nestor Ortiz, SNL

Detlof von Winterfeldt, USC

Frederick Horper, sNl.

Eric Haskin, SHL

Chris anos, SAIC

Martin Sherman, SHL

Martin Plya, FAI

Julle Gregory, SNL

Archur Payne, SkL

Susan Dingman, SNL

Mershall Berman, SNL.

Walter Huxfin, Technadyne

Willian Tarbell, SNL

Theodore Ginsberg, BNL

David Uilliams, SNL

Presentations to the MCCI Expert Panel were made by the following people:

Nestor Ortiz, SNL

Detlof von Wiaterfeldt, USC

Fredertck Harper, SNL

Ertc Haskin. SNL

Chris Amos. SAIC

Ervin Gopus, SNL

Arthur Payne, SNL

George Greene, BNL

Martin Plys, FaI

Jay VeIngardt. SAIC

Dana Powers, SNL

The elicitation meeting for the MCCI Expert Panel was held on March 1 to

3. 1988. Presentations were made by the following people:

Frederlck Harper, SNL

Ralph Keeney, USC

Kenneth Bergeron, SNL

Jay WeIngardt. SAIC

Roger Breeding, SNL

Elatne Bergeron, SNL

Davo Bradley, SNL

Mike Corradini, $U$ of $W$

George Greene. BNL

MujId Kazial. MIT

Raj Sehgal EPRI

Mike Hazzan, Salw

Arthur Payne, SNL 
The Containment Loads Expert Panel held an additional weeting between the first two meetings and the elicitation meeting. This meeting was held Independently of the NUREG-1150 project staff. The elicitation meeting for the Contalnment Loads Expert Panel was held on March $B$ to 11,1988 . Presentations vere nade by the following people:

Elaf ne Gotham, SNL Ralph Keeney, USC

Roger Breeding, SNL

Chris Amos, SAIC

Thomas Brown, SNL

Jim Mercelf, S6w

Louls Baker, ANL

Martin Shernan, SNL

Julle Gregory. SNL

Facricla Worthington, NRC

Archur Payne, SNL

Marty Plys, FAI

Alfred Torri, PLAG

Kenneth Bergeron. SNL

Kenneth Murata, SNL

Theodore Ginsberg, BNL

Walter Murfin. Technadyne

Norative experts for both Containment loads and MCCI elieltation sessions were:

Ralph Keeney, USC

Detlof von winterfeldt, USC

R1chard John, USC. 


\title{
5. COHTAINMENT LOADS ISSUES RESULTS - Part 1
}

This section presents the results of the expert panel ellcitations on Contalnment Loads 1saues. Each aubsection contains a brief description of each 1ssue, the individual expert assessments and rationale for the assessments, and the aggregated results or resolutions for each issue.

During the elicitations, many of the experts preferred to think in terms of rumber of occurrences of an event over number of trials (or in teras of the frequency of an event). Because this document presents the information recelved ftom the Containuent Loads and Molten Core/Contalnment Interaction Expert Panels and atempts to represent their thought process accurately, tnany of the parameters discussed in this document are discussed as frequencles (such as the frequency of hydrogen ignition). However, the values that vere provided by the experts vere always converted to conditional probabilities for use in the accident progression event trees.

\subsection{Contalnment Loads Issue 1 . Hydrogen, Phenomena at Grand Gulf}

\author{
Summery of Expert Panel'a Arserament of \\ Iesue 1: Hydrogen Phenomene at Grand Gulf
}

Experte consulted: Louls Baker, Argonne Hatlonal Laboratory; Janes Metcalf, stone 6 Webster: and Martin Sherman, Sandia National Laboratorfes.

\section{Issue Descriorion}

There are three parts to this issue. Gach part is presented below as a question.

Part 1. What distributions characterlze the uncertainty in the probability that hydrogen combustion occurs in the conteinnent (wetwell)?

Two cases axe considered:

1. Station blackout with loss of all de power. The aar ir pressure vessel (RPV) remains at high pressure during core damage since loss of dc power precludes depressurization.

2. Short+term stetion blackout with dic power avallable. The RPV 1s depressurized before core danage.

Part 2. What distributions characterfze the uncertalnty in the probability that hydrogen conoustion occurs tn the containnent at Grand Gulf when RPV breach occurs at high pressure?

part 3. Given that hydrogen conbustion occurs in the contalnment, what clistributions characterize: the peak staclc pressure attained in the contalnment: the maxtinue impulse loading to the drywell wall; and the - ompleteness of combustion? 
Three cases are considered:

1. Stenn partial pressure $1350 \mathrm{kPa}$, alr partial pressure is $115 \mathrm{kPa}$. and contalnaent sprays are not operating. Ignition occurs vithout recovery of power.

2. Stean partial pressure is $50 \mathrm{kPa}$, alr partial pressure is $115 \mathrm{kPa}$, and containnent sprays initiate aproximately $90 \mathrm{~s}$ after Ignition occurs (assune to resule froo ac pover recovery).

3. Steal partial pressure 1s $135 \mathrm{kPa}$, alr partial pressure is $120 \mathrm{kPa}$, and containment sprays initiate $90 \mathrm{~s}$ after an ignition source is introduced (assuned to result from ac power recovery).

For all parts of this issue, other cases are possible. The review panels were given only those cases that were assessed to have the greatest risk significance based on the experience of the analyst.

\section{Summary of Experts: Rationale}

\section{Fart 1}

Bxpert A felt that the uncertainty associated with this issue is dominated by the uncertainty in ignition. For ignition to occur, the hydrogen in the containment must be in the flomable range and a spark must occur. If ignition sources are present, the frequency of ignition depends on the hydrogen concentration and the amount of time spent at given hydrogen concentration. However, for each case the Expert felt that there was sone probability that there are no ignition sources. The Expert expressed the ignition frequency in teras of a "half-1ife" defined as the amount of time until the frequency of Ignition equals 0.5 . The "half-lives were considered functions of hydrogen concentration. The primary difference between Cages 1 and 2 is the manner in which the hydrogen is released from the vessel into the contaiment. The ignition frequency 15 greater in Case 1 than in case 2. There are two reasons for this difference. First, In Case 1 local "pockets" of hydrogen concentration can form above the suppression pool and can have a hydrogen concentration higher than the rest of the contalnent atmosphere. Second, the likellhood of generating a statle spark is greater for Case 1 than for Case 2 because of the high SRV tallpipe discharge gas velocities assoclated with the former.

Pert 2

The Expert felt the probability of igntion at vessel breach depended on the likelthood that hot debris or hot gases from the drywell enter the containgent. The Expert Indicated that if hot debrls (> 500 $\mathrm{C}$ ) enters the contalnaent, and the hydrogen concentration is in the flammable range (>5t $\mathrm{H}_{2}$ ). the hydrogen $\mathbf{1 1 1}$ 1gnite. The Expert felt that if the hydrogen $\mathrm{t}_{1}$ the drywell at vessel breach (or that whlch is released from the RPV at vessel breach) ignites, the gases and debris In the drywell will be hot enough to ignite a combustible atmosphere. However, cooling of the hot gases and tebris in the suppression pool will reduce the probability of igition. 


\section{Port 3}

For statlc loads, Expert A based his essessnent on the adiabatic 1sochorfe couplete conbustion (AICC) moda1. The resulting peak pressure rise was then nodified to account for burn completeness, pressure relaxation fron vent clearing, and heat transfer to structures. Burn coppleteness was constdered a function of hydregen concentration and contalnment atmosphere turbulence. (If the contaireent sprays vero operating. the atoosphere would be turbuient.) It was felt that inconplete conbustion would occur at contalneent hydrogen concentrations below 12\%. For burn completeness, the Expert used eupirical correlations teveloped by Wong. ${ }^{-1}$ The Expert indicated that should the gas expand into the drywall, due to deflagrations in the wetwell causing the suppression pool surfacs to lower, the peak deflagration presoure would be resiuced by approxibately 10k. Referencling Cunmings, ${ }^{A-2}$ the Expart felt that the reduction In pressur 3 due to the heat transfer to structures would be on the order of 10h. Conbining all this, the peak overpressure was expected to be on the order of 208 lower than that predicted by the AICC model.

For Case 3, the Expert cites fiammabilicy lait studies which show incomplete burning in reglons just inside the ftamebility limits. He concluded that if the Inert alxture ts slowly brought into the flamable range, it must crosa a region of weakly fiamable nixtures where deflagrations will have low pressurg riseg because of Incomplete combustion. The Expert believed overpressures for this case wauld be negligible.

The Expert felt that the likellhood that detonation will occur in a region, given that Ignition has accurted, depends on the geometry of the region and the hydrogen concentration at ignition. The methodology of Sherman and Berman, ${ }^{-3}$ were che hydrogen-air-steam mixture and the contalnnent geometry are classified on a scale, Was used to determine the likelihood of detonation. It was felt that detonations in the dome ares are highly unlikely, and only detonations in the annulus region were considered.

For Case 3, the scenario assumes that an initially steam inert hydrogen. air-stead environment is slovly brought inte a flammoble range by the condensation of stean caused by sprays. The cooling of the contairuent atmosphere is stow and Ignition sources are present. The Fixpert referenced the work of Shernan and slezak ${ }^{-4}$ that shows that for hydrogen-air-steam mixcures in large geometries the detonation linits lie inside the flamabilfey liafts. A region of "weakly tlamable nixtures" is deflued through which any inercly aixture aust pass before reaching the "strongly flammable and possibly detonable region." Thus, the Expert believes the probability of detonation is zoro.

Given that a detonation occurs, the Expert felt that reverberations cauld increase the maximu impulse from the first fmpulse. He indlicated that it was most likely that the iapulse on the drywell wouid be tuice that of the first iapulse. 
Part 1

Expart $\mathrm{B}$ bised his uncertainty distributions on his experience with hydrogen combustion phenomena. He noted that experimentel results suggest that ignition probabilities increase as the molar concentration of hydrogen increases. The Expert felt that because the ateam nole fraction Ls large, there is a low probability of lgnition fron randon dfscharges of static electricity. He also accepted the belief of the NUREG-1150 analysts that the pregence of de power in case 2 did not constitute a clear ignition source. The ather difference in contalmment volune conditions between Caseg 1 and 2 is that for Case 1 the hydrogen release occurs through a single SRV, while for Case 2 it occurs through all autonatic depressuri. zation system (ADS) valves and 1a far more diatributed, Expert B etated that the hydrogen would wix well with the containnent atmosphere and no distinction is made between Caseg 1 and 2 for th1s part of the 1 ssue.

When the Expert had selected a best-estinate ignition probability for each selected hydrogen concentration, a beta distribution vas selected which approxinately represented his judgeent as to the uncertainty in that assessuent.

\section{laxt 2}

Expert B besed his eseesewent on an assued likslthood for hot gas from the drywell to enter the contalnaent at vessel breach. He believed that the level tn the suppression pool would be severely depressed before vessel breach. Given the ahort distance between the level of the suppression pool and the top row of vents, the Expert felt that 1t 1a 1ikely that hot gas could flow froe the dryvell into the vetwell without equilibrating with the pool water. He felt that it is unlikely that hot debris could pass Into the wetwell; however, the hat gas wight be gufficient for an 1gnition, Given that stean exiting the vessel could be heated by efected debris noar the top of the welr wall, the resulting lacal temperetures could be sufficiently high to result in ignition. Since some cooling by the pool would occur, ignition ie lese than certein.

The Expert felt thet the ignition probsbility and the uncertainty in the ignition probability increase with increasing hydrogen concentration. The principal uncercalnty stems frod whether an ignition source is present or not. The same procedure for assessment was used as in Part 1.

Part 3

Expert a based hls assessment on the adlabatic pressure resulting fron conbustion of given aolar concentration of hydrogen. This maximus pressure was nodified based on his judgment about the likely completeness of the burn. Detonation was asessed to be ispogsible below a hydrogen mole fraction of 169 .

The Experc based his assessment of burn completeness on: (a) researeh results that compere peaks obtained during combustion experinents at vacious burn fectlitier with the corresponding AICC pressurex; 
discusstons with other panel mobers; and (c) his knowledge of hydrogen phenomena. Ageln, a beta distribution uas chosen to reflect Expert B's judgment about the uncertainty in burn completeness. The completeness of burn vas thought to Increase with fncreasing hydrogen concentration.

Expert $B$ believed that Ceses 1 and 2 for this part would behave Identically, as the sprays are Initlated too late In Case 2 to lmpact the peak pressure attained. For Gase 3 , he felt that the pressure attained would be reduced because the burn was slower, but the burn completeness would renaln the save as for the low-stean Cases 1 and 2 for a given hydrogen concentration.

Expert B based his ogsessuent of dynallo loads largely on the work presented by Expert A. Following that Expert, he stated that a detonation would produce a load that was independent of the hydrogen concentration at which Ignition occurred. He felt that there was little uncertainty in the load induced. Hovever, the probability of a detonation occurring was seen to be strongly dependent on the presence of a minimun hydrogen concentration.

Rxpart_f analyzed the problex by subdividing the three initial cases into three subceses each on the basis of percent of cladding and percent of channel boxes rencting. For relense before vessel failure, he constructed a CDF for average concentration based on the results of conpu'er code runs for each of the cases. A CDF was then constructed for peak concentration using his Judgaent about the effects of nodalization and alxing on the realistic peak concentrations expected. Then the probability of ignition vs. peak concentration was assessed vith uncertaincy bounds. The split fraction for the reoulting combution being a diffusion tlane, a deflag. ration or a detonation $v a$, peak concentration level was asaessed. Next, the peak pressure or 1opulis vs. pak concuntration vas found.

\section{Method of Aqqregution}

\section{Assumptiont Used To Averape pistributiong}

Levels of hydrogen concentration were used to represent the continuous range of possible hydrogen concentrations. Five levels of $\mathrm{H}_{2}$ concentration were used for the asessments of Ignicion frequency. The five levels were 0 to $40 \mathrm{H}_{2}, 4$ to $\mathrm{B}, \mathrm{H}_{2}, \mathrm{G}$ to $12 \mathrm{H} \mathrm{H}_{2}, 12$ to $16, \mathrm{H}_{2}$, and greater than $16 \mathrm{~h} \mathrm{H}_{2}$. If the Expert's digtibution corresponded to a particular hydrogen concentration, the level was charecterized by the midpoint of the interval (e.8., Ge characterizes the interval from 4 to $8 \mathrm{H}_{2}$ ). For the assessment of detonation frequency for the low atean case two levels of bydrogen concencration were used, 16 to $208 \mathrm{H}_{2}$ and greater than $20 \mathrm{H} \mathrm{H}_{2}$. For the high stean case, deconation frequencles were obtained for hydroger concentrations in the follouing two intervals, 12 to $16 \times \mathrm{H}_{2}$ and 16 to $20 \mathrm{e}$ $\mathrm{H}_{2}$,

Assumptione Applied to Expert A'a Dhatributions. This Expert felt that the Erequency of 1 gnition vas a rendon ovent and could be represented by a 
"half-11fe" nodel. The cethod and assunptions used to convert the "halfl1fe" model into a cunulative digtribution function for the five hydrogen lovele are described in the individual expert elfcitation write-up for this is sue.

For the burn coupletenes the Expert gave valueg for both turbulent (sprays on) and static (sprays off) conditions in the ateosphere. The difference in burn completeness for these two sets of conditions is small and the effect it has on the overpressure ts equally sall. Therefore, the burn comploteness factorg for turbulent and state conditions were averaged together to get an overall set of burn conpleteness factors.

Assumptions Applied to Expert B's Distributions. The Expert gave distributions for ignition frequency, detonation frequency, and burn completeness at discrete hydrogen concentrations. To obtain distributions in the Interval betwoen the assessed distributions, the node and spread factor for the new distribution were obtained by linear interpolation of the values at the endpoints of the interval.

The static overpressure wac deternined by subtracting the initial pressure in the contafnuent froe the adlabatic 1sochoric complete combustion (AICC) pressure and then multiplying the result by the burn completeress.

Ascumptions Aoplifet to sxpert $C^{+} 8$ Distributions. The Expert typlcally repregented his uncertainty in a parameter by providing the value of the parameter at the 5k, 50, and 95s fractiles. It was assumed that a stralght line could be used to connect any two consecutive points. Pareseter values at the 0 and 100 t fractile level were obtained by 1 iner extrapolation of the tuo closest points $(\mathrm{e} . \mathrm{g}$. . for 0 , the values at 5 and 50 were used).

When assessing the peak pressure, which results from a diffuston burn or a deflagration, the Expert as suned an initial containment pressure. However, this pressure $1 \mathrm{~g}$ different then the inttial pressures which correspors to the various caseg for this issue. To convert the peak pressure to the correct inltial preasure, the initial prossure assumed by the Expert was subtracted fron the peak pressure. The inftal pressure, appropriate for the case under consideration, was then added to the resulting pressure d! fference.

The Expert provided the peak pressure for both a diffusion burn and a deflagration. In order to reduce the number of cases that wust be considered. the peak pressure caused by a diffusion burn was averaged with the peak pressure caused by a deflagration. The Expert assessed the likelihood of a diffusion burn and che likelihood of a deflagratior. This split fraction was used to "welght" the two peak pressure during the averaging process.

For case 1b/2b (Expert's case structure) the Expert Indicated thot a detonation could occur in the Interval from 12 to $16, H_{2}$. However, the impulse fron chls deconation is approximately l kPa-s, which is a very minor Inpulse in terms of $1 \mathrm{ts}$ threst to the integrity of the drywell or the 
contafnnent. Thus, this level was not included in the aggregation process for detonetions. Sinilarly, for case $3 b$ the Expert indicated that a detonation could occur in the interval fron Be to 12 s $H_{2}$. Again, the Impulse resulting frop a detonation in this interval will be ninor and. therefore, this level vas also not Included in the eggregations process for detonations.

For case $1 \mathrm{~b} / 2 \mathrm{~b}$, the Impulseg from detonetions were assessed for the following two levels: 169 to $20 \mathrm{H}_{2}$ and greater than $208 \mathrm{H}_{2}$. For case $3 \mathrm{~b}$ the impulses fron detonations were also assessed for two levels of hydrogen concantration. The two levels ate $12 \mathrm{~s}$ to $162 \mathrm{H}_{2}$ and 162 to $20 \mathrm{H} \mathrm{H}_{2}$. In ordax to present thase results in a format simllar to the other two experts and to reduce the number of cages that needed to be considered, the two impulse distributions assoclated with each case (coses $1 b / 2 b$ and $3 \mathrm{~b}$ ) wete averaged together. The reault is unique inpulse distribution for each case which is no longer a function of hydrogen concentration.

\section{Anrerated_Results}

The plots on the following pages show the aggregated xosults of all the experts. 

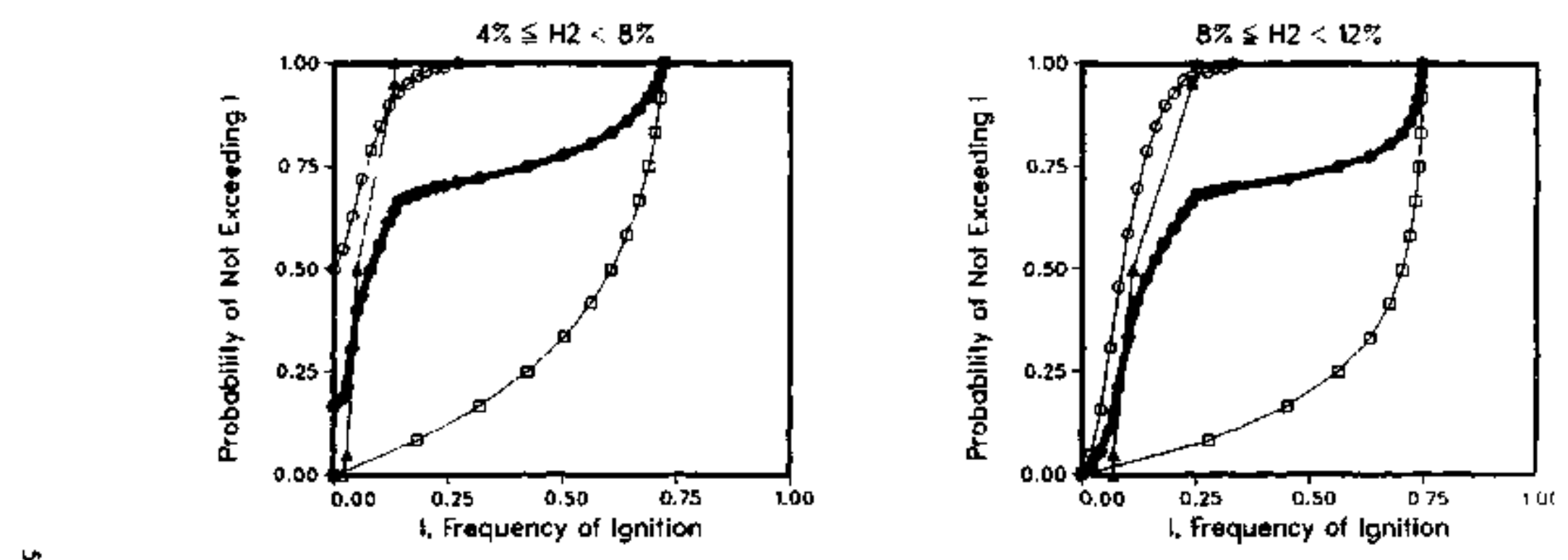

$\ddot{\infty}$
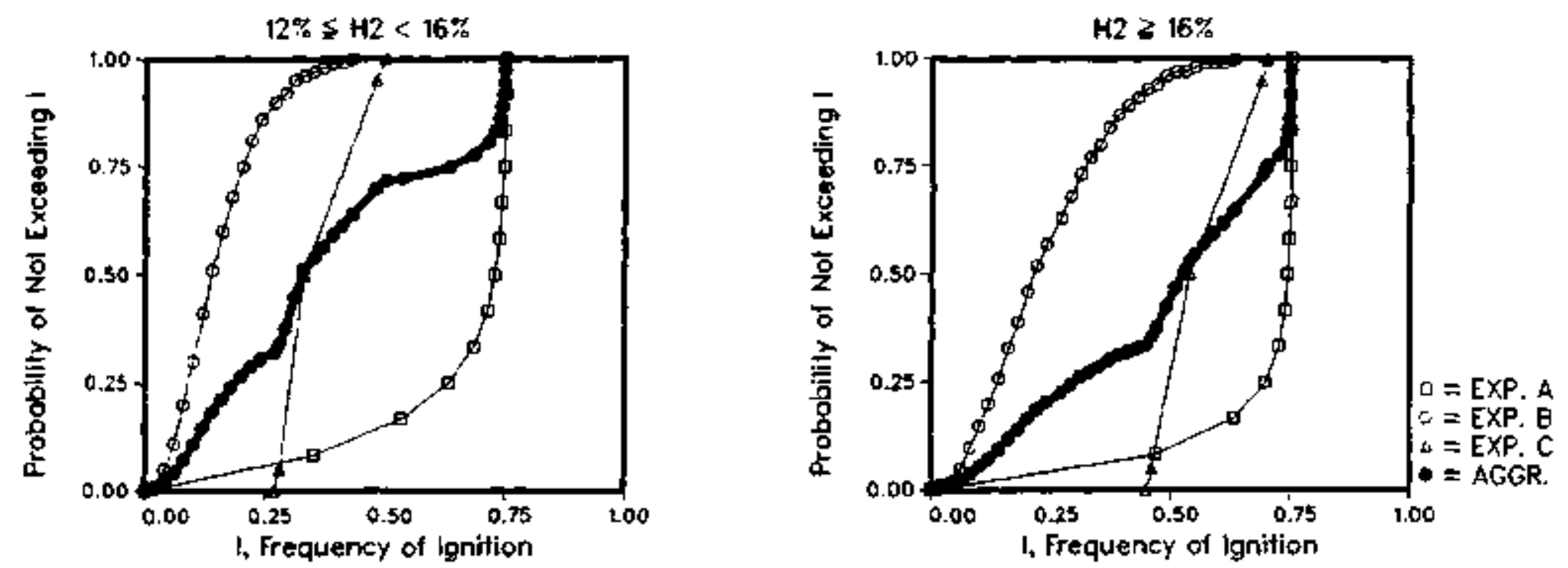

Figure 5-1. Ignition Before Vessel Breach; RPV at LOW Pressure. 


$$
\frac{B D D}{D D}
$$



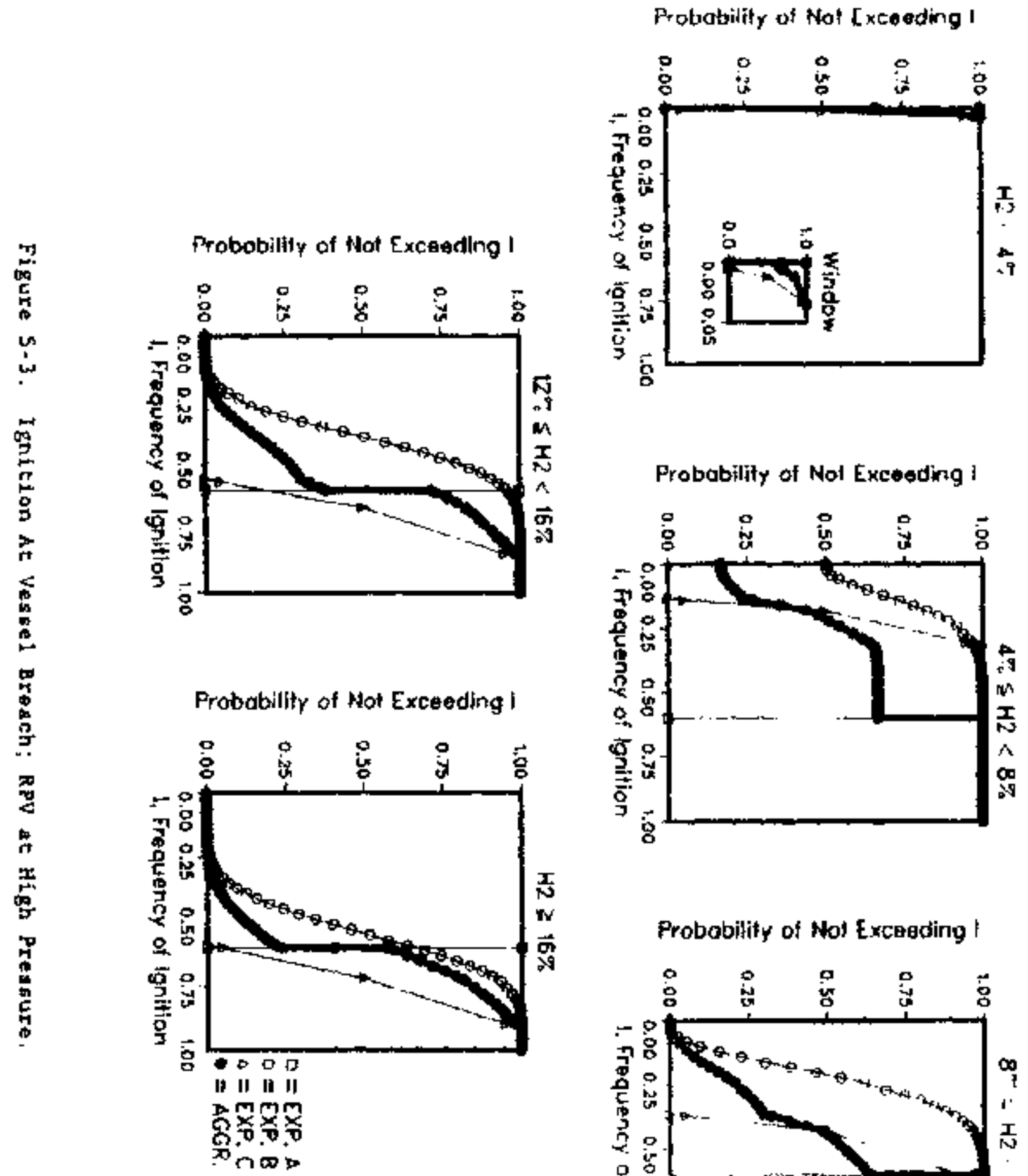

\section{Probability of Nol Excerding}

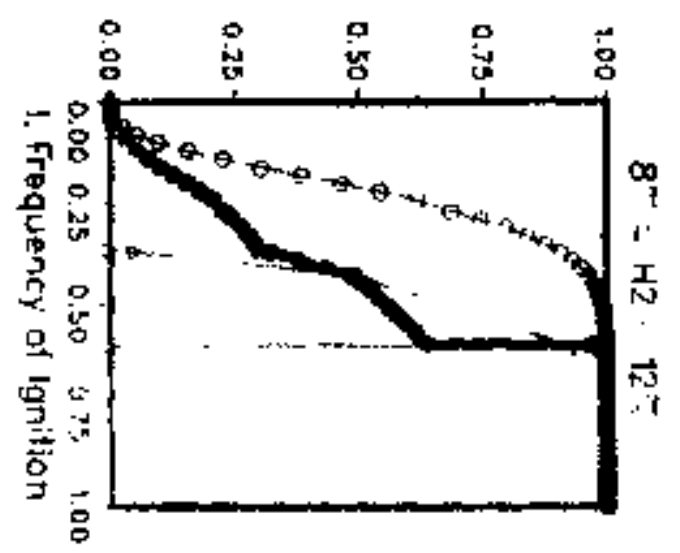



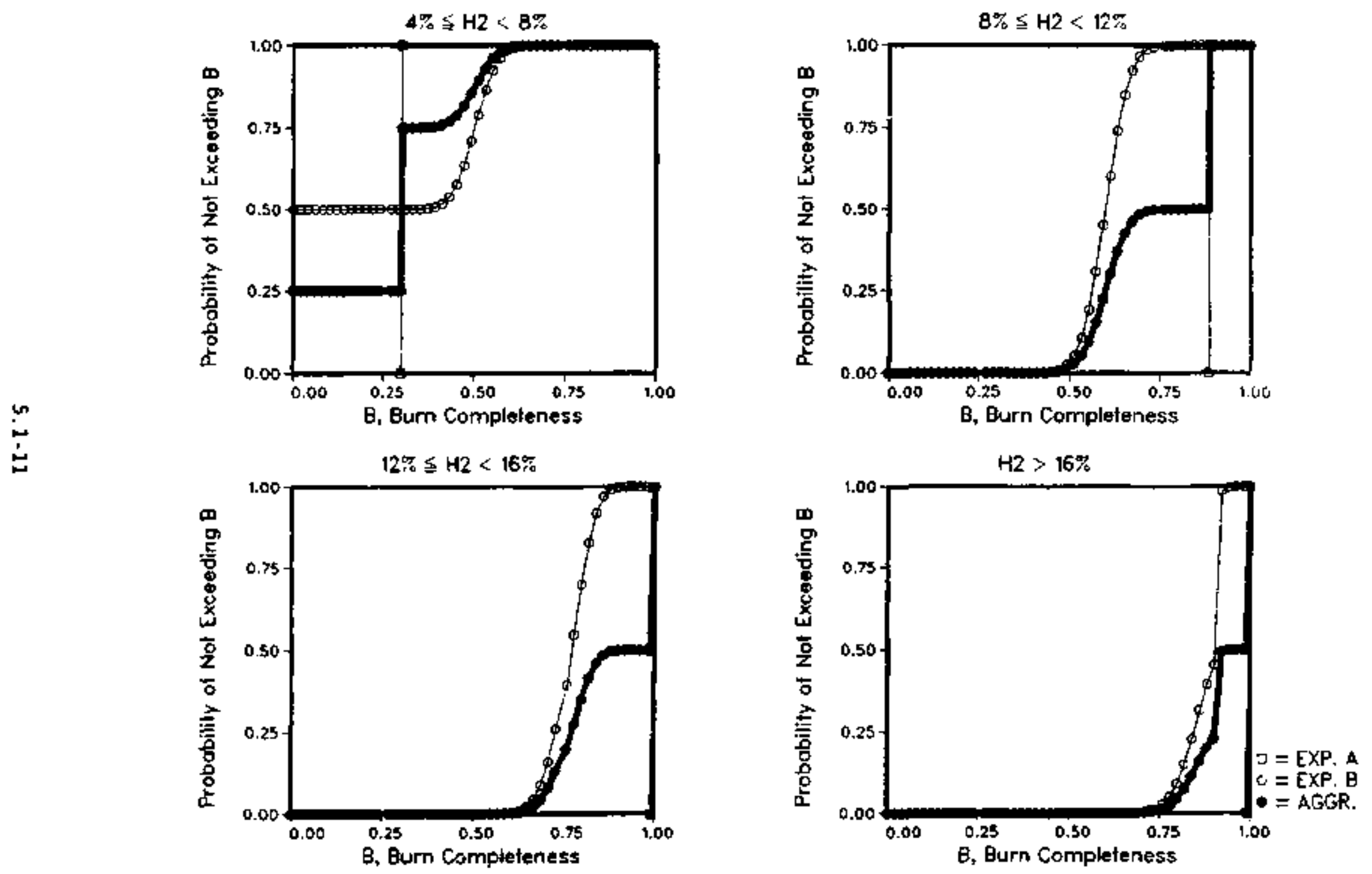

Figure 5.4. Hydrogen Burn Completeness. 

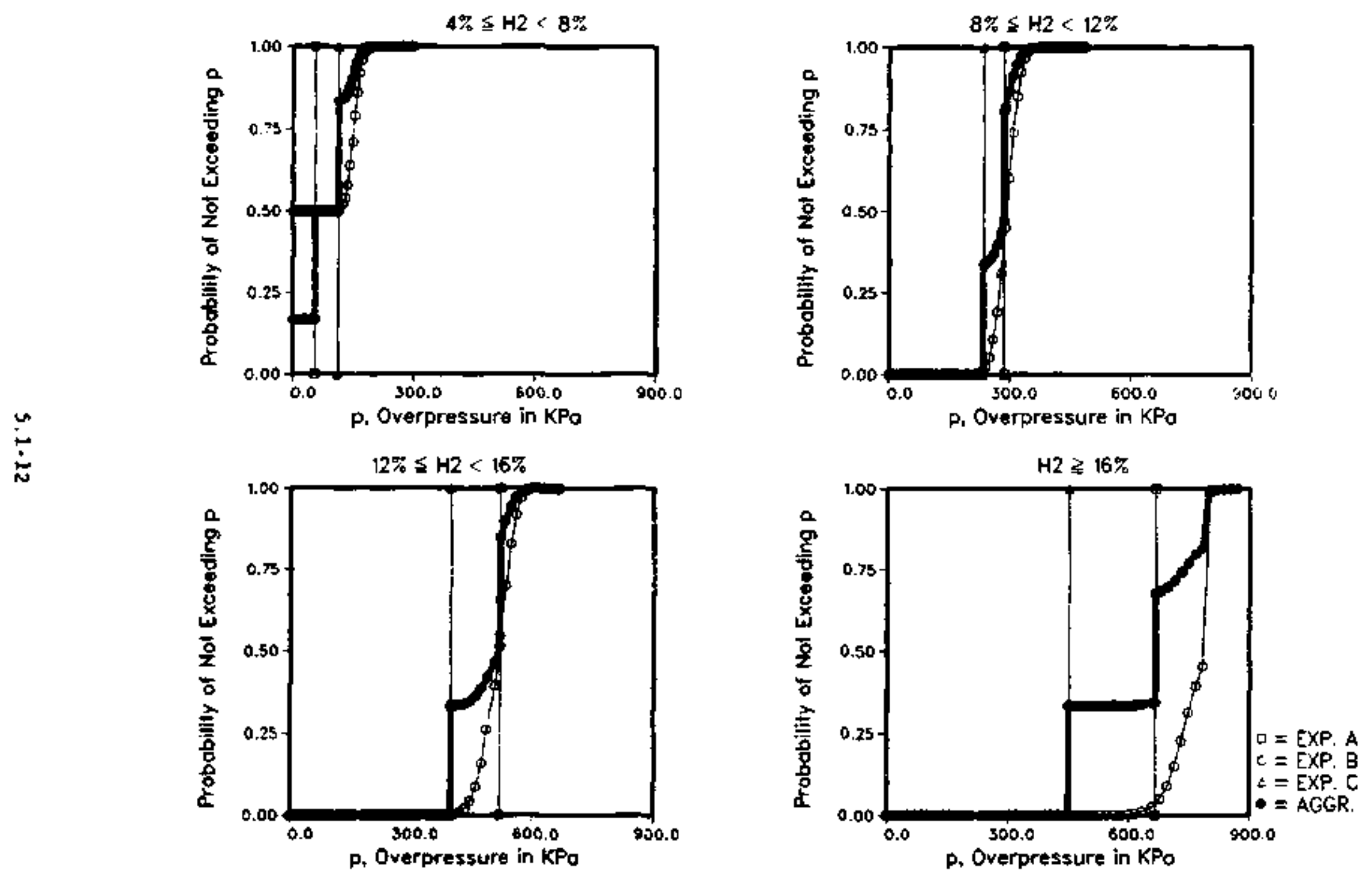

Figure 5-5. Deflagration over Pressure; Wetwel1: Low Steam. 
Probobility of Not Excending p

Probabillty of Nol Exeeading $P$

年

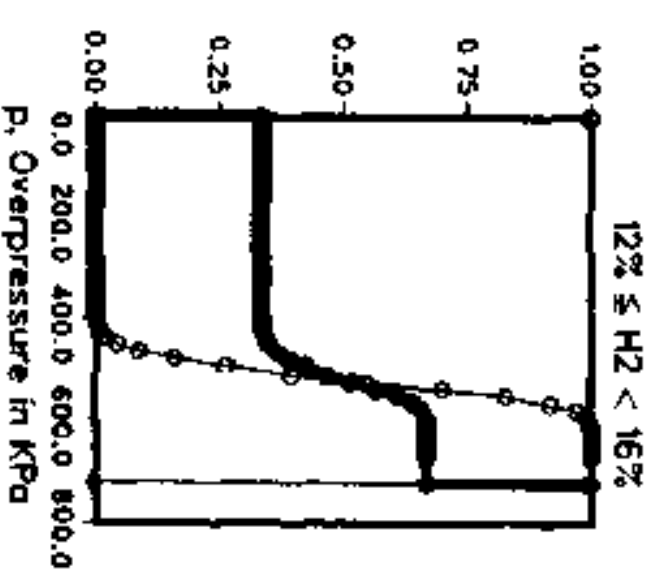

Probobility of Not Exceoding P

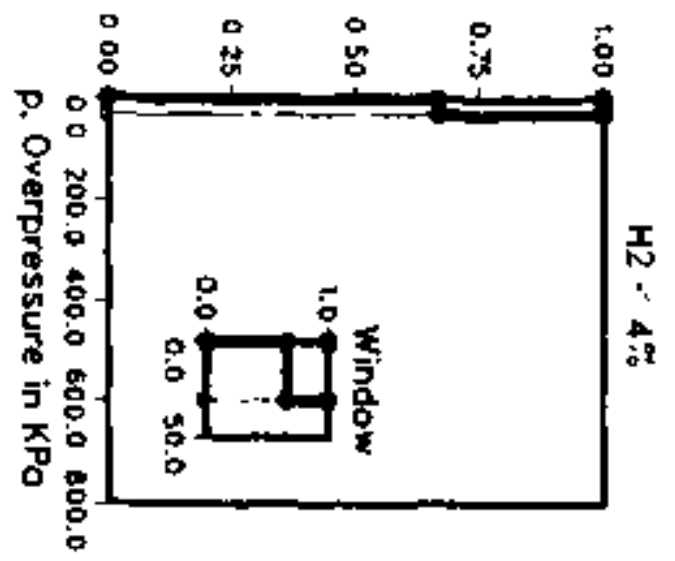

Probability of Not Exceeding P
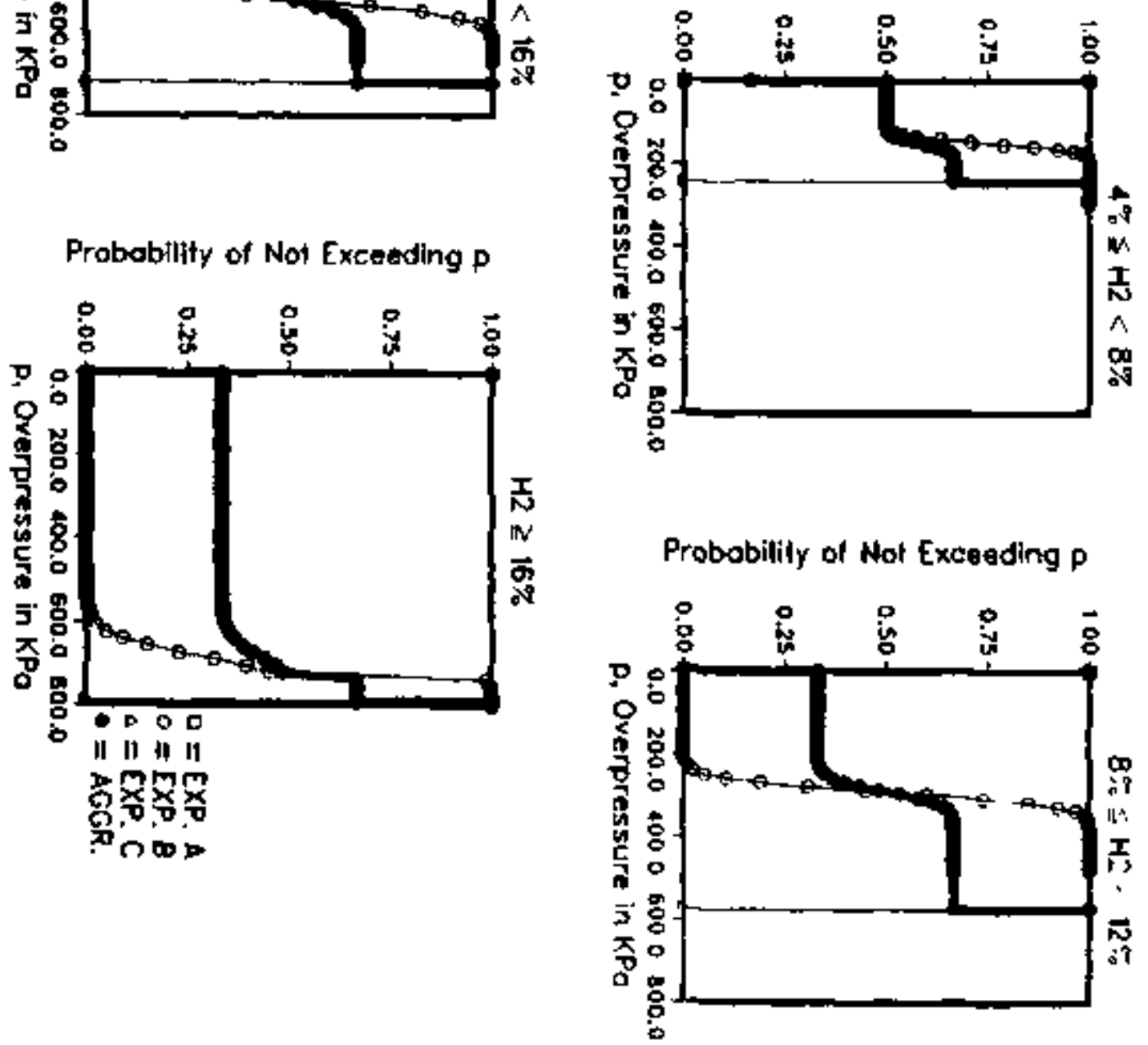

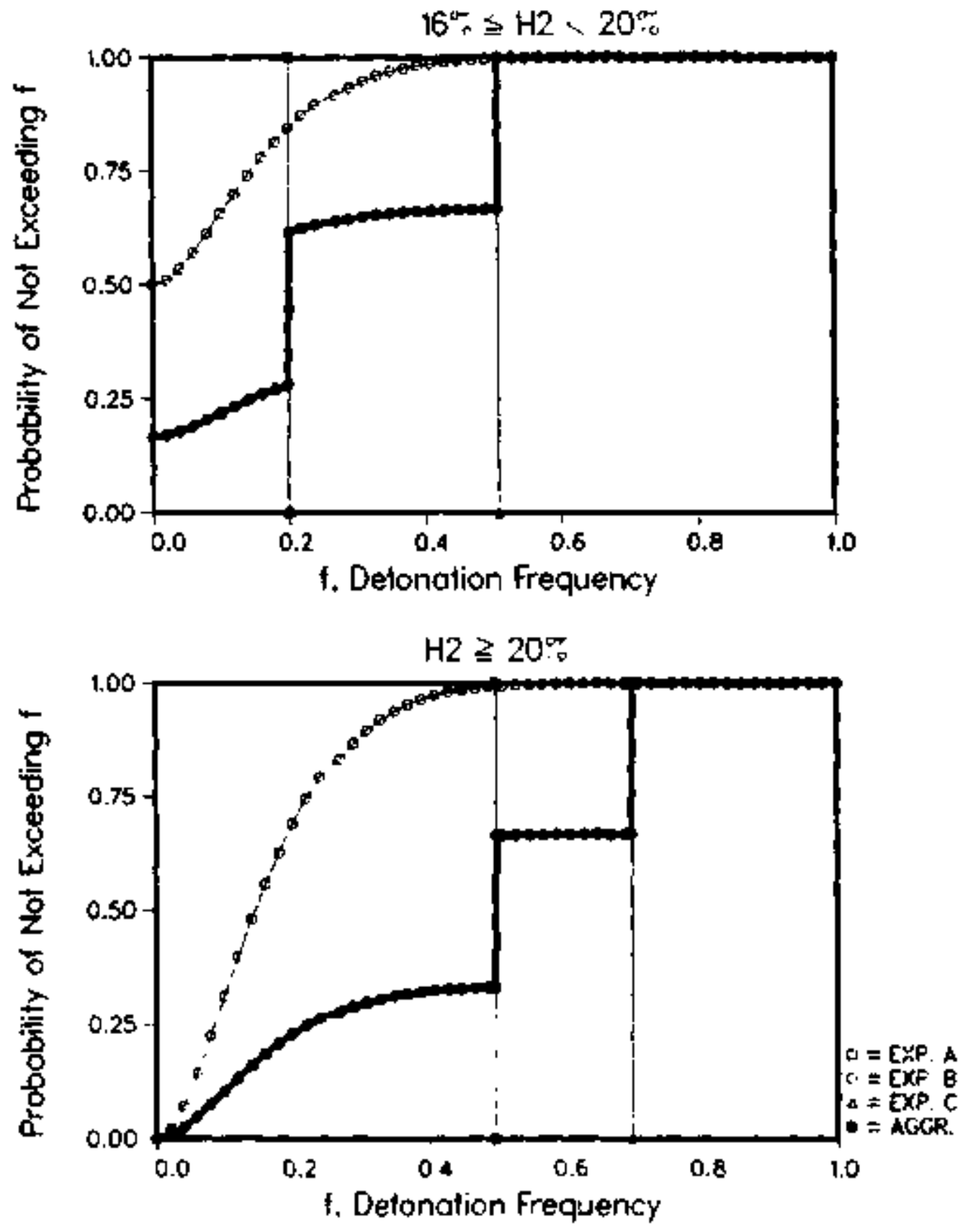

Figure 5-7. Probabtifty of Detonetlon-Low Stean. 

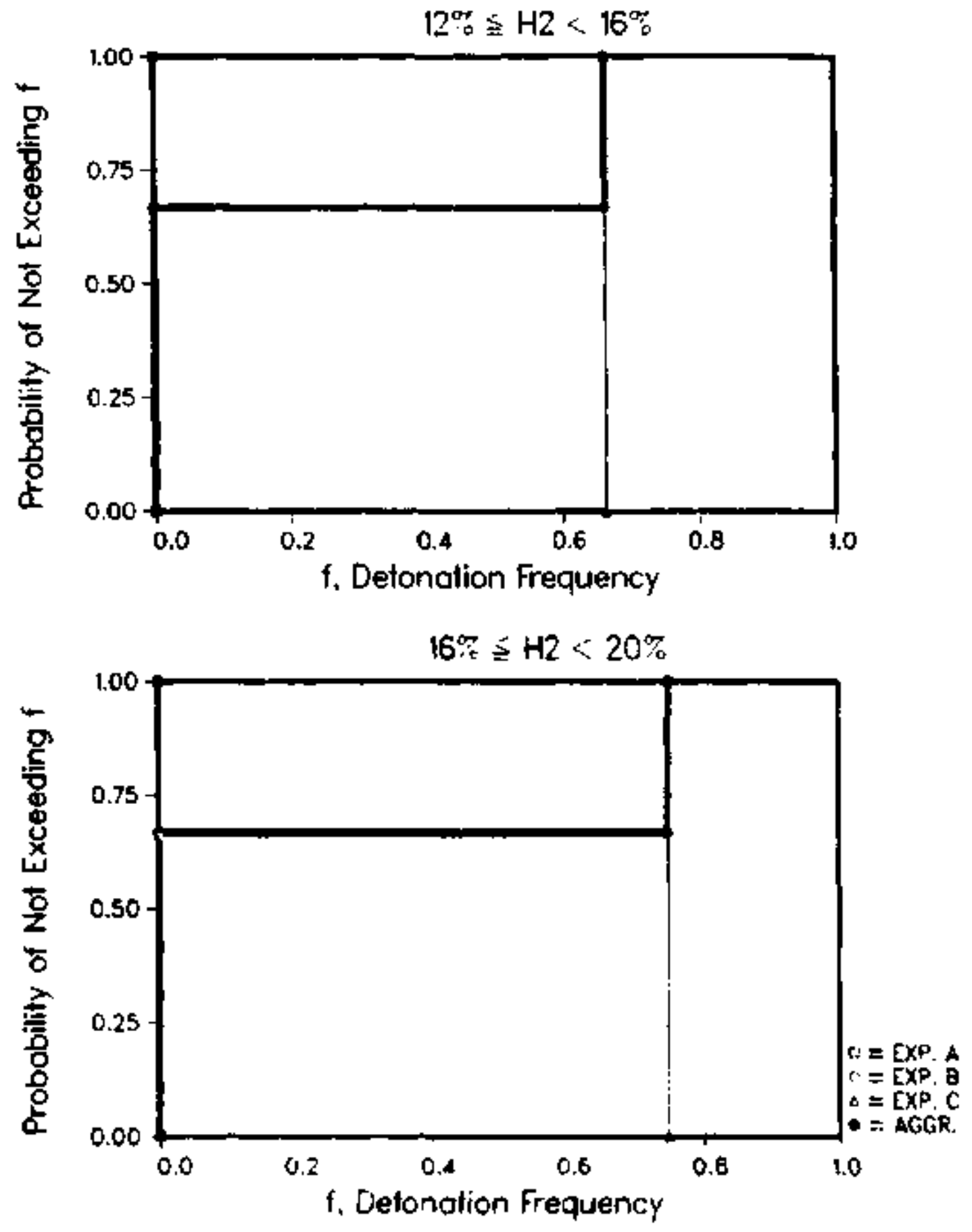

Figure 5.6. Probability of Detonation-High Steam. 
High Steam
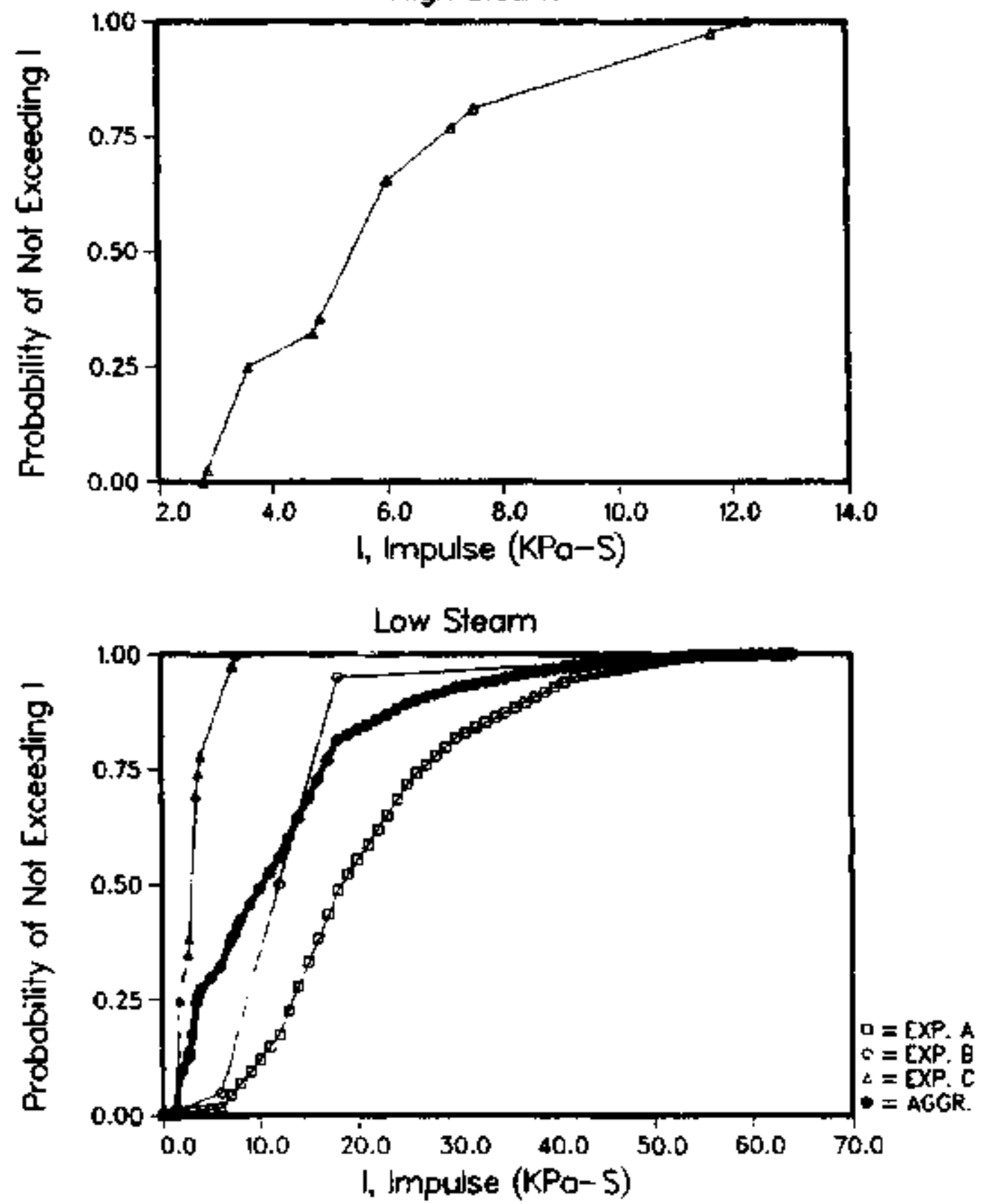

Figure 5-9, Loada Fron Hydrogen Detonation in Wetwell. 
Indlulduai fllcitations for Issue 1 
Expert A's Elicication

Issue 1. Hydrogen Thencmenon at Grand Gulf

Part 1

Description of Expert A's Bationale/Methodolory

The Expert felt that the uncertafnty assoclated with this tssue was dominated by the uncertainty in ignition. The model used by the Expert for ignition is as follows.

The hydrogen concentration in the containuent must be in the flamable range (8 hydrogen $>$ Sa) and a spark aust occur. For each case there is a certaln probability that there are no ignition sources (1.e., no sparks). If there are ignition sources. the frequency of 1 gnition depends on both the hydrogen concentration and the amount of time spent at a glven hydragen concentration. That is, the occurrence of a spark fron an ignition source is a randon process. The Expert expressed the lgnition frequency in terms of a "half-life" (aedaing the amount of time until the frequency of ignition equals 0.5$)$. The Expert considered the "half-lives" as a function of hydrogen concentration. The vary difference between Cases 1 and 2 stem from the way the hydrogen released from the vessel into the contalnment. For case 1 (reactor pressure vessel [RPV] is at high pressure) the hydrogen is perlodically released through one safety relief valve (SRV) callpipe and, therefore, local "pockets" of hydrogen form which have hydrogen concentrations higher than the mean hydrogen concentration in the containment. For Case 2 (RPV is at low pressure), the hydrogen is released uniformly in the suppression pool and the size of hydrogen "packets" are reduced accordingly. In addition, the chance of generating a statlc spark is greater for Case 1 than for Case 2 because of the $\mathrm{high}$ gas velocitles (gas beling released through one SRV tailpipe as opposed to several tallpipes) assoctated with the former.

\section{Results of Expert's A'g Enteltation}

The Ignition frequencles, expressed as "helf-lives," are presented In Table A.1 as a furction of local hydrogen asle percent in the contalnment. For Case 1, the Expert indlcated that the local hydrogen concentration 18 about 4t greater than the mean hydregen concentration. simllarly, for Case 2, the local hydrogen concentration 15 about 23 greacer than the aean hydrogen ccncentration. The local hydrogen concentrations are greater then the mean hydrogen concentrations because of local "pockets" of hydrogen thet are formed when the hydrogen is released fron the SRV tallpipes. The Expert also telt that for the low steam cases (20 to 300 steam) the probabilicy of no 1 gnition sources befing present was 0.25 . 
Table A-1

Hydrogen Ignition Half-Liveo

\section{Local $\mathrm{H}_{2}$ Concentration (Mole Fractlon)}

0.05 to 0.10

0.10 to 0.15

0.15 to 0.20

0.20 to 0.40

0.40 to 0.60
Half-Life

(min)

25.0

15.0

10.0

5.0

The 1gnition frequencles, when expreseed with "half-lives," are a function of both tine and hydrogen concentrstion. What is desired $1 \mathrm{~s}$ a COF for the frequency of 1gnition for geveral ranges of hydrogen concentration. To generate thid CDF the amount of time the hydrogen could be in the containment before vessel breach must be epec1fied. Based on reaults from MELCOR and BURSAR code calculation it was ostimated that the time interval from the start of sigalficant hydrogen production to vessel breach vas $2 \mathrm{~h}$. In addition, because most of the hydrogen is produced over relatively short perlod of time. It vas assuned that the total amount of hydrogen generated was released to the contalnnont at the beginning of the $2-h$ interval. It we then asauned that any tiwe within this tine intervel was equally interesting and a CDF for the frequency of ignition was generated for a given hydrogen concentration range. Five contalnnent hydrogen concentration (mole percent) ranges were selected: 0.0 to $4.03,4.0$ to 8.0 , 8.0 to 12 , 12 to 168 , and greater then 164. The reaulting distributions for cases 1 and 2 are presented 1 Figureg A-1 and A-2, respectively.

A short explanation of the terminology used in these two figures is needed. For a stocastic event the term "frequency" is used to describe the fraction of tiaes a particular outcone occurs, if the event were repeated a large number of tines. However, the actual value for this frequency may be uncertain. The term probability is used to describe this uncertainty. Assocfated with each frequency in Figures $A \cdot 1$ and $A \cdot 2$ is a probability whlch represents the 1 ikelihood that the actual frequency does not exceed this value.

\section{Sources of Uncertainty}

The Expert Indlcated that the major source of uncertalnty was the lack of Identiflable ignit lon sources. In addition, the Expert ol so cited the lack of experiaental results which also led to the large amount of unctratinty. 


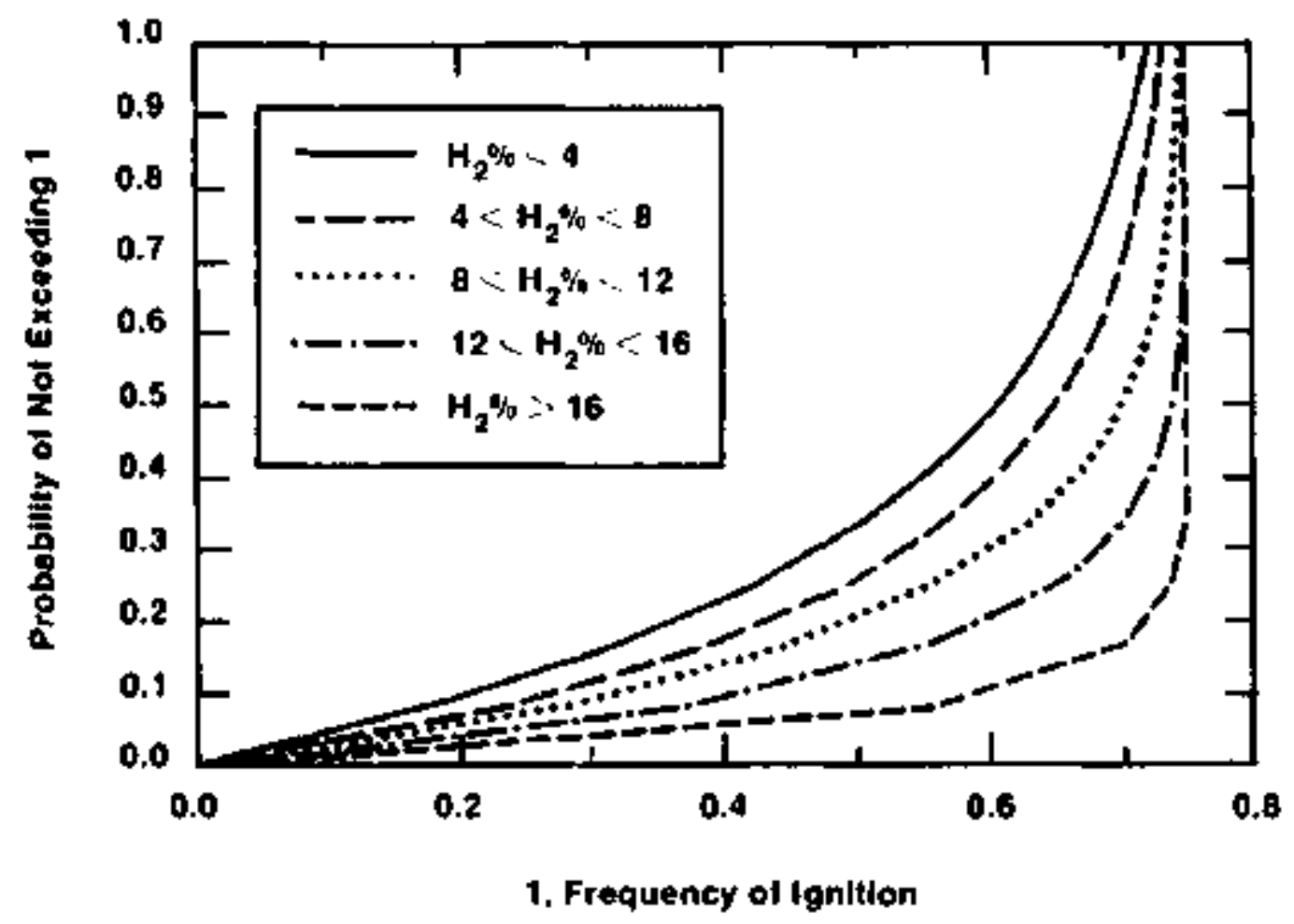

Figure A+1. Ignition Frequency Before Versel Breach short-Tern station blackout, High Presaure for Case 1

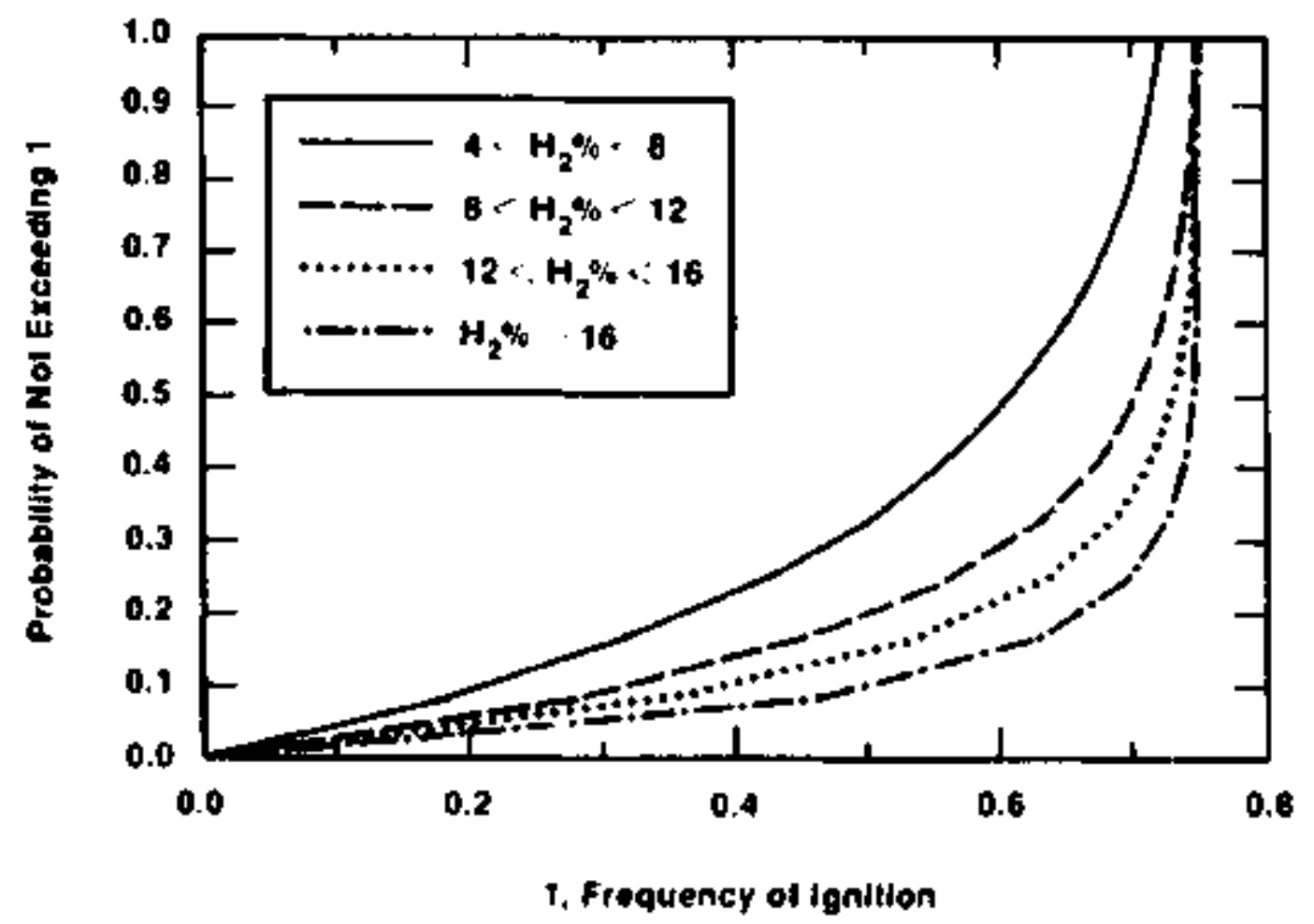

Figure A-2. Ignteton Frequency Bofore Vasel Breach Short-Tera station Blackout, High Pressure for Cese 2 


\section{Description of Fxpert A's Rationaie/Methodology}

The Expert felt the probability of 1 gnition at vessel breach depended on the likelihood that hot debris or hot gases from the drywell would enter the contalnment. The Expert Indicated that if hot debris (> $500^{\circ} \mathrm{C}$ ) enters the contaiment and the hydrogen concentration is in the flamnable range (> $58 \mathrm{H}_{2}$ ), the hydrogen will ignite. The Expert felt that if the hydrogen in the drywell at vessel breach (or that which is released from the RPV at vessel breach) ignites, hot gases and debris with sufficlent energy to ignite the hydrogen in the contalnment will exist in the drywell. (The energy released from this hydrogen burn will heat the gases in the drywell and will tend to keep the debris particles hot, which increases the likelihood that hot debris particles and gases will enter the wetwell.) However, cooling of the hot gases and debris in the suppression pool wil] reduce the probability of ignition. It is also possible that the debris will be blanke"ed by stean as it enters the contalnment, which will also reduce the probabllity of igntition.

\section{Results of Expert $A^{\prime} s$ Elifitation}

The Expert belitved that $1 \mathrm{f}$ the hydrogen in the drywell at vessel breach (or that which is released from the RPV at vessel breach) $1 \mathrm{gnites}$, the probability of Ignition in the wetwell is 0.67 . However, he assigned a probability 0.1 that there would be no hydrogen ignition in the drywell (insuffictent anount of oxygen or too much steam). Thus the overall probability of 1 gnition at vessel breach in the wetwell is $0 . t$.

\section{Sources of Uncertainty}

The Expert cited the interaction of the pool with the hot debris as a major source of uncertainty. The uncertainty in the amount of vent coverage and the possibllity of gas blow.through also contributed to the overall uncertainty associated with this parameter. If, however. hoc debris entered the wetwell and a flamaivie mixture was present, he was certain it would Ignite.

Part 3

\section{Description of Expert A's Rationale/Methodology}

\section{Stat1c load}

For static loads the Expert based his assessment on the adlabatic isachoric complete conbustion (AICC) nodel. He then modified the peak pressure rlse obtalned from this nodel to sccount for burn completaness, pressure relaxation fron vent clearing, and heat transfer to structures. The expere expressed the burn completeness as a function of both hydroges conentration (mole fraction) and contajnment atmosphere turbulence. If the con- 
cainment sprays were operating, the Expert Indicated that the atmosphere would be turbulent; ocherwlse, it would be quiescent. The Expert felt incomplete combustion would accur at contalnment hydrogen concentrations (average) below 128. For burn completeness, the Expert used the enpirical correlations developed by Wong. ${ }^{A-1}$ The Expert Indicated that deflagrations in the wetwell wli cause the suppression pool suréace to move dowmard, and if it moves downward fast enough to uncover the top vent openings, the gas can expand inco the drywell. The Expert estimated that the effect of gas expansion into the drywell would reduce the peak deflagration pressure by approximately 108 . The final reason for getting deflagration pressures below AICC is heat transfer fron the burned gases to solid surfaces. To estimate the effects of heat transfer, the Expert teferenced Figure 2.125 of Cumbings, A-2 which indicates that typicsl pressure reductions are on the order of 5 to 102. For pressure reduction due to heat transfer to structures, the Expert assumed a value of 100. Therefore, the Expert stated that the peak overpressure can be expected to be of the order of $20 \mathrm{e}$ lower than AICC due to heat transfer to solid surfaces and expansion of wetwell gases into the drywell.

For Case 3, the scenarlo assumes that an Initially stean inert hydrogenalr-gtean environment is slowly brought into a flammble range by the condensation of stean caused by sproys. For this case the cooling of the contafmment atmosphere is slaw and Ignition sources are present. The Expert cites flamabliticy limit studies which have shown 1ncouplete burning in regions just inside the flanability limits. The refore, he concludes that if an inerted mixture is slowly brought into the flamable range, it must cross tegion of weakly flamable wixtures, a region where deflagracions will have low pressure rises because of incomplete combustion. The Expert belleved overpressures for this case would be negligible.

\section{Detonet1on Loads}

The Expert stated that the likelihood that a detonation w11 occur, given that Ignition has occurred, depends on the geometry of the region in which the detonation may occur and on the hydrogen concentration at ignition. The Expert used the methodology of Sherman and Berman ${ }^{\wedge-3}$ to deternine the likelihood of a detonation. This methodology requires that both the hydrogen-air-steam mixture and the contalnment geonetry be classifled on a scale from 1 to 5 where a class of 1 indicates a condition conducive for a detonation. The Expert divided the Grand Gulf containment into two regians: the alstulus region of the wetwell and the dome region of the upper containment. The Expert felt the anjulus region would be geometrlc clsss 2. geometrles which favor tlame acceleration but are not ideal for flame acceleration Because of the large open area of the dome region. the Expert felt this region would be class 4 , geometries unfavorable to flare acceleration In addition, the Expert felt that it was unlikely that che hydrogen would 1 gnite in the dome reglon (lack of ignition sources). Thus, the Expert concluded that the probability of a detonation in the dome region was very small and, therefore, dropped this reglon from his anilysis The Expert Indicated, however, that a mare complete method of analysis would involve assessing the likelthood of ighltion in each regian. 
If the hydrogen lgnites in the annulus region, there is a certain probability that it will detonate in this region. If the hydrogen does not detonate in the annulus region, it 19 possible that the flame will propegate into the dome tegion and detonate. Slallar logle would be used for lgnitions that orliginate in the done region. But again. because detonations in the dome region were considered to be very unlikely, only detonations in the annulus region vere considered. The mixture class is deterained from Table 1 and Figure 3 of Reference 3 . The Expert assumed the strongly flammable reglon, where dangerous flawe scceleration or deflagration-to-detonation transltion (DDT) is posstble, is bounded by alxtures with a detonation cell width equal to $10 \mathrm{~m}$. Figure 5 of Reference 4 is used to determine the hydrogen/stean region in which a detonstion will not occur. Table 2 of Reference 3 is used to collapge the mfxture class and the geonetry class into a results class. Based on this methodology. the possible resulte clesses that are possible for cases 1 and 2 are: Class 3, DDT asy occur; Class 4, DDT ts possible but unlikely; and class 5. DDT is highly unlikely to imposafble. The Expert then assigned a probability of detonation to the various results classes.

Far Case 3, the scenario assumes that an initially atoa inert hydrogenair-steam environnent is slowly brought into a flanable range by the condensetion of stean caused by sprays. For this case the cooling of the contolument atmosphere $1 \mathrm{~s}$ slow and ignition sources are precent. The Expert referenced work performed by Sherwan and slezakt-4 which showed thet for hydrogen-alr-8teal mixtures in large geometrite the detonation liolts lie lnside the flamability liolts. Sherwan and slezak define a region of "weakly flamable mixtures" between the flamability liatis and the detonation limits in which a DDT or highly accelerated tlane cannot occur. The Expert stated that any inerted mixture must pass through th1s region before it gets to the "strongly flamable and possibly dotonable region." Thus, based on this work the Expert belfeves the probability of a detonation $1 \mathrm{~s}$ zero.

Given that a detonation occura, the Expert estinated the magnitude of the 1mpulse on che drywell wall fyon the deconation. The Expert Ind1cated that If the first inpulse is the peak impulae, then the impulse thould be in the range from 6 to $24 \mathrm{kPa}-\mathrm{s}$. However, the Expert folt that revorberationg could Increase the maxinuln 1mpulse. He Indicated that 1t was most likely that the Impulse on the drywell would be tolce thet of the first Inpulse (first impulse plus the integrated efiect of the remaining inpuloes).

\section{Results of Experte's As Elscitation}

\section{Stat1c Lods}

The burn completeness for Cases 1 and 2 are presented In Table A.2 as a function of contalnment hydrogen nole fraction. When the sprays are "on", the burn completeness factors for the turbulent case are uaed; otherwife, the stat1c burn completenesa factors are used. 
Tablo $A \cdot 2$

Hydrogen Burn Coupletenes

\begin{tabular}{l} 
Avernge Wetrell $\mathrm{H}_{2}$ \\
Mele. Fraction. \\
\hline 0.20 \\
0.15 \\
0.12 \\
0.10 \\
0.08 \\
0.06 \\
0.04
\end{tabular}

\begin{tabular}{cc} 
Burn Congletingsp \\
\hline & \\
statile & Turbulent \\
\hline 1.00 & 1.00 \\
1.00 & 1.00 \\
1.00 & 1.00 \\
0.87 & 0.90 \\
0.57 & 0.62 \\
0.27 & 0.33 \\
0.00 & 0.05
\end{tabular}

An AICC was used to obtain the containnent overpressure ag a function of hydrogen concentration. The burn complateness factors were used to determine the anount of hydrogen thet should be burned (6.g., if the burn completeness is 508, then 50s of the hydrogen is burned). To obtain the peak overpressure, the AICC pressure was multiplied by 0.8 . Reducing the AICC pressure by 20 accounts for pressure relaxation due to heat transfer to solid surfaces and expansion of wetwell gases into the drywell. For Cases 1 and 2 , the peak overpressure, as a function of containnent hydrogen concentration, 1s presented in Figure A.3. For Case 3 the peak overpressure $1 s$ negllgible.

\section{Detonetion Loeds}

The probability of a decanation, given that ignition has occurred, is dependent on the results class. The Expert used the nethodology of Sheraan and Beraank-3 to deternine the results classes as a function of contafnment hydrogen concentration. The results class is dependent on the geonetry class and the hydrogen-air-atean mixture class. The Expert stated that the moet probable location for a detonation was in the annulus region of the wetwell. This region was classifled as a geometry class 2 . The Expert assigned probability of detonation ta each results class. The probablifies of detonation for the three results classes are presented in Table A.3. The detonation probability for the annulus region of the wetwell. Is presented in Figure A-4.

Table A-3

Detonstion Probab1lity

\begin{tabular}{cc}
\hline Results_clasg & Detonation Probability \\
\hline 3 & 0.50 \\
4 & 0.20 \\
5 & 0.05 \\
\hline
\end{tabular}




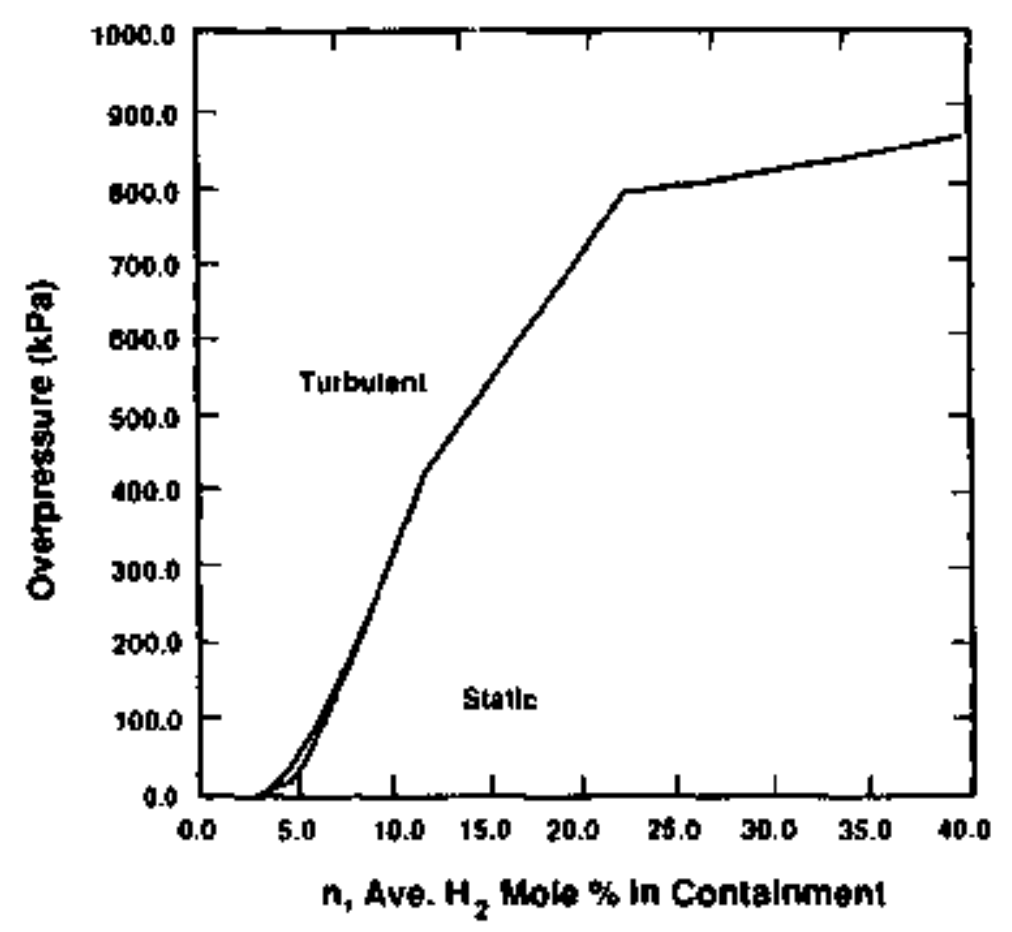

Figure A+3. Deflogration Overpressure (Wecwe1l) Low Stean Case.

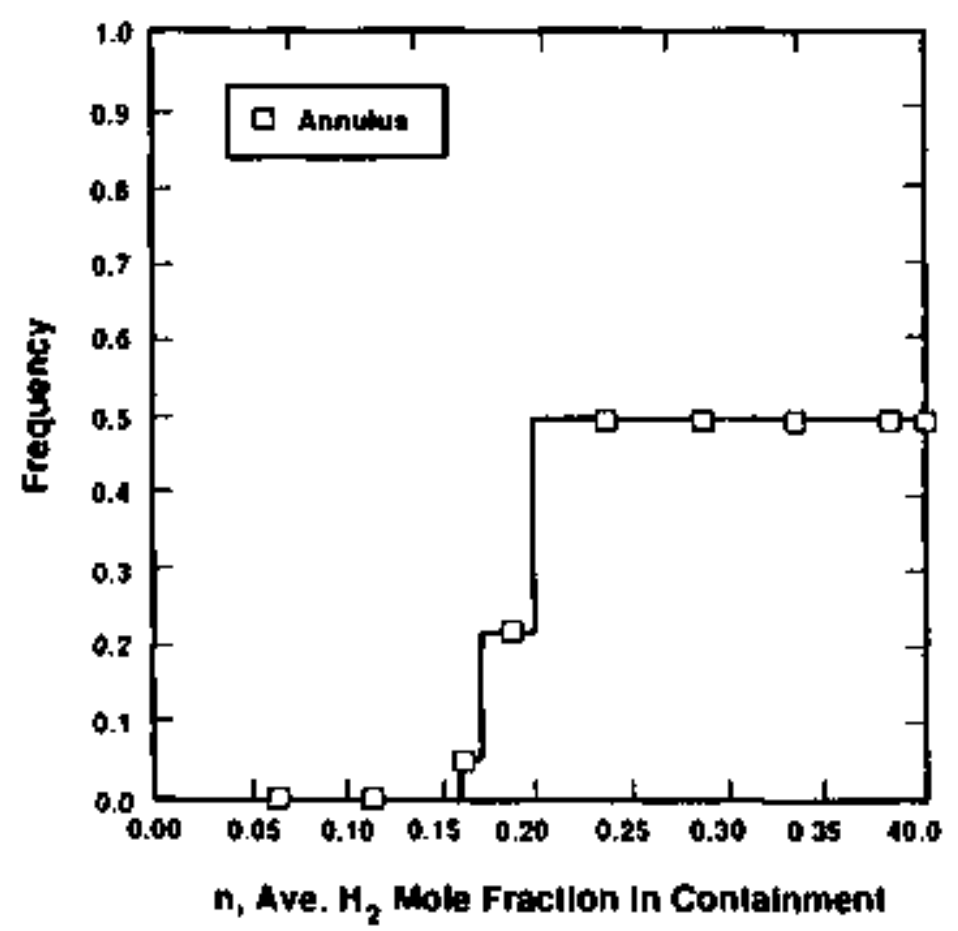

Fibure A-4. Frequency of Detonation at Crand Gulf Low Steam Case. 
Given that a detonation occurg and the first lopulse ig the peak inpulse, the Expert assigned a 900 probability that the pesk Impulse vil I be between $6 \mathrm{kPa}-\mathrm{s}$ and $24 \mathrm{kPa}-\mathrm{s}$. However, the Expert estianted that the $11 \mathrm{kellhood}$ that a subsequent 1mpulse w11 be greater than the first 1mpulse to be 65t. The relative likelihood that subsequenc peaks will be the maximun impulse are presented in Table A.4. The composte cumulative probability distribution for inpulse to the drywell fron detonation is presented in F1gure A.S.

Table A.4

Relaclve Likelihood subsequent Poaks are Maxieun Impulso

\begin{tabular}{|c|c|}
\hline $\begin{array}{c}\text { KaxImun Inpulse } \\
(\mathrm{kPa}-\$)\end{array}$ & Belotive likelthood \\
\hline $\begin{array}{l}12 \\
24 \\
36 \\
48 \\
60\end{array}$ & $\begin{array}{l}1.0 \\
1.5 \\
1.0 \\
0.4 \\
0.1\end{array}$ \\
\hline
\end{tabular}

\section{Sources of Uncexteinty}

Stat 1t Lotd:

The Expert belleves the uncettalnty assoclated with the Ignttlon frequency overshadows tho uncertainty associated with the pressure rise fron a hydrogen burn. Thus, the Expert did not assign any uncertainty to the parameters involved with static loads ( $1, e$. burn coapleteness or overptessure).

Detonation Loeds

Uncertaluty in the location of the detonarion and the potential of geometry for tlane acceleration contributed to the uncertainty in the likelihood of a detonation. In addition, the Expert indicated that the uncertainty in the location of the detonation contributed to the uncertainty in the inpulse load. The Expert felt that interactions between the detonation wave and the structures could stgnificantly affect the poak tupulse. 


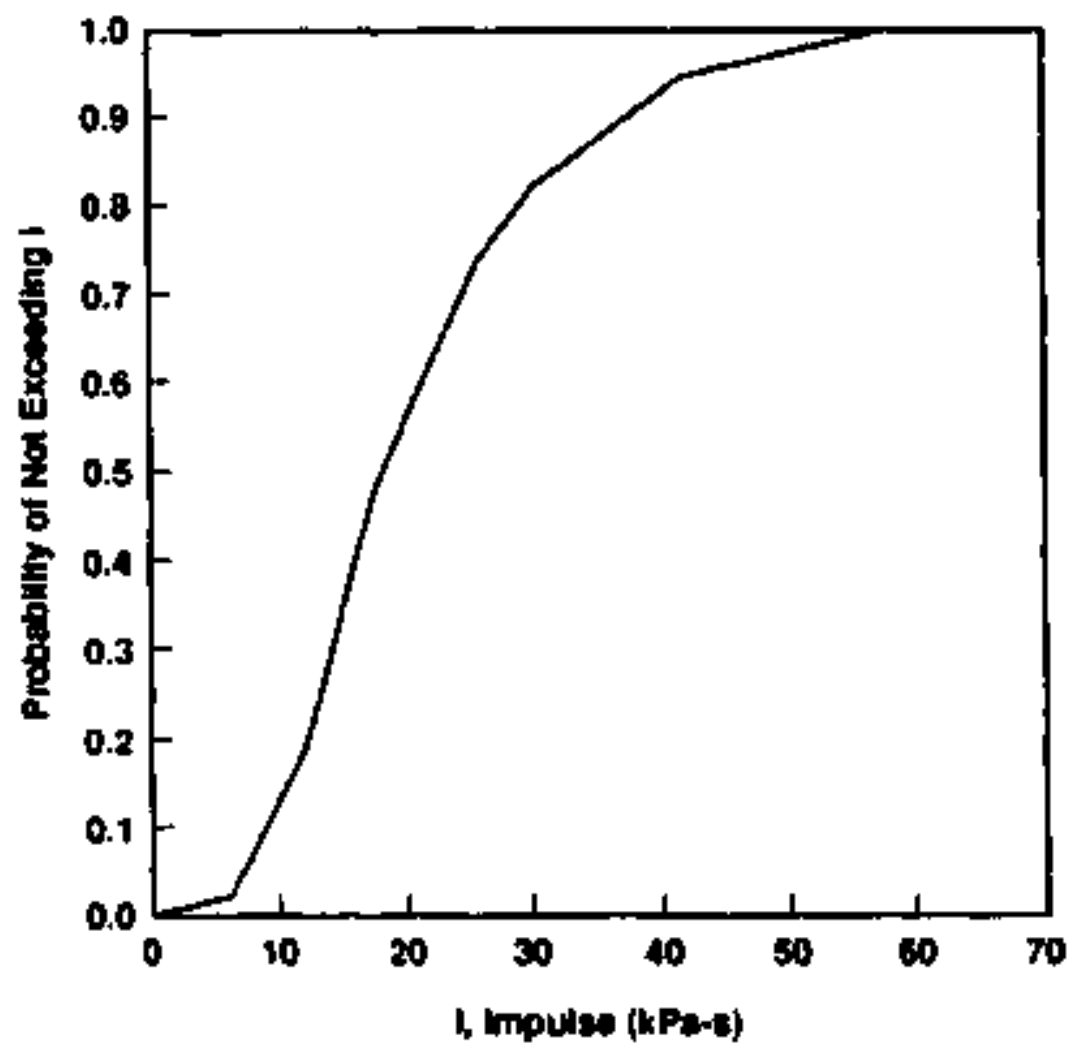

Figure A.5. Loads Frod Hydrogen Detonat lon in Grand Gulf Wetwell. 
A+1. C. C. Wong, "HECTR Analyoes of the Nevade Tegt site (NTS) Prenixed Combustion Experiments," Sandta Nationsl Laboratorles, NUREG/CR. 4916, SNDO7.0956. Novembar 1988.

A.2, J, G, Cunnings et al, "Raview of the Grand Gulf Hydrogen Igniter Syzted," Sandia National Laboratoried, NUREG/CR+2530, SAND82-0218. Fobruary 1983.

A.3. M. P. Shersen and M. Bernan, "The Possibllity of Local Detonations During Degraded-Core Accidents in the Bellefonte Nuclear Power Plant," Sandla National Laboratories, NUREG/CR-4803, SAND86-1180, Januaty 1987 .

A-4. M. P. Shormen and S. E. Slezak, "Hydrogen-Alr-Steats Conbugtlon Regines In Large Volumes," in Broceedingr of the Tuenty - Fifth Space Coneress. Cocos 8ench. Florida April 1988. 


\section{Export g': Elleftection}

I*aue 1, Hydrogen Phenonenon st Grond Gulf

Fert 1

\section{Description of the Expert B'. Raflonale/Methodology}

Expert B based his uncertainty distributions on his experience vith hydrogen combustion phenonens. He noted that experimental results suggest that igoltion probabilities increase as the wolar concentration of hydrogen Increases. Furthermore, Expert B felt that uncertaincy in the probability that ignition vould occur incteases as the hydrogen concentration increases.

Because the stean nole fraction In the containgent is large, (1n this Expert's opinion a 0.2 stean mole fraction is large), lou probability of Ignition was expected fron randow discharges of static electricity. In the presentation of the Grand Gulf plant design, 1t was stated that the NUREG-l150 analysts believe thac the presence of de power in case 2 did not constitute a clear ignition source. Expert B accepted this conclusion, since he had no other sources of information. The only other difference between Cases 1 and 2 , in terms of condicions in the containent volume, is that hydrogen release for case 1 occurs through a single SRV and thus the hydrogen enters the containent through the suppression pool over a linfed area, (The surface area of the pool chrough which hydrogen bubbled would be no greater than oneteighth of the cotal surface,) for Case 2, all autonatic depressurizacion system (ADS) valves are assumed to be open and thus the bydrogen source is tar wore distributed. Expert B stated that based on his knowledge of hydrogen behavior and combents about experinental results fron one of the other panel menbets, the hydrogen would alx well with the containnent atnosphere. No distiction 15 made between Cases 1 and 2 for this part of the lssue.

\section{Results of Expect B's Ellefloation}

Expert B gave his results in teras of the best-guess probability (fnterpreted as the node of a distribution) of Ignition for a given hydrogen concentration. The range of possible hydrogen concentrations was represented by five discrete points. Expert B stated that a 4 or lower molar concentration of hydrogen could not ignite. The lower end of the range is thus 42 hydrogen with the probability of Ignition taken as zero with no uncertainty. Above 20 molar concentration of hydrogen. Expert s stated that the probability of ignition was Independent of further Increases in concentration. Thus, 20v hydrogen concencration was taken as the upper end of the range. The range was then divided into faur intervals. Expert B provlded an assessment of ignition probabllify at clie eradpolnts of each taterval. Once he had selected a best-estimate ignition probilit)icy fur wath selected concentration (bastod on his

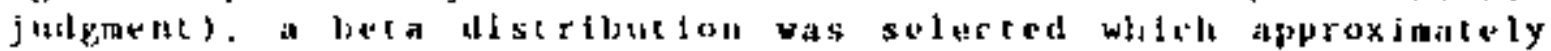

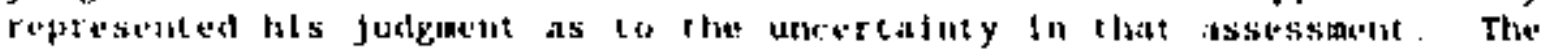


appropriate beta distribution was selected from a book of beta distri. bution plots. The results are provided below in Table B-1. Beta distributions were specifled by two parameters, the mode (Interpreted to correspond with Expert B's best guess at the 1gnition probability), and a spread factor of $(n)$ which corresponds with etther the parameter $P$ or the parameter $Q$ (depending on the velue of the mode) in the standard formulation of the beta distribution. The distributions in table B-1 are shown graphically in Figures B-1 through B-4.

Table B-1

Distributions

Hydrogen Concentration (nole fraction)

Nedfan

0.0

0.07

0.11

0.16

0.27
Mode

0.0

0.04

0.08

0.14

0.20
Spread Factor (n)

$n / a$

20

20

10

Expert $B$ Indicated that the ignition probability for hydrogen concentrations wthin an interval could be obtained by linear interpolation of the values at the endpoincs.

Sourcess of Uncertaincy

The principal source of uncertainty was identified by Expert $B$ as being that there were no clearly identified ignition sources.

Part 2

\section{Descriptien of che Expere B's Raclonale Alethotology}

Expert B based his assessnent on an essumed likelihood for hot gas from the drywell to enter the cantalnuent at vessel breach. He belleved that the lavel in the suppression pool would be severely depressed hefore vessel breach. Rapld hydrogen flow into the containment before vesisel breach was cited as the primary cause for the overflow of suppresston pool water onto the drywell floor.

clven the very short distance betwe'n the level of the suppression pool and the top cow of vents. Expert B lell that it is not utilikely that hot biss could flaw from the drywell inro the wetwell without equilibrat inp 


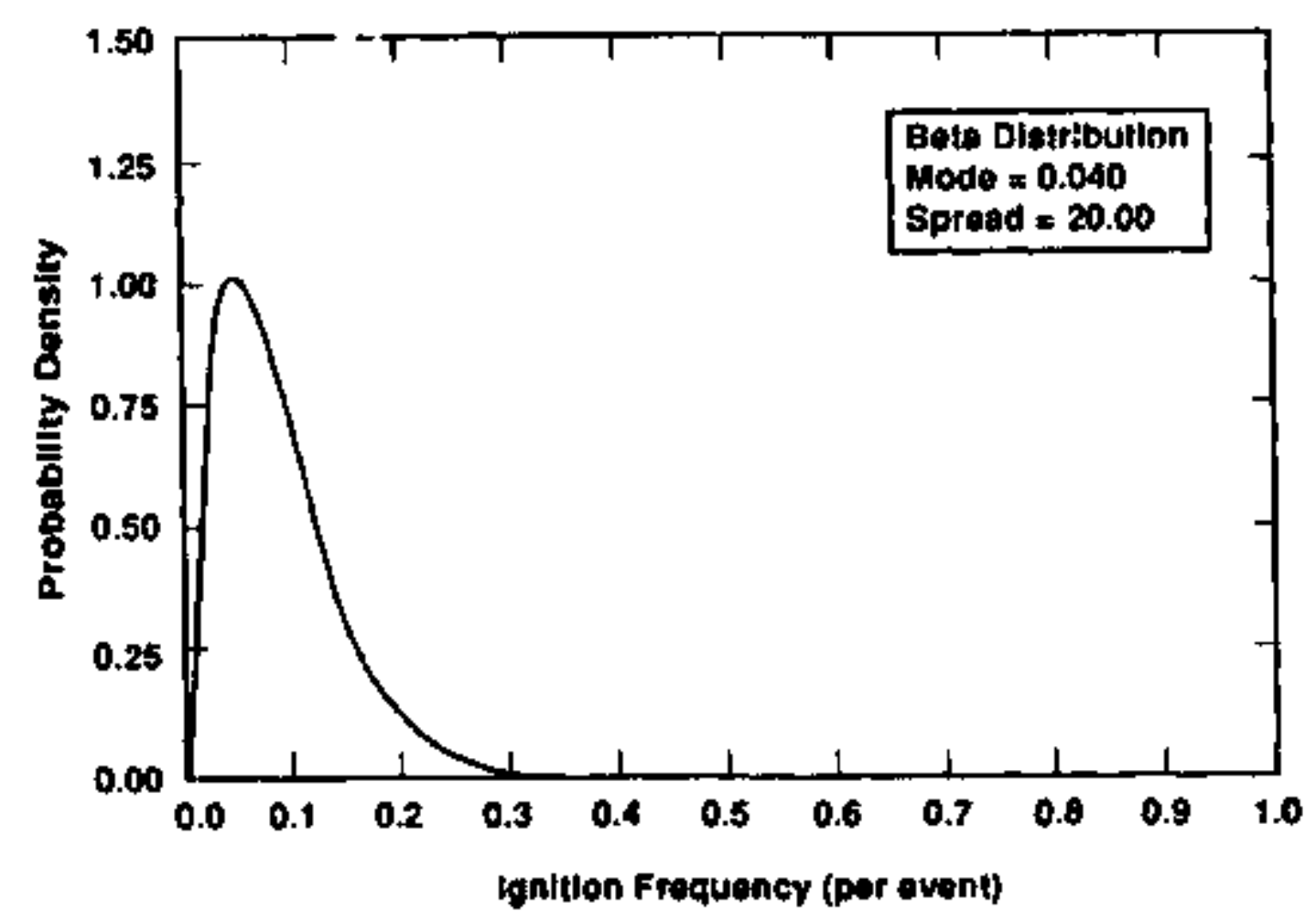

F1gure B.1. Frequency of Igntcion; Bo Mole Fraction Hydrogen--Low Stean.

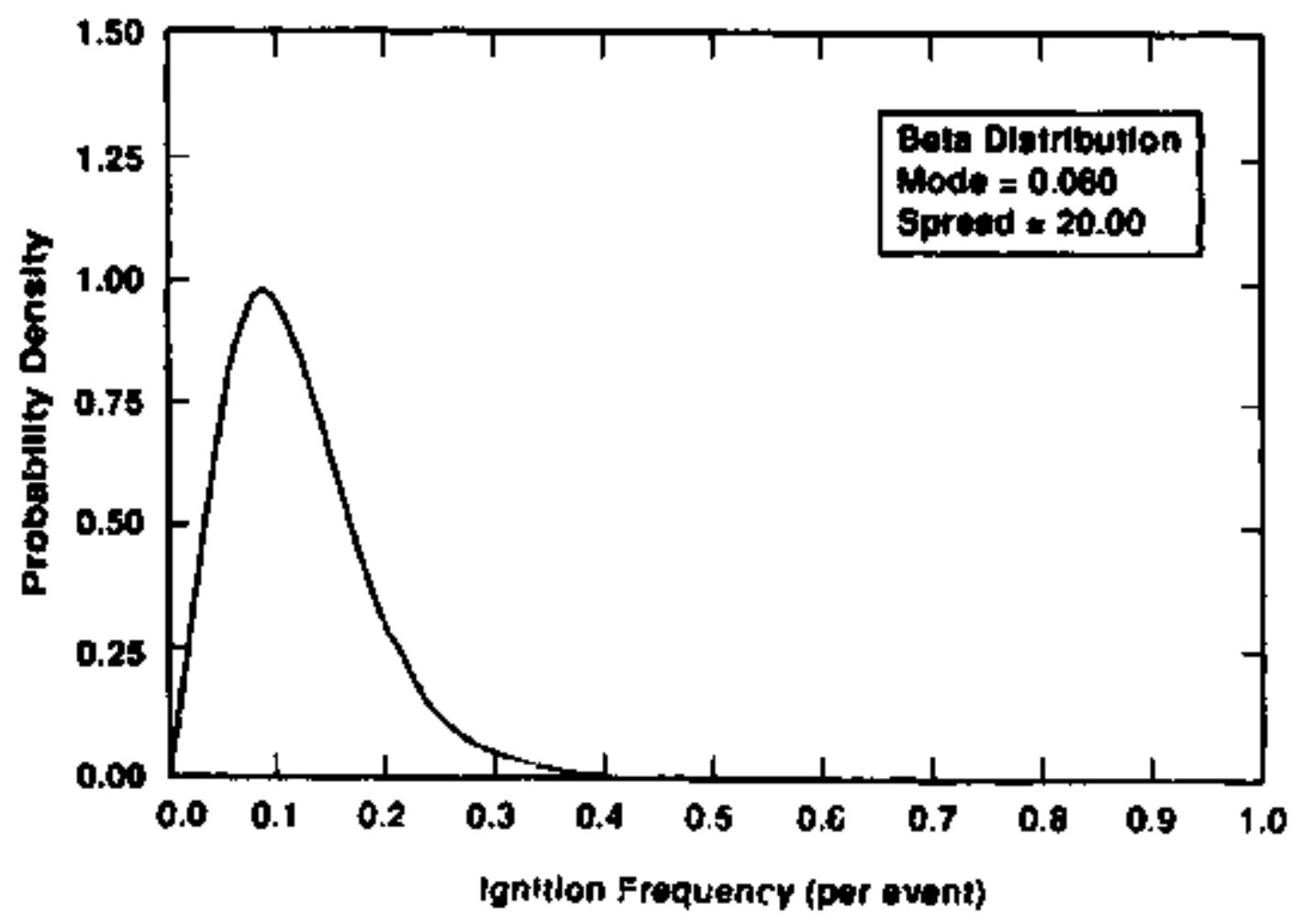

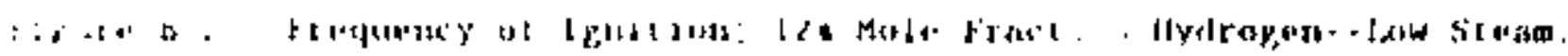




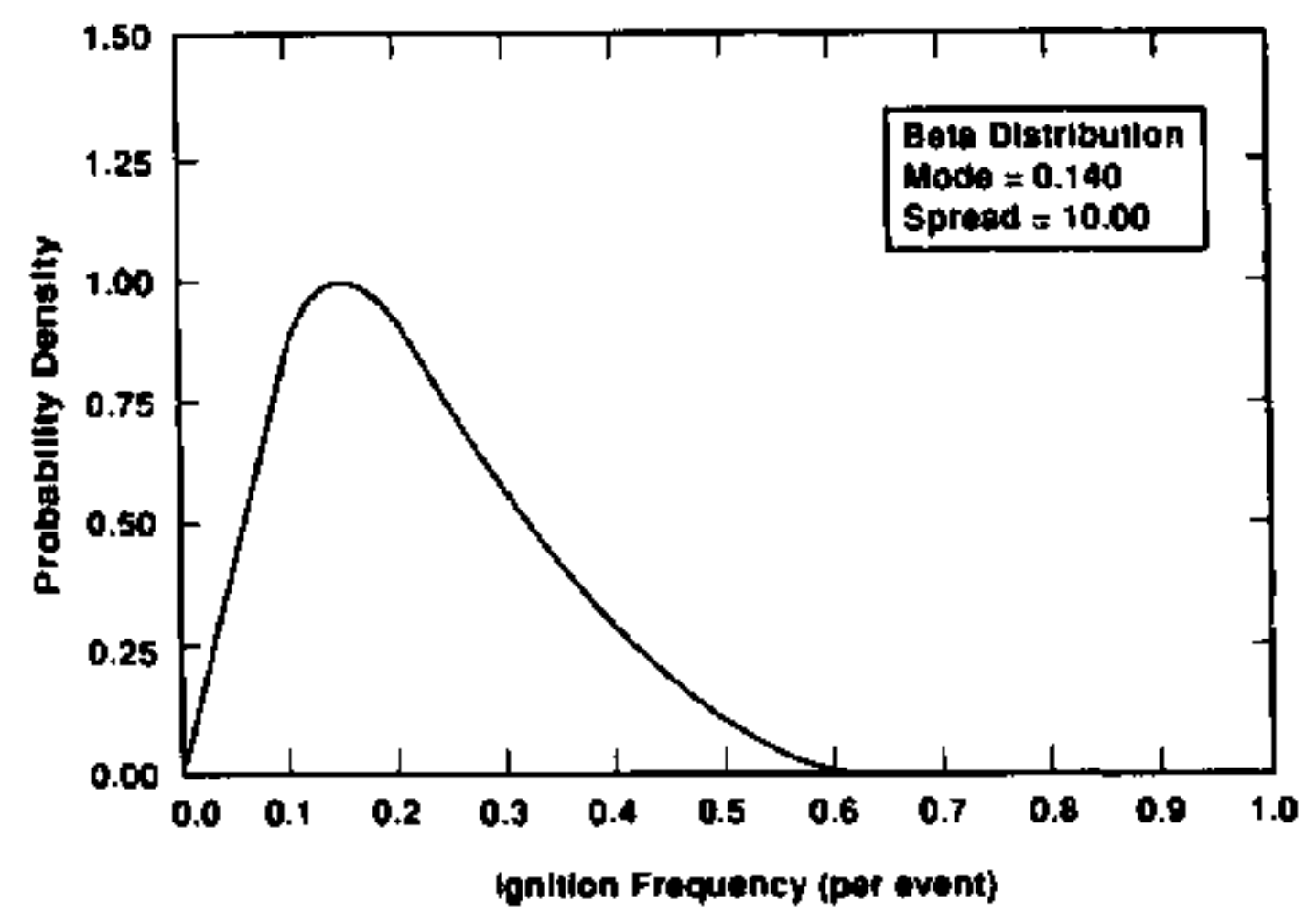

Figure 8-3. Frequency of Ignition; 16, Hole Frection Hydrogen--Low Stear.

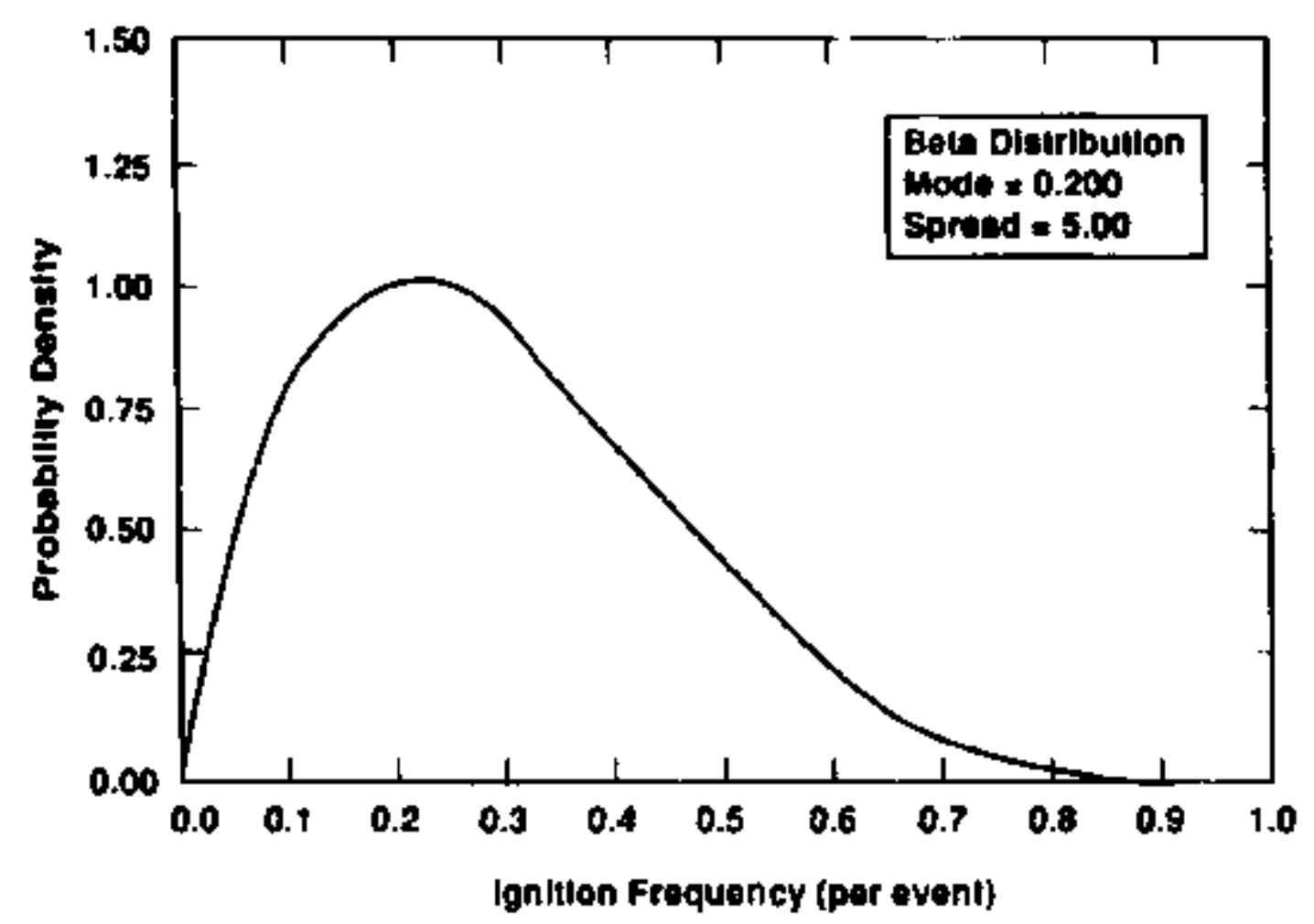

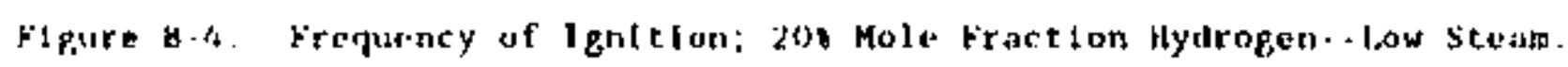


wh the pool water. the felt thet it is unllkely thet hot debris could pass Into the wetwell, but the hot ges olght be sufficient for an ignition. Any high pressure melt ejection is directed at the weic wall, and stear. exiting the vessel, is heated by the debris in the vicinity of the top of the ve1r well. It is noteworthy that the average drywell temperature is on the order of 1000 to $1300 \mathrm{~K}$ Eor a 504 debris efection case as seen In Figure 20 of the Murata Report presented in NUREG/CR-4551, Val. 2, Part 5. Thus the local cemperature could be wuch higher. These temperatures are sufficient to result in ignition, but because some cooling by the pool would occur, ignition is less chan certain.

As for Part l of this issue, igntion probabilicy increases with fincreasing hydrogen concentration. Uncettainty in the ignition probabilicy also increases with increasing hydrogen concentration. Because the lgniclon source is Idenciflable for the situation considered here. Expert $B$ expressed that hls uncertainty about a given best-estinate value far ignition probability was slightly lower than in Part 1.

\section{Results of Expert B's Elicticacion}

Expert B Judged that ignition fron hot gas being ejected into the drywell was three times more likely than ignition due to randon sources before vessel breach.

The same procedure for this assessment was used as that in Part 1. Table B-2 shows the beta distributions that were selected. These are shown graphically in Figures B-5 chrough B-B.

Table B-2

Selected Beca Distributions

tiydrogen Concentracion (nole fraction)

Mediun
0.0
0.15
0.28
0.5
0.58

Hode

0.0

0.12

0.25

0.5

0.6
Spread Factor (w)

$n / a$

15

10

10

Agaln, Expert $B$ Indicated that the Ignition probablifty for hydrogen concentations vithin an finterval could be obtained by linear interpolation of the values at the endpoints.

\section{Sources of Uncertsingty}

As for the sicuation before vissi.] breach, uncertafnty shems $f$ tom whether

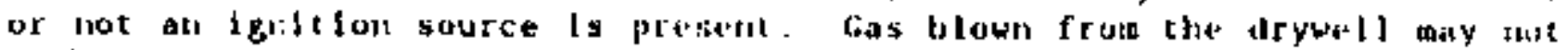

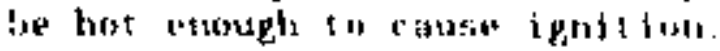




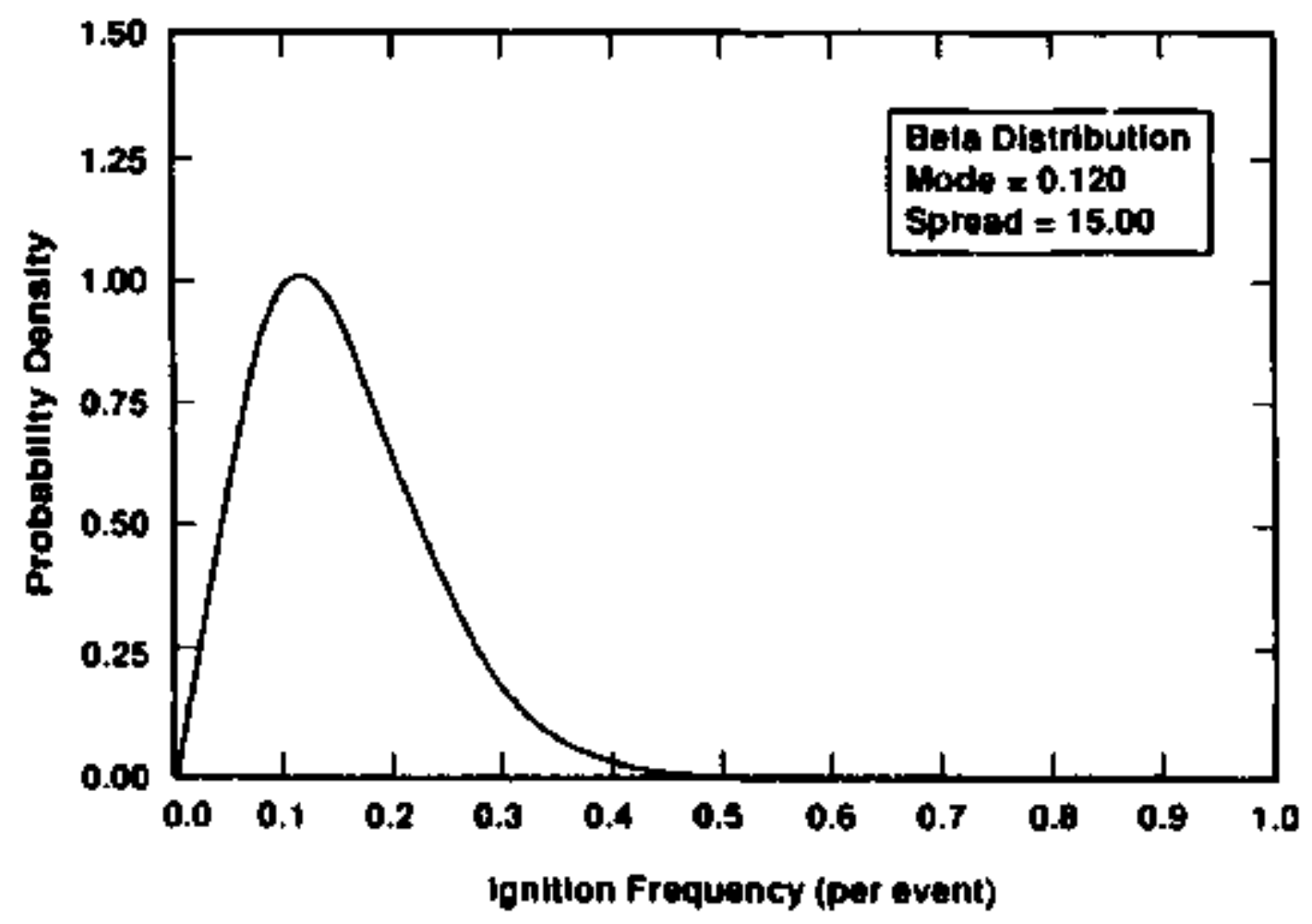

Figure B.S. Frequency of Ignition at Vessel Breach 8 sole Fraction Hydrogen.

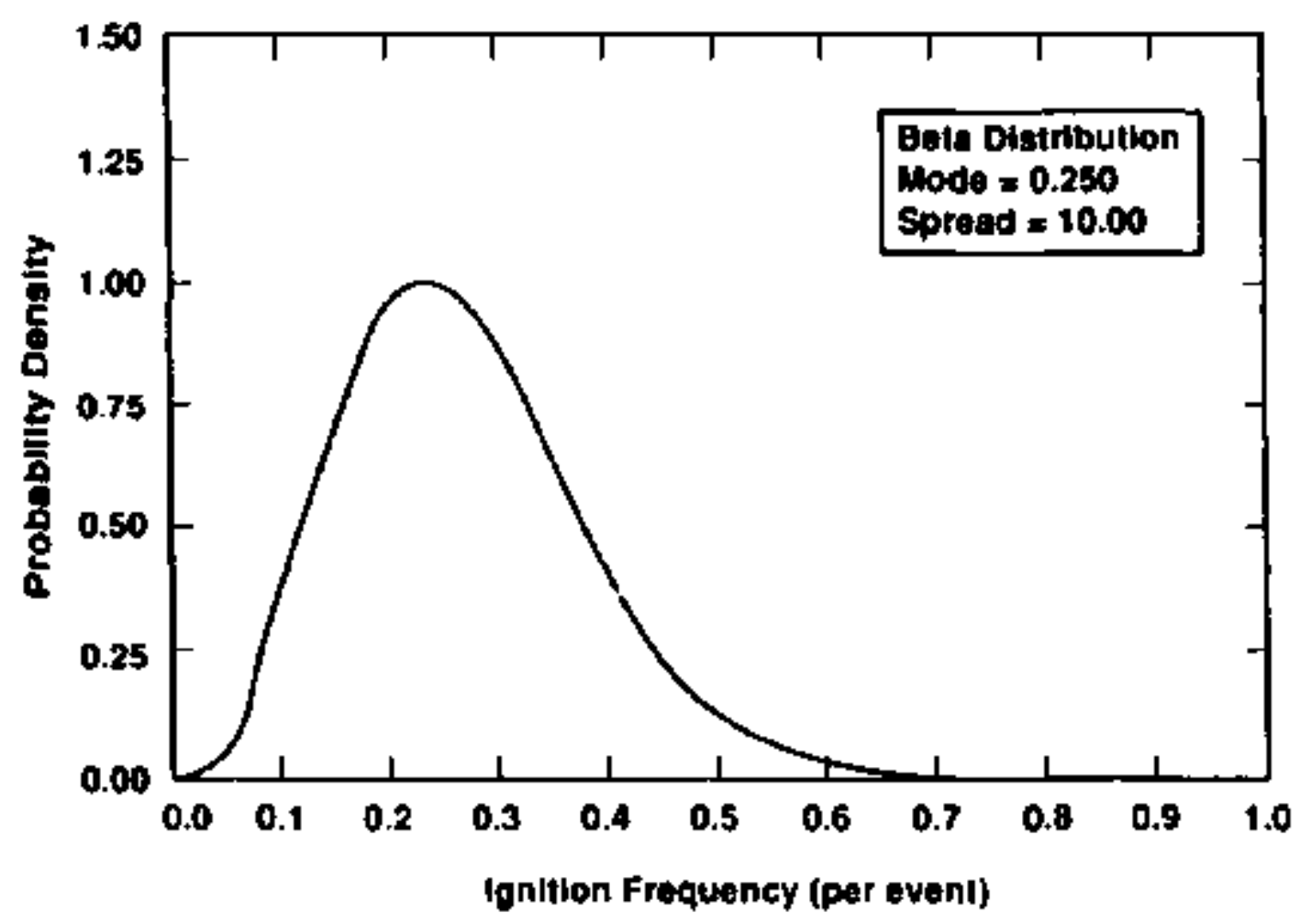

Figure s.6. Fraquency of Igultion at vessel Breach lda Mole fraction Hydrogen. 


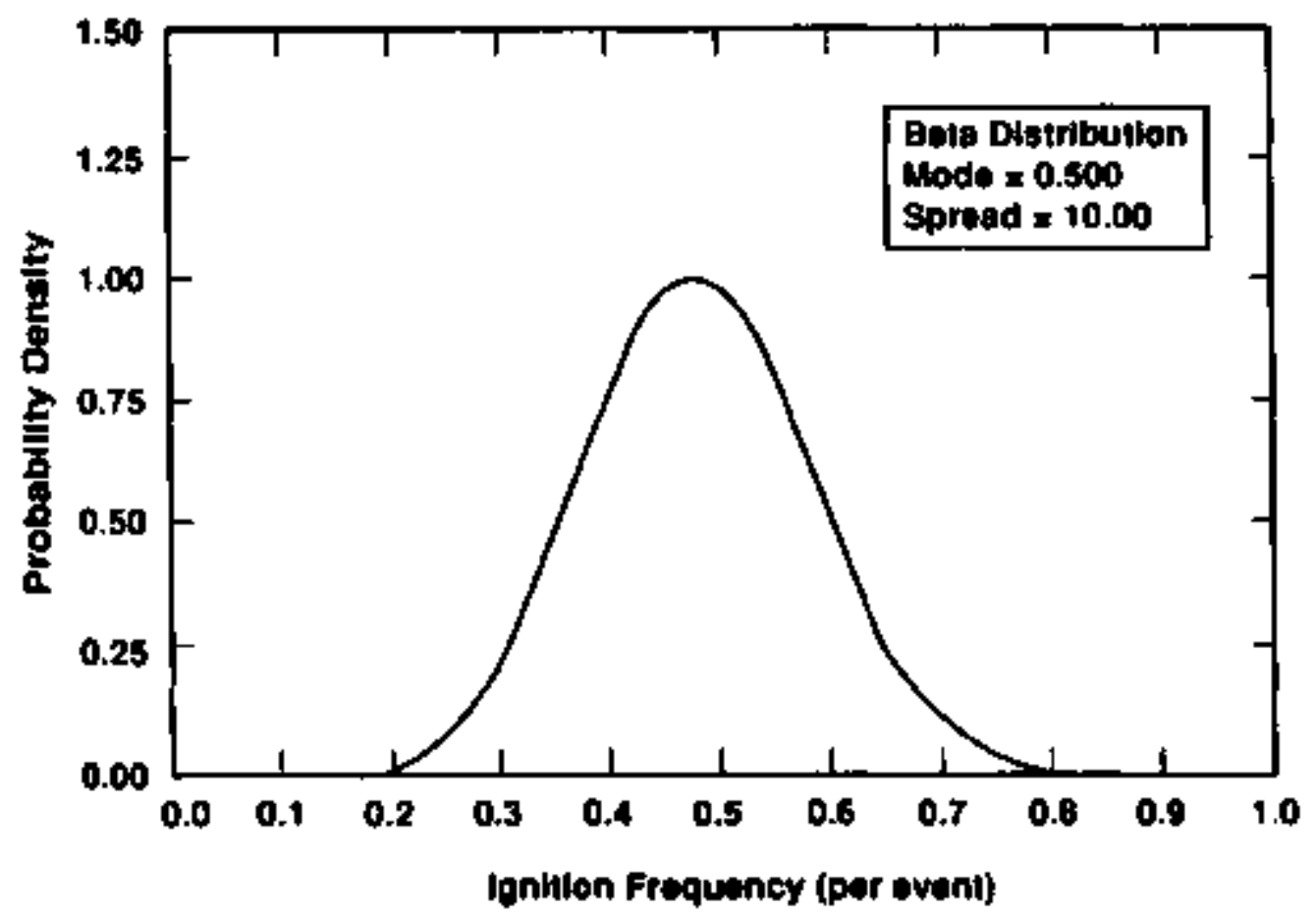

Figure B-7. Frequency of Ignition at Vesend Breach 16t Hole Fraction Hydrogen.

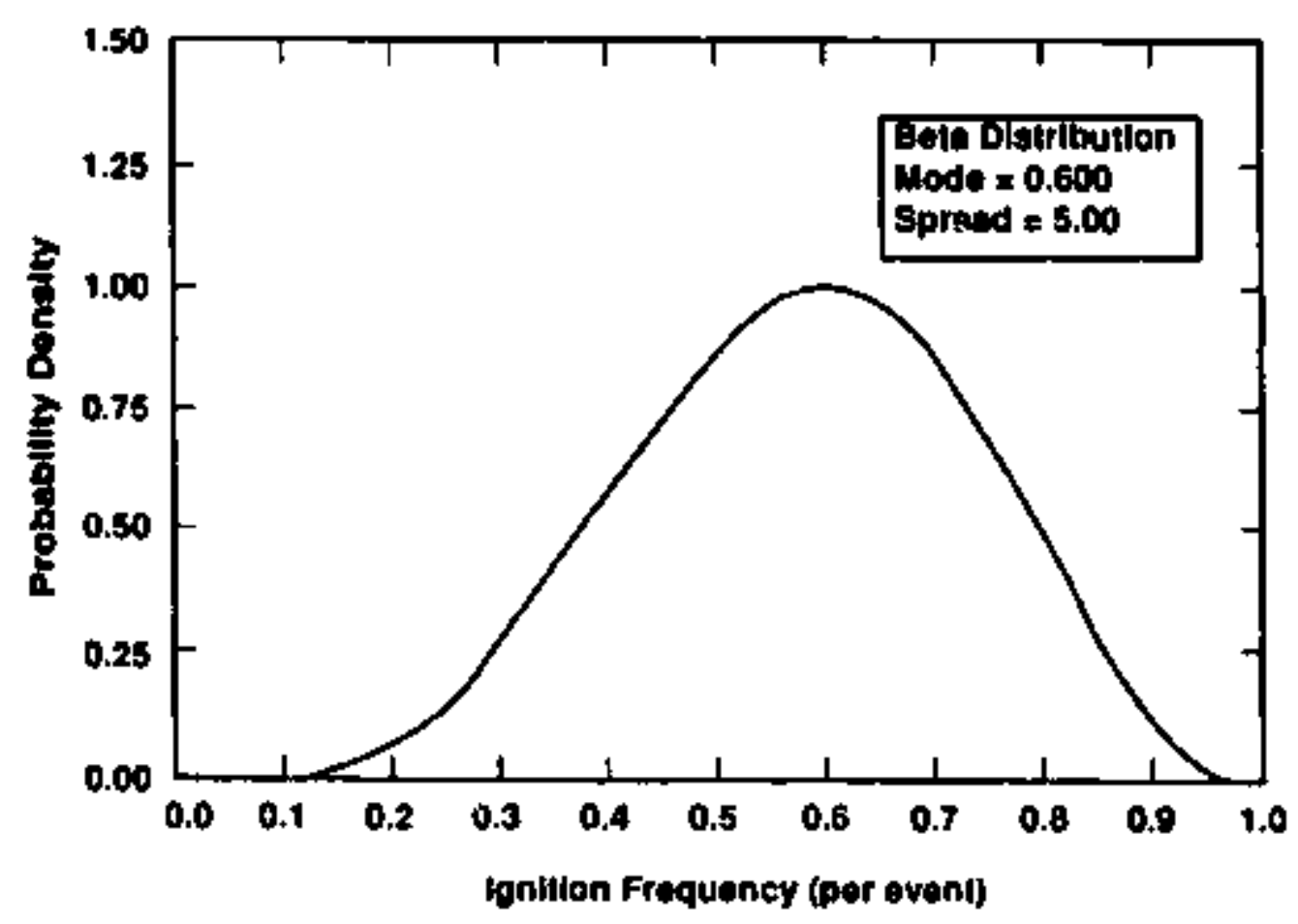

Figure B.8. Frequency of Ignttion at Vessel Breach 16 Mole Fraction Hydrogen. 
Part 3

Deractiotion of Experter's Raclenale/Uethodology

\section{Static Preasure hoad}

Expert B based his assessment on the AICC pressure reaulting fron combustion of a given molar concentration of hydrogan. This daximua pressure vas modified based on the Expert's judgment about the likely completeness of the burn.

Detonation was assessed to be laposslble below a hydrogen nole fraction of 162. Detonation probabilitias and loads were assessed separately (see below).

The adiabotic pressure rlse was assessed for two different levels of invessel zirconiun reaction: 10 and 50. These levels were converted to an equtvalent global hydrogen concentracion in the concalnnent. The AICC pressure was then determined based on these concentrations. These results are shown in Table B. 3 .

Table B-3

Results for Adiabatic Burn Pressure

\begin{tabular}{|c|c|c|c|c|}
\hline $\begin{array}{c}\text { In-Vesse } 1 \\
\text { Zirconiur Reaction }\end{array}$ & $\begin{array}{l}\text { Adlabac } \\
\text { Hydrogen } \\
\text { (MF) }\end{array}$ & $\begin{array}{l}\text { syrn Pr } \\
\text { Stean } \\
\text { (NE) }\end{array}$ & $\begin{array}{l}\text { sure } \\
\text { Afr } \\
\text { infEI }\end{array}$ & $\begin{array}{l}\text { Maxi wun Pressure } \\
\text { (bar) }\end{array}$ \\
\hline $\begin{array}{l}102 \\
504\end{array}$ & $\begin{array}{l}0.079 \\
0.29\end{array}$ & $\begin{array}{l}0.26 \\
0.19\end{array}$ & $\begin{array}{l}0.66 \\
0.52\end{array}$ & 12.5 \\
\hline
\end{tabular}

The Expert based his assessment of burn conpletenesg on: (a) rese th results that compare peaks obtained during combustion experiments at vartous burn factlitles with the corresponding AlcC pressures: (b) discusslons with other panel menbers: and (c) bis knowledge of hydrogen phenomena. Again, a beta distrlbution was chosen to reflect Expert B's Judgment about the uncertalncy in burn completeness. The conpleteness of burn us thought to increase with increasing hydrogen concentration. Expert B agaln selected a beta distribution to reflect his judgment obout the uncertainty in burn comploteness. The completeness of combustion was thought to increase with lncreasing hydrogen concentration. In general. Expert B's uncertalnty in the completeness of the burn was independent of the hydrogen concentration. He thought that reverse vent-clearing, allowing gas flow from the contalsubnt to the drywell would have a regligible tmpact on peok pressure because the time for flow to occur uas long relative to the time requlred for cunbustion.

Expert B belleved that Cases 1 and 2 for this part of the issue would behave idencically. Sprays are Initiaced too late lil case 2 to lapact the peak pressure atcained. He found that Case 3 would be different in that wore steas vould be present in the contafnmetie when lgntion 
occurred. Expert B stated that burn completeness would be unaffected (within the bounds of his uncertainty) by the sprays. Thus, for Case 3 , the pressure attalned would be reduced because the burn was slower, but the burn completeness renains the same as for the low-steam Cases 1 and 2 for a given hydrogen concentration.

\section{Detonation Logd}

Expert B based his assessment of dynamic loads largely on the work prasented by Expert A. Following that expert, he stated that a detonation would produce a load that was independent of t..e hydrogen concentration at which ignition occurted. He felt that there was little uncertafincy in the load induced.

However, the probability of a deconation occurcing was seen to be strongly dependent on the presence of a miniaum hydrogen concentration (16. MF). He statod that with 20. steam present the detonation cell width is only 100 ma, and with the contalnont voluwe being largo and relatively open, a detonation was very unlikely.

\section{Results of Expert B's Elicttation}

As for ignition probability, the range of possible hydrogen concentractons was divided Into intervals. No assesswent was made for greater than 16e hydrogen mole fraction. Expert B felt that at 20 . hydrogen mole fraction the burn completeness would be at least 90 with little uncertainty. This results in a peak static pressure of at lesst 8 bax (116 psia) which is so wuch greater than the assessed containment fallure pressure (71 psia) that elfcitacion of stacir pressure in this range would not benefit the anslysis (1,e., containment fallure could be assured certain). A beta distribution on burn completeness was selected. based on the Expert's judgment. for esch hydrogen concentration selected to discretize the range. These distributions are characterized in Table B-4. The distributions in Table B-4 are shown graphically in Figures B-9 through B-11.

Table B.4

Distribution of Burn Coupleteness

Hydrogen Concentration

(nole fraction)

$\leq 49$

Bะ

12 ง

168

$\geq 20 \mathrm{c}$
Gedien

0.0

0.50

0.70

0.84

0.90
Hade

0.0

0.50

0.70

0.85

c. 90
Spread Factor (n)

$n / a$

so

50

50

$n / a$

Completeness for hydrogen concentration within an incerval is estinated based on linear interpolation for values at the endpoints. 


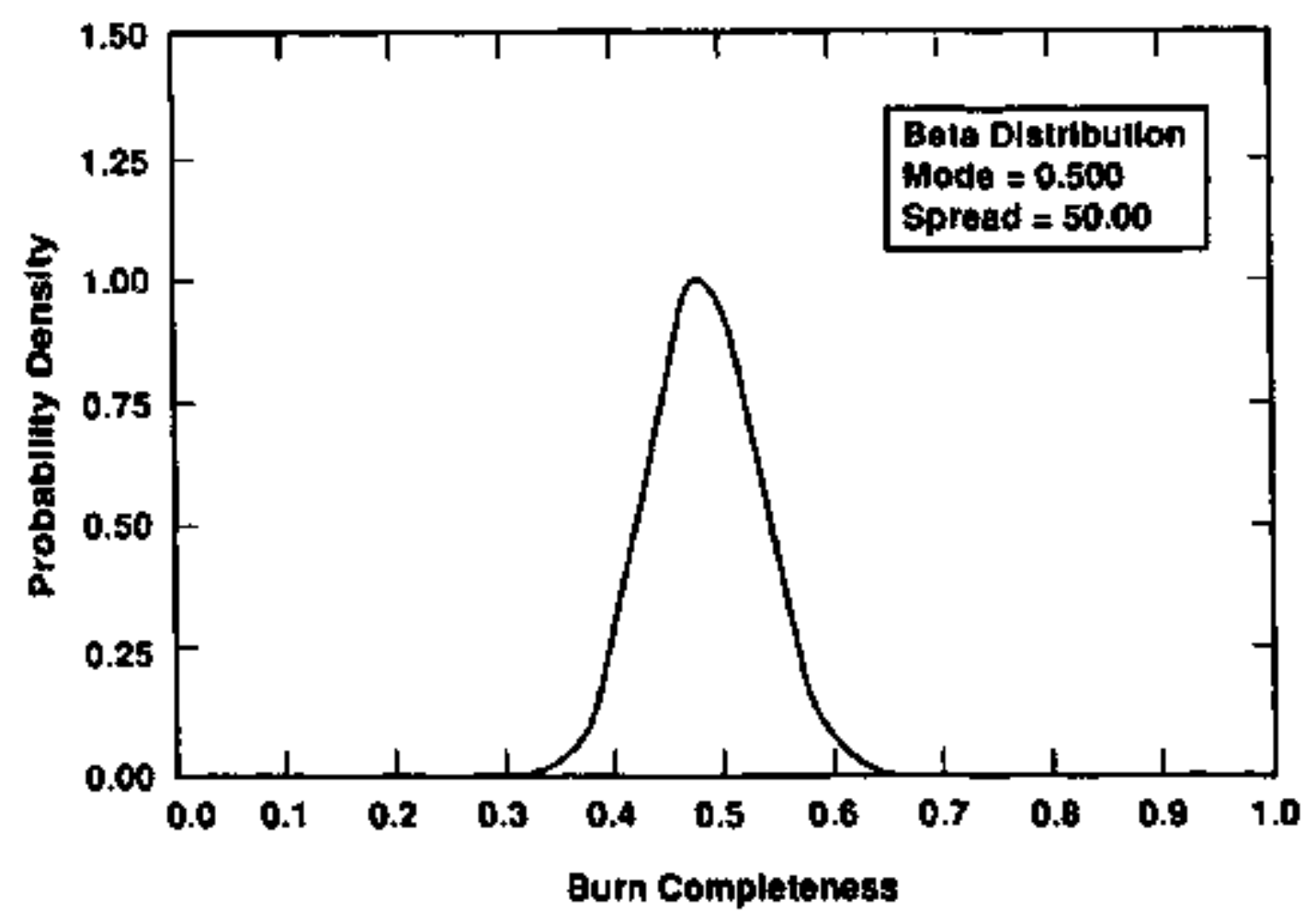

Figure B-9. Completeness of Hydrogen Burn: B: Kole Fraction Hydrogen.

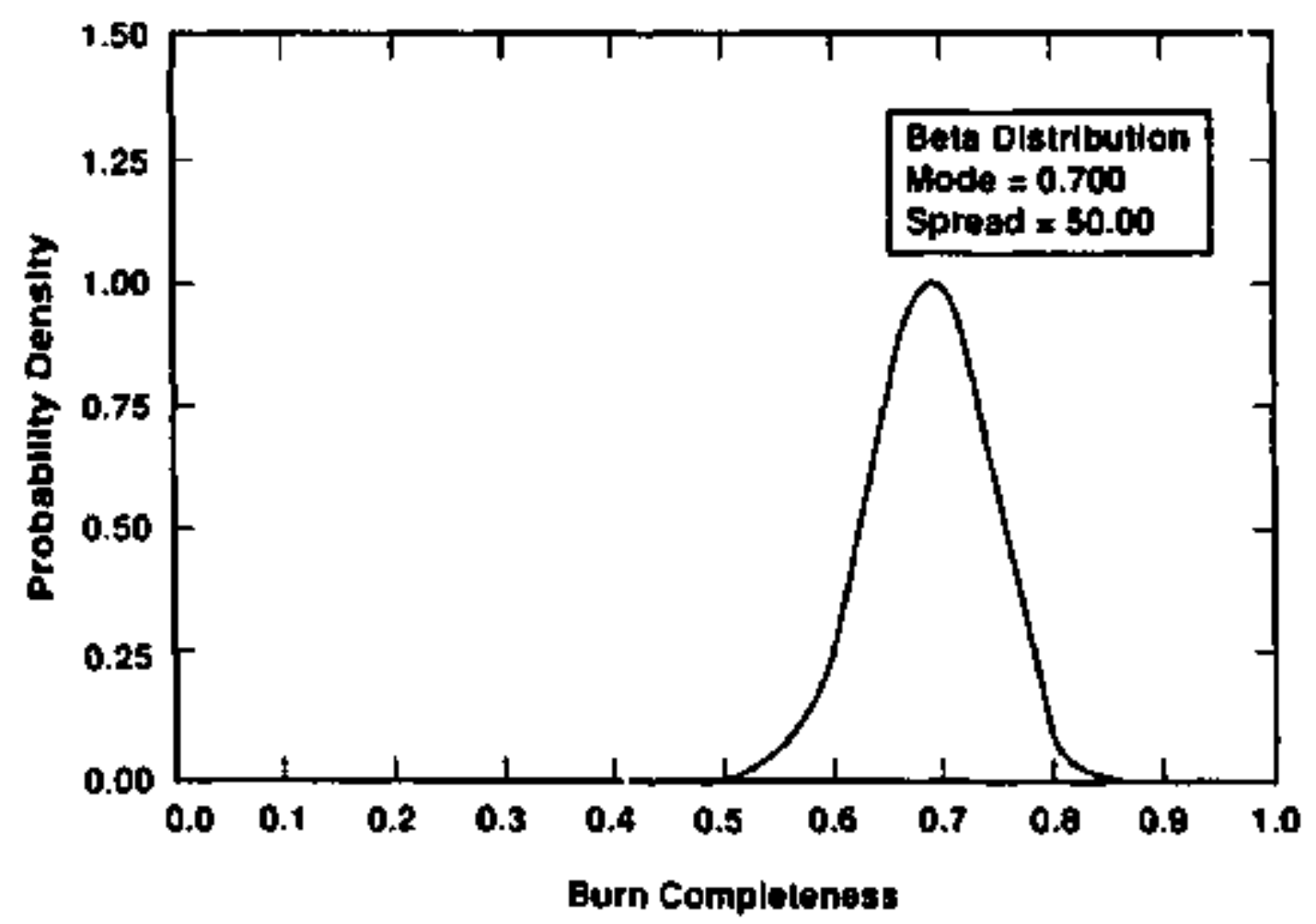

Figure B-10. Completeness of Hydrogen Burn; 12 Hole Fraction Hydrogen. 


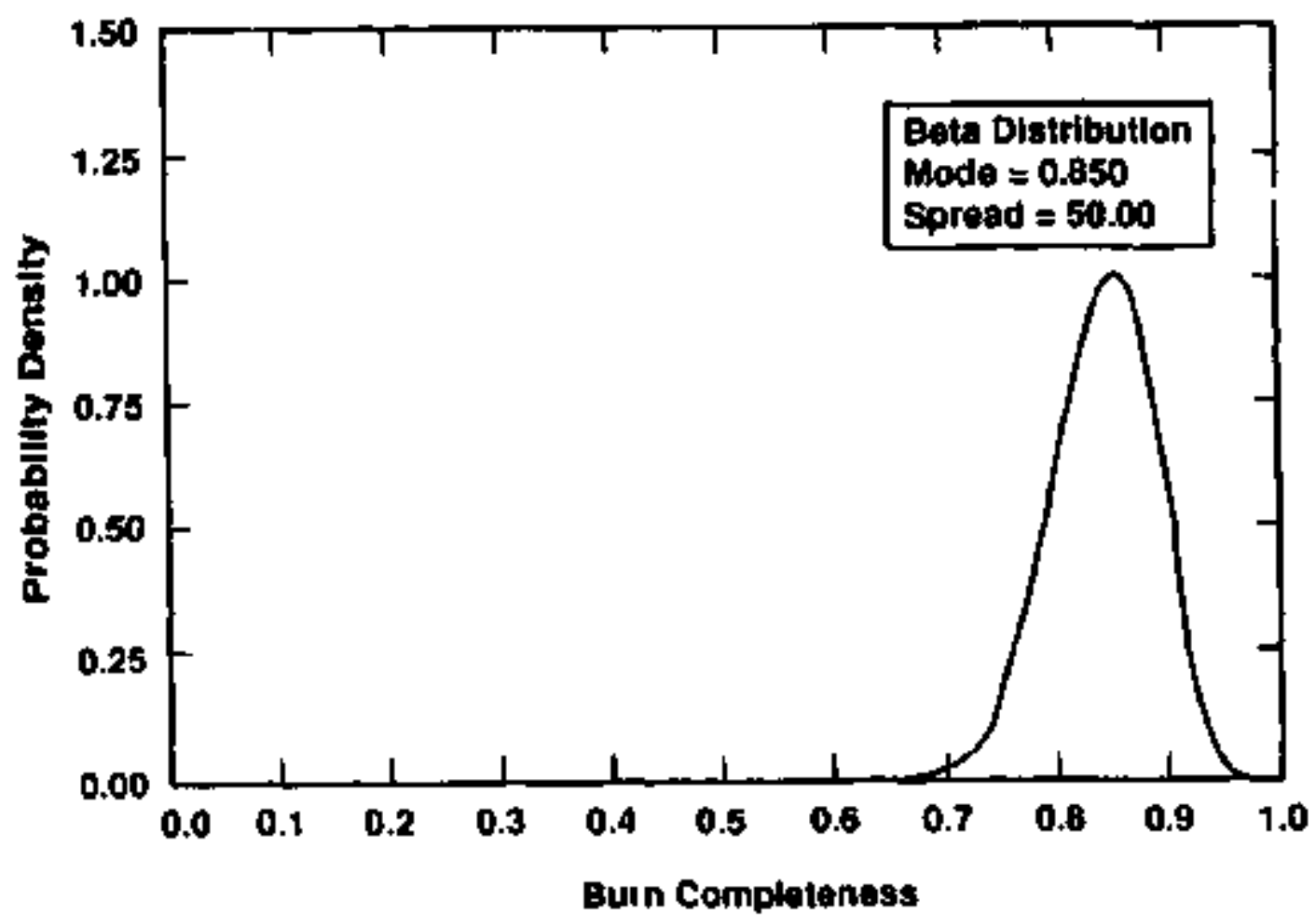

Figure B-ll. Conpleteness of Hydrogen Burn; 16* Male Fraction Hydrogen.

Once the burn coopleteness is obtained. the static pressurizacion of the containment is calculated by oulciplying the adiabatic burn pressure ratio by the burn completeness. For Case 3 of this part of the 1ssue, where the stead concentration is high (1.e.. near the limit for lnerting) and sprays operate. Expert $B$ reduced the burn pressure racio an additional 25t. No reduction in uncertalncy relative to completeness was added to account for enhanced mixing by the sprays.

\section{Detonstion load}

Expert B provided a probability for detonation, givan tiat igaition occurs, as a beta distribucton applicalle for hydrogen concentrations greater thas 20 mole trection. The beta distribution, shown in Figure B-12, is characterized by a mode of 0.10 with a spread charactertzed by $n-10$. The mean of this distribution is 0.15. For hydrogen concentrations between 16 and 20s. the probability obtained from this distribution would be reduced linearly (to 0 at 16 MF). Expert B belfoved that there was litele uncertainty associated with the dynamic load on the drywell wall. A wean value of $12 \mathrm{kPa}+\mathrm{s}$ was belioved to be apfropriate based on presentations by Expert $A$. The upper and lower bounds (which should be tnterpreted as 5 th and $95 \mathrm{th}$ percentile values) were caken as $18 \mathrm{kPH}-\mathrm{s}$ and $6 \mathrm{kPa}-\mathrm{s}$, respectively. A maximuto entropy distribution ts assumed as shown in figure B. 13 . 


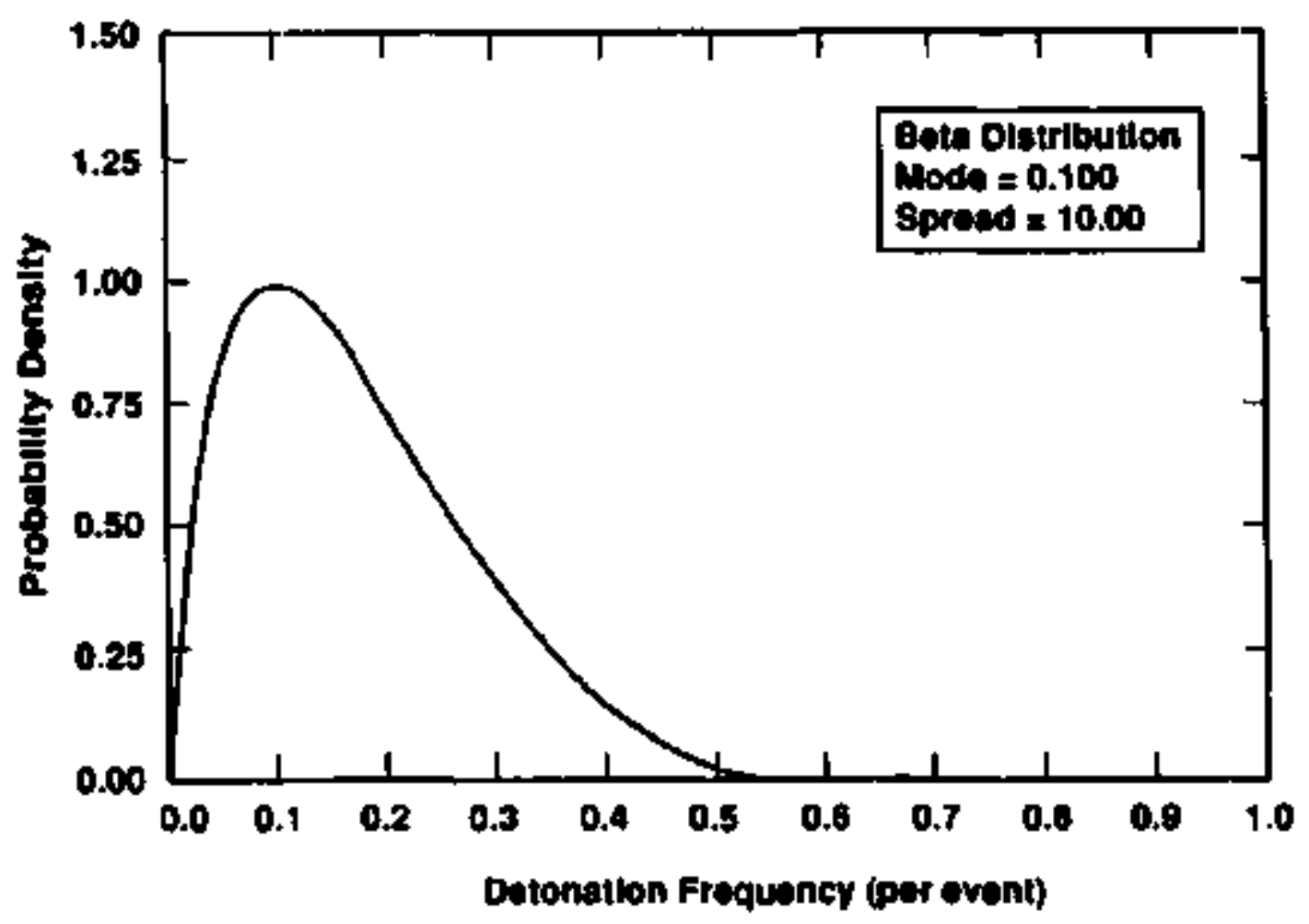

Figure B-12. Frequency of Detonation; At Leat 201 Molo Fraction Hydrogen.

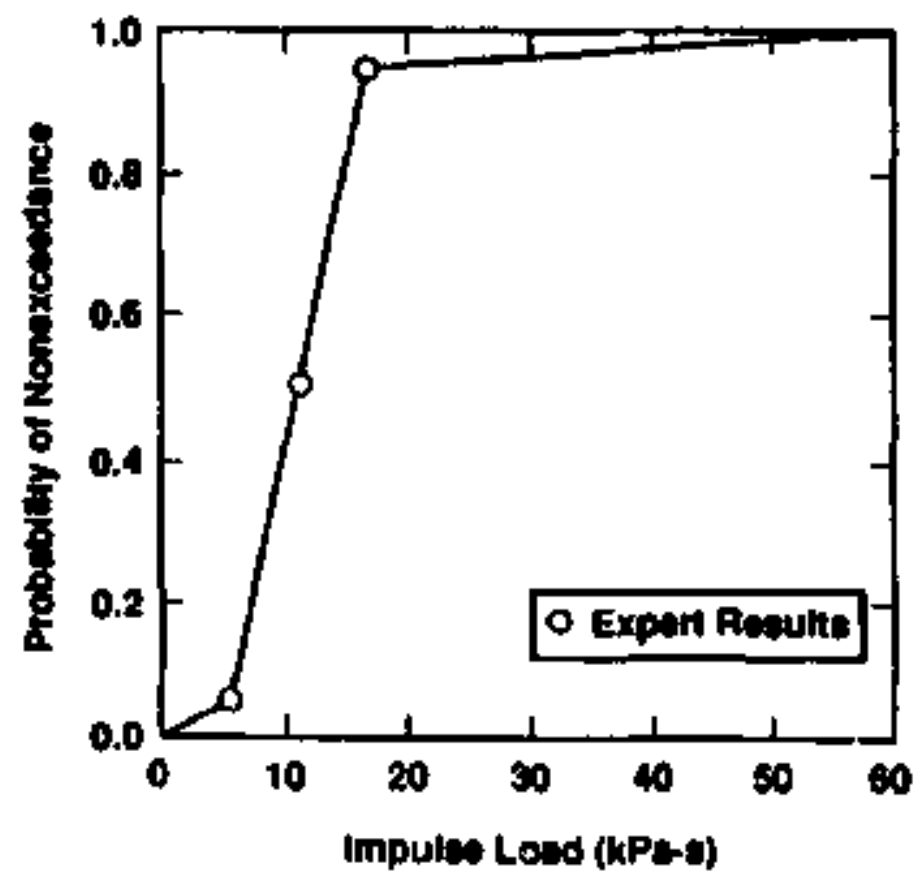

F1gure B-13. Grand Gulf Detonation Loads. 


\section{Sources of Uncertalncy}

\section{Static Pressure Laad}

Provided ignition occurs, burn completeness is belleved to be the greatest uncertalnty. Generally, the uncertainty in the loads produced is sinall relative to the ignition frobability.

\section{Dynamis load}

Expert B belleved that detonation loads are relatively well understood and have little associated uncertainty. Again, the probability of a detanation occurring governs this uncertainty. 


\section{Expert C'E Eldeftetion}

Issue 1. Hydrogen Phenonenon at Grand Gulf

Descripcton of Expert C's Rationale/ Hethodolony

Expert $C$ anslyzed the problem using the following procedure:

1. For Step 1, the three inttial cases vere subdivided into three subcases each on the basis of 10,30 and 508 of cladding and 5 , 15, and 25 of channel boxes reacting.

2. For Step 2, release before vessel fallure, the Expert constructed a CDF for average concentration based on the results of computer code runs for each of the cases in step 1 .

3. For Step 3, the Expert constructed a COF for peak concentration taking into account his judgment about the effects of nodalization and wixing on the realistic peak concentrations expected.

4 For Step 4, the Expert assessed the probability of ignition vs. peak corcentration with uncertainty bounds.

5 For Step 5. The Expert assessed the split fraction for the resulting comb, thon being a diffusion flame, a deflagration, or a detonation vs. peak concentration level.

6 For Step 6. the Expert assessed the peak pressure or inpulse vs, peak concentration.

The Expert used the following cases:

$1 \mathrm{H}_{2}$ Ignition before vessel breach (la-vessel at high pressure; 2a-vessel at low pressure):

2. $\mathrm{H}_{2}$ I gattion at vessel breach (3a);

3 Contdinment loads (lb--1 ow stearn, no sprays; zb--low sceam, spreys).

4 Contalnment loads (3b-hlgh steam, sprays). 


\section{Resulits of Expert C'B Bldcitiation}

Reculcs of the Expert's analysts for each of the cases are given below:

Step 2, Average concentration for all cased $(1 a / 2 a / 3 a)$.

Qunartile

$\begin{array}{llllll} & .0 & .25 & .5 & .75 & 1.0 \\ 108 & .03 & .04 & .045 & .048 & .05 \\ 301 & .08 & .095 & .11 & .12 & .13 \\ 508 & .13 & .15 & .17 & .185 & .20\end{array}$

Stop: 3 and 3', Peak concentration $(14 / 2 a, 3 a)$.

To go from average to peak concentretion, sample the average concentration curve: then pick the sane quartile for the peak concentration.

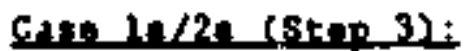

\begin{tabular}{cccccc} 
& \multicolumn{5}{c}{ Ouarelle } \\
\cline { 3 - 5 } & .0 & .25 & .5 & .75 & 1.0 \\
10. & .03 & .04 & .03 & .06 & .08 \\
s0. & .08 & .10 & .115 & .13 & .16 \\
& .13 & .15 & .175 & .2 & .23
\end{tabular}

Gate 3. (Stap 3. 3):

Qunartile

$\begin{array}{llllll} & 0 & .25 & .5 & .75 & 1.0 \\ 10 . & .05 & .052 & .055 & .065 & .08 \\ 10 . & .15 & .152 & .155 & .165 & .18 \\ 50 . & .23 & .233 & .24 & .25 & .26\end{array}$

For this analysis, the concentration will be deternined by ocher experts. Therefore, wo convert the peak concentration to average cincentration for the various subcases, which dffferentlate betwen the axtent of the zirconiue reaction. Fros the In-vessel group, we obtained the probabillty of the $1 n$-vessel welt progression reacting $x$ of the total zirconium. This Expert' a value of $x t z i r c o n f u n$ in cladding and $x / 2$ of the rest converts to (1) $50+250-404$, (2) $30+151-243$, and (3) $10+51=82$ total ziccontun reacted. By groupling the in.vessel experts' results, we can velght tho medlun and high zirconiun cases in order to average over them at polnts where the cesee overlap. For the two in-vessel cases: (1) 0 to 160 


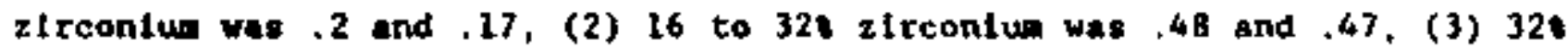
to 56 or 64 zirconius vas .32 and .36. Avaraging low - .185, addiun .475 , high -.34 and the velghte are .583 for aediun and .417 for h1gh.

Peak, Concentration

\begin{tabular}{|c|c|c|c|c|c|c|}
\hline \multirow[b]{2}{*}{ Axerage Concentration } & \multicolumn{3}{|c|}{$19 / 24$} & \multicolumn{3}{|c|}{3.} \\
\hline & 101 & $30:$ & 501 & 101 & 303 & 508 \\
\hline .03 & .03 & - & * & .05 & e & * \\
\hline .4 & .04 & . & * & .052 & $=$ & . \\
\hline .045 & .05 & . & . & .055 & . & $=$ \\
\hline .048 & .06 & - & - & .065 & - & - \\
\hline .05 & .00 & - & - & .08 & - & . \\
\hline .08 & - & .08 & - & - & .15 & - \\
\hline .095 & - & .10 & • & - & .152 & . \\
\hline .11 & - & .115 & - & - & .155 & * \\
\hline .12 & . & .13 & - & . & .165 & - \\
\hline .13 & $=$ & .16 & .13 & $=$ & .18 & .23 \\
\hline .15 & - & - & .15 & - & - & .233 \\
\hline .27 & - & - & .175 & - & - & .24 \\
\hline .185 & - & - & .2 & • & - & 25 \\
\hline .2 & - & - & .23 & - & - & 26 \\
\hline
\end{tabular}

By averaging, the three scenartos can be comblned as follows:

Peak_Concentratloll

\begin{tabular}{|c|c|c|}
\hline Averace Cencentration & $1 \mathrm{a} / 2 \mathrm{a}$ & 38 \\
\hline .03 & 03 & .05 \\
\hline .04 & 04 & .052 \\
\hline .045 & 05 & .055 \\
\hline $.04 B$ & .06 & .065 \\
\hline .05 & .0R & .08 \\
\hline .08 & .08 & .15 \\
\hline .095 & .10 & .152 \\
\hline .11 & .115 & .135 \\
\hline .12 & .13 & .165 \\
\hline .13 & .143 & .20 \\
\hline+15 & .15 & .233 \\
\hline .17 & 175 & .24 \\
\hline .285 & .20 & .25 \\
\hline .2 & .23 & 26 \\
\hline
\end{tabular}


Steps 4 and 5, ignition probab1lity and split fraction.

Gase 1a/2a: Ienticion Probability

Pegk Concentration

\begin{tabular}{lllllll}
\hline .02 & .04 & .08 & .12 & .16 & .20 & .24 \\
0 & 0 & .125 & .3 & .55 & .7 & .75 \\
0 & 0 & .05 & .15 & .4 & .55 & .60 \\
0 & 0 & .025 & .1 & .35 & .475 & .50
\end{tabular}

95 fractilo

SD fractile

.05 fractle

95 fractile

.05 fractile

.95 fractile

. 50 fractile

.05 fractile

95 fractile

.50 fractile

. 05 fractile

\begin{tabular}{ccccc}
\multicolumn{5}{c}{ Average Concentration 108 } \\
\hline .03 & .04 & .045 & .048 & .05 \\
0 & 0 & .042 & .083 & .125 \\
0 & 0 & .017 & .033 & .05 \\
0 & 0 & .008 & .017 & .025
\end{tabular}

Average Concentration 30:

\begin{tabular}{lllll}
\hline .08 & .095 & .11 & .12 & .13 \\
.125 & .213 & .278 & .363 & .55 \\
.05 & .10 & .138 & .213 & .40 \\
.025 & .063 & .091 & .163 & .35
\end{tabular}

Average Concentration 50 s

Gase 3a: villtipler of Case 1a/2a

Peak Concentration

$\begin{array}{lcccccc} & .04 & .08 & .12 & .16 & .20 & .24 \\ \text { Blowdown } & 1.1 & 1.1 & 1.1 & 1.1 & 1.05 & 1.05 \\ \text { Blowdown + HPME } & 1.5 & 1.5 & 1.5 & 1.4 & 1.3 & 1.3 \\ \text { Blowdown + Expl. } & 1.2 & 1.2 & 1.2 & 1.2 & 1.2 & 1.2 \\ \text { DW hydrogen burn } & 1.5 & 1.4 & 1.3 & 1.2 & 1.2 & 1.05 \\ \text { Average } & 1.3 & 1.3 & 1.3 & 1.2 & 1.2 & 1.2\end{array}$


To get the probability of Ignition at vessel breach, multiply the ignition probability for the case bafore vessel breach by the appropriate case. however, the in-vessel panel for bolling water reactor (BWR) botton head failure did not glve enough information to separate the various cases. We will therefore average over the cases.

Peak Concentication

$\begin{array}{lccccccc} & .02 & .04 & .08 & .12 & .16 & .20 & .24 \\ .95 \text { fractile } & 0 & 0 & .163 & .39 & .66 & .84 & .90 \\ .50 \text { fractile } & 0 & 0 & .065 & .195 & .48 & .66 & .72 \\ .05 \text { fractile } & 0 & 0 & .033 & .13 & .42 & .57 & .60\end{array}$

.95 fractile

.50 fractile

.0S fractile

95 fractile

So fractile

.05 fractile

.95 fractile

50 fractile

05 fractile

Axerage Concentration 10 :

\begin{tabular}{lllll}
\hline \multicolumn{5}{c}{ Average concentration 108} \\
.03 & .04 & .045 & .048 & .05 \\
& & & & \\
.041 & .049 & .061 & .083 & .163 \\
.016 & .020 & .024 & .033 & .065 \\
.008 & .010 & .012 & .017 & .033
\end{tabular}

Average Concencration 309

$\begin{array}{lllll}.08 & .095 & .11 & .12 & .13 \\ & & & & \\ .593 & .606 & .626 & .683 & .75 \\ .409 & .423 & .444 & .503 & .57 \\ .348 & .362 & .384 & .439 & .495\end{array}$

Averare Concentration 50 .

$\begin{array}{lllll}.13 & .15 & .17 & .185 & .20 \\ .885 & .890 & .90 & .90 & .90 \\ .705 & .710 & .72 & .72 & .72 \\ .593 & .595 & .60 & .60 & .60\end{array}$




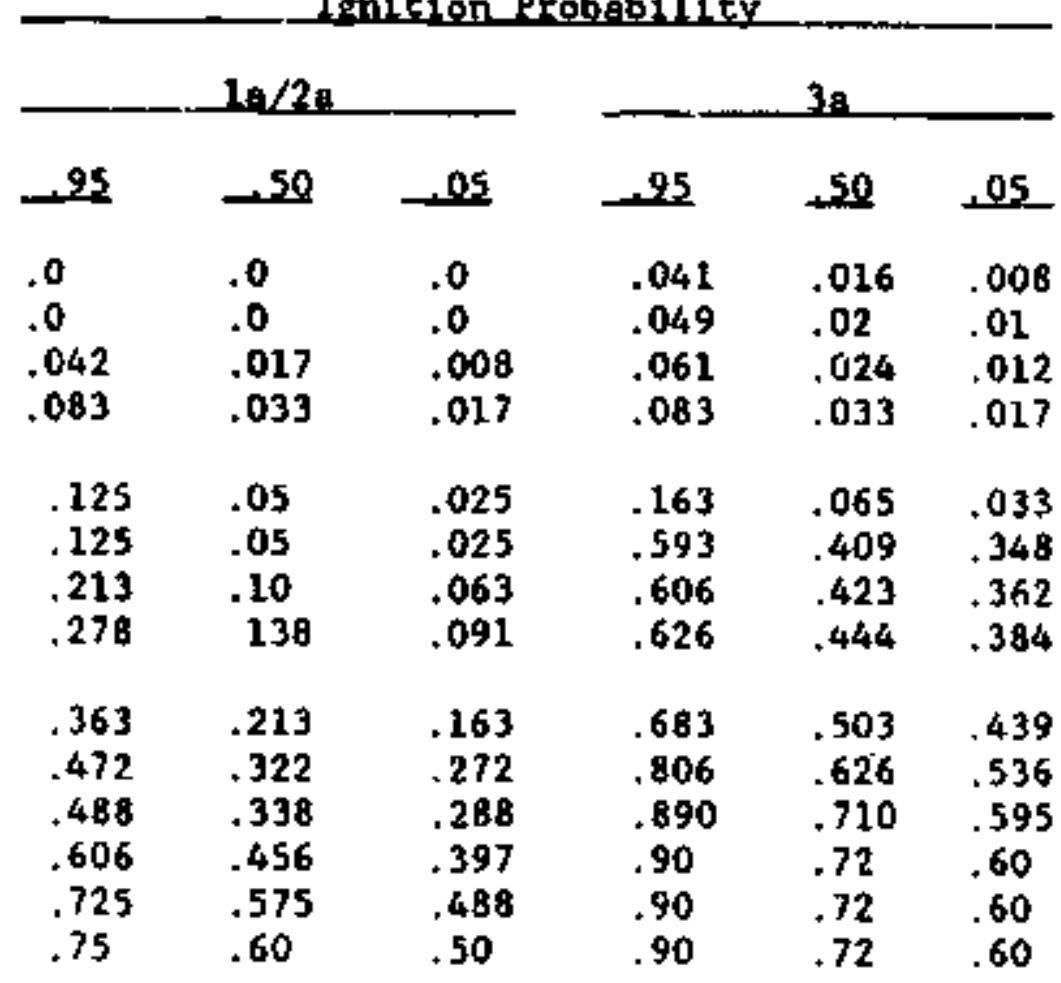

\section{Case in/2u/3aisndit fraction}

Peak Goncentration

\begin{tabular}{lccccccc}
\cline { 2 - 7 } & .02 & .04 & .08 & .12 & .16 & .20 & .24 \\
Diffugion Flane & 0 & .5 & .5 & 0 & 0 & 0 & 0 \\
Deflagration & 0 & .5 & .5 & 1 & .65 & .45 & .25 \\
Detonation & 0 & 0 & 0 & 0 & .35 & .55 & .75
\end{tabular}

For csese 1a/2a

\begin{tabular}{|c|c|c|c|c|c|}
\hline & \multicolumn{5}{|c|}{ Averate Concentration lot } \\
\hline & .03 & .04 & .045 & .048 & .05 \\
\hline \multirow[t]{3}{*}{$\begin{array}{l}\text { Diffusion } \\
\text { Deflagration } \\
\text { Detongtion }\end{array}$} & $\begin{array}{l}0 \\
0 \\
0\end{array}$ & $\begin{array}{l}.5 \\
.5 \\
0\end{array}$ & $\begin{array}{r}.5 \\
.5 \\
0\end{array}$ & $\begin{array}{l}.5 \\
.5 \\
0\end{array}$ & $\begin{array}{l}.5 \\
.5 \\
0\end{array}$ \\
\hline & \multicolumn{5}{|c|}{ Average Conrentration 302 } \\
\hline & .08 & .095 & .11 & .12 & .13 \\
\hline $\begin{array}{l}\text { D1ffusion } \\
\text { Deflagration } \\
\text { Detonation }\end{array}$ & $\begin{array}{l}.5 \\
.5 \\
0\end{array}$ & $\begin{array}{l}.25 \\
.75 \\
0\end{array}$ & $\begin{array}{l}.062 \\
.938 \\
0\end{array}$ & $\begin{array}{l}0 \\
.912 \\
.088\end{array}$ & $\begin{array}{l}0 \\
.65 \\
.35\end{array}$ \\
\hline
\end{tabular}




$\begin{array}{lccccc} & .13 & .15 & .17 & .185 & .20 \\ \text { Diffusion } & .13 & & & & \\ \text { Deflagration } & 0 & 0 & 0 & 0 & 0 \\ \text { Detoriation } & .912 & .738 & .575 & .45 & .3 \\ & .086 & .262 & .425 & .55 & .7\end{array}$

\section{For Gase 3 .}

Ayersge Concentration 109

\begin{tabular}{lccccc} 
& \multicolumn{5}{c}{ Avergige Concentration 108 } \\
\cline { 2 - 6 } & .03 & .04 & .045 & .048 & .05 \\
Diffusion & .5 & .5 & .5 & .5 & .5 \\
Deflagration & .5 & .5 & .5 & .5 & .5 \\
Detonation & 0 & 0 & 0 & 0 & 0
\end{tabular}

Diffusion

Deflagretion

Detonation

Diffusion

Deflegration

Detonation

Average Concentration 303

\begin{tabular}{lllll}
\hline & & & \\
.08 & .095 & .11 & .12 & .13 \\
0 & 0 & 0 & 0 & 0 \\
.738 & .72 & .694 & .55 & .45 \\
.262 & .28 & .306 & .45 & .55
\end{tabular}

Averace Consentration 503

\begin{tabular}{ccccc}
\multicolumn{5}{c}{ Average Concentration S08 } \\
\hline & .15 & .17 & .185 & .20 \\
.13 & .15 & 0 & 0 & 0 \\
0 & 0 & .285 & .25 & .25 \\
.3 & .285 & .25 & .75 & .75
\end{tabular}

Mode of Combustion

\begin{tabular}{|c|c|c|c|c|c|c|}
\hline \multirow[b]{2}{*}{ Average Concentration } & \multicolumn{3}{|c|}{$1, / 2 a$} & \multicolumn{3}{|c|}{$3 a$} \\
\hline & $\mathrm{DF}$ & DEF & DET & $\mathrm{DF}$ & DEF & DET \\
\hline .03 & .0 & .0 & .0 & .5 & .5 & .0 \\
\hline .04 & .5 & .5 & .0 & .5 & .5 & .0 \\
\hline .045 & .5 & .5 & .0 & .5 & .5 & .0 \\
\hline .048 & .5 & +5 & .0 & .5 & .5 & .0 \\
\hline .05 & .5 & .5 & .0 & .5 & .5 & .0 \\
\hline .08 & .5 & .5 & .0 & .0 & .738 & .262 \\
\hline .095 & .25 & .75 & .0 & .0 & .72 & .28 \\
\hline .11 & .062 & .938 & .0 & .0 & .694 & .306 \\
\hline
\end{tabular}


Mode of Combustion (continued)

\begin{tabular}{|c|c|c|c|c|c|c|}
\hline \multirow[b]{2}{*}{ Averate Concencration } & \multicolumn{3}{|c|}{$1 \mathrm{a} / 2 \mathrm{~B}$} & \multicolumn{3}{|c|}{$3 \mathrm{a}}$. \\
\hline & DF & DEF & DET & $\mathrm{DF}$ & DEF & DET \\
\hline .12 & .0 & .912 & .088 & .0 & .55 & .45 \\
\hline .13 & .0 & .759 & .241 & .0 & .388 & .613 \\
\hline .15 & .0 & .738 & .262 & 0 & .285 & .715 \\
\hline .17 & .0 & .575 & .425 & .0 & .25 & .75 \\
\hline .185 & .0 & .45 & .55 & .0 & .25 & .75 \\
\hline .2 & .0 & .30 & .70 & .0 & .25 & .75 \\
\hline
\end{tabular}

Stup 6, Peak pressure, all coses $(1 a / 2 a / 3 a)$.

Peak pressure (bars) diffusion flames

Peak_Concentration

.04
.08
.12

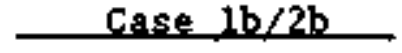

1.25

1.75

2.25

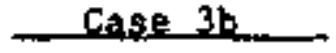

1.25

2.25

3.00

Case_1b/2b

Average Concentration 10 :

$\begin{array}{lccccr} & .03 & .04 & .045 & .048 & .05 \\ \text { Feak Pressure } & 0 & 1.25 & 1.38 & 1.50 & 1.75\end{array}$

Average Concentration 30 :

Peak Pressure

$\begin{array}{rrrrr}.08 & .095 & .11 & .12 & .13 \\ 1.75 & 2.00 & 2.19 & 2.25 & -.\end{array}$

Average Concentration $50 \mathrm{a}$

Peak Pressure

$\begin{array}{lccc}.15 & .17 & .185 & .20 \\ - & . & * & .\end{array}$


Case 3b

Average Copcentration 108

$\begin{array}{lrrrrr} & .03 & .04 & .045 & .048 & .05 \\ \text { Peak Pressure } & 1.38 & 1.40 & 1.44 & 1.56 & 1.75\end{array}$

Peak Pressure

Averace Concentration $30 \mathrm{z}$

\begin{tabular}{lllll}
\multicolumn{4}{c}{ Average Concentration 308} \\
\hline .08 & .095 & .11 & .12 & .13
\end{tabular}

Average Concentration 509

Peak Pressure

$\begin{array}{llll}.15 & .17 \quad .185 & .20\end{array}$

Peak Pressure (bars) deflagrations or post-impulse detorations

Peak Concentration

.04

.08

.12

.16

.22

.26

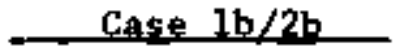

1.25

3.00

4.50

5.50

6.00

6.50
Case 3b

1.75

4.25

6,25

7,75

9.00

10.00

Case $1 b / 2 b$

Averaqe Concentration 104

Peak Pressure

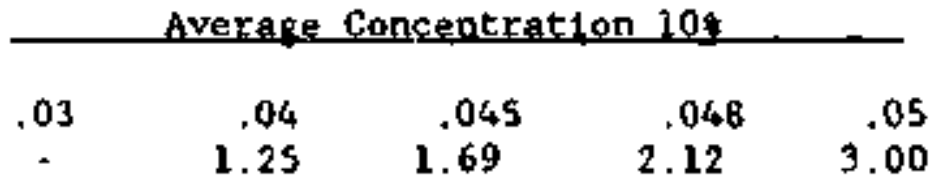

Peak Pressure

.08

Average Concencration $30 \mathrm{~s}$

$\begin{array}{rrrrr}.08 & .095 & .11 & .12 & .13 \\ 3.00 & 3.75 & 4.31 & 4.75 & 5.50\end{array}$

Average Concentration 50 :

Peak Pressure

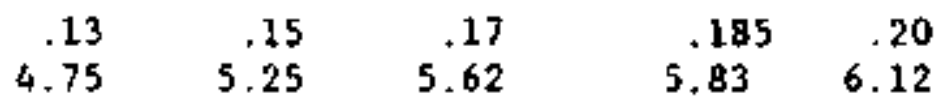

.185

.20 
Gase $3 b$

\begin{tabular}{|c|c|c|c|c|c|}
\hline \multirow[b]{2}{*}{ Peak Presaure } & \multicolumn{5}{|c|}{ Aver ape Concentration 102} \\
\hline & $\begin{array}{r}03 \\
2.38\end{array}$ & $\begin{array}{r}.04 \\
2.50\end{array}$ & $\begin{array}{l}.045 \\
2.69\end{array}$ & 3.048 & $\begin{array}{r}.05 \\
4.25\end{array}$ \\
\hline & \multicolumn{5}{|c|}{ Average Concentration 308} \\
\hline Peak Pressure & $\begin{array}{r}.08 \\
7.38\end{array}$ & $\begin{array}{r}.09 \\
7.45\end{array}$ & $\begin{array}{r}.11 \\
7.56\end{array}$ & $\begin{array}{r}.12 \\
7.85\end{array}$ & $\begin{array}{r}.13 \\
\text { B. } 17\end{array}$ \\
\hline
\end{tabular}

Ayerage Concentration 50 s

$\begin{array}{lrrrrr} & .13 & .15 & .17 & .185 & .20 \\ \text { Peak Pressure } & 9.25 & 9.32 & 9.50 & 9.75 & 10.00\end{array}$

The Initial pressure given by the Expert is not what we calculate, so we will adjust by subtracting 1.25 and 1.75 for $1 b / 2 b$ and $3 b$ diffusion flamo and add back 1.65 for $1 b / 2 b$ and 2.55 for $3 b$.

Peak Pressure

\begin{tabular}{|c|c|c|c|c|}
\hline \multirow[b]{2}{*}{ Average Concentration } & \multicolumn{2}{|c|}{$1 / 2 / a$} & \multicolumn{2}{|r|}{32} \\
\hline & DF & DEF_DET & DE & $\mathrm{DEF} / \mathrm{DEF}$ \\
\hline .03 & - & - & 1.38 & 2.38 \\
\hline .04 & 1.25 & 1.25 & 1.40 & 2.50 \\
\hline .045 & 1.38 & 1.69 & 1.44 & 2.69 \\
\hline .048 & 1.50 & 2.12 & 1.56 & 3,31 \\
\hline .as & 1.75 & 3.00 & 1.75 & 4.25 \\
\hline .08 & 1.75 & 3.00 & - & 7.38 \\
\hline .095 & 2.00 & 3.75 & - & 7.45 \\
\hline .11 & 2,19 & 4,31 & - & 7.56 \\
\hline .12 & 2.25 & 4.75 & * & 7.85 \\
\hline .13 & - & 5.19 & - & 8.62 \\
\hline .15 & - & 5.25 & - & 9.32 \\
\hline .17 & - & 5.62 & $=$ & 9.50 \\
\hline .185 & . & 5.83 & • & 9.75 \\
\hline .2 & - & 6.12 & - & 10.0 \\
\hline
\end{tabular}




\begin{tabular}{|c|c|c|c|c|}
\hline \multirow[b]{3}{*}{ Avorage Concentration } & \multicolumn{4}{|c|}{ Peak Pressure (adjusted) } \\
\hline & \multicolumn{2}{|c|}{ In/2a } & \multicolumn{2}{|c|}{$3 \mathrm{a}$} \\
\hline & DF & $\mathrm{DEF} / \mathrm{DET}$ & DF & $\mathrm{DEF} / \mathrm{DET}$ \\
\hline .03 & - & - & 2.68 & 3.18 \\
\hline .04 & 1.65 & 1.65 & 2.70 & 3.30 \\
\hline .045 & 1.78 & 2.09 & 2.74 & 3.49 \\
\hline .048 & 1.90 & 2.52 & 2.86 & 4.11 \\
\hline .05 & 2.15 & 3.40 & 3.05 & 5.05 \\
\hline $.0 B$ & 2.15 & 3.40 & - & 8.18 \\
\hline .095 & 2.40 & 4.15 & - & 8.25 \\
\hline .11 & 2.59 & 4.71 & - & 8.36 \\
\hline .12 & 2.65 & 5.15 & . & 8.65 \\
\hline .13 & - & 5.59 & - & 9.42 \\
\hline .15 & - & 5.65 & - & 10.12 \\
\hline .17 & - & 6.02 & - & 10.3 \\
\hline .185 & - & 6.23 & - & 10.55 \\
\hline .2 & - & 6.52 & - & 10.8 \\
\hline
\end{tabular}

Peak Inpulse (kPa-g)

$\begin{array}{cccc}\text { Peak Eoncentration } & .05 & .50 & .95 \\ & & & \\ .12 & 0 & 0 & 0 \text { (our extrapolation) } \\ .16 & 1.00 & 1.00 & 1.00 \\ .20 & 1.50 & 2.00 & 4.50 \\ .24 & 4.00 & 5.00 & 10.00 \\ .26 & 6.50 & 8.00 & 15.00\end{array}$

Csse $1 b / 2 b$

$\begin{array}{ll}.95 & \text { Impulse } \\ .50 & \text { Inpulse } \\ .05 & \text { Impulse }\end{array}$

$\begin{array}{ll}.95 & \text { Impulse } \\ .50 & \text { Inpulse } \\ .05 & \text { Impulse }\end{array}$
Augrage Concentration 10:

$\begin{array}{lllll}0.03 & 0.04 & 0.045 & 0.048 & 0.05 \\ 0 & 0 & 0 & 0 & 0 \\ 0 & 0 & 0 & 0 & 0 \\ 0 & 0 & 0 & 0 & 0\end{array}$

Avernge Concentration 30.

$\begin{array}{lllll}0.08 & 0.095 & 0.11 & 0.12 & 0.13 \\ 0 & 0 & 0 & 0.25 & 1 \\ 0 & 0 & 0 & 0.25 & 1 \\ 0 & 0 & 0 & 0.25 & 1\end{array}$


.95 Impulse

.50 Impulse

.05 Inpulse

Case 3b

.95 Impulse

.50 Inpulse

.05 Impluse

.95 Inpulse

.50 Impulse

.05 Impulse

.95 Impulse

.50 Inpulse

.05 Impulse

Average Concentration 508

$\begin{array}{lllll}0.13 & 0.15 & 0.17 & 0.185 & 0.20 \\ 1 & 1 & 2.31 & 4.5 & 7.25 \\ 1 & 1 & 1.38 & 2 & 3.50 \\ 1 & 1 & 1.19 & 1.5 & 2.75\end{array}$

Average Concentration 108

\begin{tabular}{ccccc}
\hline .03 & .04 & .045 & .048 & .05 \\
- & - & - & - & - \\
- & - & - & - & -
\end{tabular}

Average Concentraction 308

$\begin{array}{lllll}.08 & .095 & .11 & 0.12 & 0.13 \\ .875 & .9 & .94 & 1.44 & 2.75 \\ .875 & .9 & .94 & 1.12 & 1.50 \\ .875 & .9 & .94 & 1.06 & 1.25\end{array}$

Averace Concentration 508

$\begin{array}{ccccc}0.13 & 0.15 & 0.17 & 0.185 & 0.20 \\ 8.62 & 9.04 & 10.0 & 12.5 & 15.0 \\ 4.25 & 4.48 & 5.00 & 6.50 & 8.00 \\ 3.38 & 3.56 & 4.00 & 5.25 & 6.50\end{array}$

Peak Impulse

Average Concentration

$1 b / 2 b$

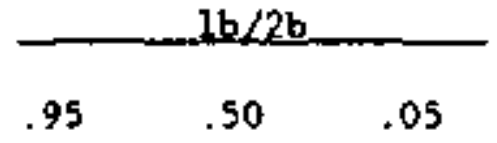

.03

.04

.045

.048

. OS

08

.095

.11

.12

.13

.15

$\begin{array}{llllll}.95 & .50 & .05 & .95 & .50 & .05 \\ . & - & . & - & . & . \\ - & - & - & - & - & - \\ - & - & - & - & . & . \\ - & - & - & - & . & - \\ - & - & - & 0 & 0 & 0 \\ - & - & - & .75 & .75 & .75 \\ 0 & 0 & 0 & .8 & .8 & .8 \\ .25 & .25 & .25 & 1.44 & 1.12 & 1.06 \\ .583 & .583 & .583 & 5.20 & 2.65 & 2.14 \\ 1.00 & 1.00 & 1.00 & 9.04 & 4.48 & 3.56\end{array}$


Peak Inpulse (continued)

\section{Ayerage_Concentration}

.17
.185
.2

\begin{tabular}{rrrrrrr} 
& & & & \multicolumn{3}{c}{$3 \mathrm{~b}$} \\
\cline { 1 - 2 } \cline { 5 - 6 } & $1 \mathrm{~b} / 2 \mathrm{~b}$ & & & & & \\
& .50 & .05 & & .95 & .50 & .05 \\
2.31 & 1.38 & 1.19 & & 10.0 & 5.00 & 4.00 \\
4.50 & 2.00 & 1.50 & & 12.5 & 6.50 & 5.25 \\
7.25 & 3.50 & 2.75 & & 15.0 & 8.00 & 6.50
\end{tabular}

\section{Sources of Uncertainty}

The Expert in his assessment of quartiles for the concentration level for each case's three scenarios accounts for the uncertainty due to the anount of hydrogen produced. Uncertainty in the efficlency of wixing is accounted for by a factor used to modify the average concentration curves to get poak concentration curves for the various cases; quartiles vere assessed. Uncertainty in the probability of conbustion vas represented in .05, 50 , and .95 confidence curves for the probability of ignftion vs. concentration level. Uncertainty in the node of combustion was accounted for by a split fraction over the varlous modes vg. concentration level. Uncertaincies in the detonation impulse was assessed vs. intial peak concentration level by $.05, .50$, and .95 bounds. Uncertalnty bounds were not assessed for the peak pressures.

\section{Correlations ytch 0ther varlables}

The external variables of hydrogen and stean concentration were used as input variables: these need to be related to the in-vessel melt and bottom head fallure scenarlos 1n order to correlate with hydxogen production variables. The anount hurned needs to be subtracted from any subsequent production.

\section{Surpested Methods for Reducing Uncercalncy}

No explicit recommendations vere made for reducing uncertainty. 
5.2 Containment Loads Isgue 2, Hydrogen gurn Before Vessel Breach at Sequavah

Sunmary of Expert Panel's Assessuent of Isque 2: Aydrogen Burn Defore Vesse1 breach at Sequoyah

Experta consulted: James Metcalf, Stone \& Webster; Martin Sherman, Sandia National Laboratories; Pat Worthington, Nuclear Regulatory Comm1ssion.

\section{Issue Description}

What distrbutions characterize the loads to containment due to hydrogen combustion prior to vessel breach at sequoyali? What distributions characterize the loads in the ice condenser due to dezonations in the lce condenser prior to vessel breach at Seguoyah?

\section{Case Structure}

All the cases are for the condition of neither igniters nor alr return fans operating. The principal sequence is station blackout with faflure of auxiliary feedwater.

Casse 1. The reactor coolant system (RCS) is at the systen setpoint pressure of $17.2 \mathrm{MPa}(2500 \mathrm{ps}(\mathrm{a})$. The only release from the RCS is via a perlodically cycling power-operated relief valve (PORV).

Case 2. The RCS vas initially at high pressure, but a leak has developed in the reactor coolant punp (RCP) seals, equivalent to an S3 cold leg loss-of-coolant accident (LOCA).

Case 3. The RCS was Initially at high pressure, but a LOCA of Intermediate size has developed in the hot leg, equivalent to a stuck open PORV.

Gase 4. The RCS was inttially at high pressure, but a large LOCA has developed in the hot legs, equivalent to a temperature-induced hot leg or pressurizer surge line fallure.

\section{Sunmary of Experts: Baclanale}

Expert A reviewed relevant sequence celculations frod NUREC/CR-3912, A-1 Haskin et al. A-2 BMI-2104, A-3 IDCOR Task 23.1, ${ }^{A-4}$ IOCOR Task B5.SA, A-5 and BMI-2139.A-B A crucfal point in this Expert's decomposition was whether or not the upper plenum and the dome were well mixed. If several of the upper deck doors were to remain closed, failure to mix could occur. However, it was considered probable that the upper deck doors would be open and that the probability of upper plenum mlxing could not be lower than 0.5 . If the upper plenus and dome were not milxed, the hydrogen cancentrations in the upper plenur and the ice condenser were expected to be approximately the same. 
Separate distributions for the frequency of Ignition were given for three ranges of hydrogen mole fractions. These ranges were: 0,06 to $0.10,0.10$ co 0.14 , and $>0.14$. Tise ignition energy should be deljvered 1r a very short time, with very high spotial densucy, even though the total energy requirements were quite low. The Expert therefore selected relacively low values for frequency of igrition; the maximum Erequency cited was estimated to be 0.5 . As leaner rixtures require more energy for detoriation, the frequency of detonation was reduced for lower mole fractions.

This Expert considered that $1 \neq$ ignition sources were present at al1, chey were more likely to be in the upper plenum than in the ice condenser. The reduced probability of igntefon in the ice condenser was handled by multiplying the distributions for frequency of ignition in the upper plenum by a distribucion which is always less than 0.5 . If Ignition occurs. detonation is only possible if the hydrogen mole fraction exceeds 0.14. For mole fractions less than this, every combustion event is a deflagration.

If combustion is a deflagration, the peak pressures are functions of mole fraction of hydrogen. Since detonation can only occur for mole fractions exceeding 0.14 , impulses are not functions of concentration. Expert $A$ considered that burning, if it occurred, would be complete, or tearly so.

Expert A assigned the greatest uncertainty to the mixing of the upper plenum and dome, although considerable uncertalnty was also assigned to the probability of ignition.

Expert B reviewed calculations from NUREG/CR-3912,8-1 SAND85-1824C,1-2 Haskin et al. B-3 and IDCOR Task 23.1. B-4 He placed the greatest rellance on References $\mathrm{B}+1$ and $\mathrm{B}-2$. The Expert provided a decomposition tree which was evaluated and solved by a Monte Carlo method. The simplified logic of the tree is that the necessary conditions far conbustion would be that an ignttion source qust be available; that it must be in the 1ce condenser, upper plenum, or dome; and that the gas aix in the compartment where the ignition source occurs must be flamable or detonable. The cases were not distingulshed: however, the decomposition is somewhat different for low and high zircontum oxidation levels.

The Expert aspessed flamability by observing the calculated gas compostion over a 1000-s time perlod. The probability that the mixture was flamable at any time was taken to be the fraction of time that the mixture was in the flammable regine. Detonability was considered posstble only in the lce condenser and was addressed in the $s$ ame manner as flamability.

Expert B decided to use the model for pressure rise due to a deflagration in the dome provided by Expert $C$. The model uses the AICC pressure ratio, with corrections made for burn completeness, heat transfer ta solid surfaces, and adiabatic expansion into nomparticipating volumes. Pressures in the ice condenser and upper plenum lie considerably below the dis. tributions takeli from the Structural Response Expert Panel for containat 
failure. The Expert Indicated that burn completion was to be estimated using the model of Wong. ${ }^{\text {g-5 }}$

Distributions for the masses of hydrogen in each compartment were not given. The wethod described in the mechod of aggregation section for estimating mole fractions in each conpartment was used.

Expert $C$ 's rationale for the quantification of this issue is presented in two papers that appear as Attachments $A$ and $B$ at the end of Expert C's detalled elicitatiori.

Expert $C$ considered the presence of an ignition source to be the essential uncertainty for this issue, because code calculations predict detonable mixtures within the ice condenser for apprectable periods during this serivence. If Ignlters and fans are operating, hydrogen is never a problen. The most likely Ignition source was ovaluated to be the contact between the metal intermediate deck doors.

Combustion was considered in the ice condenser, the upper plenum, and the dome; the concentration in the done was only flanmable for the highest level of in-vessel hydrogen production and only towards the end of the accident. Expert $C$ gave a rather low likelihood for combustion in the dome. The lce condenser would have been detonable for long periods of time before the dome is flamuable and would have much more chance of a damaging combustion, involving acceleration to detonation.

Deflagrations would be of isaportance only if they occurred in the dome. The amount of hydrogen in the ice condenser or upper pletur is too small to be of any consequence for deflagration. Expert $c$, therefore, restricted the focus to events which would lead to detonation in the lee candenser or deflogration in the dome.

\section{Method of Aggregation}

\section{Relationship to Accident Progression, Eyent Tree}

The following questions in the accident progression event tree (APET) are evaluated using the data elicited in this issue:

1. What fraction of the hydrogen produced in the vessel is released to contasunent before vessel breach?

2. What fraction of the hydrogen 1 s cransmitted to the lce condenser, upper plenum of the 1ce condenser, and upper corpartment (dome)?

3. Does 1gnition occur in the lce condenser?

4. Does ignition occur in the upper plenum?

5. Does ignition ocrur in the dome?

6. Does corbustion propagate to the dome from ocher comartments? 
7. Does deflagration-to-detonation transition (DDT) occur in the ice condenser?

8. Does DET occur in the upper plenum?

9. What is the inpulsa in the Ice condenser or upper plenum?

10. What is the pressure in containment?

The fraction of hydrogen released from the RCS before vessel breach was assessed using Expert $A^{\prime}$ 's distribution [1], from Table A-8. (Distributions are Indicated by bracketed symbols, e.g.. [A].) The other experts did not provide data for this question, but agreed to use Expert $A^{\prime} s$ data.

Experts $A$ and $C$ provided dats on wixing of hydrogen into the dome. Expert A's distribution [B] gives the probability that the upper plenun and dome will be well-nixed. Good mixing accurb between the upper plenur and done when several upper deck doors (essentially made of blanket insilation) are thrown open. The amount of hydrogen in the dome in the well-mixed case was assumed to be 1008 of the amount predicted by HECTR calculations, ${ }^{-1}$ reported In Table 2.1 below. The anount in the unnixed case was estinated to be $10 \mathrm{~s}$ of the smount predicted by HECTR. Expert C estimated probability of a clear path to be 0.1 . A cloar path occurs when several intermediste deck doors are open. When a clear pach was avallable, 100 of the hydrogen predicted by HECTR was used. In the absence of a clear path, 50 of the amount predicted by HECTR was assumed to be in the dome. Table 2-2 below shows the fraction $F_{u c}$, which is to be applied to the HECTR predicted fraction from Table 2-1. The fraction which is not admitted to the dome, $1-F_{u g}$, is distrfbuted through the remaining compartments in the same ratios as were predicted by HECTR.

Table $2-1$

Distribution of Hydrogen in Containnent; Compartmental Fraction of Total Hydrogen Released fron the RCS

\begin{tabular}{|c|c|c|}
\hline Compirtment & 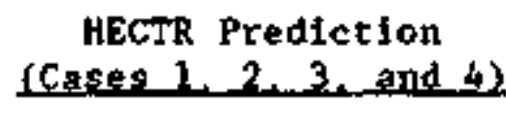 & $\begin{array}{l}\text { CONTAIN Prediction } \\
\text { (Alternate cose 2) }\end{array}$ \\
\hline $\begin{array}{l}\text { Lower Compartment } \\
\text { Ice Condenser } \\
\text { Upper Plenum of } \\
\text { Ice Condenser }\end{array}$ & $\begin{array}{l}0.35 \\
0.36 \\
0.03\end{array}$ & $\begin{array}{l}0.44 \\
0.13 \\
0.01\end{array}$ \\
\hline Upper Compartment & 0.26 & 0.42 \\
\hline
\end{tabular}

For Case 2, Expert $c$ chted a COWTAIN calculation that indicated that the majority of the steam and hydrogen would flow through an open drain line, effectively bypassing the ice condenser. The concentration of hydrogen in containment for the bypass condition is provided in Table 2+1. Expert $C$ estimated a 508 probability that the coNTAIN calculation was realistic. 
Table $2 \cdot 2$

Mixing of Hydrogen Into the Done

\section{F}

10

50

100
Probab1lity

$$
\begin{aligned}
& 0.1042 \\
& 0.4500 \\
& 0.5542
\end{aligned}
$$

Cumulative Probab1lity

0.1042

0.5542

1,0000

Because the results of Experts $A$ and $C$ are being averaged to assess hydrogen distribution, 25* was taken to be the aggregated probabllity of the bypass condition that is indicated by the CoNTAIN calculation.

Frequency of igntion in the lce condenser and upper plenun was assessed by all three experts. Experts $A$ and $C$ used slightly different ranges of hydrogen concentration for assessing the effect of concentration. For the puxpoges of aggregation, the aole fraction boundarles have been averaged for the two experts. Expert B, on the other hand, geve the same distribution for any nole fraction. Ignition will not be allowed in any case if the hydrogen nole fraction 1s below 5.5\%. Only Experts $B$ and $C$ provided distributions for frequency of $1 \mathrm{gnit}$ ion in the done. A distribution was not provided by Expert $A$ due to the assumption that the concentretion of hydrogen in the dowe would never attain the flammable linit.

\section{Aprequatedisults}

Tables 2-3 through 2-5 show frequencles of Ignition for the 1ce condenser, upper plenus, and dome, for the three ranges of mole fractions.

Table $2-3$

Distribution For Ignition Frequency in the Ice Condenser

Cunulative

Probability
0.01
0.05
0.25
0.50
0.75
0.95
0.99

\begin{tabular}{|c|c|c|}
\hline $\mathrm{H}_{2}, \mathrm{ne}, 5-5-11 \mathrm{~A}$ & $\mathrm{H}_{2}$ ef $11+169$ & $\mathrm{H}_{2} \mathrm{mf} \geq 16$ \\
\hline 0.000 & 0.010 & 0.009 \\
\hline 0.002 & 0.024 & 0.067 \\
\hline 0.014 & 0.065 & 0.134 \\
\hline 0.127 & 0.144 & 0.169 \\
\hline 0.189 & 0.215 & 0.252 \\
\hline $\begin{array}{l}0.278 \\
0.629\end{array}$ & 0.290 & 0.296 \\
\hline
\end{tabular}

Ignition Frequency in Ice Candenser For Hydrogen Mole Fraction Ranees 
Table 2-4

Distribution For Ignition Frequency in the Upper Plentun

\begin{tabular}{|c|c|c|c|}
\hline \multirow[b]{2}{*}{$\begin{array}{l}\text { Cumulat lve } \\
\text { Probability }\end{array}$} & \multicolumn{3}{|c|}{$\begin{array}{l}\text { Ignition Frequency In Upper Plenum } \\
\text { For Hvdropen Mole Fraction. Banges }\end{array}$} \\
\hline & $\mathrm{b}_{2} \mathrm{mf} 5,5-11 \mathrm{~g}$ & $\mathrm{H}_{2}$ at $11-168$ & $\mathrm{H}_{2} \operatorname{mf}>168$ \\
\hline $\begin{array}{l}0.01 \\
0.05 \\
0.25 \\
0.50 \\
0.75 \\
0.95 \\
0.99\end{array}$ & $\begin{array}{l}0.001 \\
0.005 \\
0.035 \\
0.174 \\
0.278 \\
0.454 \\
0.491\end{array}$ & $\begin{array}{l}0.011 \\
0.055 \\
0.149 \\
0.214 \\
0.322 \\
0.571 \\
0.594\end{array}$ & $\begin{array}{l}0.013 \\
0.102 \\
0.226 \\
0.342 \\
0.467 \\
0.587 \\
0.597\end{array}$ \\
\hline
\end{tabular}

Table 2.5

Distribution For Ignition Frequency in the Dome

Cumulative

Probability

0.01

0.05

0.25

0.50

0.75

0.95

0.99
Ignition Frequency in Dose

For Hydrogen Mole Eraction Ranges

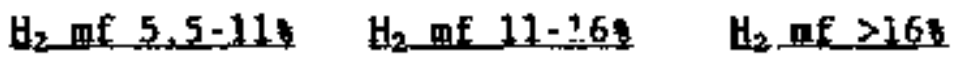

$\begin{array}{lll}0.003 & 0.006 & 0.012 \\ 0.014 & 0.025 & 0.040 \\ 0.051 & 0.070 & 0.075 \\ 0.074 & 0.087 & 0.093 \\ 0.104 & 0.104 & 0.104 \\ 0.176 & 0.176 & 0.176 \\ 0.212 & 0.212 & 0.212\end{array}$

The question of flame propagation from the upper plenum to the done was explicitly addressed only by Expezt $C$. He believed that propagation would be assured if the concentration in the done exceeded 48 . When considering the pressure rise associated with a concentration of 48 , the boundary of 5.58 mole fraction was considered adequate for a threshold ignition concentration in the dome. This value of 4 is quite close to the previously considered boundary of 5.58. Thus, the APET assunes that propagation will always occur for concentrations exceeding 5.58 and will never occur for lower concentrations.

The Erequency of DDT was differently assessed by all thret experts. Expert A provided a distribution which applies to all mole fractions above 148; Expert B provided a discrete probability which applies to all nole fractions above 14\%, and Expert $C$ provided a discrete probability far each of three mole fractions. Ranges were assigned to Expert C's mole fractions. Table 2.6 shows the frequency of DDT for each of three tnole fraction ranges, given rhat an fgnition has occurred 
Table 2-6

DLstribution For DDT

Cunulative

Probabilicy
0.01
0.05
0.25
0.50
0.75
0.95
c. 99

Frequency of DDT

For Hydrogen Hole Fraction Ranges

$L_{2}$ inf $5.5+118$

0.10

0.10

0.10

0.50

0.65

0.94

0.99
$\mathrm{H}_{2}$-nt 11 - 168

$\mathrm{H}_{2} \mathrm{mf}>16 \mathrm{~B}$

0. 50

0.50

0.50

0.50

0.50

0.50

0.60

0.65

0.94

0.99

0.80

0.90

0.94

0.99

All three experts provided distributions for iapulse, given a detonation. These distributions are independent of hydrogen concentration, provided that the concentration is at least high enough for a detonation co accur. The imputse distributions are given in Table 2.7 .

Tab1e $2 \cdot 7$

Distribution for Detonation Inpulse

\begin{tabular}{cc}
$\begin{array}{c}\text { Cumulative } \\
\text { Probability }\end{array}$ & $\begin{array}{c}\text { Inpulsive Lad } \\
\text { (kRa-s) }\end{array}$ \\
\hline 0.01 & 2.0 \\
0.05 & 2.5 \\
0.25 & 4.9 \\
6.50 & 10.0 \\
0.75 & 12.6 \\
0.95 & 22.8 \\
0.99 & 43.1 \\
\hline
\end{tabular}

Exper: : provided the wodel for burn complateness and pressure increaent as functions of initial hydrogen concentration. Table 2-B lists pressure rises and cempleteness of combustion for all cases (low stean concentration in the dome), and alternate case 2 (higher steam concentration in the dome). Burn completeness is estinaced to be look for conpartments in which a detonation occurs. 
Table 2-B

Burn Completion and Pressure Rise; Cases 1, 2, 3, und 4

\begin{tabular}{ccc} 
Vele Eraction $\left\langle\mathrm{H}_{2}\right\rangle$ & Burn_completion & APRa) \\
\cline { 2 - 3 } & & \\
0.05 & 0.242 & 36 \\
0.05 & 0.547 & 98 \\
0.07 & 0852 & 174 \\
0.08 & 1.000 & 223 \\
0.10 & 1.000 & 266
\end{tabular}

\begin{tabular}{|c|c|c|}
\hline Wale Fraction $\mathrm{CH}_{2}-$ & Burn Complecton & $\Delta P(\mathbf{P P a}$ \\
\hline $\begin{array}{l}0.08 \\
0.10 \\
0.12 \\
0.14\end{array}$ & $\begin{array}{l}0.372 \\
0.666 \\
0.764 \\
0.964\end{array}$ & $\begin{array}{l}132 \\
265 \\
343 \\
483\end{array}$ \\
\hline
\end{tabular}

The completeness of combustion is extimated by the empirical equation to be used in the HECTR Version 2.0 , developed by $\mathrm{C}$. Wong. ${ }^{\mathrm{i}-\mathrm{s}, \mathrm{c}-2}$ The equation is given by:

Completeness - Minimum of unity or $\left(30.499 * X_{2}-1.287\right) * \exp (A)$

where $X_{\theta}$ is the hydrogen mole fraction, $A$ is defined by:

$h-X_{s} *\left(.4 .1966+3.3985 * X_{s}\right)$

and $X_{g}$ is the stesm mole fraction. The overpressure is deteroined by calculating the AICC pressure ratio and applying corrections for completeness, heat transfer to solid surfaces (factor of 58 ), and adiabstic expansion into nonparticipating volures. 
Individual Elicitations for Issue 2

$5.2-9$ 


\section{Expert 4** Elicitation}

\section{Iasue 2: Hydrogen Burn Before Vensel Breach at Sequoyah}

\section{Description of Expert A's Bationale/Alethodology}

Expert A reviewed relevant sequence calculations fron NUREG/CR-3912, ${ }^{-1}$

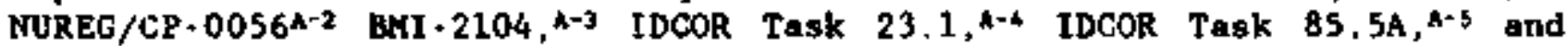
BMI +2139,A-B No calculations were avallable for Case 3 , so a calculation of the S2D sequence from BHI 2139 was used as a proxy.

Expert A's decomposition is shown in Figuxe A-1. Distributions axe indicated by bracketed synbols, for example [A]. From this Expert's decomposition, the probabilities of detonation in the upper plenun ( $\mathrm{Pr}_{\mathrm{DUP}}$ ). combustion in the upper plenum without detonation $\left(\operatorname{Pr}_{\text {CUP }}\right)$, detonation in the sce condenser ( $\mathrm{Pr}_{\mathrm{DIC}}$ ), and combustion in the lce condenser without detonation $\left(\mathrm{Pr}_{\mathrm{cIC}}\right)$ are:

$$
\begin{aligned}
& \left.\left[\operatorname{Pr}_{\text {DUP }}\right]-\{1 .-[B\}) *\left(E_{.15}\right] *[F] \text { (m.f. } \geq 0.14\right) \\
& \left.\left[\mathrm{Pr}_{\text {our }}\right]-0.0 \text { (m.f. }<0.14\right) \\
& {\left[P x_{C U P}\right]-\{1 .-(B]) *\left[E_{t t}\right] *(1 .-[F])} \\
& \left(P r_{D I C}\right]-(1 .-(B]) *\left[E_{.16}\right] *[C] *(F) \quad(D, E, \geq 0,14) \\
& \left\{\mathrm{Pr}_{\mathrm{HIC}}\right]=0.0(\mathrm{a}, \mathrm{f},<0.14) \\
& {\left[F \mathbf{r}_{C I C}\right]-\{1,-[B]\} *\left[E_{t: t}\right] *\{C] *\{1,-(F]\} \text {. }}
\end{aligned}
$$

A crucial point in this Expert's decomposition was whether or not the upper plenum and the done were rell wixed. Fallure to nix could be explained by several upper deck doors remaining closed. If most of the upper deck doors were open, mixling was considered to be more likely. This Expert considered that the upprs deck doors would probably be open, and that the probability of upper plenum mixing could not be lower than 0.5 . The [B] distribution-mixing of the upper plenum and dome atmosphere..is shown in Table A-l.

If the upper plenuw and dome were not mixed, the hydrogen concentrations in the upper plenuw and the lce condenser vere expected to be approximately the sane. The (D) distribution (Table A-2) gives the mole fraction of hydrogen in the upper plenum and lee condenger by the formula:

$$
M F_{\text {t2 }}-[D] * I V P * R * T /(V * P)
$$

where
IVP is the in-vessel production of hydrogen,
$R$ is the universal gas constant,
$T$ is the temperature (assumed $560^{\circ} \mathrm{F}$ ),
$V$ is the volume of the upper plenum, and
$P$ is the absolute pressure (assumed 24 psia). 


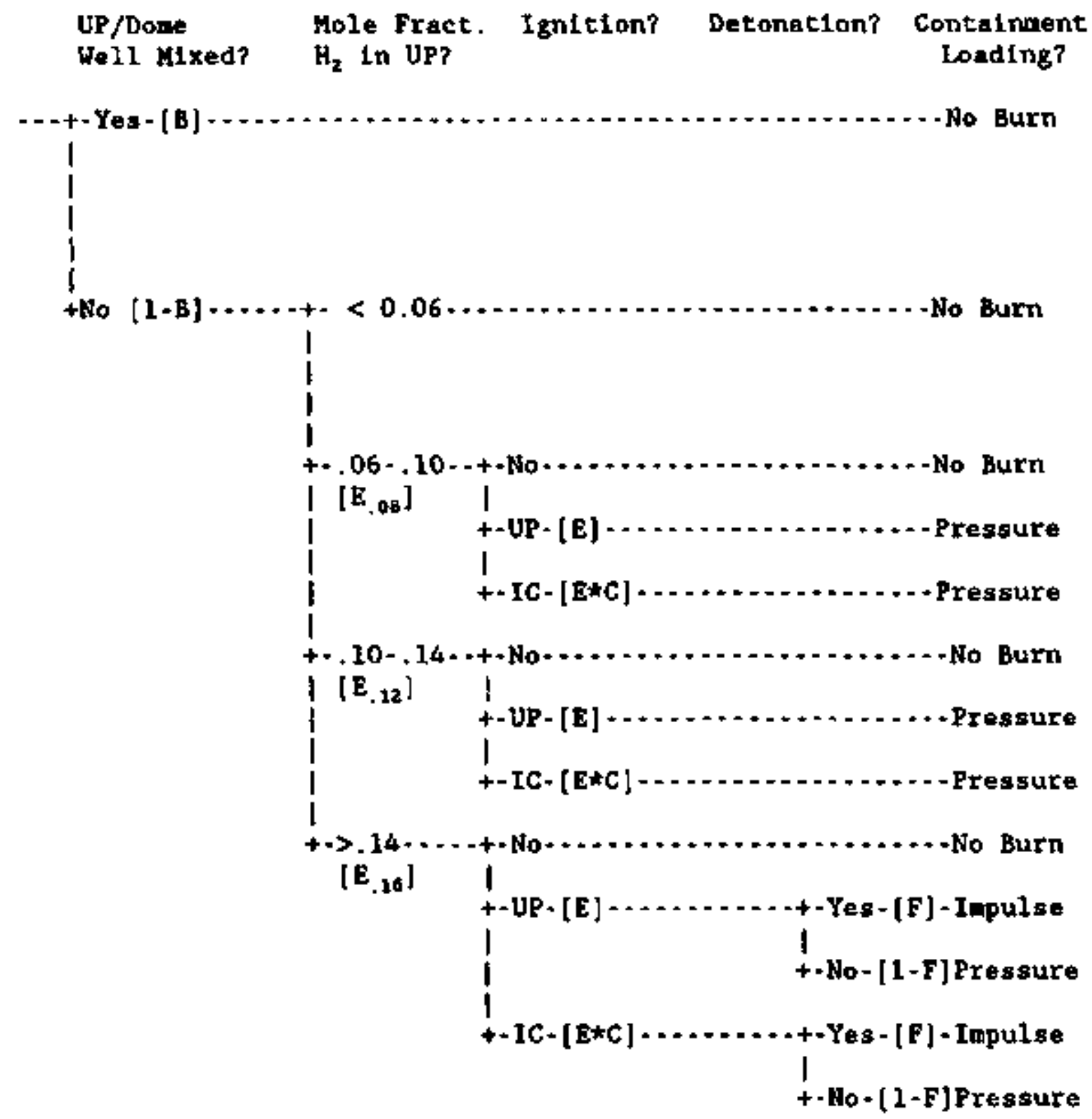

Flgure A-1. Expert A's Decomposition Tree. Deconposition for Hydrogen Burn.

The frequency of ignition in the upper plenum is [ $E_{a k}$ ], where af is the nole fraction of hydrogen in the (unmixed) upper plenum. Separate distributions are used for wole fractions of 0.06 to 0.10 [E.08], 0.10 to $0.14\left[E_{.12}\right]$, and wole fractions greater than 0.14 [E.18]. The distributions for $\left\{E_{, 06}\right\rfloor,\left\lfloor E_{.12}\right\rfloor$, and $\left[E_{.16}\right\rfloor$ are shown in Table $A-3$. 
Table A-1

Distribution for Mixing of Upper Plenum and Dome; [B] Distribution

\begin{tabular}{cc}
\hline Gumulative Probability & [BLDistribution \\
0.01 & 0.5 \\
0.25 & 0.7 \\
0.50 & 0.8 \\
0.75 & 0.9 \\
0.99 & 1.0 \\
\hline
\end{tabular}

Table A-2

Distribution for Mole Fraction in Unmixed Upper Plenum: [D] Distribution

Gumulative Probabilty

0.01
0.25
0.50
0.75
0.99

DDL DIstribution

0.04

0.06

0.07

0.075

0.08

Table A-3

Distribution for Frequency of $I$ gnition in the Upper Plenum $\left[E_{.08}\right]+\left[E_{.12}\right]$ and $\left[E_{.18}\right]$ Distributions

\begin{tabular}{|c|c|c|c|}
\hline $\begin{array}{l}\text { Cumulative } \\
\text { probsblilty }\end{array}$ & LE. & $15_{122}$ DLst_L & {$\left[E_{10} \perp\right.$ Dist, } \\
\hline $\begin{array}{l}0.01 \\
0.25 \\
0.50 \\
0.75 \\
0.99\end{array}$ & $\begin{array}{l}0.00 \\
0.01 \\
0.02 \\
0.05 \\
0.09\end{array}$ & $\begin{array}{l}0.05 \\
0.12 \\
0.16 \\
0.20 \\
0.29\end{array}$ & $\begin{array}{l}0.15 \\
0.33 \\
0.31 \\
0.41 \\
0.53\end{array}$ \\
\hline
\end{tabular}


The Expert explained that the energy had to be delivered in a very short time, with very high spatial density, even though the tatsl energy requitrements were quite low. Considering the requirements for rapid energy delivery and high energy density. this Expert selected relatively low values for frequency of ignitfon: the maxinum possible frequency of detonation was estimated to be 0.5 . Leaner mixtures require more energy for detonation, so that the frequency of detonation has to be reduced for lower pole fractions.

This Expert considered that if ignition sources were present at all, they were more likely to be in the upper plenum than in the ice condenser. The reduced probability of ignition in the ice condenser was handled by multiplying the [E] distributions for Erequency of ignition in the upper plenun by the [C] distribution, which is atways less than 0.5 (Table A-4).

If ignition occurs. detonation is only considered possible if the hydrogen mole fraction exceeds 0.14 . The probability that a combustion event is a detonation, given mole fractions greater than 0.14 , Is given by the [F] distribution (Table A-5). For mole fractions less than 0.14, every combustion event is a deflagration.

If combustion is a deflagration, the peak pressures ane functions of mole fraction of hydrogen. Pressures for deflagrations in the ice condenser or upper plenum are given by the [Gmf] distriburions In Table A-6. Because detoration can only occur for mole fractions exceeding 0.14 , impulses are not functions of concentration. Impulses are given by the [H] function in Table A-7.

\section{Mass of Remainting Hydrogen}

The mass of hydrogen released from the RCS is IVP*[I], where IVP is the total in-vessel hydrogen production, and the [I] distribution is given in Table A-8. Values in this table are based principally on MAAP calculations, except for the upper ends of the distributions. The fraction of in-vessel production released to the upper plenun or dome is given by $[A] \star I V P$, where the [A] distribution is shown in Table A-9. The mass of hydrogen delivered to the ice condenser was estimated by the method described in the general discussion. Expert A considered that burning, if ic occurred, would be complete, or nearly so.

Expert A did not provide [I] and [A] distributions for Case 4. The distributions for Case 3 represent high fractions of hydrogen released, and Case 3 is expected to be physically ofmilar to case 4. Therefore, Case 3 distributlons are used as a proxy for Case 4. 
Table A-4

Distribution for Frequency of Ignition

In Ice Condenser Relative to Frequency

in Upper Plenum; [C] Distribution

Cymoulactue Probability

icl Distribution.
0.01
0.10
0.25
0,30
0.50
0.40
0.75
0.45
0.99
0.50

Table A-S

Distribution for Frequency of Detonation

in Ice Condenser or Upper Plenum, GLen Ignition;

[F] Distribution

Cumulacive_Probabtlicy

0.01

0.25

0.50

0.75

0.99
LF」 Discribution

0.50

0.65

0.80

0.90

1.00

Table A-6

Distribution for Peak Pressure, Given Deflagration in IC or UP; [G.f] Discribution

Cunlative Probabjllty

0.01

0.25

0.50

0.75

0.99
G.0o (kPa)

145

152

160

170

180
Cunulstive Probability

0.01

0.25

0.50

0.75

0.99
$\mathrm{G}_{.12 \text { (kPa) }}$

200 
Table A-6 (continued)

\begin{tabular}{cc}
\hline Cumilative Probability & G.16 (kPa) \\
0.01 & 180 \\
0.25 & 190 \\
0.50 & 200 \\
0.75 & 205 \\
0.99 & 210 \\
\hline
\end{tabular}

Table A-7

Distribution for Impulse, Given Detonation;

[H] Dfstribution

Cunulative Probabllity $\quad$ (Hل1 Distribution (k Pu-s)

$\begin{array}{lr}0.01 & 2 \\ 0.25 & 3 \\ 0.50 & 4 \\ 0.75 & 5 \\ 0.99 & 15\end{array}$

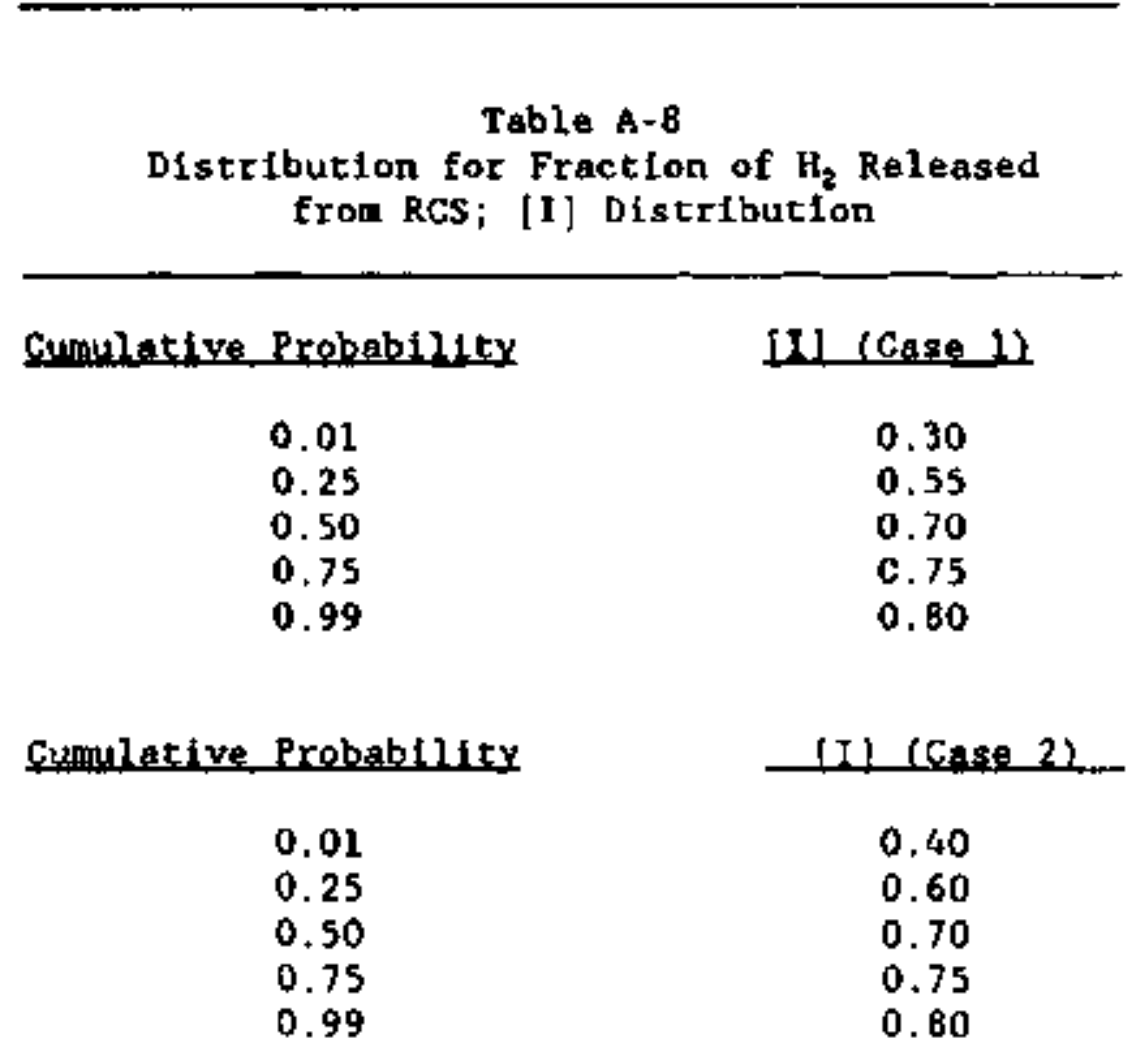


Table A-B (continued)

Cumulative Probab114ty
0.01
0.25
0.50
0.75
0.99

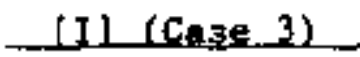
0.60
0.65
0.70
0.75
0.80

Table A-9

Distribution for Fraction of $\mathrm{H}_{2}$ Released to Done/Upper Plenun; [A] Distribution

Cumulative Probability

0.01

0.25

0.50

0.75

0.99

Curnulative Probability
0.01
0.25
0.50
0.75
0.99

Cunulative Probability
0.01
0.25
0. 50
0.75
0.99

IAl (Case 1)

$0.0 \mathrm{~B}$

0.095

0.11

0.12

0.13

LA] (Case 2)

0.10

0.12

0.14

0.15

0.16

Aal_case 3)

0.12

0.15

0.17

0.185

0.20 


\section{Besults of Expert A's Ellctiation}

Expert A's logic tree was programed and evaluated using a Monte Carlo method $(N=1000)$. By the Kolmogoroff-Smirnoff test, che Monte carlo distribution does not differ fron the "true" distribution by more than 0.039 . A solution was carried out for each case and for both 258 and 60 a zirconiuin oxidation. Inpulses in the ice condenser and upper plenur were found to differ only trlvially by case and fraction oxidized. This Expert only had deflagrations occurting ta the lice condenser and upper plenum. The pressures are uniformly low and pose no threat to contalnment and will not be used in the final aggregation.

As a check on the distributions, consider combination of the nedian values. The probability of detonation in the ice condenser is $(1,-B) * E, 14 * C * F$, where the symbols $B, E, C$, and $F$ indicate the median velues of the $[B] .[E],[C]$, end $[F]$ distributions.

$P_{\text {otcoedn }}=(1 .+0.8)(0.35) *(0.4) *(0.8)=0.0224$; hence, the probability of no detonation is 0.9776 . The median impulse is $8 \mathrm{kPa}-\mathrm{s}$, and the probability of an impulse less than this, given that a detonation occurs, is 0.5 . Therefore, the unconditional probability of an impulse less than $8 \mathrm{kPa}-\mathrm{s}$ is $1 .(0.5)(.0224)-9888$. The probabllicy that the impulse 1 s less than 8 $\mathrm{kPa}-\mathrm{s}$ is slightly greater than 0.99 . or very close to the value calculated From the medians of the Indfvidual distributions.

\section{Sources of Uncertainty}

Expert A assigned the greatest uncerteinty to the mixing of the upper plenum and dome, al though considerable uncertainty was also assigned to the probability of ignition. If the done ard upper plenus are well aixed, combustion was not considered credible. He believed that combustion of hydrogen in the dom was not credible, given the amounts of hydrogen production generally belleved possible. The conclusion that combustion in the dome was impossible was based on MAAP calculations, which indicate only a fraction of the hydrogen released from the RCS before vessel breach. The amount avaflable for aixing into the done atmosphere would be too small for combustible concentrations in the done, or in the upper plenum if the plenun and dome were well mixed. If a station blackout with core neltdown occurred at Sequoyah, and the dome was known to have falled by overpressure due to a hydrogen burn before vessel breach, Expert A would say that production of hydrogen must have exceeded any current estimate. Consequently, Expert A did not provide a distribution for pressure rise in containment due to a hydrogen deflagration in the dome. 
A-1. A. L. Camp, V. L. Behr, and F, E. Haskin, "MARCH-HECTR Analysis of Selected Accidents in an Ice-Condenser Containment," Sandia National Laboratories, NUREG/CR-3912, SAND83-0501, December 1984.

A-2. F. Haskin et al., "HECTR Results for Ice Condenser Containment Standard Problem," Proceadings of the Second Workshop on Containment Integrity, Crystal City, VA, NUREG/CP-00S6, SAND84-1514, August 1984.

A.3. J. A. Gieseke ot al., "Radionuclide Releage Under spectific LwR Accident Conditions," Volune IV: PWR Ice Condenser Design, Battelle Columbus Division, BMI-2104, 1984 .

A-4. Industry Degraded Core Rulemaking Progran (IDCOR), "Sequoyah Nuclear Plant Integrated Containnent Analysis, IDCOR Task 23.1," Technical Tennessee Valley Authority, Nuclear Englneering Branch, Report 23.1, July 1984.

A-5. Industry Degraded Core Rulemaking Program (IDCOR), "Sequoyah Nuclear Plant Integrated Containment Analysis, IDCOR Task 85.5A," Tennessee Valley Authorlty, Nuclear Engineering Branch, Technical Report BS.SA, July 1984 .

A-6. R. S. Denning et al., "Supplementsl Radionuclide Release Calculations for Selected Severe Accident Sequences," Battelle Columbus Division, WUREG/CR-4624, BMI-2139, 1986. 
Expert B.. Bllcitation

\section{Hydrogen Burn Bafore Vessel Breach at Sequeyab}

\section{Bercription of Expert B's Rationale Methodology}

Expert B roviewed calculations fron NUREG/CR-3912, b-1 SAND85-1924C, Haskin et al, , and IDCOR Task 23.1. ${ }^{\text {b-4 }}$ However, he placed the greatert rellance on References B-1 and B-2.

Expert B provided a decomposition tree shown In Figure B-1. The siaplified logic of the tree is that the necessary conditlons for combustion would be that an Ignition source wist be avaliable; that $1 t$ sust be in the ice condenser, upper planum, or done; and that the gas aix in the compartment where the ignition source occurs must be flamable or detonable.

Expert B did not distinguish between cases; however, the decomposition is somewhat different for low and high zirconiue oxidation levels. Figure B-1 shows this Expert's dacomposition. Distributions are indiceted by brack. eted syobola, for example [A]. Fron the deconposition, the probabilities of combustion in the dowe ( $\left.\mathrm{Pr}_{\mathrm{ct}}\right)$, combustion in the upper plenum ( $\mathrm{Pr}_{\mathrm{cup}}$ ), coubustion in the ice condenser ( $\left.P f_{c i c}\right)$, and detonation in the fee condenser ( $\left.\mathbf{P r}_{\mathrm{ptc}}\right)$ are:

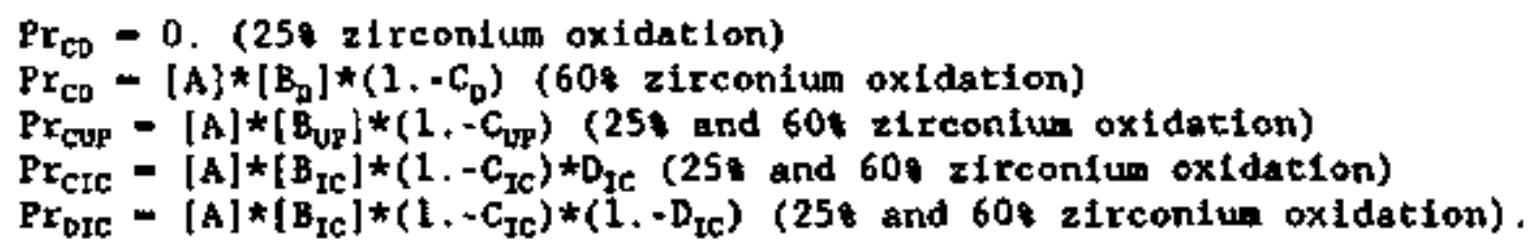

\section{Resulteg of Expert $B^{\prime}$ s Ellojitation}

Expert B's decomposition tree was programmed and solved by a Monte Carlo method $(\mathrm{N}-1000)$.

\section{Impulse and Pressure}

The most crucial points in Expert $B^{\prime} s$ decomposition were the existence of an ignition source and its location, and nost of the uncertainty in the probabilities of combustion and detonation are assigned to the uncertainties of 1gnition. The existence of an ignition source, is represented by distribution $[A]$, a normal distribution with a nean of 0.50 and a standard devfation of 0.1216 . Distribution [A] is rrovided in Table B.1. The assessuent of the lacation of the ignition source is provided by the $\left[B_{0}\right]$. [ $\left[B_{u p}\right]$, and $\left[B_{I c}\right]$ distributions, which are shown in Table $B-2$. The final convolved distributions for lgnition fn each of the locations Independent of concentration is provided in Table B-3. 


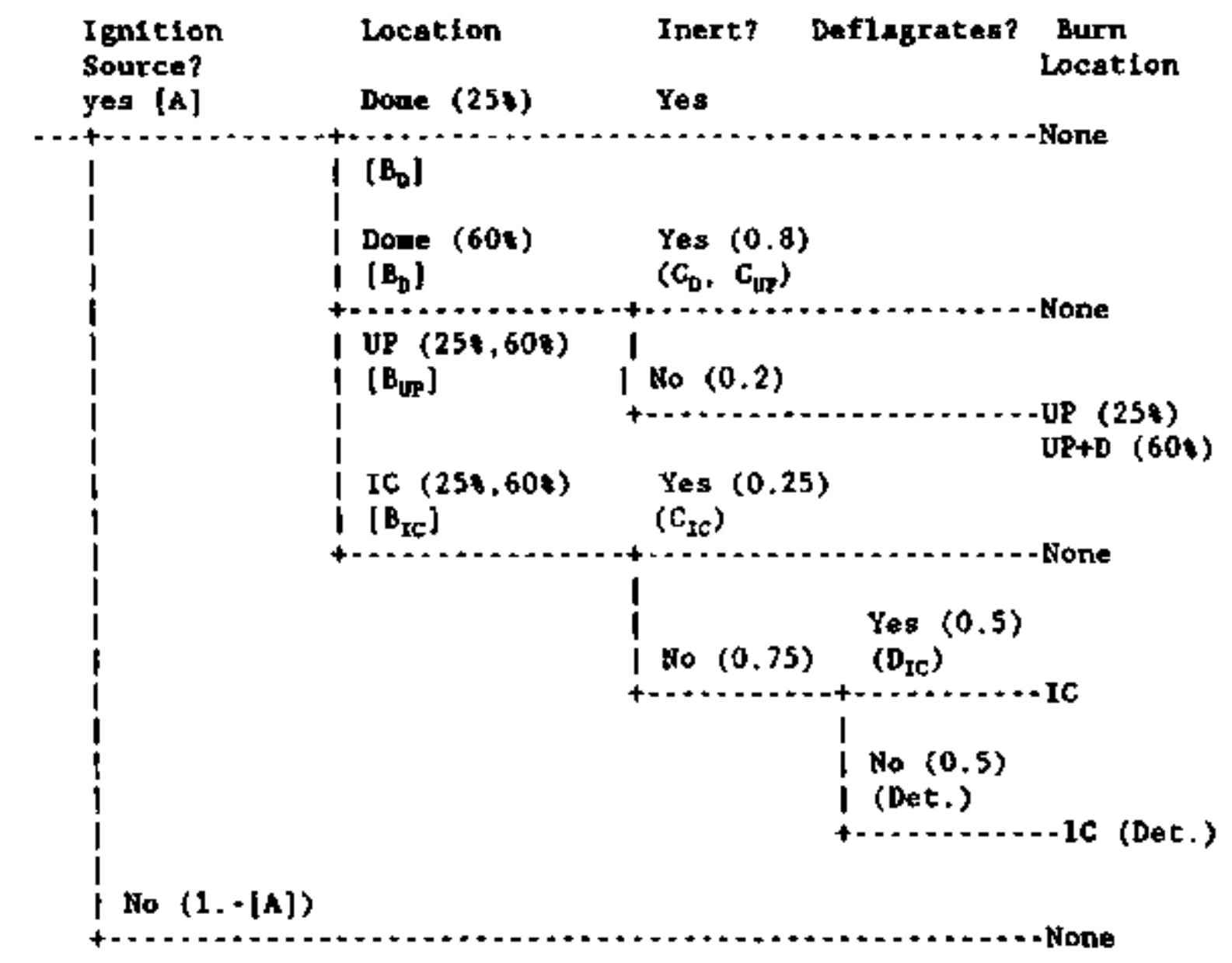

Figure B-1. Expert B's Decomposition Treo. Percentager under "Burn Location" Indicete the fraction of zirconiur oxidation.

Table B-1

Distribution for Existence of Ignition Source

\begin{tabular}{cc} 
Cumulative & \\
Erobability & IAl_Distifibution \\
0.05 & 0.3 \\
0.50 & 0.5 \\
0.95 & 0.7 \\
\hline
\end{tabular}


Table B-2

Distrlbutions for Probablitty of Ignition Location

$\left[B_{D}\right],\left[B_{U P}\right]$ and $\left[B_{2 c}\right]$ Distributions

Cumulative

Probab111ty
0.05
0.50
0.95

Probabllity That Ientition lacurs in:

\begin{tabular}{|c|c|c|}
\hline Dome & Upper Plenium & Ice Condenser \\
\hline$\left\lfloor B_{0} \perp\right.$ Dift. & $\left\lfloor B_{\mathrm{OP}} \perp\right.$ DLst. & 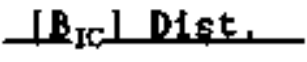 \\
\hline 0.33 & 0.33 & 0.33 \\
\hline 0.22 & 0.44 & 0.33 \\
\hline 0.14 & 0.57 & 0.29 \\
\hline
\end{tabular}

Table B-3

Distributions for Ignition Frequency

\section{Cumulative}

Brobabllity
0.01
0.05
0.25
0.50
0.75
0.95
0.99

Ice Condenser

0.075

0.094

0.139

$0.15 B$

0.196

0.233

0.254 leper Plenu:

Dore

0.097

0.122

0.181

0.219

0.261

0.324

0.361
0.046

0.063

0.076

0.104

0.152

0.283

0.222

Expert B assessed flanmability by observing the calculated gas corposftion over a 1000-s tiae perlod. The fraction of time that the ruixture was in the flamable regine was taken to be the probability that the mixture was flammable at any time. The flamability is quantifled in the variables, $C_{D}, C_{U P}$, and $C_{I C}$ as expressed for the different zirconiun oxidation levis in Table B-4.

Table B-4

Probability of Flamability

\begin{tabular}{|c|c|c|c|}
\hline Locacton & Varcable & 258 2r oxid. & 600 75 oxid \\
\hline $\begin{array}{l}\text { Dome } \\
\text { Upper Plenum } \\
\text { Ice Condenser }\end{array}$ & $\begin{array}{l}C_{p} \\
C_{u p} \\
C_{1 c}\end{array}$ & $\begin{array}{l}0.00 \\
0.20 \\
0.75\end{array}$ & $\begin{array}{l}0.20 \\
0.20 \\
0.75\end{array}$ \\
\hline
\end{tabular}


Detonability was considered possible only in the lce condenser and was addressed in the oane manner as flanmability. Given ignition of a flamable mixture in the lce condenser, the mixture is detonable and will transition fron deflagration to detonation 50 of the tine. Thus, the value of $D_{\text {IC }}$ is 0.50 . The inpulse distribution conditional on occurrence of a detonation is shown in Table B-S. Expert B did not expect impulse to be a function of the fraction of zircontum oxidized, as long as at least 15. was oxidized.

Table B-S

Distribution for Detonation Impulse

\begin{tabular}{cc}
\hline $\begin{array}{r}\text { Cuamlative } \\
\text { Probablificy }\end{array}$ & $\begin{array}{c}\text { Iopulsive Load } \\
(\mathrm{kPa}-\mathrm{s})\end{array}$ \\
\cline { 2 - 2 } 0.05 & 8.0 \\
0.25 & 11.0 \\
0.50 & 12.0 \\
0.75 & 13.0 \\
0.90 & 14.0 \\
0.95 & 14.5 \\
\hline
\end{tabular}

Expert B agreed to use the nodel for pressure rise due to a deflagration in the dowe that was provided by Expert $c$. The nodel utilizes the AICC pressure ratio, with corrections made for burn conpleteness, heat transfer to solid surfaces, and adiabatic expension into nonparticlpating volunes. Pressures in the lce condenser and upper plenum lie considerably below the distributions from the structural experts panel for containment fallure.

\section{Mass of Hydrogen Burned}

Expert B did not give distributions for the masses of hydrogen in each compartment. The method described in the description of method of aggregation for estimating wole fractions in each compartnent was used. Expert B Indicated that burn conpletion was to be estimated using the model of Wong. ${ }^{\text {-s }}$ The burn conpletion model applied for conditions of no stean in containaent and no fans operating is summarfzed in Table B-6. The mass burned in any compartment is the product of the burn completion and the mass of hydrogen in the compartment. given sufficlent oxygen for the burn.

Expert B did not distinguish between cases. However,hydrogen concentrations were required for calculation of hydrogen burned fraction, and Expert $B$ agreed to use Expert A's distributions for hydrogen released from the RCS and to the upper plenum and done, as provided in Tables B-7 and B-g. 
Table B.6

Burn Completion

\begin{tabular}{cc}
\hline Holdian Fration $\left(\mathrm{H}_{2}\right)$ & \\
0.04 & 0.00 \\
0.05 & 0.24 \\
0.06 & 0.55 \\
0.07 & 0.85 \\
0.08 & 1.00 \\
0.10 & 1.00 \\
\hline
\end{tabular}

Table B-7

Distributions for Fraction of Hydrogen

Released Fron RCS

\begin{tabular}{lllllll}
\hline Gase & & \multicolumn{5}{c}{ Fractile } \\
\cline { 3 - 6 } & & 0.01 & 0.25 & 0.50 & 0.75 & 0.99 \\
\cline { 3 - 6 } 1 & 0.30 & 0.55 & 0.70 & 0.75 & 0.80 \\
2 & 0.40 & 0.60 & 0.70 & 0.75 & 0.80 \\
3 & 0.60 & 0.65 & 0.70 & 0.75 & 0.80
\end{tabular}

Table B-8

Distributione for Fraction of Hydrogen to Upper Plenu and Done

\begin{tabular}{|c|c|c|c|c|c|}
\hline \multirow[t]{2}{*}{ Case } & \multicolumn{5}{|c|}{ Fracti1le } \\
\hline & Q.01 & 0.25 & 0,50 & 0.75 & 0.99 \\
\hline 1 & 0.08 & 0.095 & 0.11 & 0.12 & 0.13 \\
\hline 2 & 0.10 & 0.12 & 0.14 & 0.15 & 0.16 \\
\hline 3 & 0.12 & 0.15 & 0.17 & 0.185 & 0.20 \\
\hline
\end{tabular}

Sources of Uncertalincy

Major sources of uncertainty are the existence and location of an ignition source. Addt tional uncertainty has been Introduced by the use of Expert A s distributions for fractiona of hydrogen released from the RCS. Uncertainties were also assigned to the peak Inpulse, glven that a detonation occurced. 


\section{RTFERENCES}

B.1. A. L. Caop, V. L. Behr, and F. E. Haskin, "MARCH-HECTR Anelysis of Selected Accidents In an Ice-Condenser Contalnuent, "Sandia Hational Laborator 1es, NUREG/CR-3912. SAND83-0501, December 1984.

B-2. S. E. Dingman and A, L. Gaup, -Pressure-Temperature Reaponse in an Ice-Condenser Contalnment for solected Accidents," Trans, 23th water Reactor Safety_Infoxmation_Hesting, SAND85-1824C, NUREG/CP-0071, Gat thersburg. ND, 1985.

B-3. F. Haskin ot al., "HECTR Results for Ice Condenser Contalnnont Standard Problem, - Proceedings of the Second Workshop on Containment Integrtity, Crystal Cicy, VA, NUREg/CP-0056, SAND84-1514, August 1984.

B-4. Industry Degradod Coro Rulenaking Progran (IDCOR). "Sequoyah Nuclear Plant Integrated Containeont Analysis, IDCOR Task 23.1," Tennessee Valley Authority, Nuclear Englneering Branch, Technical Report 23.1, July 1984.

B-5. C. C. Wong, "HECTR Analyeis of the Nevada Test Stte (NTS) Premixed Combustion Experiments," Sandia National Loboratories, NUREG/CR-4916, SAND87-0956, Novenber 1988. 


\section{Hydrogen Burn Before Vessel Breach at Sequoyah}

\section{Descriotion of Expert C's Rationale/Mechodology}

Expert $C$ used References C-1 through C-9 for purposes of this elfcitation. The attached papers ticled "Possibllity of Detonation and other Contalnment Loads for Sequoyah" (Attachnent A) and "Additional Material for Sequoyah Elicitation" (Attachment B) by Expert C. present much of the rationale for the quantification of this issue. However, Expert $C$ was unable to predict the concentrations of bydrogen in the varlous compartments; the method described in the description of method of aggregation was used.

Expert $c$ considered presence of an ignition source to be the essential uncertainty for this issue, because code calculations predict detonable mixtures within the 1 co condenser for appreciable periods during this sequence (1f igniters and fans are operating, hydrogen is never a problem). The possible Ignicion sources were evaluated and it was decided that slambing of the tecal inceruediate deck doors is the most likely ignition source. The upper deck doors can flop over so that they remain open, but the upper deck doors are designed to stop by colliding into each other.

Expert $C$ consldered combustion in both the lce condenser and the dome. The concentration in the dome would only be flamable for the highest level of in-vessel hydrogen production, and anly towards the end of the accident. The ice condenser would have been detonable for long perlods by this time, and thus would have had wuch more chance of damaging conbustion. Consequently. Expert $C$ gave a rather low likelthood for combustion in the dome .

Deflagrations would be of importance only if chey occurred in the dome. The amount of hydrogen in the lce condenser or upper plenum is too saall to be of any consequence for deflagration. Expert $C$ therefore restricted the focus to events which would lead to detonation in the lce condenser or deflagration in the dome.

\section{Results of Expert C's Elicitation}

\section{Impulse and Pressure}

Cases 1, 3, and 4

Expert C's decomposttion is show in Figure C.1. This Expert estimated the probability of a path being open to the dome at 0,1 , based on the likelihood of intermediate deck doors being scuck open. If the doors were stuck open, the frequency of ignition in the lce condenser, upper plenum, and dome are shown by $\left[C_{t c}\right]$. $\left[C_{U P}\right]$, and $\left[C_{b}\right]$ on Figute $C-1$. Expert $C$ gave "half-11ves" to ignition (the tiwes at which an ignition trequency of 0.5 would be expected) as shown in Table C.l. The cimes of interest range up to about 50 minutes. It is assumed that any time within this interval is equally interesting. The Expert estimated the maximun frequencies of 


$\begin{array}{llll}\text { Path Ignition } & \text { DDT? } & \begin{array}{l}\text { Propagate } \\ \text { to Dome? }\end{array} & \begin{array}{l}\text { Lacation } \\ \text { Open to Burnits) }\end{array}\end{array}$

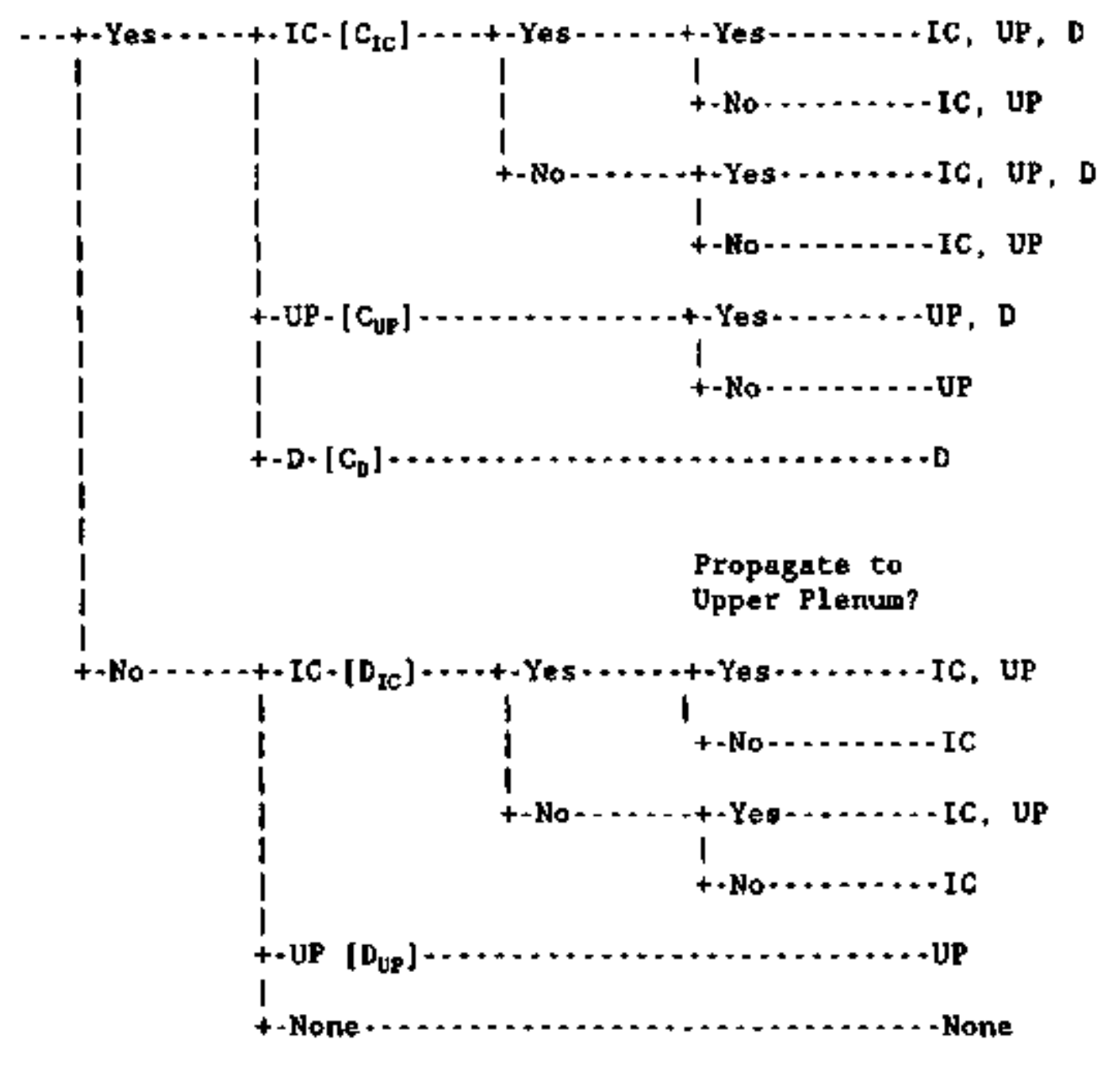

Figure C-1. Expert c's Decomposition Tree.

Table C-1

Half-Lives for Ignition

Nole Fraction $\mathrm{H}_{2} \quad$ Ionition Half-Life

5 to 129

12 to 189

18 to 458

20 minutes

10 minutes

5 minutes 
Ignition to be $0.3,0.6$, and 0.1 In the leo condenser, upper plemu, and dome, respectively. It should be understood that ignition inftiated in the done is only of interest if there has been no previous ignition in the lce condenser or upper plenun. A combustion in the upper plenum whether detonation or deflagration..-vould spread to the dome if the dome wole fraction were groater than 0.04 .

The probability of a clear path was estineted ta be 0.1 . In the more likely event that the path was not open to the done, frequency of $1 \mathrm{gnition}$ in the 1ce condenser and upper plenum are shown by $\left[D_{I c}\right]$ and $\left[D_{G F}\right]$ on $F 1_{g u r e}$ C.1. Expert $C$ estiated that the eaximum frequency of ignition in the lce condenser and upper plenum in this case vould be 0.90 and 0.05 . respectively. A conbustion in the lce condenser would spread to the upper plenun if the mole fraction of hydrogen in the upper plenum vere gxeater than $10 \%$.

The Ignition frequency distributions for each cospartment for the two cases (open/unopen path) described above can be resolved when the relative frequency of the casea is incorporated into the nodel. The resulting ignition frequency distributions are provided in Tables C-2 through C-4.

Table C.2

Distribucion for Igntition Frequency

In the Ice Condenser

Cumulative

Brobability

0.01

0.05

0.25

0.50

0.75

0.95

0.99
Ignition Frequency in Ice Condenser For Hydrogen Hole Fraction Ranges

$\begin{array}{ccc}\mathrm{H}_{2} \text {. If_5.5.113 } & \mathrm{H}_{2} \text { nf } 11.163 & \mathrm{H}_{2} \text {. mf }>16 \\ 0.005 & 0.010 & 0.021 \\ 0.026 & 0.051 & 0.093 \\ 0.109 & 0.177 & 0.251 \\ 0.177 & 0.233 & 0.270 \\ 0.249 & 0.274 & 0.288 \\ 0.519 & 0.716 & 0.857 \\ 0.712 & 0.873 & 0.891\end{array}$


Table $C \cdot 3$

Distribution for Ignition Frequency

in the Upper Plenum

\begin{tabular}{|c|c|c|c|}
\hline \multirow{2}{*}{$\begin{array}{l}\text { Cumulative } \\
\text { Probibjlity }\end{array}$} & \multicolumn{3}{|c|}{$\begin{array}{l}\text { Ignition Frequency in Upper Plenun } \\
\text { For Hydrogen Mole, Fraction Ranger }\end{array}$} \\
\hline & $\mathrm{b}_{2}$ nff $5,5-1.1 \mathrm{k}$ & $\mathrm{H}_{2}$ af $11-16 \mathrm{~A}$ & $\mathrm{H}_{2} \mathrm{mf}>16 \mathrm{~s}$ \\
\hline $\begin{array}{l}0.01 \\
0.05 \\
0.25 \\
0.50 \\
0.75 \\
0.95 \\
0.99\end{array}$ & $\begin{array}{l}0.003 \\
0.017 \\
0.147 \\
0.319 \\
0.424 \\
0.485 \\
0.497\end{array}$ & $\begin{array}{l}0.004 \\
0.020 \\
0.260 \\
0.464 \\
0.551 \\
0.590 \\
0.598\end{array}$ & $\begin{array}{l}0.005 \\
0.023 \\
0.408 \\
0.557 \\
0.578 \\
0.596 \\
0.599\end{array}$ \\
\hline
\end{tabular}

Table C-4

Distribution for Ignition Frequency

in the Dome

Cumulative

Probab1115y

0.01
0.05
0.25
0.50
0.75
0.95
0.99
Ignition Frequency in Upper Plenun

for Hudrogen vole Fraction Ranges

$H_{2}$ If 5.5-113 $\mathrm{H}_{2}$.nf 11-169

$\mathrm{H}_{2} \_\mathrm{nf}>16 \%$

0.001

0.003

0.006

0.007

0.014

0.025

0.030

0.047

0.068

0.053

0.078

0.092

0.071

0.092

0.096

0.083

0.098

0.099

0.090

0.100

The probability of a DDT as a function of hydrogen mole fraction, is shown in Table 0.5 . This was fitted as a log-normal distribution with median at 0.1833 mole froction, and $10 \mathrm{ch}$ and $90 \mathrm{th}$ percentiles at 0.14 and 0.24 mole fractions. respectively. The probability of a DDT for tines of either an open or unopen pach to the dome is the same.

If detonstion occurs in the ice condenser or upper plenum, the magnitude of the tmpulse is given by the distribution of Table C-6; this was fitted by a log-normal distribution with a median at $12 \mathrm{kPa-s}$, and $10 \mathrm{th}$ and $90 \mathrm{th}$ percentiles at 6 and $24 \mathrm{kPa}-\mathrm{s}$. The 1mpulse distributions differ only $1 \mathrm{n}$ unimportant detalls between 25 and 602 zirconium oxidation. If a deflagration occurs in the dowe, or if combustion spreads to the dome, the pressures in the dome are given by Table $c-7$. 
Table $\mathrm{C}-5$

Deflagration-to-Detonation Transition

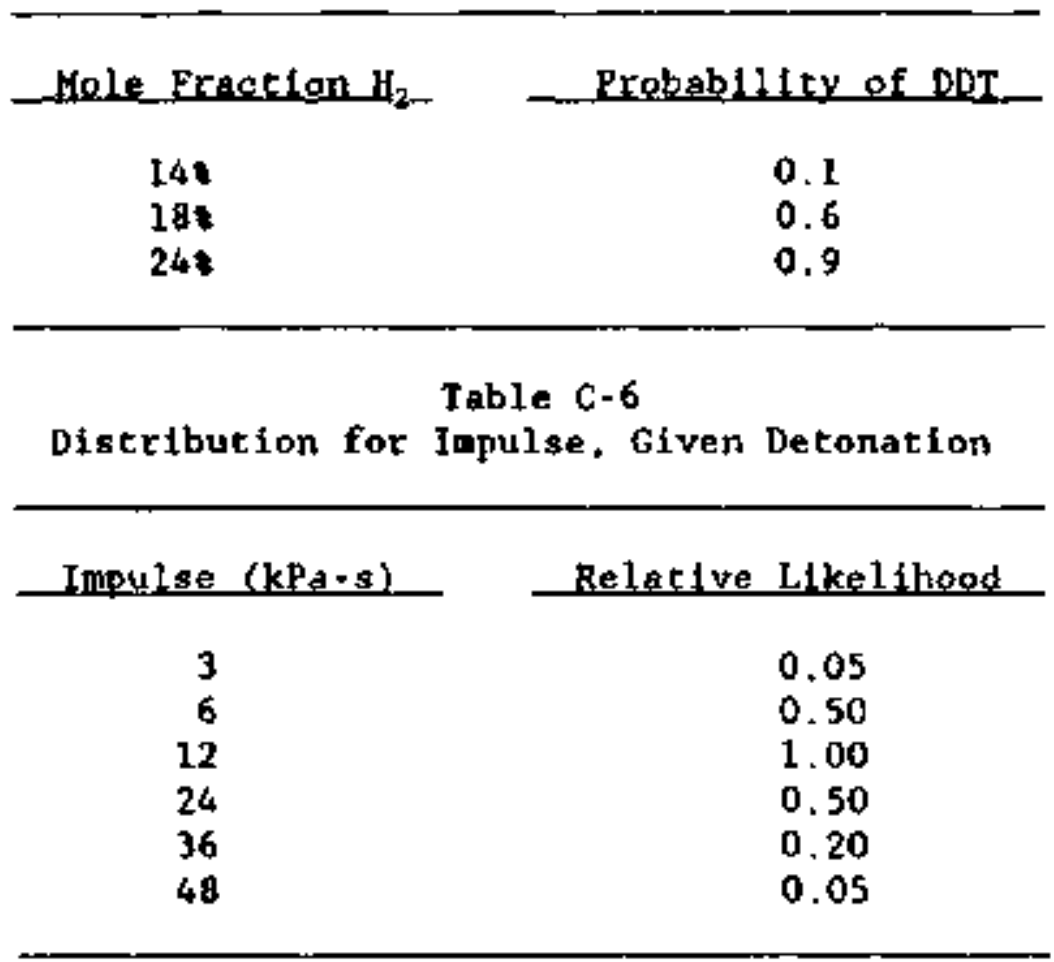

Table C.7

Pressure in Dome, Ice Condenser Not Bypassed (Cases 1, 2, 3, and 4)

\begin{tabular}{cc}
\hline Moje Fraction $\mathrm{H}_{2}$ & Pressure in Dome $K P a$ \\
\cline { 2 - 2 } 0.05 & 50 \\
0.06 & 113 \\
0.07 & 189 \\
0.06 & 238 \\
0.10 & 281 \\
\hline
\end{tabular}

Case 2

Expert c cited a CONTAIN calculation which Indlcated that most of the steam and hydrogen would pass directly to the upper contalnment via a drain line in the tefueling canal. largely bypassing the ice condenser. If this happens, there would be no possibllicy of detonation or deflagration in the lce condenser or upper plenum, slthough deflagration is still possible in the dome. Table C-B shows pressures fron a deflagration in the upper compartment as a function of tole frsctian, lncluding the effects of the high steam fraction expected in the done if the ice condenser is bypassed. only the single CONTAIN calculation exists for this case, and the behavlor of the steam and hydrogen is highly uncertain. Therefore, for Case 2, bypass of the ice condenser and passage through the lce condenser (as in Cases 1,3 , and 4) are considered to be equally likely. 
Table $6-8$

Pressure in Dowe, Ice Condenser Bypassed

(Alternate Gase 2)

Mole Fraction $\mathrm{H}_{2}$

0.08

0.10

0.12

0.14
Fressure in Dome, ikPa

117

260

$3 \mathrm{JB}$

478

\section{Distributien of Hydrezen in Containment}

Expexc $C$ provided data on the fraction of hydrogen released from the RCS that is in each compartment before vessel breach. The data were obtained from the HECTR calculationst-1 and the CONTAIN calculation. For no 1ce bypass, the amount of hydrogen in the done in the clear path case was assuned to be 100s of the amount predicted by HECTR calculations reported in Table G.9. The amount in the case with no bypass of ice and the absence of a clear path, was estinated to be 50 of the anount predicted. The 508 which is not adnitced to the done, is distributed through the remaining compartments in the same ratios as were predicted by HECTR. Table C.9 shows the fraction of hydrogen in each compartment.

Table C-9

Distribution of Hydrogen 1n Containment; Compartnental Fraction of Totsl Hydrogen Released from the RCS

\begin{tabular}{|c|c|c|}
\hline Conpartment & $\begin{array}{c}\text { HECTR Prediction } \\
\text { (Cases_1 } 2,3 \text {, and } 4)\end{array}$ & $\begin{array}{l}\text { CONTAIN Prediction } \\
\text { (Alternate Case 2l }\end{array}$ \\
\hline Lower Compartaent & 0.35 & 0.44 \\
\hline Ice Condenser & 0.36 & 0.13 \\
\hline $\begin{array}{l}\text { Upper Plenum of } \\
\text { Ice Condenser }\end{array}$ & 0.03 & 0.01 \\
\hline Upper Conpartment & 0.26 & 0.42 \\
\hline
\end{tabular}

Mass of Hydrogen Burned

The mass of hydrogen in each compartment was estimated as described in the general discussion. Expert $C$ spectfled that the completeness of combustion should be estinated by che empirical equation to be used in the HECTR Version 2.0 , developed by $C$. Hong.c-2 Burn completion as a function of wole fraction is given in Table C-10 for Cases $1,2,3$, and 4 , and in Table C.11 for alternace Case 2 with the ice condenser bypassed. 
Table C.10

Burn Completenes., Ice Condenser Hot Bypassed

(Cosen 1, 2, 3, and 4)

\begin{tabular}{cc}
\hline vole Fraction $\mathrm{H}_{2}$ & \\
\cline { 2 - 2 } 0.05 & .242 \\
0.06 & .547 \\
0.07 & .852 \\
0.08 & 1.000 \\
\hline
\end{tabular}

Table C.11

Burn Completeness, Ice Condenser Bypassed

(Alternate Case 2)

Hole Fraction $\mathrm{H}_{2}$

Burn Completeness.

$\begin{array}{ll}0.08 & .372 \\ 0.10 & .666 \\ 0.12 & .764 \\ 0.14 & .960\end{array}$

\section{Sources of Uncertainty}

Expert $C$ assigned the najor source of uncertainty to the existence and timing of an ignition source. This Expert belleved that the atnosphere in the ice condenser would eventually detonate if there were enough time. The principal uncertainty is whether there is enough time ta be sure that an Ignition source is present while the 1 ce condenter atmosphere is detonable. The probability of a DDT is a function of hydrogen concentration, so that uncertainties in the production, release, and distribution of hydrogen also impact the uncertaincy. The magnitude of impulse resulting from a detonation is also highly uncertain.

\section{Sugaested Methods for Reducing Uncertainty}

One source of uncertainty is the likelihood of bypass of the ice condenser in Case 2. More excensive calculations of the very small leak scenarla, and a better understanding of the paths for bypass, would help to reduce the uncertainty in Case 2 .

The greatest source of uncertainty is in the probability of ignition. Expert $C$ does not believe that experiments could be meaningfully pursued at this time, beceuse the important paraneters are not known. This Expert suggests a literature search--which should not be confined to the literature specific to nuclear power-oto help delineate current understanding of 
randon ignition processes. The literature seacch would take about six months. After avallable knowledge has been summorized, an experimental or theoretical progran ight be justifled. 


\section{REFERENCES}

C-1. A. L. Camp, V. L. Behr, and F. E. Haskin, "MARCH-Hectr Analys1s of Selected Accidents in an Ice-Condenser Contalnment," Sandla National Labaratories, NUREG/CR-3912, SAND83-0501, Decenber 1984.

C.2. G. C. Wong. "HECTR Analyses of the Nevada Test Site (NTS) Prenlxed Combustion Experiments, " Sandia National Laborstorles, NUREG/CR-4916, SAND87-0956, November 1988.

C-3. S. E. Dinguan and A. E. Camp, "Pressure-Temperature Regponse in an Ice-Condenser Containment for Selected Accidents," Trans.13th Water Beactor 5afety Information Meeting, SAND85-1824C, NUREG/CP-0071, Gaithersburg, HD, 1985.

C-4. J, E. Shepherd, "Chemical Kinetics of Hydrogen-Air-Diluent Detonations," pynagicg of Explostons, Pp. 263-293. Vol. 106, Progress in Astronautics and AeronoutIcs, AIAA, New York, NY, 1986.

C.5. M. P. Sherman and M. Berman, "The Possibflity of Locel Detonations During Degraded-Core Accidents in the Bellefonte Nuclear Power Plant, " Sandla National Labotatories, NUREG/CR-4803, SAND86-1180, 1987.

C.6, B. W. Marshall, Jr., "Hydrogen;Air:Steam Flammbility Limits and Combustion Characteristics in the FITS Vessel," Sandia National Laboratories, NUREG/CR-3468, SAND84-0383, Decerber 1986.

G-7. M, P. Sherman, "Hydrogen Combustion in Nuclear Plant Accidents and Associated Containment Loads," Nuclear Engineering and Design, Vol, 82. pp. $23-24,1984$.

C-B. D. W. Stanps, C. C. Wong and L. S. Nelson, "Uncertainties in Hydrogen Combustion," 15th Likht Hater Regctor Safeby Infornation Mesting. Gal thersburg. MD, 1987.

C-9. M. P. Sheruan, S. R. Tleszen and W. B. Benedick, "Flame Acceleration and Transition to Detonation In Channels," Sandla National Laboratories, SANDB7.1444C, 1987. 
ATTACHENET A--Pago 1

\section{POSSIBILITY OF DETONATION AND OTBER CONTAIMENT LOADS FOR SEQUOYAB}

Februmy 23, 1988

Several membere of the coptainment londe expert panel including myelif heve been acked to exemine the poecible londs due to bydrogen combuction in the Saquoyab plant prior to vesel breach for everel etetion bleckout type eceidente [1]. The two large eir returg fane between the upper and lower compartmenta are not operating, the deliberate ignition eymtem ie not operatiog, and the upper compertment epraye are not operating. These cuger are: a TMB', a bell LOCA (S.) hich preeture weltdow, a ctecion blackout with a etvek open PORV ( $\left.S_{3}\right)$ LOCA. and tetion blackout with cycling PDRV and a naequent induced lerge hot leg fejlur.. The panti egroed to coneider two lovele of zirconium oxidation, 25x io the lon level and $60 \%$ is the bich lovel. The purpose of this memorandum is to document my thinkine on the nubject, and pousibly help the other membere working on th* istov.

The following teble gives uteful values of volures, ateset and wolet for Sequoyah. The roluned are taken fron computer input to Ref. A; the zirconium wast wo taken from * etudy by C. C. Wong, Sandie Div. 6427. The number of kmoled of ais were obtained from the perfoft chs law ( N * PV/RT) veing P * 101 kPa, $T=298 \mathrm{~K}, V=33,740 \mathrm{~m}$, and $\mathrm{R}=8.317 \mathrm{~kJ} / \mathrm{keol} * \mathrm{~K}$

\author{
Rezion \\ lower compertment \\ dead-ended region \\ lower plenut \\ ice condenuer \\ upper plenum \\ upper cobpartsent \\ total
}

meve Zirconium ktooles Zr. kmolos ih (300\% oxidation) mave $h_{2}$ ( $100 \%$ oxidation)

\begin{tabular}{c} 
Percent Totel \\
\hline 4.3 \\
7.9 \\
2.0 \\
7.2 \\
3.0
\end{tabular}

54.6

\section{kmoled air in containeant $=3375 \mathrm{kmol}$} kmol te of $D_{1}$ in conteinoent = 287 koole

In the oxamination of Refe. 2,3 together with the computer priptout ued in thees atudiea, certain general fostures common wo all these eceident. becune elwar. These featuras caude the

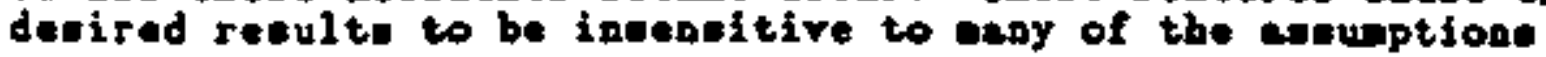


used. In the following eetione we eddress the comon features of these cccidents and the differences between them.

The lack of return eir far operetion domidates the conditione in conteinment prior to the firgt bydrocen burn. Witb fans operatiog, the hydrogen mole frectione in the verioue compartwente tend to be oimilar. There are no detoneble mixture*. Deflacretione tead to be slobel. Deliberate ignition i. then rery important in preventiog the buildup of bydroged. Ae lons ae the lice condeneer fupctione to condenes not of the oteraf, and the emell ares bypene from the lower to upper compartment in the Jofueling channel is not oisnificent, the containmed apraye in tbo uppor compartient do not alter conditione wuch. Without the return air fane, conditione are totally difforent a diecueas in the following paragraphe.

Th* lower compertmont ie inerted due to the low level of

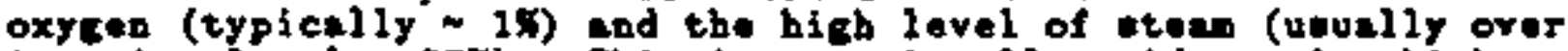
inerting I ovel - 55\%). Thi is tru in all acsidente in which the initicl roloaes of oteas from the primary oretem drives the eir from the lowor coepertient. Conenquently, there eppears to be no chance of a diffusion flame at the hydrocen mource. Condenuntion of tan in the lower compertment is not importent once the ourface terperaturea ro above the dew point.

Consequently, conditione in the lower compartoent tend to be incentitive to the rater of utear and hydrogen release, but eneitive only to tb* totel amount.

Ther* sre dead-ended regiong off the lower compertwent wuch * the probeuriser dot boute. The cat wixture in thent rotiont ens be combutible, and burne are predicted there in atoverel casee. Howter, these buras are of little isportebce.

Deflegretione in these regione can not propackte ioto tb* lower compertment. The volumes involved are not large enough to give

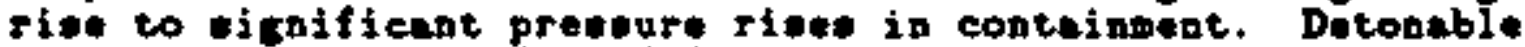
- ixture: are not predicted for thees regiont. Evon if * detonetion did occur in the preseuriser dog boute, the impules on the containowt well would sot be grest.

In order to buve a lerge preseure ribe due to a deflagration.

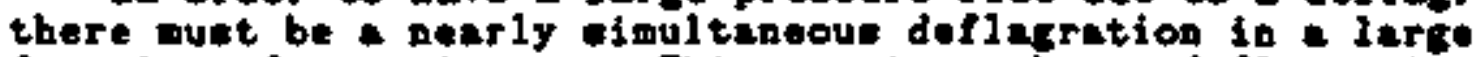
fraction of conteineent. Thie required that a deflecretion necur in the upper compartment, al though the deflagration buy hav originated olsewhere. Unlese there it eignificant bypunelog of the ice condenser. 1ittlo oteas it convected into the upper compartnent. With the condensation of oten in the ice condenser, HECT retulto predict bydroten is convected olowly into the upper compertont. In way eccident ecenerion, the hydrocen mole fraction in the upper compartient nover exceed the 11nombility limit. In carne whire a upper compartment burn it 
ATTACHWENT A $*$ Page 3

predicted, large prescure spikes eccompeny these buras.

Consequently, the iseve of the maximum overpressure predicted in Sequoyab due to hydrogen deflarration is lergely dependent on the areesement of the poseibility of an upper compartient deflagration. The upper compertment far mixture never epprosches - possible detonable mixture. If the senm-bydrogen relense

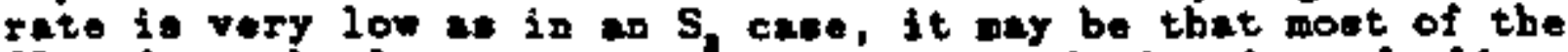
flow frow the lower to upper compertment is by the refueling pit bypaet opening and not by the ico condenest. In thit caet high - that concantrationt are poseible in the upper cospartment. $A$ preliminery calculation with the CONTAIN code indicates the upper compartment etmouphere could get to $45 \%$ team, $8 \%$ bydrogen. Ibio mixture if just inside the flemmebility limit.

In all ceses considered by HECTR, the eteam concentration in the ice condenter is low and the bydroged concentration reaches detoneble valuee. For as $S_{1} H F$ ceet coneiderad in Ref. B the composition wap $25.9 \%$ hydrogen, $0.38 \%$ ottem, 14.7\% oxygen, and the rest nitrogen. Uaing a preseure of 130 kPa end e tamperature of $283 \mathrm{~K}$, the Shepherd ZND computer code [4] was run by $\mathrm{S}$. E. Slezak to obtain a detonation cell width of $20.1 \mathrm{~mm}$. In the ntudy of Sherman and Bermen [4] hydrogen-air-etean wixturef were cleseified a to detonability in fire elases. Mixtures witb detonation cell widthe up to $20 \mathrm{~mm}$ were cleesified extremely detonable, clene 1 . Consequently, the mixture coneidered is on tbe border of clese 1 and clete 2 , where clast 2 in easily detoneble. The reometry of the surrounding was cles ified by it: fleme eceleration poteotial into five clesset. The ice condenerer ceometry it coneidered clete 2, promoter fleme ecceleretion, by Shormen. Bermas contidered it clest 1 . He felt thet in downwerd flame propagetion, the fleme would be forced adewise coing around tbe ice basket: and coneratint turbuledee. Sherban conaidered it clete 2 , becaute although there are mosy obstaclet to promote flane acceleretion in eircunferential burn, there it treneveres venting upwerd. The wixture clan and the ceometric clase are ued to tive a resulte clese for the poneibility of deflatration-to-detonation trantition (DDT). For gixture clase 1 and geometrie clane 1 or 2 , the resulte class ia 1, "DDT is highly likely." For Geonetric clate 2 and mixture clave 2 , the result clese it 2 , "DDT it likely." In moy otber caete the hydrogen conceptration is about 225, with atean concentrations of one or two percent. This would increase the detonation cell width about 30 f from the previous cene, elightly reducing the detonability of the mixture and putting the redulte into clane 2, "DDT in likely."

In the ice condeneer upper plosud, little oteam enters by convection frow the ice condenser below. The hydrocen concentretione are nuch lower thes in the ice condeneer. In 11 cases, the wixture are flemeable, but in many, the bydrogen wole 
frection is below the $9 \%$ downward flamability liwit. It is an interesting quetion if the ignitere in the upper plenum operate if the flame can propugete into the ice condeneer. The flows generated by the combution tay cause now hot ection of gasec to move downward and i gnite the gat in the ice condenser, even if the mixture is nominelly outuide the dowward flamability limit. 
ATTACHENT A--Page 5

\section{AEFERENCES}

1. Sandia Natioanl Laboratorier NUREg 1150 Staff, "Containment Lated at Sequoyah Due to Hydrogen Deflagration/Detonation Prior to Vetsel Breach," position paper prestited to conteinment loade expert review group, Dec.1087.

2. A. L. Canp, V. Behr, and 2. Haskine, HARCH-HECTR Analyeit of Selected Accidente in an ice-Condencer conteintent. NUÄEG/Ck-3912, SANDB3-0501, sendia National Leboratories, Dec. 2084.

3. S. B. Dingman and A. L. Camp, Preseure-Tempereture Reaponese in an Ice-Condener Conteingent for Selected Accidente. SANDB5-I824C, Sandia National Leboratoriea, Juge, 1084.

4. J. E. Shepherd, "Chomical Kinetice of Fydrogen-Air-Diluedt Detonetione, Dynemice of Explotione, pp. 263-203. Vol. 10s, Progrees in Aetronsutice and Aeroneutice, AIM, New York, NY 1086.

5. M. P. Sberman and N. Berann, The Poesibility of Locel

Detontions Durint Derreded-Core Accidente in the Bellelopte Nuclent Power plent, NuREG/Ch-4803, SAMD86-2180, to be publiched Nuclear Technology, Apsil 1088. 
ATTACHENT B--Page 1

Apr11 1, 1986

Additional Materiol for sequoyah Elicitation

We consider the presaure rise due to deflagration in the sequoyah upper conpartment for the cate of no steag and 404 stean. The upward flamability limits for hydrogen-bir-steam mixtures cas be estinated by the emplrical equation of Marahall [1].

7steam $=200$. $-\mathrm{Hz}-37.7 * \exp (-0.007+312)-518.0 \mathrm{kexp}(-0.488+4 \mathrm{~Hz}$ :

The above gives the following reoults:

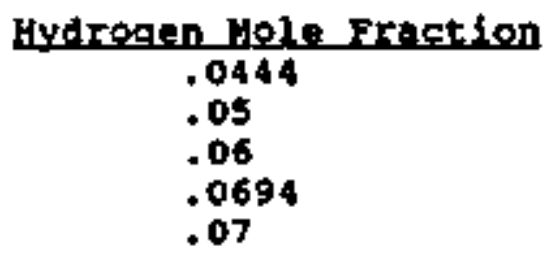

stith Mol
.000
.130
.305
.400
.404

The completeness of combustion is estinated by the empirical equation to b* used in HECTR Version 2.0 developed by $c$. $c$. Wong. The correlation of experiment dato is for a quiescont case (no eprays or fans), and for turbulent case (aprays and/or fans).

Completenets (quiencent) = Mininum of unity or

$\left(30.499 X_{H}-1.2827\right) \exp (A)$

where $X_{H}$ 15 the hydrogen mole fraction, $X_{s}$ lo the steam mole traction, and

$$
\lambda=X_{t} *\left(-4.1966+3.3985 * X_{2}\right)
$$

For the turbulent calte,

Conpleteness (turbulent) - Miniaum of unity or $\left(28.638 * X_{H}-1.0463\right) * \exp (\mathrm{A})$

The reatita are

\begin{tabular}{|c|c|c|c|}
\hline \multirow{2}{*}{$\frac{\text { stita yole } \mathrm{Er}}{0.0}$} & \multirow[b]{2}{*}{$\begin{array}{c}\text { Hydrogen_yole } \\
.08 \\
.07 \\
.06 \\
.05 \\
.045\end{array}$} & \multicolumn{2}{|c|}{ Completen } \\
\hline & & $\begin{array}{l}1.00 \\
.852 \\
.547 \\
.242 \\
.090\end{array}$ & $\begin{array}{l}1.00 \\
.958 \\
.672 \\
.386 \\
.242\end{array}$ \\
\hline 0.4 & $\begin{array}{l}.15 \\
.24 \\
.12 \\
.10 \\
.08 \\
.0694\end{array}$ & $\begin{array}{l}1.00 \\
.960 \\
.764 \\
.666 \\
.372 \\
.268\end{array}$ & $\begin{array}{l}1.00 \\
.952 \\
.768 \\
.676 \\
.400 \\
.303\end{array}$ \\
\hline
\end{tabular}


The estimated deflagration pressures will be dotermined as follows. The initial pressure and tenperature of the mixtures will be estimated. The pressure ratiof for the no steam case, and the pressure for the steam cace will be determined from the plots aubmitted by shermon to the etructural and the louds groups [2]. The pressure ratio or overprotsure will bo reduced by multiplication by the completenes. The overpressures will be ottumed to b* roduced by $5 \%$ for heat transfer to solid surfaces losses. Finaliy the pressure reduction due to expansion into the lower compartment will be estimated.

The correction for expansion into the lower compartment is based on isentropic expansion from the upper into the lower compartment until the pressure 10 balanced. This type analysis was done in the nemorandum for Grand Gulf. About $1 / 4$ of the totel volume ie in the ice condenser, upper and lower plonum. These volumes nust be considered as part of the combustion volume, part of the volume for expansion, or as ibolated. If $v_{1}$ is the volune of the volume that has combustion, $P_{1}$ the corresponding constant volume pressure, $v_{2}$ the volume into which gas will expand (lower compartment volume, etc.), $P_{2}$ the corresponding constant volume pressure, bv the increase in combustion gas volume due to expansion into $V_{2}$, and $P_{3}$ the equilibrated pressur atter this expansion, we have

$$
\begin{aligned}
& \Delta V / V_{2}=\left[\left(P_{1} / P_{2}\right)(1 / \gamma)-1\right] /\left[\left(V_{2} / V_{1}\right)+\left(P_{1} / P_{2}\right)(1 / \gamma)\right] \\
& P_{3} / P_{1}=1 /\left[1+\Delta V / V_{1}\right] \gamma
\end{aligned}
$$

\section{Ho STEAY CASE}

The tomperature in the upper conpartnent w111 be near normal. The pressure vill be increased bocause of the ston prosent in the lower compartment and the hydrogen. For einplicity, assume a pressure of 1.3 Ber independent of the hydrogen bole fraction, and compution in all volumes except the lower conpartient. Hence $v_{2}$ $=10,646 \mathrm{~m}, \mathrm{v}_{1}=22,894=3, v_{2} / v_{1}=0.474$.

\section{AICC Presente}

$x_{\mathrm{H} 2}$ Batio $P$ (hat)

\section{emplotentry}

.104 .1

.083 .6

$.07 \quad 3.4$

.063 .2

.05
6.25

5.40

5.10

4.80

2.9

4.35
2.00

1.00

.852

.547

.242
1.00

1.00

.958

.672

.386

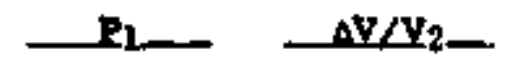

\subsection{9}

5.27

4,42

3.22

2.27
5.99

5.21

4.78

3.61

2.55
.529 .529

.493 .493

.941 .466

.330 .372

.189 .238

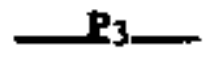

4.314 .31

$3.88 \quad 3.88$

3.393 .61

2.632 .88

2.012 .20

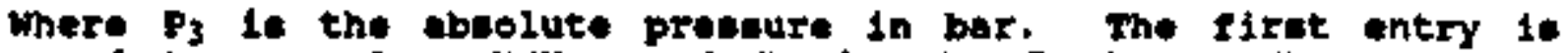
completenese, $P_{1}, \Delta V / V_{2}$, and $P_{3}$ le the oquiecent" case; the wecond entry 10 the turbulent cate. 
ATTACHMENT B--Page 3

40t STENY

The tomperature in the upper conportment vill be elevated. The pressur will be higher than for the no tealn case. A 10 mole fraction of steam corresponds to a containment proseuro of about 1.7 bar. Aesume the Initial prefeure is 1.7 bar. The ctearn partial proseure will b* 0.68 bar, corrosponding to a otturation tempersture of $362 \mathrm{~K}$. Uting the AICC preeture figure to be used with caturated steaw, we get,

\begin{tabular}{|c|c|c|c|c|c|c|c|c|c|}
\hline \multirow{2}{*}{$\begin{array}{l}x_{42} \\
.06 \\
.20 \\
.12 \\
.14\end{array}$} & \multirow{2}{*}{$\begin{array}{r}\text { Arce } \\
\text { P(barl } \\
7.2 \\
9.1 \\
9.0 \\
10.0\end{array}$} & \multicolumn{2}{|c|}{ Completeness } & \multicolumn{2}{|c|}{ Pl(bar) } & \multicolumn{2}{|c|}{$\Delta \mathrm{V} / \mathrm{V}_{2}$} & \multicolumn{2}{|c|}{ P3...(bar) } \\
\hline & & $\begin{array}{l}.372 \\
.666 \\
.764 \\
.960\end{array}$ & $\begin{array}{l}.400 \\
.676 \\
.768 \\
.953\end{array}$ & $\begin{array}{l}3.64 \\
5.75 \\
7.90 \\
9.27\end{array}$ & $\begin{array}{l}3.79 \\
5.81 \\
7.03 \\
9.21\end{array}$ & $\begin{array}{r}.329 \\
.485 \\
.543 \\
.615\end{array}$ & $\begin{array}{r}.344 \\
.498 \\
.544 \\
.614\end{array}$ & $\begin{array}{l}2.87 \\
4.30 \\
5.08 \\
6.48\end{array}$ & $\begin{array}{l}3.07 \\
4.34 \\
5.10 \\
6.44\end{array}$ \\
\hline
\end{tabular}




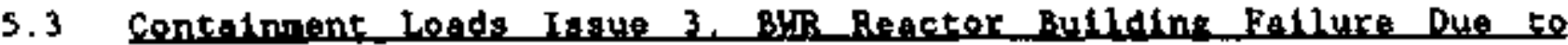 Hydrogen Burns
}

\author{
Summixy of Issue 3: Expert Panel" s hasespent of \\ Peach Botton Resctor Bullding Pallure Dus to Hydrogen Burn:
}

Experto consulted: Marty Plys, Fauske and Associstes; Fred Torri, Pickard, Lowe Garrick, Inc.; Pat Worthington. Nuclear Regulatory Comalssion.

\section{Issue Description}

What distributions characterize the uncertainty in loada, both quasi-static and 1mpulsive, produced by hydrogen burns or detonations in the Peach Botton reactor bullding?

This issue relates to the possibility that hydrogen burns within the reactor bullding lead to gross structural fallure. In the Februaty 1987 draft of NUREG+1 150 it was determined that the efficiency of figsion product retention by the reactor buflding was an important determinant to risk. Structural fallure would reduce that efficlency. This issue focuses on hydrogen conbustion loads large enough to precipltate structural fallure. The expert panel was at liberty to drop cases (or subcases) of this issue for which they were certain that the induced loads fron hydrogen combustion nould not compromise the reactor building's integrity.

Three cases were considered for this issue:

1. Containent fallure elther at of following vessal braach in a longterm sequence. The suppression pool is saturated and thus large quantities of stean continue to flow into the reactor bullding following a leak or rupture of the contalneent.

2. Late contalnment fallute at least an hour after vessel breach in a short-term sequence. The suppression pool is subcooled and thus little stean flows into the reactor bullding following containment fallure.

3. Contalnaent fallure occurs before core damage. The suppression pool is saturated at the tine of fallure and large quantities of stean flow into the reactor building before core danage ensues. Steam continues to flow into the bullding throughout the scenarlo.

Cases 1 and 2 are nost 1 ikely the statlon blackout scenarlos. Case 2 may involve a lass of both ac and dc power. During the presentacion of the issue, the MUREG-11S0 analysts felt that 1 gnition sources would always be present. Some members of the expert panel volced support for this assessinent. Case 3 corresponds to scenarios Involving fallures of the reactor protection system (l.e., there is no reactor scran). Such sirjuences are commonly referred $t$, as anticlpated transient without scran (ATWS) 


\section{Summary of Expercs" Rationale}

Expert 1 felt that inpulse loading was not gernane to this issue since ignition was certain before detonable concentrations were attained. Thus, only peak static pressure was assessed.

Three factors were considered by Expert A: (1) whether hydrogen burning would be characterized by continuous conbustion (1.e., diffusion flames) or by discrete burns (L.e., multiple deflagrations); (2) given that hydrogen combustion involved deflagracions, the molar concentration at which ignition occurs; and (3) the flame speed during deflagration burns.

For those scenarios characterized by diffusion flame burning or by disctece burns with flame speeds less than $4 \mathbf{n} / \mathbf{s}$. Expert A felt that the failure of the refueling bay blow-out panels, Iffting of hatch covers, and the blowout of interior doors would mitigate the pressure rise within the bullding. Expert A felt that during these scenarlos, the pressure rise would not be suffictent to cause gross failure of the reactor bullding.

For those scenarios characterized by discrete burns with flame speeds greater than $4 \mathrm{~m} / \mathrm{s}$, Expert $A$ assessed the distribution of the static pressure rlse; the peak static pressure rises vere based on calculations perfarmed with the MELCOR and HECTR codes.

Uncertainties associated with hydrogen ignition were seen to be the largest contributor to uncertatnties in peak statlc pressure. If the combustible gases were 1 gnited as they escaped the contalnoent, Expert $A$ felt that an essentially static diffusion flame would be present. Ignition at points in the building distant fron the source cauld occur at varlous concentrations of combustible gas depending on the location, avallable ignttion sources. and the quantity of steat that had accumulated. Peak static pressure would be a strong function of the conbustible gas concentration at ignition.

Expert B's approach was to assess the uncertainties associated with the type of burn, the ignition, the hydrogen $\left(H_{2}\right)$ concentration in the reactor building, and the pressure rlse frow a hydrogen burn using a probability equation.

The Expert chought that hydrogen vould efther burn as a jet as it is injected into the reactor building or as a deflagration. For the blackout case, the Expert felt that a jet would not exist due to the lack of igntiton sources. For the non-blackout case, the probability of a jet burn was related to the contalnoent hydrogen concencration and temperacure.

Expert B felt that the lgnition probability depended on the type of burn that occurred and the on the hydrogill concentration in the reactor buildtng. If the hydrogen burned as a jet, the Expert assumed a unlform probablity distribution between reactor butlding hydrogen concentrations of $\rightarrow$ and 88 .

The Expere developed a simple model to estimate the pressure rise from a ":itrogen burn using an ldeal venting equation. (Je was the Expert's judgment that venting controls the pressure rise.) The Expert then used 
this model to calculate the pressure rise assuming varlous hydrogen concentrations, fleme speeds, compartaent volumes, and loss coefficients. From this Inforsation the Expert developed probability distribution functions for the presiure rise for reactor building hydrogen concentrations of 4,8 , and 12 ,

The Expert indicated that the location of the leak was not important because the steam concentration would not differ signiflcently at different leak locations. Furthermore, he thought that even for high steam concentrations, large amounts of steam would condense in the reactor building and. thus, the amount of steam did not have to be explicitly considered. For the canditians presented $1 \pi$ this 1ssue, the Expert felt the differences between the impulsive load and the static pressure rise was negligible.

Expert $q$ perforned a base case analysis based on the calculations in the general literature and then assessed the impact by considering the differences in the assigned cases. Transitions to detonation were considered she doninant source of detonations; direct detonations were not thought possible since no ignition sources in the reactor building are likely to be strong enough. The Expert thought that ignition probability was essentlally 1,0 and would occur as soon as steam de-Inerting would allow. For low steam cases, the impact of flame speed on peak pressure was coristdered more Important than in the high stean cases.

\section{Hethod of Ageregation}

The information from the experts was modified to average the results. For the final aggregation of this 1ssue, two sets of cases were defined. The first set (Table 3-1) was based on the case structure, as defined in the Issue Description. and the additional resolution fmplied by the experts' decomposition (see Table 3.3 and Figures 3.1 to $3-6$ under Aggregated Results).

Table $3 \cdot 1$

Final Case Set 1

\begin{tabular}{|c|c|c|c|c|}
\hline \multirow[b]{2}{*}{ Eind Case } & \multirow[b]{2}{*}{ Oxlolnal Case } & \multicolumn{3}{|c|}{ Expert case } \\
\hline & & A. & 8 & $\mathcal{C}$ \\
\hline l & 1 & 1 & 1 & 1 \\
\hline 2 & 1 & $\hat{\mathbf{z}}$ & 1 & 1 \\
\hline 3 & 2 & 1 & 1 & 2 \\
\hline 4 & 2 & 2 & 1 & 2 \\
\hline 5 & 3 & 3 & 2 & 3 \\
\hline 6 & 3 & 4 & 2 & 3 \\
\hline
\end{tabular}

The Peach Botton plant analyst restructured the cases upon phenomenologlcal considerations. 
The second set of cases (Table $3 \times 2$ ) was more compatible with the accldent progression event tree logic, and the results of this were used in the accident progression event tree for Peach Botton (see Table 3-4 and Figures 3.7 through 3.12 under Aggregated Results).

Table $3-2$

Final Case Set 2

\begin{tabular}{|c|c|c|c|c|c|c|c|}
\hline \multirow[b]{3}{*}{ Efnal Case } & \multirow{3}{*}{$\begin{array}{l}\text { Containment } \\
\text { Pressure }\end{array}$} & \multicolumn{2}{|c|}{ Phenomenoloxy } & \multirow{3}{*}{$\begin{array}{c}\text { Original } \\
\text { Case } \\
\end{array}$} & & & \\
\hline & & High & Station & & \multicolumn{3}{|c|}{ Bxpert Gase } \\
\hline & & Stean: & Blackout & & $A^{* *}$ & $B$ & $t$ \\
\hline 1 & High & $\mathbf{Y}$ & $\mathbf{Y}$ & 1 & 2 & 1 & 1 \\
\hline 2 & High & $\mathbf{N}$ & $\mathbf{Y}$ & 2 & 2 & $\mathbf{1}$ & 2 \\
\hline 3 & Low & $Y / N$ & $\mathbf{Y}$ & 3 & 2 & 1 & 3 \\
\hline 4 & H1gh & $\mathbf{Y}$ & $\mathbf{N}$ & 1 & 2 & 2 & 1 \\
\hline 5 & High & $\mathbf{N}$ & $\mathbf{N}$ & 2 & 2 & 2 & 2 \\
\hline 6 & Low & $\mathbf{Y} / \mathbf{N}$ & $\mathbf{N}$ & 3 & 2 & 2 & 3 \\
\hline
\end{tabular}

"Corresponds to saturated suppression pool or subcooled suppression pool.

"Expert A's final results were essentially the same for all cases ovaluated and his Case 2 ivas used for the aggregation.

The following modifications have been ade to the Individual axpart's results in order to aggregate them.

For Expert A :

Expert $A$ decided that the oxjdized Cases 1, 2, and 3 were the same withtn uncertalnty bounds: therefore, he did not consider then separately. Based upon what be considered as the three important sequence factors, ve dafined four new cases, shown in the second part of the table below. Detonation inpulses will not be large enough to affect reactor bullding fallure probabilfty and are lgnored. The probability of a burn, if DC power is avallable is 1.0 (see column P2 in the first part of the table below). This is based on the subsequent discusslons with the Expert.

Branch Polnt Probabllities

(See Table A-1 in Expert A

elicitation, write up ?

$\begin{array}{lcccc}\text { Factors } & \text { 81 } & \text { P2 } & \text { P3 } & \text { P4 } \\ \text { DWMTH } & . \text { B } & .5 & .8 & .8 \\ \text { OP } & .2 & - & - & - \\ \text { DC Available } & & 1.0 & & \end{array}$




\begin{tabular}{|c|c|c|c|c|c|}
\hline \multirow[b]{2}{*}{ Cases. } & \multicolumn{5}{|c|}{$\begin{array}{l}\text { Scenario Frobabilicies } \\
\text { (See Figure A.1 in } \\
\text { Expect A.eltaltation write-up }\end{array}$} \\
\hline & Sl. & 52 & 53 & S4 & s.5 \\
\hline DWMTH, SB & .8 & .08 & .02 & .08 & .02 \\
\hline DGMTH, NSB & .8 & .16 & .04 & .0 & .0 \\
\hline OP,SB & .2 & .32 & .08 & .32 & .08 \\
\hline OP. NSB & .2 & .64 & .16 & .0 & .0 \\
\hline
\end{tabular}

DWMTH - Containment failure by drywell meltthrough,

Op - Containment failure by overpressure in the vetwell.

SB, NSB - Station blackout (no ac or dc), any ac or dc power syallable,

In order to calculate the scenarlo probabilities for each of the four cases defined by Expert $A$, we put in the branch point probabilities as appropriate and multiplied.

\begin{tabular}{|c|c|c|}
\hline \multirow[b]{2}{*}{$\begin{array}{l}d p \\
(k P a)\end{array}$} & \multicolumn{2}{|c|}{$\begin{array}{c}\text { Peak Reactor Building } \\
\text { Pressure Distributions for Each } \\
\text { Scenario }\end{array}$} \\
\hline & $(83,8 S)$ & S1,S2,54 \\
\hline $\begin{array}{l}0.0 \\
13.78 \\
20.67 \\
27.56 \\
84.0 \\
67.0 \\
99.0\end{array}$ & $\begin{array}{l}0.0 \\
0.35 \\
0.675 \\
0.9 \\
0.9 \\
0.95 \\
1.0\end{array}$ & $\begin{array}{l}0.0^{\circ} \\
0.667^{\circ} \\
1.0 \\
1.0 \\
1.0 \\
1.0 \\
1.0\end{array}$ \\
\hline
\end{tabular}

"The Expert sald no possibility of pressures $>3$ psig but did not give a distribution; therefore, we assumed linear. Following are results obtained from combining the prossure distributions with scenario probabilites.

Expert A: Peak Reactor Bullding Pressure Dietribution: Case 1 (Original Caso 1: Drywe11 Meltthrough: Original Case 2: Drywell Meltthrough).

\begin{tabular}{|c|c|c|c|c|c|c|}
\hline dp (kPas) & sl & s2 & 53 & \$4 & _S5 & Axerage \\
\hline 0.90 & 0.0 & 0.0 & 0.0 & 0.0 & 0.0 & 0.00 \\
\hline 13.78 & 0.533 & 0.0533 & 0.007 & 0.0533 & 0.007 & 0.654 \\
\hline 20.67 & 0.8 & 0.08 & 0.0135 & 0.08 & 0.0135 & 0.987 \\
\hline 27.56 & 0.8 & 0.08 & 0.018 & $0.0 \mathrm{~g}$ & 0.018 & 0.996 \\
\hline 84.00 & 0.8 & 0.08 & 0.018 & 0.08 & 0.018 & 0.996 \\
\hline 87.00 & 0.8 & 0.08 & 0.019 & $0.0 \mathrm{~B}$ & 0.019 & 0.998 \\
\hline 99.00 & 0.8 & 0,08 & 0.02 & 0.08 & 0.02 & 1.00 \\
\hline
\end{tabular}


Expart A: Patk Reector Bullding Fressure Digtelbution: Case 2 Coriginal Gase 2: Overpreasure: Origing1 Cose 2: Ovarpressur*).

\begin{tabular}{|c|c|c|c|c|c|c|}
\hline dp(kFe) & s1 & s2 & 53 & \$4 & s5 & Averagk \\
\hline 0.00 & 0.0 & 0.0 & 0.0 & 0.0 & 0.0 & 0.00 \\
\hline 13.78 & 0.133 & 0.213 & 0.028 & 0.213 & $0.02 B$ & 0,616 \\
\hline 20.67 & 0.2 & 0.32 & 0.054 & 0.32 & 0.054 & $0.94 \mathrm{~B}$ \\
\hline 27.56 & 0.2 & 0.32 & 0.072 & 0.32 & 0.072 & 0.964 \\
\hline 84.00 & 0.2 & 0.32 & 0.072 & 0.32 & 0.072 & 0.984 \\
\hline 87.00 & 0.2 & 0.32 & 0.076 & 0.32 & 0.076 & 0.992 \\
\hline 99.00 & 0.2 & 0.32 & 0.08 & 0.32 & 0.08 & 1.00 \\
\hline
\end{tabular}

Expert A: Peak Reactor Bullding Pressure Distribution: Case 3 Coriglnal Gase 3: Dryvel1 Meltehrough)

\begin{tabular}{|c|c|c|c|c|c|c|}
\hline $\operatorname{dp}(k P a)$ & s1 & s2 & s3 & _. & ...s5. & Average \\
\hline 0.00 & 0.0 & 0.0 & 0.0 & 0.0 & 0.0 & 0.00 \\
\hline 13.78 & 0.533 & 0.107 & 0.014 & 0.0 & 0.0 & 0.654 \\
\hline 20.67 & 0.8 & 0.16 & 0.027 & 0.0 & 0.0 & 0.987 \\
\hline 27.56 & 0.8 & 0.16 & 0.036 & 0.0 & 0.0 & 0.996 \\
\hline 84.00 & 0.8 & 0.16 & 0.036 & 0.0 & 0.0 & 0.996 \\
\hline 87.00 & 0.8 & 0.16 & 0.038 & 0.0 & 0.0 & 0.998 \\
\hline 99.00 & 0,8 & 0.16 & 0.04 & 0.0 & 0.0 & 1.00 \\
\hline
\end{tabular}

Expert A: Peak Reactor Bullding Pressure Distribution; Cese 4 (Original Case 3: Overprensure)

\begin{tabular}{|c|c|c|c|c|c|c|}
\hline $\operatorname{do}\left(\mathrm{kPa}_{\mathrm{a}}\right)$ & sl & S2 & s3 & \$S & S5 & Average \\
\hline 0.00 & 0.0 & 0.0 & 0.0 & 0.0 & 0.0 & 0.00 \\
\hline 13.78 & 0.133 & 0.427 & 0.056 & 00 & 0.0 & 0.616 \\
\hline 20.67 & 0.2 & 0.64 & 0.108 & 0.0 & 0.0 & 0.948 \\
\hline 27.56 & 0.2 & 0.64 & 0.144 & 0.0 & 0.0 & 0.984 \\
\hline 84.00 & 0.2 & 0.64 & 0.144 & 0.0 & 0.0 & 0.984 \\
\hline 87.00 & 0.2 & 0.64 & 0.152 & 0.0 & 0.0 & 0.992 \\
\hline 99.00 & 0.2 & 0.64 & 0.16 & 0.0 & 0.0 & 1.00 \\
\hline
\end{tabular}

One can soe that the final distribution is essentlally the same for all cases. We will therefote use Case 2 for all cuses for this expert in the aggregation. This gives slightly conservative results as more of the distribution is at higher pressure.

Fot Expert B:

The Expert provtded an equation to calculate the probability of obtaining a specified change in pressure (dp) given the inftial primary containment temperature, the Initial primary contalnuent $H_{z}$ concentration, and whether or not a blackaut had occurred. We calculated the probability of obtaining a specified dp for blackout and nonblackout, for tenperatures from $300 \mathrm{~K}$ to $1200 \mathrm{~K}$, and for initial prinary containment $H_{2}$ concentrations from 05 to .20. However, for the eccident sequences of interest, the expected $H_{2}$ 
concentrations in the prinary containment are expected to be high (in the range of >.15). For these cases, the detail in the lower concentration range are not important and the temperature and the $\mathrm{H}_{2}$ concentration in primary containment are unimportant. The only variable that makes a difference is whether or not a blackout has occurred. The results are shown below.

Peak Reactor Building Pressure Cumnlative Probability

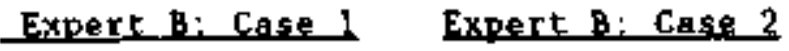

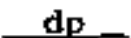

0.00

1.03

1.99

3.02

4.05

5.08

6.05

7.08

8.11

9.07

10.10

15.12

20.20

25.28

30.30

50. 50

101,0

151.5

202.0
Blackout Nonb lackout.

orig Cases d and 2 Orik Case_3

0.50

0.50

0.50

0.50

0.51

D. 50

0.50

0.50

0.51

0.51

0.59

0.62

0.65

0.52

0.67

0.53

0.69

0.53

0.70

0.62

0.83

0.69

0.92

0.76

0.97

D. $B 2$

1.00

0.89

1.00

0.96

1.00

1.00

1.00

1.00

1.00

Since reactor building fallure is assessed at $3 \mathrm{pgig}$ (20 kPa), the probability of failure is.31 for the blackout case and,08 for the nonblackout case. This makes sense in terms of the expert's elicitation since the delay in ignition in che blackout case results in higher $\mathrm{H}_{2}$ concentracions. The Expert said that, for che conditions tn this tssue. the difference between the impulstve loads and the stacic pressure were negligible and they could be treated the same. The probability of a burn is .50 from the probability of 0 pstg on the origlnal data (see Individual write-up), we subtracted the, so and renormalized to get the condicional probability given a hurn [i.e., $(x-5) * 2$, where $x$ - probabllity at dp - y]. 
For Expert C:

The probability of a burn 1s 1.0 .

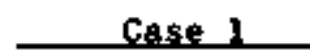

PB

Diffusion Flame

Deflagration

Detoration

Total
.05

.9025

.0475

1,0
Case 2

PB

.10

81

09

1.0

1.0

For detonations, the following inforation is applicable:

Table A peak pressure after deconation:

$\begin{array}{llllllll}\text { Pressure (kPa) } & 150 & 175 & 200 & 225 & 250 & 275 & 300 \\ \text { Probab1lity } & 0.0 & .10 & .40 & .68 & .85 & .94 & 1.0\end{array}$

Table B reflection frat ion of original wave:

Reflection Frac $1 \quad 1.5 \quad 2.0 \quad 2.25 \quad 2.5 \quad 3.0$

$\begin{array}{lllllll}\text { Probab1lity } & 0.0 & .10 & 20 & .50 & .80 & 1.0\end{array}$

Table C meximu Inpulse of unreflected wave:

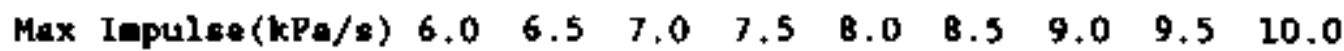

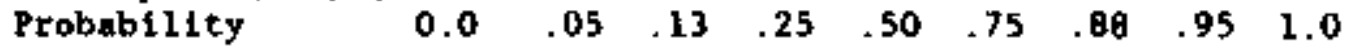

For deflagrations, the peak reactor buflding pressure (dp) 1s:

Cage 1: Stetion Bleckout, Dryoll Moltthrough or Overpreseure

dp (KPa) Cumulative Rrobabulity

$\begin{array}{ll}1.34 & 0.008-0 \\ 2.68 & 5.31 \mathrm{E}-4 \\ 5.37 & 1.44 \mathrm{E}+2 \\ 7.38 & 5.37 \mathrm{E}+2 \\ & \\ 8.72 & 9.99 \mathrm{E}-2 \\ 11.41 & 2.39 \mathrm{E}-1 \\ 14.09 & 4.14 \mathrm{E}-1 \\ 15.43 & 5.04 \mathrm{E}-1\end{array}$


cese 1: (continued)

\begin{tabular}{cc} 
Ap (kPal & Cumulative Probabulity \\
\cline { 2 - 2 } 17.45 & $6.29 \mathrm{E}-1$ \\
20.80 & $7.95 \mathrm{E}-1$ \\
24.83 & $9.15 \mathrm{E}-1$ \\
27.51 & $9.57 \mathrm{E}-1$ \\
& \\
32.88 & $9.91 \mathrm{E}-1$ \\
39.59 & $9.99 \mathrm{E}-1$ \\
46.30 & $1.00 \mathrm{E}+0$
\end{tabular}

Case 2: Station Blackout, Dryoll Meltthrough or Overpresine dp (kPa) Cumulaclye Probabluty

$\begin{array}{ll}0.00 & 0.00 \mathrm{E}-0 \\ 0.67 & 1.63 \mathrm{E}-4 \\ 1.34 & 1.91 \mathrm{E}-3 \\ 2.01 & 7.12 \mathrm{E}-3 \\ & \\ 2.68 & 1.68 \mathrm{E}-2 \\ 3.36 & 3.12 \mathrm{E}-2 \\ 4.70 & 7.22 \mathrm{E}-2 \\ 6.71 & 1.51 \mathrm{E}-1 \\ & \\ 9.72 & 2.36 \mathrm{E}-1 \\ 10.07 & 2.96 \mathrm{E}-1 \\ 12.75 & 4.39 \mathrm{E}-1 \\ 14.09 & 5.18 \mathrm{E}-1 \\ & \\ 16.10 & 6.26 \mathrm{E}-1 \\ 20.13 & 7.65 \mathrm{E}-1 \\ 22.14 & 8.04 \mathrm{E}-1 \\ 24.83 & 9.52 \mathrm{E}-1 \\ 27.51 & 9.03 \mathrm{E}-1 \\ 28.85 & 9.27 \mathrm{E}-1 \\ 30.20 & 9.48 \mathrm{E}+1 \\ 32.88 & 9.78 \mathrm{E}-1 \\ 34.89 & 9.90 \mathrm{E}-1 \\ 3 \mathrm{~B} .25 & 9.98 \mathrm{E}-1 \\ 42.28 & 1.00 \mathrm{E}-1 \\ 46.30 & 1.00 \mathrm{E}-0\end{array}$


Case 3: No Station Blackout, Drywell Helthrough or Overpressure

$\begin{array}{cc}\text { do }(\mathrm{kPa}) & \text { Cumulative Probability } \\ 3.36 & 0.00 \mathrm{E}-0 \\ 5.37 & 8.72 \mathrm{E}-4 \\ 8.05 & 1.01 \mathrm{E}-2 \\ 10.74 & 4.65 \mathrm{E} \cdot 2 \\ & \\ 12.75 & 1.03 \mathrm{E}-1 \\ 15.43 & 2.22 \mathrm{E}-1 \\ 18.79 & 4.18 \mathrm{E}-1 \\ 20.13 & 5.01 \mathrm{E}-1 \\ & \\ 22.14 & 6.19 \mathrm{E}-1 \\ 26.17 & 8.07 \mathrm{E}-1 \\ 29.53 & 9.05 \mathrm{E}-1 \\ 32.21 & 9.51 \mathrm{E}-1 \\ 38.25 & 9.92 \mathrm{E}-1 \\ 44.29 & 9.99 \mathrm{E}-1 \\ 51.00 & 1.00 \mathrm{E}+0\end{array}$

If we combine the detonation (DET) and deflagtation (DEF), dtffuston flame (DF) dp curves (maintaining the peak reactor building pressure bound), we get :

Case 1: Station Blackout, Dryvell Veltthrough or Overpressure

\begin{tabular}{|c|c|c|c|}
\hline & DFE_DF & DET & Average \\
\hline $\begin{array}{c}\text { dp } \\
(\mathrm{kHa})\end{array}$ & $\begin{array}{r}\text { Cumulative } \\
\text { Probablticy }\end{array}$ & $\begin{array}{l}\text { Cumulative } \\
\text { Probability }\end{array}$ & $\begin{array}{l}\text { Cumulative } \\
\text { Probability }\end{array}$ \\
\hline 1.34 & $0.00 \mathrm{E}-0$ & $0.00 E-0$ & $0.00 \mathrm{E} \cdot \mathrm{c}$ \\
\hline 2.68 & $5.31 E-4$ & $0.00 \mathrm{E}+0$ & $5.07 E-4$ \\
\hline 5.37 & $1.44 \mathrm{E}-2$ & $0.00 \mathrm{E}-0$ & $1.38 E-2$ \\
\hline 7.38 & $5.37 \mathrm{E}-2$ & $0.00 \mathrm{E} \cdot 0$ & $5.13 \mathrm{E}-2$ \\
\hline 8.72 & $9.99 \mathbf{E}-2$ & $0.00 \mathrm{E}-0$ & $9.54 \mathrm{E} \cdot 2$ \\
\hline 11.41 & $2.38 \mathrm{E}+1$ & $0.00 \mathrm{E}-0$ & $2.27 E \cdot 1$ \\
\hline 14.09 & 4. $14 E-1$ & $0,00 \mathrm{E}-0$ & $3.95 E-1$ \\
\hline 15.43 & $5.04 \mathrm{E}-1$ & $0.00 E-0$ & $4.81 \mathrm{E}-1$ \\
\hline $1^{+}+4$ & $629 \mathrm{E}-1$ & O. ONE.O & $6918-1$ \\
\hline$\therefore r^{\circ} .80$ & $7.95 \mathrm{E} \cdot 1$ & $0.00 \mathrm{E} \cdot 0$ & $7.59 \mathrm{E}-1$ \\
\hline 24.83 & $9.15 \mathrm{E} \cdot 1$ & 0 OOE - 0 & B. $74 \mathrm{E} \cdot 1$ \\
\hline 27.51 & $957 \mathrm{E}-1$ & $0 O O E+0$ & $9.14 \mathrm{E}+1$ \\
\hline 3288 & $9.91 \mathrm{E} \cdot 1$ & 0 OOE-O & $9.46 \mathrm{E}]$. \\
\hline 3959 & $\circ 99 \mathrm{E} \cdot 1$ & 0 OOE.0 & 9. $54 \mathrm{E}-1$ \\
\hline $7,6,10$ & $1.00 E+0$ & 1).00E: & $9.55 E .1$ \\
\hline 4900 & $100 \mathrm{E}+0$ & () $00 \mathrm{OOE}$ & 9. $55 \mathrm{E}-1$ \\
\hline
\end{tabular}


Case 1 (Continued)

\begin{tabular}{|c|c|c|c|}
\hline & DEF DF & DET & Average \\
\hline $\begin{array}{c}\text { dp } \\
(\mathrm{kPa})\end{array}$ & $\begin{array}{l}\text { Cumulative } \\
\text { Probability }\end{array}$ & $\begin{array}{l}\text { Cumblative } \\
\text { Probability }\end{array}$ & $\begin{array}{r}\text { Cumulative } \\
\text { Probability }\end{array}$ \\
\hline $\begin{array}{l}74.00 \\
99.00 \\
24.00 \\
149.00\end{array}$ & $\begin{array}{l}1.00 \mathrm{E}+0 \\
1.00 \mathrm{E}+0 \\
1.00 \mathrm{E}+0 \\
1.00 \mathrm{E}+0\end{array}$ & $\begin{array}{l}1.00 \mathrm{E}+1 \\
4.00 \mathrm{E}-1 \\
6.80 \mathrm{E}-1 \\
8,50 \mathrm{E}-1\end{array}$ & $\begin{array}{l}9.60 \mathrm{E}-1 \\
9.73 \mathrm{E}-1 \\
9.86 \mathrm{E}-1 \\
9.93 \mathrm{E}-1\end{array}$ \\
\hline $\begin{array}{l}174.00 \\
199.00\end{array}$ & $\begin{array}{l}1.00 \mathrm{E}+0 \\
1.00 \mathrm{E}+0\end{array}$ & $\begin{array}{l}9.40 \mathrm{E}-1 \\
1.00 \mathrm{E}+0\end{array}$ & $\begin{array}{l}9.97 \mathrm{E}-1 \\
1.00 \mathrm{E} \cdot \mathrm{C}\end{array}$ \\
\hline
\end{tabular}

Case 2: Station Blackout, Dryuell Weltthrough or Overpressure

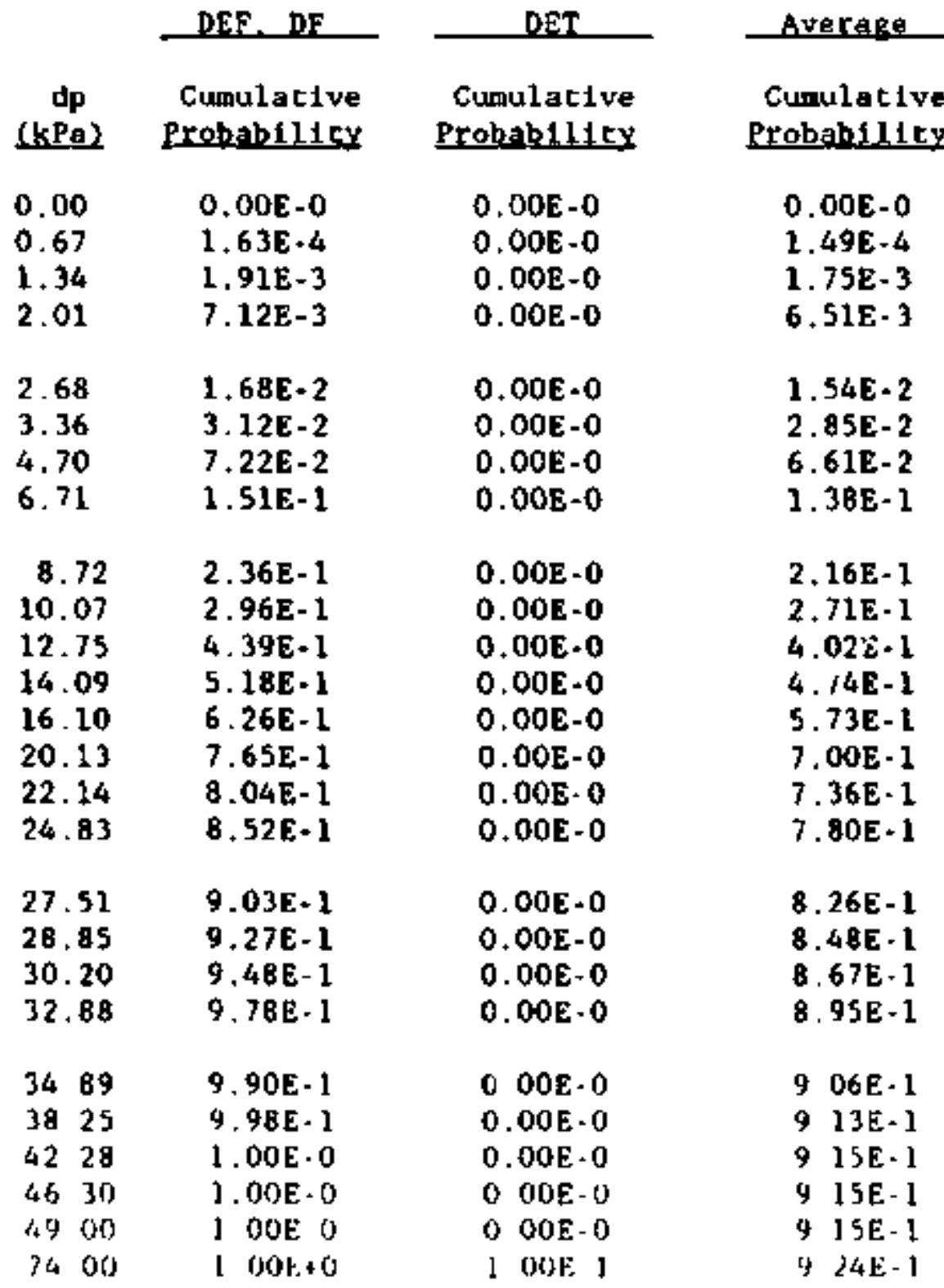




\begin{tabular}{|c|c|c|c|}
\hline & DEE_ DF & BET & Averere \\
\hline$\underset{(\mathrm{kPa})}{\mathrm{dp}}$ & $\begin{array}{l}\text { Cumulative } \\
\text { Probabilfty }\end{array}$ & $\begin{array}{l}\text { Cumulative } \\
\text { Brobabllity }\end{array}$ & $\begin{array}{l}\text { Cunulat Ive } \\
\text { Probabllity }\end{array}$ \\
\hline $\begin{array}{l}99.00 \\
124.00 \\
149.00 \\
174.00 \\
199.00\end{array}$ & $\begin{array}{l}1.00 \mathrm{E}+0 \\
1.00 \mathrm{E}+0 \\
1.00 \mathrm{E}+0 \\
1.00 \mathrm{E}+0 \\
1.00 \mathrm{E}+0\end{array}$ & $\begin{array}{l}4.00 \mathrm{E}-1 \\
6.80 \mathrm{E}-1 \\
6.50 \mathrm{E}-1 \\
9.40 \mathrm{E}-1 \\
1.00 \mathrm{E}+0\end{array}$ & $\begin{array}{l}9.49 \mathrm{E}-1 \\
9.73 \mathrm{E}-1 \\
9.87 \mathrm{E}-1 \\
9.95 \mathrm{E}-1 \\
1.00 \mathrm{E}-0\end{array}$ \\
\hline
\end{tabular}

Gase 3 No station Blackout, Drywell Heltthrough or Overpreanure

\begin{tabular}{|c|c|c|c|}
\hline & $\mathrm{DEF} \_\mathrm{DF}$ & DFT & Averape \\
\hline $\begin{array}{c}\text { dp } \\
(k P A)\end{array}$ & $\begin{array}{r}\text { Cunulative } \\
\text { Brabablilicy }\end{array}$ & $\begin{array}{l}\text { Cumulative } \\
\text { Brobabilitey }\end{array}$ & $\begin{array}{r}\text { Cumulative } \\
\text { Probabllity }\end{array}$ \\
\hline $\begin{array}{r}3.36 \\
5.37 \\
8.05 \\
10.74\end{array}$ & $\begin{array}{l}0.00 \mathrm{E}-0 \\
8.72 \mathrm{E}-4 \\
1.01 E-2 \\
4.65 \mathrm{E}-2\end{array}$ & $\begin{array}{l}0.00 \mathrm{E}-0 \\
0.00 \mathrm{E}-0 \\
0.00 \mathrm{E}-0 \\
0.00 \mathrm{E}-0\end{array}$ & $\begin{array}{l}0.00 \mathrm{E}-0 \\
8.33 \mathrm{E}-4 \\
9.65 \mathrm{E}-3 \\
4.44 \mathrm{E}-2\end{array}$ \\
\hline $\begin{array}{l}12.75 \\
15.43 \\
18.79 \\
20.13\end{array}$ & $\begin{array}{l}1.03 \mathrm{E}-1 \\
2.22 \mathrm{E}-1 \\
4.1 \mathrm{BE}-1 \\
5.01 \mathrm{E}-1\end{array}$ & $\begin{array}{l}0.00 \mathrm{E}-0 \\
0.00 \mathrm{E}-0 \\
0.00 \mathrm{E}-0 \\
0.00 \mathrm{E}-0\end{array}$ & $\begin{array}{l}9.84 E-2 \\
2.12 E-1 \\
3.99 E-1 \\
4.78 E-1\end{array}$ \\
\hline $\begin{array}{l}22.14 \\
26.17 \\
29.53 \\
32.21\end{array}$ & $\begin{array}{l}6.19 \mathrm{E}-1 \\
8.07 \mathrm{E}-1 \\
9.05 \mathrm{E}-1 \\
9.51 \mathrm{E}-1\end{array}$ & $\begin{array}{l}0.00 \mathrm{E}-0 \\
0.00 \mathrm{E}-0 \\
0.00 \mathrm{E}+0 \\
0.00 \mathrm{E}-0\end{array}$ & $\begin{array}{l}5.91 \mathrm{E}-1 \\
7.71 \mathrm{E} \cdot 1 \\
8.64 \mathrm{E} \cdot 1 \\
9.08 \mathrm{E}-1\end{array}$ \\
\hline $\begin{array}{l}38.25 \\
44.29 \\
51.00 \\
74.00\end{array}$ & $\begin{array}{l}9.92 \mathrm{E}-1 \\
9.99 \mathrm{E}-1 \\
1.00 \mathrm{E}+0 \\
1.00 \mathrm{E}+0\end{array}$ & $\begin{array}{l}0.00 \mathrm{E}-0 \\
0,00 \mathrm{E}-0 \\
0,00 \mathrm{E}-1 \\
1,00 \mathrm{E}-1\end{array}$ & $\begin{array}{l}9.47 \mathrm{E}-1 \\
9.54 \mathrm{E}-1 \\
9.55 \mathrm{E}-1 \\
9.60 \mathrm{E}-1\end{array}$ \\
\hline $\begin{array}{l}99.00 \\
124.00 \\
149.00 \\
174.00 \\
199.00\end{array}$ & $\begin{array}{l}1.00 \mathrm{E}+0 \\
1.00 \mathrm{E}+0 \\
1.00 \mathrm{E}+0 \\
1.00 \mathrm{E}+0 \\
1.00 \mathrm{E}+0\end{array}$ & $\begin{array}{l}4.00 \mathrm{E}-1 \\
6.80 \mathrm{E}-1 \\
8.50 \mathrm{E}-1 \\
9.40 \mathrm{E}-1 \\
1.00 \mathrm{E}+0\end{array}$ & $\begin{array}{l}9.73 E-1 \\
9.86 E-1 \\
9.93 E-1 \\
9.97 E-1 \\
1.00 E-0\end{array}$ \\
\hline
\end{tabular}

Since the fallure pressure of the reactor building $1540 \mathrm{kPad}$, any detonation will result in failure.

\section{Aggregated Results}

The results are presented on the following pages. 
4.toll 3-3

Averate of Experts' Eisitiotions. Finel Caser Sot 1

Pank Ratetor Yulldint Prassure in kF*

\begin{tabular}{|c|c|c|c|c|c|c|c|c|c|c|c|c|c|c|c|}
\hline & & & & & & Ec1-1: & Cane 1 . & Drymall & ththrouth & (DNM) & & & & & \\
\hline Fractile & $\underline{0.001}$ & 0.010 & 0.050 & 0.190 & $020 x$ & $\underline{0,300}$ & $0 .+00$ & 2.500 & Q_600 & 0,200 & 2000 & 0.900 & ㅇ..오요 & 0.980 & D. \\
\hline Exptrt $A$ & 0.021 & 0211 & $1.05 t$ & 2.107 & 1.216 & 6.321 & 0.428 & 20.373 & 12.642 & 14,732 & 16.001 & 14.870 & 19,904 & 22.967 & 93.000 \\
\hline Experc & 5126 & 5.563 & 0.300 & 11.216 & 14.006 & 17.287 & 20.926 & 26.554 & 20.627 & 34.957 & 37.314 & 93.706 & 119.037 & 145.207 & 150,869 \\
\hline Exptetc C & 2.360 & +.601 & 3.310 & 8.614 & 10.458 & 12375 & 14,168 & 15.750 & 17.4 .33 & 18.549 & 22.231 & 26.572 & 36.235 & 138.265 & 100.667 \\
\hline ASELAGE & 0063 & 0.632 & 3.106 & 3.662 & 0.045 & ll sto & 13.033 & 13.701 & 27.063 & 20.403 & 25.436 & 46.033 & 08.171 & 130.786 & 174,000 \\
\hline \multicolumn{16}{|c|}{ FC1-2: Case 1: Overpreteute (OP) } \\
\hline $\begin{array}{l}\text { Expure A } \\
\text { Experte }\end{array}$ & $\begin{array}{l}0.022 \\
3.128\end{array}$ & $\begin{array}{l}0.224 \\
5.365\end{array}$ & $\begin{array}{l}2.228 \\
0.590\end{array}$ & $\begin{array}{r}2.237 \\
11.216\end{array}$ & $\begin{array}{r}4.474 \\
16.006\end{array}$ & $\begin{array}{r}6.711 \\
17.297\end{array}$ & $\begin{array}{r}\text { d. } 048 \\
20.026\end{array}$ & $\begin{array}{l}12.145 \\
24.554\end{array}$ & $\begin{array}{l}13.422 \\
28.627\end{array}$ & $\begin{array}{l}13.523 \\
30.957\end{array}$ & $\begin{array}{l}17.598 \\
57.714\end{array}$ & $\begin{array}{l}19.674 \\
93.706\end{array}$ & $\begin{array}{r}21.053 \\
119.937\end{array}$ & $\begin{array}{r}16.250 \\
145.18 \%\end{array}$ & $\begin{array}{r}97.500 \\
150.560\end{array}$ \\
\hline Expart. 5 & 2700 & 4,801 & 7.310 & 0.814 & 10.056 & 12.575 & 14.160 & 15.750 & 17.433 & 28.549 & 22.237 & 26.572 & 36.235 & 138.206 & 190.667 \\
\hline AlERere & 0067 & $6 y_{1}$ & 3.278 & S. BAB & 0.305 & 11.001 & 13.092 & 15.085 & 10.279 & $20.7+7$ & 25.807 & 47.758 & 89,539 & $\$ 38.706$ & 174.000 \\
\hline $\begin{array}{l}\text { Export } \\
\text { Experte }\end{array}$ & $\begin{array}{l}5128 \\
1.028\end{array}$ & $\begin{array}{l}5.563 \\
2273\end{array}$ & $\begin{array}{r}\$ .396 \\
4.326\end{array}$ & $\begin{array}{r}11.216 \\
5.840\end{array}$ & $\begin{array}{r}1.004 \\
0.308\end{array}$ & $\begin{array}{l}17.207 \\
10.663\end{array}$ & $\begin{array}{l}20.926 \\
12.709\end{array}$ & $\begin{array}{l}24.554 \\
14.828\end{array}$ & $\begin{array}{l}29.627 \\
16.997\end{array}$ & $\begin{array}{l}36.937 \\
20.230\end{array}$ & $\begin{array}{l}57.716 \\
25.995\end{array}$ & $\begin{array}{l}93.786 \\
33.794\end{array}$ & $\begin{array}{l}119.937 \\
100.042\end{array}$ & $\begin{array}{l}143.187 \\
150,375\end{array}$ & $\begin{array}{l}250,068 \\
104.000\end{array}$ \\
\hline AVERAGE & 0.063 & 0.629 & 2. 701 & 4.030 & 7.047 & 10.767 & 13.026 & 15.212 & 17.905 & 20.692 & 27.626 & 53,201 & 95.504 & 142.918 & 184.000 \\
\hline & & 0.224 & 1.119 & 2,237 & 4,404 & 6.711 & 0.240 & 11.185 & 13,422 & 35.523 & 57.599 & 10.674 & 21.053 & 86.250 & 07.300 \\
\hline Expert : & 5.128 & 5585 & 1. 590 & 11.216 & 14.004 & 17.297 & 20.928 & 24.554 & 21.627 & 38.057 & 37.714 & 93.386 & 119.037 & 145.107 & 150.069 \\
\hline Exp*st C & 1026 & 2.273 & .126 & $5.6+0$ & $6,30 \mathrm{~B}$ & 30.653 & 12.700 & 16,618 & 26.057 & 20.130 & 25.995 & 33.794 & 200.042 & 158.375 & 194.000 \\
\hline AVURAG & 0067 & $0.66 \mathrm{t}$ & 2.011 & 4.896 & 0.150 & $10 . \$ 96$ & 13.284 & 15.596 & 38.265 & 21.646 & 27.924 & $5 \pi .032$ & 05.060 & 142.919 & $18+.000$ \\
\hline Expert A & c 021 & 0.213 & 1054 & 2.107 & 4.214 & 6.321 & 0.428 & 20.535 & 12.642 & 14.232 & 16.801 & 18.070 & 39.904 & 22.867 & 03.000 \\
\hline Expसr: $B$ & o os 2 & $0 \$ 15$ & 2.243 & 3.335 & 3.403 & 7.080 & 10.100 & 22.031 & 11.962 & 16.249 & 19.071 & 23248 & 26.117 & 29.463 & 30.216 \\
\hline Expert C & 5423 & 0.035 & 10.940 & 12,706 & \pm 5.147 & 37.011 & to. $\Delta 007$ & 20.521 & 22,341 & $2+, 580$ & 27.218 & 31.723 & 10.139 & 130,206 & 190.667 \\
\hline A'THAEE & 0043 & 0449 & 2170 & 3.006 & 6.690 & 9.906 & 12,427 & 16.575 & 16,765 & 10.904 & 21.367 & 25.897 & 29.510 & 94.631 & 174.000 \\
\hline \multicolumn{16}{|c|}{ FCJ-6; Case 3: OP } \\
\hline Expetz A & 0.022 & 0224 & 1.119 & 2237 & 4.4 & 6.711 & 0.948 & 11.185 & 13.422 & 15.523 & 17.599 & 19.674 & 21.053 & 96.250 & 97.500 \\
\hline Exfert & $\cos 2$ & 0313 & 2247 & 3535 & 5.003 & 7.080 & 10100 & 12.031 & 23.962 & 16.249 & 19.071 & 23.248 & 26.117 & 29.463 & 30.210 \\
\hline$E \times F+5 C C$ & $\leq 421$ & $B, 072$ & 10.948 & 12780 & 15.147 & 17011 & 10.07 & 20.521 & 22341 & 24.580 & 27.219 & 31.323 & 40.036 & 136.266 & 100.667 \\
\hline ALESAOE & 00.7 & 0.468 & 2.242 & +.034 & 6. 154 & 10.213 & 12.703 & 14.853 & 17.020 & 19.165 & 21.833 & 26.206 & 29.925 & 96.472 & 174.000 \\
\hline
\end{tabular}



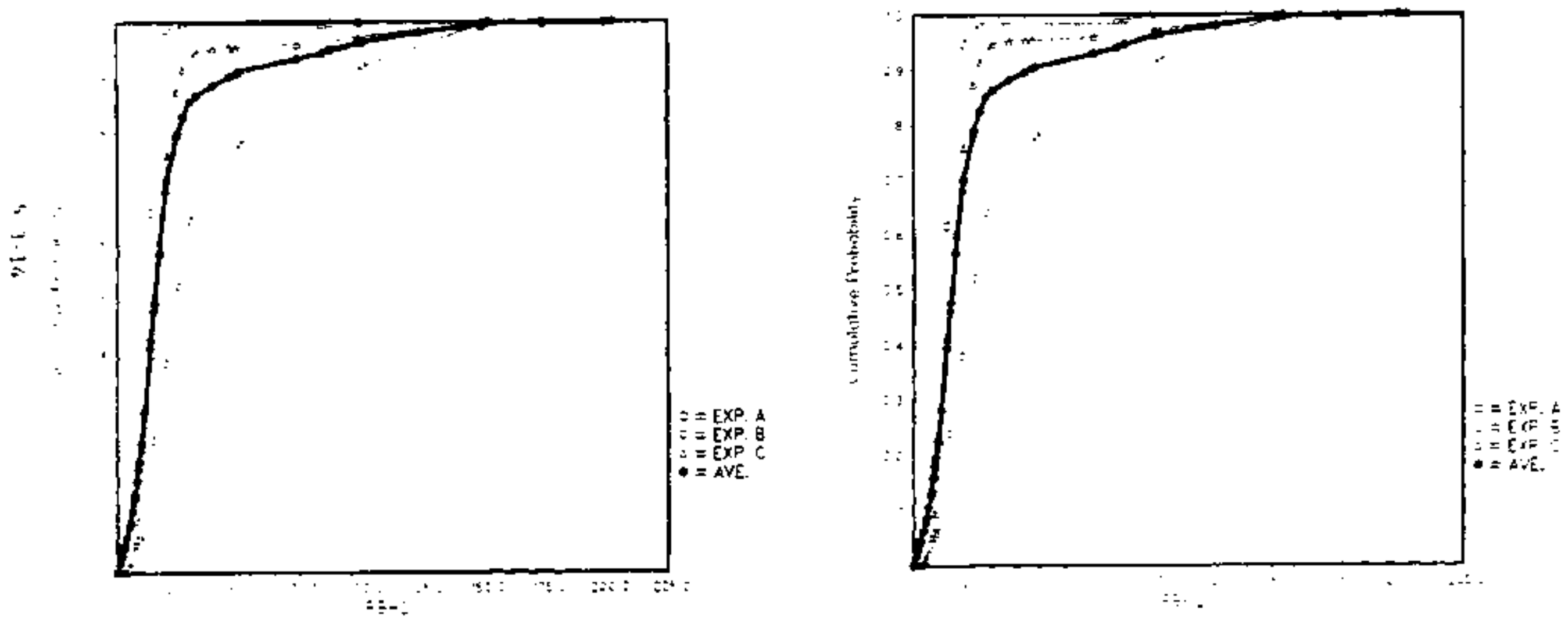

Figure 3.1 (left). Peak Reactor Building Pressure (kRa). Case 1 Drywall Melcthrough (DiN). Figure 3.2 (right). Peak Reactor Building Pressure (kRa). Case I Drywall Meltthrough (OP). 
Final Cose Set $1-3$ CASE 2 DWM

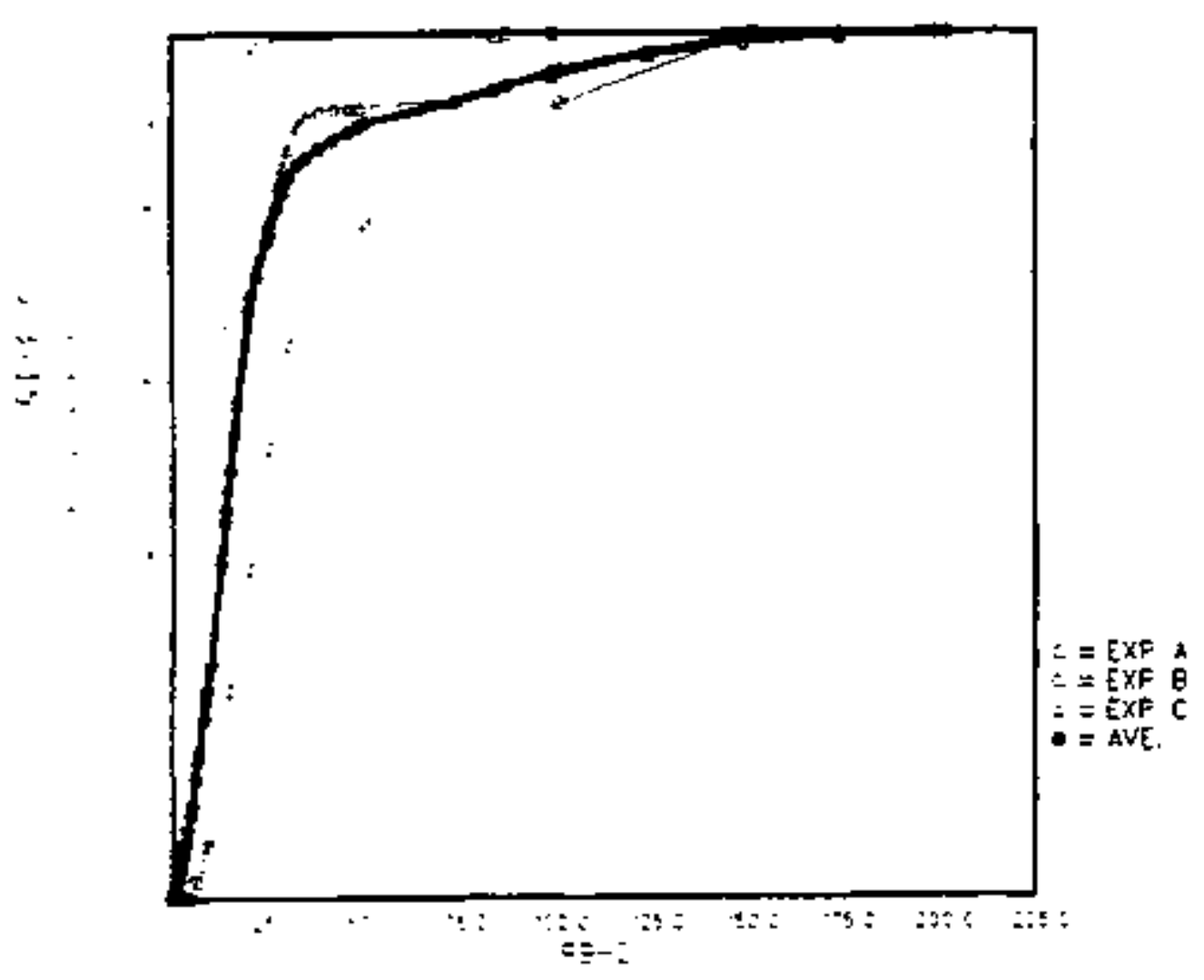

Final Case Set $1-4$ CASE 2 OP

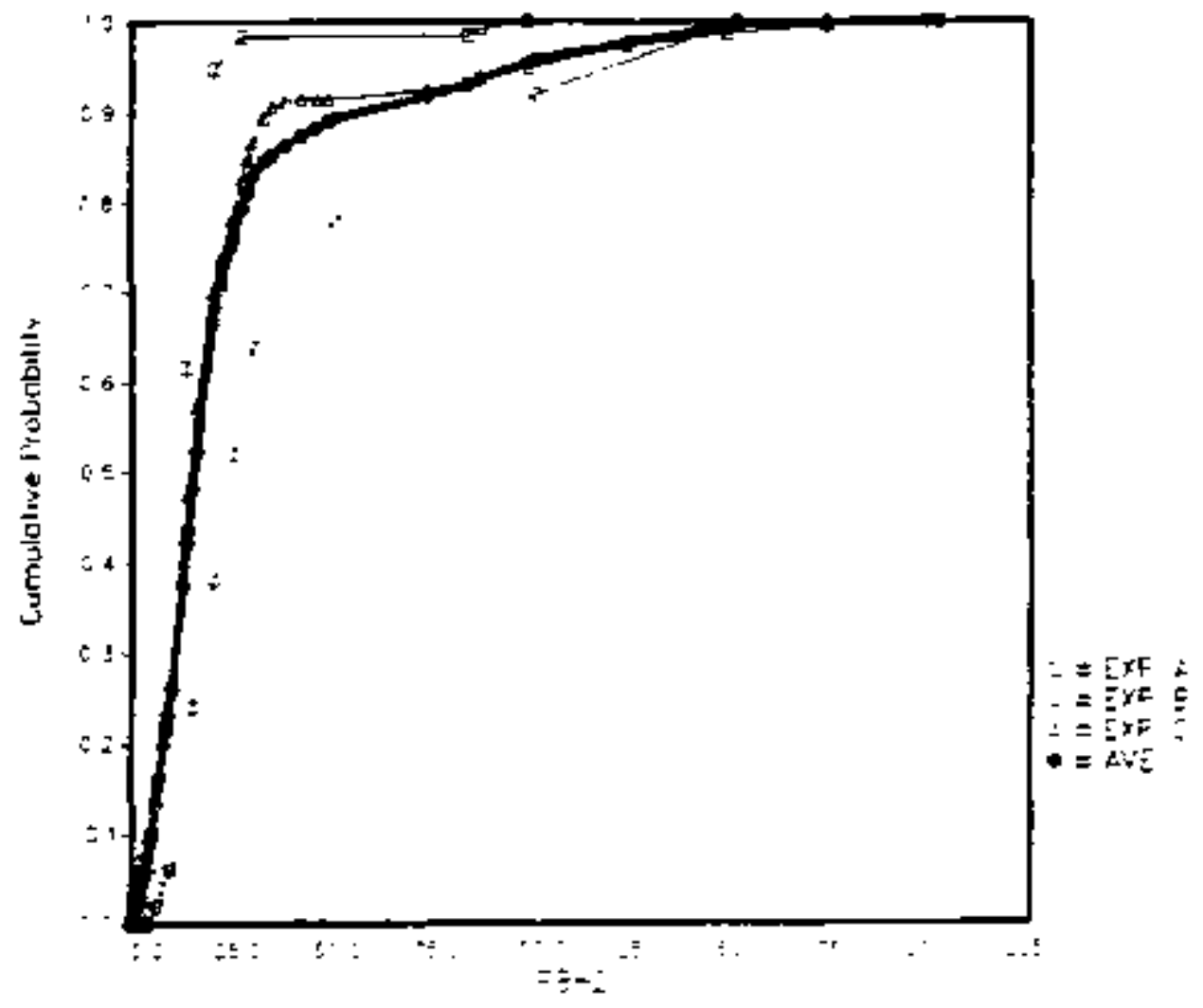

Figure 3.3 (left). Peak Reactor Building Pressure (kPa) Case 2 DWM.

Figure 3-4 (right). Peak Reactor Building Pressure (kPa) Case 2 OP. 

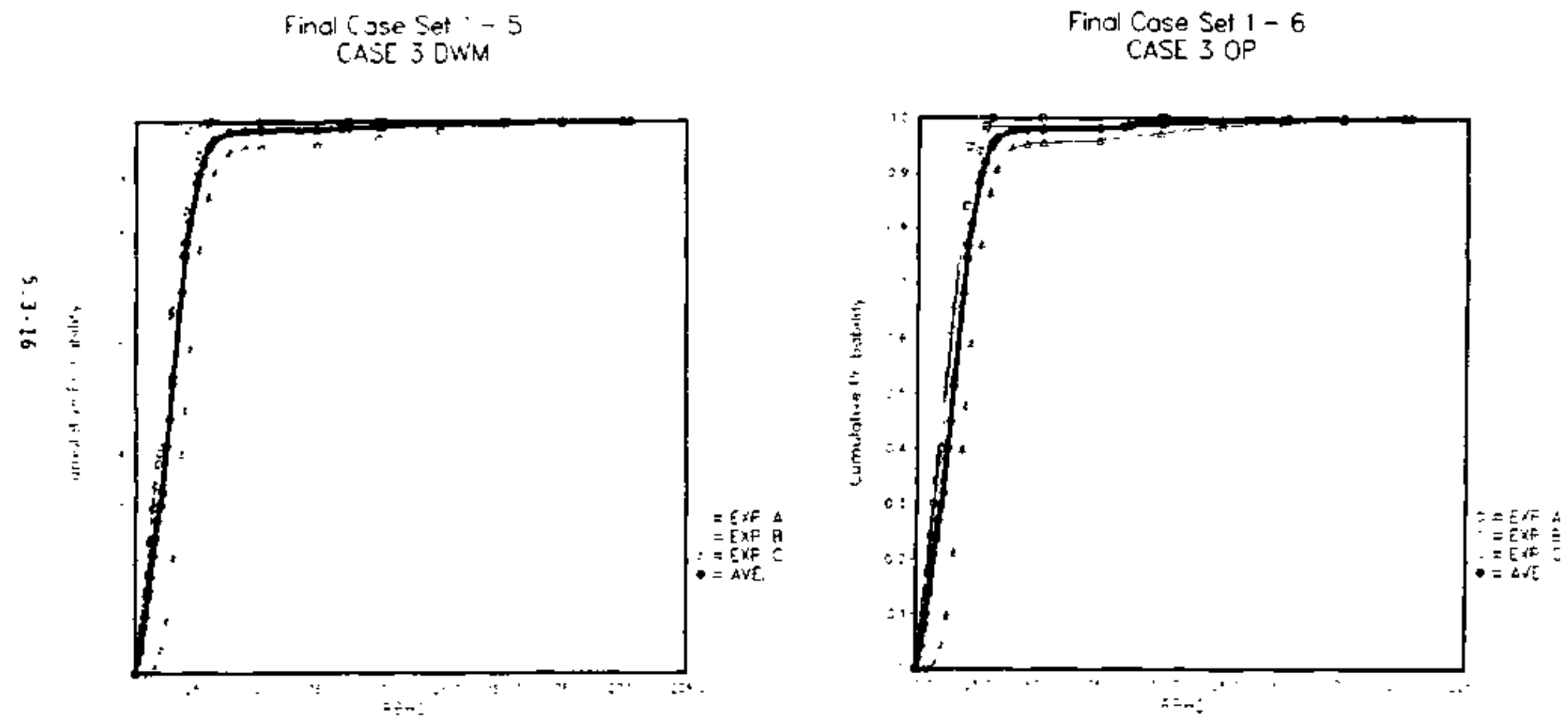

Fígure 3.5 (left). Peak Reactor Building Pressure (kPa) Case 3 DWM.

Figure 3.6 (right). Peak Reactor Building Pressure (kPa) Case 3 OP. 
Table 3.4

Pank poector Bus lding Pressure \{kPa Final Gases set

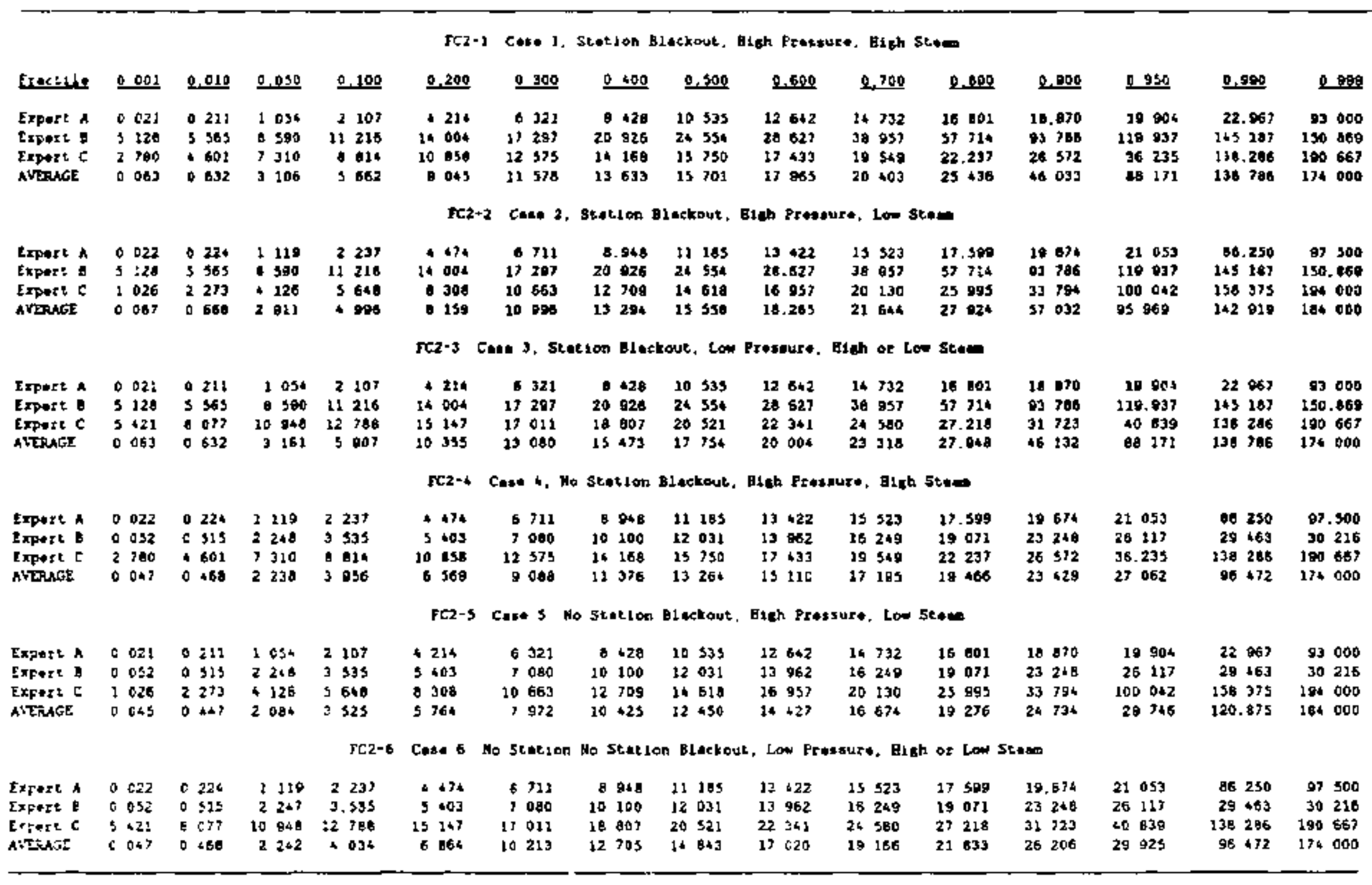


Find Case Set 2 - 1

SB. Hi Pres5, Hi STM

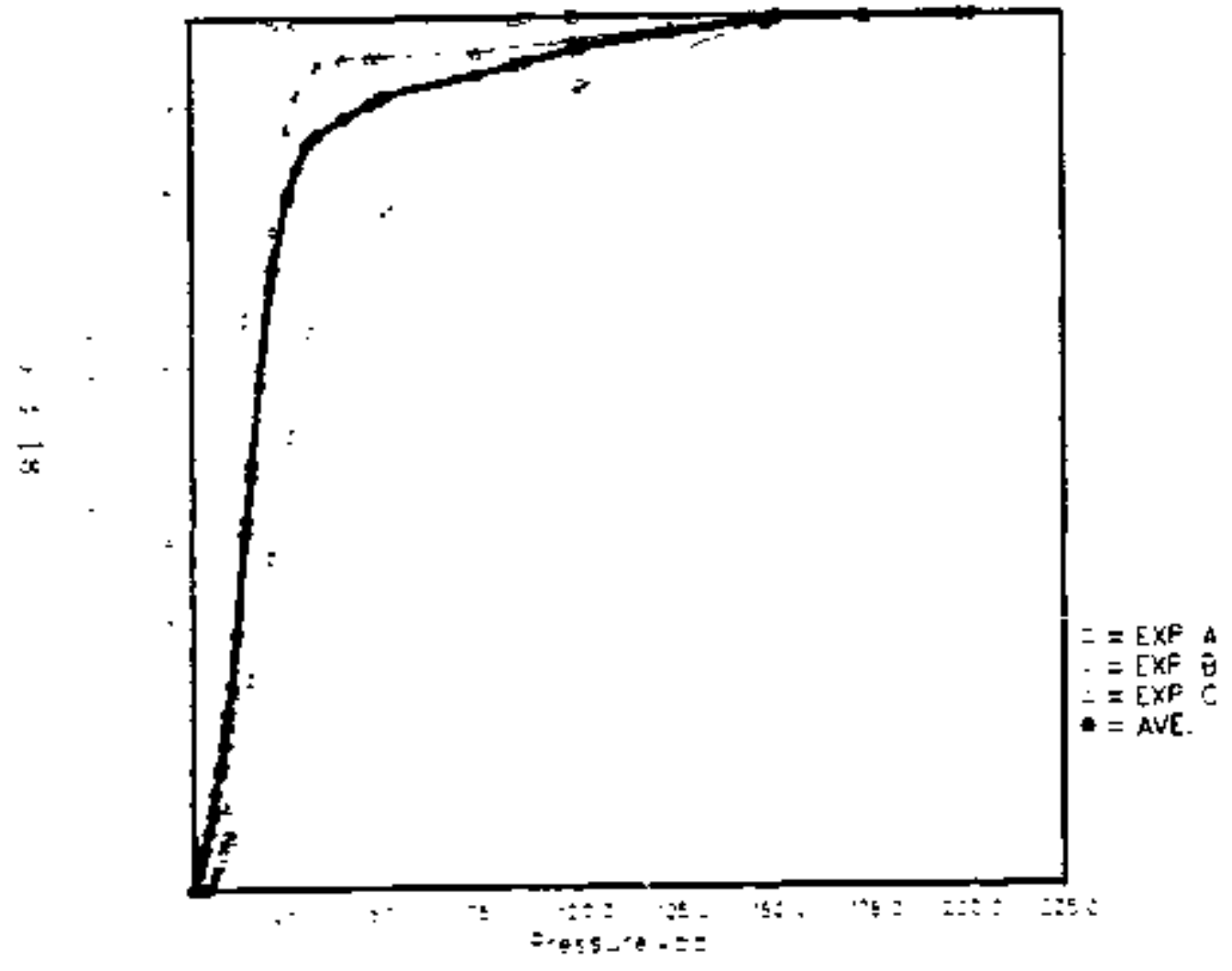

Final Cose Set 2 - 2 SB. Hi Press. Low STM

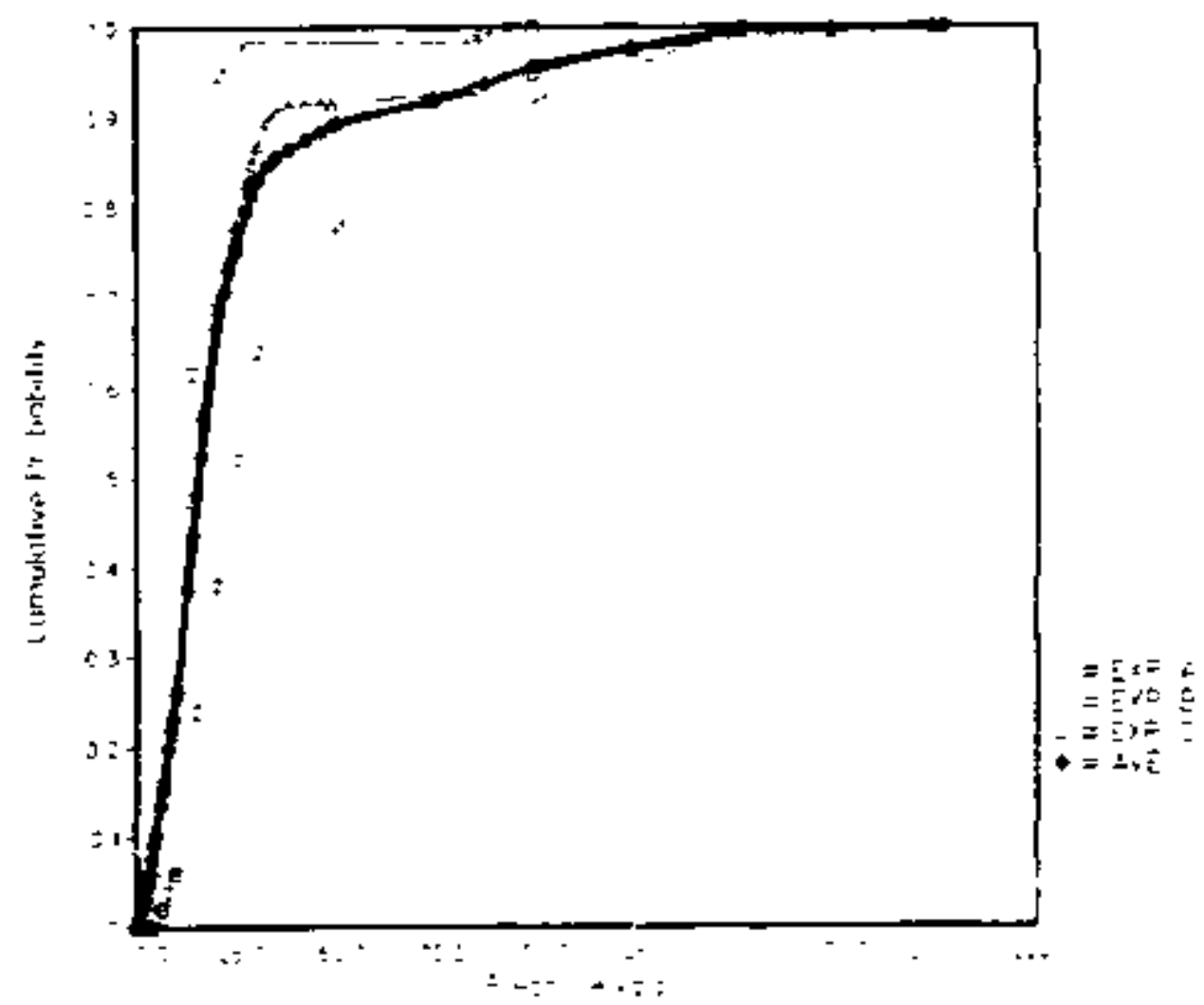

Figure 3.7 (left), Peak Reactor Building Pressure (kPa) Case 1: SB, High Pressure, High Steas. Ffgure 3-g (tight). Peak Reactor Bullding Pressure (kPa) Case 2: \$B, High Pressure, Law Steam. 


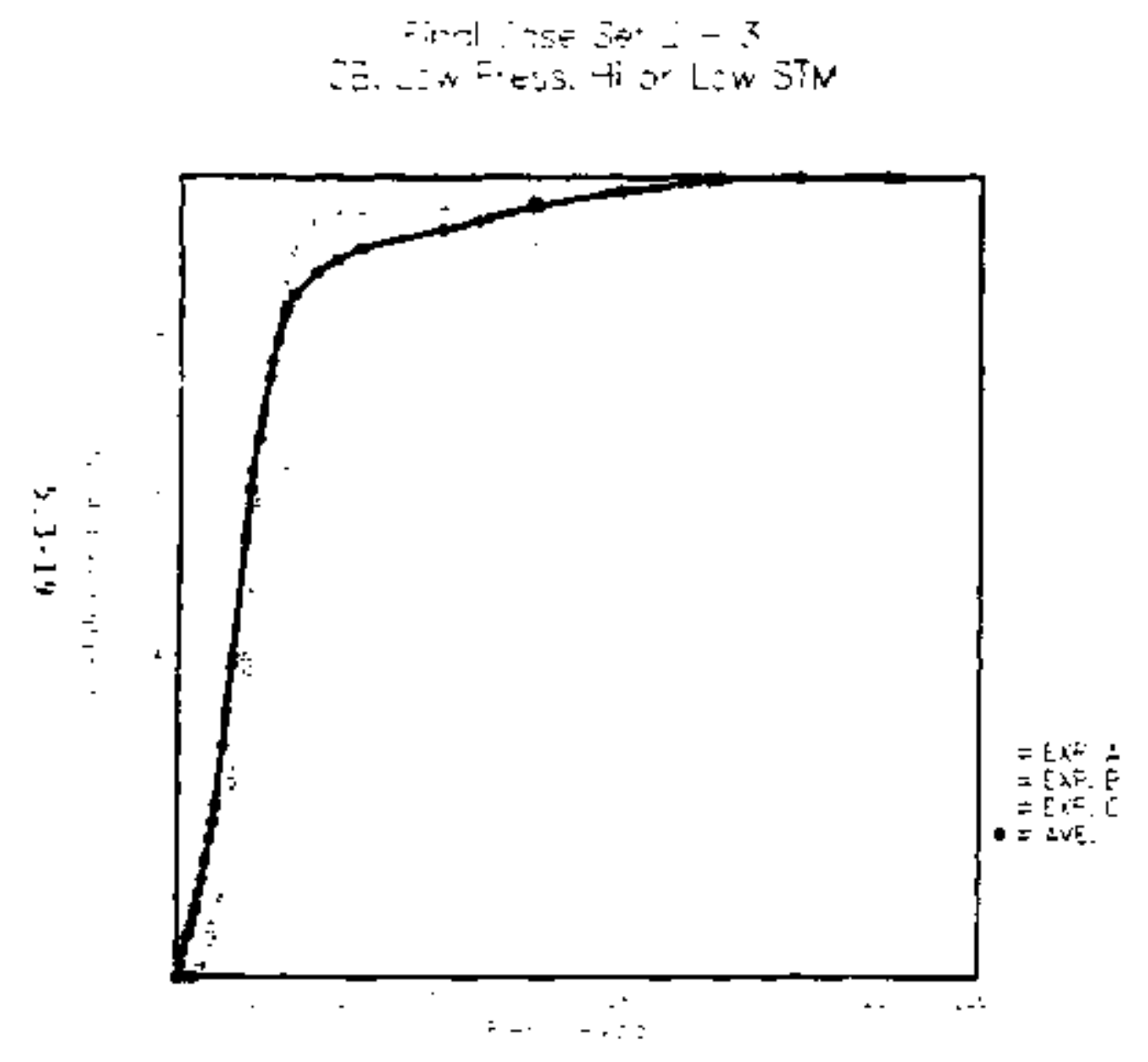

Final Cose Se+ $2-4$ nSB. Hi Press. Hi STM

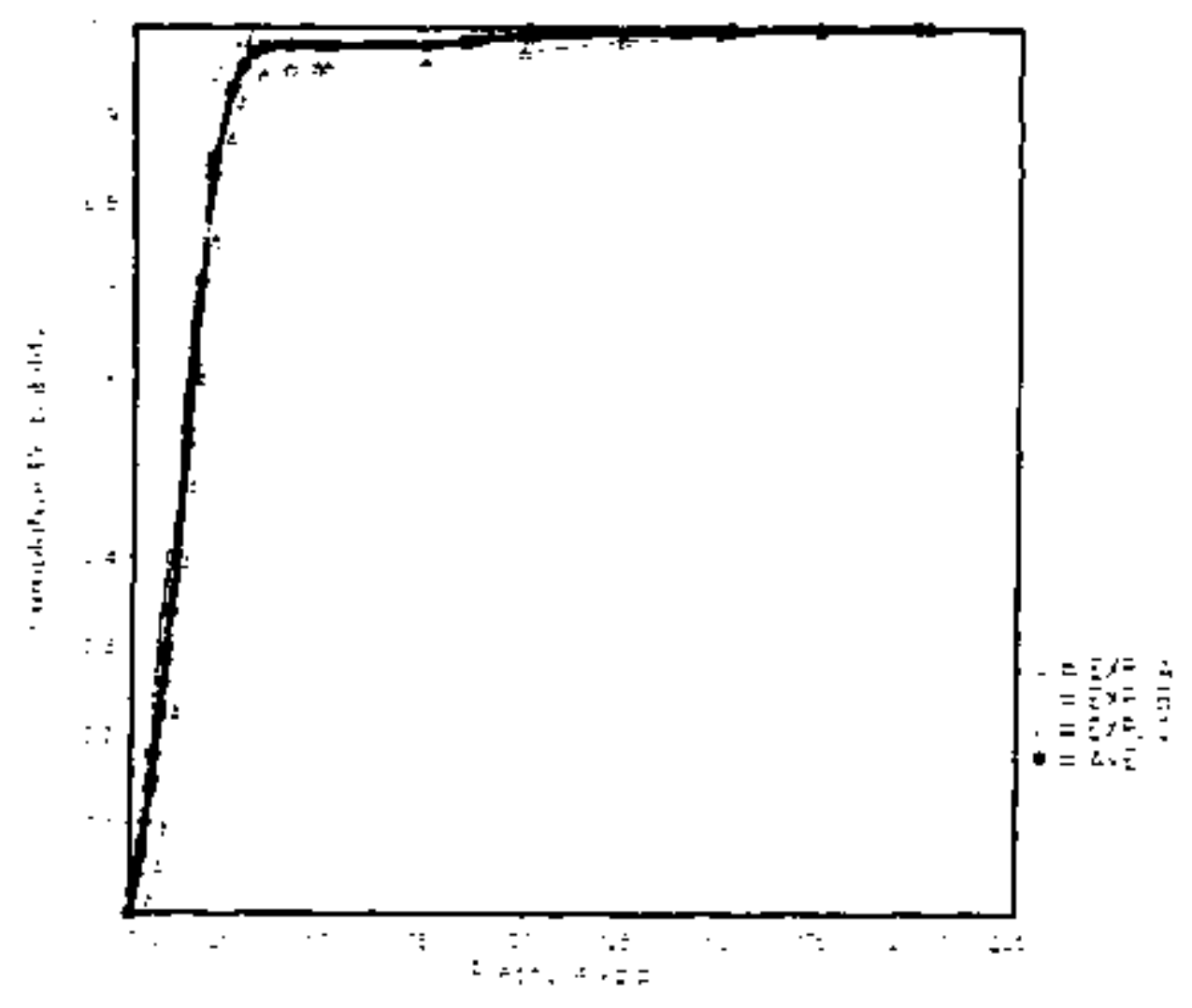

Figure $3-9$ (left). Peak Reactor Bulding Pressure Case 3: SB, Low Pressure, High or Low Steam. Figure 3-10 ( $\mathrm{r}^{\mathrm{ight}}$ ). Peak Reactor Building Pressure Case 4: No SB, itigh Pressure, High Steam. 
Find Cose Set 25 nSE. Hi Press. Low STM

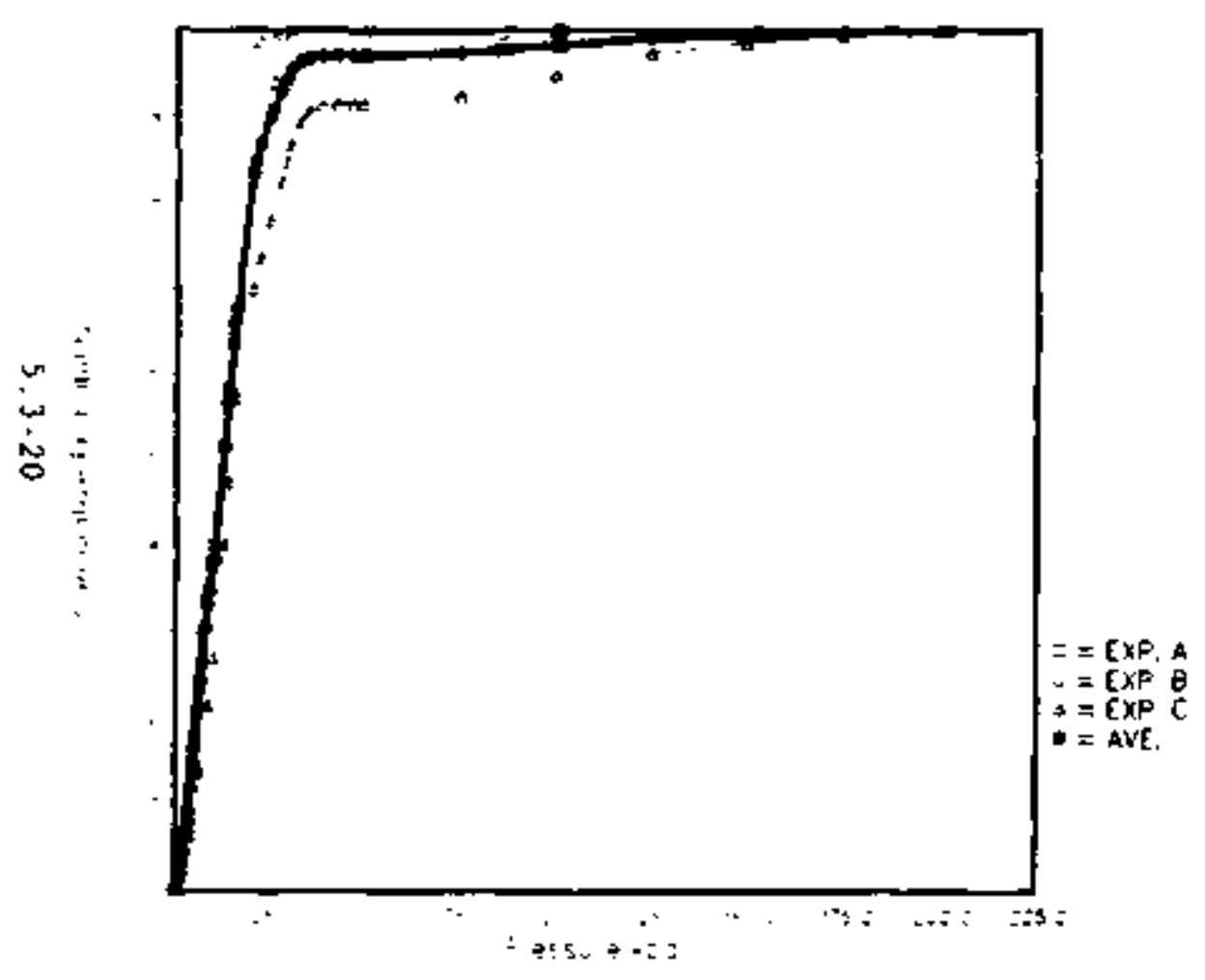

Final Cose Set $2-6$ nSB. Low Press. Hi or Low STM

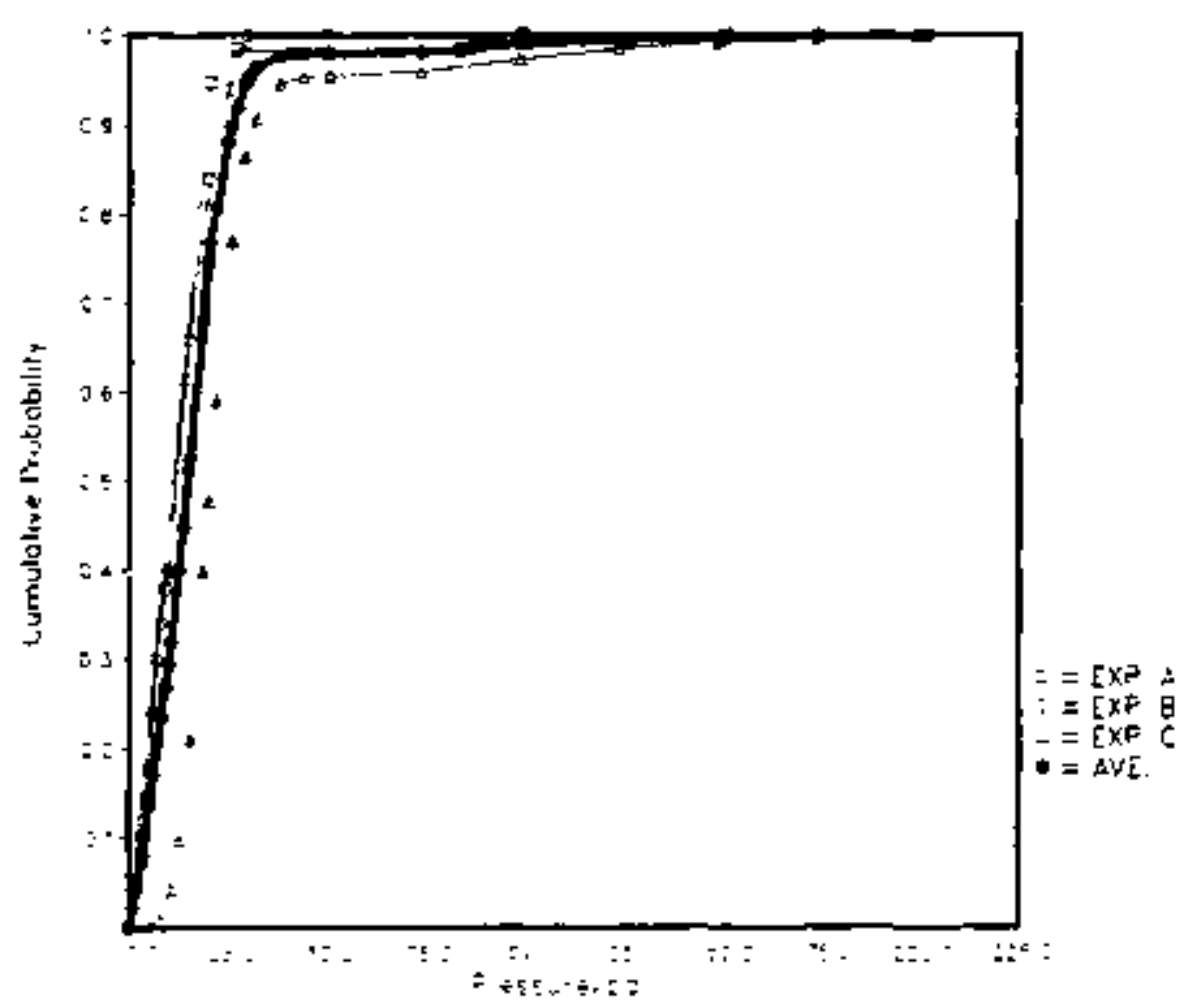

Figure 3-11 (left). Peak Reactor Building Pressure Case 5: No SB, High Pressure, Low Steam. Figure 3-12 (right). Peak Repctor Building Pressure Case 6: No SB, Low Pressure, High or Low Stean. 
Individual Elicitations for Issue 3

5. $3 \cdot 21$ 


\section{Expert A's Elieitation}

Issue 3: Pasch Bottow Reactor Bullding Faflure Due to Hydrogen Burns

Description_of Expart A's Ratienale/Methedology

Expert A felt that impulse loading was not gerwane to this issue since ignition was certain before detonable concentrations were attained. Thus, only peak static pressure was assessed. Figure A-1 below shows the decomposition that Expert $A$ used to address this issue.

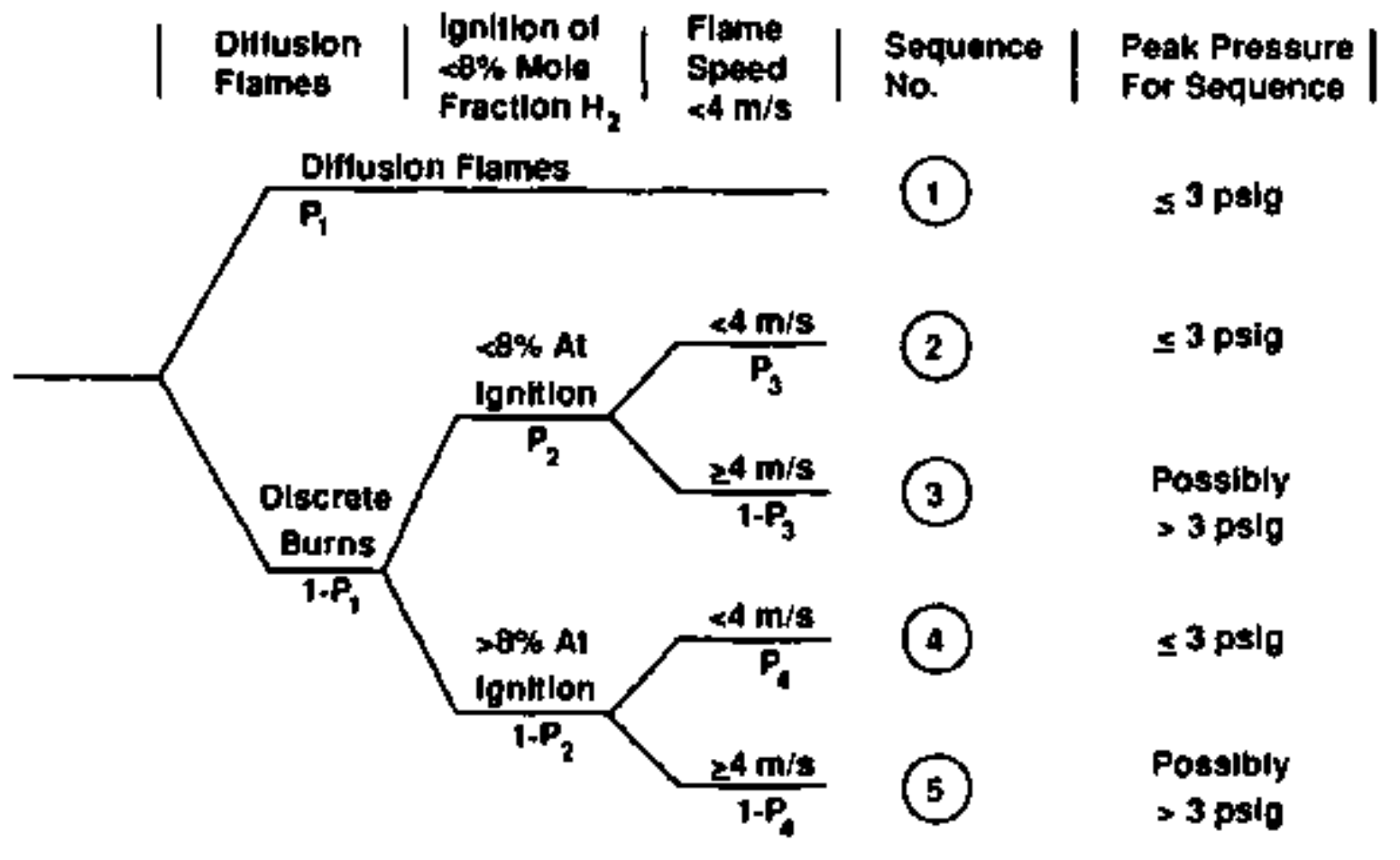

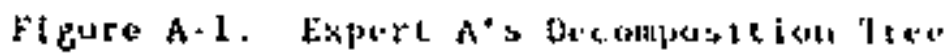


Three factors were constdered:

1. Whether hydrogen burning would be characterized by continuous combustion (1.e. diffusion flanes) or by discrete burns (i.e., multiple deflagrations).

2. Given that hydrogen combustion involved deflagrations, the molar concentration at which ignition occurs becomes important. Expert A divided the ignition threshold into two regions: ignition at molar concentrations below $B$ and ignition at nolar concentrations above 8 .

3. Flame speed during deflagration burns is also a key determinant of the peak statle pressure. As with hydrogen concentration at ignition. Expert A divided the possible range of flame speeds into two reglons: flame speeds less than $4 \mathrm{~m} / \mathrm{s}$ and flane speeds at or above $4 \mathrm{n} / \mathrm{s}$.

The tree shown in Figure A-1 rasults in five scenarlos (numbered 1 through 5 in Figure A-l). A subjective probability was assigned to each branch polnt in the tree $\left(P_{1}\right.$ to $\left.P_{4}\right)$. These probabilities are multiplied to arrive at an estimate of the probabliti for ach scenario.

For scenarios 1, 2, and 4 Expert A felt that the failure of the refueling bay blow-out panels, lifting of hatch covers, and the blow-aut of interior doors would mitigate the pressure rise within the bullding. Based on a preliminary review of the ellcitations from the structural review panel by the analysts and Expert A's own knowledge, tt was judged that gross fallure of the reactor bullding would require statie pressures greater than $20 \mathrm{kPa}$ over atmospheric ( 3 psig). Expert $A$ was certain that scenarlos 1,2 , and 4 could not rafse the reactor building pressure more than $20 \mathrm{kPa}$. Further assessment of these scenarlos vas thus not required.

For scenarlos 3 and 5 Expert $A$ considered the distribution of the static pressure rise for each of the three cases and the probability for the branch probability deflning scenarios. Peak static pressute wes assessed for scenarto $\$$ given Case 2 based on calculations perforned with the MELCOR and HECTR codes. These calculat lons vere performed by SNL and Oak RIdge siational Laboratory (ORNL). The ORNL calculations were for the Brown's Ferry plant which bas a considerably different design from Peach Bottom. Expert a assigned a subjective probability that the result obtained in each calculation considered was correct for the case being assessed. A nuch lower probability was assigned to the ORN calculations being cortect since they were for a different plant. However. Expert a felc that there was sothe chance that the Brown's Ferry model resulcs would reflect vhat would happen at Peach Bot tom. Thus the comblned SNL resulcs were assigned a 0.9 welght. A weight of 0 . I was assigned to the OkNL results

The Expert determined, as a result of the essessment of Case 2. that separate assessments for Cases 1 and 3 of thls 15 sue were not needed except as indlcated by the avallabllity of ac or de power. Expert A stated that the uncertalnties in the assessment were large relative to the differences between the cases. Case 2 was selected for assessment since he felt that I tw avallatsle code runs correspanded most closely to these cases 


\section{Resul ts of Expert A's Ellicitation}

Expert A assessed Case 2 of this issue assuning that the scenario was a short-term station blackout with failure of both ac and de power (corresponding to the FBUX plant danage state). Containment failure was assumed to occur a a result of drywell meltchrough. The varlous probabilities shown in Figure A-l were gssessed as indicated in Table A-1.

Table A-1

Deconposition Tree Probabilities

(Case 2, Station Blackout with Drywell Meltthrough)

\begin{tabular}{|c|c|c|}
\hline $\begin{array}{c}\text { Probability } \\
\text { (Sectgure } 0-1)\end{array}$ & Meanting & $\begin{array}{l}\text { Assessed } \\
\text { Value }\end{array}$ \\
\hline 1 & Probability that diffusion flane occurs & 0.8 \\
\hline 2 & $\begin{array}{l}\text { Probability that combustion begins below } \\
\text { 9 nolar } \mathrm{H}_{2} \text { concentracion }\end{array}$ & 0.5 \\
\hline 3 & $\begin{array}{l}\text { Probability that deflagration flane spetd } \\
\text { 1s below } 4 \text { on/s given } 1 \text { gnttion at or below } \\
83 \mathrm{H}_{2} \text { concentration }\end{array}$ & 0.8 \\
\hline 4 & $\begin{array}{l}\text { Probabllity that deflagration flawe speed } \\
\text { ls belot } 4 \mathrm{~m} / \mathrm{s} \text { given ignitfon above be } \mathrm{H}_{2} \\
\text { concentration }\end{array}$ & 0.8 \\
\hline
\end{tabular}

If the contalnment fallure node was overpressurization of the wetwell, Expert A would assign probability 1 a value of 0.2 rather than 0.8 . If dc power were available, probability 2 would increase but Expert A did not provide a value.

Table A-2 shows the various calculations that Expert $A$ cansidered and the weights assigned to each. Figure A-2 shows the resulting curulative distribution function for peak static pressute. The distribution shown is binodal. Expert a stated that this feature correctly represented his opinion and that peak static pressures in the range from 130 to $180 \mathrm{kPa}$ would essentially never occur since one of the two nodels used was, in fact, correct. These results correspond to Sequence 5, No assessment was provided for sequence 3 .

Expert A felt that adjustwent should be made to his result based on the quantity of hydrogen produced ln-vessel (assessed by the In+vessel Phenomena Expert Panel) and the size and location of containuent failure (assessed by the Structural Expert Panel). For in.vessel hydrogen production, Expert A recomanded linear extrepolation of his tesults based on the amount of hydrogen produced in-vessel. He stated that his results corresponded to $910 \mathrm{~kg}$ of hydrogen being produced. To adjust for contalnment leak area, Expert A recommended using the variation in peak pressure seen with leak area in the ORNL calculacions as a basis for extrapolating bis results. 
Table A-2

Assessmant of Peak Reactor Building Pressure

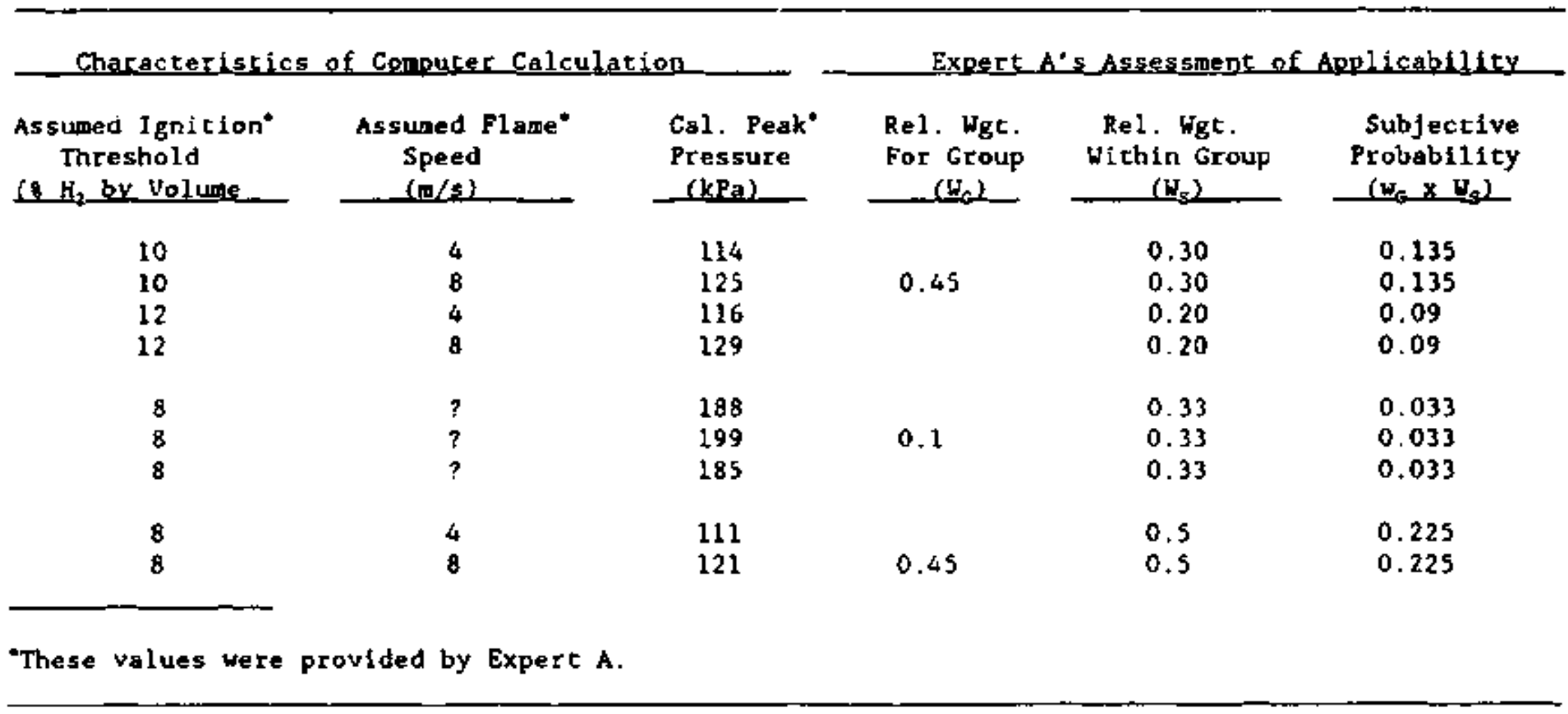


tonition $D>8 \%>4 m / s$ Flame spoed

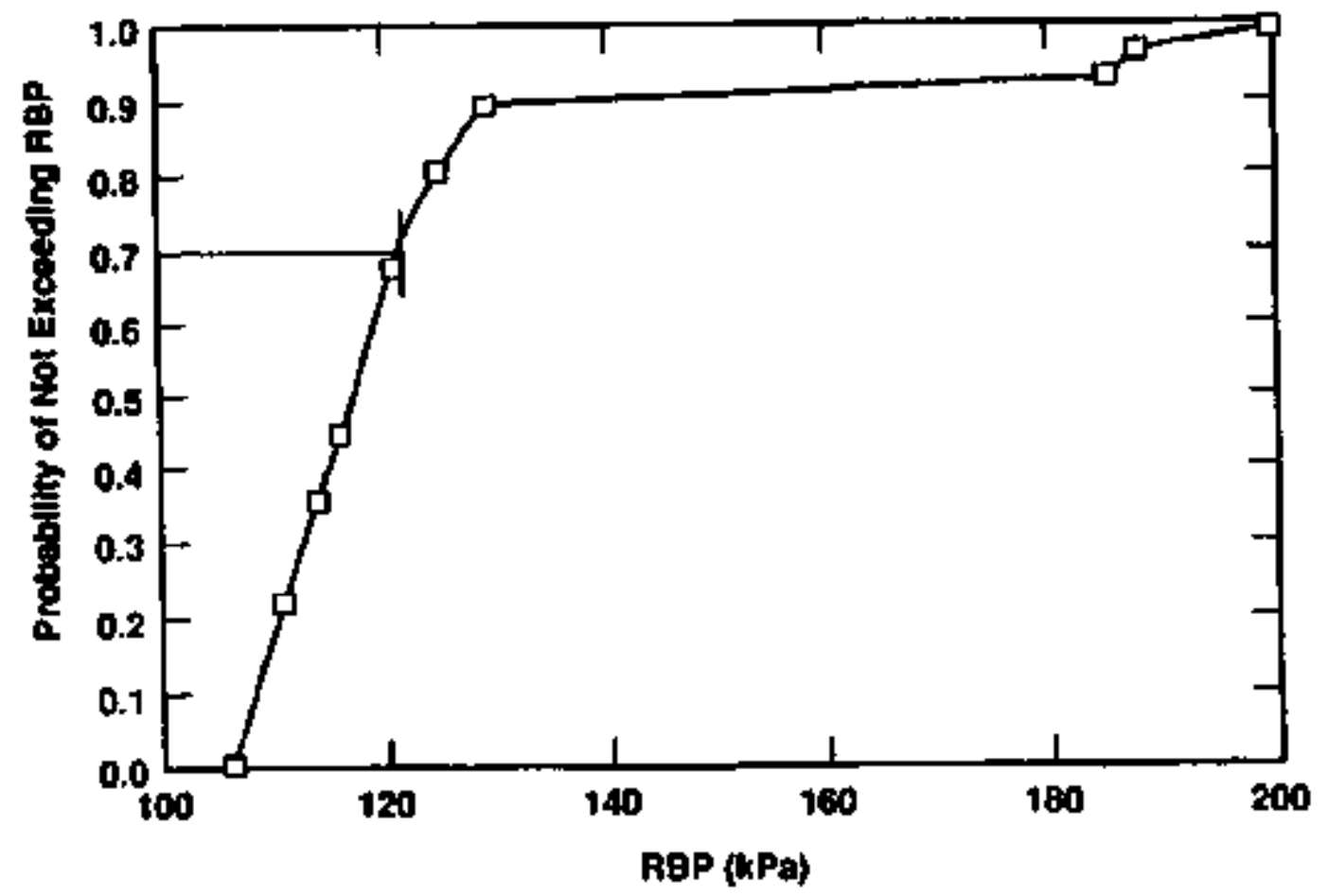

Figure A-2. Reactor Bullding Pressure Rise

\section{Sourcer of Uncertainty}

The major sources of uncertainty for this issue that were identifled by Expert $A$ are denoted by the branch points of the decomposition tree shown in Figure A-l. Uncertaintles assoctated with hydrogen Ignition were seen to be the largest contrlbutar to uncertaintles in peak static pressure, If the combustible gases were ignited as they escaped the contalnment, Expert A felt that an essentially static diffusion flame would be present and that buliding pressurtzation became a moot question. On the other hand, ignition at points in the bullding distant from the source could occur at various concentrations of combustible gas depending on the location. available lgnition sources, and the quantity of stean that had eccumulated. l'eak static pressure would be a strong functitn of the combustible gas concentration at Ignition.

The rapldity of the burn was seen as the second major source of uncertainty. Hlgh flame speeds result in rapld burns whlch produce relatively high static pressures.

\section{Correlations Whet other Vartables}

No correlations were specifled by the Expert for thlo issue as noted above (i.e.. in-vessel hydrogen production and contalnment faflure size and location). 
Sugqersed Methods for Reducing Uncertainty

No suggestions were node for reducing uncertainties.

3. 32 
Expert Bra Elicitetion

\section{Istue 3: Pesch Bottom Resctor Bullding Fallur Dus to Hydrogen Burns}

\section{Descrintion of Expext 8's Rationade/Methodologx}

The Expert indicated thet the location of the leak was not lmportant because the stean concentration would not be significantly different at different leak locations. Furchermore, he thought that even for high stear concentrations, large anounts of steam would condense in the reactor building and, thus, the mount of steam did not have to be explicitly considered. Therefore, the only two cases the Expert considered were blackout sequences and non-blackout sequences. The Expart defined a blackout as the loss of both ac and dc power.

For the conditlons presented in this 15sus, the Expert felt the differences between the inpulsive load and the static pressure rise was negligible. Therefore, in his assessaent, the Expert considered flane acceleration but not detonatsons.

The Expert's appraach was to filter Into his assessment the uncertainties associated with the type of butn, the probsbillty of ignition, the hydrogen $\left(\mathrm{H}_{2}\right)$ concentration in the reactor bullding, and the pressuxe rise from a hydroges burn. To do this, the Expert developed the following probability equation:

$$
\begin{aligned}
& p\left(\Delta P \mid X_{t}, B_{-}\right)=\int_{0}^{X_{\text {ant }}}\left[P_{J=6}\left(X_{t}, T\right) \cdot P\left(\Delta P \mid X_{t b}\right) \cdot p\left(\text { burn } \mid X_{6 b}, B_{0}\right)\right. \\
& \left.+P_{n j a r}\left(X_{c}, T\right) \cdot p\left(\Delta P \mid X_{r b}\right) \cdot p\left(b u r n \mid X_{r b} \cdot B_{b}\right)\right) p\left(X_{r b} \mid X_{c}\right) \cdot d X_{r b}
\end{aligned}
$$

where

$$
\begin{aligned}
& \text { AP - the pressure increase from the bura: } \\
& X_{c} \quad \text { - the concentration of hydrogen } 1 \mathrm{n} \text { the cantainuent: } \\
& \text { B. - the blackout state (1.e., blackout or nonblackout): } \\
& x_{\text {max }} \text { - the maxiaus } H_{2} \text { concentration in the reactor building; } \\
& \text { Pjat - the probabllity of a jet: } \\
& T^{-} \text {- the contalnent temperature; } \\
& \mathrm{X}_{\mathrm{rb}} \text { - the } \mathrm{H}_{2} \text { concentration in the reactor bulldiag: } \\
& \text { burn - the tgation state: } \\
& P_{n j e t}=\text { the probability of no jet. }
\end{aligned}
$$

The tera $p\left(X_{s b} \mid X_{c}\right)$ represents the uncertainty in the hydragen concenteration in the resctor bulding. p(burn| $\left.x_{x b}, B_{0}\right)$ represents the pulbablity that the hydrogen ofxture will 1 gnite and burn, $\beta_{J=L}\left(x_{c} . T\right)$ is the probabiltey the hydrogen wll burn as a Jet, and $p\left(A P \mid X_{r b}\right)$ represtels the uncertainty its lte pressure $r$ ise which resulis from the hydrogeti hurn 
The Expert thought that ther vere two possibilities for the hydrogen burn: (1) It could either burn os a jet en it is injected into the reactor bullding or (2) it could burn as a deflagration. For the blackout case, he felt a jet could not exist because of the lack of 1gnition sources. For the non-blackout case the probability of a jet, Pjat, was related to the containment hydrogen concentration and tamperature. The Expert baged the Ignition probabllity of a jet on data presented in Figure B-1. Above a containment temperature of $1060 \mathrm{~K}$ or above a contalnaent hydrogen concentration of 123 the probabllity of a jet burn is 1 . If the hydrogen concentration is below 12 and the containment temperature is less than $1060 \mathrm{~K}$. the probability of a jet depends on both cemperature and hydrogen concentration. To determine the probability of a jet in this reglon, the Expert provided the following set of equations:

$$
X_{c}=9.6 \times 10^{-5}(925-T)+0.06 \text { for } 300<T<925 \mathrm{~K}
$$

and

$$
X_{c}=4.44 \times 10^{-4}(1060 \cdot T) \text { for } 925<T<1060 \mathrm{~K}
$$

Above this curve the probability of jet is 1 and below this curve the probabllity of a jet is 0 . In other words, 1f the hydrogen concentration In the contalnment is greater than the hydrogen concentration predicted by chis equation, then the probability of a jet 1s 1; otherwise, the ptobabllity of jet is zero.

The ignition probability depends on the type of burn that occurs and the hydrogen concentration in the reactor bullding. If the hydrogen burns as a jet, the Expert assuned uniform probabllity distribution between reactor buliding hydrogen concentrations of 4 and $\mathrm{Bt}$ for the non-blackour case and zero for the blackout case. For feflagrations, the Expert chose a low "anchor" (lower bound) and a high "anchor" (upper bound) for lgnition probability. The low anchor was assigned probability of 0 snd the high anchor a probabillty of 1 . The median vas arbitrarily chosen as the midpolnt between the low and high enchors. For the non-blackout cose the lot anchor corresponded to the lower flamabllity linlt for upward flame propagation (4t). Stntlarly. the high anchor corresponded to the lower flatumabllity linit for downord flame propagation (B). For the blackout case, the Expert indicated that there chould still be sources of sparks throughout the building. For chls case the lov anchar corresponded to the lower flamab1lity ! imit for downard propagation (BD). The Expert thought that hydrogen mixture of 12 would be highly flamable and, therefore. chose this value as his high onchor.

The next step of the Expere's nethodology was to develop probeblitty distributions for the pressure rise that results from a hydrogen burn in the reactor bulding. The Expert Indicated that when a burn occurs in a single volume, the pressure is far below the ldeal pressure because the reactor bullding rooms are vented through large areas. It was the opinton of the Expert that venting controls the pressure rise. The Expert used an ideal venting equation to estimate the pressure rise from a hydrogen burn. by isswing, some reasonable intelal condiclons and propecties the Expert was able to get good agreement hetween his simple model (see attached 


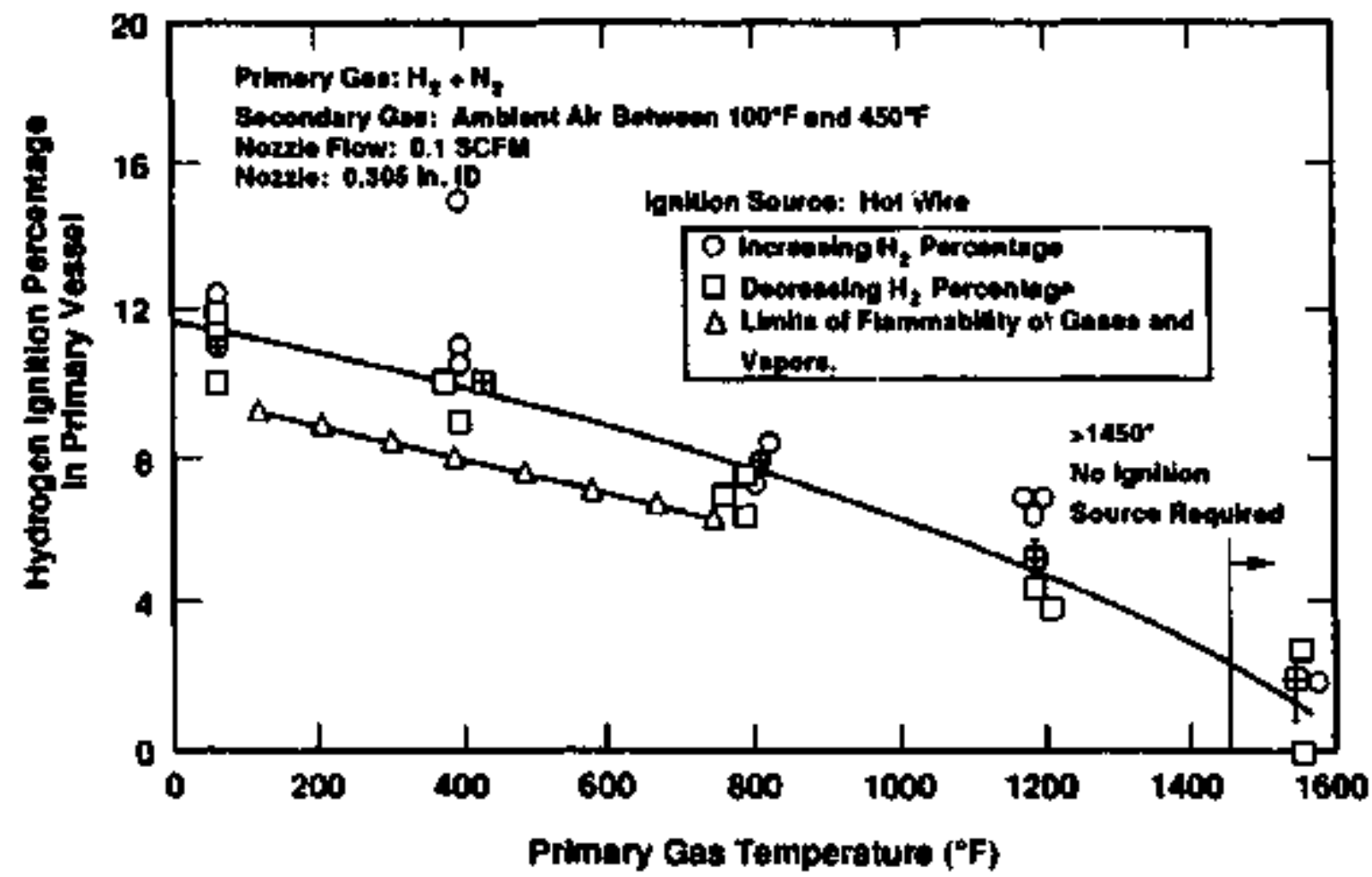

Flgure B+1. Ignition of Hydrogen-Nitrogen Jet (Without Sodium) as a Function uf Jet Tenperature.

appendix to this elicitation). He then used his model to calculace the pressure rise assuning varlaus hydrogen concentrations, flame speeds, compartment volumes, and loss coefficients. From this information the Expert developed probability distribution functions for the pressure rise For reactor bullding hydrogen concentrations of 4,8 , and 128 . Ae hydrogen cancentratlons of 4 . the Expert felt the pressure rise from a burn would be low because of Incomplete combustion. The low end of the dtstribution represents repetitive burns or incomplete burns. Midway between the $O$ fractlle and the odlan (at the 0 fractile), the value the Expert chose corresponds to the pressure rise required to open the blow. out panels. The pressure rlse at the aedlan was based on hand calcula. tions. Strilarly, the high "anchor" was based on hand calculations re. cognizing a low flare acceleration and Incomplete conbustion. At hydrogen concentrations of $B$ and 12 , the lov anchor values correspond to the pressure rise requited to open the blowaut panels. For the hlgh anchor values the Expert assumed a highly accelerated flame. The median values are based on a moderate flame acceleration. The Expert felt that the pressure rises he provided for hydrogen concentrations at and 120 may be 500 large because the ideal vent formula is not dynamic, and these pressures may cause other vent areas to open and thus allow greater venting.

To express the uncertainty in the hydrogen concentration In the reactor building the Expert assumed a unt form distribut lan between two hydrogen concentrations which are related to the range of hydrogen concentrations 
considered for the ignition probability. For a jet the Expert assuned a uniform digtribution between 4 and $b$ hydrogen. For deflagractons, the Expert assumed antford distribution between the low anchor for ignition probability and $x_{\max }$ where

$$
x_{\text {ex }} \text { - min(high anchor for Ignition, } x_{\text {men }} \text { ) }
$$

where $X_{\text {ax }}$ * Is the maximum hydrogen concentration in the reactor bullding assuning there are no hydrogen butns. Although the Expert did not essess this value. he felt that it should be obcained from a deceruinistic calculation (e.g.. MtLCOR calculation). It should be noted that $X_{\text {mex }}{ }^{*}$ is a function of the hydrogen concentration in the contalnment.

\section{Regults of Expert B's Elicitation}

\section{Jec Probability}

For the blackout case, the probability that the hydrogen will burn as a jet is zero. For the non-blackout case. the following two equatlons are used to determine the probability of a jet:

$$
\begin{aligned}
& x_{c}-9.6 \times 10^{-5}(925-T)+0.06 \text { for } 300<T<925 \mathrm{~K} \\
& \text { and } \\
& x_{c}=4.44 \times 10^{-4}(1060-T) \text { for } 925<\mathrm{T}<1060 \mathrm{~K} .
\end{aligned}
$$

In other words. If the hydrogen concentration in the containment Is greater than the hydrogen concentration predicted by these equations, then the probability of a jet is 1 ; otherwise, the probability of a jet is zoro.

\section{Lenition Probability}

The ignition probabllity for jet is a uniform distribution between reactor building hydrogen concentrations of 4 and 8 . These values are tabulated In Tabie B-1. For a deflagracion burn, the ignition probabilities for the blackout case and non-blackout case are presented in Table B+2.

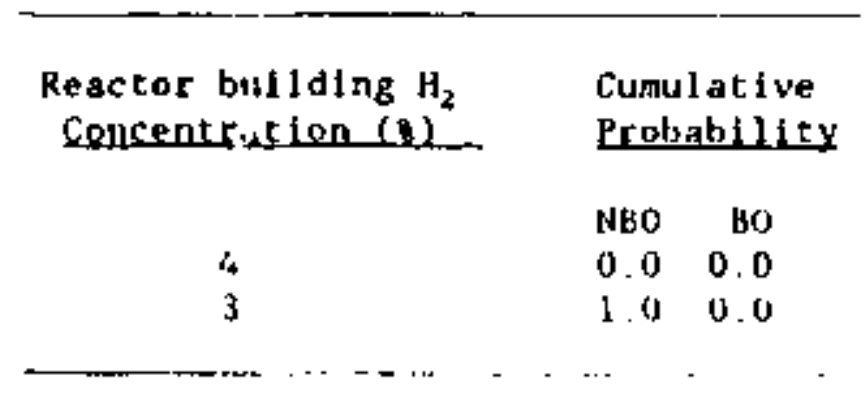


Table $B .2$

Ignition Probabllities for Deflagrations

Cuncalive Probability

0.0

0.1

0.5

0,9

1.0
$\mathrm{Rx}$ Blde $\mathrm{H}_{2}$ Concentracton (M) Biackout

8. 0

9.0

10.0

11.0

12.0
Nonblackout

4.0

5,0

6.0

7.0

a. 0

\section{Pressure Rlse Probgbility}

The pressure rise probabilities for reactor building hydrogen concentrations of $4, B$, and 12 are presented In Table B-3. The Expert indicated that pressure rise versus hydrogen concentration curves for a given fractile are linear from 4 to 11 bydrogen and have a "s" shape from 11 to 120 hydrogen.

Table 1.3

Pressure Rise In Reactor Building

Due to a Hydrogen Burn (Ats.)

\begin{tabular}{|c|c|c|c|}
\hline \multirow[b]{2}{*}{ Cunulative Probabiluty } & \multicolumn{3}{|c|}{ BX. Bidp $\mathrm{H}_{2}$ Concentration (U) } \\
\hline & -4 & B_ & 120 \\
\hline 0.00 & 0.00 & 0.05 & 0.05 \\
\hline 0.05 & $(0.005)$ & $(0.075)$ & 0.10 \\
\hline 0.10 & $(0.01)$ & 0.10 & $(0.20)$ \\
\hline 0.50 & 0.05 & 0.15 & 0.30 \\
\hline 0.90 & $0.0 B$ & 0.25 & 1.00 \\
\hline 1.00 & 0.10 & $0.3 \%$ & 2.00 \\
\hline
\end{tabular}

\section{kacker Buliding Hydrogen Concentration Probability}

To express the uncertainty in the hydrogen concentration in the reactor bullding the Expert assumed a unlform distribution between a low and high anchor. The results are presented in Tabic B-4. 
Table $\mathbf{p . 4}$

Reactor Buflding Hydrogen Concentration Uncertainty

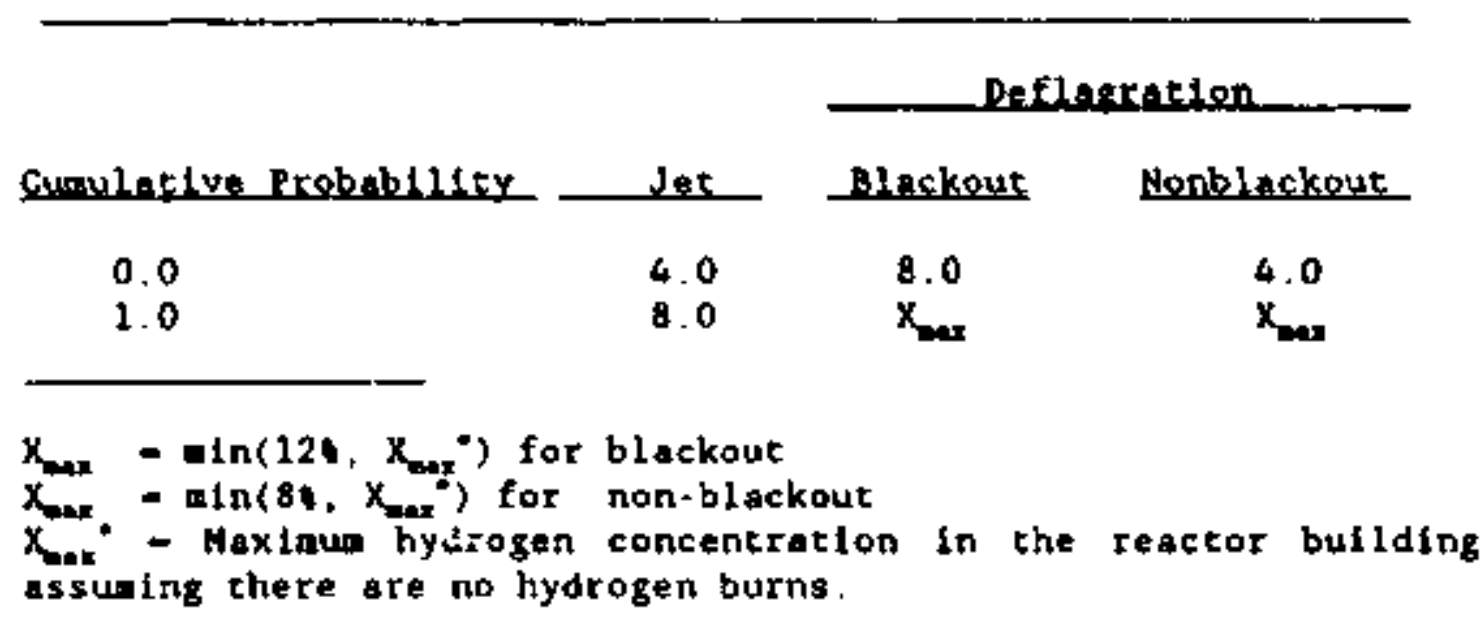

\section{Sources of Uncercelnty}

The major sources of uncertainty were the values used for flame acceleration and the "effective" vent ateas

\section{Correlations with Qther Varlables}

No correlaclons vere discussed between varlables in the evtint trees and the vartables discussed as parr of chis issue.

\section{Sugpested Merhods for Beducing Uncercalnty}

No recomendations vere made for reducing uncertainty 


\section{Expert B's Model}

The Expert's model equations for continuity and energy assued ideal and calorically perfect gases:

$$
\begin{aligned}
& \text { (1) } \frac{d n}{d t}=-A \quad \frac{\frac{2 n\left(P \cdot P_{a}\right)}{M V k}}{a} \\
& \text { (2) } \frac{d P}{d t}=\frac{\dot{Q} R}{M c_{v} v}+\frac{P P}{n}\left(\frac{d n}{d c}\right)
\end{aligned}
$$

where

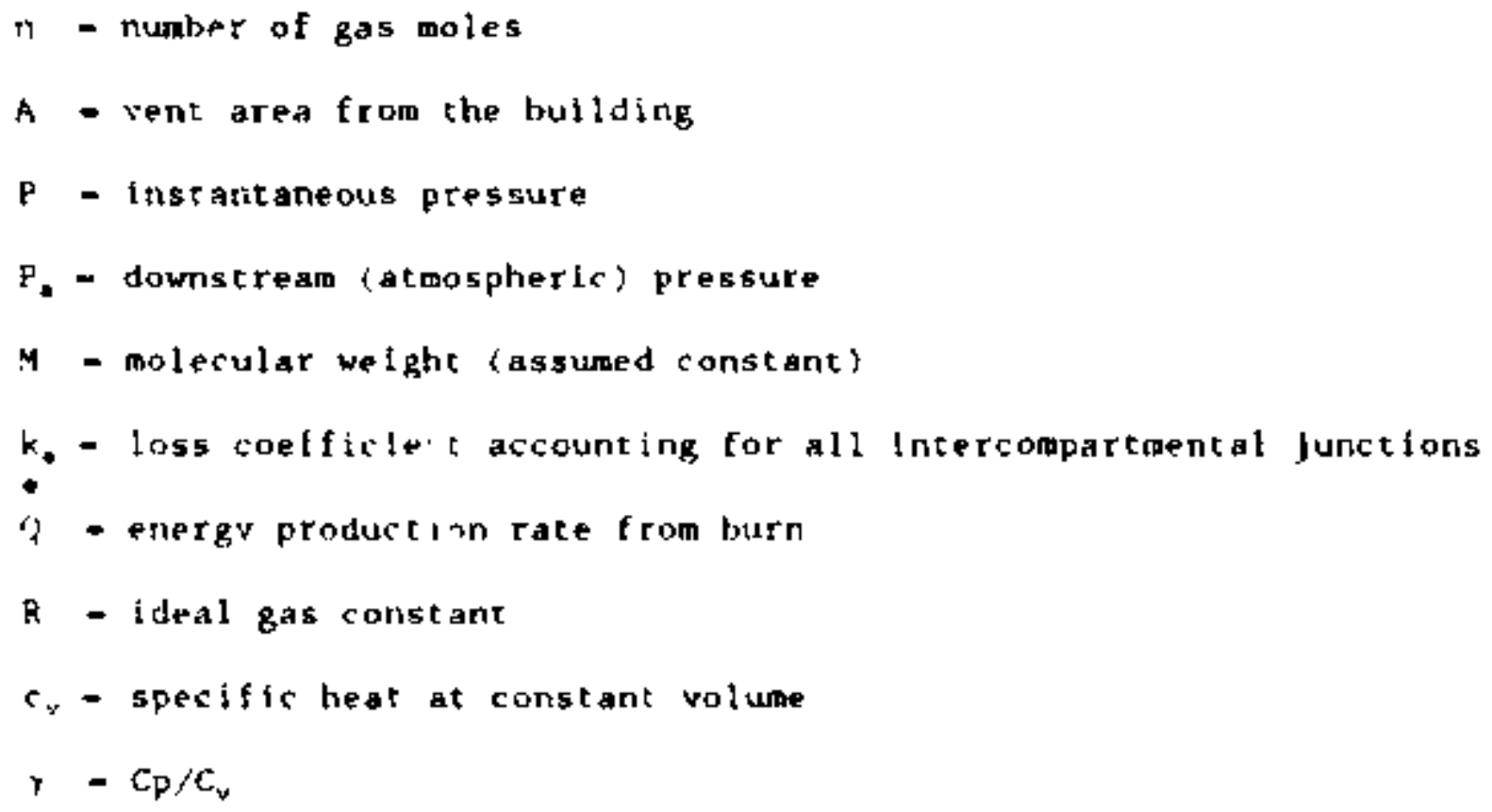

Thie maximum pressure 1 se $1 \mathrm{~s}$ thus given by

(3) $\frac{D_{R}}{4 c_{v} V}-\frac{X A P}{n}\left[\frac{2 n\left(P \cdot P_{g}\right)}{M V k_{p}}\right]^{1 / 2}$

The lus th release teim is given by knowledge of the hydrogen casicilisijon, the butring enthalpy release, and the burn time, allowing furt!.. simplification:

(i) $\frac{x \Delta h}{M c} v_{0}^{T}-\frac{\gamma A P}{P_{o}}\left[\frac{2\left(P-P_{g}\right)}{n_{o} H V k_{e}}\right]^{1 / 2}$ 
where the subscript o denotes initlel resctor bullding conditions, $x$ hydrogen concentration, $\Delta$ h - burn enthalpy. $r$ - burn time,

The purpose of these equations is to denongtrate the efficacy of venting on reduction of the combustion pressure rlse, and thus show that adiaba. tfc. Isochoric values for the pressure rlse are not appropriate to reactor bullding analysis.

For purely lllustrative purposes, che expert applted (3) to reproduce Haskin's [2] results. He assumed:

$$
\begin{aligned}
& V=10^{4} \mathrm{~m}^{3}, \Delta \mathrm{h}-60 \mathrm{E} 6 \mathrm{~J} / \mathrm{kg} \text {. mol } \mathrm{H}_{2} \text {, } \\
& P_{o}=10^{3} \mathrm{~Pa}, \mathrm{~T}_{\mathrm{o}}=400 \mathrm{~K}, \mathrm{n}_{0}-301 \mathrm{~kg} \text {. 0ol, } \\
& M=20, c_{y}=1000 \mathrm{~J} / \mathrm{kgk} \\
& L-10+\text { for }(\varphi-L / W)
\end{aligned}
$$

CASE INPUT

$\begin{array}{lrrrrrr}\text { Case } & \mathrm{B3} & \mathrm{B} 4 & \mathrm{~B} 11 & \mathrm{~B} 12 & \mathrm{B19} & \mathrm{B20} \\ \mathrm{X}_{\mathrm{H}_{2}} & .08 & .08 & .10 & .10 & .12 & .12 \\ \mathrm{u}_{\text {Burn }} & 4 & 8 & 4 & 8 & 4 & 8\end{array}$

DFRIVE

\begin{tabular}{|c|c|c|c|c|c|c|}
\hline Case & B3 & $B$ & BH1 & B12 & B19 & $\mathrm{B} 20$ \\
\hline$P($ Haskin)/2] & 1.11 & 1. 21 & 1.13 & 125 & 1.15 & 1.29 \\
\hline$k_{0}-2.5$ & 1.07 & 1.17 & $\cdots$ & 1.22 & 1.11 & 1.28 \\
\hline-5.0 & 1.21 & 1.26 & 1.14 & 1.35 & 1.18 & 1.43 \\
\hline$k_{0}=7.5$ & 1.24 & 1,34 & $\cdots$ & $\cdots$ & $\ldots$ & .. \\
\hline
\end{tabular}

$\begin{array}{lrrrrrr}\text { (s) } & 2.5 & 1.25 & 2.5 & 1.25 & 2.5 & 1.25 \\ \mathrm{H}_{2} & 24 & 24 & 30 & 30 & 36 & 36 \\ \Delta Q \text { (J) } & 1444 E 6 & 1444 \mathrm{E6} & 1800 \mathrm{E} 6 & 1800 \mathrm{E} 6 & 2260 \mathrm{6} 6 & 216086 \\ \dot{\mathrm{Q}} \text { (W) } & 578 \mathrm{E} 6 & 1155 \mathrm{E} 6 & 220 \mathrm{E} 6 & 1440 \mathrm{E} 6 & \text { B64E6 } & 1728 \mathrm{E} 6\end{array}$

$$
\begin{array}{r}
\text { Assuning } A-22 \mathrm{~m}^{3} \text { blowout panel area and } \\
\Delta P-k P a \text { controlling the venting. }
\end{array}
$$

\section{... Plessure In Rars ...}


While the agreement is very good, a notlceable blas exists such that the

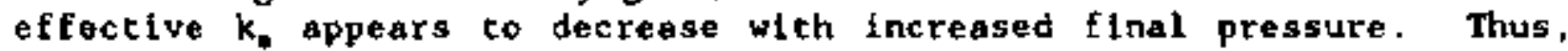
the simple model can be used to evaluate venting fron a reactor bullding, but some of the physics of intercompartmental flow is obscured by its use. That 1s, the real bullding tn Haskin's calculations conststed of a serles of rooms and hatches which one lumped into the single $k$. The "round numbers" used in the sample calculation also contribute to a bias In $k_{0}$.

The fundamental conclusion to be drawn from the analysis is that the reactor bullding pressure response to hydrogen burns is governed by venting. Such a pressure rise can be sccurately predicted with a simple nodel whlch is "tuned" to the spectfte bullding. and the sinple model can be used to analyze sensitivity and generate probability distributions. 


\section{Expert C'a Elicitecion}

\section{Insue 3: Poech Bottos Reactor Bullding Follure Due to hydrogen Burns}

\section{Description of Expert C's Rationale/Methodology}

The Expert performed a base case analysis based on the calculacions in the genersl literature and then assessed how the differences in our cases would affect the results. The steam will result in transitions to detonation beling the dominant source of detonations; direct detonations are not possible since no sources in the reactor bulding are likely to be strong enough. The Expert thought that ignition was essentilily 1.0 and would occur as soon as steam derinerting would allow. For low stean cases, flame speed will be more itmportant than in the high sceam cases in affecting the peak pressure. The Expert did not present the results in terms of hydrogen concentration but from the computer runs included the vartation in possible hudropen production in the results.

\section{Results of Expert C's Ellcitation}

The three cases are: Case 1, high pressure, stean: Case 2, high pressure, little steam: and Case 3 low pressule, steam. (DF - diffuston flatne, DET detonation. DEF - deflagration, FS - flame speed, PP - peak pressure, RF reflection function, UI - maximum unreflected inpulse (mode, N). Ba - beta distribution.

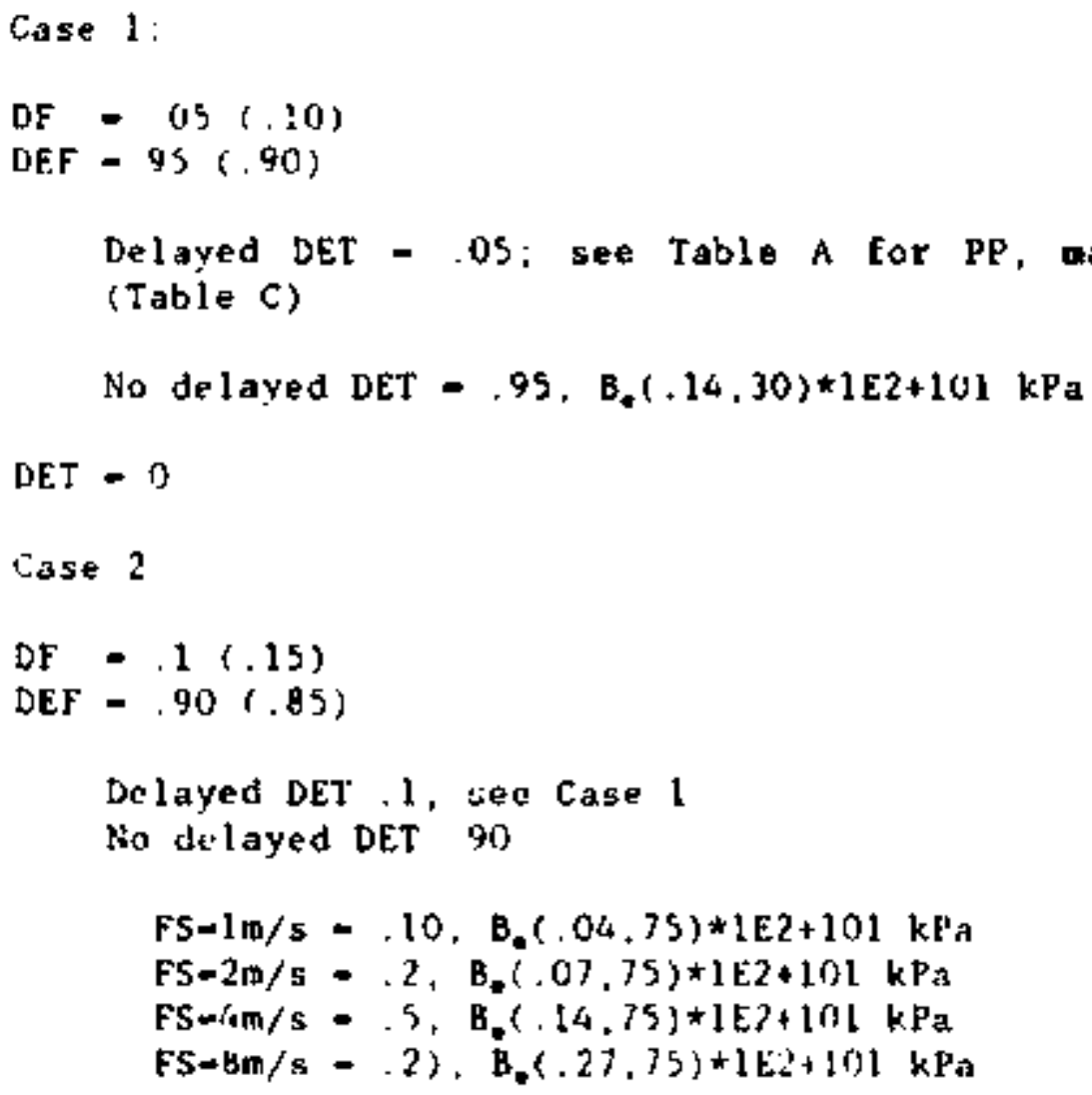




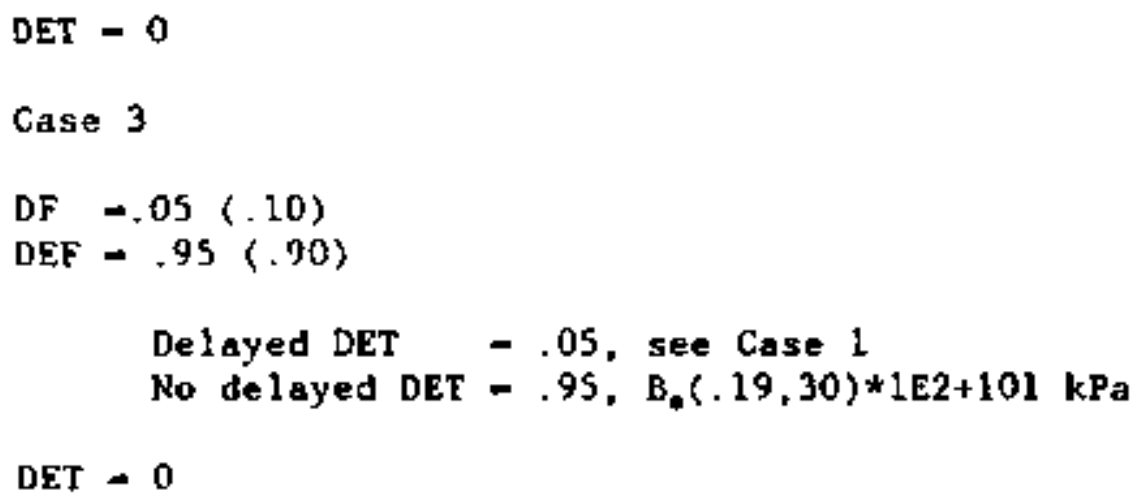

Reformatting, the probabllity of the vartous modes of coldbutlon is:

\begin{tabular}{llll} 
& Case_1 & Casa 2 & Case 3 \\
\cline { 3 - 4 } & & & \\
DF & .05 & .10 & .05 \\
DEF & .9025 & .31 & .9025 \\
DET & .0475 & .09 & .0475
\end{tabular}

For detonations, the following inforation is applicable:

Table A peak pressure after detonation:

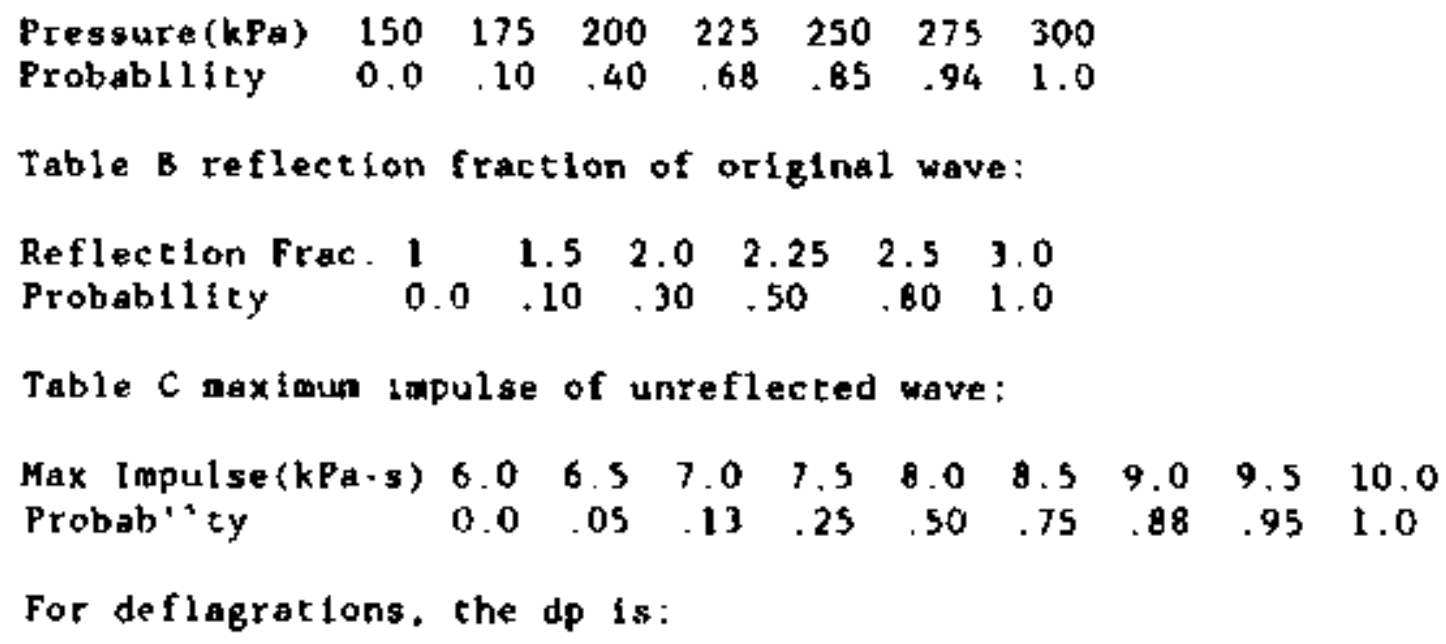

Case 1

dp(kp) Cumulative Probahllty

$\begin{array}{ll}1.34 & 0.00 E-0 \\ 2.68 & 5.318-4 \\ 5.37 & 1.44 \mathrm{E}-2 \\ 7.38 & 5.37 \mathrm{E} \cdot 2 \\ 8.72 & 9.99 \mathrm{E}-2 \\ 11.41 & 2.38 \mathrm{E}-1 \\ 14.09 & 4.14 \mathrm{E}-1 \\ 15.43 & 5.04 \mathrm{E}-1 \\ 17.45 & 6.29 \mathrm{E}-1 \\ 20.80 & 7.95 \mathrm{E}-1\end{array}$


Case 1 (Continued)

- dp(kp) Curulative Probabt1ty

$\begin{array}{ll}24.83 & 9.15 \mathrm{E}-1 \\ 27.51 & 9.57 \mathrm{E}-1 \\ 32.88 & 9.91 \mathrm{E} \cdot 1 \\ 39.59 & 9.99 E-1 \\ 46.30 & 1.00 E+0\end{array}$

Case 2

Cunulative Probabilty

\begin{tabular}{|c|c|c|c|c|c|}
\hline dp (ko) & $1,0 \mathrm{~m} / \mathrm{s}$ & $2.0 \mathrm{~m} / \mathrm{s}$ & $4.0 \mathrm{n} / \mathrm{s}$ & $8,0 \mathrm{~m} / \mathrm{B}$ & Walphted Average \\
\hline $\begin{array}{l}0.00 \\
0.67 \\
1.34 \\
2.01\end{array}$ & $\begin{array}{l}0.00 E-0 \\
1.63 E-3 \\
1.86 E-2 \\
6.03 E-2\end{array}$ & $\begin{array}{l}0.00 \mathrm{E} \cdot 0 \\
0.00 \mathrm{E}-0 \\
2.61 \mathrm{E}-4 \\
2.44 \mathrm{E}-3\end{array}$ & $\begin{array}{l}0.00 E \cdot 0 \\
0.00 E \cdot 0 \\
0.00 E+0 \\
0.00 E+0\end{array}$ & $\begin{array}{l}0.00 \mathrm{E}-0 \\
0.00 \mathrm{E} \cdot 0 \\
0.00 \mathrm{E}-0 \\
0.00 \mathrm{E}-0\end{array}$ & $\begin{array}{l}0.00 \mathrm{E}-0 \\
1.63 \mathrm{E}-4 \\
1.91 \mathrm{E}-3 \\
7.12 \mathrm{E}-3\end{array}$ \\
\hline $\begin{array}{l}2.68 \\
3.36 \\
4.70 \\
6.71\end{array}$ & $\begin{array}{l}1,47 \mathrm{E}-1 \\
2.52 \mathrm{E}-1 \\
4.85 \mathrm{E}-1 \\
7,64 \mathrm{E}-1\end{array}$ & $\begin{array}{l}1.06 \mathrm{E}-2 \\
3.00 \mathrm{E}-2 \\
1.18 \mathrm{E}-1 \\
3.62 \mathrm{E}-1\end{array}$ & $\begin{array}{l}0.00 E-0 \\
0.00 E-0 \\
2.00 E-4 \\
5.07 E-3\end{array}$ & $\begin{array}{l}0.00 \mathrm{E} \cdot 0 \\
0.00 \mathrm{E} \cdot 0 \\
0.00 \mathrm{E} \cdot 0 \\
0.00 \mathrm{E} \cdot 0\end{array}$ & $\begin{array}{l}1.68 \mathrm{E}-2 \\
3.12 \mathrm{E}-2 \\
7.22 \mathrm{E}-2 \\
1.51 \mathrm{E}-1\end{array}$ \\
\hline $\begin{array}{l}8.72 \\
10.07 \\
12.75 \\
14.09\end{array}$ & $\begin{array}{l}9.11 \mathrm{E}-1 \\
9.5 \mathrm{E}-1 \\
9.92 \mathrm{E}-1 \\
9.97 \mathrm{E}-1\end{array}$ & $\begin{array}{l}6.29 \mathrm{E}-1 \\
7.68 \mathrm{E}-1 \\
9.2 \mathrm{EE}-1 \\
9.63 \mathrm{E}-1\end{array}$ & $\begin{array}{l}3.74 \mathrm{E}-2 \\
9.35 \mathrm{E}-2 \\
3.10 \mathrm{E} \cdot 1 \\
4.51 \mathrm{E}+1\end{array}$ & $\begin{array}{l}0.00 \mathrm{E}-0 \\
0.00 \mathrm{E}-0 \\
0.00 \mathrm{E}-0 \\
2.4 \mathrm{LE}-4\end{array}$ & $\begin{array}{l}2.36 E-1 \\
2.96 E-1 \\
4.39 E-1 \\
5.18 E-1\end{array}$ \\
\hline $\begin{array}{l}26.10 \\
20.13 \\
22.14 \\
24.83\end{array}$ & $\begin{array}{l}9.99 E-1 \\
1.00 E+0 \\
1.00 E+0 \\
1.00 E+0\end{array}$ & $\begin{array}{l}9.88 \mathrm{E}-1 \\
9.99 \mathrm{E}-1 \\
1.00 \mathrm{E}+0 \\
1.00 \mathrm{E}+0\end{array}$ & $\begin{array}{l}6.56 \mathrm{E}-1 \\
9.14 \mathrm{E}-1 \\
9.64 \mathrm{E}-1 \\
9.91 \mathrm{E} \cdot 1\end{array}$ & $\begin{array}{l}2.06 \mathrm{E}-3 \\
4.05 \mathrm{E}-2 \\
1.10 \mathrm{E} \cdot \mathrm{l} \\
2.83 \mathrm{E}-1\end{array}$ & $\begin{array}{l}6.26 E-1 \\
7.65 E-1 \\
\text { 8. } 04 E-1 \\
\text { g. } 52 E-1\end{array}$ \\
\hline $\begin{array}{l}27.51 \\
28.85 \\
30.20 \\
32.88\end{array}$ & $\begin{array}{l}1.00 E+0 \\
1.00 E+0 \\
1.00 E+0 \\
1.00 \varepsilon+0\end{array}$ & $\begin{array}{l}1.00 \mathrm{E}+0 \\
1.00 \mathrm{E}+0 \\
1.00 \mathrm{E}+0 \\
1.00 \mathrm{E}+0\end{array}$ & $\begin{array}{l}9.98 \mathrm{E}-1 \\
9.99 \mathrm{E} \cdot 1 \\
1.00 \mathrm{E}+0 \\
1.00 \mathrm{E}+\mathrm{C}\end{array}$ & $\begin{array}{l}5.19 \mathrm{E} \cdot 1 \\
6.37 \mathrm{E}-1 \\
7.41 \mathrm{E}-1 \\
8.90 \mathrm{E} \cdot 1\end{array}$ & $\begin{array}{l}9.03 E-1 \\
9.27 E-1 \\
9.48 E-1 \\
9.78 E-1\end{array}$ \\
\hline $\begin{array}{l}34.89 \\
38.25 \\
42.28 \\
46.30\end{array}$ & $\begin{array}{l}1.00 E+0 \\
1.00 E+0 \\
1.00 E+0 \\
1.00 E+0\end{array}$ & $\begin{array}{l}1.00 E+0 \\
1.00 E+0 \\
1.00 E+0 \\
1.00 E+0\end{array}$ & $\begin{array}{l}1.00 E+0 \\
1.00 E+0 \\
1.00 E+0 \\
1.00 E+0\end{array}$ & $\begin{array}{l}9.50 E-1 \\
9.90 E-1 \\
9.99 E-1 \\
1.00 E+0\end{array}$ & $\begin{array}{l}9.90 \mathrm{E}-1 \\
9.98 \mathrm{E}-1 \\
1.00 \mathrm{E}-0 \\
1.00 \mathrm{E}-0\end{array}$ \\
\hline
\end{tabular}


C.se 3

do(kp) Cumulative Probabilty

$\begin{array}{rr}3.36 & 0.00 \mathrm{E}-0 \\ 5.37 & 8.72 \mathrm{E}-4 \\ 8.05 & 1.01 \mathrm{E}-2 \\ 10.74 & 4.65 \mathrm{E}-2 \\ 12.75 & 1.03 \mathrm{E}-1 \\ 15.43 & 2.22 \mathrm{E}-1 \\ 18.79 & 4.18 \mathrm{E}-1 \\ 20.13 & 5.01 \mathrm{E}-1 \\ 22.14 & 6.19 \mathrm{E}-1 \\ 26.17 & 8.07 \mathrm{E}-1 \\ 29.53 & 9.05 \mathrm{E}-1 \\ 32.21 & 9.51 \mathrm{E}-1 \\ 38.25 & 9.92 \mathrm{E}-1 \\ 44.29 & 9.99 \mathrm{E}-1 \\ 51.00 & 1.00 \mathrm{E}+0\end{array}$

Sources of Uncertainty

The major source of uncertainty was the wide envelope of initial conditions. A secondary source of uncertalnty was the effect of flow patterns in the bullding and where hydrogen might build up.

Correlations with other Variables

No correlations were speclfted by the Expert for this issue.

Supgested Mechods for Reducing Uncertainty

No suggestions vere thade for reducing uncertainty. 


\title{
5.4 Contalmment Loads_Isaue 4, Grand Gulf Gontaliment Lads at Vessel Brench
}

\author{
Sunmery of Istur 4 \\ Grand Gulf conteinment Loads at Vacal Breach
}

Experts consulted: Loufs Baker, Argonne Narional Lobotatary: Ken Bergeron, Sandia National Laboratortes; Ted Ginsberg. Brookhaven National Laboratory.

\section{Issue Description}

Considering the phenomena associated with vessel breach at Grand Gulf, what distributions characterlze the uncertainty in the loads on containnent structures? Three structures within the contalnment were considered:

1. The drywell;

2. The contalnment shell (assuning fallure of that drywell or other mechanisas of supptession pool bypass); and

3. The RPV pedestal.

The peak quasi-stacic pressure experlenced by each stracture was to be quantified. For the drywell vall and tic RPV pedestal, Impulse resulting from explostve events (1.e., steam explostons) was also to be quantified.

Three cases were to be considered:

1. The RPV is at high pressure (6.9 to $7.6 \mathrm{MPa}$ ) before aeltehrough of the botton head. At least $230 \mathrm{a}^{3}$ of water has accumulated on the drywell floor (a depth greater than 2 . In the pedestal) as a result of water overflow frod the suppression pool

2. The RPV is at low pressure (300 to $600 \mathrm{kPa})$ before welcthrough of the botcom head. At least $230 \mathrm{a}^{3}$ of water has accurulated on the drywell floor.

3. The R.PV $1 \mathrm{~s}$ at high pressure (6 9 to $7.6 \mathrm{MPa}$ ) before meltthrough of the botton head. The only vater on the drwell floor is the 2 to $5 \mathrm{~m}^{3}$ in the sumps at the botcom of the pedestal.

The panel decided to conslder the following vartacions on these bastc cases:

a. Zfrcontun oxtdations: h1gh (328) and low (108)

b. Inttial RPV hole size: large $\left(2 \mathrm{~m}^{2}\right)$ and small $\left(0.1 \mathrm{~m}^{2}\right)$

c. Melt fraction ejected: high (50) and small (25).

Ocher cases are posstble for this issue (e.g... low-pressure RPV and no water on the drywell floor). The three cases above were selected by the illatysts because they were assessict to have the preatest possibility of

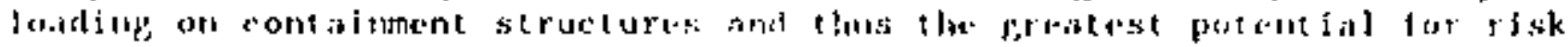
significance. 


\section{Sumpary of Experts.'Rationale/Methodelogy}

\section{EXFERTA.}

\section{Stacks Pressurization of the Drwell}

Expert A based his assessuent of the static pressure differential across the drywell for Cases 1 and 3 on the results of CONTAIN calsulations rhis are published in NUREG/CR-45S1, Volume 2, Part 5 . He believed tha' the CoNTaIN results represent estimates of the maxinun possible pressure rise in the drywell for each set of initial and boundary conditions. The Expert $f e] t$ that the reduction in the water level of the suppression pool (which was not considered by CONTh(N) would yleld a shorter period for drywell pressurizetion (due to earlier clearing of the drywell vents) and ultimately would result in a lower peak pressure.

Expert $A$ felt that the pesk pressure in the drywell was proportional to the square root of the fraction of the core material that is ejected but was insensitive to the necallic content of the ejected debris (in the 100 to son in-vessel zirconiun oxidation range). Peak pressure was also found to depend on the size of the hale in the vesgel bottom through which blowdown occurred

For the case where the RPV is at low pressure and there is water in the drvwell, the Expert felt that fuel-coolant interaction (steam explosion) wis the only mechaniso for drywell pressurization. He felt that a significant explosion is prevented by the quenching of debris in a scratified configuration coused by structures below the RPV. This fitessurization of the drywell would scale sccording to the ratio of the peiestal volune to the dryvell volune.

Expert A felt that for all three cases, fupulsive loading on either the dribilf of the pedestal would be negligible.

\section{Seit is Pressurization of the Containment}

Fipeli A toduated the peak pressurization of the contaliunent by consi. as 1 ug fuur combinations of boundary conditlons based on two paralletits aristing toin the in-vessel accident progression. The purameters were: the - Sellt ut in-vessel zirconium oxldation and the fraction of the core debris rjorted It was felt that the principal mechanisa for the pressurization uf the cuntalonent was the combustion of the hydrogen produced by oxidacion int the unoxidized portion of the ejected aetal. A 25 mislmun oxidation of the unteacted $z$ !rcontun (attributed to contalN resulcs) was considorod, burn completeness was assigned tor each combination of in.vessel 2 trconiur: cxidized based on the Expert's kiowledge of hydrogen combustion. Expert $A$ stated that the peak pressure would be reduced if contalunent sprays vere: optrating but did not quantify the extent of the reduction. He telt that the uncitalnties in direct conteinment heating, stean explosions, and any

her phenomena are covered by the greater uncertalnty in the quantity of t. ir rogen produced. 


\section{Stathe Pressurdzation of the Pedestal}

Expert A used the results of the CONTAIN calculations in assessing the pressurization of the pedestal for cases 1 and 3 . The pedestal pressure was considered to be determined mainly by two parameters, the rate of melt ejection and vessel blowdown, which are senstitive primarily to the size of the vessel breach. The peak pedestal pressures scale lineatly with the fraction of the core affected and are independenc of the quantity of unoxidized zirconiur in the debris. The CONTAIN resitls identifled Case 3 as having a lower peak pressure than case 1 , because the lack of wacer reduces the avajlability of stean for zirconium oxidation. The Expert viewed this as a rate-limited process with greacer fractions of the core ejected and larger vessel breach sizes leading co higher rates. It was deturmined that adequate supplies of zirconiun and scean for reaction were aval lable for all ctrcunstances considered.

For Case 2, molten core-coolant interaction (MCCI) was seen as the only source of high pressure. The Expert belisved that a stratified interaction following the injection phase was possible. This inceraction would be incependent of the size of the vessel breach. The utcertainty in the peak pedestal pressure due ta variations in the debris" airconium content was considered small compared with the uncertalnty in the yield of the debris. coolant inceraction. The maximura steam explosion was considered to be 1 s efficient with the carkpresstots of the gas in tlie pedestal taken as 1 ing isentroplc. Berman's method in computing stean explosion efficiencie tias inverted to obtain che ertent of debris particlpacion. The assumed etfleiency was varied up to clie assuned maximum to represent uncertaincy in peak pressure

\section{EXPERT_B}

Expert B relied on lis knowledge of cottiniment foading phenomena coupled with relevant references to arrive at his distributlans. Fur calculations, he used a CONTAIN study of the Grand Culf containment response ro higli pressure reactor faliures. He felc that the dombant sources of uluertaincy were: (a) the lack of analyses of the events, (b) the lack of understanding of the comblined HPME/FCI scenatios, and (c) for the peak contajnone pressure the artificiality of the requirement not to consider the conbuston of pre-existing lydrogen (t.e., hydrogen releated to the containgenc before vessel breach) in the contalnaent at vessel breach.

\section{Scasic Pressurization of the Dryatl}

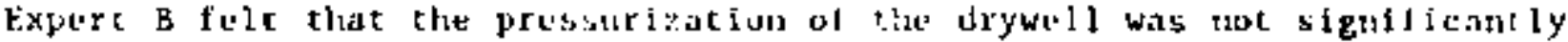
. 1 f ected by the anuunt of zircoulium oxidation or the lotal antrust of cole debris. The inportant paranetar (the otsly one the Export consideresl) was the RPV hole size.

The Expert described Case 1 as a higle pressure iadt injection (Lime) whlch weild result in drywell pressurization. He folt chat the suppresslun pool vertits would clear relatively early and that lydyogen burns were unl thely, The inedfarl value in lifs distribution wils caketa as the pressuro $r$ ise 
assoclated with the design basis accident (DBA). The low end of the range reflects the Expert's feeling that the precursor stean release would open the vents before a large amount of the core had been efected, lowering the peak drywell pressure. For large RPV holes, the high end of the range accounts for the possibility of rapid source terms where the vents do not clear rapidly enough to reduce the drywell pressure. With small RPV holes, the source rate 111 be lower and it was felt that the vents would cleat early enough to reduce the drywell pressure.

For Case 2, the Expert determined the doninant issue to be fuel coolant interaction. However, he felt that the debris/stean flow would becone choked in the pedestal and the suppression pool vents would open before the drywell pressures becane too high. Thus, he concluded that Case 3 could not be worse than Case 1.

For Case 3, the Expert relied on results fron the CoNTAlN calculations and determined that the drywell pressures would be approximately 20 higher for this rase than for Case 1.

\section{Static Pressurizaction of the Contalinent}

For burns in the containment, Expert B considered only bydrogen released or generated at vessel breach. He also assumed that the containnent sprays were not working. For Case 1 , the only parameter of importance was the amount of core ejected. As the Experc folt that there would not be enough oxygen $1 \pi$ the containnent for burns after vessel breach, the median pressure value considers only the partial pressure of the noncondenstbles. The lou end of the pressure range accounts for the Expert's concern that the CONTAIN results, which were used to determine the median value, may have overestimated the pressure. The high end of the range reflects the Expert's belief that shallow coverage of the vents could yleld signiflcant suppression pool blowthrough.

For Case 2, the only significant paraneter considered was the level of zirconfum oxidation. Expert B felt that the only way to achieve a large pressure $z$ ise in the wetwell was to have large FCI in the pedestal. The Expert did belleve, however, that there will be some containment pressuriation due to non-condenstbles generated by the FCI. This represents the median of the Case 2 pressure distribution. The upper end accounts for the possibility of large FCIs. This base case was for subcases with large zirconium oxidacion levels. For small anounts of zitcontum oxidation, the Expert wultiplied the base case by 1.8 .

For the high pressure Cases 1 and 3 , the Expert felt that the presence of $w-\ldots$ in the pedestal was not an 1mportant factor. Thus, the same distribution was used for both cases.

\section{Static Pressuctzotion of the Pedestal}

CONTAIN results vere used by Expert B as a starting point for Case I with

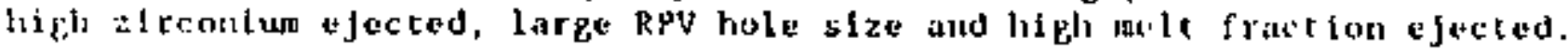

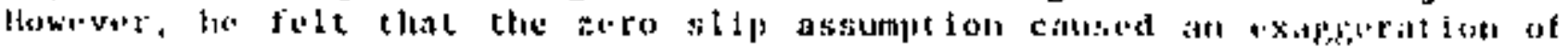

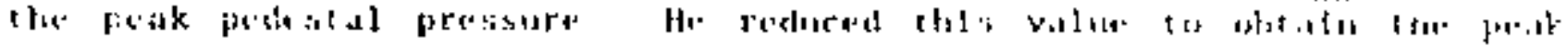


pedestal pressure. The low and of this discribution reflects the concern that a slower blowdown or mole slip could occur than was assuned in the contaIN study. The high end includes the RPV plus extra pressure due to direct containent heating (DCH). For subcases where there was a small anount of core debris ejected, the results were reduced by $20 \mathrm{~b}$. Where a suall RPV hole was considered, the results were reduced by $15 \mathrm{k}$.

No avatlable calculatlons were directly appllcable to Gase 2; however. the Expert felt that the pressures for this case would be less than those of Case 1. The distributions assoclated wth the subcases based on Case 2 were obtained by multiplying the appropriate distributi is Eron Case 1 by specific factors.

For Case 3 (dry cavity), the CoNTAIN study indicated that the peak pedestal pressures were approxinately 70 of the pedestal pressures associated with a wet cavity. Therefore, the Expert multiplied case l distributions to abtain the Case 3 distributions.

\section{Exaerc C.}

The Experc considered the various phenomenologies that could be present in this issue. The phenomenologles considered were: (l) "early" inelt-water and melt-acmosphere interactions; (2) melt jet breakup, wixing and fragmentation in the water; (3) steam generation before explosion: (4) difect containeent heating (DCH); and (S) hydrogen burns in the diywell. The major sources of uncertaincy identified by Expert B were: (1) the rate of vent uncovery: (2) the race of wixing. entrafupent, ecc.: (3) the rite of steam generation: and (4) the rate of hydrogen burn in the drywll

The general procedure used was to get a "best guess" scenario, an upper ald a lower bound scenario, use CONTAIN results to assess the teasonabletess of the scenarios, and use best judgment to fill in the other cases.

The base case was constructed assuring the total mass partictpating was of secondary importance and only the short-term phenonend dominated, that the percent zirconium was a secondary effect, and that the percent hydrogen released before vessel breach gave ap of 4 bars (best guess). The uppu: bound considered both short wixing times and larger percent mass particlpation. While the lower bound corisidered longer mixing cimes.

\section{Method of Aaprepition}

Three experts were elicited for this lssue. Experts $h$ alld $B$ sonsfingted loads to the dryoll scructure. iontalnment structure, afid the RPV pedestal structur and provided distribut lons for all clires cases. Expert $c$ ony considered loads to the drywell structure and vily provided distribut luts for cases 1 and 3 . It the expert did not provlde paraneter values at life 0.0 and 1.0 fractiles, these values were ubiuitted by iisear extrapolatia. of the two closest points (provided the value vitained was phystially

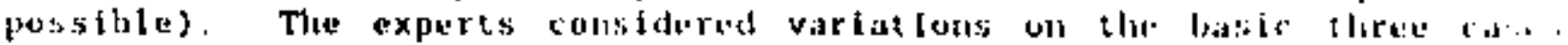

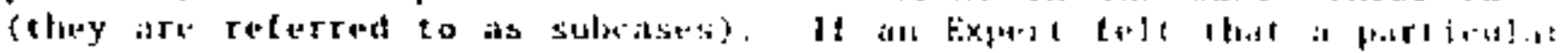

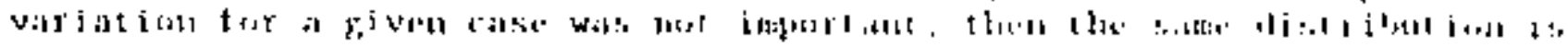


used for the subcases that arise from the variation. For a given subcase the experts' distributions were linearly averaged. If an expert did not provide distributions for a case then he was not considered for that case and only the distribution from the participating experts were aggregated.

The distributions provided by the experts for the various cases and subcases are listed in Tables 4-1 through 4-5 and are shown in Figures 4-1 through 4-B. In these tables and figures the various subcases are identifled using the following characters:

0: Large fraction of the zirconium was oxtdized;

0 : Swall fraction of the zirconiu vas oxidized;

H: Initial RPV hole size was large;

$h$ : Initial RPV hole size was small;

C: Large fraction of the melt is ejected;

c: Small fraction of the melt is ejected.

\section{Aggregated Results}

Table 4-2

Aggregate Drywell Pressurization ( $A p$, bar)

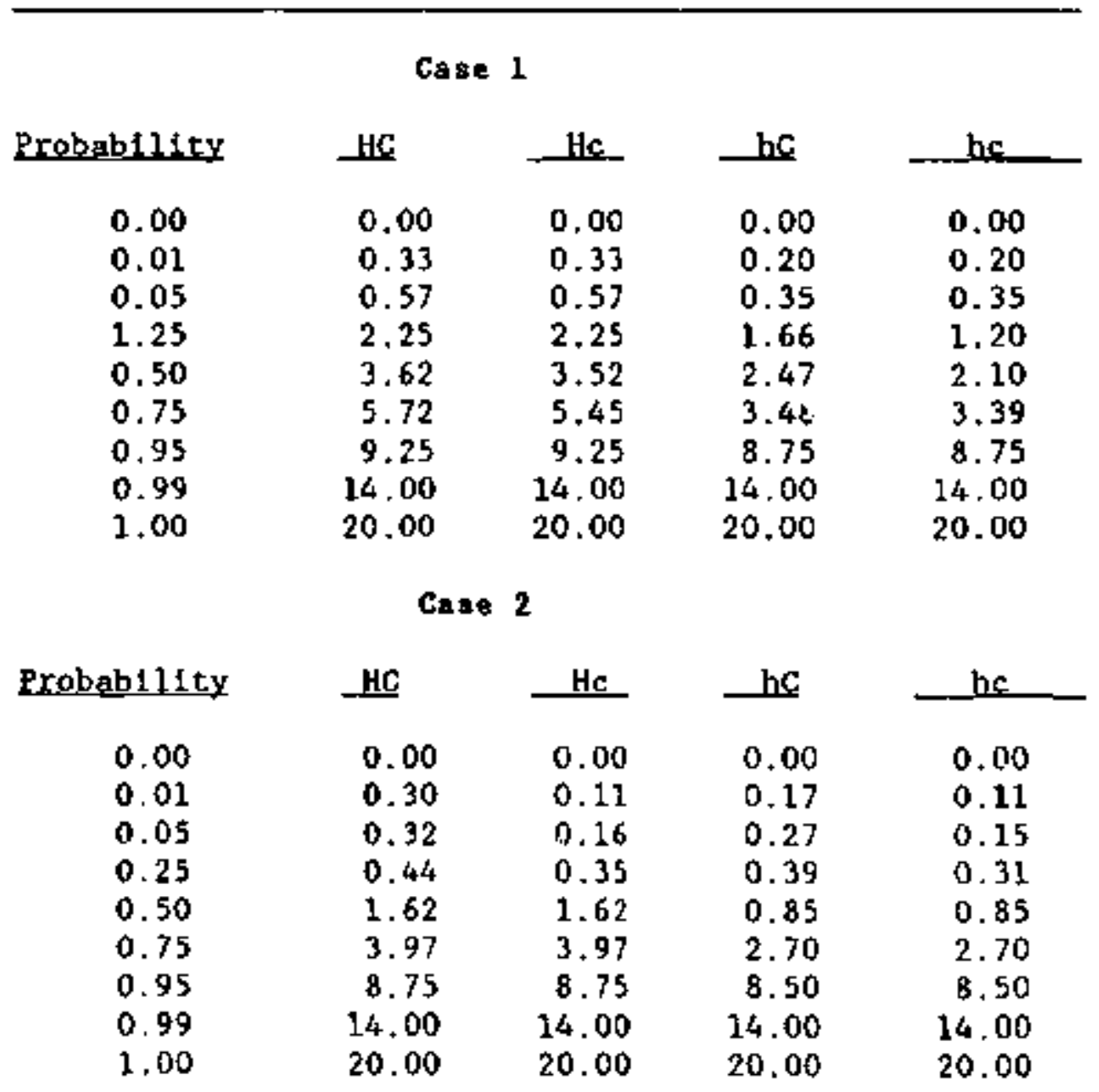


Case 3

\begin{tabular}{ccccc} 
Probability & HC & Hc & nC & he \\
\cline { 2 - 5 } \cline { 5 - 5 } 0.00 & & & & \\
0.01 & 0.33 & 0.33 & 0.20 & 0.20 \\
0.05 & 0.39 & 0.39 & 0.24 & 0.24 \\
0.25 & 0.60 & 0.60 & 0.36 & 0.36 \\
0.50 & 2.07 & 1.80 & 1.30 & 1.30 \\
0.75 & 3.49 & 3.13 & 2.50 & 2.27 \\
0.95 & 5.60 & 4.53 & 3.43 & 3.04 \\
0.99 & 8.01 & 6.89 & 4.44 & 3.98 \\
1.00 & 9.10 & 8.19 & 4.97 & 4.91 \\
& 9.50 & 8.85 & 5.31 & 5.31 \\
\hline
\end{tabular}

Table $4-2$

Aggregate Containment Pressurization ( $\Delta$ p, bar)

Cases 1 and 3

\begin{tabular}{|c|c|c|c|c|}
\hline Brobability & $\mathrm{OC}$ & $O c$ & $O C$ & or \\
\hline 0.00 & 0.9 & 0.7 & 0.9 & 0.7 \\
\hline 0.01 & 1.1 & 0.8 & 1.1 & 0.9 \\
\hline 0.05 & 1.8 & 1.1 & 1.8 & 1.2 \\
\hline 0.25 & 2.9 & 2.2 & 3.9 & 2.3 \\
\hline 0.5 & 4.4 & 3.9 & 5.7 & 4.1 \\
\hline 0.75 & 6.9 & 6.4 & 7.5 & 6.5 \\
\hline 0.95 & 11.2 & 9.0 & 11.2 & 9.0 \\
\hline 0.99 & 13.5 & 10.8 & 13.5 & 10.8 \\
\hline 1.00 & 14.5 & 11.6 & 14.5 & 11.6 \\
\hline
\end{tabular}

Case 3

\begin{tabular}{ccccc} 
Probablity & 아 & Oh & of & oh \\
\cline { 2 - 5 } \cline { 4 - 5 } 0.00 & & & & \\
0.01 & 0.00 & 0.00 & 0.00 & 0.00 \\
0.05 & 0.00 & 0.00 & 0.00 & 0.00 \\
0.25 & 0.00 & 0.00 & 0.00 & 0.00 \\
0.50 & 0.00 & 0.00 & 0.00 & 0.00 \\
0.75 & 0.08 & 0.08 & 0.14 & 0.14 \\
0.95 & 0.70 & 0.70 & 1.26 & 1.26 \\
0.99 & 4.35 & 4.35 & 7.83 & 7.83 \\
1.00 & 6.90 & 6.90 & 12.42 & 12.42 \\
& 8.10 & 8.10 & 14.58 & 14.58
\end{tabular}


Table $4-4$

Aggregate Pedestal Pressurization ( $\Delta \mathrm{p}$, bars)

\begin{tabular}{|c|c|c|c|c|c|c|c|c|}
\hline \multirow[b]{2}{*}{ Prqublikty } & \multirow[b]{2}{*}{ OAfC } & \multirow[b]{2}{*}{ Ofite } & \multicolumn{2}{|c|}{ Caso 2} & \multirow[b]{2}{*}{ ofic } & \multirow[b]{2}{*}{ 一斯 } & \multirow[b]{2}{*}{ onst } & \multirow[b]{2}{*}{ phe } \\
\hline & & & Onc & Olase & & & & \\
\hline 0.00 & 2.00 & 1.00 & 1.38 & 1.00 & 2.00 & 1.00 & 0,69 & 0.69 \\
\hline 0.01 & 2.16 & 1,12 & 1.63 & 1.12 & 2,16 & 1.12 & 0.81 & D. 81 \\
\hline 0.05 & 2.79 & 1.60 & 2.10 & 2.53 & 2.70 & 1.53 & 2,06 & 1.05 \\
\hline b.25 & 4.62 & 3.16 & 3.40 & 2.50 & 4.82 & 2.50 & 2.43 & 1. 80 \\
\hline 0.50 & 7.02 & 6.06 & 5.85 & 4.60 & 7.92 & 4.60 & 4.47 & 3.50 \\
\hline 0.75 & 14.00 & 12.55 & 0.00 & 7.75 & 24,00 & 7.75 & 7.37 & 5,80 \\
\hline 0.95 & 29.00 & 28.00 & 16.01 & 16.91 & 20.00 & 14.01 & 12.00 & 9.54 \\
\hline 0.99 & 30.00 & 30,00 & 21.60 & 10.00 & 30.00 & 19.00 & 21.60 & 24,40 \\
\hline 1,00 & 12.00 & 42.00 & 24.00 & 21.00 & 42.00 & 21,00 & 26.00 & 16.00 \\
\hline
\end{tabular}

Table 4-5

Aggregate Pedestal Pressurization (Ap, bar)

\begin{tabular}{|c|c|c|c|c|}
\hline \multicolumn{5}{|c|}{ Case 1} \\
\hline Probabtldty & $\mathrm{HC}$ & $\mathrm{He}$ & $h c$ & he \\
\hline $\begin{array}{l}0.00 \\
0.01 \\
0.05 \\
0.25 \\
0.5 \\
0.75 \\
0.95 \\
0.99 \\
1.00\end{array}$ & $\begin{array}{r}5.5 \\
6.5 \\
9.8 \\
24.0 \\
36.4 \\
46.7 \\
60.7 \\
76.3 \\
83.8\end{array}$ & $\begin{array}{r}4.4 \\
5.2 \\
7.8 \\
21.8 \\
33.4 \\
44.1 \\
54.3 \\
61.0 \\
67.0\end{array}$ & $\begin{array}{r}4.7 \\
5.5 \\
8.3 \\
18.0 \\
25.2 \\
36.8 \\
51.6 \\
64.8 \\
71.2\end{array}$ & $\begin{array}{r}3.7 \\
4.4 \\
6.6 \\
13.4 \\
20.2 \\
28.4 \\
41.3 \\
51.9 \\
57.0\end{array}$ \\
\hline \multicolumn{5}{|c|}{$\mathrm{C}_{4} \mathrm{H} \cdot 3$} \\
\hline $\begin{array}{l}0.00 \\
0.01 \\
0.05 \\
0.25 \\
0.50 \\
0.75 \\
0.95 \\
0.99 \\
1.00\end{array}$ & $\begin{array}{r}3.8 \\
4.5 \\
6.8 \\
20.5 \\
31.6 \\
42.5 \\
52.4 \\
58.2 \\
60.0\end{array}$ & $\begin{array}{r}3.1 \\
3.6 \\
5.5 \\
16.8 \\
28.6 \\
40.7 \\
50.0 \\
58.0 \\
60.0\end{array}$ & $\begin{array}{r}0.0 \\
0.6 \\
3.0 \\
8.3 \\
16.2 \\
23.9 \\
36.2 \\
45.4 \\
49.8\end{array}$ & $\begin{array}{r}2.6 \\
3.1 \\
4.6 \\
8.1 \\
12.9 \\
19.2 \\
28.9 \\
36.3 \\
39.9\end{array}$ \\
\hline
\end{tabular}


$\mathrm{HC}$

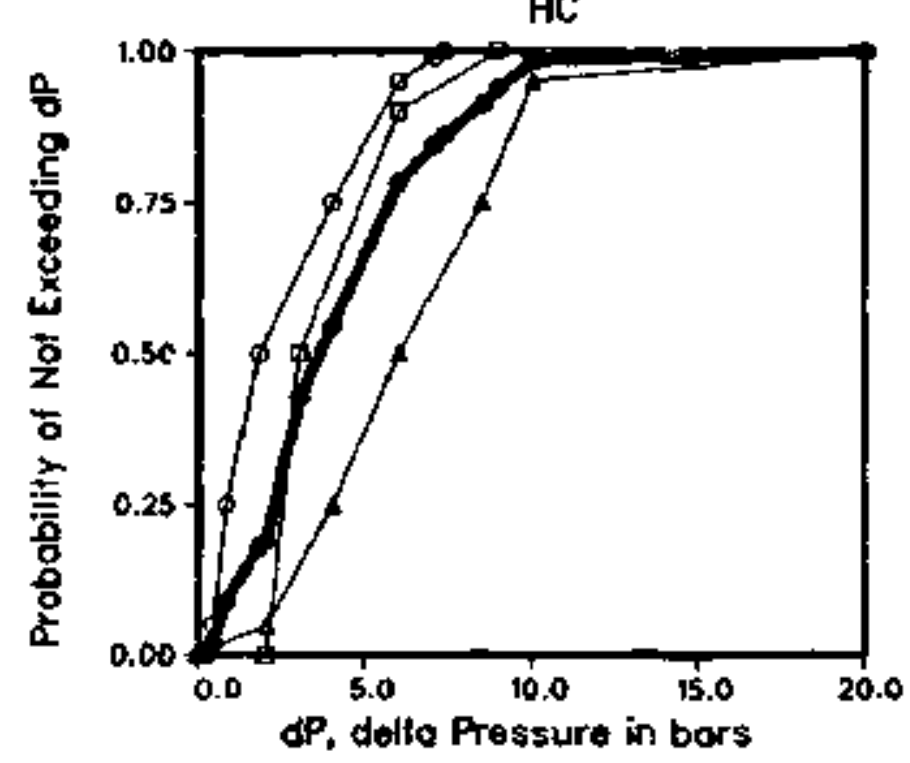

$\mathrm{hC}$

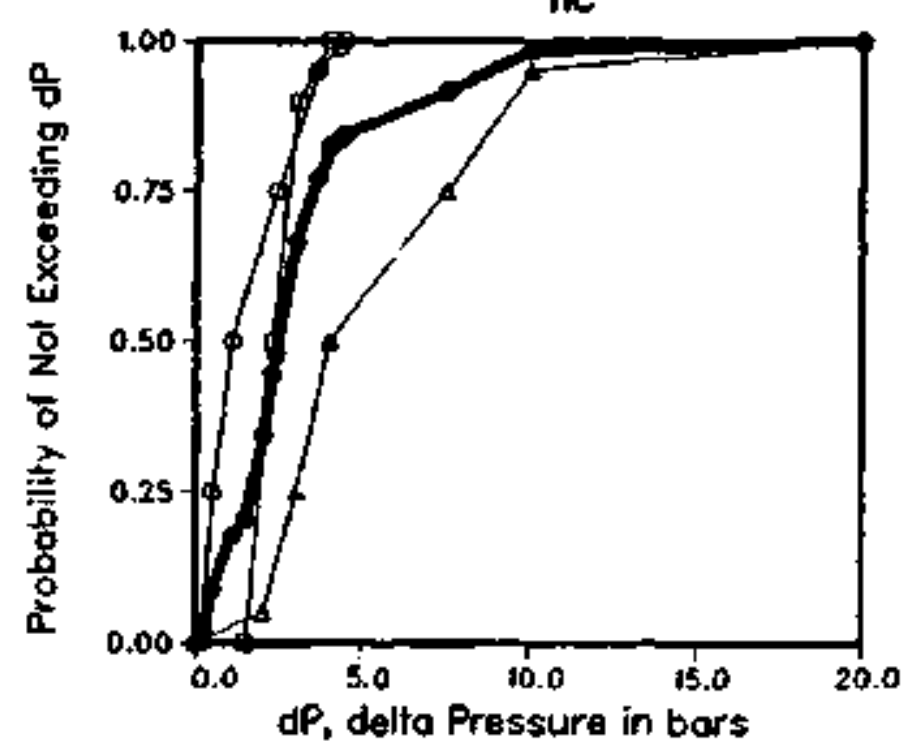

Hc

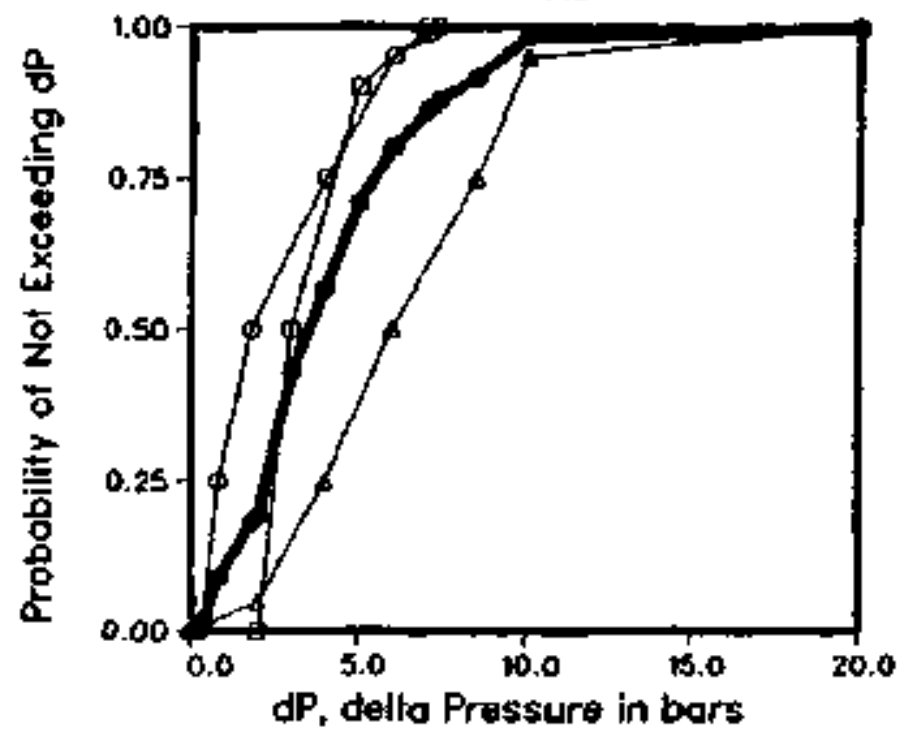

he

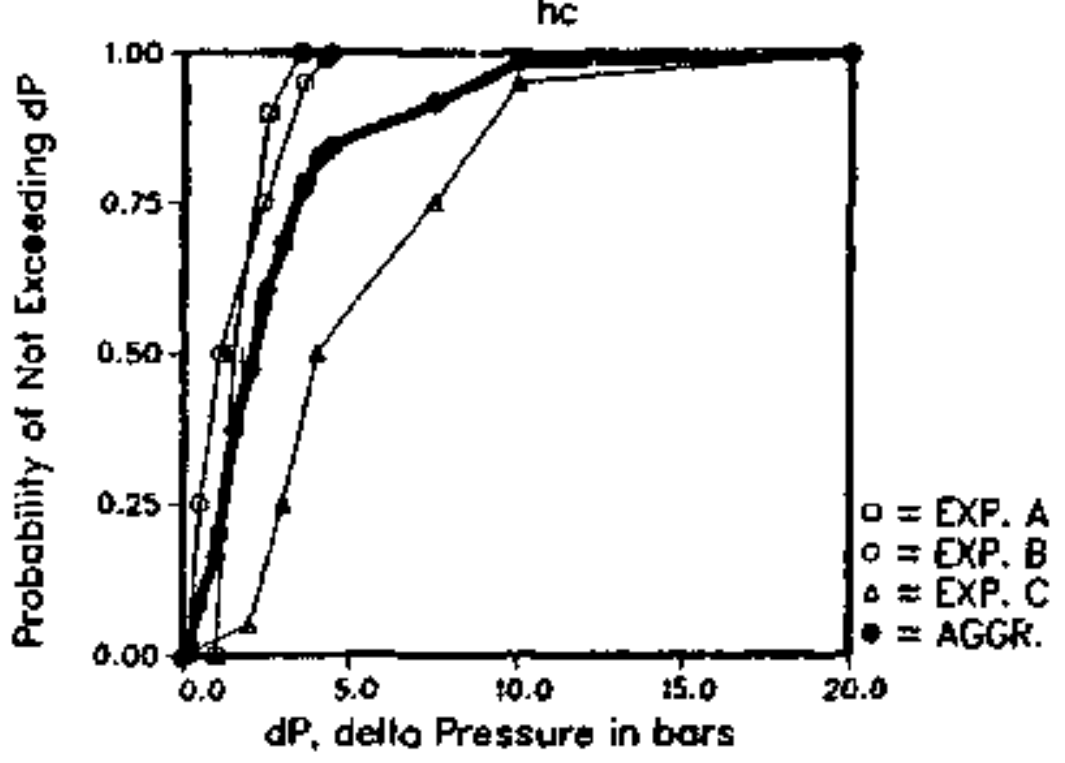

Figure 4-1. Case 1 Grand Gulf Peak Drywell/Wetwell Differential

Pressure at Vessel Breach, High RPV Pressure With Wat Cavicy. 

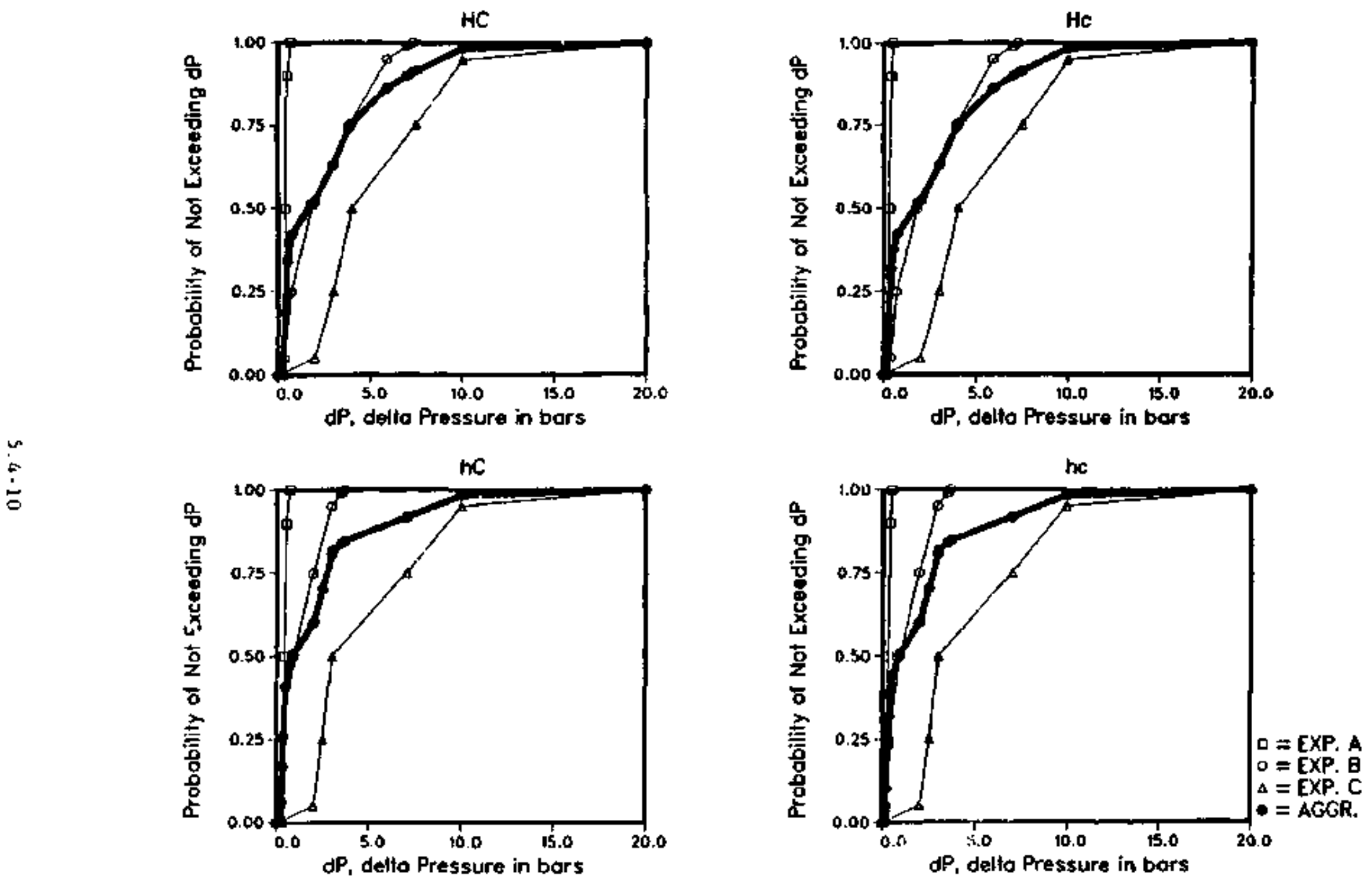

Figure 4-2. Case 2 Grand Gulf Peak Dryweli/Wetwell Differential

Pressure at Vessel Breach. Low RPV Pressure With Wet Gavity. 

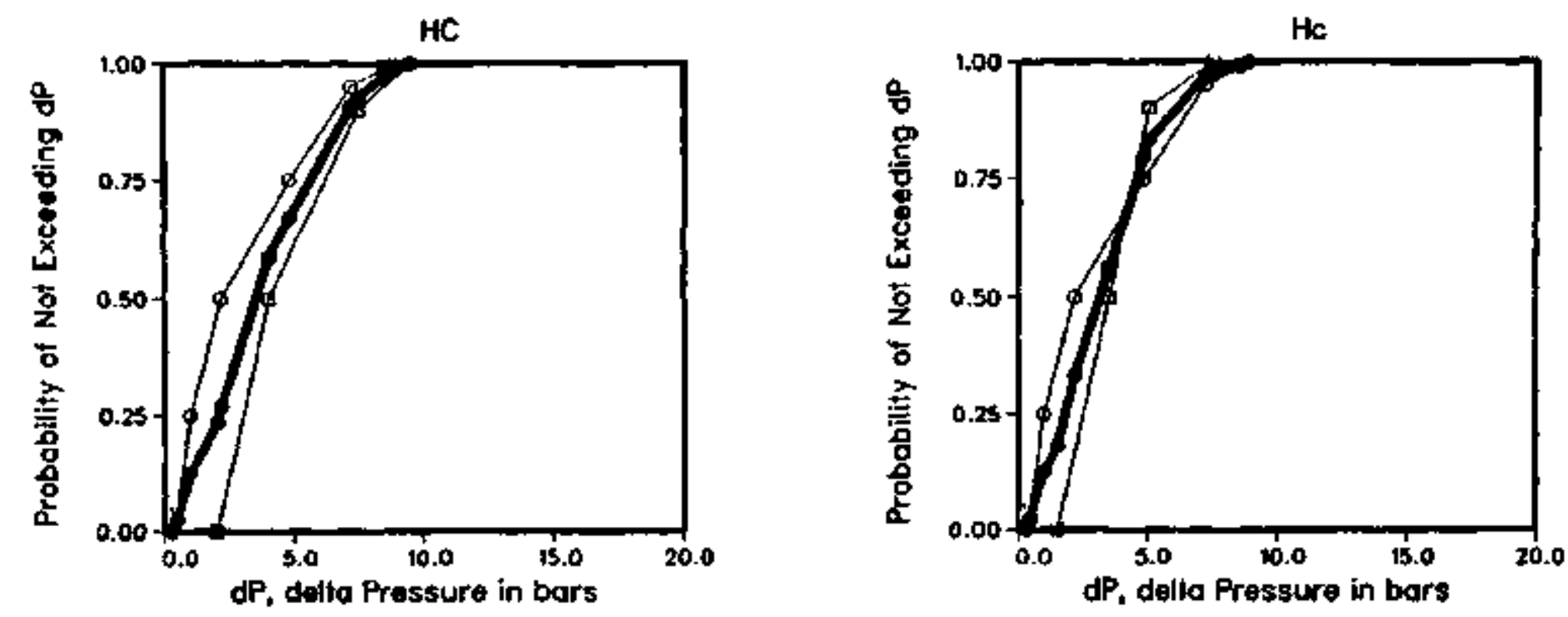

$\stackrel{n}{5}$
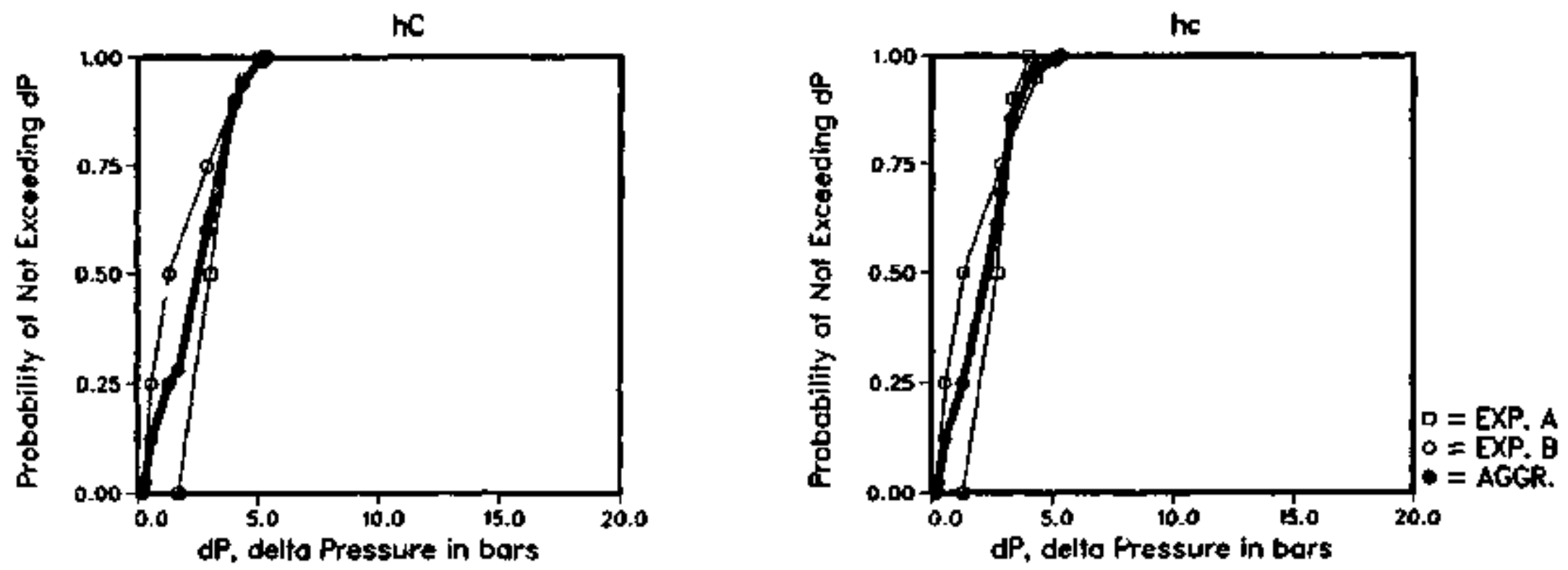

Figure 4-3. Case 3 Grand Gulf Peak Drywell/Wetwell Differential

Pressure ac Vessel Breach. High RPV Pressure with Dry Gavity. 

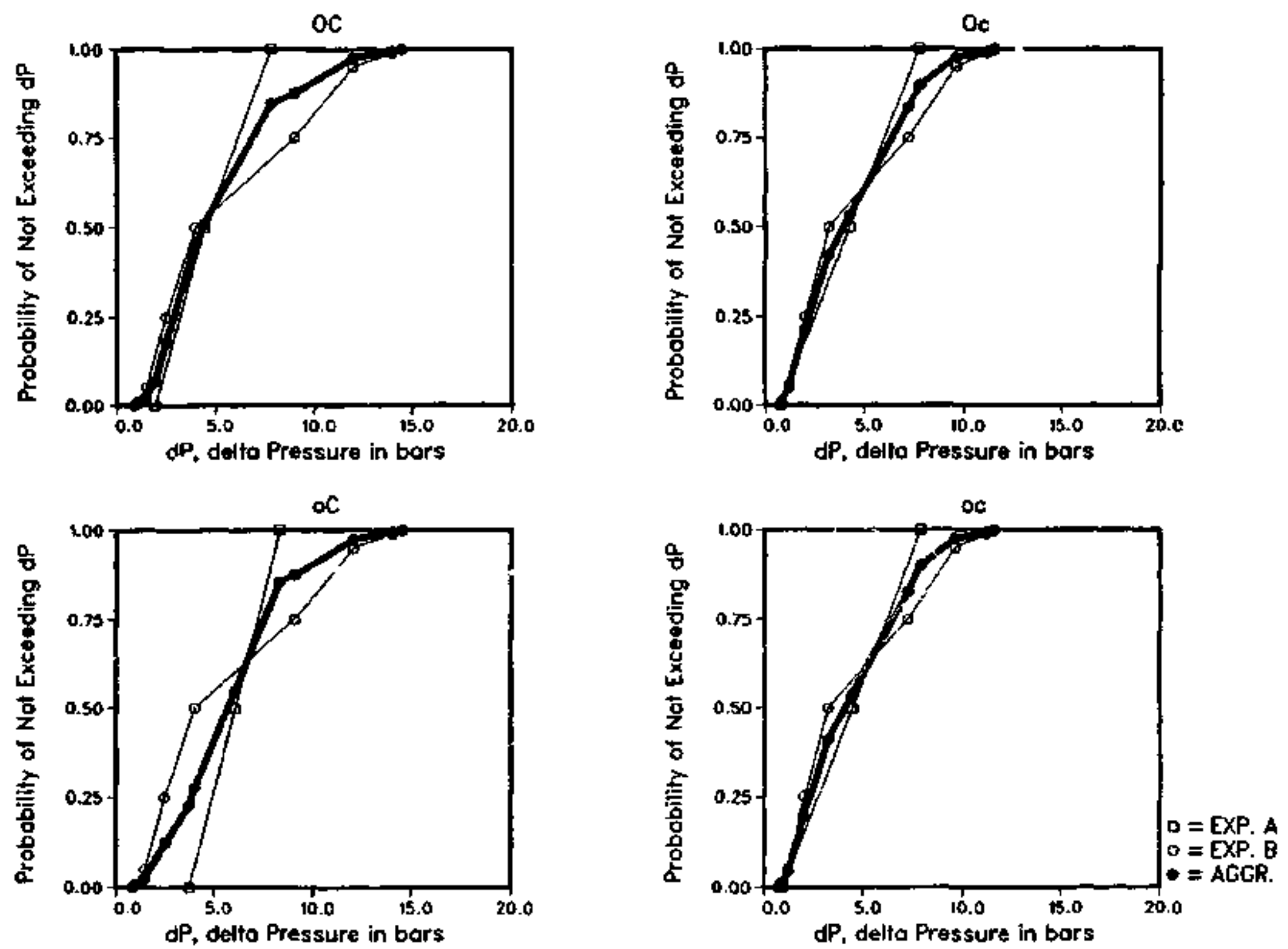

Figure 4-4. Gases 1 and 3 Grand Gulf Peak Containment

Ptessure at Vessel Breach. High RPV Pressure With Wet or Dry Cavity. 
$\mathrm{OH}$

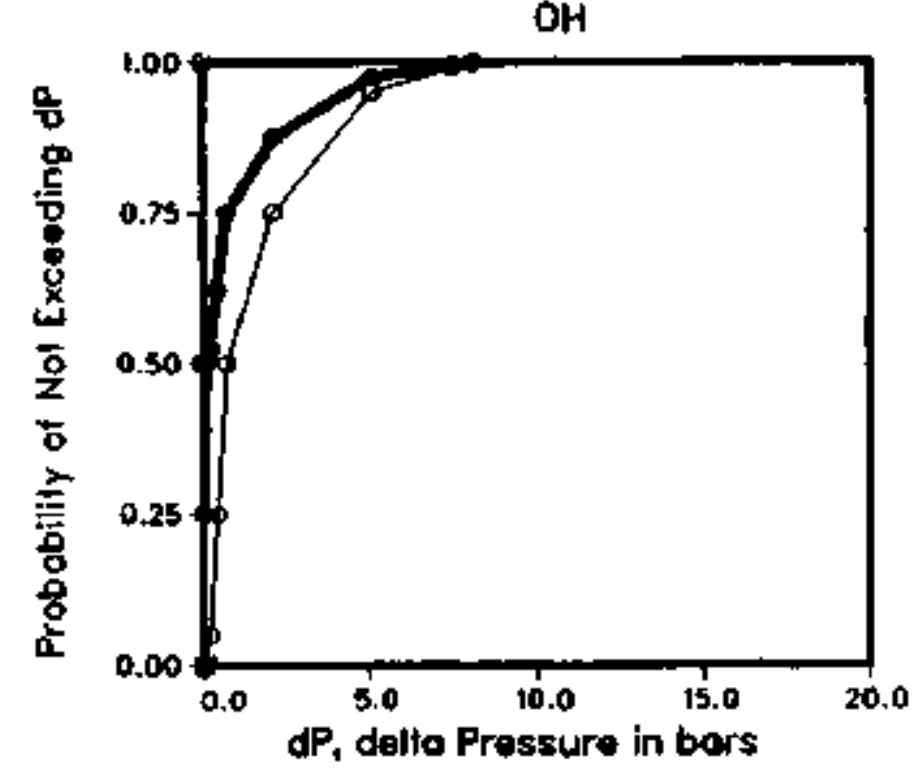

oH

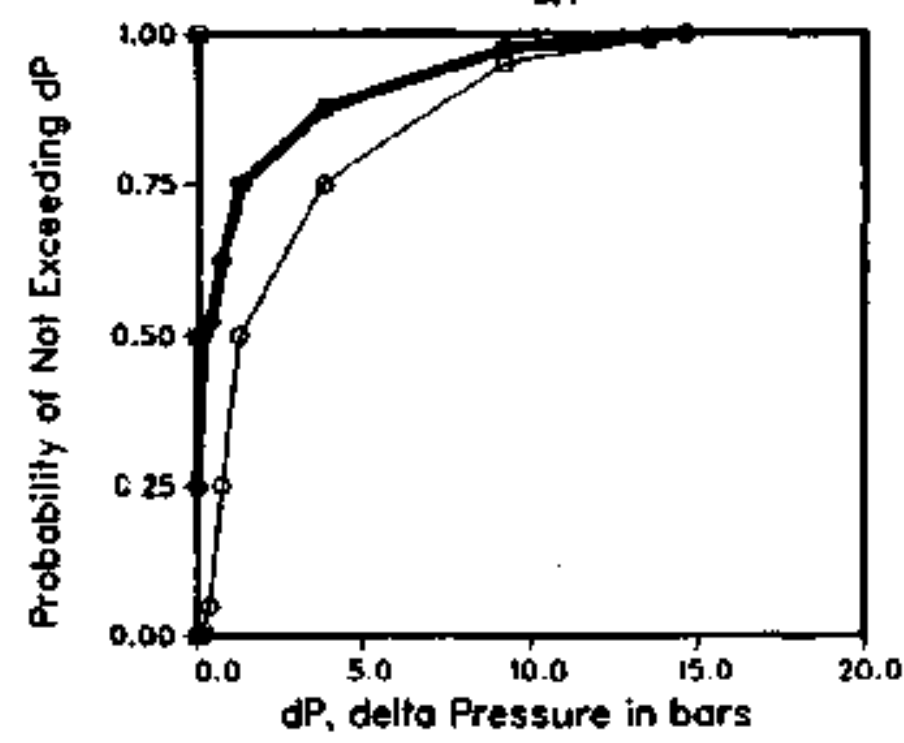

Oh

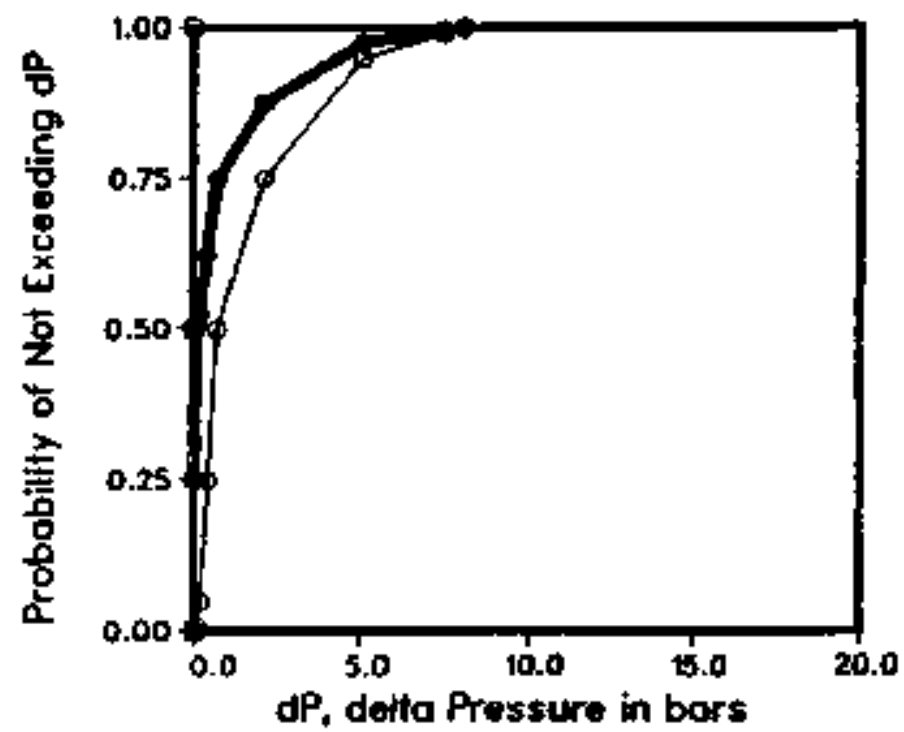

on

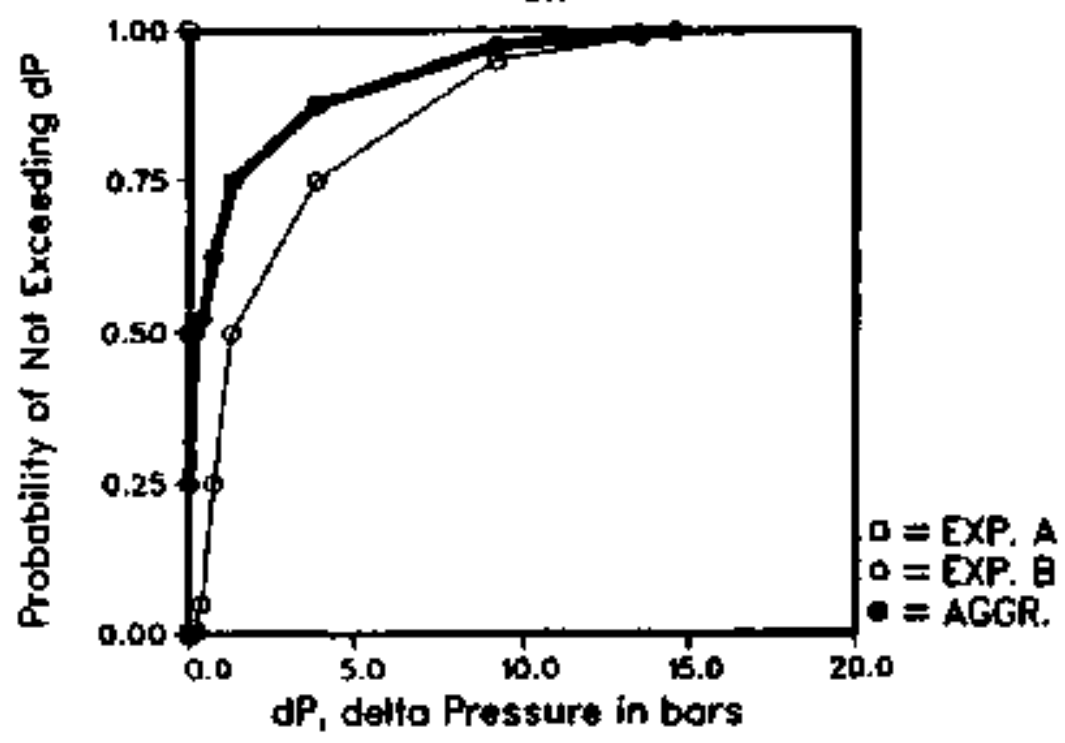

Figure 4-5. Case 2 Grand Gulf Peak Containment

Pressure at Vessel Breach. Low RPV Pressure With Wet Cavity. 
Probobility of Not Exceeding dP

Probobility of Not Excending dP

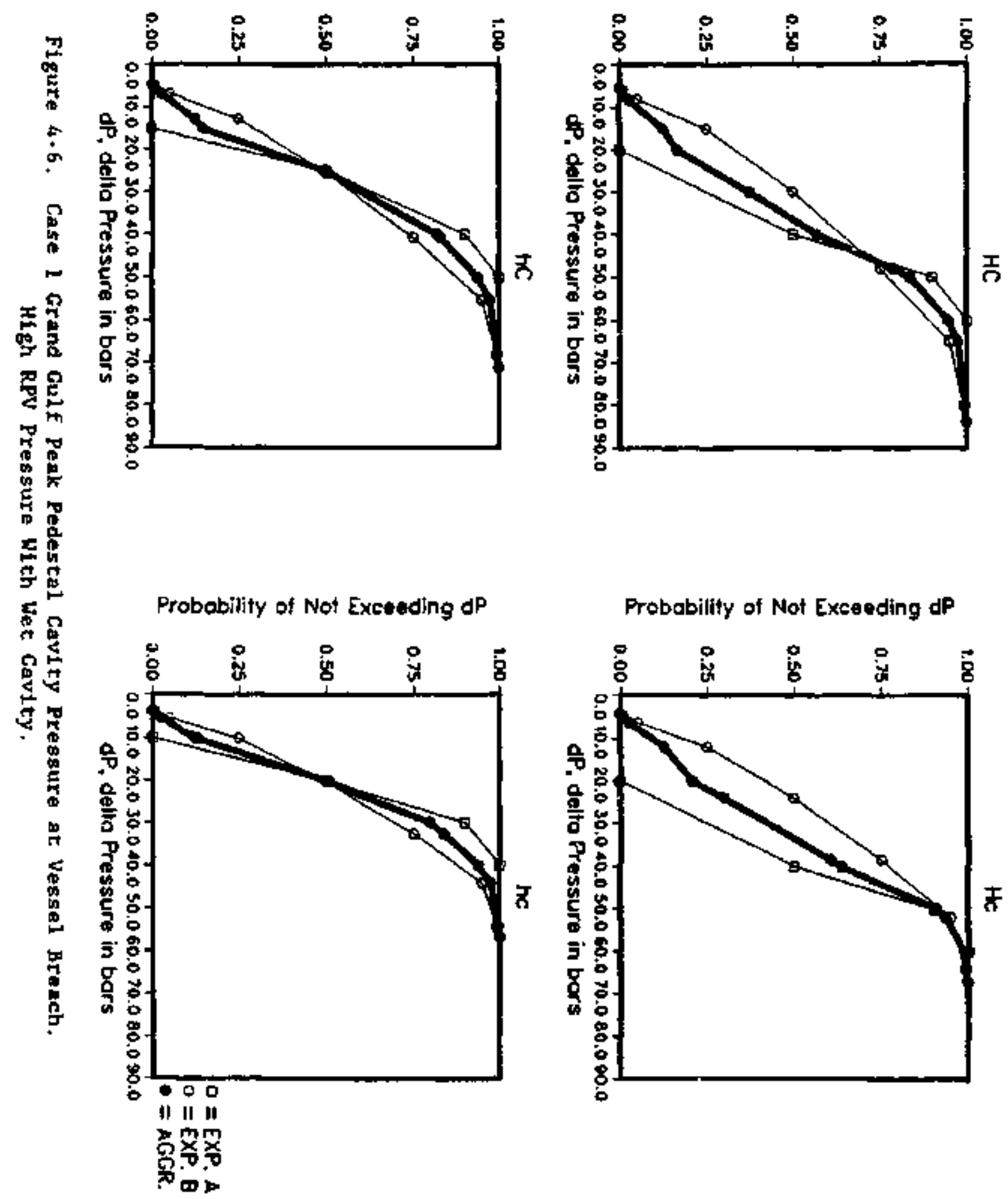



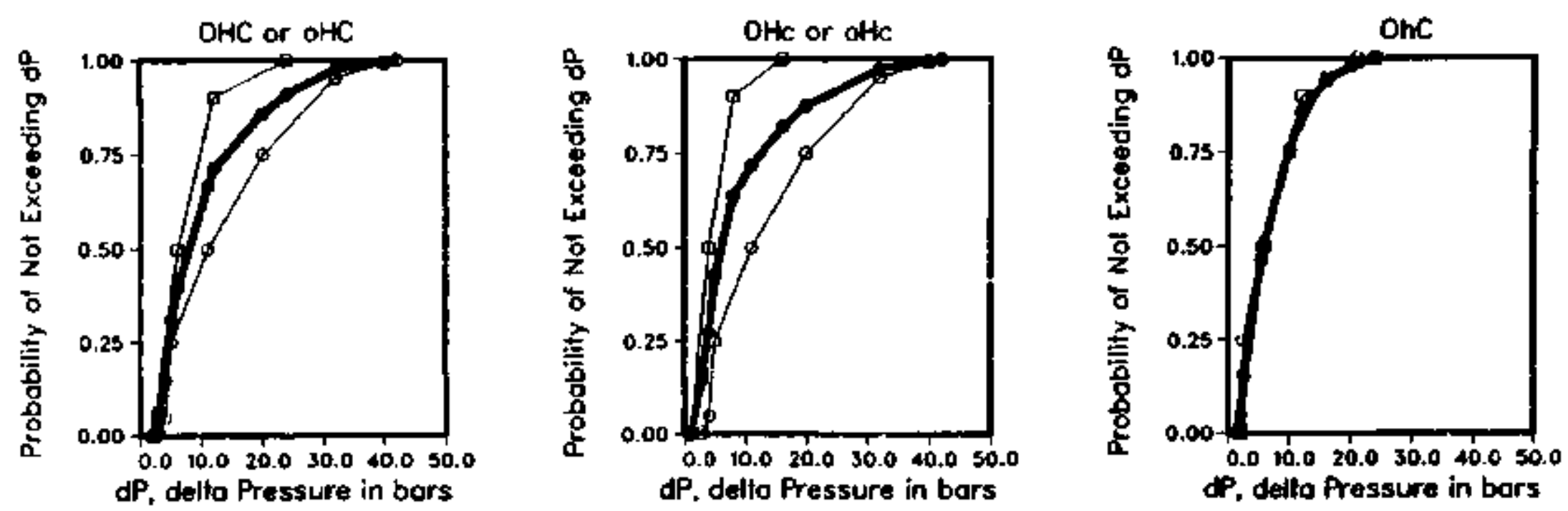

$\vdots$
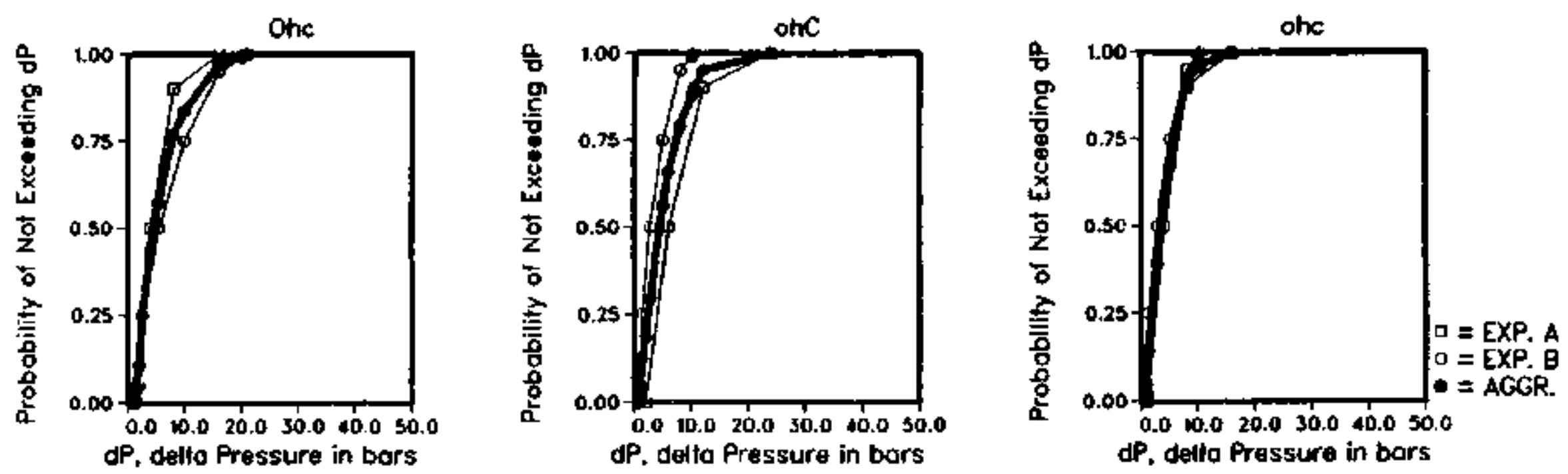

Figure 4-7. Case 2 Grand Gulf Peak Pedestal Cavity Pressure at Vessel Breach. Low RPV Pressure with Wet Cavity. 
Probobility of Not Excoeding ofP

Probability of Nol Excouding dP

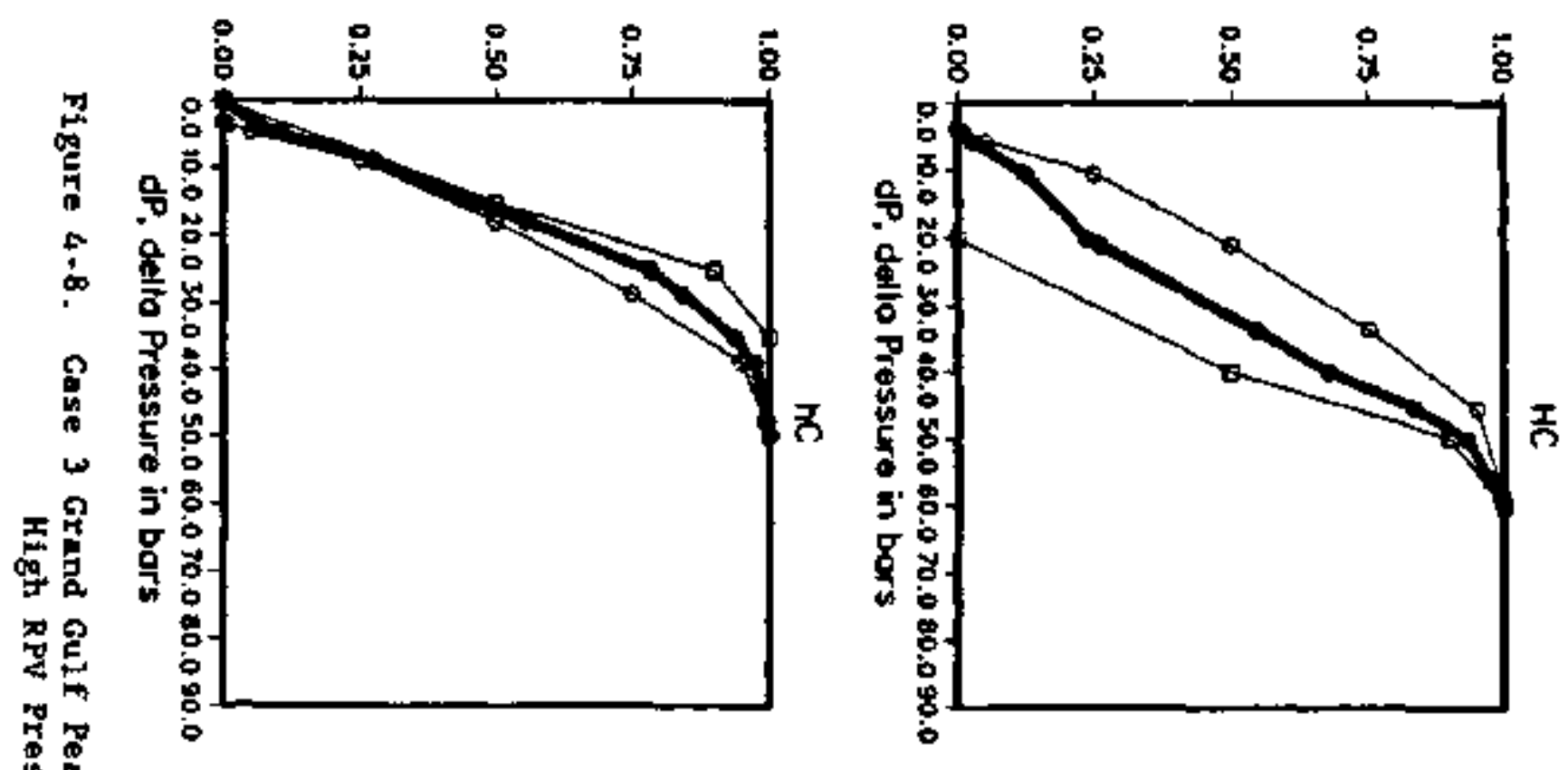

Probability of Not Exceeding dP

Probobility of Nol Exceeding of

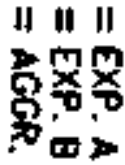


Individual Elfcltations for Issue 4 
Expert A's Ellaitation

\section{Issue 4. Grand Gulf Contalnment Loads at Vessel Breach}

Description of Expert A's Rationale/Methodology

\section{Static Pressurization of the Drrwell}

Expert A based his assessment of the statis pressure differential across the drywell wall for Cases 1 and $3^{*}$ on the results of ConTaIN calculations that were presented to the panel. However, he believed that the CONTAIN results provided estimates of the maximum possible pressure rise in the drywell for each set of initial and boundary conditions considered. This belief arose from the fact that reduction of the suppression pool level from nominal conditions, due to water overflow into the drywell, was not represented in the CONTAIN input. Expert A believed liat this reduction in water level would lead to earlier clearing of the drywell vents than was predicted by CoNTAIN. A shortel period for drywell pressurization between vessel breach and vent clearing would result in a lower peak pressure.

Expert A stated that the peak pressure in the drywell scales according to the square root of the fraction of the core material that is ejected. He felt that the peak pressure was insensitive to the metallic content of the ejected debris (within the range of 10 to 50 in-vessel 21 rconium oxidation). There would clways be sufficient metal present in the debris to react, over the period of interest, with the available steam. Peak pressure was found to depend on the size of the hole in the vessel botrom chrough which blowdown occurred. This is because peak pressure is a strong function of the rate at which drywell pressurization occurs.

For Case $2^{*}$ (low pressure RPV, water in the drywe11), fuel-coolant interaction is the only possible mechanism for drywell pressurization. Expert A referred to this Interaction ss a steam explosion but said that impulsive loadings were negligible. A significant (i.e., coherent) explosion is prevented by the dispersal of debris by structures below the RPV. Quench. ing of the debris in a stratified configuration would occur, with little oxidation of the unreacted zirconiun in the melt. Expert A stated that this situation would lead to drywell pressurization, that would scale according to the ratio of pedestal volume to drywell volume. Steanl is compressed in the pedestal by the debris-coolant interaction and then expands isentroplcaliy into the drywell. These results are thus related to the pedestal pressurization results by the pedestal-to-drywell volume ratio.

\section{Inpulse Loadings}

For all three cases, ir.pulstve loading on either the drywell or pedestal walls was believed to be negligible. As stated above, in the low-pressure case (Case 2) the dispersal of debrisflowing from the vessel by the

* Cases 2 and 3 have been reversud from what was presented 1 in the original elicitation wite-ap for this expert 
control rod drive (CRD) housings and CRD support steel ("shoot.out steel") would prevent a coherent interaction. For the high-pressure ejection with water in the pedestal case (Case 1), Expert a believed that the dispersal of the water by high-velocity gas flows would prevent an explosive inter. action between the welt and any water in the pedestal. No process that would create an explosive Interaction can be identified for Case 3.

\section{Static Pressurization of the Containnent}

Expert A evaluated the peak pressure in the containment for Cases 1 and $3^{*}$ considering four different comblnations of boundary conditions artsing from the in-vessel accident progression. The two parameters were the extent of In-vessel zirconiur oxidation and the fraction of the core debris that was ejected. Combustion of the hydrogen produced by oxidation of the unoxi. dized portion of the ejected zirconfum metal was cited as the principal mechanist for expected pressurization of the containnent. Oxidation of 25 of the unreacted zirconium and iron was the sinimum consilesed, 100s axidation was taken past the upper bound. The 25 minimun was attributed to CONTAIN code results. Expert A assigned a burn conpleteness for esch combination of in-vessel zircontum oxidation, fraction of the core ejected, and percentage of in-vessel zirconlum oxidized. Burn completeness was assigned based on the Expert's knowledge of hydrogen combustion. Figure A1 shows Expert A's decomposition of this problen. Expert A stated that the peak pressure would be reduced if containment sprays were operating but did not quantity the extent of the reduction.

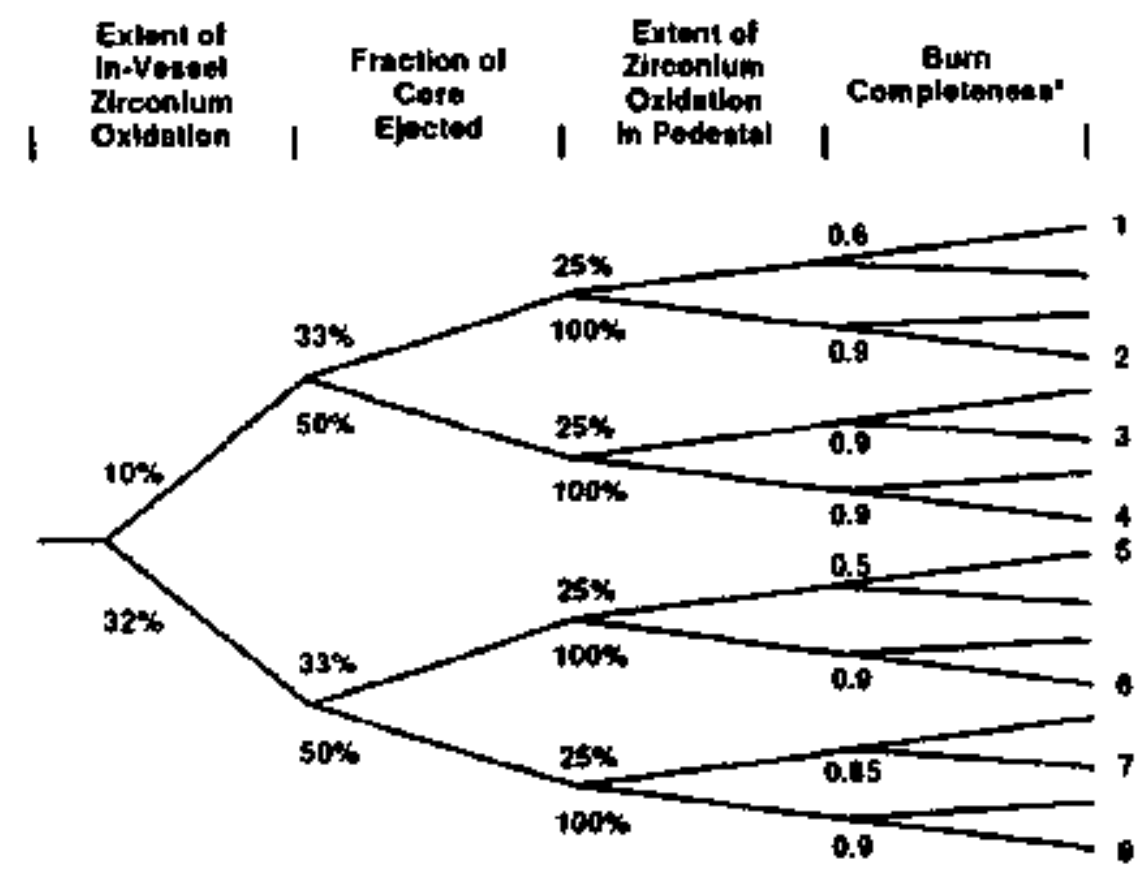

"Nol censadered uncerting In this alleltation.

Figure A.l. Contairuent Pressure Rise at Vessel Breach. 
It was stated that pressure rise due to hydrogen burn was the doninant cause of containment pressurization. Uncertalnties about direct contalnment heating, stean explosions, and any other phenomena are covered by the greater uncertainty in the quantity of hydrogen produced.

\section{Static Pressurization of the Pedestal}

Expert A based his assessment of the pressurization of the pedestal for Cases 1 and $3^{*}$ on the results of the CONTAIN calculations mentioned above. Pedestal pressure was seen to be determined principally by the rate of melt efection and vessel blowdown. These parameters are sensitive primarily to the size of the vessel breach (although the quantity of melt ejected is also dependent on the amount of debris that is nolten when vessel breach occurs). Peak pedestal pressure scales linearly with the fraction of the core ejected and is independent of the quantity of unoxidized zirconium in the debris. In a comparison of Cases 1 and $3^{\circ}$ Expert $A$ found Case $3^{*}$ had reduced peak pressures. This reduction was based on the CONTAIN results. Presusably the lack of water reduces the avallability of stean for zirconium oxidation. As for drywell pressurization, Expert A saw this as a rate-limited process, Greater fractions of the core efected and larger vessel breach sizes lead to higher rates. Adequate supplies of zirconium and stean for reaction vere assessed to be avallehle in all circumstances considered.

For Case 2," MCCI is the only source of high pressure. As discussed above. a major steam explosion was believed to be averted by the fragnentation and holdup of debris on the shoot-out steel. A stratified interaction following the injection phase was belleved to be possible. This interaction would be independent of the size of the vessel breach since the ejection phase would be largely over. Expert A atated that the uncertafnty in peak pedestal pressure caused by variations in the zirconium content of the debris is small in comparison with the uncertainty in the yield of the debris-coolant intersction. The naximun stean explosion was assumed by Expert $A$ to be 1 \% efficient (1... 18 of the debris' thermal energy was assuned to do compression work on the steam in the pedestal). Compression of gas in the pedestal was taken as being isentropic. The method of Berwan in cooputing steam explasion efficlencies was inverted to obtain the extent of debris particlpation. The thermal energy of the debris was considered to be $1.2 \mathrm{~mJ} / \mathrm{kg}$. The assumed efflclency was varied up to the assuned maximum to represent uncertainty in peak pressure.

\section{Besults of Expert $A^{\prime} s$ Ellcitation}

\section{Static Pressurization of the Drywell}

Case 1: High-pressure ejection, water in pedestal.

The Expert's results are presented in Table A-l. These distributions are shown graphicaliy in Figure $A-2$.

* Cases 2 and 3 have been reversed from what was presented in the ortginal elicltation wite-up for this expert. 
Table A-1

Drywell Pressure Rise for Case 1

(bar)

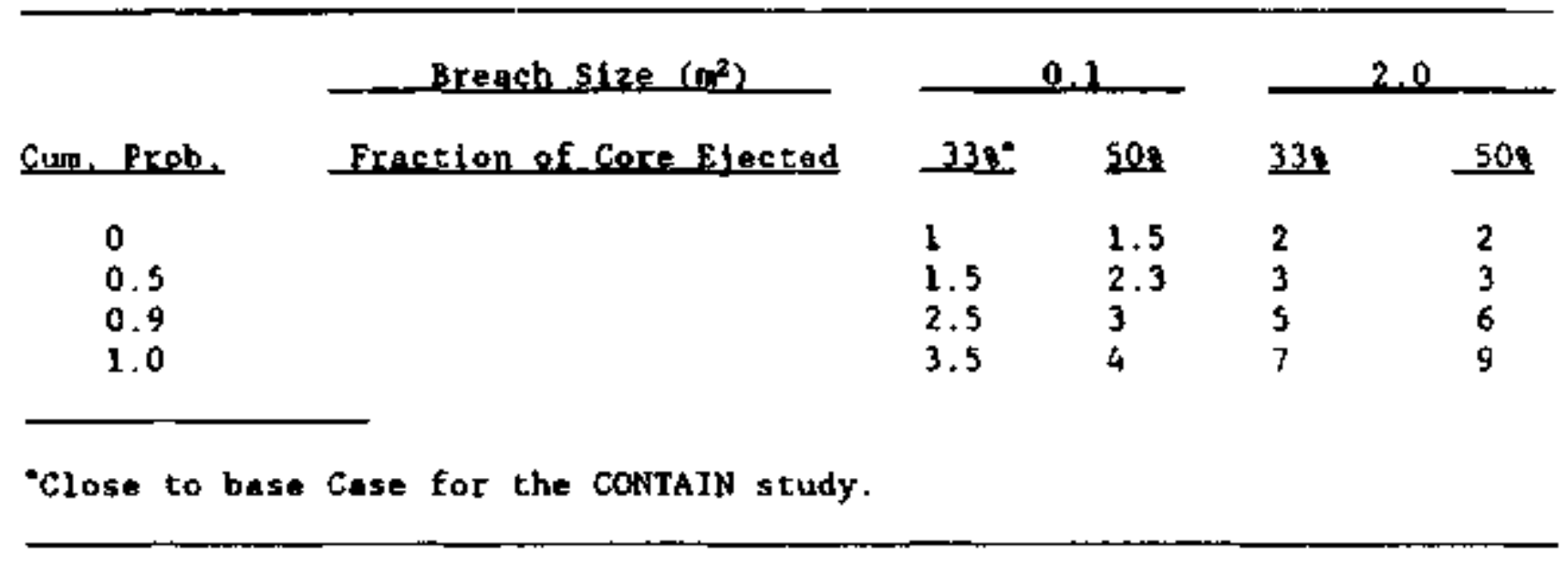

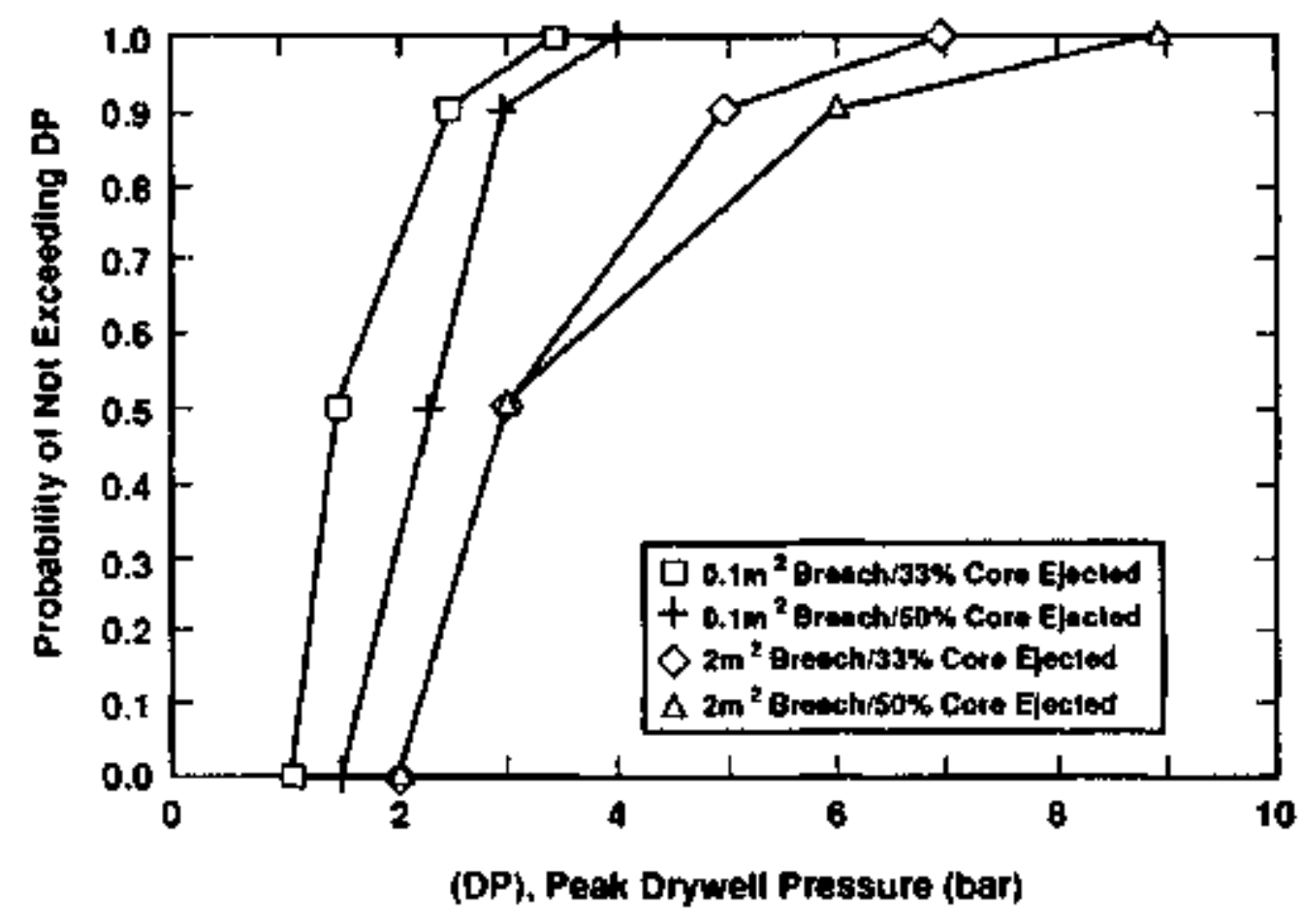

Figure A.2. Peak Static Drywell/Wetwell Pressure Differental: Case 1: High Pressure, Wet Pedestal. 
Case 3*: High-pressure ejection, no water 1n podestal.

The Expert's results are presented in Table A-2. These distributions are shown graphically in Figure A-3.

Table A.2

Drywell Pressure Rise for Case $3^{*}$ (bar)

\begin{tabular}{|c|c|c|c|c|c|}
\hline \multirow[b]{2}{*}{ Cun_Prob. } & \multirow{2}{*}{$\begin{array}{l}\text { Breach Size }\left(m^{2}\right) \\
\text { Fraction of core Ejected }\end{array}$} & \multicolumn{2}{|c|}{0.1} & \multicolumn{2}{|c|}{2,0} \\
\hline & & $338^{\circ}$ & 508 & 331 & 501 \\
\hline $\begin{array}{l}0 \\
0.5 \\
0.9 \\
1.0\end{array}$ & & $\begin{array}{l}1.3 \\
2.7 \\
3.3 \\
4.0\end{array}$ & $\begin{array}{l}1.7 \\
3.0 \\
4.0 \\
5.0\end{array}$ & $\begin{array}{l}1.5 \\
3.5 \\
5.0 \\
7.5\end{array}$ & $\begin{array}{l}2.5 \\
4.0 \\
7.5 \\
9.5\end{array}$ \\
\hline
\end{tabular}

close to base case for the CONTAIN study.

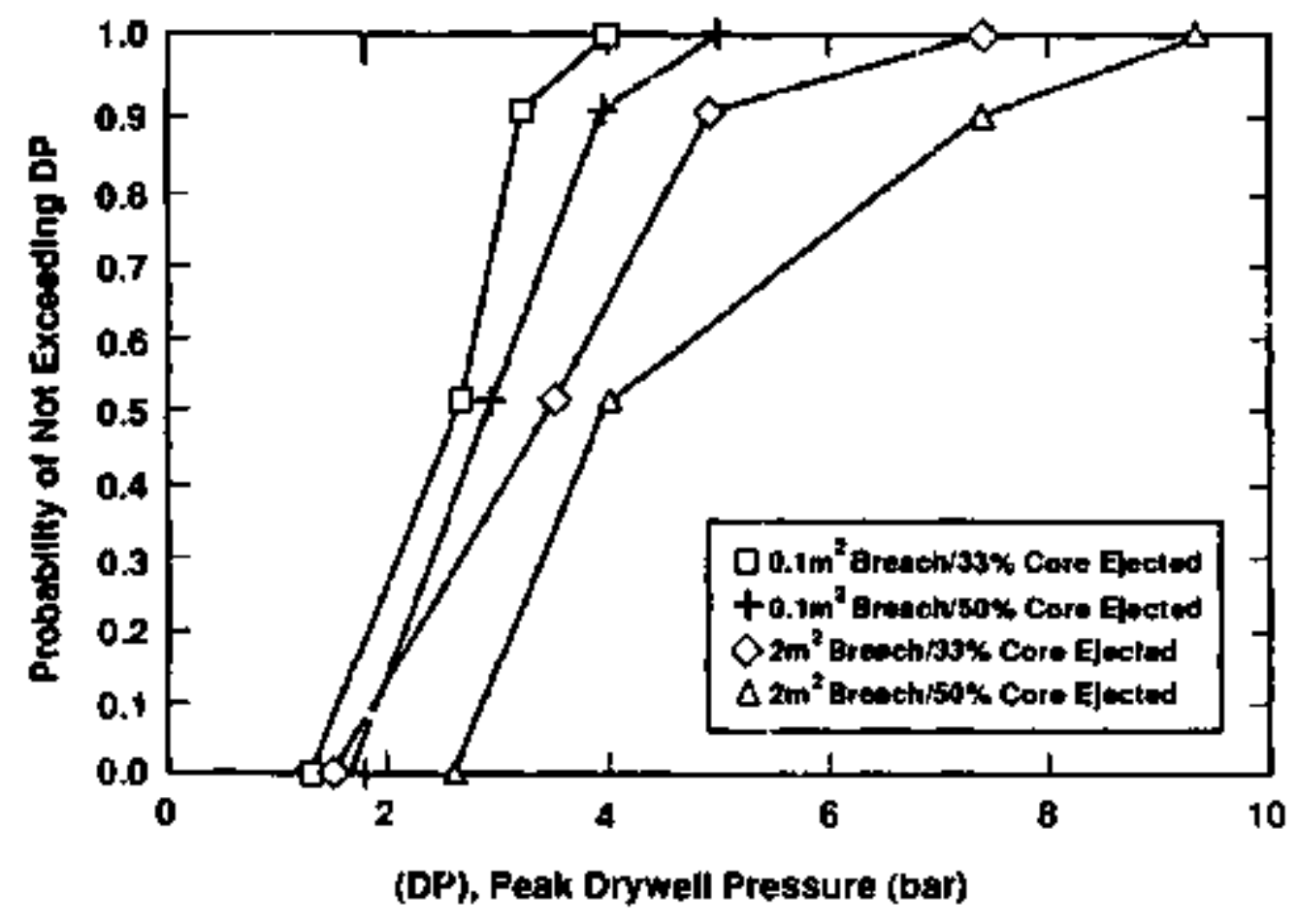

Figure A.3. Drywell Peak Static Pressure; Case 3*: High Pressure, Dry Pedestal. 
Case 2*: Low-preasure *jection, water in pedestal.

The Expert's reaults are presented $1 \pi$ Table $A-3$. These distributions are shown graphically in Figure $A+4$.

Table A-3

Drywell Pregsure Rise for Case 2"

\begin{tabular}{ccc} 
& \multicolumn{1}{c}{ Fraction of core Ejected } \\
\cline { 2 - 3 } Cunulative Probabificy & 338 & 508 \\
0 & 0.1 & 0.13 \\
0.5 & 0.3 & 0.4 \\
0.9 & 0.4 & 0.5 \\
1.0 & 0.5 & 0.7 \\
\hline
\end{tabular}

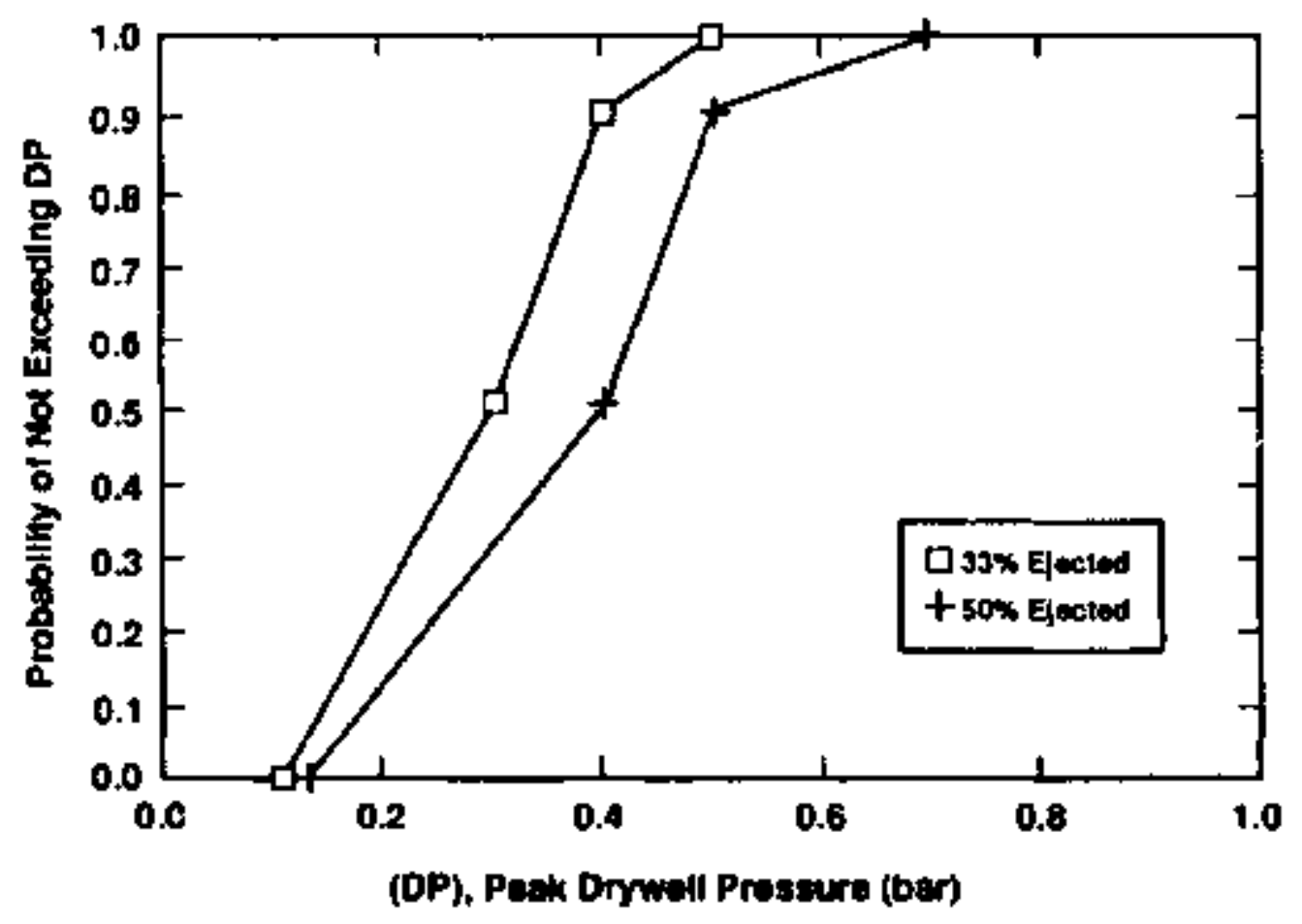

Figure A-4. Drywell Peak Statfc Pressure; Case 2*: Low Pressure, Wet Pedestal. 


\section{Static Presaure of the Contalment}

The Expert's results are provided in Table A-4. These distributions are shown graphically in Flgura A-5.

Table A-4

\section{Containmant Pressure Rise for Cases 1 and $3^{*}$ (bar)}

\begin{tabular}{|c|c|c|c|c|c|}
\hline \multicolumn{2}{|c|}{ In Vessel 25 oxidacion. } & \multicolumn{2}{|c|}{10.} & \multicolumn{2}{|c|}{321} \\
\hline Cum. Prob. & Fraction of Core Fiected & 331 & 50: & $33:$ & $50 \mathrm{~s}$ \\
\hline $\begin{array}{l}0.00 \\
0.5 \\
1.0\end{array}$ & & $\begin{array}{l}2.5 \\
6.0 \\
9.4\end{array}$ & $\begin{array}{l}5.3 \\
7.6 \\
9.8\end{array}$ & $\begin{array}{l}2.3 \\
5.8 \\
9.3\end{array}$ & $\begin{array}{l}3.5 \\
6.5 \\
9.6\end{array}$ \\
\hline
\end{tabular}

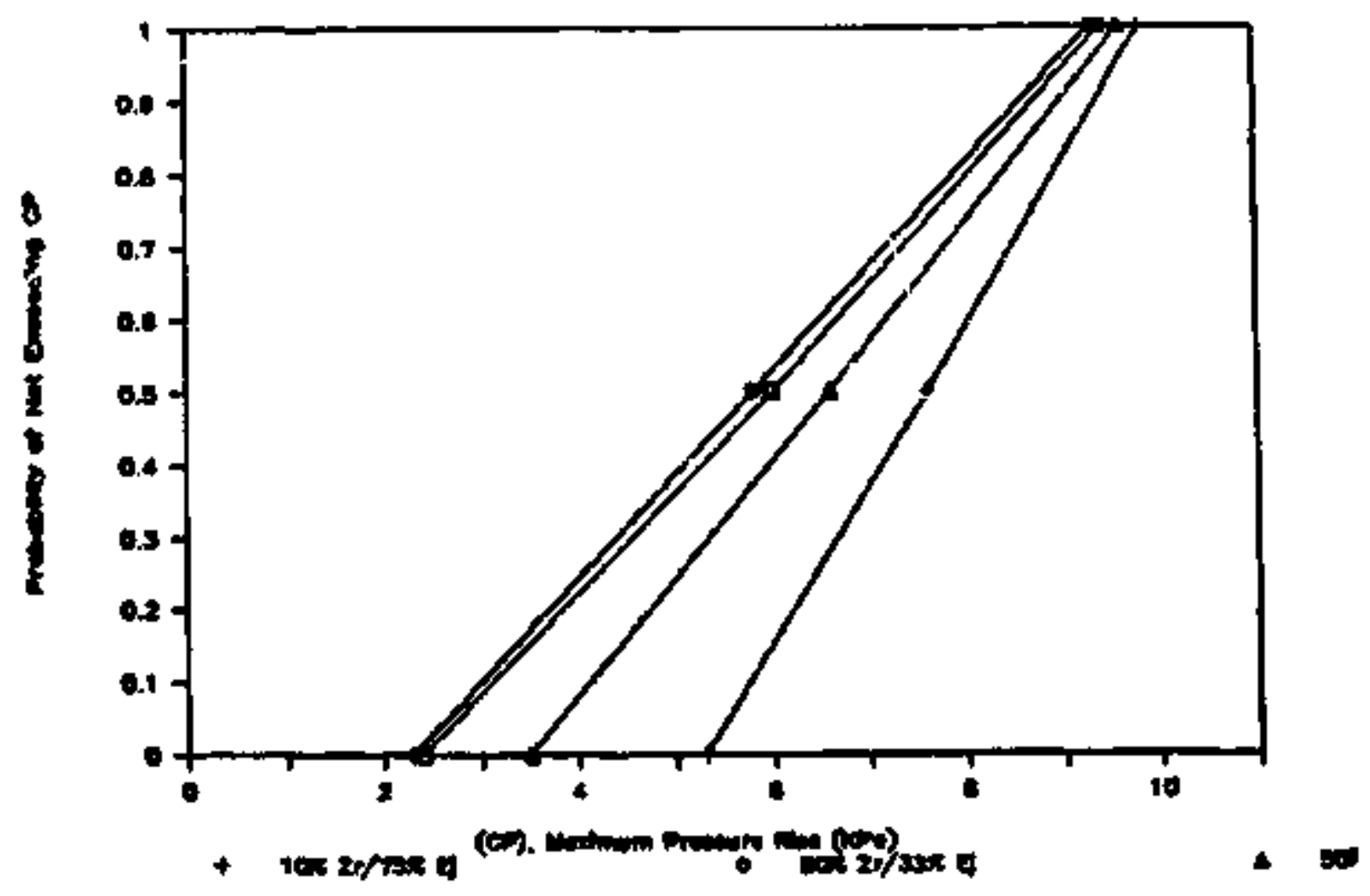

Figure A-5. Containment Pressure Rise; Cases 1 and $3^{*}$ High Pressure Ejection. 


\section{Stratic Prossuriantion of the Pedestal}

Case 1: High-pressure ejection, water In pedestal

The Expert's results are presented in Table A-5. These distributions are shown graphleally 1n Figure A-6.

Table A-5

Pedestal Pressurization for Case 1

(bar)

\begin{tabular}{|c|c|c|c|c|}
\hline \multicolumn{2}{|c|}{ Exeach Stize $\left(\mathrm{m}^{2}\right)$} & \multicolumn{2}{|c|}{0.1} & \multirow[b]{2}{*}{2.0} \\
\hline Cum, Prob. & Fraction of core Ejected & 338 & 508 & \\
\hline 0 & & 10 & 15 & 20 \\
\hline 0.5 & & 20 & 25 & 40 \\
\hline 0.9 & & 30 & 40 & 50 \\
\hline 1.0 & & 40 & so & 60 \\
\hline
\end{tabular}

"For this breach size pedestal pressure depends more on vessel pressure than on the fraction of the care invalved.

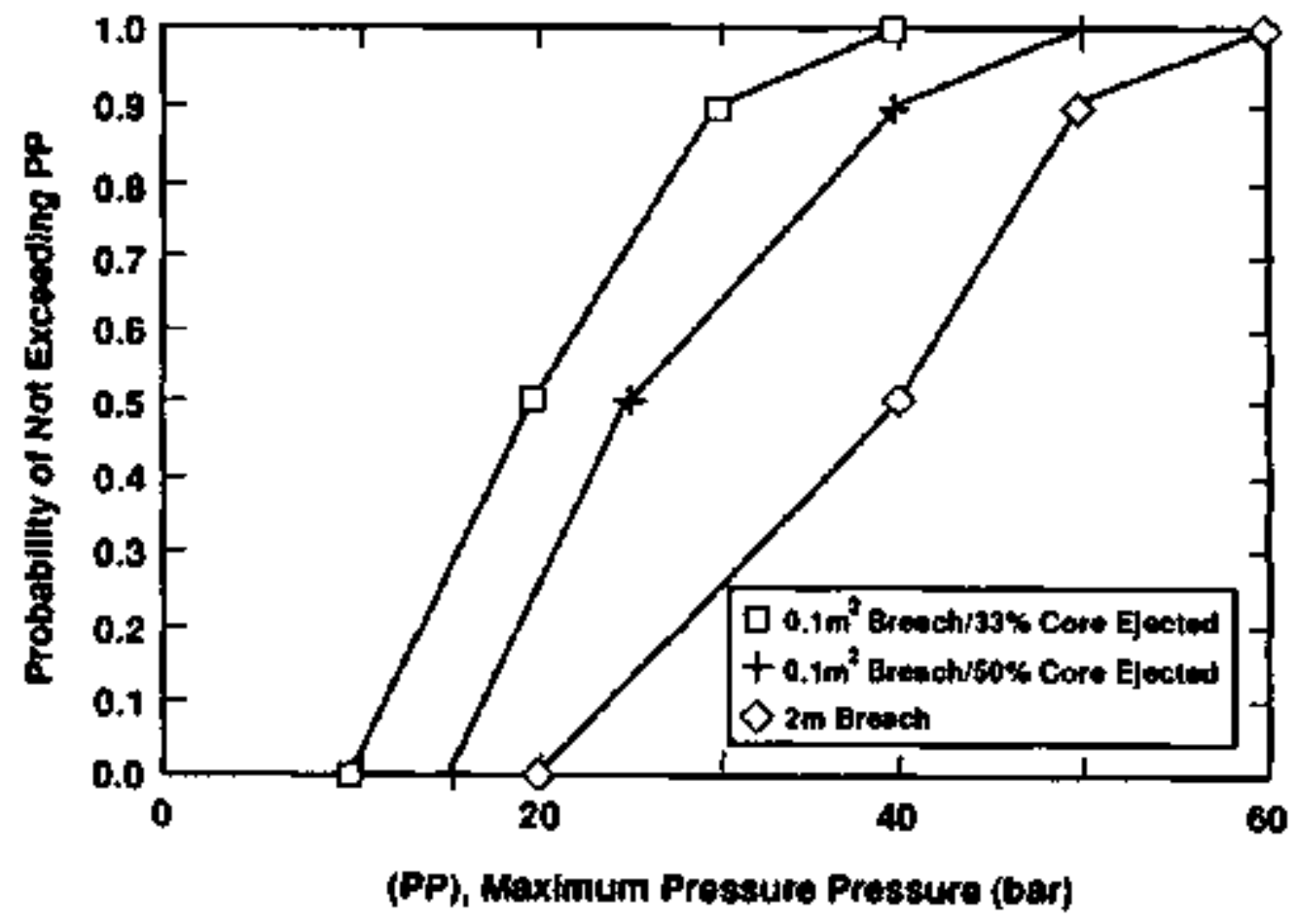

Figure A-6, Maximum Pedestal Pressure; Case 1:

High Pressure, Wet Pedestal. 
Case 3*: H1gh-pressure ejection, no vater in pedestal.

The Expert's results are presented fn Table A-6. These distributions are shown graphically in Figure A.7.

Table A.6

Fedestal Pressurization for Case 3*

(bar)

\begin{tabular}{|c|c|c|c|c|}
\hline \multicolumn{2}{|c|}{ Breach slze $\left(m^{2}\right)$} & \multicolumn{2}{|c|}{0.1} & \\
\hline Crum, Prob. & Fraction of Core Ejected & 338 & 508 & $2.0^{*}$ \\
\hline $\begin{array}{l}0 \\
0.5 \\
0.9 \\
1.0\end{array}$ & & $\begin{array}{r}5 \\
12 \\
20 \\
25\end{array}$ & $\begin{array}{l}10 \\
15 \\
25 \\
35\end{array}$ & $\begin{array}{l}20 \\
40 \\
50 \\
60\end{array}$ \\
\hline
\end{tabular}

"For this breach size pedestal pressure depends more on vessel pressure than on the frection of the core 1nvolved.

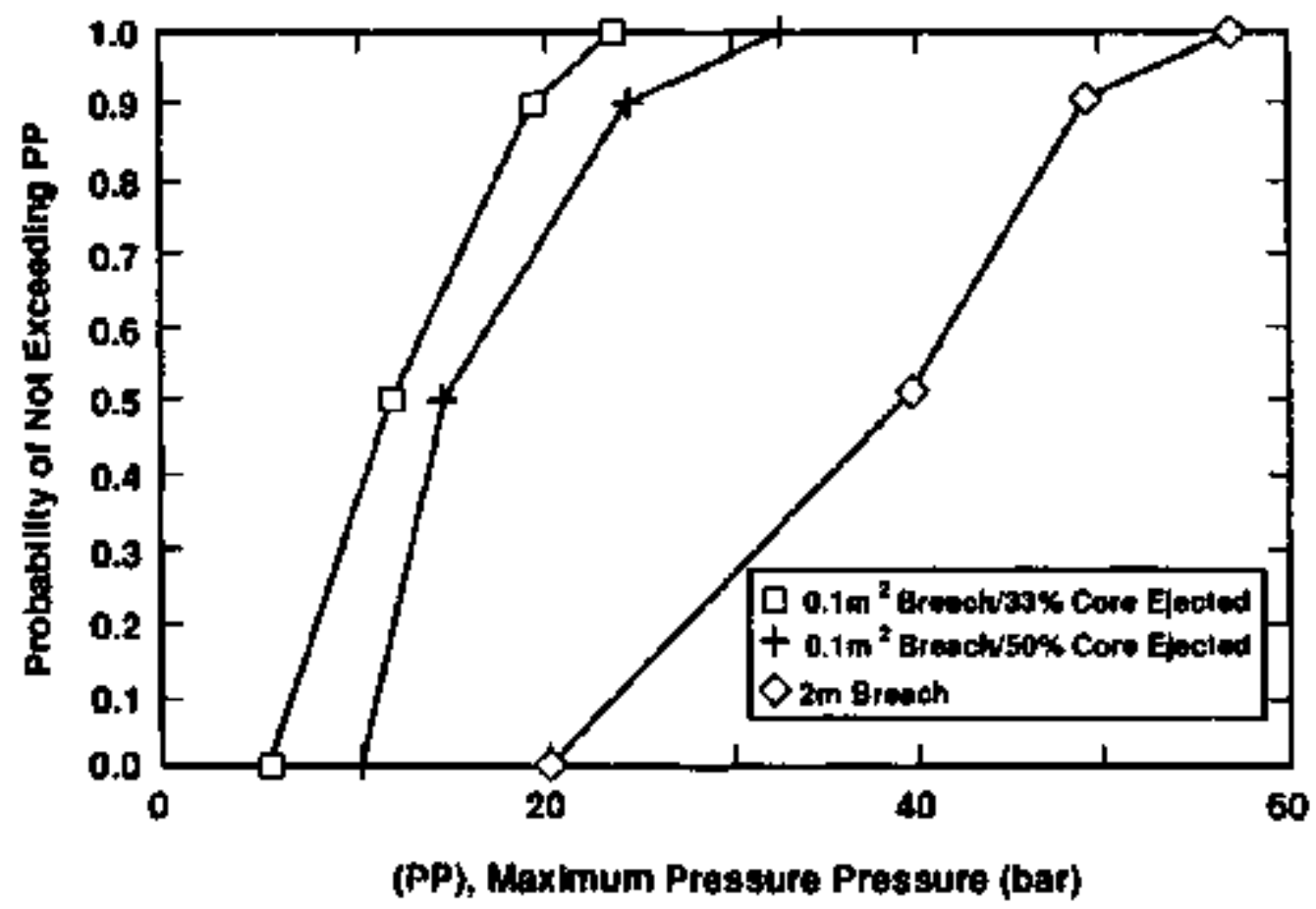

Figure A.7. Maximum Pedestal Pressure; Case 34: High Pressure, Dry Pedestal. 
Case 2*: Low-pressure ejection, water in pedestal.

The Expert's results are presented in Table $A-7$. These distributions are shown graphically in Figure A-8.

Table A-7

Pedestal Pressurizacion for Case 2* (bar)

\begin{tabular}{ccc} 
& & \\
Eraction of Core Ejected \\
\cline { 2 - 3 } & 339 & Sol \\
\cline { 2 - 3 } 0 & 1 & 2 \\
0.5 & 4 & 6 \\
1.9 & 8 & 12 \\
& 16 & 24 \\
\hline
\end{tabular}

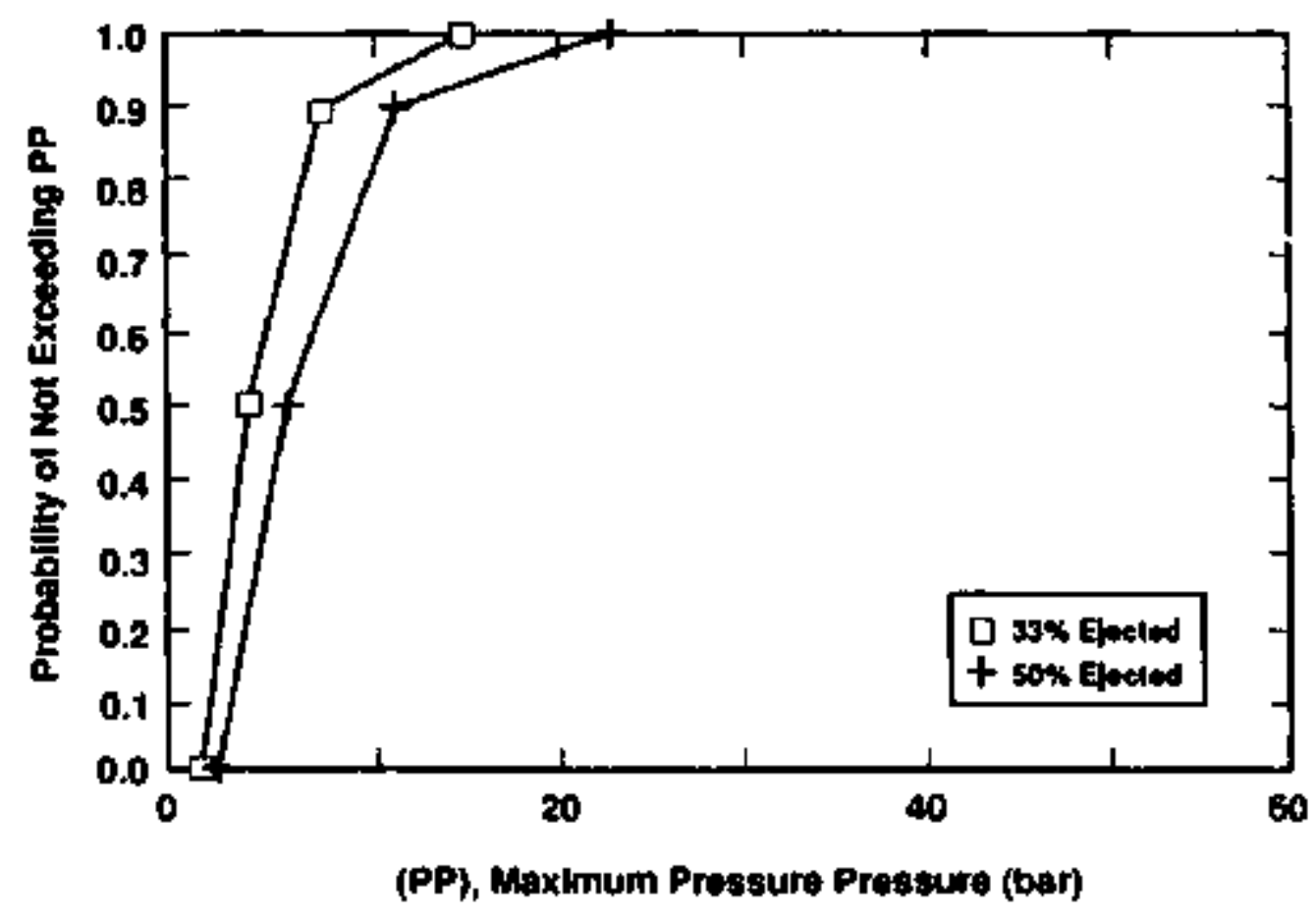

F1gure A.B. Maxioum Pedestal Pressure; Case 2*: Low Pressure, Wet Pedestal. 


\section{Sources of Uncertainty}

\section{Static Pressurization of the Drpwell}

The time at which the drywell vents cleared was belleved to govern the uncertainty. Oxidation reactions in the pedestal were seen to be limited by reaction rates and choked flow. Vent clearing was assumed to arrest the pressure tise (as ovidenced by calculated results) and thus be the key factor in determining peak pressure. For Cases $l^{*}$ and $3 *$, the rate of zirconiun oxidation in the pedestal was an additional uncertainty. For Case $2^{*}$ the efficiency of the assumed steas explosion was seen to be the governing uncertainty.

\section{Bressurization of che Containment}

The quantity of hydrogen produced by oxidation of zirconium in the pedestal was identified as being the key uncertainty for Cases $1 *$ and $3 *$. For Case $2 *$. stean explosion efflciency is controlling.

\section{Pressurization of the Pedestal}

The rate of vessel blowdown and thus the size of the vessel breach was identified as the key uncertainty for this quantity. However, in this elicitation the size of vessel breach was treated as a knowm parameter, supplied by the in-vessel expert group. Uncertainty in pedestal pressure, given the vessel blowdown rate, was governed by the residence $t$ ime of the gas and particles in the pedestal. This, in turn, is governed by the flow rate of gas through the pedestal penetrations, Expert $A$ believed these quantities were underestimated in the CONTAIN calculation. Therefore, uncertainty in the results was seen to be largely in the direction of being lower than the CONTAIN results.

For Case 2*, stean explosion efficiency was again identified as the geverning uncertainty. 
Expert i's Elctation

Issue 4. Grand Gulf Containpent Lods at Vessel Bresch

\section{Descripcion of Expert B's Racionale/Methodology}

The Expert's approach was to analyze and quantify two base cases and then to vary the base case distributions for each of the subcases. The subcases were parameter variations ( 1 .e. zircontun oxidation, melt fraction ejected, and initial hole size) on the original chree cases. The Expert used a Eive letter/number code to describe the cases. The first letter in the code denoted the plant. "G" for orand Gulf, the second number referred to the case, and the last three letters identified the subcase. The three letcers which ldentify the subcase have the following interpretations:

\begin{tabular}{|c|c|c|c|c|c|}
\hline Postition & Description. & Lett로다 & Word & Nominal & Range \\
\hline First & Zirconium Oxidation & $\begin{array}{l}0 \\
0\end{array}$ & $\begin{array}{l}\text { High } \\
\text { Low }\end{array}$ & $\begin{array}{l}32 \% \\
10 \%\end{array}$ & $\begin{array}{l}>210 \\
<210\end{array}$ \\
\hline Secotid & RPV Hole Size & $\begin{array}{l}\mathbf{H} \\
\mathbf{h}\end{array}$ & $\begin{array}{l}\text { High } \\
\text { Low }\end{array}$ & $\begin{array}{c}2 n^{2} \\
0.1 \omega^{2}\end{array}$ & $\begin{array}{lll}>1 & \mathrm{~m}^{2} \\
<1 & \mathrm{~m}^{2}\end{array}$ \\
\hline Third & Core Fraction Ejected & $c$ & $\begin{array}{l}\text { High } \\
\text { Low }\end{array}$ & $\begin{array}{l}508 \\
25 \%\end{array}$ & $\begin{array}{l}>33 \% \\
<338\end{array}$ \\
\hline
\end{tabular}

For example, case GioHc is Case 1 wth a high level of in-vessel zirconium oxidation, the core is ejected through a large hole in the RPV, and a large mount of core is efected at vessel breach.

The two cases the Expert chose as base cases vere GloHC and G2OHC.

To arrive at his distributions. the Expert coupled his knowledge of contrinment loads phenomena with irfornation he obtained from references relevart to this issue. For calculations, the Expert primarily relied on a CONTAIN scudyb-2 of the Grand culf contalnment response to high pressure reactor fatlures.

\section{Results of Expert B's Eltcitation}

\section{Impulse Loadings}

It was decided that this panel would not include in their assessments the impulsive effects of ex-vessel steam explosions: therefore the Expert did not provide any assessments of impulse loadings.

However. it is interesting to note that the Expert considered impulse loadings to the drywell wall. from events in the drywell, unlikely. He felt that hydrogen detonations in the drywell were very unlikely and impulses fiom steam explosion in the pedestal cavity would be confined to the pedestal cavity regton. 
Static Pressurizative of the Drwell

The Expert felt $t$ \& pressurization of the drywell was controlled by phenowena that tak plsce bofore the suppression pool vents clear. Furthermore, result: presented in Reference B-1 Indicated that hydrogen burns in the drywell do not algnificantly affect the drywell pressurization. Therefore, netther the anount of zircontum oxidaticn ar the total anount of core debris is inportant. That is Important is the RPV hole size because it affects the source rate (1.e., rate at which $s$ tean and core debris are ejected into the drywell). Thus, RPV hole size was the only parameter the Expert chose to consider for this loading.

The Expert described the first base case, Glohd, as a high pressure melt ejection (HPME) which would result in drywell pressurization; however, the suppression pool vents would clear relatively early. The Expert felt hydrogen burns were unlikely for this case because of the high stean concentration in the drywell that would be coincident with this case. The Expert felt References D-1, B-2, and the NUREG-1150 Issue Paper "Pressure Rise at Vessel Breach at Grand Gulf" were relevant for this case. The Expert thought the drywell pressure differential would range from 0.3 to 7.1 bar. Reference B-2 11kens HPKE to a large break LOCA. The Expert chose the pressure rise associated vith the design basis accident (OBA) as the median value in his distribution. However, the Expert felt the precursor stean release would open the vents before a large amount of the core had been efected, which would tend to reduce the drywell pressure. The low end of the range reflects this rationale. The high end of the range accounts for the possibility of very rapid source terns (as assumed in Reference B-1) in which case the vents do not clear in time to effectively reduce the drywell pressure. Because RPV hole size is the only parameter being varied, this base case corresponds to the large RPV hole cases, GlxHz, where $x$ and $z$ refer to $O$ or $D$ and $c$ or $c$, respectively. With a small RPV hole the source rate will be lower than for the large hole case. Because of the lower source rate, the Expert felt the vents would clear early enough to reduce the drywell pressure. For this set of cases, G1xhz, the Expert reduced the base case pressure by 408 to account for the vents opening.

For the second base case, G20tC, the Expert thought References 8-1 through and B-4 were relevant. In addition, NUREG-1150 Issue Paper Pressure Rise at Vessel Breach at Grand Gulf" included Information from the Grand Gulf final safety analysis report (FSAR). The dominant Issue for this case was fuel coolant interaction (FCI), Drywell pressures cited in Reference B-3 ranged fron 0.24 bar to 3.8 bar. Based on criticisms of Reference $B-3$ the Expert assuned these pressures were non-conservative. In addition, based on vork presented in Reference B-1, the Expert felt the debris/stesm flow would become choked in the pedestal and the suppregsion pool vents would open before the drywell pressures got too high. Thus, the Expert concluded that this base case could not be worse than the base case corresponding to Case 1. Therefore, the Expert reduced $61 \times \mathrm{Hz}$ by 0.1 bar to get $\mathrm{G} 2 \times \mathrm{Hz}$. For the small hole opening cases, G2xhz, the Expert multiplied G2OHC by 0.5 to account for the fact that a slow pour implies a sagller amount of debris would participate in an FCI and, therefore, only siall steam explosion can occur with this case. 
For Case 3, the Expert relied on results presented in Reference B-1 whlch Indicated that drywell pressures are approxiagtely 208 higher for the dry cavicy case than for the wet cavity case. Therefore, the Expert multiplied the Case 1 distributions, GlxHz and Glxhz, by 1.2 to get the Case 3 distributions, $G 3 \times \mathrm{xHz}$ and G3xhz. The letters $x$ and 2 correspond to 0 or 0 and $C$ or $c$, respectively.

The results for Cases 1,2 , and 3 and their corresponding subcases are presented in Table B-l.

Table B-1

Peak Drywell Static Pressure (bar)

(relative to the contalnment)

\begin{tabular}{|c|c|c|c|c|c|c|c|}
\hline \multirow[b]{2}{*}{ Cases" } & \multicolumn{7}{|c|}{ Cumulative Probabllicy } \\
\hline & 0.01 & 0.05 & 0.25 & 0.50 & 0.75 & 0.95 & 0.99 \\
\hline $\begin{array}{l}\text { G1xHz } \\
\text { Glxhz }\end{array}$ & $\begin{array}{l}0.30 \\
0.18\end{array}$ & $\begin{array}{l}0.40 \\
0.24\end{array}$ & $\begin{array}{l}0.80 \\
0.48\end{array}$ & $\begin{array}{l}1.80 \\
1.08\end{array}$ & $\begin{array}{l}4.00 \\
2.40\end{array}$ & $\begin{array}{l}6.00 \\
3.60\end{array}$ & $\begin{array}{l}7.10 \\
4.26\end{array}$ \\
\hline $\begin{array}{l}\mathrm{G} 2 \mathrm{xHz} \\
\mathrm{G} 2 \mathrm{xhz}\end{array}$ & $\begin{array}{l}0.30 \\
0.15\end{array}$ & $\begin{array}{l}0.40 \\
0.20\end{array}$ & $\begin{array}{l}0.70 \\
0.35\end{array}$ & $\begin{array}{l}1.80 \\
0.90\end{array}$ & $\begin{array}{l}3.90 \\
1.95\end{array}$ & $\begin{array}{l}5.90 \\
2.95\end{array}$ & $\begin{array}{l}7.00 \\
3.50\end{array}$ \\
\hline $\begin{array}{l}\text { G3xHz } \\
\text { G3xhz }\end{array}$ & $\begin{array}{l}0.36 \\
0.22\end{array}$ & $\begin{array}{l}0.48 \\
0.29\end{array}$ & $\begin{array}{l}0.96 \\
0.58\end{array}$ & $\begin{array}{l}2.16 \\
1.30\end{array}$ & $\begin{array}{l}4.80 \\
2.86\end{array}$ & $\begin{array}{l}7.20 \\
4.32\end{array}$ & $\begin{array}{l}8.52 \\
5.11\end{array}$ \\
\hline
\end{tabular}

\section{Stacic Pressurdzation of che Containment}

The pressure rise caused by burning hydrogen which was genersted before vessel breach was addressed in another issue. Therefore, for burns in the containment the Expert only considered hydrogen which was released or generated at vessel breach. The expert assumed that the containment sprays were not operating. However, the Expert did indicate that if the sprays were on. they, would drastically reduce the pressure rise in the wetwell caused by a hydrogen burn.

For the first case the only parameter that the Expert considered important was the amount of core ejected. Case 5 in Reference B-1 indicated that. approximately $1600 \mathrm{~kg}$ of hydrogen is produced at vessel breach. However. the Expert felt that preexlsting hydrogen would have been burned before vessel breach and, thus, there would not be sufficient oxygen in the containnent for burns after vessel breach. Thus, for his median value, the Expert only considers the partial pressure of the non-condensibles in hls assessment of the pressure rise. The Expert used results presenced in Referince B-1 to estimate this pressure rise. The low end of the distribution accounts for the Expert's concern that the results in Reference B.l 
may have overestiasted the pressure rise. On the other hand, the high end of the range reflects the Expert's bellef that the shallow coverage of the vents could lead to significant suppression pool blow-through. In additlon, if some of the oxygen is still avallable in the wetwell, a hydrogen burn would result in a significently higher pressure rise. For the cases with a swall amount of core ejected, Glxyc, the Expert felt there was a reduced likelihood of combustion. Therefore, he reduced the base case distribution. Glxyc, by 20 to get the distribution for the small core ejection cases, G2xyc.

For Case 2, low pressure case, the level of zirconitu oxidation was the only paramerer that was considered significant. The Expert did not consider the RPV hole size a significant parameter for this case because he felt the pressure rise was deterained efther by conbustion events or by accumulstion of non-coidensibles, neither of which is greatly influenced by the blowdow rate. The Expert felt that the only way to get a large pressure rise in the wetwell was to have a big FCI in the pedestal. The total anount of core debris ejected is not important because anly a small amount of the debris particlpates in the stean explosion. The FCI would drive the non-condensibles into the wetwell. The Expert felt Reference B-1 was relevant because the nixing/heat transfer process could represent the FCI as well as a HPME. However, the Expert believes a gravity pour through the complex structure beneath the vessel will give premature fCIs and clear the pedestal of water. Thus, the Fxpert does not give nuch credibility to high entratnment fractions presented in Reference b-1. This reasoning leads to low drywell pressurization and not much suppression pool blowthrough. The Expert belleves there will be some contalment pressurization due to non-condensibles generated by the FCI. This rationale represents median value in the base case distribution, G2OHC. The high end of the distribution accounts for the possibility of large FCIs. Reference B.5 Indicates that laxge amounts of hydrogen can be generated during an FCI. The upper end of the distribution includes combustion of this hydrogen. The base case is representative of cases with a large zirconium oxidation leve1, G20yz. For subcases with a snall amount of zirconium oxidation, G2oyz. the Expert multiplied the base case by 1.8 because with a low amount of zirconiun oxidized in-vessel there is more available to be oxidized ex. vessel.

For the high pressure cases, Cases 1 and 3 , the Expert did sot feel the presence of water in the pedestal cavity was an important factor with regard to wetwell pressurization. Therefore, he used the same set of distributions to describe Case 3 as he did for Case 1.

The results for Cases 1,2 , and 3 and their corresponding subcases are presented in Table B.2. 
Table B-2

Peak Containment Static Pressure (bar)

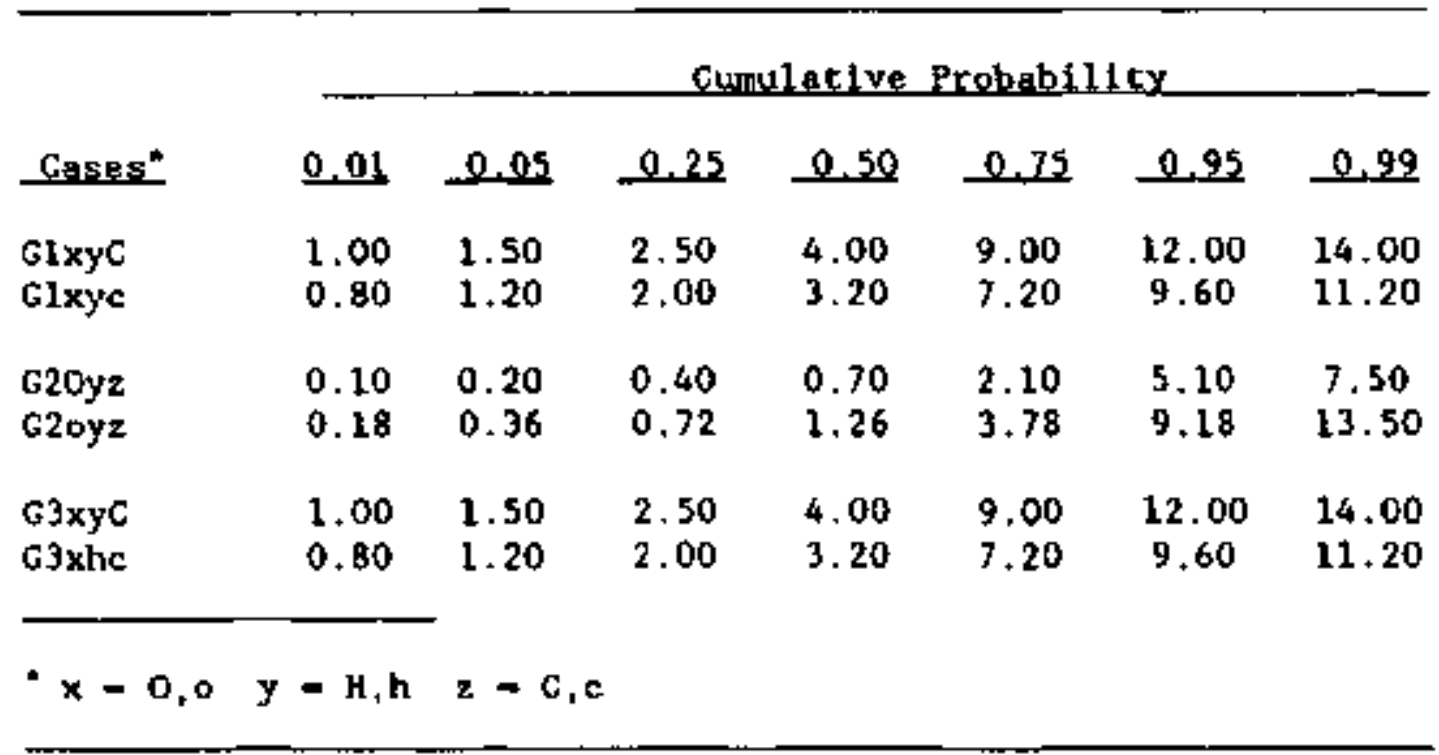

\section{Static Pressurization of the Pedestal}

The Expert used Reference B-1 as a starting polnt for the first base case, clohC. The Expert felt the credible cases presented in Reference B.1 were those with S09 of the core ejected with less than 509 entrained water. He thought Case $6^{\mathrm{B}-1}$ ( $50 \mathrm{~s}$ of the core ejected with 25 entralned water) was the most believable; however, he felt the zero slip assumption exaggerates the peak pedestal pressure. The peak pedestal pressure for Case $6^{\mathrm{t}-1}$ was 37 bar. After a review of the relevant cases in Reference B-1, the Expert reduced the peak pedestal pressure by 7 bar to correct for silp. Thus, the Expert concluded that the nedian (.5) peak pedestal pressure would be 30 bar. Because the only analysis that was avallable to the Expert was Reference B-1. the Expert was concerned that there was some possibility that Reference 8-1 overestimated the peak pressure. There could be a slower blow-down or more slip than what was assuped in the CoNTAIN study. The low end of the distribution, $0.25,0.5$, and 0.01 fractiles, reflects this concern. On the other hand, a review of the relevant CoNTAIN cases (Cases 1, 2, 3, 5, 6, 15) Indicated the peak pressure is in the range of 40 to 50 bar. the Expert assigned to the 0.75 fractlle a value of 48 bar. The Expert assigned the 0.95 fractile value 65 bar because he felt there was some chance that the pedestal pressure would approach the reactor pressure. The very high end of the distribution, 00 bar at the 0.99 fractile, Includes the RPV pressure plus sone extra pressure due to direct containsent heating (DCH) and FCI. For subcases where a small amount of cote debris is ejected, Glxyc, the Expert reduced the base case by 20\%. To account for the slow blow down associated with a small hole size, the Expert reduced the base csse by 15 s to get Glxhz. The breadth of these distributions reflects the sparse amount of information (primarily Reference B-1) avallable for the Expert to analyze. 
There were no calculations that were directly applicable to Gase 2 . The Expert Indicated that he had very little to work with and that some calculation should be done for this case. The Expert felt the pedestal pressures for this case would be less than the pressures obtained for Case 1. As a first estimate, the Expert wultiplied the base distribution for Case 1, GloHC, by 0.5 to get the second base case distribution, G2OHC. The Expert felt that with a large RPV hole size the anount of zirconium axida. tion and the antount of core debris ajected were not important. Thus, the distribution used for the second base casa was applied to subcases G2OHc and G2oHC. Subcase G2Ohz was obtalned by tultipling case G2OHC by 0.5 . The reason for this reduction was that the slower pour rate associated with the small RPV hole implied a smaller anount of debris would participate in FCI. Subcase G2oHc was also obtalned by multipling case G2OHC by 0.5 . Subcases G2ohz were obtained by multipling case G2ohz by 0.5 .

The CONTAIN studys-1 indicated that peak pedestal pressures associated with a dry cavity were approximately 70 s of the pedestal pressure associated with a wet cavity. Therefore, the Expert multiplied the Case 1 distributions, G1xyz, by 0.7 to get the Case 3 distrfbutions, G3xyz.

The results for Cases 1, 2, and 3 and their corresponding subcases are presented in Table B-3.

Table B-3

Peak Pedestal Static Pressure (bar)

\begin{tabular}{|c|c|c|c|c|c|c|c|}
\hline \multirow[b]{2}{*}{ Cases } & \multicolumn{7}{|c|}{ Cumulat ive Probabilitey } \\
\hline & $\underline{0.01}$ & 0.05 & 0.25 & 0.50 & .0 .75 & 0.95 & 0,99 \\
\hline $\mathrm{GlxHC}$ & 6.00 & 8.00 & 15.00 & 30.00 & 48.00 & 65.00 & 80.00 \\
\hline GlxHc & 4.80 & 6.40 & 12.00 & 24.00 & 38.40 & 52.00 & 64,00 \\
\hline GlxhC & 5.10 & 6.80 & 12.75 & 25.50 & 40.80 & 55.25 & 68.00 \\
\hline G1xhe & 4.08 & 5.44 & 10.20 & 20.40 & 32.64 & 44.20 & 54.40 \\
\hline $\mathrm{G} 2 \mathrm{OHz}$ & 3.00 & 4.00 & 5.00 & 11.00 & 20.00 & 32.00 & 40.00 \\
\hline G2OHC & 3.00 & 4,00 & 5.00 & 11.00 & 20.00 & 32.00 & 40.00 \\
\hline G20hz & 1.50 & 2.00 & 2.50 & 5.50 & 10.00 & 16.00 & 20.00 \\
\hline G2oHc & 1.50 & 2.00 & 2.50 & 5.50 & 10.00 & 16,00 & 20.00 \\
\hline G2ohz & 0.75 & 1.00 & 1.25 & 2.75 & 5.00 & 8.00 & 10.00 \\
\hline $\mathrm{G} 3 \times \mathrm{HC}$ & 4.20 & 5.60 & 10.50 & 21.00 & 33.60 & 45.50 & 56.00 \\
\hline $63 \times \mathrm{HC}$ & 3.36 & 4.48 & 8.40 & 16.80 & 26.88 & 36,40 & 44.80 \\
\hline G3xhC & 3.57 & 4.76 & 8.92 & 17.85 & 28.56 & 38.67 & 47.60 \\
\hline G3xhe & 2.86 & 3.81 & 7.14 & 14.28 & 22.85 & 30,94 & 38.08 \\
\hline
\end{tabular}

- $x=0,0 \quad y=4, b \quad z-C_{1}, c$ 


\section{Sources of Uncertainty}

The Expert Identified three factors that contributed to the uncertainty associated with thig issue: (1) the absence or scarcity of careful analyses of the events; (2) the lack of understanding of conbined HPME/FCI scenartas (it is a conplex process and all the experiments have selfdestructed); and (3) the artificiality of the requirement not to consider the combustion of pre-existing hydrogen ( $1, e,$. hydrogen released before vessel breach) in the containnent at vessel bresch. 
B-1, K. K. Murata, "Porametric CoNTalN Calculetiong of the Containment: Response of the Grand Gulf Flant," Sandia National Laboratortes, Letter Report, February 15, 1988.

B-2. R. J. Lipinski, "High Pressure Melt Ejection Effects in Grand Gulf," Appendix $B$ to Quest study on Grand Gulf in "Uncertainty in Radionuclide Release Under Specific tuR Accident Conditions," Vol. IV, F, K, Mast et al., Sandia Mational Labotatories, SAND84-0410, Decenber 1985.

B-3. Letter, M. L, Corradin1 (University of Wisconsin) to A. S, Benjamin (Sandla National Laboratories), "Ex-vessel PCIa for Grand Gulf Risk Analysta," November 13, 1986.

B-4. Memo, M. Berman (Sandia National Labocatories) to A. S. Benjamin (Sandia National Laboratorles), "Bx-vessel FCIs for Grand Gulf Risk Analysis," Deceaber 10, 1986.

B.5. B. Marshall, "Hydrogen Generation During Fuel-Coolant Interactions: Results from the FITS-D Series," SAND88-1335C, Sandia National Laboratorles, June 1988. 
Bxpert $C^{*}=$ Elicitation

\section{Issue 4. Grand Gulf Containment Loads at Vessel Bresch}

\section{Description of Expert Cis Racionale/Nethodology}

The Expert first considered the varlous phenomenologies that could be present in this sttuation. The phenomenologles considered were: (1) "early" melt-water and melt-atmosphere lnteractions such as steam explosions or FCIs and hydrogen burns; (2) melt jet breakup, mixing, and fraghentation in the water; (3) stean generation before explosion; (4) direct contalnment heating (DCH); (5) hydrogen burns in the drywell. The Expert decided that the major sources of uncertalnty to consider were: (1) rate of vent uncovery, (2) rate of mixing, entrainment, etc., (3) rate of steam generation, and (4) race of hydrogen burn in the drywell.

The general procedure used was to get a "best guess" scenario, get a upper and a lower bound scenario; use conTAIN results to assess the the reasonableness of the scenartos, and use best judgnent to fill in other cases.

The base case was constructed assuming the total mass participating was of secondiary Inportance and only the short-tern phenomena dominated, that the percent of zirconfum was a secondary effect, and that the percent of hydrogen released previous to vessel breach gave a dp of 4 bars (best guess). The upper bound considered both short mixing thes and larger percent of mass partfipating, while the lower bound considered longer mixing times.

\section{Besults of Expert C's Ellatiation}

The Expert only gave results for the maximum drywell pressure and assuned watex was present in all cases and the no-water case was not elicited.

The Expert defined 16 cases (11sted in Table C-1) based on his decompositfor. for the important parameters: vessel pressuce, percent of cotsl core mass participating, size of vessel breach, and percent of tatal zirconium unoxfdized. Water was assumed to be present in the drywell in all cases. 
Table C-1

Definition of Cases

\begin{tabular}{|c|c|c|c|c|}
\hline Crasee & $\begin{array}{c}\text { Pressure } \\
-(0 \mathrm{si})\end{array}$ & $\begin{array}{l}\text { Mass } \\
\text { (a) }\end{array}$ & $\begin{array}{l}\text { Size } \\
\left(\mathrm{m}^{2}\right)\end{array}$ & $\begin{array}{c}\mathrm{zr} \\
\text { (unoxidized) }\end{array}$ \\
\hline 1 & 1000 & 50 & .1 & $6 B$ \\
\hline 2 & 1000 & 50 & .1 & 34 \\
\hline 3 & 1000 & 50 & 2 & 68 worst \\
\hline 4 & 1000 & 50 & 2 & 34 \\
\hline 5 & 1000 & 25 & .1 & 68 \\
\hline 6 & 1000 & 25 & .1 & 34 \\
\hline 7 & 1000 & 25 & 2 & 68 \\
\hline 8 & 1000 & 25 & 2 & 34 \\
\hline 9 & 100 & 50 & .1 & 68 \\
\hline 10 & 100 & 50 & .1 & 34 \\
\hline 11 & 100 & 50 & 2 & 68 base \\
\hline 12 & 100 & 50 & 2 & 34 \\
\hline 13 & 100 & 25 & .1 & 68 \\
\hline 14 & 100 & 25 & .1 & 34 best \\
\hline 15 & 100 & 25 & 2 & 68 \\
\hline 16 & 100 & 25 & 2 & 34 \\
\hline
\end{tabular}

For each of the cases the Expert gave a probability distribution for the pressure rise.

Toble 0.2

Probability Distributions $\Delta$ (bars)

\begin{tabular}{cllllllll}
\hline & & & 7 & & \\
Case & 0.0 & 0.05 & 0.25 & 0.5 & 0.75 & 0.95 & 1.0 \\
1 & 0 & 2 & 3 & 4 & 7.5 & 10 & 20 \\
2 & 0 & 2 & 3 & 4 & 7.5 & 10 & 20 \\
3 & 0 & 2 & 4 & 6 & 8.5 & 10 & 20 \\
4 & 0 & 2 & 4 & 6 & 8.5 & 10 & 20 \\
5 & 0 & 2 & 3 & 4 & 7.5 & 10 & 20 \\
6 & 0 & 2 & 3 & 4 & 7.5 & 10 & 20 \\
7 & 0 & 2 & 4 & 6 & 8.5 & 10 & 20 \\
8 & 0 & 2 & 4 & 6 & 8.5 & 10 & 20
\end{tabular}


Table C-2 (cont1nued)

\begin{tabular}{lllllllll}
\hline & & & & & & \\
Crase & 0.0 & 0.05 & 0.25 & 0.5 & 0.75 & 0.95 & 1.0 \\
9 & 0 & 2 & 2.5 & 3 & 7 & 10 & 20 \\
10 & 0 & 2 & 2.5 & 3 & 7 & 10 & 20 \\
11 & 0 & 2 & 3 & 4 & 7.5 & 10 & 20 \\
12 & 0 & 2 & 3 & 4 & 7.5 & 10 & 20 \\
13 & 0 & 2 & 2.5 & 3 & 7 & 10 & 20 \\
14 & 0 & 2 & 2.5 & 3 & 7 & 10 & 20 \\
15 & 0 & 2 & 3 & 4 & 7.5 & 10 & 20 \\
16 & 0 & 2 & 3 & 4 & 7.5 & 10 & 20 \\
\hline
\end{tabular}

The Expert sald to linearly interpolate and that all the cases were celatively close with secondary effects making up the differences. We can see frow the results that the percent of zirconium unoxidized did not turn out to be a signiflcant contributor to the differences.

The Expert did not give information on the lapulse loading of the drywell wall, containnent pressure rige, and maximud pressure and impulse to pedestal.

\section{Correletions with other Varjables}

We can see that the resulis are correlated to the output of the in-vessel issue on bottom head fallure where the vessel pressure, percent of mass participating, size of the breach, and percent of zirconium unoxidized are spectfied.

\section{Suggested Hethads for Reduclng Uncertainty}

The anor uncercaincles are in the short-terd phenomena. No explicit recommendation was made for reducing uncertalnties. 
5.5. Containment loads Isque 5: Pressure Increnent dn the Sequoyah Gontalnment at Vessel Breach

Sumnary of Expert Fanel's Assossment of Issue 5

Pressure Increment In the Sequoyah Containment at Vessel Brepch

Experts consulted: Ken Bergeron, Sandia National Laboratories; Ted Ginsbers. Brookhaven National Laboratory; Marty Plys, Fauske and Assoclates.

\section{Issue Description}

What distributions characterize the uncertainty in the pressure $r 15 e$ in containment at vessel breach for Sequoyah. This pressure rise may result from one or more of the following events:

1. Blowdown of the Reactor Coolant System (RCS);

2. Ex-Vessel Molten Core-Coolant Interactions (HCCI);

3. Hydrogen Combustion:

4. Direct Contafinent Heating (DCH) .

RCS blowdown and DCH cause signiflcant loads to the containment only if the RCS pressure is ten to twenty atmospheres or more above that of the containnent at vessel breach.

The Initial presentation of this issue delineated four RCS pressure ranges. When water in the cavity, sprays, and lce are considered, the case structure for Sequoyah is as follows:

\begin{tabular}{|c|c|c|c|c|}
\hline Case & $\begin{array}{l}\text { RCS Pressure } \\
\text { (psia) }\end{array}$ & $\begin{array}{l}\text { Cavity } \\
\text { Water }\end{array}$ & $\begin{array}{c}\text { Sprays } \\
\text { Operating }\end{array}$ & $\begin{array}{c}\text { Ice } \\
\text { Benglntng }\end{array}$ \\
\hline $\begin{array}{l}1 \\
1 a \\
1 b\end{array}$ & $\begin{array}{l}2500 \\
2500 \\
2500\end{array}$ & $\begin{array}{l}\text { Wet } \\
\text { Dry } \\
\text { Dry }\end{array}$ & $\begin{array}{l}\text { Either } \\
\text { No } \\
\text { No }\end{array}$ & $\begin{array}{l}\text { Yes } \\
\text { Yes } \\
\text { No }\end{array}$ \\
\hline $\begin{array}{l}2 \\
2 a \\
2 b\end{array}$ & $\begin{array}{l}2000 \\
2000 \\
2000\end{array}$ & $\begin{array}{l}\text { Wet } \\
\text { Dry } \\
\text { Dry }\end{array}$ & $\begin{array}{l}\text { E1 ther } \\
\text { No } \\
\text { No }\end{array}$ & $\begin{array}{l}\text { Yes } \\
\text { Yes } \\
\text { No }\end{array}$ \\
\hline $\begin{array}{l}3 \\
3 a \\
3 b\end{array}$ & $\begin{array}{l}500-1000 \\
500-1000 \\
500-1000\end{array}$ & $\begin{array}{l}\text { Wet } \\
\text { Dry } \\
\text { Dry }\end{array}$ & $\begin{array}{l}\text { B1ther } \\
\text { No } \\
\text { No }\end{array}$ & $\begin{array}{l}\text { Yes } \\
\text { Yes } \\
\text { No }\end{array}$ \\
\hline $\begin{array}{l}4 \\
4 a \\
4 b\end{array}$ & $\begin{array}{l}15-200 \\
15.200 \\
15-200\end{array}$ & $\begin{array}{l}\text { Wet } \\
\text { Dry } \\
\text { Dry }\end{array}$ & $\begin{array}{l}\text { Either } \\
\text { No } \\
\text { No }\end{array}$ & $\begin{array}{l}\text { Yes } \\
\text { Yes } \\
\text { No }\end{array}$ \\
\hline
\end{tabular}

A wet cavity is defined as water up to the bottom head of the reactor vesse1, which corresponds to a depth of $16 \mathrm{ft}$; the nominal depth assumed 18 $10 \mathrm{ft}$. For times when water is above the bottom head of the vessel, the 
experts belleved that the dispersal of corlum into the contalnment will not occur; the pressure rise in the containment for this scenarlo was assumed to be simflar to that of Gase 4 . In the original definition of the issue, 1t was stated that Cases $2,2 a$, and $2 b$ could have different in-vessel hydrogen production due to partial upper head injection (UHI) operation. but the differences in Cases $1,1 a$, and $1 b$ might be minimal. Since that time, the NRC has given Tennessee Valley Authority (TVA) permission to remove the UHI system from Sequoyah at the next refueling outage. The NRC also decided that it wished Sequoyah to be analyzed whout UHI for this project.

The panel decided to consider the following variations or these basic cases:

Zr oxtdation: high (608) and low (258);

Melt fraction ejected: high (75t) and low (33t); and

Initial hale alze: large $\left(2 \mathrm{~m}^{2}\right)$ and small $\left(0.1 \mathrm{~m}^{2}\right)$.

\section{Sumbary of Experts Racionale/Methodology}

Expert A relied heavily on the results of CONTAIN calculations, the results of the Surtsey Direct Containnent Heating (DCH) experiments, and EPRI NP. 5127. Expert A's judgment was that the CoNTAlN calculations with unconditional hydrogen burn approxinate an upper bound pressure rise for the following phenonenological reasons:

1. All debris is assuned in CONTAIN to be finely particulated and available for DCH upon entering the lower compartment. Realisti. cally, soue debris can enter the compartuent In a wavelike manner and transfer much less energy to the atmosphere than predicted in CONTAIN. Th1s phenomenon would also result in lower hydrogen generation rates than predicted in ConTAIN.

2. The presence of structures in the lower compartment and the geonetry of the ice condenser inlets appear to preclude transport of significant quantities of debris into the lce condenser. Very little debris can be expected to enter the upper compartment. since debris will be mostly confined to the lower compartaent, heat transfer from debris will be imited by the high temperatures attained by the gas. Hydrogen generation will be limited by the availability of steam relative to cases in which debeis can be transported outside the lower compartment. Expert A felt that ConTaln overestimates the debris that would enter the upper compartment.

Experc A felt that the pressure $r$ ise at vessel breach could be decomposed Into pre-burn and burn increments. The cotal pressure rise was expressed; therefore, as the product of the pressure rise ratio $\left(P_{2} / P_{1}\right)_{\text {and }}$ due to senstble heating and the pressure rise ratio $\left(P_{5} / P_{2}\right)_{\text {burn }}$ as a resulc of hydrogen burns:

$P_{1} / P_{1}=\left(P_{2} / P_{1}\right)_{\text {amm }} *\left(P_{1} / P_{2}\right)_{\text {burn }}$. 
The senstble energy ia a Eunetion of dispersal fraction and is sensitive to the assumption of particulate vs. filn/wave dispersal. The hydrogen burn pressure rise varies for ejected core fractions between 20 and 408 and with dispersal tine.

Expert $A$ approached the problew by assessing specific cases and adjusting the results to obtain subcase essessments. The adjustments were based on sensitivities to the vatiables of hole size. presence of water in the cavity, and 1ce bypass. For Sequoyah, in-core oxidation was not consldered, because it was considered to be Insigniflcant as a sensitivity variable. It was Expert A's judgoent that with respect to the reactor coolant system (RCS) pressure at vessel breach, there was no difference betwen 2000 psia and 2500 psia, given the other uncertainties involved with the issue. There is no probability of a detomation for any of the cases,because uncond1tional hydrogen burns take place ss the hydrogen 15 belng created.

Expert B approached the problem by using avallable CONTAIN, MAAP, and Surtgey results to carefully assess pressure rise distributions for six base cases. Using a PC spreadsheet program, he adfusted the six base cases to get values for the other 138 subcases required. The extremes of his ranges for the base cases were based on energy balance calculations. The best estinate is based on code results, primarily CONTAIN results and some subsequent calculations.

Expert B fele that a full cavity of water could either increase the pressure rise due to increased staga production, or decrease the pressure rise due to quenching. He expected the hot gases resulting from vessel breach at any pressure above a fow hundred psia to result in 1 gnition and complete combustion in any cell (volume) there a combustible mixture of hydrogen and oxygen is present. Some cells were not expected to burn due to lack of oxygen. Expert B concluded that detonations were unlikely.

At Sequoyah, when hydrogen Ignition occurs before vessel breach, much of the hydrogen that was generated 1n-vessel is consumed. Expert B felt it was necessary to create an additional case-defining parameter to establish the containment hydrogen inventory at the time of vessel breach. Thus, the level of pre-existing hydrogen was added as an additional paraneter to consider in the subcase definition.

Expert B considered Case 1 (2500 psia) and Case 2 (2000 psia) together as he thought there would be no apprectabla differences betueen them. Factors other than the amount of pre-existing hydrogen, fn-vessel zirconium oxidation, vessel hole size, and the fraction of mass ejected were accounted for by broadenting the uncertainty bounds. In the course of this analysis, Expert B concluded that the pressure rise is fairly insensitive to the amount of in-vessel zircontun oxidation.

Expert $c$ based the events he consideted wost likely to occur during pressurized thelt ejection based on experiments and colculations. He belifeved that the DCH scenario involved large amounts of the core debris leaving the cavity in the form of small corfur droplets. Suspension of the droplets allows for efficlent and complete chemfcal reaction of the metals contained in the melt. High gas velocitles frov the cavity into the 
concainwent are expected. Two $90^{\circ}$ turns are required for the entrained debris droplets to nake before entering the ice condenser. It 1s expected that the droplets will be trapped before entering the 1ce candenser, but. stean and high teaperature hydrogen will be eranspotted through the ice condenser. Expert $c$ belleves the high temperature hydrogen will Ignite when admitted into the upper containment, where oxygen is avallable.

The Expert based his "besc estimates" on contals calculations and on scaled experimencs of the very siollar Watts Bar conteinment. He based the high side of his distributions on stean blowdown scenario which optimized entrafnwent and burned the realining tron. The low side of his distributions constdered phenomena whtch wight reduce pressure, e.g., larger drop díameter, or faster trapping.

Dependence on extent of zirconlun oxidation, vessel breach area, and fraction of melt ejected were also considered. CONTAIN calculations had Indicated that there was littele dependence on previous zircontum oxidation.

Expert $C$ felt that the reason for low dependence on previous zirconium oxidation was oxygen starvation In the cavity. Cavity wacer can either enhance or reduce the pressure rise. The effect of a larger hole in the RPV increases the pressure increment because the gas would exit with higher velocity.

\section{Method of Acqrapation}

All the experts datermined that Cases 1 and 2 could be represented by the sane distribution and so Case 2 is not reported, All three experts provided distributions for Cases 1,3 , and 4 in which the lce is fully Eunctional. There were dfffering levels of participation, hovever, in providing separste distributions for the different subcases. Only Expert A provided separate distributions for different pre-existing levels of $\mathrm{H}_{2}$. For the different subcases in which the ice is functional and the experts did not provide distributions, the distributions for higher level cases were replicated for experts not particlpating.

Only Experts $A$ and $B$ provided distributions for Cases 1,3 , and 4 in which the ice is not functionsl. Thus, only two distributions were aggregated. Again, hlgher level case distributions were replicated for unsupplied subcase distributions, if necessary. Using the ANOVA method for reducing case structure, 45 subcases for tines fn whlch the lce is functional were reduced to 25 subcases and for tines in whlch the ice is not functional, 15 subcases were reduced to 9 subcases.

\section{Aqquegated Resulcs}

Aggregated results are given in Tabies 5-1 and 5-2 and In associated Figures 5-1 through 5-20. 
Table $5-i$

Aggregate for Low Presinte or Non-HPME Gases

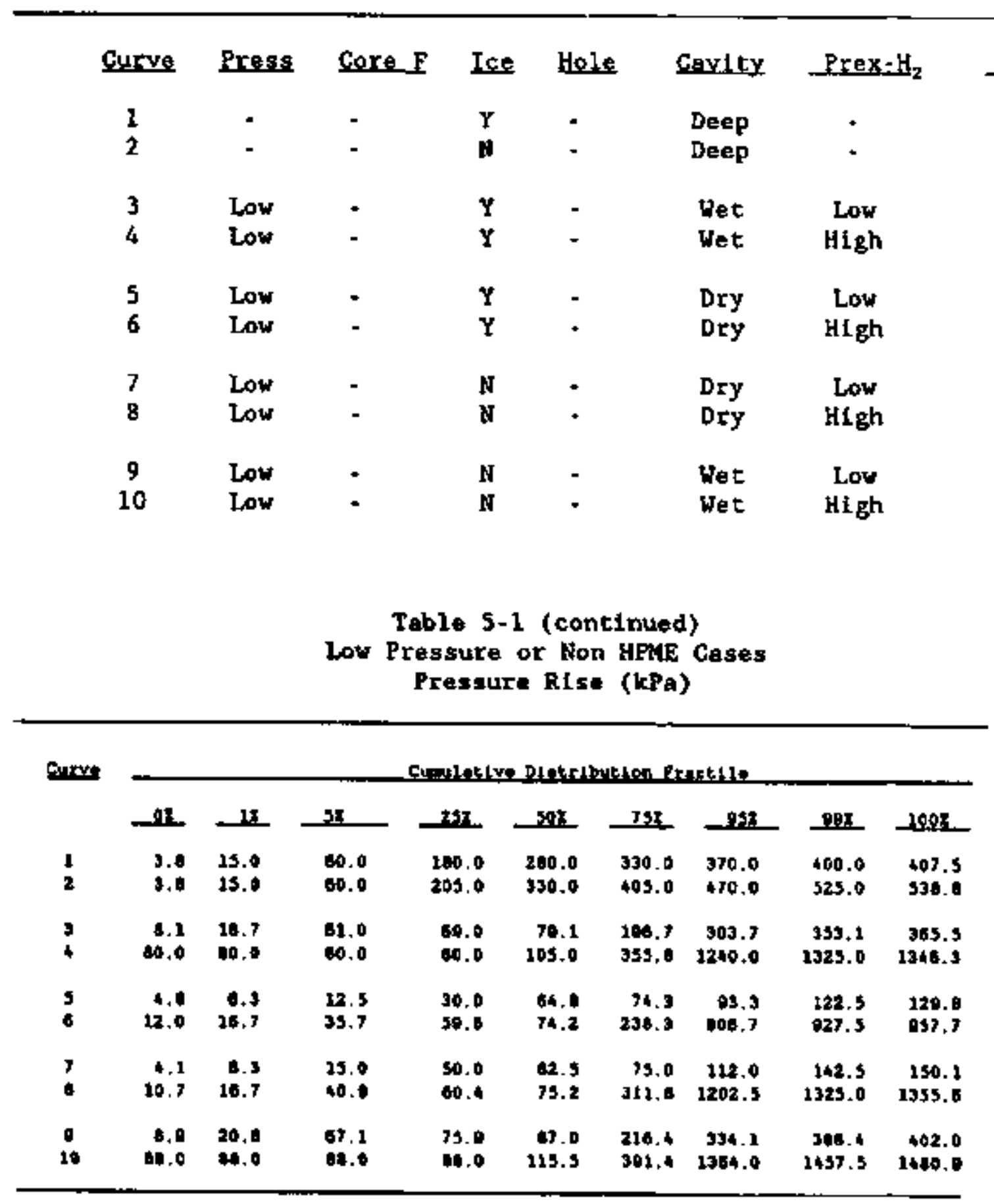




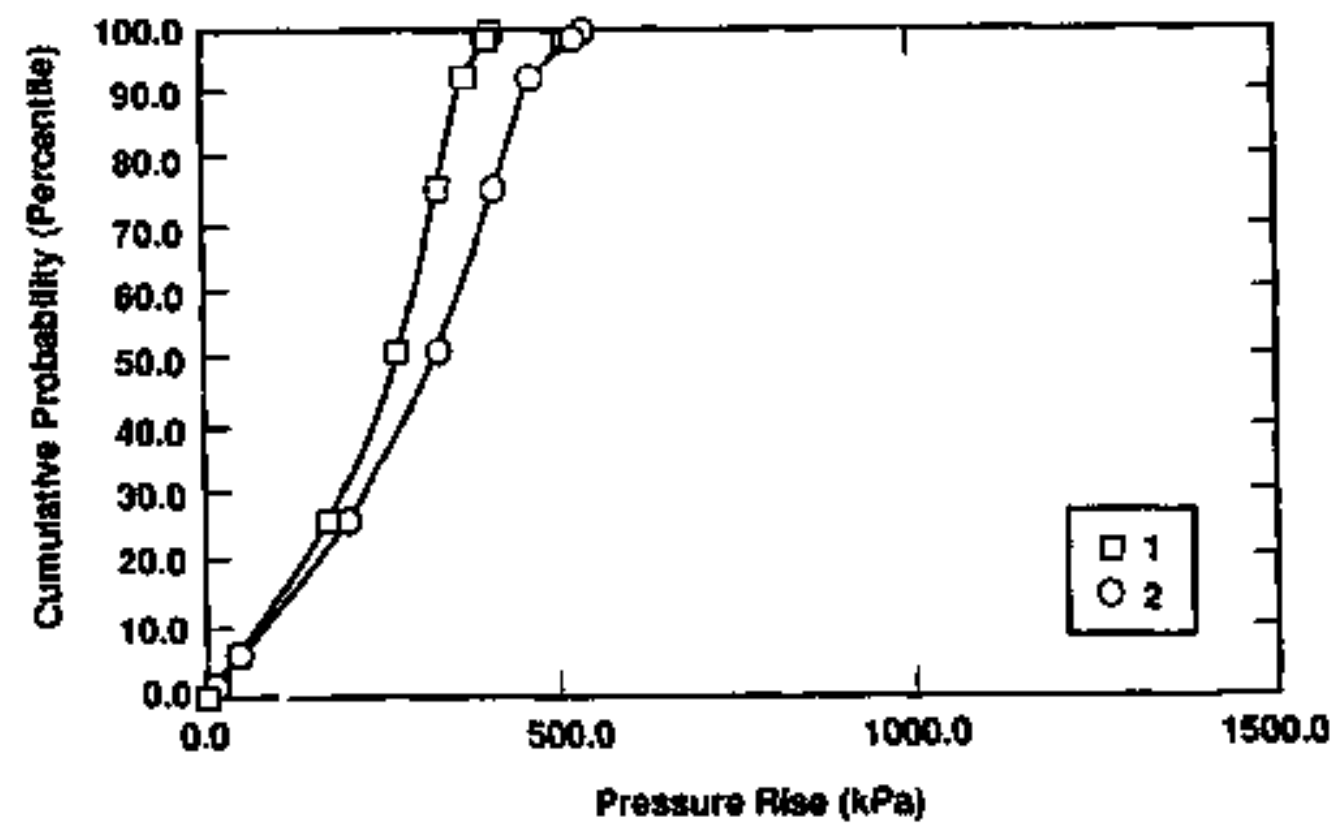

Figure 5-1. Cavity Deeply Flooded; Above the Botconhead of the Vessel (Curves $1 \& 2$ ).

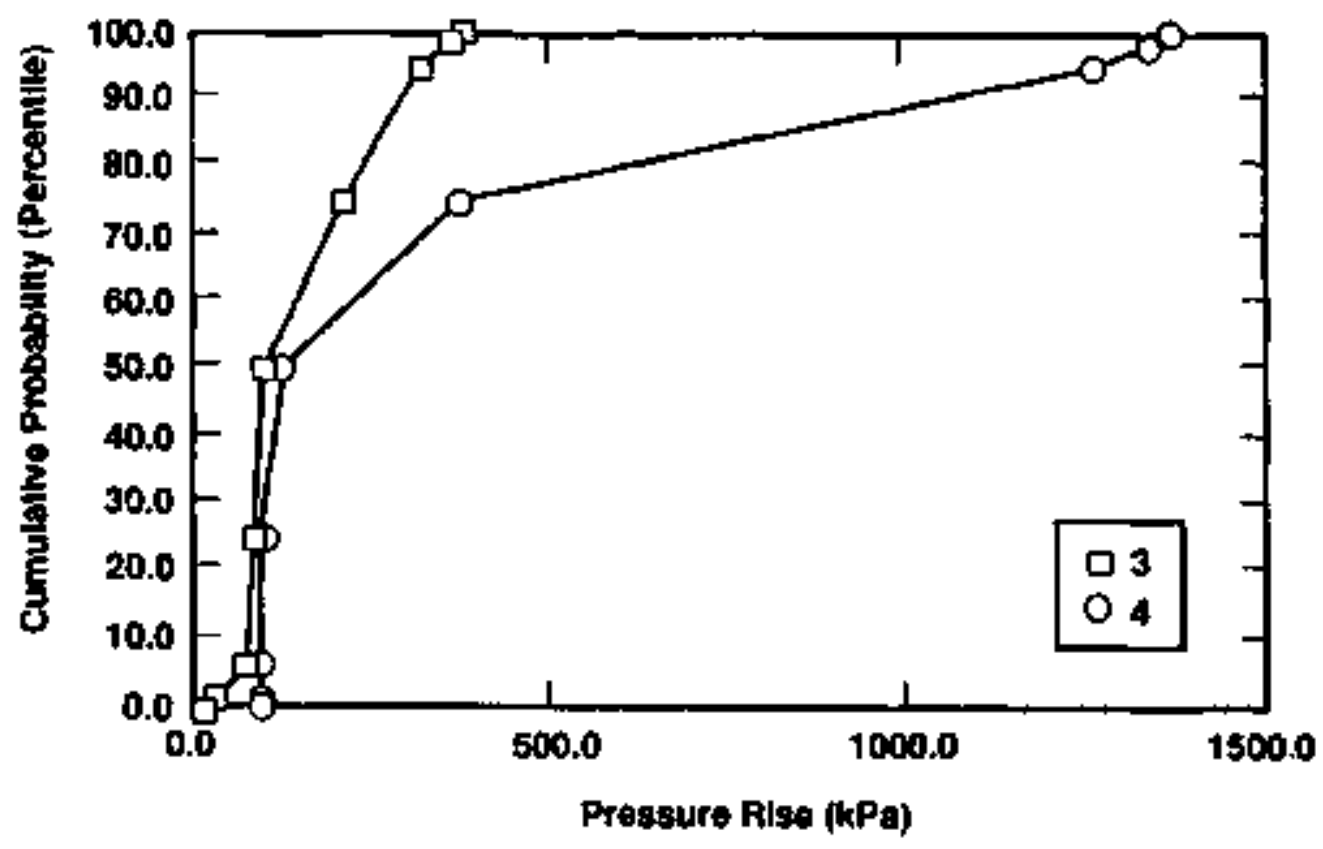

Figure 5-2. RCS Low Prassure; Less Than 200 psla (Curves 3 4). 


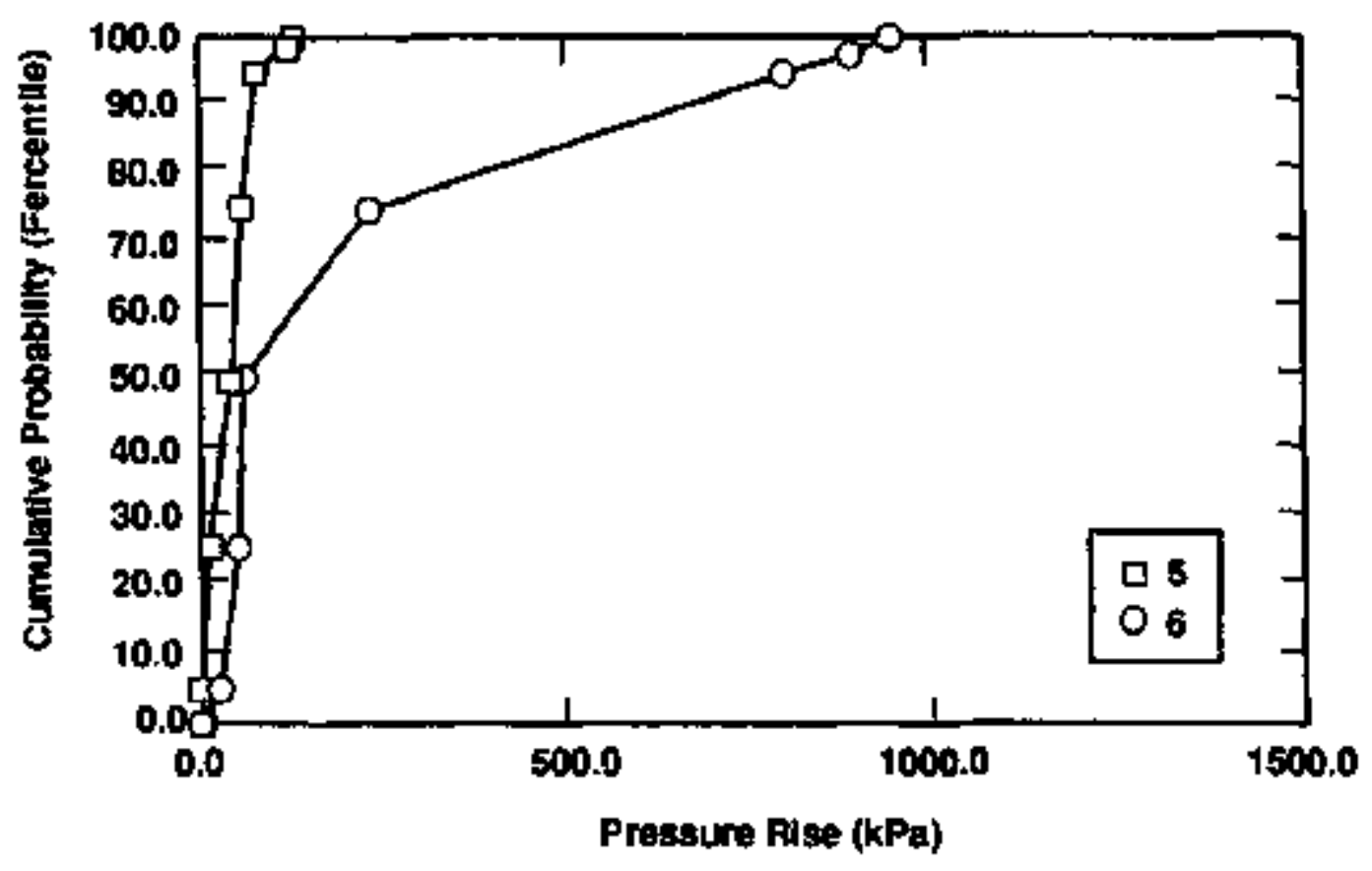

Figure 5-3. RCS Low Pressure; Less Than 200 psia (Curves 5 \& 6 ).

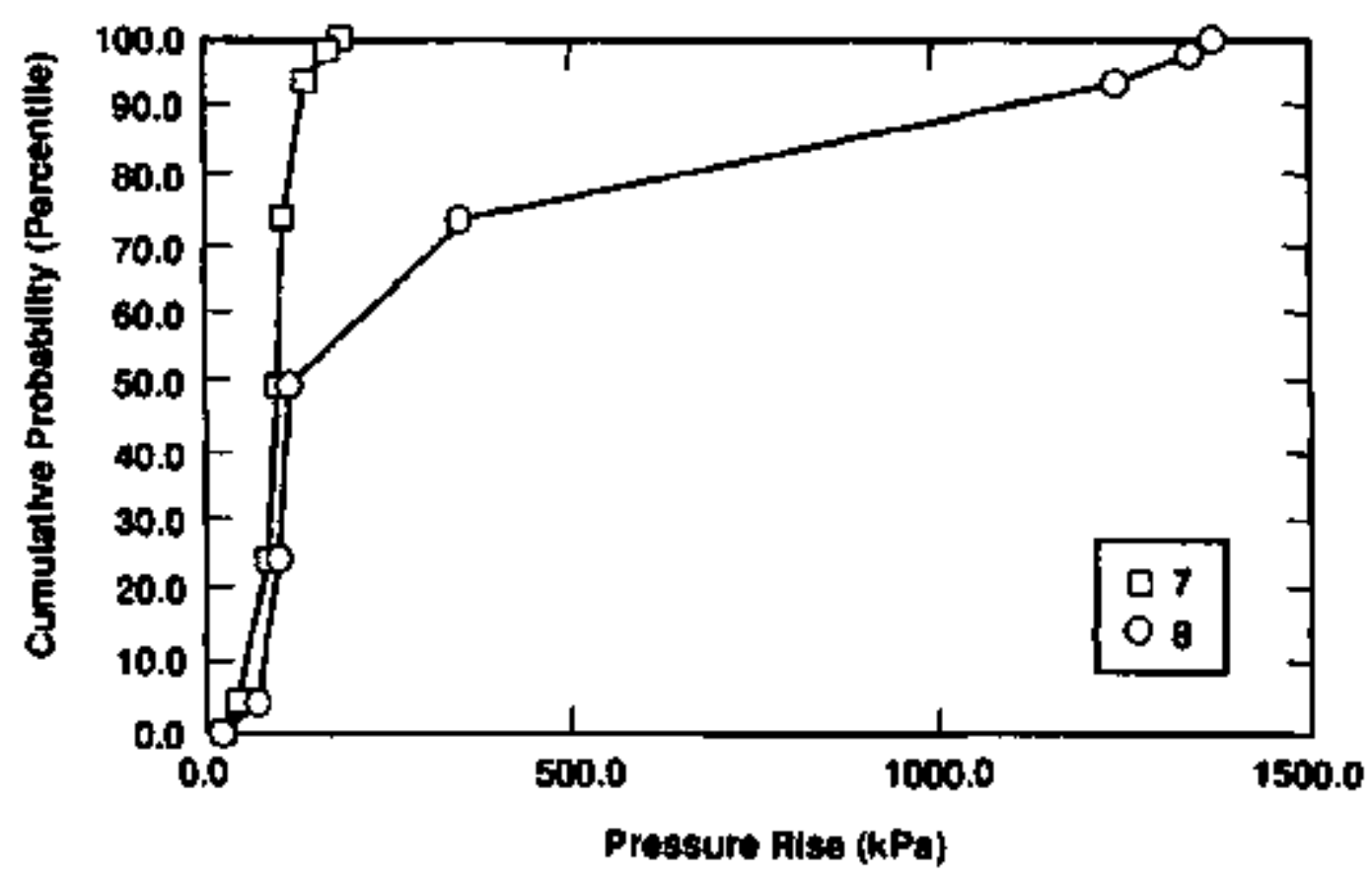

Figure 5-4, RCS Low Pressure: Less Than 200 psia (Curves 7 \& 8). 


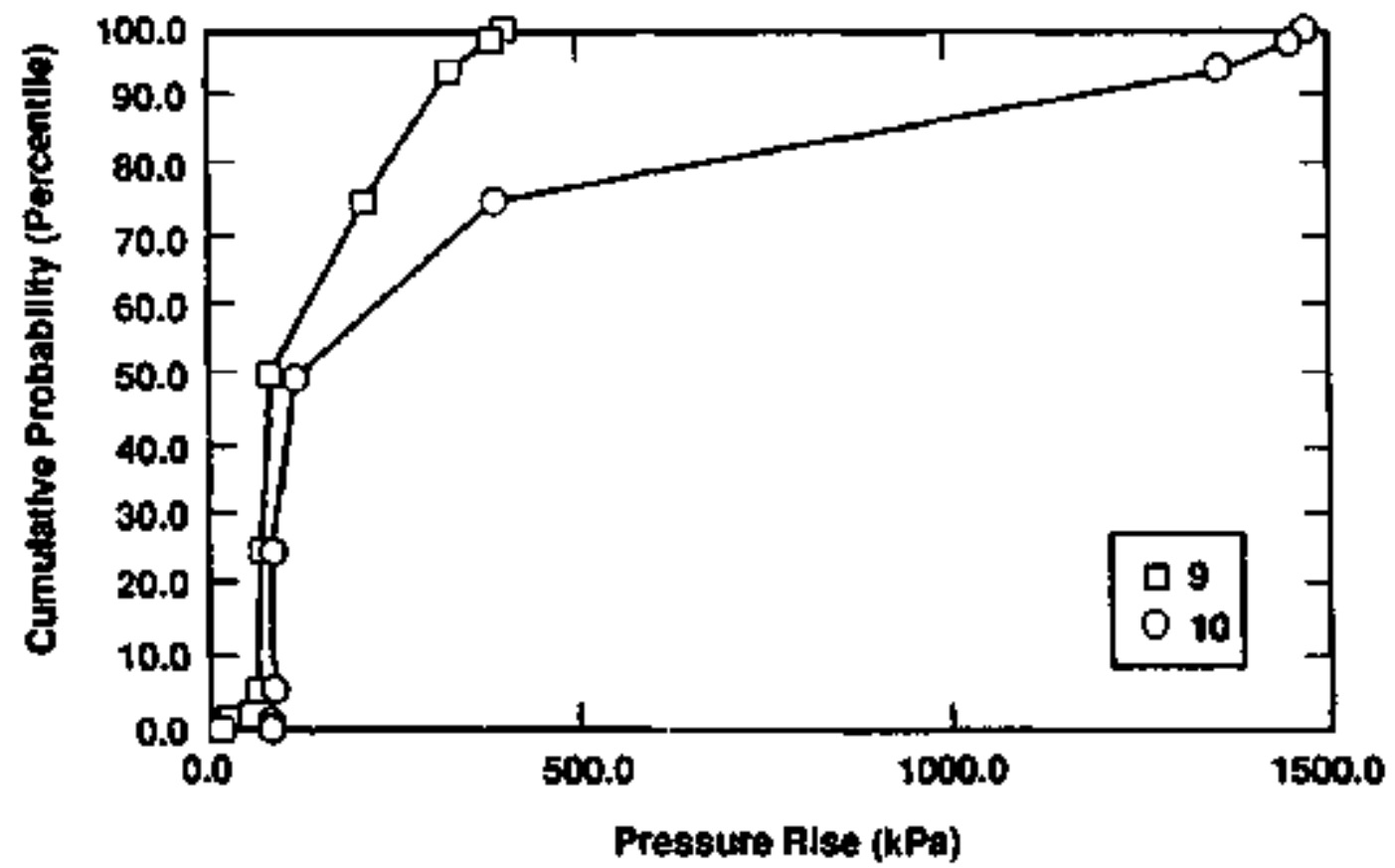

Figure 5-5. RCS Low Presgure; Lesg Than 200 psia (Curves $9 \& 10$ ). 
Table 5.2

Aggregate for Internedfate Pressure Cases

\begin{tabular}{|c|c|c|c|c|c|c|c|}
\hline curve & Eress & Core $\mathbf{F}$ & Ice & Hole & Gayity & Prex- $\mathrm{H}_{2}$ & Zrex \\
\hline $\begin{array}{l}1 \\
2 \\
3\end{array}$ & $\begin{array}{l}\text { Int. } \\
\text { Int. } \\
\text { Int. }\end{array}$ & $\begin{array}{l}\text { High } \\
\text { Med, } \\
\text { Low }\end{array}$ & $\begin{array}{l}Y \\
Y \\
Y\end{array}$ & $\begin{array}{l}\cdots \\
\therefore\end{array}$ & $\begin{array}{l}\text { Wet } \\
\text { Wet } \\
\text { Wet }\end{array}$ & $\begin{array}{l}\text { Low } \\
\text { Low } \\
\text { Low }\end{array}$ & $\begin{array}{l}- \\
- \\
-\end{array}$ \\
\hline $\begin{array}{l}4 \\
5 \\
6\end{array}$ & $\begin{array}{l}\text { Int. } \\
\text { Int. } \\
\text { Int. }\end{array}$ & $\begin{array}{c}\text { High } \\
\text { Med. } \\
\text { Low }\end{array}$ & $\begin{array}{l}\mathbf{Y} \\
\mathbf{Y} \\
\mathbf{Y}\end{array}$ & $\begin{array}{l}\text { Lrg. } \\
\text { Lrg. } \\
\text { Lrg }\end{array}$ & $\begin{array}{l}\text { Dry } \\
\text { Dry } \\
\text { Dry }\end{array}$ & $\begin{array}{l}\text { Low } \\
\text { Low } \\
\text { Low }\end{array}$ & $\begin{array}{l}\cdots \\
\cdots\end{array}$ \\
\hline $\begin{array}{l}7 \\
8 \\
9\end{array}$ & $\begin{array}{l}\text { Int. } \\
\text { Int. } \\
\text { Int. }\end{array}$ & $\begin{array}{l}\text { High } \\
\text { Med. } \\
\text { Low }\end{array}$ & $\begin{array}{l}\mathbf{Y} \\
\mathbf{Y} \\
\mathbf{Y}\end{array}$ & $\begin{array}{l}\text { Sm. } \\
\text { Sr . } \\
\text { Sn. }\end{array}$ & $\begin{array}{l}\text { Dry } \\
\text { Dry } \\
\text { Dry }\end{array}$ & $\begin{array}{l}\text { Low } \\
\text { Low } \\
\text { Low }\end{array}$ & $\begin{array}{l}- \\
-\end{array}$ \\
\hline $\begin{array}{l}10 \\
11 \\
12\end{array}$ & $\begin{array}{l}\text { Int. } \\
\text { Int. } \\
\text { Int. }\end{array}$ & $\begin{array}{l}\text { High } \\
\text { Ned. } \\
\text { Low }\end{array}$ & $\begin{array}{l}Y \\
y \\
y\end{array}$ & $\begin{array}{c}\mathbf{L r g} \\
\ldots \\
\cdots\end{array}$ & $\begin{array}{l}\text { Wet } \\
\text { Wet } \\
\text { Wet }\end{array}$ & $\begin{array}{l}\text { High } \\
\text { High } \\
\text { High }\end{array}$ & $\begin{array}{l}\because \\
\cdots\end{array}$ \\
\hline $\begin{array}{l}13 \\
14\end{array}$ & $\begin{array}{l}\text { Int. } \\
\text { Int. }\end{array}$ & $\begin{array}{l}\text { High } \\
\text { High }\end{array}$ & $\begin{array}{l}y \\
Y\end{array}$ & $\begin{array}{l}\text { Sat. } \\
\text { Sin. }\end{array}$ & $\begin{array}{l}\text { Wet } \\
\text { Wet }\end{array}$ & $\begin{array}{l}\text { High } \\
\text { High }\end{array}$ & $\begin{array}{l}\text { High } \\
\text { Low }\end{array}$ \\
\hline $\begin{array}{l}15 \\
16 \\
17\end{array}$ & $\begin{array}{l}\text { Int. } \\
\text { Int. } \\
\text { Int. }\end{array}$ & $\begin{array}{c}\text { High } \\
\text { Hed. } \\
\text { Low }\end{array}$ & $\begin{array}{l}\mathbf{Y} \\
\mathbf{Y} \\
\mathbf{Y}\end{array}$ & $\begin{array}{l}\text { Lrg. } \\
\text { Lrg. } \\
\text { Lrg. }\end{array}$ & $\begin{array}{l}\text { Dry } \\
\text { Dry } \\
\text { Dry }\end{array}$ & $\begin{array}{l}\text { High } \\
\text { Hi gh } \\
\text { HI gh }\end{array}$ & $\begin{array}{l}\text { HIgh } \\
\text { HIgh } \\
\text { HIgh }\end{array}$ \\
\hline $\begin{array}{l}18 \\
19 \\
20\end{array}$ & $\begin{array}{l}\text { Int. } \\
\text { Int. } \\
\text { Int. }\end{array}$ & $\begin{array}{c}\text { H1gh } \\
\text { Hed. } \\
\text { Low }\end{array}$ & $\begin{array}{l}\mathbf{Y} \\
\mathbf{Y} \\
\mathbf{Y}\end{array}$ & $\begin{array}{l}\operatorname{Lrg} . \\
\operatorname{Lrg} . \\
\operatorname{Lrg} .\end{array}$ & $\begin{array}{l}\text { Dry } \\
\text { Dry } \\
\text { Dry }\end{array}$ & $\begin{array}{l}\text { High } \\
\text { High } \\
\text { High }\end{array}$ & $\begin{array}{l}\text { Low } \\
\text { Low } \\
\text { Low }\end{array}$ \\
\hline $\begin{array}{l}21 \\
22 \\
23\end{array}$ & $\begin{array}{l}\text { Int. } \\
\text { Int. } \\
\text { Int. }\end{array}$ & $\begin{array}{c}\text { High } \\
\text { Med. } \\
\text { Low }\end{array}$ & $\begin{array}{l}\mathbf{Y} \\
\mathbf{Y} \\
\mathbf{Y}\end{array}$ & $\begin{array}{l}\text { Sm. } \\
\text { Su. } \\
\text { Sm. }\end{array}$ & $\begin{array}{l}\text { Dry } \\
\text { Dry } \\
\text { Dry }\end{array}$ & $\begin{array}{l}\text { High } \\
\text { High } \\
\text { High }\end{array}$ & $\begin{array}{l}- \\
- \\
-\end{array}$ \\
\hline $\begin{array}{l}24 \\
25 \\
26\end{array}$ & $\begin{array}{l}\text { Int. } \\
\text { Int. } \\
\text { Int. }\end{array}$ & $\begin{array}{c}\text { H1gh } \\
\text { Ked. } \\
\text { Low }\end{array}$ & $\begin{array}{l}\mathbf{N} \\
\mathbf{N} \\
\mathbf{N}\end{array}$ & $\begin{array}{l}\cdots \\
\cdots\end{array}$ & $\begin{array}{l}\text { Dry } \\
\text { Dry } \\
\text { Dry }\end{array}$ & $\begin{array}{l}\text { Low } \\
\text { Low } \\
\text { Low }\end{array}$ & $\begin{array}{l}- \\
- \\
=\end{array}$ \\
\hline $\begin{array}{l}27 \\
26 \\
29\end{array}$ & $\begin{array}{l}\text { Int. } \\
\text { Int. } \\
\text { Int. }\end{array}$ & $\begin{array}{l}\text { H1gh } \\
\text { Hed. } \\
\text { Low }\end{array}$ & $\begin{array}{l}\mathbf{N} \\
\mathbf{N} \\
N\end{array}$ & $\begin{array}{c}\mathrm{Lrg}+ \\
-- \\
-\end{array}$ & $\begin{array}{l}\text { Dry } \\
\text { Dry } \\
\text { Dry }\end{array}$ & $\begin{array}{l}\text { HIgh } \\
\text { HIgh } \\
\text { High }\end{array}$ & $\begin{array}{l}\cdots \\
\cdots \\
\cdots\end{array}$ \\
\hline $\begin{array}{l}30 \\
31\end{array}$ & $\begin{array}{l}\text { Int } \\
\text { Int. }\end{array}$ & $\begin{array}{l}\text { HIgh } \\
\text { HIgh }\end{array}$ & $\begin{array}{l}\mathrm{N} \\
\mathrm{N}\end{array}$ & $\begin{array}{l}\text { Sn. } \\
\text { Sin. }\end{array}$ & $\begin{array}{l}\text { Dry } \\
\text { Dry }\end{array}$ & $\begin{array}{l}\text { High } \\
\text { High }\end{array}$ & $\begin{array}{l}\text { High } \\
\text { Low }\end{array}$ \\
\hline
\end{tabular}


Table 5-2 (continued)

\begin{tabular}{|c|c|c|c|c|c|c|c|c|c|c|c|}
\hline \multirow[t]{2}{*}{ Surts. } & \multicolumn{11}{|c|}{ 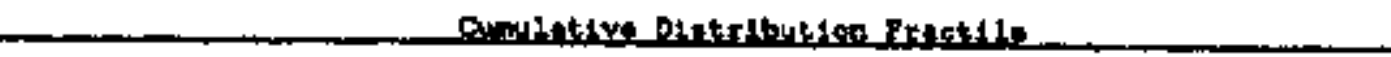 } \\
\hline & at & & $1 \mathbf{x}$ & L. & $5 \%$ & 251 & s. & 752 & 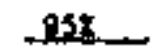 & 928 & 1000) \\
\hline 1 & 34 & 0 & $38:$ & 9 & $5 e .7$ & 1265 & 225.0 & 458.6 & 220.0 & 015.4 & 84.3 \\
\hline $\boldsymbol{z}$ & 22 & 8 & 27.8 & & 48.5 & 2073 & 1024 & 321.2 & 334.8 & $60 \$ .3$ & 426.7 \\
\hline $\mathbf{1}$ & Is & 4 & 233 & 3 & 54 & BS 2 & 130 & 2500 & 102 & 4007 & 4061 \\
\hline 4 & 37 & $s$ & $46:$ & 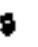 & 3. 3 & $2+1.7$ & $384+$ & 4960 & (601). & 916.3 & 071.0 \\
\hline 3 & 25 & 1 & 11.3 & & 363 & 1042 & 204.0 & 375.8 & 518.2 & 621.4 & 847,2 \\
\hline 6 & 14 & 9 & 108 & 8 & 34 & 1121 & 179 & 2251 & 3050 & 3720 & 300.5 \\
\hline 7 & 30. & & $\$ 7.5$ & & 67.5 & 171.7 & 3013 & 404,5 & 640.6 & 7464 & 780.3 \\
\hline $\mathbf{E}$ & 20. & & 23.0 & & 45.0 & 137.2 & 2262 & 209.2 & 402.2 & $\$ 12.7$ & 525.3 \\
\hline 9 & 22 & + & 257 & 7 & 28.0 & on 4 & 1453 & 1006 & $2 \pi$ & 3176 & 3275 \\
\hline 10 & 43 & 8 & 52 & 8 & $13 \mathrm{~B}$ & 117 & $28+9$ & $5,5,2$ & 2650 & $\$ 28.8$ & 0695 \\
\hline 11 & +3. & & 476 & & 64.1 & 130.2 & $20+6$ & 3556 & 5404 & 632.1 & 653.0 \\
\hline 12 & 25 & s & 332 & 2 & 62,6 & op. 6 & 2404 & 2763 & +221 & +82.8 & 5102 \\
\hline 13 & 45. & & 50 & $\bullet$ & 70. & 344.0 & 2592 & 4010 & $700 \mathrm{~s}$ & $864 \mathrm{e}$ & 005.8 \\
\hline 14 & 43 & 8 & 103 & 3 & $67 \mathrm{~B}$ & t35. 7 & 221.4 & 4550 & 800. & $\$ 67.7$ & 6840 \\
\hline 15 & 95 & 5 & 106 & 4 & 1500 & 280,5 & 412.8 & 5322 & 128,7 & 954.4 & to:0.0 \\
\hline 16 & $\mathbf{8 B}$ & 7 & 076 & 6 & 233.9 & 235.3 & 318,0 & 3003 & 5250 & 682.9 & 723.5 \\
\hline 17 & 46 & 7 & 520 & 0 & 720 & 1320 & 191 & 2323 & 3002 & 403.2 & 4267 \\
\hline 18 & 67 & 5 & 00,3 & & 2301 & 2465 & 405.7 & \$20. & 727,5 & 043.0 & $007+a$ \\
\hline 10 & 32 & • & 45.0 & & $93 \mathrm{~s}$ & 200.0 & 304.1 & 302.6 & 322.7 & 682,5 & 697.5 \\
\hline 10 & Jo & $\mathbf{a}$ & 25 & 7 & 350 & 1200 & 1045 & $228 . J$ & $300 \mathrm{D}$ & 3025 & 4136 \\
\hline $\mathbf{z l}$ & 58. & & 102 & 2 & $123 \mathrm{~B}$ & 218.9 & 3250 & 431. 8 & 628.6 & 7810 & 705.7 \\
\hline 22 & 34 & 0 & 4 & a & 901 & 134.6 & 2431 & 3005 & 467.0 & S43 & 3620 \\
\hline 23 & 19 & + & $2 \mathrm{E}$ & 7 & 550 & $\theta \omega .0$ & 1500 & 2910 & $290 \mathrm{E}$ & 3332 & 3403 \\
\hline $2 n$ & 25. & & 97 & 5 & at 4 & $253+$ & 430.6 & 8ts 3 & 1000 & $220) 1$ & 2236 \\
\hline 25 & 17 & 0 & 23 & 0 & 371 & 1012 & 316,7 & 162.7 & 5312 & 0243 & 0476 \\
\hline 25 & 10 & 6 & 15 & 7 & 361 & 1216 & 3896 & 2780 & 4218 & 533 & 5480 \\
\hline 27 & 50 & $B$ & 72. & & 158 & 341.6 & 597.3 & $16+0$ & 11126 & 3228 & 12340 \\
\hline 28 & 24 & 7 & 44 & 6 & 1242 & 2530 & 3030 & $310 \%$ & 03: 1 & 9242 & at 5 \\
\hline 20 & 14 & 4 & 25 & 5 & $B \theta E$ & 1320 & $222 B$ & 206.0 & 472.6 & 5334 & 5480 \\
\hline 30 & el & 1 & $90:$ & 2 & 1685 & 343.4 & 5821 & 720.0 & 1005 5 & 12065 & 12383 \\
\hline 31 & 32 & 3 & $54:$ & 3 & 142 & 3130 & 5021 & 684 & 10403 & 12081 & 12366 \\
\hline
\end{tabular}




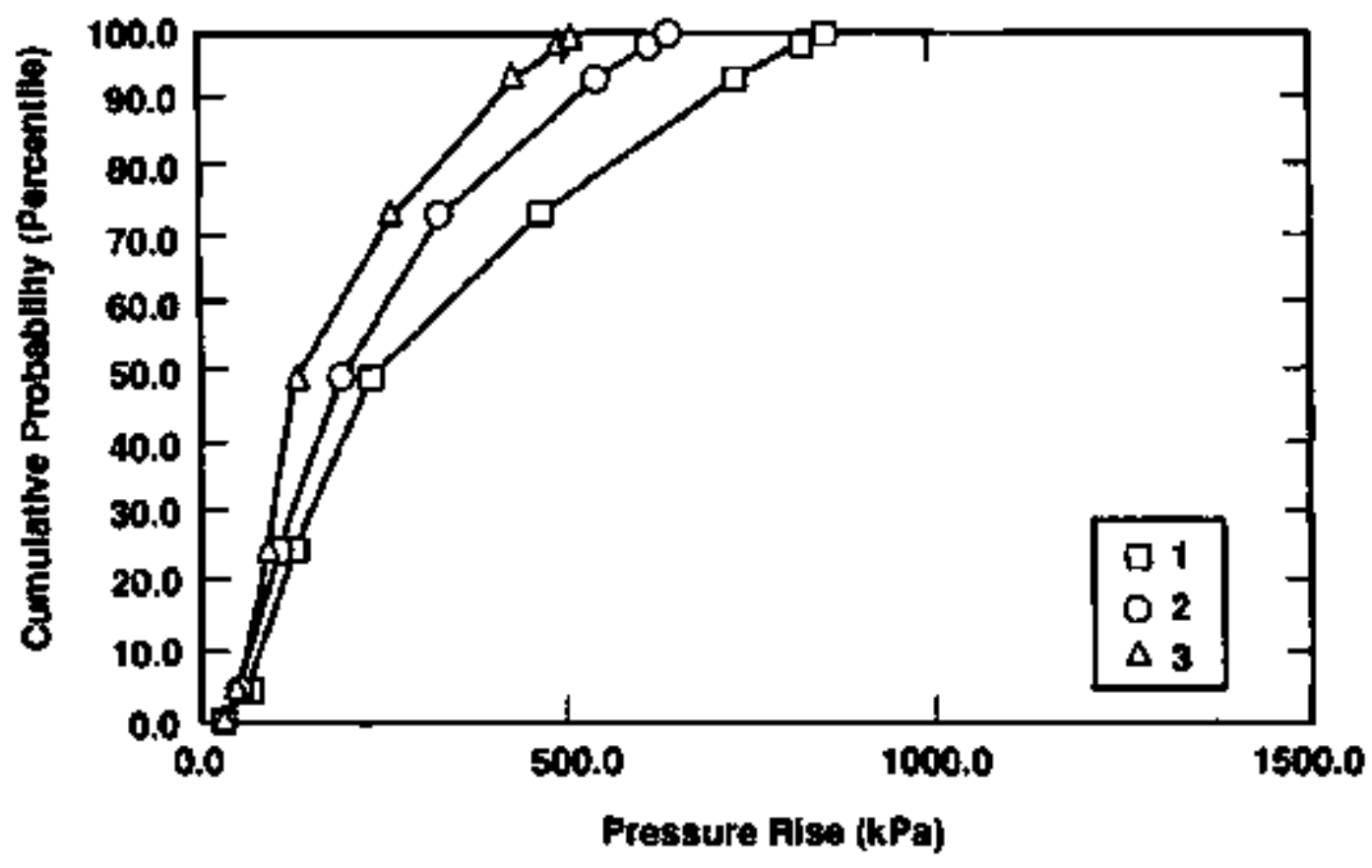

Figure 5-6. RCS Intermediate Pressure: 500 to 1000 psia (Gurves 1, 2, 3).

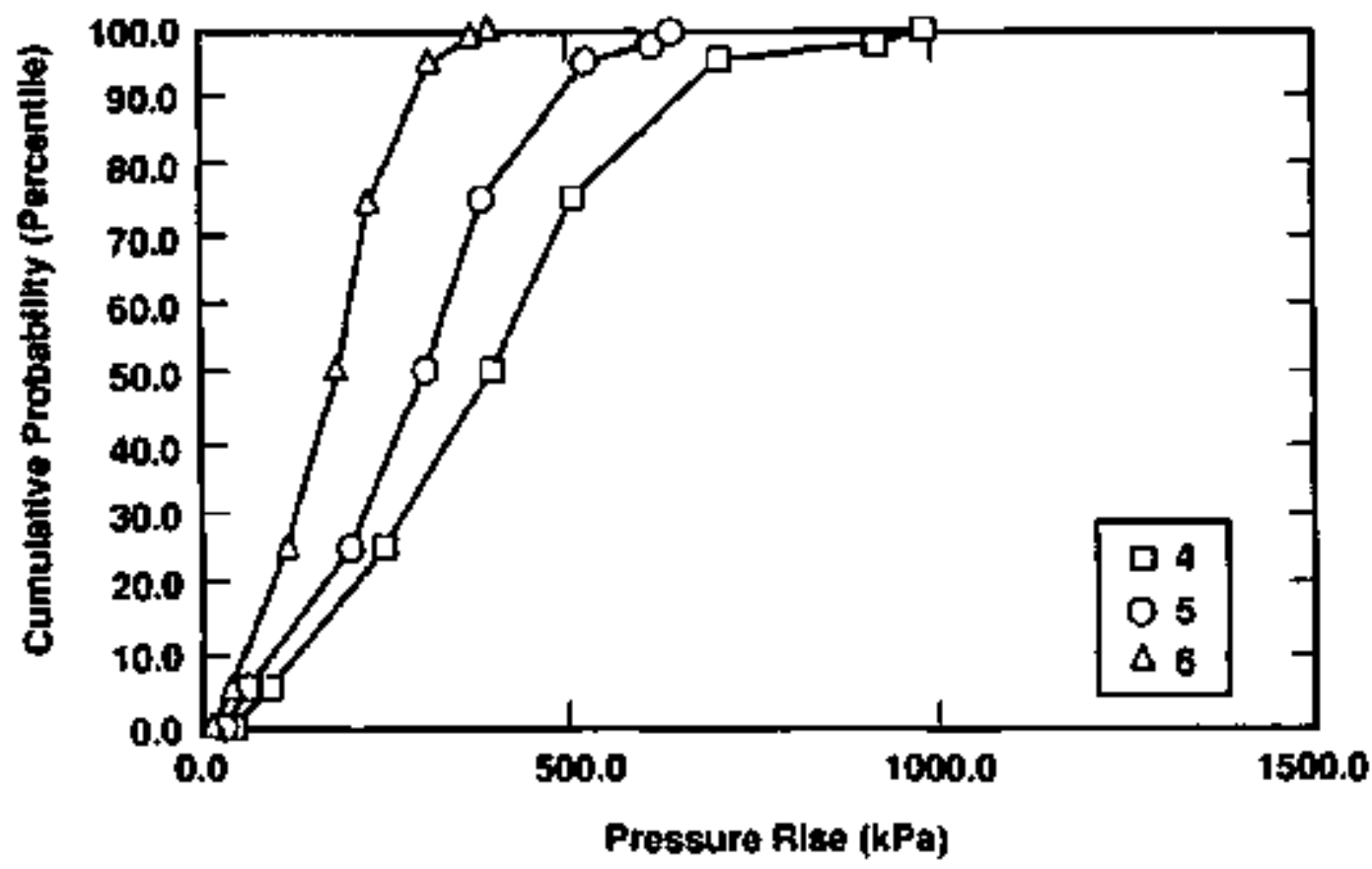

Figure 5.7. RCS Iutcracdiate Pressure- 900 to 1000 psia (Cuvu, 4, 5, 6) 


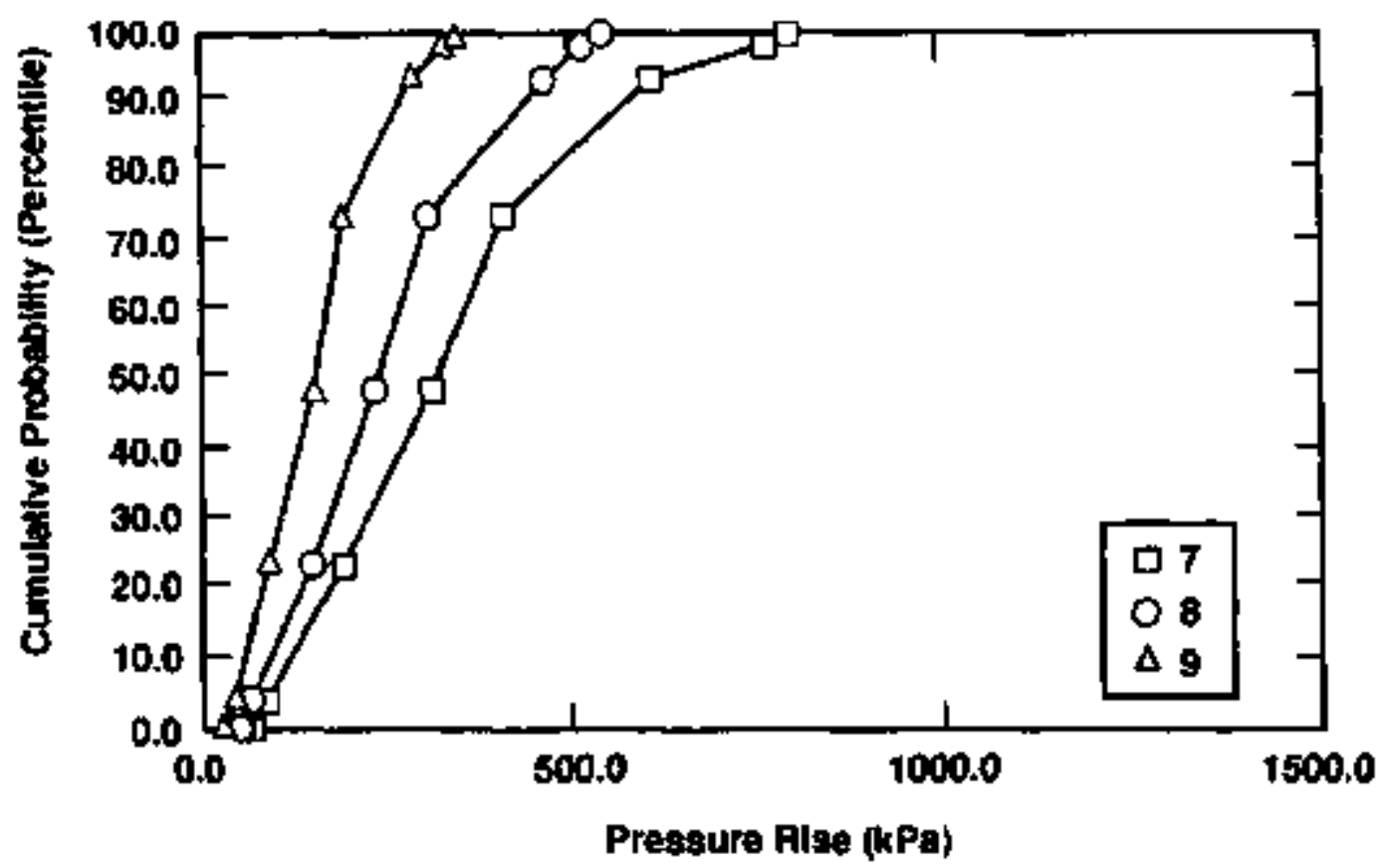

Figure 5-8. RCS Intermediate Pressure: 500 to 1000 psta (Curves 7, 8, 9).

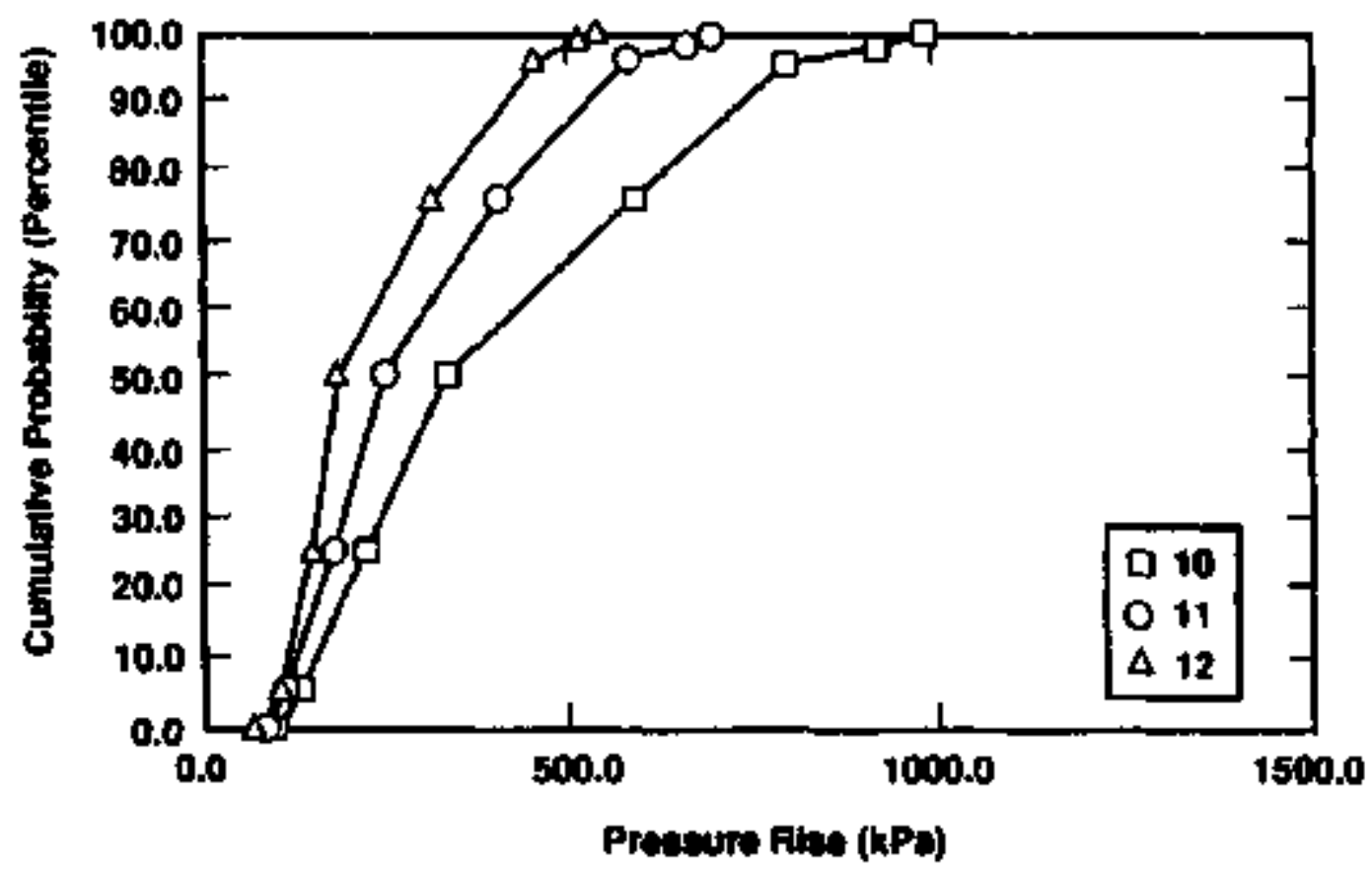

Figure 5-9. RCS Interaediate Pressure: 500 to 1000 psia (Curves 10, 11, 12). 


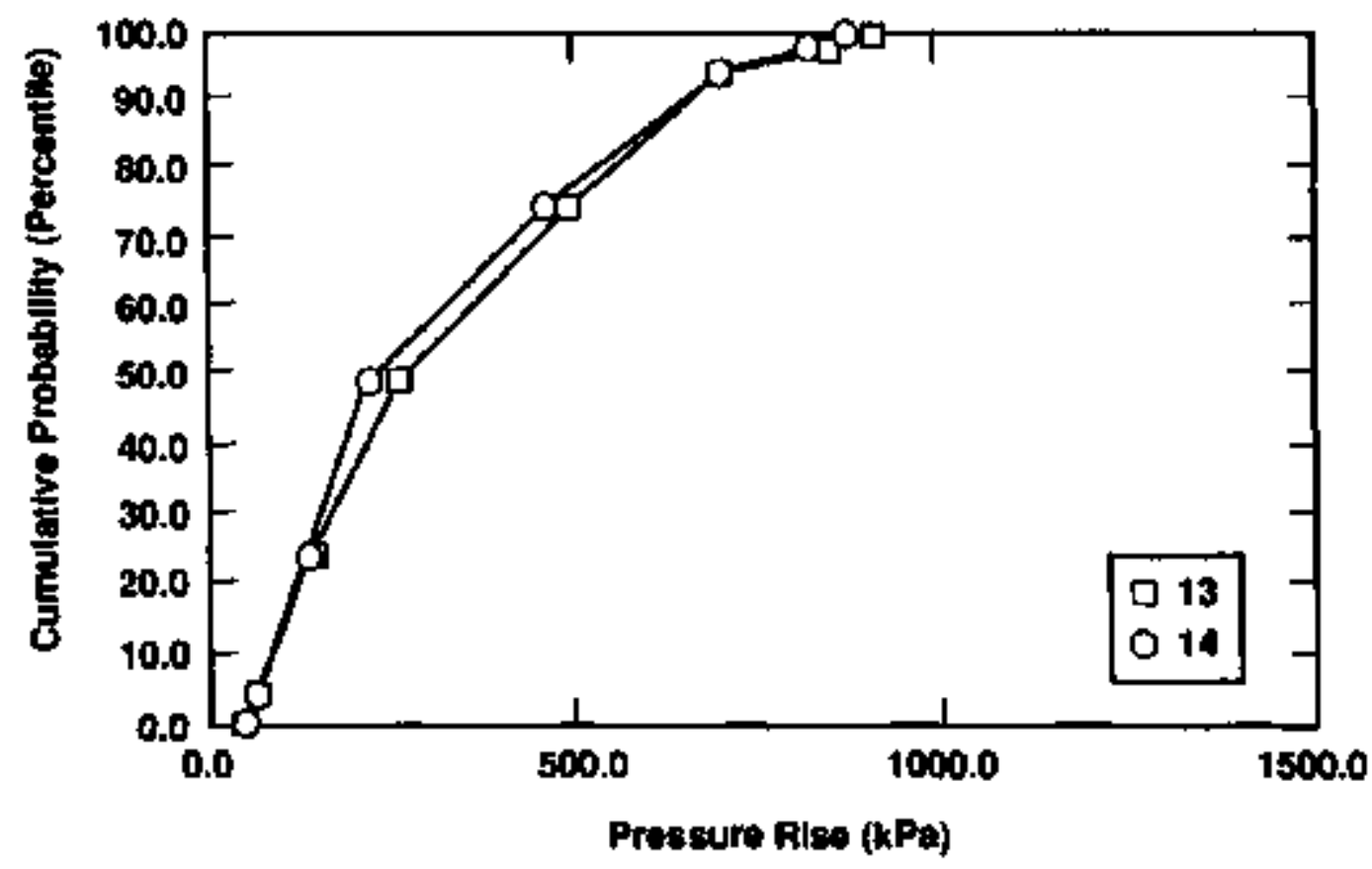

Figure 5-10, RCS Intermediate Pressure:) 500 to 1000 psia (Curves 13,14 ).

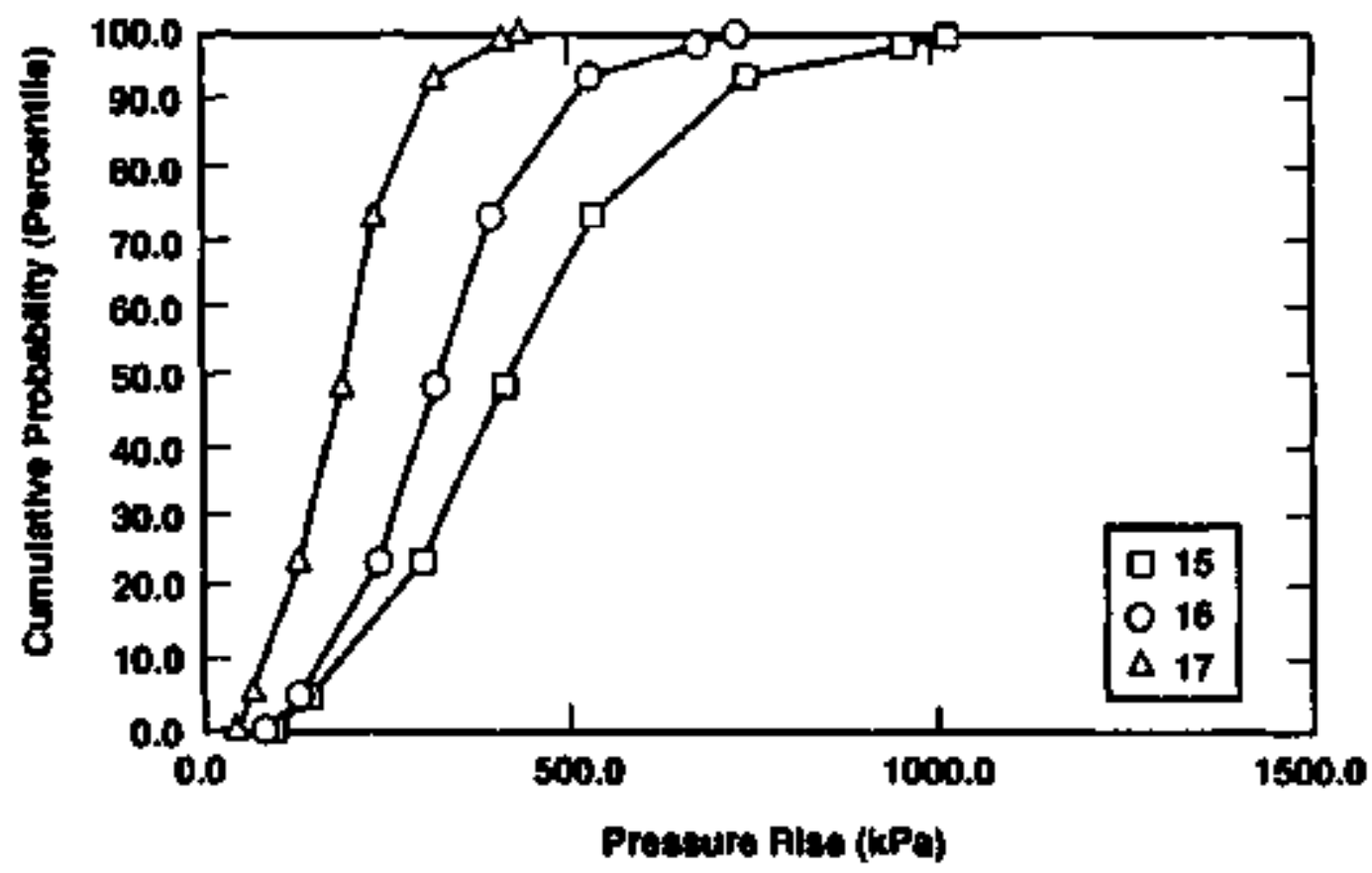

Figure 5.11. RCS Intermediate Pressure: 500 to 1000 psta (Curves 15, 16, 17). 


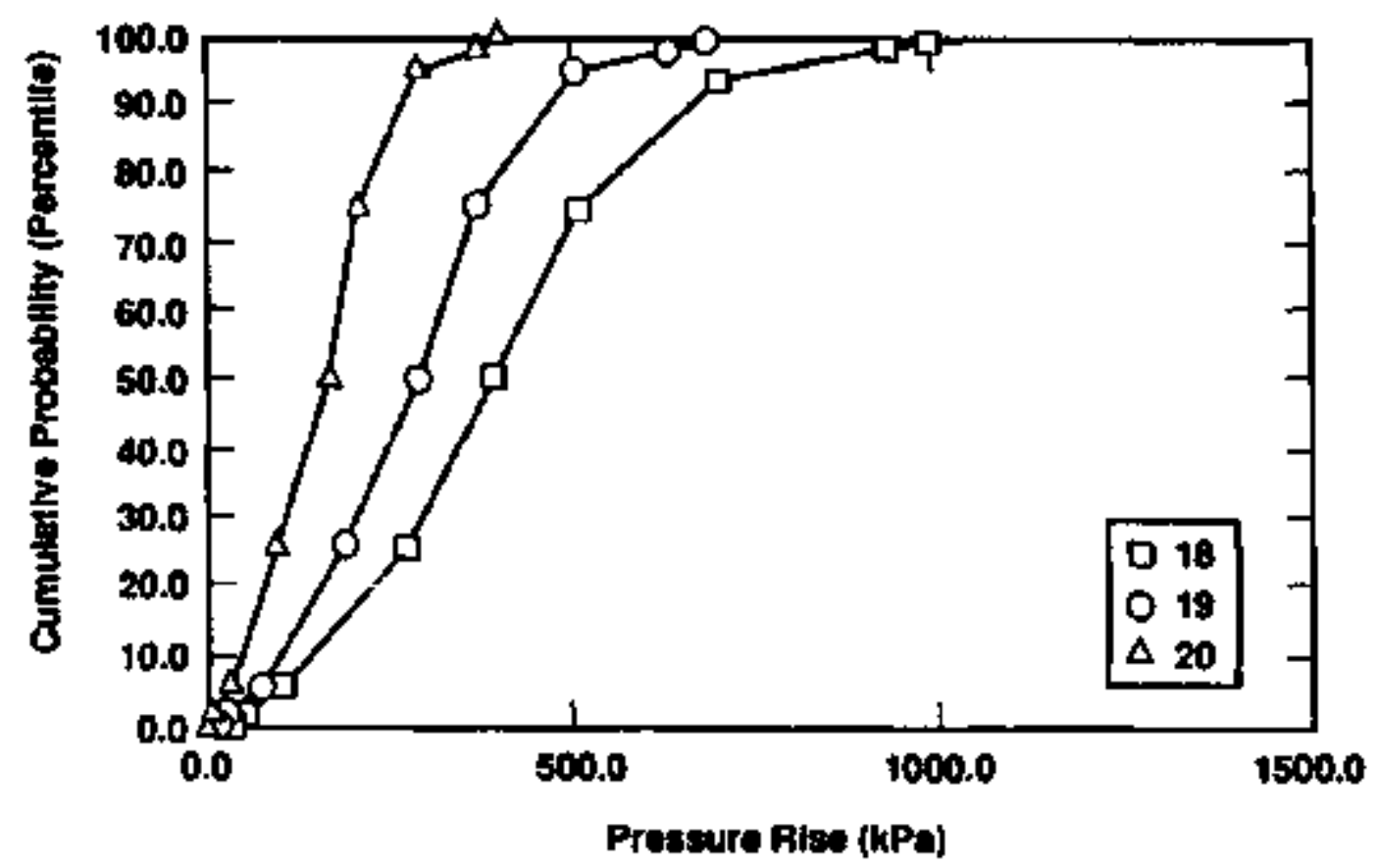

Figure 5-12. RCS Internediate Pressure: 500 to 1000 psia (Curves 18, 19, 20).

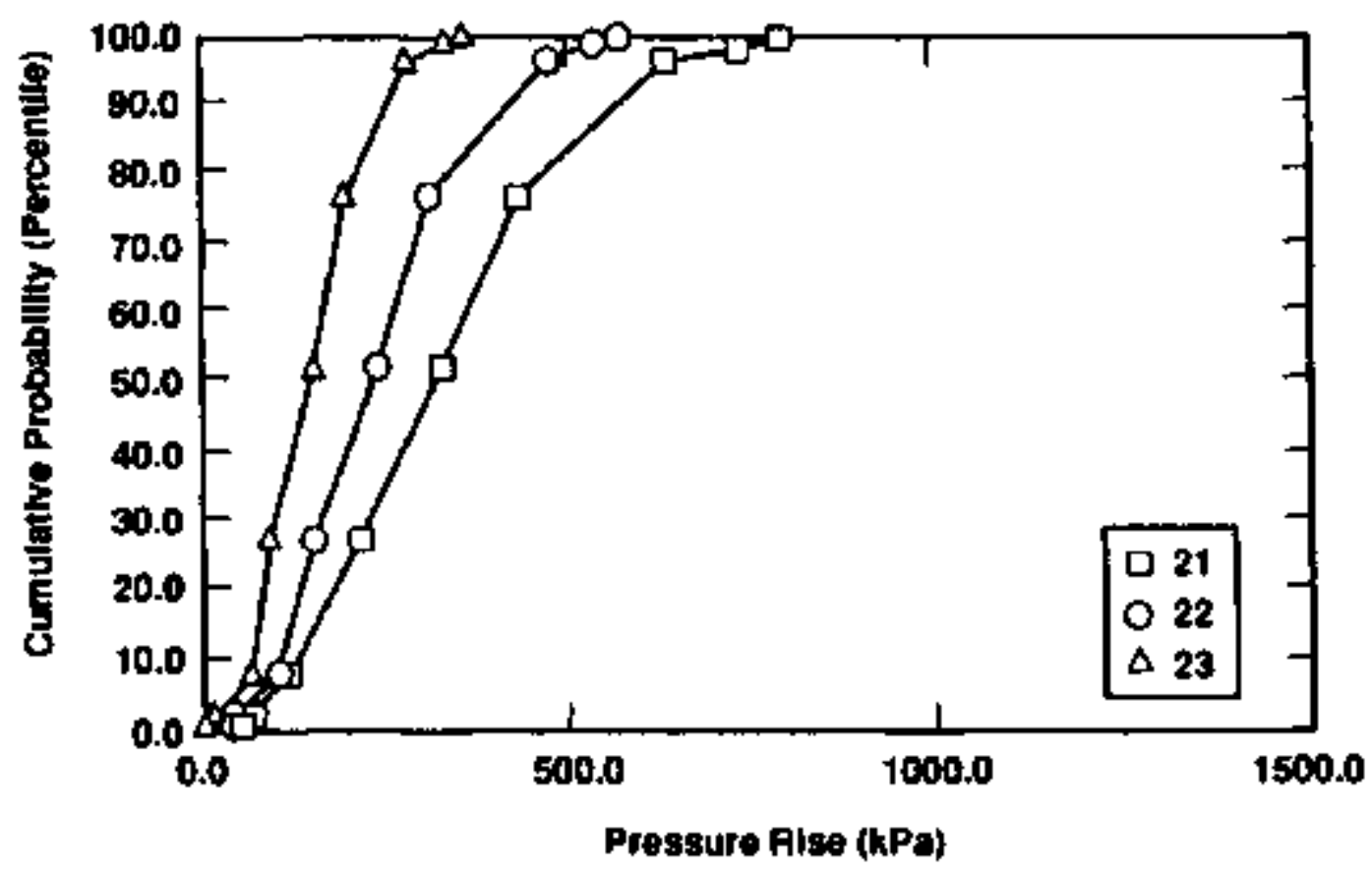

Figure 5-13. RCS Internediate Pressure: 500 to 1000 psia (Curves 21, 22, 23). 


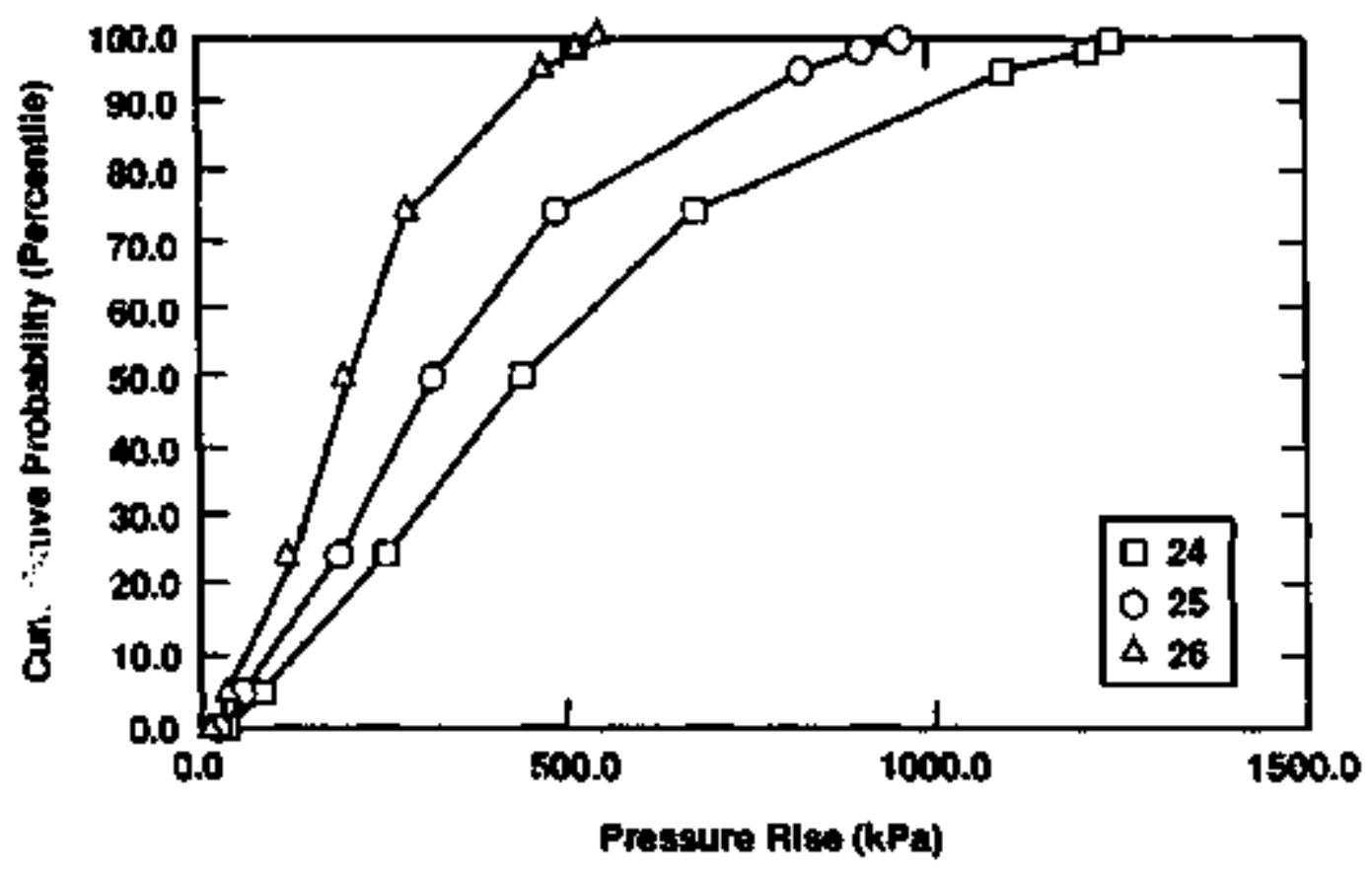

Figure 5-14. RCS Intermediate Pressure: 500 to 1000 psis (Curves 24, 25, 26).

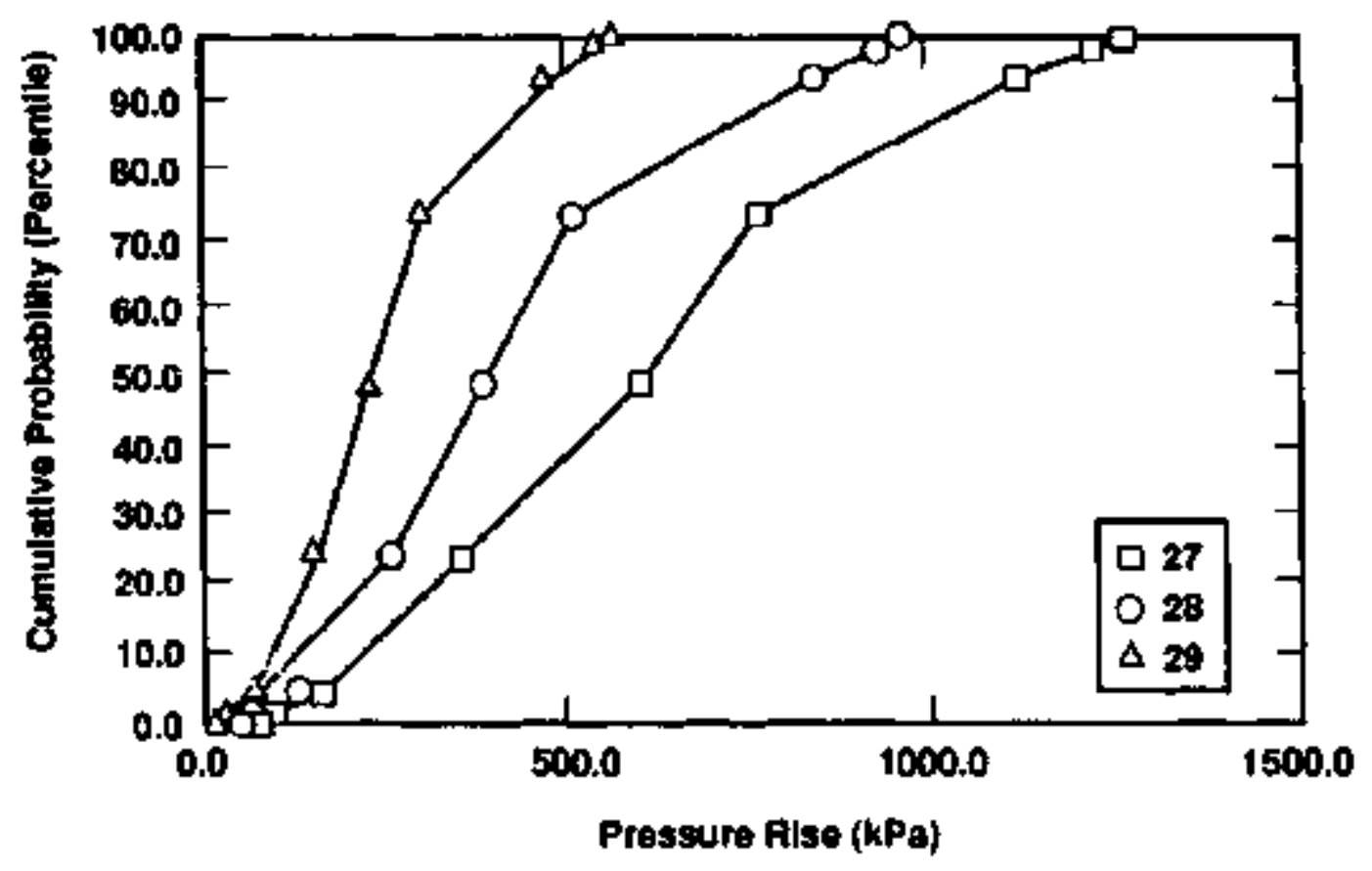

Figure 5-15, RCS Intermediate Pressure: 500 to I000 puia (Curves 27, 28, 24). 


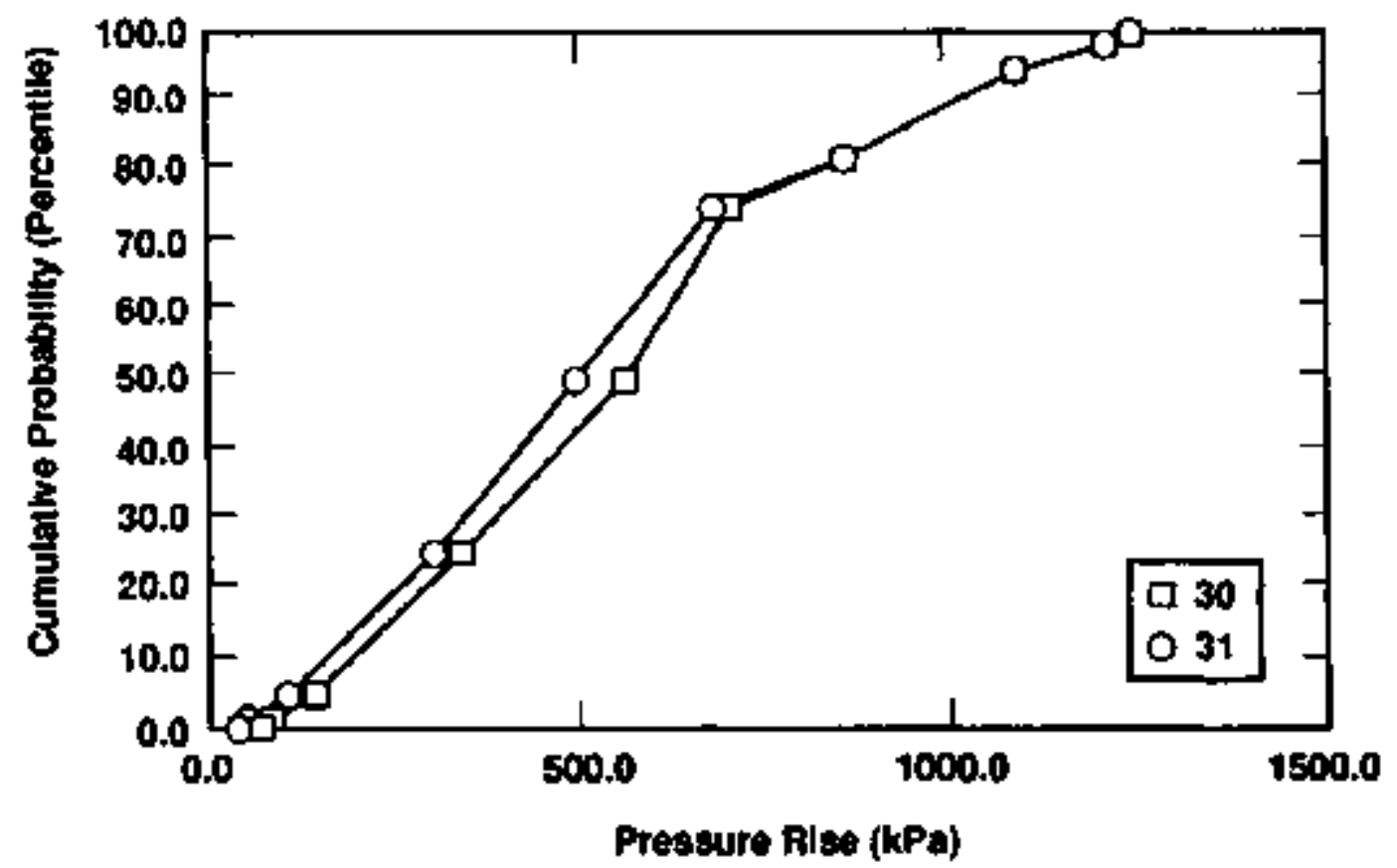

Figure 5-16. RCS Interaediate Pressure: 500 to 1000 psia (Curves 30, 31). 
Table 5.3

Aggregate for High Pressure Cases

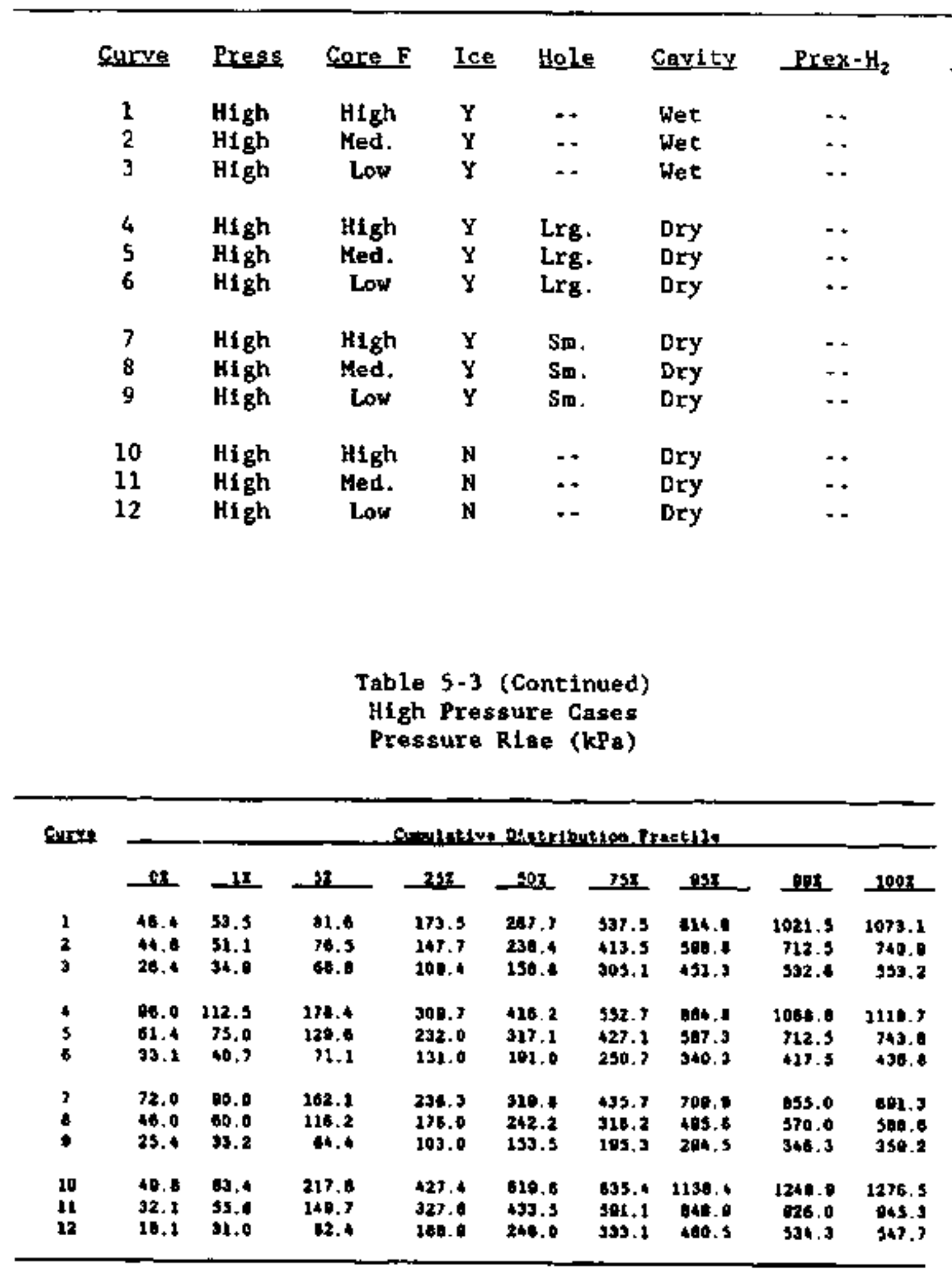




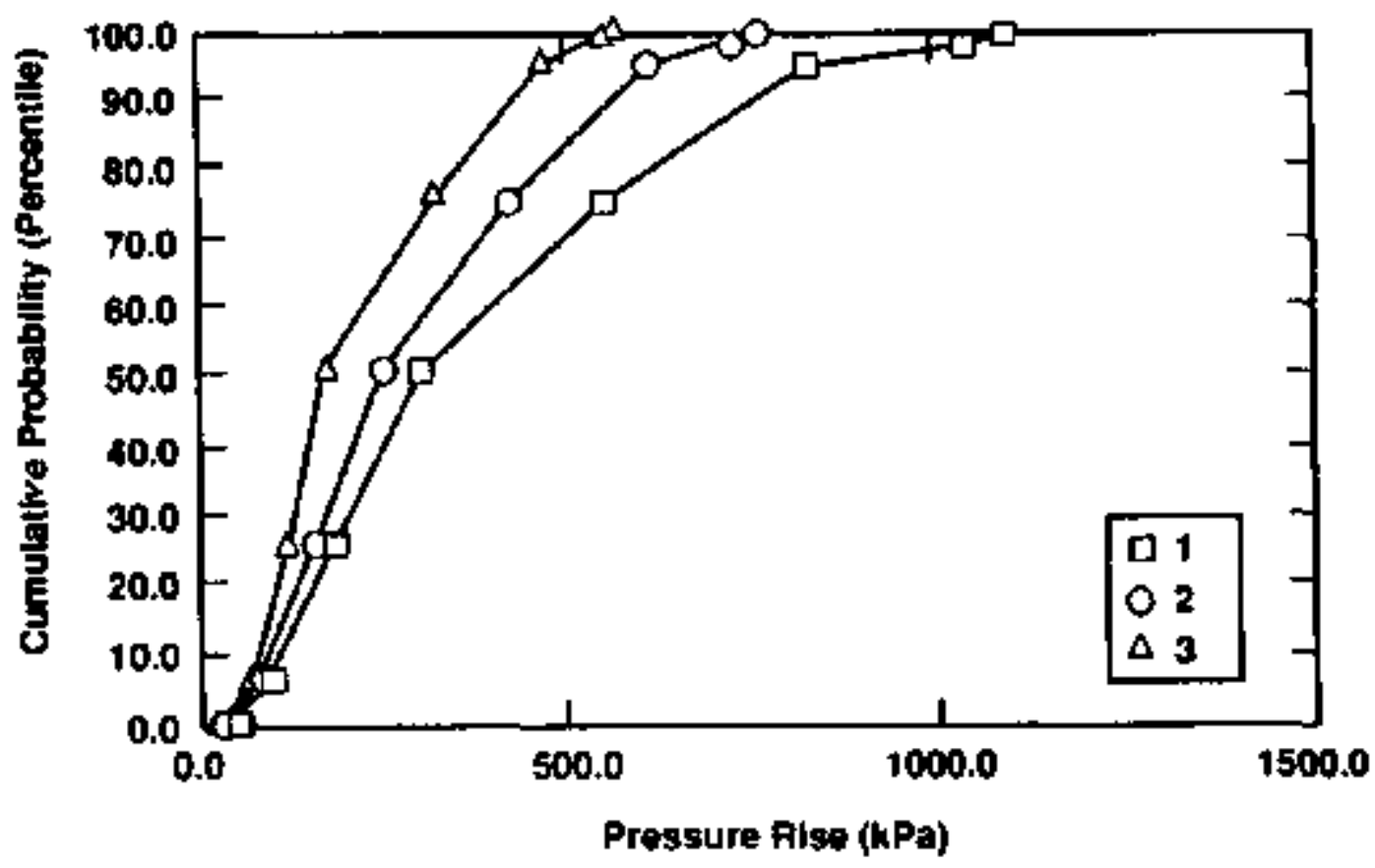

Figure 5-17, RCS High Pressure: 2000 to 2500 psia (Curves 1, 2, 3).

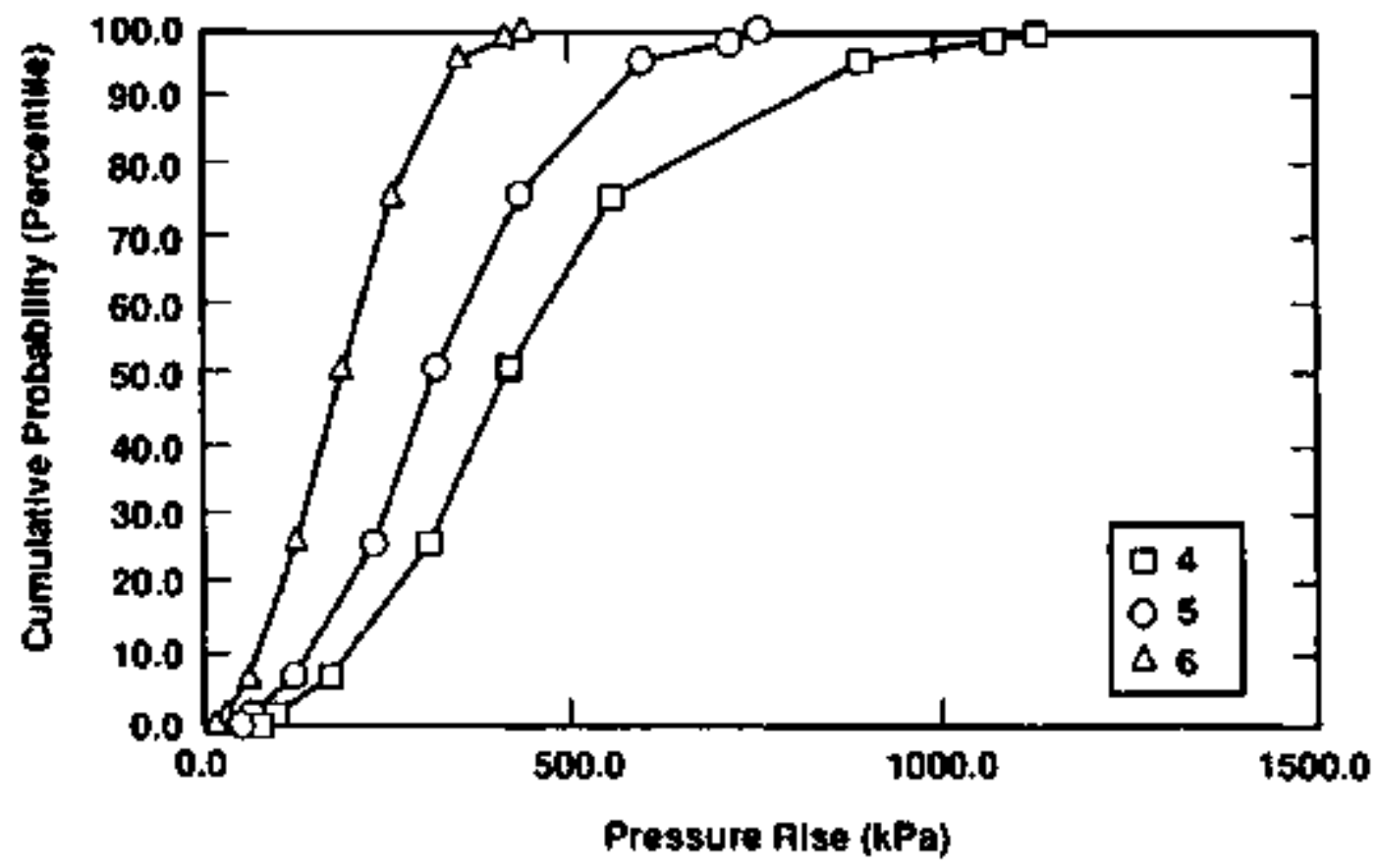

Figure S-18. RCS High Pressure: 2000 to 2500 psia (Curves 4, 5, 6). 


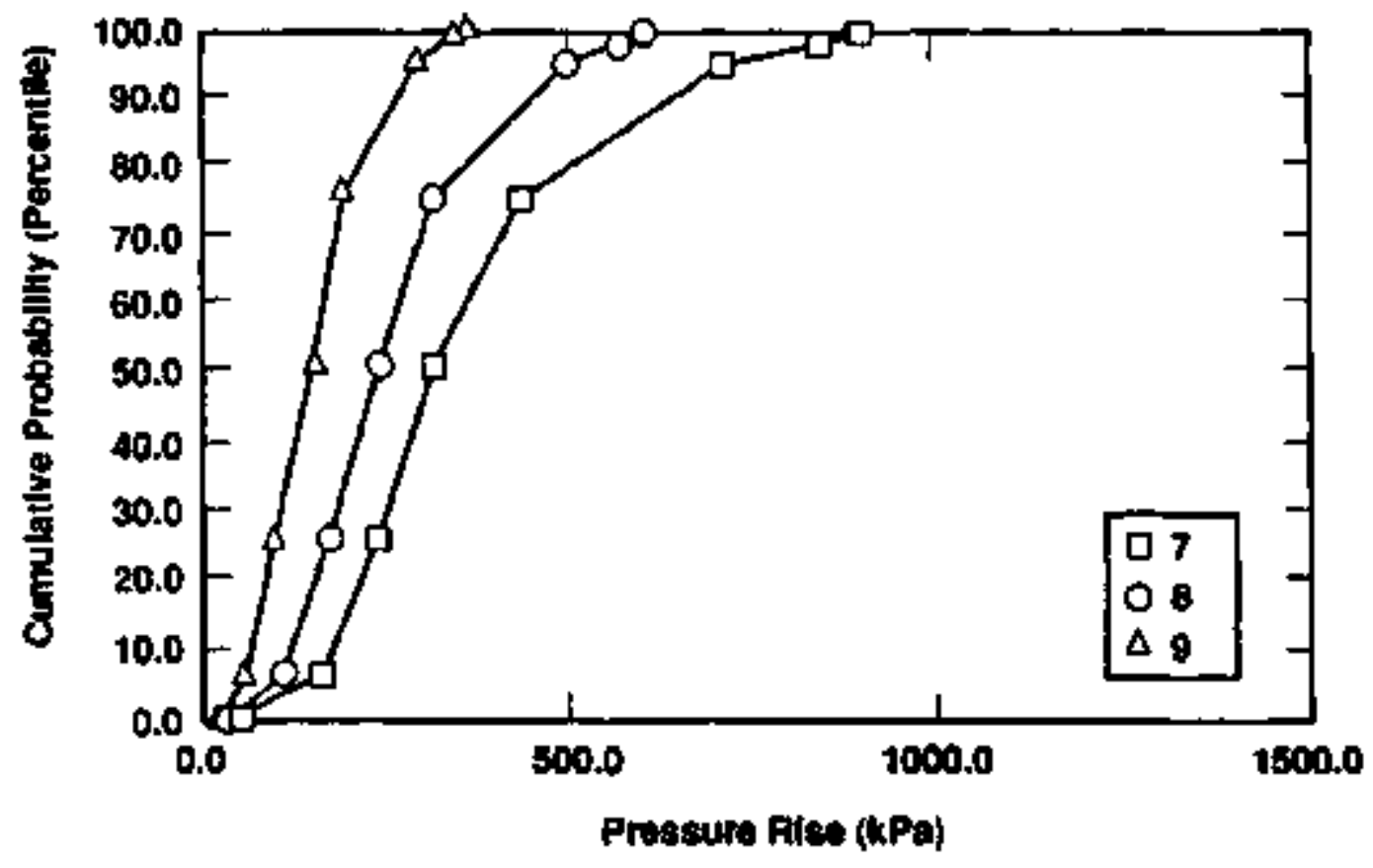

Figure 5-19. RCS High Pressure: 2000 to 2500 psia (Curves 7, 8, 9).

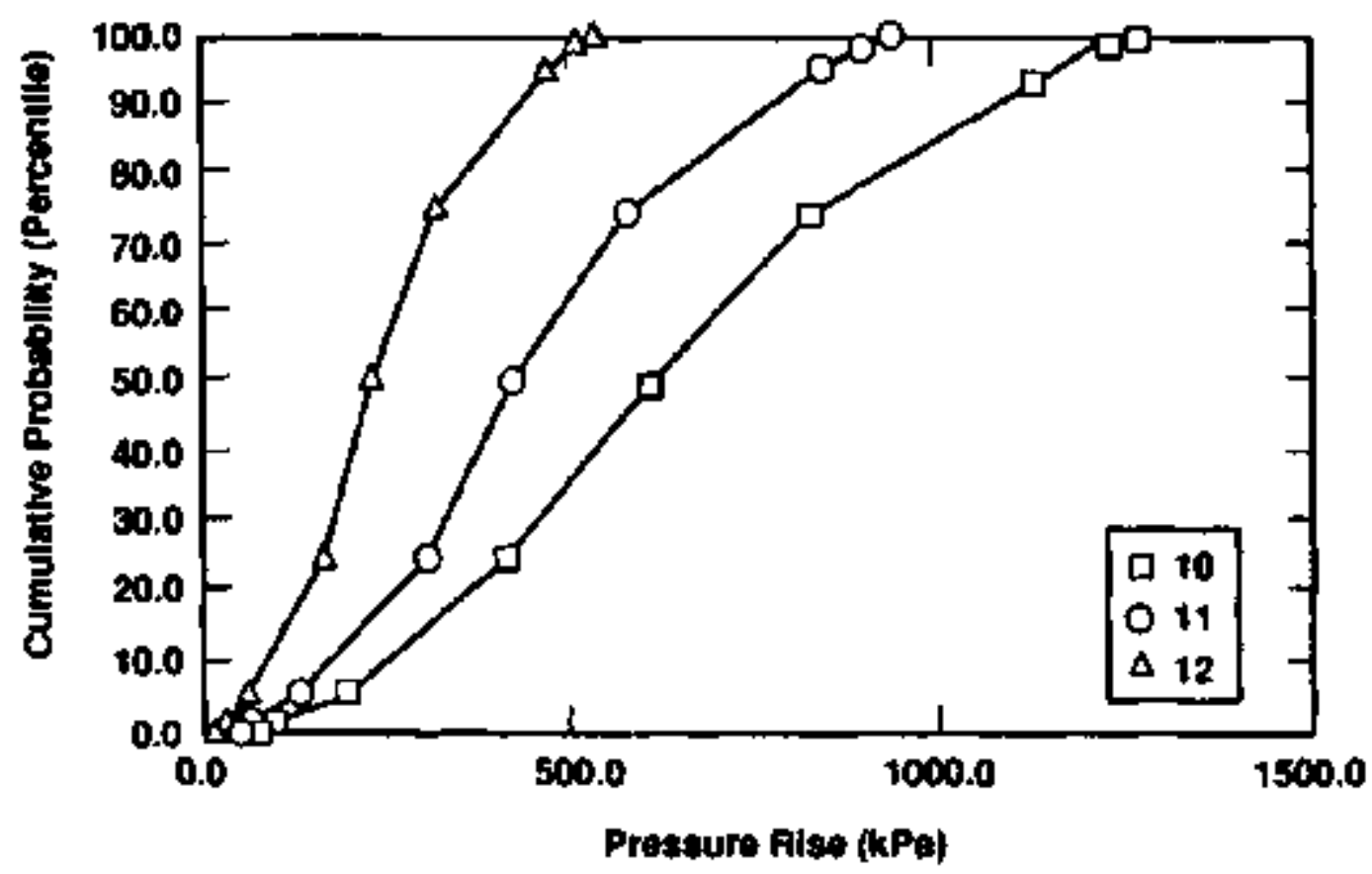

Figure 5-20, RCS High Pressure: 2000 to 2500 fsia (Curves 10, 11, 12), 
Individual Elficitations for Issue 5

$5.5 \cdot 21$ 


\section{Expert A's Elicitation}

\section{Issu* 5: Prossure Increment in the Sequoyah Contalnment at Vessel Breach}

\section{Description of Expert A's Rarionale/Methodolopy}

Expert A used References A-1 to A-17. With main emphasis for the 1saue quantification on NUREG/CR-4896A-1 and its update," EPRI NP-5127, ${ }^{A-2}$ and results of the Surtsey DCH experiments. ${ }^{-3}$ to $A^{-B}$ Although there were some calculations for reference or extrapolation to most of the subcases, there was usually only one calculation and no data. This necessitated that judgment be used for effects of variations in explfic critical parameters in order to determine distributions for the subcases.

Expert $A^{\prime} s$ judgnent was that the CoNTAIN calculations with unconditional hydrogen burn approxlmate an upper bound pressure rise for the following phenomenological reasons:

1. All debris is assured to be finely particulated and available for DCH upon entering the jower compartment; however, sone debris can enter the compartment in a wavelike manner and transfer little energy to the atmosphere;

2. As a consequence of the previous reason, hydrogen generstion is lower when interactions with the atmosphere are limitad;

3. The presence of atructures in the lower compartment and the geometry of the ice condenser inlets appear to proclude transport of significant quantities of debris into the ice condenser;

4. As a consequence of the previous reason, very little debris can be expected to enter the upper compartment; and

5. Since debris will be mostly confined to the lower compartment, heat transfer from debris will be limited by the high temperatures attalned by the gas and hydrogen generation will be limited by the availabllity of steam relative to cases in which debris can be transported outside the lower compartment.

Expert A noted that updated calculations ${ }^{\star}$ with a $9 \cdot c e l l$ model of Sequoyab lead to lower pressutes than those presented in Reference A-l. Thus, the Reference A-l calculations appear to provide an upper bound for DCH predictions. Also mentioned in the update were improvements to the lce condenser heat transter model leading to a geak pressure reduction of about 1.0 atm as compared to that of Reference A-1.

"J. L. Tills, "An Update on Diriet Contaínent lix.ating for Ice Condenser Plants," Sandia National Laboriloories, Albuquerque, NM, 1988. 
Expert A noted a pattern exhlated fn the calculations, that demonstrated that the pressure rise at vessel breach was decomposable into pre-burn and burn inerements. The total pressure rise was expressed, therefore, as the product of the pressure rise ratio $\left(P_{2} / P_{1}\right)_{\text {oms }}$ due to sensible heating and the pressure rise ratto $\left(P_{1} / P_{2}\right)_{\text {burn }}$ as a result of hydrogen burns:

$\mathrm{P}_{t} / \mathrm{P}_{t}-\left(\mathrm{P}_{2} / \mathrm{P}_{1}\right)_{\text {aena }} *\left(\mathrm{P}_{t} / \mathrm{P}_{2}\right)_{\text {burn }}$

The sensible energy is a function of dispersal fraction and is sensitive to the assunption of particulate vs. fllm/wave dispersal. The hydrogen burn pressure rise varies for efected core fractions between 20 and 40 and also with dispersal time. The assessment of Expert A was provided in cerms of pressure rise ratios, and the 1 initial pressure $P_{1}$ was always assuned to be 1.5 bar for the quantification of the issue.

The problem was approached with "base case" assesgments, then the results were adjusted in order to obtain the subcase assesments. The adjustments vere based on sensitfvities to the variables of hole size, presence of water in the cavity, and ice bypass. For Sequoyah, 1n-coce oxidation was not considered, becouse it was considered to be insigniflcant as a sensitivity variable. The effect of core fraction ts incorporated as a variable in the determination of the pressure rise ratios, and was therefore considered inherently in the distributions provided.

It was Expert $A^{\prime} s$ judgment that with respect to RCS pressure at vessel breach, there was no difference between 2000 psia and 2500 psia, given the ather uncertainty involved with the issue. Thus, the results for cases 1 and 2 are provided together. A "base case" was presented for cases $1 \mathrm{la}$ and $2 s, 1, e$, with high pressure, a dry cavity, lee present, and a sall bole (penetration failure) at vessel breach. A "base case" was also presented for Case 3a, with internediate pressure, a dry cavity, lce present, and a small hole at vessel breach. Distributions were not provided for Case 4, because the RCS pressure is too low to disperse significant (1f any) debris. The upper bound was specifled as the 994 percentile and the lower bound was spectfied as the 1 percentile.

\section{Base Cases la and 2a}

Expert A obtalned the factors in Equation (1) above as follows. From Reference $A \cdot 18$, considering 758 of the core, the sensible pressure rlse ratio is $3.0 / 1.5-2.0$ and the ratio after the burn is $6.0 / 3.0-2.0$. A prompt pressure increase to about 2.5 atm can be attributed nostly to vessel blowdown. and is 1ndependent of the asount of debrts ejected. Therefore, an expression which accounts for the fraction $f$ of debris particlpating is:

$\left(P_{2} / P_{1}\right)_{1 \text { and }}-1.5+(2.0-1.5) * f / 0.75$

When $f-0, P_{2}-2.2 \mathrm{~s}$ is recovered, and when $f-0.75, P_{2}-3.0$ is recovered. Expression (2) is taken as the median. In forming the upper and lower bounds. the value of 1.5 is fixed because it is assoclated with 
the blowdown. The slope of the equation below the medlan is decreased and the slope of the equation above the nedian 18 inctessed. The lower bound slope multiplier is 0.75 :

$\left(P_{2} / P_{1}\right)_{\text {o*to }}-1.5+(2.0-1.5\rangle \star f * 0.75 / 0.75$

and the upper bound slope nultiplier ts 1.25 :

$\left(P_{2} / P_{1}\right)_{1 \mathrm{~ms}}-1.5+(2.0 .1 .5) / \star f \star 1.25 / 0.75$.

The median for the burn pressure rise for core fractions greater than 0.4 is taken from the 9.cell case in Reference A-18, 5,0/3.4 $=1,5$. However, there $1 \mathrm{~s}$ a threshold affect for the anset of hydrogen generation and burning as seen frow Reference A-18 and aentioned above. The burn pressure rise ratio also depends on the fraction of debris ejected. The median value for the distribution is as follows:

$$
\left(F_{q} / P_{2}\right)_{\text {burn }}=\begin{gathered}
1.0, f \leq 0.2 \\
11.0+0.5 / 0.2 \\
1.5, \quad 00.4 .
\end{gathered} *(f-0.2), 0.2<f \leq 0.4
$$

The value of .2 is s threshold for sufficient hydrogen production. The lower bound of the distribution is:

$$
\begin{aligned}
& 1,0, f \leq 0.3 \\
& \left(P_{f} / P_{2}\right)_{\text {bux }}-(1.0+0.25 / 0.1 *(f-0.3), 0.3<f \leq 0.4 \\
& 1.25 \text {, }>0.4 \text {. }
\end{aligned}
$$

The upper bound ratio is taken fron the 3-cell case as derived sbove:

$$
\left(P_{t} / P_{2}\right)_{\text {bum }}=\begin{aligned}
& 1.0, f \leq 0.1 \\
& (1.0+1 . / 0.3 \\
& 2.0,00.4
\end{aligned} *(f-0.1), 0.1<f \leq 0.4
$$

There is no probabilicy of detonation for any of the cases, because unconditional hydrogen buxns take place as the hydrogen is being created.

\section{Basse Cense ja}

For Case 3a, In which the RCS is at intermediate pressure, the adjustment factor $g$ accounts for the lesser quantity of debris whtch may participace In DCH, and the greater propensity for vavelike versus particulate dispersal in the lower compartaent. The burn factor in equation (1) is nultiplied by $g$ directly because hydrogen generation will scale by direct proportion to the anount of debris interacting in the lover compartment. The factor 8 is applled to the slope of the sensible heating multiplier. Therefore, the hydrogen burn ratio expressions above in (5), (6), and (7) are recasc as: 
Median:

$$
\left.P_{f} / P_{2}\right)_{\text {burn }}=\begin{aligned}
& 1.0, \mathrm{f} \leq 0.2 \\
& (1.0+0.5 / 0.2 *(\mathrm{f}+0.2) * \mathrm{~g}, 0.2<\mathrm{f} \leq 0.4 \\
& 1.0+0.5 * \mathrm{~g}, \mathrm{f}>0.4
\end{aligned}
$$

Lower bound:

$$
\left.P_{1} / P_{2}\right)_{\text {burn }}=\begin{aligned}
& 1.0+f \leq 0.3 \\
& 11.0+0.25 / 0.1 *(f-0.3) \star g, 0.3<f \leq 0.4 \\
& 1.0+0.25 * g, f>0.4
\end{aligned}
$$

Upper bound:

$$
\left.P_{1} / P_{2}\right)_{\text {burn }}=\begin{aligned}
& 1.0, f \leq 0.1 \\
& 11.0+1 . / 0.3 *(f-0.1) * g, 0.1<f \leq 0.4 \\
& 1.0+1.0 * g, t>0.4
\end{aligned}
$$

The sensible heat expresstons are equations (2), (3), and (4) recast as:

Median:

$\left(\mathrm{P}_{2} / \mathrm{P}_{1}\right\rangle_{\text {tone }}=1.5+(2.0-1.5) / 0.75 * \mathrm{E}_{\mathrm{B}}$

Lower Bound:

$\left(P_{2} / P_{L}\right)_{1 \text { an* }}=1.5+(2.0-1.5) / 0.75 * f * 0.75 * g$

Upper Bound:

$\left(P_{2} / P_{1}\right)_{\text {tons }}-1.5+(2.0-1.5) / 0.75 * t * 1.25 * \mathrm{~g}$

The distribution on $g$ is considered uniform for $0.5 \leq g \leq 1.0$, and is correlated with the distributions on the pressure rise ratios with a correlation coeffirient of 1,0 . The lower bound for $B$ is 0.5 because sone DCH is credited or a lower initial vessel pressure of $1000 \mathrm{psi}$, and its upper bound cannot exceed unity because Case 3 pressures must never exceed Case 1 pressures.

\section{Base Case Example Calculations}

An example calculation is presented for Case la (and 2a) with high RPV pressure, dry cavicy, and a saall vessel hole size. Consider $f-0.75$. i.e., 750 of the core is efected. The median (50th percentile) sensible pressure rise factor $1 \mathrm{~s} 1.5+0.666 *(0.75)=2.0$, the burn factor $1 \mathrm{~s}$ l. So, and the intigal pressure fs 1.5 bar always, so:

$P_{e}$ (case 10, f $=.75 .50$ percentile) $-1.5 * 2.0 * 1.5=4.5 \mathrm{bar}$

Which is about 0.5 bar lower than the Reference $189 . c e 11$ calculation. The maximur is given by conslderigg $f-1.0$ and using the upper bound. The sensible rise factor is $1.5+0.666 * 1.0 \star 1.25-2.333$, the burn factor is 2,0, so: 
$P_{f}$ (case la, $f-1.0,99$ percent1le) $-1.5 * 2.33 * 2.0-7.0 \mathrm{bar}$.

Note that the maximul value for Case 3a with intermediate RPV pressure, dry cavity and a small vessel hole size cannot exceed the value for case 1a, since an upper limlt is glven by $g-1.0$. The median of the distribution for $g$ in Case $3 a$ is given by $g-0.75$. Considering that $f-0.75$ to compare with example (a), the median for sensible heat factor is 1.5 * $0.666+0.75 * 0.75-1.88$, the burn factor is $1.0+0.5 * 0.75-1.375$, so

$P_{f}($ case $3 \mathrm{a}, f=.75,50$ percent1le $)=1.5 * 1.88 * 1.375=3.87 \mathrm{bar}$.

\section{Subcase Agrassment}

Among the sensitivity variables to consider for influencing pressure rises ac vessel breath are: oxidation fraction, core fraction ejected, hole size, water In cavicy, and ice bypasis. Expert $A$ believed that oxidation fraction was the least significant varlable, and omitted this to reduce the number of variables. The dependency on core fraction ejected was alresdy given above. Adjustments were therefore provided for hole size, water in cavity, and ice bypass.

Hole Size Adjustment. Since no sanple calculations were available to assess the effect of holp size, Expert A used an analogy to the effect of lce depletion. In Reference $A-1$, the effect of ice depletion in the absence of a hydrogen burn lead to a pressure Increase fron 4.3 to 6.7 bar, or 2.4 bar. The larger the vessel hole size, the greater the interconpartmental flow rates, and the less time avallable for hest transfer to the Ice. Therefore, this pressure rise can be take is a limit for zero heat transfar. Expert A concluded that a median pressure increase of 1.0 bar could be added to any dry case result to account for a large hole size. The upper bound could increase by 2.0 bar, and the lower bound would retatn the same.

As an example, the median for Case la, with $f-0.75$ and small vessel hole size, In exaplo (a) would be increased from 4.5 bar to 5.5 bar, then adjusted for large hole size. The upper bound for Case $1 \mathrm{a}$, $f=1.0$ in example (b) would be increased from 7.0 bar to $9.0 \mathrm{bar}$, when the hole size adjustment is made.

Water In Cavity Adiustpent. Expert A noted that the effect of coentrained water at Sequoyah from Reference A-1 was a pronounced reduction in pressure, but that another posalble outcone of a wet cavity case would be a complete debris quench. Therefore, the lower bound final pressure resulted from a complete quendh. adding 0.5 bar to the initial contalument pressure, regardless of Initlal vessel pressure. The wedlan and upper bound would scale between this value and the corresponding value for $D C H$ given in a dry cavity case. The final pressure congidering a wet cavity is thus:

Lower Bound:

$$
P_{\text {fuat }}=P_{1}+0.5-2.0 \text { bar }
$$


Median and Upper Bounds:

$P_{\text {fmot }}-1 / 2 *\left(P_{\text {tdry }} \cdot\left(P_{1}+0.5\right)\right)+\left(P_{1}+0.5\right)$ bax.

where $P_{\text {tdry }}$ is calculated for the dry case as described above, Including the adjusteant for hole size, if applicable. No uncertainty was ascribed to the factor of $1 / 2$ because it was felt that 1 would be an unnecessary embellishuent, considering the other uncertainties.

As an example, the median value for dry case 1 a (and $2 a$ ) with $f=0.75$ and a small vessel fallure [example (a)], is 4.5 bar. The corresponding nedisn far the wet cavity Case 1 (and 2) is $1 / 2 \star\langle 4.5-2\rangle+2=3.25$ bar. The upper bound pressure for Case la with $f-1.0$ in example (b) 157.0 bar, and the corresponding wet cavity case upper bound is thus $1 / 2 *(7.0-2)+$ 2 - 4.5 bar. The upper bound case for wet cavity Case $1, \mathbf{f}-1.0$, large hole slze is $1 / 2 *(9.0 \cdot 2)+2-5.5 \mathrm{bsr}$.

\section{Ice Bypass Adiustonent: Cases $1 \mathrm{~b}$ and 2b}

The senstble pressure rise ratio for Case $1 b$ and $2 b$ for 1 ce bypasa was determined for the median value and then adjusted for the distribution. For $f=0.75$ and no ice, the firial pressure from Reference $A-1$ is 6.7 bar without a hydrogen burn, so the pressure ratio for that case is $6.7 / 1.5=$ $4,47=4,50$. This is taken as an upper bound ratio. The upper bound rat io with ice is $1.5+(.666) * 0.75 * 1.25-2.12$, so the nultiplier to transiate from an upper bound with ice case to an upper bound without tce case is $4.50 / 2.12-2.1=2.0$. For the median, considering cases 6 (no ice) and 4 (ice) of Reference $A-1$ with $f-0.75$, the ratio here is $6.7 / 4.3$ $-1.56 \approx 1.5$. A lower bound multiplier mist exceed 1.0 , and ts chosen to be 1.25. The adjustnent of the Ice bypass cases is made by multiplying the sensible portion of the base case by these factors:

$\left.\left(P_{2} / P_{1}\right)_{\text {sund }}\right|_{\text {bypant }}-\left.\left(P_{2} / P_{1}\right)_{\text {nons }}\right|_{\text {no bypats }} \star f_{\text {bypasas }}$

where

$f_{\text {bypust }}= \begin{cases}1.25 & \text { lower bound } \\ 1.5 & \text { median } \\ 2.0 & \text { upper bound }\end{cases}$

This procedure leaves open the possibility that unrealistically large pressures may result. From Reference A-1, p. 77 , a maximun pressure of 14.9 bars was predicted by a DHEAT2 calculation. Therefore, the product of the pressure ratio and the initlal pressure of 1.5 atm 1 s 11 mited to this value:

$P_{2}=\min \left(14,9, P_{1} *\left(P_{2} / P_{1}\right)_{\text {sens }}\right)$

The sensible heat multiplier is identical for both small and large vessel hole sizes, and thus, when there is ice bypass, the hole size adjustment is not utilized. 
The hydrogen burn pressure riae ratio can approach the AICC value for whatever hydroges concentration would be in contalnnent. However, there is no guarantee of complete mixing and hence some hydrogen may not burn due to steam inerting or oxygen tarvation in the lower compartment. Furthermore, determinstion of the burn pressure rise ratio is complicated by the fact that $1 \mathrm{t}$ is a function of both steam and hydrogen concentrations. A maximum ratio for complete combustion 18 near 3.0 in the presence of steam for reasonable $H_{2}$ and $H_{2} 0$ concentrations, and a minimur is near 1.5. Since there is inadequate information to determine the $\mathrm{H}_{2}$ and $\mathrm{H}_{2} \mathrm{O}$ concentrations In each compartuent, and thus the proper burn pressure rise ratio, a flat distribution is assumed between 1.5 and 3.0 for complete combustion. An uncertainty factor must be applied to account for incomplete combustion, which would reduce this ratio. Since sone hydrogen is expected to not burn due to stean inerting or oxygen vitration, this multiplier cannot approach 1.0. The conbustion completeness multiplier $f_{c e} 15$ chosen to be evenly distributed between 0.5 and 0.8 , and it is applied as follows:

$\left(P_{f} / P_{2}\right)_{\text {burs }}-1+f_{c e} *\left[\left(P_{f} / P_{2}\right)_{\text {bust }}-1\right]$.

As in the cases with ice, the burn pressure rise ratio depends upon the fraction of core expelled, and is unity for $f<0.2$, reaches its maximum for $f>0,4$, and varles linearly between. The burn pressure ratios are thus given by:

Median:

$\left(P_{t} / P_{2}\right)_{\text {burn }}=\left\{\begin{array}{l}1.0, f \leq 0.2 \\ 1.0+f_{c q} *(1.25 / 0.2) *(f+0.2), 0.2<f \leq 0.4 \\ 1.0+f_{c c} * 1.25, f>0.4 .\end{array}\right.$

Lover Bound:

$\left(P_{t} / P_{2}\right)_{\text {butn }}-\left\{\begin{array}{l}1.0, f \leq 0.2 \\ 1.0+f_{c c} *(0.5 / 0.2) *(f-0.2), 0.2<f \leq 0.4 \\ 1.0+f_{c \varepsilon} * 0.5, f>0.4 .\end{array}\right.$

Upper Bound:

$\left(P_{\mathrm{f}} / P_{2}\right)_{\text {burn }}-\left\{\begin{array}{l}1.0, f \leq 0.2 \\ 1.0+f_{c e} \star(2,0 / 0,2) *(f-0.2), 0.2<f \leq 0.4 \\ 1.0+E_{c e} \star 2,0, f>0.4\end{array}\right.$

Reviewing equations (19) through (21), the maximum yalue of this multiplter would be 3.0 for complete coribustion but $f_{\text {se }}$ is limiter to 0.8 , so the maximum multiplier is 2.5 The median multiplier with $f_{c e}-1.0$ would be 2.25 . but wth the media: $f_{\mathrm{cr}}-0.65$, the value becomes 1.81 . The hydroger factor is not adjusted for vessel failure size.

As an example, the medion for $f-0.75$ with no 1ce is constructed by taking, the sensible multiplier with 100. 2.0, and applying the medlan $f_{\text {byres }}-1$ ', to yield 3.0. As a check, $3.0 \times 1.5-4.5$ is lests than 14.9. Thu buru multiplier is taken with the mediat $f_{c c}=0.6,5$ to yiald 1.81 The final 
pressure is $1.5 * 3.0 * 1.81-8.1$ bar. For an upper bound, considering $f$ - 1.0, the sensible multiplier is 2.33 (with 1ce) *2.0 ( $f_{\text {bypess }}$ ) $=4.66$, and the aximum burn multiplier 1s 2.6 , so the final pressure is $1.5 * 4.66$ * 2.6 - 18.17 bar.

\section{Ise_Bprass_Adjustmenti Case 3h}

For Case 3b, the burn pregsure ratio for cases $1 b$ and $2 b$ are conputed. Then a "pressure adjustment" to the sensible portion is made as was done earlier. In adjusting fron high RPV pressure to intermediate pressure:

$\left(P_{2} / P_{1}\right)_{3 b}-1-\left\{\left(P_{2} / P_{1}\right)_{1 b, 2 b}-1\right\} * g$

where $.5<\mathrm{g}<1$, and the olstribution on $B$ is uniform, and correlaced $w i t h$ the distribution of $F_{3} / P_{1}$.

Tabular Results - Gases 1 , 2 and 3

Maximal uncertainty/entropy probability wethods were used to obtain the distributions. The resulting values for jected core fractions of 108 , 337, 50:, 75:, and 100 are presented in Tables A-1 through A-10, for the cases given above. Tables A-1 to A-10 specify swall/large vessel fatlure size paraneter.

Table A-1

Bage Gasea 1a, 2a with Sall veasel Fallure

(FInal Containgent Pressure, bar)

\begin{tabular}{rrrrrr}
\hline Percenclue & $f=1$ & $t=33$ & $f=.5$ & $f=.75$ & $f=1.0$ \\
1 & 2.33 & 2.68 & 3.28 & 3.52 & 3.75 \\
5 & 2.33 & 2.74 & 3.35 & 3.60 & 3.84 \\
25 & 2.34 & 3.04 & 3.69 & 4.00 & 4.30 \\
50 & 2.35 & 3.42 & 4.13 & 4.50 & 4.88 \\
75 & 2.36 & 4.07 & 4.95 & 5.46 & 5.96 \\
95 & 2.37 & 4.60 & 5.62 & 6.22 & 6.83 \\
99 & 2.38 & 4.70 & 5.75 & 6.38 & 7.00 \\
\hline
\end{tabular}


Table A.2

Base Cases 1a, 2a with Large Vessel Failure (Final Contalnwent Pressure, bar)

\begin{tabular}{|c|c|c|c|c|c|}
\hline Bercentile & $f=1$ & $E=33$ & $f=.5$ & $\pm=.75$ & $f=1.0$ \\
\hline $\begin{array}{r}1 \\
5 \\
25 \\
50 \\
75 \\
95 \\
99\end{array}$ & $\begin{array}{l}2.33 \\
2.41 \\
2.83 \\
3.35 \\
3.87 \\
4.29 \\
4.38\end{array}$ & $\begin{array}{l}2.68 \\
2.83 \\
3.53 \\
4.42 \\
5.58 \\
6.52 \\
6.70\end{array}$ & $\begin{array}{l}3.28 \\
3.43 \\
4.18 \\
5.13 \\
6.46 \\
7.54 \\
7.75\end{array}$ & $\begin{array}{l}3.52 \\
3.68 \\
4.49 \\
5.50 \\
6.97 \\
8.14 \\
8.38\end{array}$ & $\begin{array}{l}3.75 \\
3.92 \\
4.79 \\
5.88 \\
7.47 \\
8.74 \\
9.00\end{array}$ \\
\hline
\end{tabular}

Table A-3

Base Case 3a with Small vestel Failure (Final Containment Pressure, bar)

\begin{tabular}{|c|c|c|c|c|c|}
\hline Parcentsile & $f-1$ & $f=.33$ & $f-5$ & $f=.75$ & $f=1.0$ \\
\hline 1 & 2.29 & 2.46 & 2.74 & 2.85 & 2.95 \\
\hline 5 & 2,29 & 2,52 & 2.81 & 2.93 & 3.05 \\
\hline 25 & 2.31 & 2.78 & 3.17 & 3.35 & 3.53 \\
\hline so & 2.33 & 3.11 & 3.61 & 3.87 & 4.13 \\
\hline 75 & 2.35 & 3.92 & 4.70 & 5.15 & 5.59 \\
\hline 95 & 2.37 & 4.57 & 5.58 & 6.17 & 6.77 \\
\hline 99 & 2.38 & 4.70 & 5.75 & 6.38 & 7.00 \\
\hline
\end{tabular}

Table A-4

Base Case 3a With Large Vessel Failure

(Final Containaent Pressure, bar)

\begin{tabular}{rrrrrr}
\hline Percentile & $\mathrm{f}=\mathrm{l}$ & $\mathrm{f}=.33$ & $\mathrm{f}-\mathrm{s}$ & $\mathrm{f}=.75$ & $\mathrm{f}=1.0$ \\
1 & 2.29 & 2.46 & 2.74 & 2.85 & 2.95 \\
5 & 2.37 & 2.60 & 2.89 & 3.01 & 3.13 \\
25 & 2.80 & 3.27 & 3.66 & 3.84 & 4.02 \\
50 & 3.33 & 4.11 & 4.61 & 4.87 & 5.13 \\
75 & 3.35 & 4.92 & 5.70 & 6.15 & 6.59 \\
95 & 3.37 & 5.57 & 6.58 & 7.17 & 7.77 \\
99 & 3.38 & 5.70 & 6.75 & 7.38 & 8.00 \\
\hline
\end{tabular}


Table A.5

Base Cases 1 and 2 with Saall Vessel Failure (Final Containnent Presgure, bar)

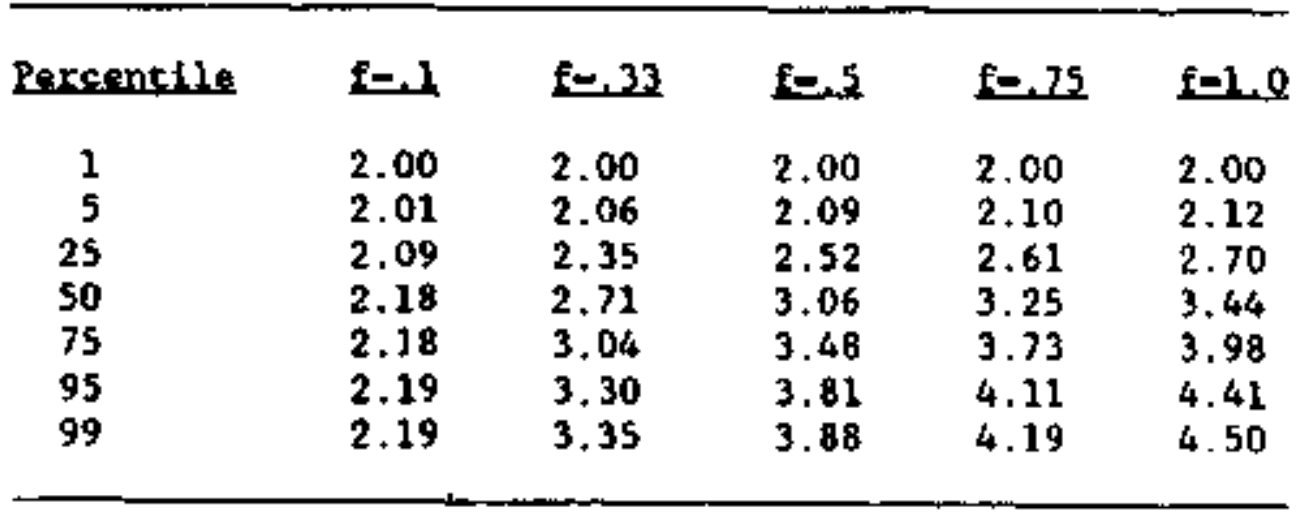

Table A. 6

Base Cages 1 and 2 Wi th Large Vessel Failure (Final Contalnment Pressure, bar)

\begin{tabular}{|c|c|c|c|c|c|}
\hline Percentile & $f$ & $f=, 33$ & $f=5$ & $f=.75$ & $E-1.0$ \\
\hline $\begin{array}{r}1 \\
5 \\
25 \\
50 \\
75 \\
95 \\
99\end{array}$ & $\begin{array}{l}2.00 \\
2.06 \\
2.33 \\
2.68 \\
2.94 \\
3.15 \\
3.19\end{array}$ & $\begin{array}{l}2.00 \\
2.10 \\
2.59 \\
3.21 \\
3.79 \\
4.26 \\
4.35\end{array}$ & $\begin{array}{l}2.00 \\
2.13 \\
2.77 \\
3.56 \\
4.23 \\
4.77 \\
4.88\end{array}$ & $\begin{array}{l}2.00 \\
2.14 \\
2.86 \\
3.75 \\
4.48 \\
5.07 \\
5.19\end{array}$ & $\begin{array}{l}2.00 \\
2.16 \\
2.95 \\
3.94 \\
4.73 \\
5.37 \\
5.50\end{array}$ \\
\hline
\end{tabular}

Table A.7

Base Cuses 3 With Suall Vessel Fallure

(Final Contalnment Pressure, bar)

\begin{tabular}{cccccc}
\hline Percenclle & $\mathbf{f = 1}$ & $\mathrm{f}=\mathbf{3 3}$ & $\mathbf{f = 5}$ & $\mathbf{f = . 7 5}$ & $\mathbf{f = 1 . 0}$ \\
$\mathbf{2}$ & 2.00 & 2.00 & 2.00 & 2.00 & 2.00 \\
5 & 2.01 & 2.05 & 2.07 & 2.08 & 2.09 \\
25 & 2.08 & 2.27 & 2.39 & 2.46 & 2.52 \\
50 & 2.16 & 2.55 & 2.80 & 2.93 & 3.06 \\
75 & 2.18 & 2.96 & 3.35 & 3.57 & 3.80 \\
95 & 2.19 & 3.29 & 3.79 & 4.09 & 4.39 \\
99 & 2.19 & 3.35 & 3.88 & 4.19 & 4.50 \\
\hline
\end{tabular}


Table $A \cdot B$

Base Case 3 with Large Vessel Failure

(FInal Contalnment Pressure, bar)

\begin{tabular}{cccccc}
\hline Percentsig & $\mathbf{f = 1}$ & $\mathbf{f = 3 3}$ & $\mathbf{f = 5}$ & $\mathbf{f = 7 5}$ & $\mathbf{f = 1 . 0}$ \\
1 & 2.00 & 2.00 & 2.00 & 2.00 & 2.00 \\
5 & 2.05 & 2.09 & 2.11 & 2.12 & 2.13 \\
25 & 2.32 & 2.52 & 2.64 & 2.70 & 2.77 \\
50 & 2.66 & 3.05 & 3.30 & 3.43 & 3.56 \\
75 & 2.68 & 3.46 & 3.85 & 4.07 & 4.30 \\
95 & 2.69 & 3.79 & 4.29 & 4.59 & 4.89 \\
99 & 2.69 & 3.85 & 4.38 & 4.69 & 5.00 \\
\hline
\end{tabular}

Table A.9

Base Cases $1 b$ and $2 b$ with Largo Vessel fallure

(Final Containment Pressure, har)

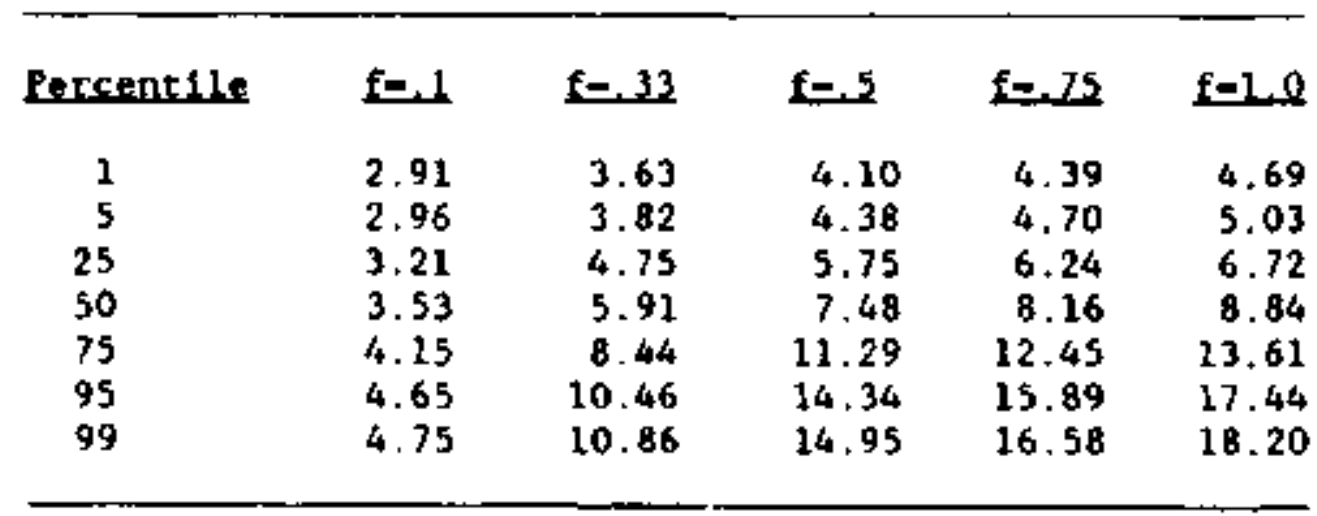

Table A-10

Base Cage 3b with Sma11 or Large Vessel Fallure

(Final Contalnment Pressure, bar)

\begin{tabular}{|c|c|c|c|c|c|}
\hline Percentlle & $f=.1$ & $f=.73$ & $t=5$ & 0.75 & $E=1.0$ \\
\hline $\begin{array}{r}1 \\
5 \\
25 \\
50 \\
75 \\
95 \\
99\end{array}$ & $\begin{array}{l}2.20 \\
2.27 \\
2.60 \\
3.02 \\
3.90 \\
4.61 \\
4.75\end{array}$ & $\begin{array}{r}2.69 \\
2.88 \\
3.82 \\
5.01 \\
8.00 \\
10.39 \\
10.86\end{array}$ & $\begin{array}{r}2.99 \\
3.26 \\
4.60 \\
6.29 \\
10.71 \\
14.24 \\
14.95\end{array}$ & $\begin{array}{r}3.13 \\
3.43 \\
4.93 \\
6.80 \\
11.79 \\
15.78 \\
16.58\end{array}$ & $\begin{array}{r}3.28 \\
3.61 \\
5.25 \\
7.31 \\
12.86 \\
17.31 \\
18.20\end{array}$ \\
\hline
\end{tabular}


Case 4. 4a. and 4b

As mentioned earlier, Expert A provided no distributions for Case 4. A polnt value, however, ias provided. Expert A believed the pressure Increment for Case 4 would be the sane as Cage 1 provided in Reference A-1. in which the blowdown pressure only is computed, resulting in a final containment pressure of 2.3 bar.

Hydropen Production. Expert A provided a diatribution for the fraction of potentially oxidizable metal in the ejected core that actually becomes oxidized during efection for cases 1,2 and 3 . The distribution ranges from 50 to 100 t and is uniford. The process is limited only by steam starvation which affects the upper and of the distribution, but it was judged that chis distribution would be adequate. For case 4 , on the other hand, there is negligible hydrogen produced In the core ejection (gravity pour) process.

Hydrogen Consumption. Most of the hydrogen produced in direct containment heating will be consuned during subsequent burns. For sequoyah, no values were provided in Reference A-1. Although values were provided for $\mathrm{Zion}$, the contaiments are too different to nake any accurate inferences fron those values. Expert A therefore provided a value of 75 sydrogen consumption.

\section{Sources of Uncertainty}

Expert A felt the and uncerteinties arise in this assessment with respect to the mode of debris dispereal (fild vs. particle). There is also uncertainty assoclated with the creation of hydrogen (stean availability, debris dispersal, etc.), and the degree of oxygen availability due to hydrogen burns before vessel breach.

\section{Sugetsted Hethods for Reducing Uncertainty}

Expert $A$ belines that the lce bypass cases should be run with CONTALN using large crapping fractions in the lower compartment. This would provide a baseline for fully $1 / 3$ of the cases, since no such calculations were avatlable thot include the effects of hydrogen burns. 


\section{REFERENCES}

A-1, D. C. Wtilfams et al, "Containment Loads Due to Direct Contafnment Heating and Assoclated Hydrogen Behavior: Analysis and Calculations with the CONTAIN Code," AUREG/CR-4896, SAND87-0633, Sandia Nat lonal Laboratories. May 198 ?

A-2. Electric Power Research Institute, "Hydrodynagics and Heat Transfer Aspects of Corium-Water Reactions," EPRI NP-5127, Electric Power Reseatch Institute, 1987.

A-3. W. W. Tarbell et al., "Resulis from the DCH-1 Experiment." NUREC/CR-4871, SANDB6-2483, Sandta National Laboratorles, June 1987.

A.4. M. Pilch and W. W. Tarbel1, "High Pressure Ejection of Melt from a Reactor Pressure Vessel: The Discharge Phase," NUREg/CR-4383, SAND85-0012, Sandia National Laboratorles. September 1985.

A-5. M. Pilch and W. W. Tarbell, "Preliminary Calculatians on Direct Heacing of a Containnent Atrosphere by Afrborne Debris," NUREC/CR. 4455, SAND85-2439, Sandia National Loboratories, July 1986.

A-6. W. W. Tarbell et al., "Pressurized Melt Ejection into Scaled Reactor Cavitles," NUREG/CR-4512, SAND86-0153, Sandia National Laboratorles. Octaber 1986.

A-7. L. C. Pong et al., "Application of a Direct Heating Model to the Sandia Surtsey Test." ANS Iransactions. 53. 558.559, (1985).

A-B. T. Ginsberg and $N$. Tutu, "A Direct-Heating of Containnent Vessel Interaction Code (DHCVIC) and Predictions of SNL Surtsey Test DCH-1." ANS Transactions, 53 ; $559+\$ 61$, (1986).

A-9. T. M. lee, "High Pressure Melt Ejection (Ditect Contaltment Heat. ing)." in Uncertatnty Papers on Severe Acsident Source Terms. MUREG.

1265. Washington DC: U.S. Nuclear Regulacory Conmission, (1987)

A-10. A. L. Camp et al., "MARCH+HECTR Analysis of selected Accidents in an Ice Condenser Contalinent." NUREG/CR-3912. SANDg3-0S01, Sandia National Laboratories, December 1984.

A-11. L. C. Pong et al., "Surry Severe Acctdent Containnent Laads Calculations Using HMC." ANS Transactions, 53: 562-564, (1986).

A-12. J. J. Sientckl and B, W. Spencer, "Corium Droplet Size in Direct Conteindent Heating." ANs Transactfons. 53; 557.558, (1986).

A.1). F. E. Hasktn and V. L. Behr, "HECTR Results for Ice Condenser Containment Standard Problem," Proceadings of the second Conkainment lntearliy Workshop. Crystal city, VA, CP-0056, SAND84. 1514,1984 . 
A-14. F. E. Haskin et al., "Combustion-Induced Loads in Large Dry PHR Containments, * Procegdings of the Second Contalnment Integrtity Workshop_Crystal C1ty, VA, CP-0056, SAND84-1514, August 1984.

A-15. L. C. Pong et a1., "Surry S2D Severe Accident Contafnment Loads Calculations Using HMC," Madison, WI: Nuclear Englneering Department, University of Wisconsin, 1986.

A-16. B. W. Spencer et al., "Hydrodynanics Aspects of Ex-Vessel Debris Dispersal in Zion-Type Containment Design." ANL/LWR/SAF-B3-1. Argonne National Laboratory, 1983.

A-17. D, E. Mitchell and N, A, Evans, "Steam Explosion Experiments at Intermediate Scale: FITSB Serles," NUREG/CR-3983, SANDB3-1057, Sandia National Laboratories, February 1986. 


\section{Expert B's Elicitation}

\section{Issue 5: Pressure Increment in the Sequoyah Gontainment at Vessel Breach}

\section{Descriation of Expert B's_Rationale/Methodology}

Expert B observed that there was less known about DCH than about the other causes of the pressure rise listed above. There have been four DCH experiments at Sendla using the surtsey facility. The initial CONTAIN predictions matched the DCH-1 experiment fairly well, and matched the DCH. 2. DCH-3, and DCh-4 tests poorly. A much better match to the later three DCH tests was obtalned by changing the trapping parsmeter in conTAIN from the value used for the DCH-1 test.

The effects of a wet cavity are hard to estimate; the water could make the pressure rise larger due to increased stean production. or the wacer could rake the pressure rise smaller due to quenching.

The offects of a partially falled lce condenser are particularly hard to estimate since there are no experimental data and no andysis of this case.

The hot gases resulting from vessel breach at any pressure above a few hundred psla are expected result in ignition and complete conbustion in any cell (volume) where a cambustible mixture of hydragen and oxygen is present. Sorae cells in the model do not burn because they inve no oxygen avallable. Expert $B$ concluded that detonations were unlikely, but credible, at sequoyah.

At Sequoyah, when hydrogen ignition occurs before vessel breach, much of the t:ydrogen that was generaced $t n$-vessel is consumed. Ignition occurs before vessel breach when igniters are operating. and with an estimated $f t$. lency whout the operation of 1 gniters (addressed by containment loads experts in Issue 2). Expert B felt 1 t was necessary to create an additional case-defining parameter to establish the containment hydrogen inventory at the time of vessel breach. Thus, the level of pre-existing hydrogen was added as an additional parameter ta consider in the subcase definition.

Expert B considered Case 1 (2500 psia) and Case 2 (2000 psia) together as he thought there would be no appreclable iffferences between then. Factors other than the amount of pre-existing hydrogen. In-vessel zirconlum oxidation, vessel hole size, and the fraction of mass ejected were accounted for by broatening the uncertainty bounds. In the course of this analysis, Expert $\mathrm{B}$ concluded that the pressure rise was fairly insensitive to the amount of in-vessel 2 irconium oxidation. Expert B provided pressure rlses for sixteen subcases for each of the cases defined above. These subcases are defined by a four-letter code: 


\begin{tabular}{|c|c|c|c|c|c|}
\hline Pesition & Description & Letter & Word & Nominal & Range \\
\hline First & Pre-Existing Hydrogen & $Q$ & $\begin{array}{l}\text { High } \\
\text { Low }\end{array}$ & $\begin{array}{l}858 \\
258^{\circ}\end{array}$ & $\begin{array}{l}50 \text { to } 1008 \\
0 \text { to } 508\end{array}$ \\
\hline Second & In-Vessel Zr OxIdation & $\begin{array}{l}0 \\
0\end{array}$ & $\begin{array}{l}\text { HI gh } \\
\text { Low }\end{array}$ & $\begin{array}{l}608 \\
258\end{array}$ & $\begin{array}{l}40 \text { to } 808 \\
10 \text { to } 408\end{array}$ \\
\hline Third & Vessel Hole Size & $\begin{array}{l}\mathbf{H} \\
\mathbf{h}\end{array}$ & $\begin{array}{l}\text { Large } \\
\text { Snall }\end{array}$ & $\begin{array}{l}2 \mathrm{a}^{2} \\
0.1 \mathrm{~m}^{2}\end{array}$ & $\begin{array}{l}>0.5 \mathrm{~m}^{2} \\
<0.5 \mathrm{n}^{2}\end{array}$ \\
\hline Fourth & Core Fraction Ejected & $\begin{array}{l}\mathrm{C} \\
\mathrm{c}\end{array}$ & $\begin{array}{l}\text { Large } \\
\text { Small }\end{array}$ & $\begin{array}{l}754 \\
338\end{array}$ & $\begin{array}{l}>500 \\
<500\end{array}$ \\
\hline
\end{tabular}

"The level of pre-existing hydrogen refers to the percentage of hydrogen released in-vessel that still remains in contalnent at the time of vessel breach

Expert B denoted the Sequoyah cases with tpper and lower case letter "Q". Thus, Case Q3b-OHc $1 \mathrm{~s}$ Case $3 \mathrm{~b}$ as defined above, with a high level of preexisting hydrogen in contalnment, high oxidation of zirconiue in.vessel, a Iarge hole size, and a snall fraction of the core ejected. Case q3b-OHe Is identical to Q3b-OHc, except there is a low level of pre-existing hydrogen in containment.

Expert $B$ approached the problen by using the available CONTAIN, MAAP, and Surtsey results to carefully assess pressure rise distributions for six base casas. Using a PC spreadsheet progran, he then adjusted the $5 \mathrm{Ix}$ base cases to get values for all the other 138 subcases required.

The extremes of his ranges for the base cases were based on energy balance calculations which are relatively straightforward. The best estimate is based on code results, primarily conTaIN results, D-i and sone subsequent calculations.a-2.a-3 Expert $B$ spent most of his time on the base cases trying to get the center of his distributions correct, since that is where the bulk of the probabllity lies. Not as wuch time was spent with the low pressure rise end of the curves since the pressure rises in this regiol will not fail the containment. A fair amount of tme was spent on the upper ends. however, even though contalnment fallure is virtually assured for these pressure rises, because the base case is often reduced in calculating the subsidiary cases. As the base cases were plaked to be about the most severe expected for the three RCS pressure levels, the base case is never increased enough in obtaining a derivative case that the low pressure rlse end of the curve becomes Important.

For Sequovali. Expert B selected six base cases, denoted 1Q, 2Q, 1Q, Iq, $2 q$, and $3 q$ The full designation for each case and the reason it was selected Ife 
1Q.19 Q1-oHC.q1.OHC

2Q.2q Q3a-oHC, $q^{3 a-O H C}$

$3 Q, 3 q \quad Q 4 b-0 H C, q 4 b-O H C$
Full cavity likely for high pressure cases Dry cavity will probably give the highest $\Delta p$ No ice will probably result in the highest ap

Base Case 1Q: 2000 to 2500 psia in RCS, wet cavity, ice condenser functioning with lee remaining. The subcase is high pre-existing tyorogen in containnent, low zirconiun oxidation 1n-vessel, a large hole, and large fraction of core fected. This is also denoted Case Q1-oHC. For his median value, Expert B started from Sequoyah Case 11 in Reference B-1. He reduced the fraction of the core participating in DCH from 75 because the

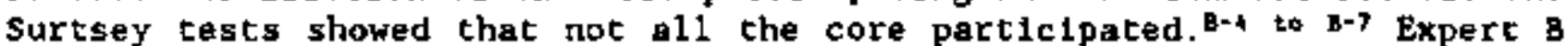
also consulted other references, -0.8-8 made further adjustments in the value from Reference $B-1$, and arrived at a median value of 5,5 bars.

The following is Expert B's complete presqure rise distribution for base case 1Q:

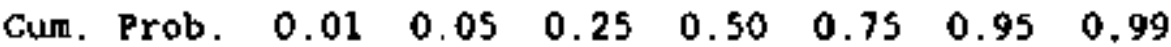

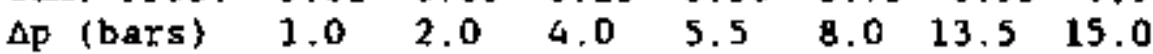

For his base Case 1Q. Expert B obtained range from 1 to 15 baxs with the median at 5.5 bars. Note that these are pressure rises, not total resultant pressure as reported in Reference B-1. Specific reasoning, with detailed references, are avallable for each value given above in the notes of Expert B, which are tou voluninous to be included here.

Expert B chose his upper bound (99, probabllity) to be sonewhat above the largest pressure $r i s e, 13.5$ bars (the 95 value) for which there was corresponding code result. For the lower bound (1) probability), he assumed that we had all seriously nisunderstood the basic nature of melt ejection at high pressure and that the ejected material would all be quenched by the water in the cavity and the lce condenser. The resulting pressure rise is only 1 bar. For the 758 probability value, Expert B compared Surry cases 17 and 7 in Reference B-1. Assuming the 1 bar reduction is in error, l,e added 3.5 bars to his median value to get a $\Delta p$ of 8.0 bars. For the 25 probability value, Expert $B$ assuned that all the water was ejected from the cavicy in the beginning by a stean explosion.

Qase Case lq: The case description is tdentical to base Case lQ, except that there is a low level of pre-existing hydrogen In concalnuent. This is also denoced Case q1-oHC. Considerable evidence in Reference B-6 suggests chat cases " $q$ " and "Q" are indistingulshable for this range of vessel pressure at breach. For high vessel pressure, large amounts of hydrogen are generated ex-vessel at breach. The hydrogen is transported throughout

*J. L. Tills, "An Update on DI rect Contalument keating for tce Condenser Plants," prosintation to Containment loads Panel, 1/12/88, Jack Tills and Assocfates. Albuquerque, NM. 1986 
containment due to the pressure driven nature of the event, If there 15 any pre-existing hydrogen, it contributes little to the overall pressure rise. The fanily of cases assoclated with the 17 cases, therefore, are identical to the $1 Q$ cases, and the pressure rise distribution for base case 19 is:

$\begin{array}{llllllll}\text { Cul. Prob. } & 0.01 & 0.05 & 0.25 & 0.50 & 0.75 & 0.95 & 0.99 \\ \text { Ap (bars) } & 1.0 & 2.0 & 4.0 & 5.5 & 0.0 & 13.5 & 15.0\end{array}$

Base Case 2Q; 500 to 1000 psia in RCS. cavity dry, and IC functioning with lce remaining. The subcase is high level of pre-existing hydrogen. low zircontun oxidation, large hole, and large fraction of core ejected. This Is also denoted Case Q3a-oHC. In these intermediate pressure cases, a substantial portion of the pressure rise comes from burning the pre. existing hydrogen, so reducing the fraction of the core which participates In DCH does not reduce the pressure rise accordingly.

Expert B arrived at the following pressure rise distribution for base case 2Q:

$\begin{array}{lllllllr}\text { Cum. Prob. } & 0.01 & 0.05 & 0.25 & 0.50 & 0.75 & 0.95 & 0.99 \\ \Delta \mathrm{p} \text { (bars) } & 0.7 & 1.1 & 2.8 & 5.5 & 7.0 & 10.0 & 14.0\end{array}$

The upper bound is 1.0 bar less than the upper bound $1 \mathrm{n}$ base Case 10 , and che median value is the same value as the median in base case 1Q. The median value for this base case is also based on the results of Sequoyah Case 11 in Reference B-1 even though the RCS pressure at vessel failure is much lower than in base Case 19 . This reflects the relatively small number of CONTAIN calculations which were available for Sequoyah. The reasoning process away from CONTAIN Case 11 is quite different in base Case $2 Q$ than in base Case 1Q. The reduced driving pressure in base Case $2 Q$ is partially compersated by the fact that the cavity is dry in base Case $2 Q$, conpared to the full cavity in base case lQ. After making several adjustments to account for hole size, fracion ejected, and other facturs, Expert B arrived at 5.5 bars for his median pressure rise for base Gase $2 Q$. For his 25 probability value $(2.8$ bars). Expert $B$ assumed poor debris-steam contact as in some of the DCH experiments.

Expert B pointed out that the ice condenser is not effective in reducting the pressure $t$ ise when the stean concentration is low. High hydrogen-olow stean gases are more likely in the high pressure scenarios than in the intermediate pressure case being considered here. There are several threshold effects whlch are diffleult to account for satisfactorily.

Base Case 2q: The case description is Identical to base case 2Q, except that there is a low level of pre-existing hydrogen in contalnment. This ts also denoted Case qua-oHC. For internedtate vessel pressures at breach. the amount of pre-existing hydrogen becomes gore important for the intermedlate pressure cases than for the high pressure cases. Expert B noted that the weak stent driving force may result in less combustion of hydrogen generated ex-vessel, due to fallure to transport the hydrogen from the lower compartment to other reglons in containent. The values of pressure rlse for base case $2 Q$ are therefore reduced tor base case $2 n$. 
Expert B provided the following pressure rise distribution for base case $2 q \div$

$\begin{array}{lllllllr}\text { Cum. Prob. } & 0.01 & 0.05 & 0.25 & 0.50 & 0.75 & 0.95 & 0.99 \\ \Delta p \text { (bars) } & 0.5 & 0.75 & 1.5 & 4.5 & 6.5 & 9.0 & 13.0\end{array}$

Baso Case 3Q: Less than 200 psia in RCS, dry cavity, and the lce condenser is bypassed or the $1 \mathrm{ce}$ is melted. The subcase is high level of preexisting hydrogen, high zirconium oxidation, large hole, and large fraction of core ejected. This 1 is also denoted Case Q4b-OHG. For this case, the important thing is the pre-existing bydrogen since DCH is negligible at these low RCs pressures. A large coherent burn can be expected, without mitigation due to ice. The middle and $h f_{g h}$ end of the curve were based on various HECTR results (cases N.00, A.00, and B.00 in Reference B-10) since this is a straightforward hydrogen burn problem. The lower end assumes no ignition or tncoherent burns due to steas fnerting, and negligible pressure rise due to corium contact with the cenent.

Expert $B$ arrived at the following pressure rise distribution tor base Case 3Q:

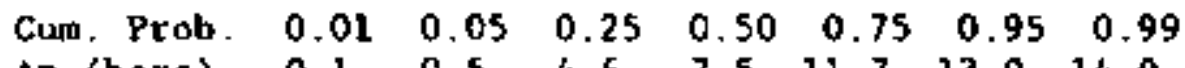

$\begin{array}{llllllll}\Delta \mathrm{p} \text { (bars) } & 0.1 & 0.5 & 4.6 & 7.5 & 11.7 & 13.0 & 14.0\end{array}$

Base case 3q: The case description is identical to base Gase 3Q, except that there is a low level of pre-existing hydrogen in containment. This is also denoted Case $q 4 \mathrm{~b}$-OHC. Expert $c$ allowed some pre-existing hydrogen in thls case (nominal value is 25s of the in-vessel hydrogen production), which would result in a global concentration of 3.3 in containment. This is below the ignition criterion. Burns were assuned only at the upper end of the distribution (above the 7 st probability value), allowing for higher local concentrations of hydrogen, yet still weak incoherent burns. The pressure rlses at the lovet end of the distribution would be due to snatl amounts of stean being released at vessel fallure.

Expert B provided the following pressure rise distribution for base case 3q:

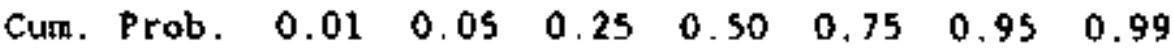

$\begin{array}{llllllll}\Delta p \text { (bars) } & 0.05 & 0.1 & 0.3 & 0.5 & 0.8 & 1.2 & 1.5\end{array}$

Expert B derived the pressure rise distributlons for all the other cases by means of adjustments to the three base cases described above. Tnese adjustments and the ressoning behind them are described in Expert B's notes which are not included here. As an example, in obtaining the small fraction of core ejected cases from the large fraction of core efected cases, he roduced the median pressure rise by 0.5 bar since reducing the fraction of the core ejected in vartous CONTAIN runs showed such an effect. 


\section{Berulte of Expert B's Ellctiation}

Expert B provided a table giving the 18, 58, 258, 508, 758, 958, and 998 values for 144 cases and subcases, For listing here, only the 58, 508 and 95t velues are shown. Furtherwore. Expert 8 concluded that the effects of sone of the subcase parameters could not be distinguished in the presence of other uncertalnties for certaln cases. For the Q1 and $q 1$ family of cases, the amount of pre-existing hydrogen is unimportant, as well as the anount of in-vessel zirconium oxidation. The effect of the amount of $i n$ vessel zirconlum oxidation could not be distinguished for the $q^{3}$ cases. Thus the results for Q1-OHC and $\mathrm{ql-OHC}$ are the same as for Q1-oHC and $q 1$. oHC, for exanple. Thls variable has therefore been elininated for the Q1 and $q \mathrm{l}$ cases, and only four subcases (HC, $\mathrm{hC}, \mathrm{Hc}$, and hc) are shown for each case in the following table. For most of the $Q_{4}$ casas, Expert B concluded that only the amount of zirconiun oxidation in vessel vos important. For example, the results for g4-OKC axe the same as his pressure rises for $\mathrm{Q} 4-\mathrm{OhC}, \mathrm{Q} 4 . \mathrm{OHc}$, and $\mathrm{Q} 4-\mathrm{Ohc}$. Therefore, this variable has been eliminated for the $Q 4$ case, and only two subcases ( $O$ and 0 ) are shown. The pressure rises in the following tables are in bars.

Pressure Rlse at VB for High

Pressure Cases

\begin{tabular}{|c|c|c|c|}
\hline Cașe & 58 & 508 & $95:$ \\
\hline $\begin{array}{l}\mathrm{Q} 1-\mathrm{HC}, \mathrm{q} 1-\mathrm{HC} \\
\mathrm{Q} 1-\mathrm{Hc}, \mathrm{q} 1-\mathrm{Hc} \\
\mathrm{Q} 1-\mathrm{hC}, \mathrm{ql}-\mathrm{hC} \\
\mathrm{Q} 1-\mathrm{hc}, \mathrm{ql}-\mathrm{hc}\end{array}$ & $\begin{array}{l}2.0 \\
1.0 \\
1.6 \\
0.8\end{array}$ & $\begin{array}{l}5.5 \\
2.8 \\
4.4 \\
2.2\end{array}$ & $\begin{array}{r}13.5 \\
6.8 \\
10.8 \\
5.4\end{array}$ \\
\hline $\begin{array}{l}\text { Qla-HC, qla-HC } \\
\text { Qla-hc, qla-Hc } \\
\text { Qla-hC, qla-hC } \\
\text { Qla-hc, qla-he }\end{array}$ & $\begin{array}{l}2.0 \\
1.0 \\
1.6 \\
0.8\end{array}$ & $\begin{array}{l}5.0 \\
2.5 \\
4.0 \\
2.0\end{array}$ & $\begin{array}{r}13.5 \\
6.8 \\
10.8 \\
5.4\end{array}$ \\
\hline $\begin{array}{l}\text { Qlb-HC, qlb-HC } \\
\text { Qlb-hc, qLb-Hc } \\
\text { Qlb-hc, qlb-hC } \\
\text { Qlb-hc, qlb-hc }\end{array}$ & $\begin{array}{l}2.0 \\
1.0 \\
1.6 \\
0.8\end{array}$ & $\begin{array}{l}9.4 \\
4.7 \\
7.5 \\
3.7\end{array}$ & $\begin{array}{r}14.9 \\
7.4 \\
11.9 \\
5.9\end{array}$ \\
\hline
\end{tabular}




\section{Pressure Rlse at VB for High \\ Pressure Cases}

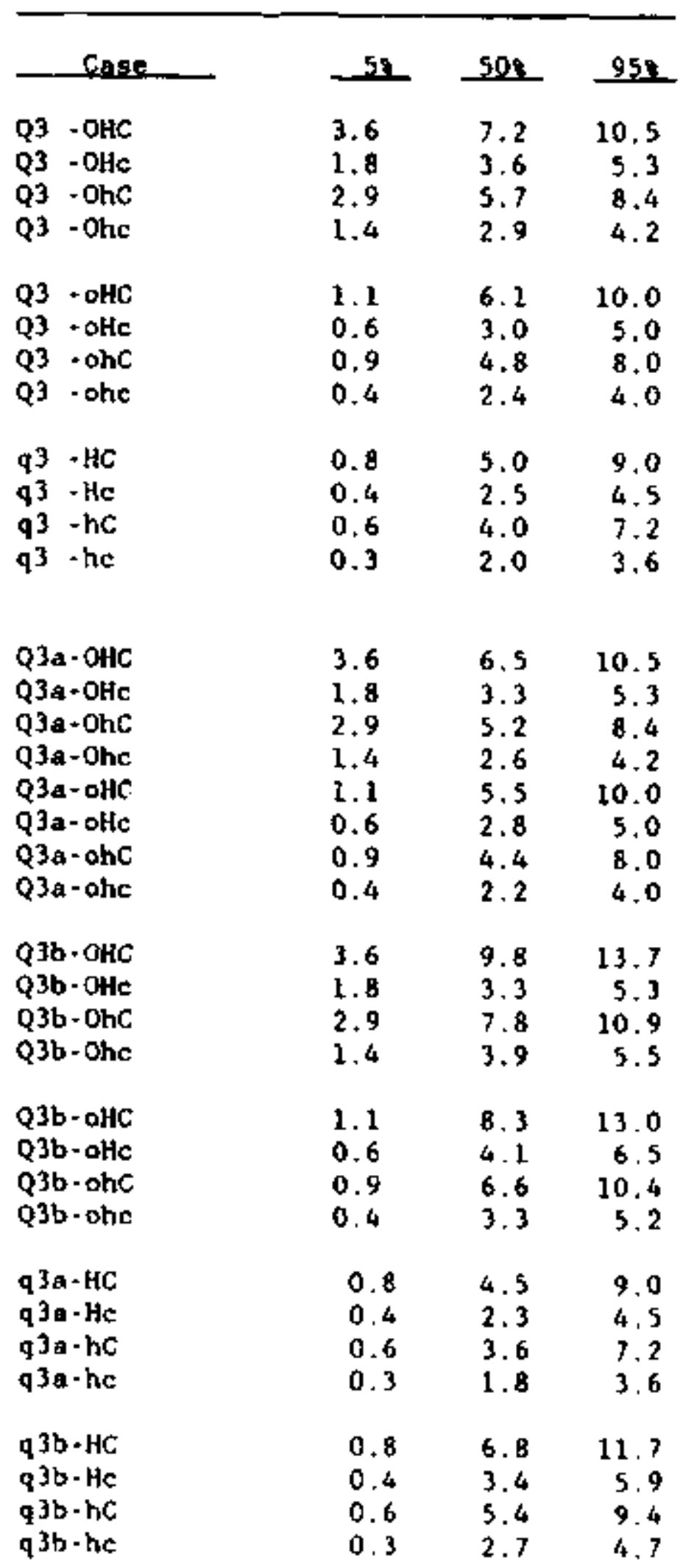


Pressure Rise at VB for $\mathrm{High}$

Pressure Cases

\begin{tabular}{|c|c|c|c|}
\hline Case & 50 & 503 & 958 \\
\hline$Q 4-0$ & 1.5 & 8.3 & 13.0 \\
\hline$Q_{4}-0$ & 1.3 & 2.0 & 4.2 \\
\hline Q4a-0 & 0.5 & 6.0 & 9.1 \\
\hline Q4a-o & 0.3 & 1.0 & 2.9 \\
\hline Q4b-0 & 0.5 & 7.5 & 13.0 \\
\hline Q $4 \mathrm{~b}-0$ & 0.3 & 1.2 & 4.2 \\
\hline $94-\mathrm{OHC}$ & 0.6 & 2.3 & 3.2 \\
\hline $\mathrm{q}^{4-O H c}$ & 0.6 & $1 . B$ & 2.7 \\
\hline$q^{4}-0 h c$ & 0.6 & 1.8 & 2.7 \\
\hline q4. Ohe & 0.6 & 1.3 & 2.2 \\
\hline $94-0 \mathrm{HC}$ & 0.6 & 2.8 & 3.7 \\
\hline$q^{4}-$ oHc & 0.6 & 2.3 & 3.2 \\
\hline$q^{4}$ - ohe & 0.6 & 2.3 & 3.2 \\
\hline q4-ohe & 0.6 & 1.8 & 2.7 \\
\hline $94 a-0$ & 0.1 & 0.3 & 1.0 \\
\hline q4a-o & 0.1 & 0.3 & 1.0 \\
\hline$q 4 b-0$ & 0.1 & 0.5 & 1.2 \\
\hline q4b-o & 0.1 & 0.5 & 1.2 \\
\hline
\end{tabular}

\section{Sources of Uncertainty}

Expert B emphasized that there were many uncertainties in estimating containment loads, especlally containnent loads at vessel breach. Self. heating of the molten material as 1 l Lravels from the vessel throughout containment tn not accounted for in the lumped-paraneter codes. This phenonenon is not captured in the Brookhaven experimenta. Entralnment and Weber break-up are not mechanistically treated in the detailed codes. A zirconiun oxide crust on the ejected droplets nay cause them to behave 1 ike solid particles rather than liquid particles. Internal gas generation may fragment the droplets, thus offecting the particle size distribution.

Nitrogen chemistry is not included in any of the models. If nitrogen combines with the metal oxides in the droplet, the flow of nitrogen into the droplet may cause fragmentation if the nitrogen is subsequencly released. The interactions of corluil droplets with surfaces are not well understood: while $t \mathrm{t}$ is known that molten corlum does not wet concrete surfaces, and concrete spalls when covered with enough molten corium, cxactly how the corlua droplets sill interact with concrete surfaces in a DCH event is unkrown. The DCH experiments have shown that there is 
considerable variability in trapping rates. Finally, the flow paths in the contafnaent may change during the event as a result of the event itself. Expert B also polnted out that some facets of the pressure rise at vessel breach are nonlinear. For example, in a DCH event at sequoysh, the pressure rise daes not fall as the fraction of the core particlpating falls because much of the pressure rise is due to hydrogen combustion.

Two additional uncertainties apply to Sequoyah. The first is the possibility of a detonation at vessel breach, which is enhanced due to the high temperature gas conditlons. As Expert B felt he had no way to approach the probablifty or results of a detonation at this time, he could not make explicit allowances for th. It is his opinton that the breadth of his distribution accounts for the possibility of detonation at least in part. The lce condenser itself introduces several uncertaincies. In addition to the possibilities of chenneling and partial lce depletion, the interaction of DCH with the ice condenser is very poorly understood. 
B.1. D. C. Wfilfams et al., "Containnent Loads Due to Direct Containnent Heating and Assoclated Hydrogen Behavior: Anslysis and Calculations with the CONTAIN Code," NUREG/CR-4896, SAND87-0633, Sandia Nat tonal Laboratorles, Ma: 1987.

B-2. D. C. Wlllians, "CONTAIN DCH Calculations for PWR's," Vlewgraphs for NUREG/CR-1150 Containment Loads Panel (documented in Reference 3), December 17, 1987

B.3. D. C. Willians et al., "Integrated Phenomenological Analysis of Containnent Response to Severe Core Damage Accidentg," Progress in Nuclear Energy, 19, 69, 1987.

B-4. M. Pilch and $W$. $H$. Tarbell, Prelfminary Calculations on Direct Heating of a Concalnment Atmosphere by Alrborne Debris," NUREG/CR. 4455, SANDBS-2439, Sandia National Laboratories, July 1986.

B-5. W. Tarbell et al., "Results Frot the DCH-1 Expertment," NUREG/CR4871, SAND86-2483, Sandla National Laboratories, June 1987.

B-6. M. P1lch and W. W. Tarbe11, "High Pressure Ejection of Melt from a Reactor Pressure Vessel: The Discharge Phase," NUREG/CR-4383. SAMb85-0012. Sandia Nationa1 Laboratorles, September 1985.

B-7. W. W. Tarbell et al., Pressurjzed Melt Ejection inco Scaled Reactor Cavitles." NUREG/CR-4512, SAND86-0153, Sandia National Laboratories, October 1986 .

B-B. F. Haskin et al,. "HECTR Results for Ice Condenser Containment Standard Problea," in Proceedings of the Second Concainment. Interarity workshop. Crystal C15y, VA. MUREG/CP-0056, SANDE4-1514, August 1984.

B.9. Sequoyah Nuclear Plant Integrated Containment Analysis IDCoR Task 23.1." IDCOR Technical Report 23.1. Tennessee Valley Authortey. Nuclear Engineerting Branch. July 1984..

B-10. A. L. Camp et al., "MARCH-HECTR Analysis of Selected Accidents in Ice Condenser Contalnments," Sandia Nakional Laboratories, NUREC/CR-3912, SAND83-0501, 1983. 


\section{Export C's Elicfeation}

\section{Is sue 5: Pressure Increpent in the sequoyah Containiment at Vestel Breach}

\section{Description of Fxpert Cis Rationale}

Expert $C$ consulted References $c-1$ through $C-9$ and provided a narrative description of the events he considered most likely to occur during pressurized nelt ejection, based an experiments and calculations. When melt first enters the cavity, it spreads onto all the walls. The following gas entrains the liquid from the cavity. The tlow would "dead end" at the saal table, then turn. The Expert does not belleve that the melt will Ereeze on the valls. Approximately Bos of the melt will exit the cavity as droplets. The gas velocity will be several hundted $\mathrm{m} / \mathrm{s}$, and the droplet diamecers wust be in the range of tenths of ollitimeters. The droplets contsin unteacted metallics, and zitconium wold react in a fraction of a second. Therefore, if the droplets can be kept suspended for about one second, 100: zirconlum reaction could occur, provided the atmosphere was not sceam starved. The expert does not belleve that the reaction w11 be turned off by low temperature. The chemical reactions will be very efficient and complece; all of the zirconiun and 50 s of the iton will be reacted, and all pre+extscing hydrogen vill bo burned.

The gas has to make two $90^{\circ}$ curns Into the ice condenser, and droplets will be trapped before entering the lce condenser. Only steam and hydrogen will be transported through the lce condenser. Htgh temperature hydrogen will exit the top of the lice condenser, and there will be a burn in the upper compartment, and the amount of hydrogen avallable is signiflcant.

The Expert based his "best estinates" on CONTAIN calculaclons and on scaled experiments of the very sindlar watts ar containment. The case for RCS pressure 500 to 1000 psia was taken as a base, and the cumulative distribution function (CDF) Eor that case was perturbed for other cases. Cavity water could of ther enhance or reduce the pressure. The median was kept the same for wet cavicy cases, but the distribution was stretched at both ends. On the low side, an overabundence of water migh reduce pressure by two bars, On the hIgh stde, calculations indicate the possibility of lncreasigg pressure by one bar.

lie lyased the high stde of bis distributions an getting a stean blowdown which optimized entrainment, and on burning the remaining iron. On the low side, he considered phenomena which might reduce pressure; larger droj diameter. or faster trapplng. Calculations had indicated that pressure might be reduced by one bar for larger drops and one bar for better trappling. He thus consldered that the base case pressure could be reduced by three bars for the sth percenetle.

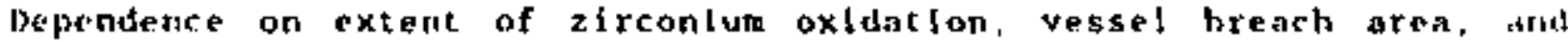
fraction of thelt ejected was also to be corsldered. CONTAIN calculations

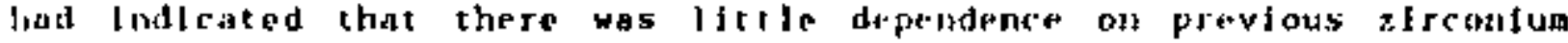

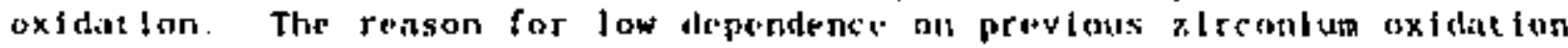

$$
2.3 \cdot 4
$$


might be oxidation starvation or steas starvation in the cavity; he considers the latter to be doubtful. The effect of greacer hole area is to give higher pressure across the entire band, because the gas would exit with higher velocity. The effect of fraction of core ejected was handled by scaling the base case ratio of final to initial pressure. If the fraction of melt is reduced from 75 to 25 , this would reduce pressure tncrement by a factor of 0.6 .

\section{Resulss of Expert Cis Elicitation}

Tentatively, the Expert suggested applying the results below for Cases 3 and $3 A$ to Cases $1,1 A, 2$, and $2 A$.

Table $\mathrm{C}-1$

Case 3A (Pressure Increment. Bars)

\begin{tabular}{|c|c|c|c|c|c|c|}
\hline \multirow{2}{*}{$\begin{array}{l}\text { Melt Mass } \\
\text { Elected }\end{array}$} & \multirow{2}{*}{$\begin{array}{l}\text { Break } \\
\text { Area } \\
g^{2}\end{array}$} & \multicolumn{5}{|c|}{ Fractiles } \\
\hline & & 05 & 25 & 50 & .75 & .95 \\
\hline \multirow[t]{2}{*}{750} & 0.1 & 3.0 & 4.0 & 5.0 & 6.5 & 8.0 \\
\hline & 2.0 & 4.0 & 5.0 & 6.0 & 7,5 & 9.0 \\
\hline \multirow[t]{2}{*}{253} & 0.1 & 2.0 & 2.5 & 30 & 4,0 & 5.0 \\
\hline & 2.0 & 2.5 & 3.0 & 3.5 & 4.5 & 5,5 \\
\hline
\end{tabular}

Table $\mathrm{C}-2$

Case 3 (Pressure Increment, Bars)

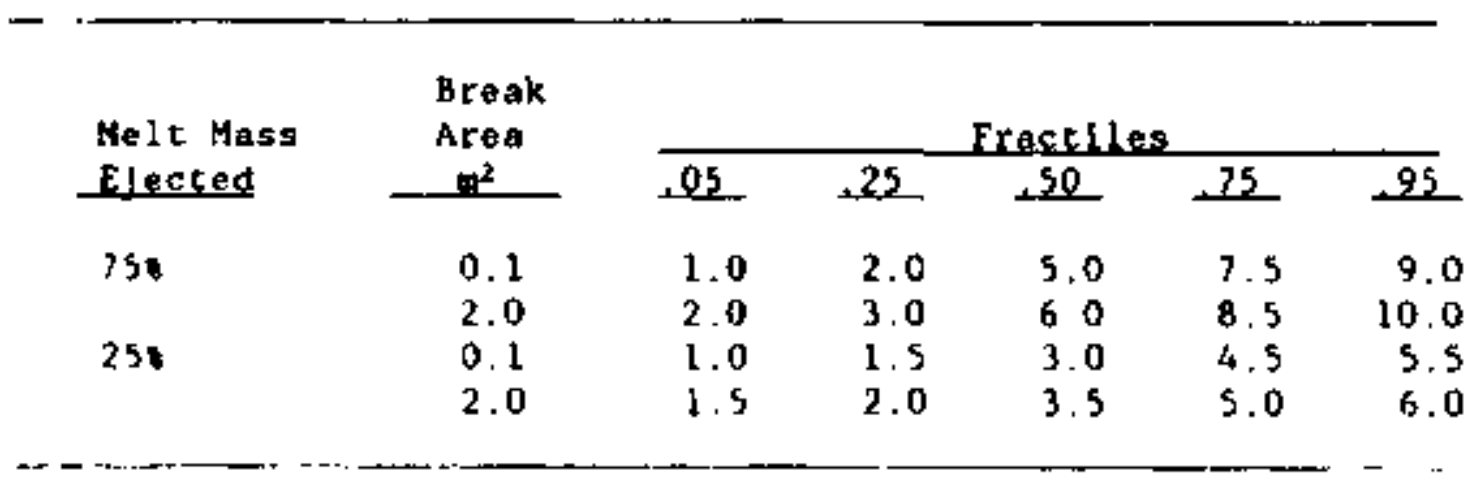

Sources of Uncertalnty

A major source of uncertalnty 1 s the effect of cavity water. Thls could -ither increase or decrease the pressure Increment. Other sources of wacertaluly are the effects of drop dianeter, the extent of iron oxiditlon. and the elflelency of trappling. 
As shown in Tables $\mathrm{C}-1$ and $\mathrm{C}-2$, uncertainty in the fnitial conditions also leads to a large uncertainty in the results. The mass ejected and character of the blowdown could lead to large differences in the pressure increment. 
C-1. D. C. Willians et al. Fontalnment Lads Due to Ditect Containment Heating and Associated Hydrogen Behavior: Analysis and Calculations with the CONTAIN Code," NuREG/CR-4896. SAND87-0633, Sandla National Laboratorles. May 1987.

C.2. Electric Power Research Institute, "Hydrodynamics and Heat Transfer Aspects of Corlun-Water Reactions," EPRI NP-5127, Electric Power Research Institute, 1987.

C.3. W. V. Tarbell et a1.. "Results fron the DCH.1 Experiment." NUREG/CR-4871, SAND86-2483, Sandia National Laboratorfes, June 1987.

C-4. M. Pilch and W. W. Tarbell, "High Pressure Ejection of Melt fran a Reactor Pressure Vessel: The Discharge Phase," NUREg/CR-4383, SAND85-0012, Sandia National Laboratories, September 1985.

C.5. M. Pilch and W. W. Tarbell, "Preliminary Calculations on Direct Heating of a Containnent Atmosphere by Airborne Debrls," NUREG/CR. 4455, SAND85-2439, Sandla National Laboratories, July 1986.

C-6. W. W. Tarbell et al, "Pressurized Melt Ejection into Scaled zeactor Cavitles," NUREG/CR-4512, SAND86-0153, Sandia National Laboratories, Dctober 1986.

C-7. L. C. Pong et al., "Application of a Direct Heating Model to the Sandia Surtsey Test," ANS Transactions. 53: 558-559, (1986).

C.B. T. Ginsberg and N. Tutu, "A Direct-Heating of Contuinment vessel Interaction Code (DHCVIC) and Predictions of SNL Surtsey Test DCH-1," ANS Transactoons. 53: $559.561,(1986)$.

C.9. D. E. Mtchell and N. A. Evars, "Stean Explosion Experinents at Intermediate Scale: FITSB Series, * NUREG/CR-3983, SAND83-1057. Sandia National Laboratories, February 1986. 


\subsection{Gontainngnt 1oads Issue 6: Loads at Vessel Breach.. Surry}

\section{Sumary of Expert Panel's hasessment of Isaue 6: Toads at Vessel Breach--Surry}

Experts consulted: Ken Bergeron, Sandia National Laboratorjes; Ted Ginsserg, Brookhaven National Lahoratory: James Metcalf, Stone \& Webser; Freri Torri, Plckard Lowe Garrick.

\section{Is sue Description}

What distributions characterize the uricertainty in the pressure rise in cantalnene st vessel breach for surry. This pressure rise ray result from one ar more of the following events:

1. Blowdown of the reactor coolant system (RCS):

2. Ex-vessel molten core-coolant interactions (MCCI);

3. Hydrogen combustion;

4. Ditect contalnment heating (OCH),

RCS blowdown and DCI cause slgniflcanc loads to the containment only if the RCS pressure is ten to twenty atmospheres or more above that of the contalnument at vessel breach.

The initial presentation of this issue delineated four RCS pressure ranges for consideration. The four rressure ranges were later reduced to three, rid the case structuze for Surry was redefined as follows:

\begin{tabular}{|c|c|c|c|}
\hline Case & $\begin{array}{c}\text { RCS Pressute } \\
\text { (psla) }\end{array}$ & Cavicy Wates & Sprays Operating \\
\hline 1 & 2000 to 2500 & Full & Yes \\
\hline $2 a$ & 2000 to 2500 & Half & Yes \\
\hline $1 \mathrm{~b}$ & 2000 to 2500 & Dry & No \\
\hline lc & 2000 to 2500 & Full & No \\
\hline 3 & 500 ts 1000 & Full & Yes \\
\hline $3 a$ & 500 to 1000 & $\mathrm{HaJf}$ & Yes \\
\hline $3 b$ & 500 co 1000 & Dry & No \\
\hline 4 & is to 200 & Half & Yes \\
\hline
\end{tabular}

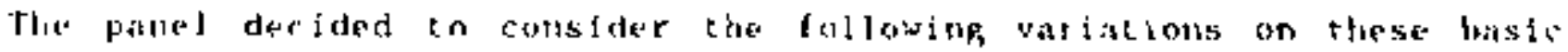
Case's

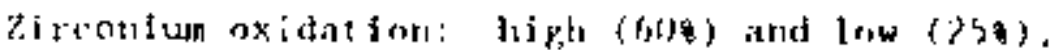

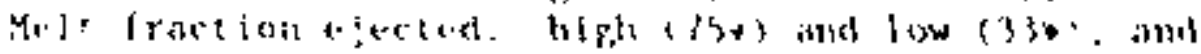

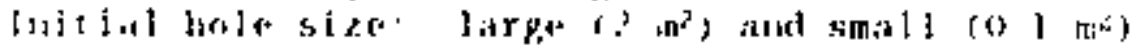

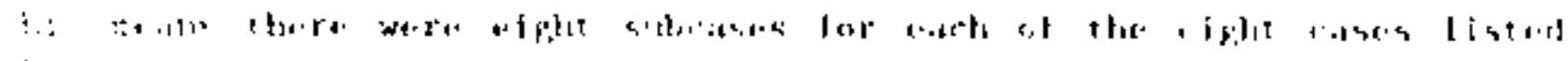




\section{Swmary of Expercs' Becionale/Hethodoloby}

Expert a calculated three base case distributions for the pressure $r$ ise at vessel breach at Surry. He then derived the distributions for rest of the cases presented in the issue description by adjusting the three base case distributions. The base cases chosen were expected to represent the most severe pressure rises for the three different RCs pressure levels analyzed. The threa base cases chosen by Expert $A$ are:

\begin{tabular}{|c|c|c|c|}
\hline Base Case & RCS Pressure(psia) & Cavley Water & Sprays operaring \\
\hline $1 \mathbf{b}$ & 2000 cd 2500 & Dry & No \\
\hline $3 \mathbf{b}$ & 500 to 1000 & Dry & No \\
\hline 4 & 15 to 200 & Haif & Yes \\
\hline
\end{tabular}

The Expert also considered the differences in pressure tise due to the amount of in-vessel zitconium dxidation, the RCS hole size, and the traction of mass ejected. For the base case calculations, the Expert chose a speciflc set of these additional parameters to consider.

Expert A approached the groblem by using the avallable CONTAIN, MAAP. and Surtsey results to carefully assess pressure rise distributions for three base cases. Using a PC spreadsheet program. he then adjusted these base cases to get values for the other 61 subcases required to quantify the requested cases.

The extremes of hls ranges for the base cases were based on energy balance calculations. The best estimates were based on code results, primarliy CONIAIN results as reported in :UREG/CR-4896, ${ }^{\mathrm{A}-1}$ and same 5 ubsequell colculations ${ }^{\mathrm{B}-2}$ in $\mathrm{A}^{-6}$

Expert B based his "best astitates" on contaln calculations and un scabed experiments. The case for the 500 to 1000 psia pressure range was taken as a bisfe, and the CDF fok that case was perturbed for other cases. Cavily willer could either entutise or reduce the pressure. The mudlan was kepe the silbe for wet cavicy cases, but the distributon was sereccilud at both ents (J) che luw side, an overabundance of water might reduce pressure by tuo bars. On the high side. calculations indicate the possibility of tucreasing pressure by one bar.

He based the high slde of his distributlons on a one+cell, adiabatic

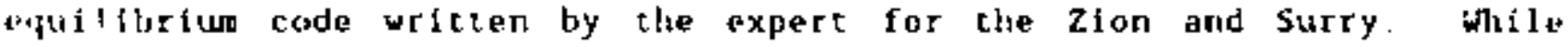
caiculating the las side of the dfstributian, he consldered phenosens that thiglit reduse pressure: lisger drop diancer, or faster trapping.

Also considered were dependence on extent of zlrconium oxldation. vessul briach area, alid the fraction of relt ejected. CONTAin calculacions lave indicated that there is litele dependence on privious zirconium oxidation probably die to uxidation starvation lin the cavicy. The effuct of greater lorle area is to give litgher pressite across the entire distribution, 
because the gas would exit with higher velocity. The effect of fraction of cor ejected was handled by scaling the base case ratio of final to initial pressure.

The Expert described what he thought would occur during pressurized nelt efection, based on experiments and calculations: when elt first enters the cavtly, it spreads onto all the walls. The following gas entrains the liquid trow the cavity. The Expert does not belleve that the melt will freeze on the walls. Approximately 80 of the melt wll exit the cavity as droplets. The gas velocity will be several hundred $\mathrm{m} / \mathrm{s}$, and the droplet diameters must be in the range of tenths of milliweters. The droplets contain unreacted metallics, and zirconfum vould react in a fraction of a serand. Therefort, if the droplets can be kept suspended for about 15 . 10t) zirconium reaction could occur, provided the atnosphere was not steam. starved. The Expert does not belleve that the reaction will be lutned of $f$ by low tenperature. The chenlcal reactions vill be very effictent and complete; all of the $z 1$ rconlun and 502 of the 1 ron will be reacted, and all pre-exlsting hydrogen will be burned.

Expert $G$ referenced HMC calculations by Corradinl (HMC is a computer program which conbines the RECTR, MEDICE-M1. and CORCON-NOD2 codes into an integrated package), Sandia CONTAIN calculations, and MAAP calculations. He tabulated the cases described in the issue descripcion and applled syallable code calculations that he could to each cage. In any cases. modifications were made by the Expert co account for differences between the Initial confltions in the code calculations and the case under consideration

The Expert used the FMC calculations for several cases in whtch there was water in the caviry. The Expert cons:dered the highest pressure calculated by iritradint to be the upper bound. He constdered the gressure increnent wthr): direct heating to be the lower bound.

The xpert used CONTAIN and MAAP results in cases in which the cavity was dry CONTAIN calculatcons for unconditional hydrogen burn and default burn wer. averaged and used for the upper part of the distrlbution. The ruap ressits were used for the lower part of the distrtbution. The medien was selw: ed between the two sets of calculations.

Allia'dgh he belfeved tho CONTAlN calculations co be consistently above the mediti, he considerei. the results credlble. He used the contatn senstivity calculatioli, to estante the effects of changes in initial condicions, and applied hese to the requested case structure.

Expert D used CONTAIN results as the basis for his analysis because CONTAIN Is currently the nuly, ade which has a DCH model. Expert D defined his base case as follows: l.e siatted from the 18 -node Surry model wh unconditional hydrogen burn (114klsi. He then nade several adjusteents to thls value constdering altert..te particle slzes, an alternate trapping nodel and the effect of the tij: steel in the contalnment on peak pressure. This case appl les to the stitrase with the large fraction of nelt ejected (75) and the small Initial tiole. Expert $D$ concluded that the effocts of codlspersed water should not be included and that the fraction of the zircontum 
oxidized in-vessel was not particularly important (CONTAIN runs in which the in-vessel oxldation was varied showed small differences in pressure $r$ ise), He also concluded that detonations would not occur.

For the small hole cases, Expert $D$ adjusted the CONTAIN pressures upward somewhat since there is the possibility that more than one penetration may fall st or about the same time.

The Expert calculated that the peak pressure with oprays operating is expected to be about 1.5 to 2.5 bars lover than the equivalent case whthout the sprays operating.

There is considerable dependence on the particle size in the upward direction. If the particle size assumed in the CONTAIN runs $(1,0 \mathrm{mn})$ is fncreased, the pressure rise will decrease because the material in the center of the particle will not have reacted befare the particle is quenched if the particle size is decreased from that sssumed In CONTAlN. there is a regligtble effect since all the metal in the particle is reacting already

CONTAIN assumes that the core debris distributed throughout the contatnment during the blowdown phase of the DCH process is homogeneous Expert $D$ expects the entrained materlal to be richer in oxides than a homogenous wixture Expert D also pointed out that, when DCH occurs, anly a very small portion of the hydrogen pre-extsting in the contalument or produced during the HPME can be expected to remain unburned after the event is over.

\section{Method of Aggregation}

Expert D gave estimates only for the $5 t h$, 50th, and 95 th percentiles. To rake Expert $D$ 's discributions more compatible with those of the other experts, his $5 t h$ and $95 \mathrm{th}$ percentlle values were excrapolated linearly to the lst and 99 th percentiles Expert $D$ also did not give distributans for Case 4. the values for Case 4 were taken from the aggregated distribution for the ather three expers Only one expert had any differences whatso. ever for high vs low zirconium oxidation, and he had small differances only for cells having low pressures Therefore, low and high zircontur oxfdation levels have been combined There are thus four subcase levels. corresponding to combinations of low and high tractlon ejected with large and small hale areas

The data were analvzed as a "block factortal" or "facoorial repeated measures" expertment, that is, an experinent having more than one type of treatment, it which every comitination of treatment levels is applied to each subject. The treatment types are considered to be "rases", with elght levels, and "Subcrses", wh four levels. An analysis ot vartance (ANOVA) was carried out on the data for the $1 \mathrm{st}$, 50th, and $99 \mathrm{ch}$ percentlles of the expercs' distrlbutions. An ANOVA compares two independent estimates of the population variance: one computed from the treatment means (1.P., the "between trcatments" varlance) and the othor as the "withln treatments" variance. Thls is equivalent to comparing the varlance in the depenclent vartable attributable to the treatments with the unexplatined (restadul) vaslance 
The differences between experts are indeed signifleant. For some percenchles more of the variance is attributable to the differences between experts than to the differences between cases, alchough the differences due to cases were also significant. There are no significant case $x$ subcase interactions, Indicating that the experts applied the subcase varlations consistently to each case.

Contrasts of main effects for cases were tested. "Main effects" means are the neans of the dependent var $1 \mathrm{able}$ (the prossure inctement) averaged over all subcases and experts for each caso. The differences between main effects means were tested by a least signiflcanc difference (LSD) test, The LSD is the smallest absolute value of the differences between two theans which should be considered slgniflcant. In order to retafn as aany cases as necessary, the significance level for the LSD test was set quite high (20v). Even with this high value, the ANOVA showed that Cases 1, 1a, and 30 can be combined, as can Cases $1 b$, and $i c$ and cases 3 and $3 a$.

In order to test the differences attributable to Individual subcases, a simple maIn effects ANOVA was perforaed. This ANOVA comares the variance actributable to the subeases evaluated at each of the cases to the residual variance. At leasc for the $50 \mathrm{ch}$ and $99 \mathrm{kh}$ percentlles, subcases are significantly different for all cases For Case 4, however, there is only a marginat significance at the $99 \mathrm{th}$ percentile. All subcases could thus be cotubined for Case 4, but not for any other cases

There were ortginally 64 subcases, but the elinination of the distinction made on 21 rconitu oxidacion reduced the number to 32 when cases 1 , la, and $3 b$. and $l b$ and $l c$. and 3 and $3 a$ are conbined and subcase distinctions dre dropped tor case 4, there remain only 13 distinct subcases. These subcases are 1 isted in Table 6-1. Each expert's data for Cases 1 and 1 , and $3 b$ and for $1 b$ and $l c$ and for 3 and $3 a$ were averaged, as vere subcases for Case 4 
Table 6-1

Characteristics of Combinad Cases

\begin{tabular}{|c|c|c|c|c|}
\hline Casse & BCS Pressure & Cavity & Vessel Hole size & Core Praction Ejected \\
\hline $\begin{array}{l}1 \\
2 \\
3 \\
4\end{array}$ & $\begin{array}{l}\text { Highe.b } \\
\text { Highe, } \\
\text { Higho,b } \\
\text { Highe,b }\end{array}$ & $\begin{array}{l}\text { Wet* } \\
\text { Wet* } \\
\text { Wet* } \\
\text { Wet* }\end{array}$ & $\begin{array}{l}\text { Larged } \\
\text { Large } \\
\text { Saall" } \\
\text { Sasil }\end{array}$ & $\begin{array}{l}\text { KIghc } \\
\text { Low } \\
\text { HIgh } \\
\text { Low }\end{array}$ \\
\hline $\begin{array}{l}5 \\
6 \\
7 \\
8\end{array}$ & $\begin{array}{l}\text { High } \\
\text { High } \\
\text { High } \\
\text { High }\end{array}$ & $\begin{array}{l}\text { Dry } \\
\text { Dry } \\
\text { Dry } \\
\text { Dry }\end{array}$ & $\begin{array}{l}\text { Large } \\
\text { Large } \\
\text { Stosil } \\
\text { Small }\end{array}$ & $\begin{array}{l}\text { High } \\
\text { Low } \\
\text { High } \\
\text { Low }\end{array}$ \\
\hline $\begin{array}{l}9 \\
10 \\
11 \\
12\end{array}$ & $\begin{array}{l}\text { Interned lated } \\
\text { Intermedlate } \\
\text { Intermediate } \\
\text { Intermediate }\end{array}$ & $\begin{array}{l}\text { Wet } \\
\text { Wet } \\
\text { Wet } \\
\text { Wet }\end{array}$ & $\begin{array}{l}\text { Large } \\
\text { Large } \\
\text { Stal1 } \\
\text { Stoa } 11\end{array}$ & $\begin{array}{l}\text { High } \\
\text { Low } \\
\text { High } \\
\text { Low }\end{array}$ \\
\hline 13 & Low & Any & Any & Any \\
\hline $\begin{array}{l}\text { Also } \\
2000 \\
\text { c } 750 \\
\text { d2 } \mathrm{m}^{2} \\
-0.1 \\
5330 \\
500 \\
500\end{array}$ & $\begin{array}{l}\text { pplies to Inter } \\
02500 \text { psi }\end{array}$ & 1 ate & $y$. & \\
\hline
\end{tabular}

\section{Agreserated Results}

Data were reduced by arithmetic averaging; for each pressure increment value. probabilities were determined for each expere by interpolation, and the probabllities were chen averaged. Interpolation was then used on the averaged CDFs to flind values for the $1 \mathrm{st}$. $5 \mathrm{th}, 25 \mathrm{th}, 50 \mathrm{th}$, $75 \mathrm{th}, 95 \mathrm{th}$, and $99 \mathrm{th}$ percentiles. In view of the large differences between experts, it is untiecessary to use a finer subdiviston of the CDF than this. Table 6-2 shows the results for the aggregated CDFs. 
Table $6 \cdot 2$

Aggregate Results Pressure Rise at

Vessel Breach for Surry (bars)

\begin{tabular}{|c|c|c|c|c|c|c|c|c|c|}
\hline \multirow[b]{2}{*}{ Case } & \multirow[b]{2}{*}{ Hole state } & \multirow{2}{*}{$\begin{array}{l}\text { Amount } \\
\text { Elected }\end{array}$} & \multicolumn{7}{|c|}{ Eractile } \\
\hline & & & 0.01 & 0.05 & 0.25 & 0.50 & 0.75 & 0.95 & 0.99 \\
\hline 1 & Large & Hagh & 1.4 & 2.3 & 4.1 & 5,8 & 7.8 & 10.7 & 13.2 \\
\hline 2 & Large & Low & 1.1 & 1.6 & 2.5 & 4.2 & 5.9 & 8.2 & 10.4 \\
\hline 3 & Small & High & 1.0 & 1.9 & 3.6 & 5.2 & 6.7 & 9.6 & 11.7 \\
\hline 4 & Sma11 & Low & 0.8 & 1.4 & 2.4 & 3.5 & 4.9 & 6.8 & C.g \\
\hline 5 & Large & High & 1.7 & 2.8 & 4.9 & 7.3 & 9.3 & $11 . B$ & 13.6 \\
\hline 6 & Large & Low & 1.3 & 1.9 & $3 \cdot 3$ & 5.0 & 6.6 & 9.3 & 10.8 \\
\hline 7 & Sinall & HIgh & 1.2 & 2.2 & 4.3 & 6.0 & 7.7 & 10.0 & 11.7 \\
\hline 8 & $\operatorname{Sms} 11$ & Low & 1.0 & 1.7 & 2.6 & 3.8 & 5.7 & 7.5 & 9.1 \\
\hline 9 & Large & High & 1.1 & 1.8 & 3.4 & 4.8 & 6.8 & 9.8 & 12.2 \\
\hline 10 & Large & Low & 0.7 & 1.1 & 2.0 & 4,0 & 5.2 & 7.7 & 9.3 \\
\hline 11 & Sma 11 & High & 0.9 & 1.6 & 3.2 & 4.5 & 5.8 & 9.4 & 11.7 \\
\hline 12 & Small & Low & 0.6 & 1.1 & 1.9 & 3.0 & 4.4 & 6.8 & B. 6 \\
\hline 13 & Any & Any & 0.2 & 0.4 & 0.7 & 1.0 & 1.5 & 3.1 & 5.0 \\
\hline
\end{tabular}

For use in the user function of the Accldent Progtession Event Tree, the fraction of melt ejected was divided into three groups: 0 to 202, 20 to 408 . and 40 to 604 . The renson for doing this $1 \mathrm{~s}$ that the dividing point between higl: and low fraction ejected ( 50 ejected) used by the Loads Panel turns out to be very near the high end of the sggregate distribut ton given for the fraction of nelt ejected by the in-vessel panel. If the bigll-low division glvn by the Loads Panel was used, over Bot of the cases would fall tn the lo categary.

Since It was not possible to get the Contairuent Loads Panel to evaluate a new sot of distributions, the daia can be mantpulated in tha following way. For the 20 to 40 ejected group, the low-Fractlor-ejected results from the Loads panel can be used directly since the nominal value used by the Laads experts was 334 ejected. For the 40 to 60 ejected group, the loads low.fraction-ejected and high-fraction-ejected can be averaged. The average of the nom!nal fractions ejected is 54b. which is reasonably close to the center of thls group. For the 0 to 20 e ejected group, the average of the low fraction and the case 4 results $(<200$ psia) can be used.

Tatje 6.3 gives the new description of the, now, 19 cases In terms of RCS pressure, anount of cavity water, whether the sprays are operatin. the core fraction ejected, and the vessel hole sjze. Tabla of shows the aegregate resules for the pressure rise at Surry (Table b.2) expanded to three iraction-ejected groups by the mathod descrlbed above. Toblo $b_{3}-4$ Is

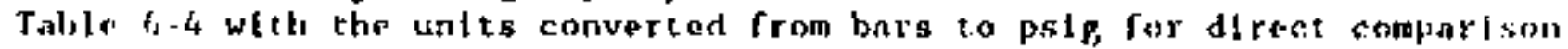
with the results of the structural Response texprert pants. 
Table $6-3$

Chatacteristics of combined Cases

\begin{tabular}{|c|c|c|c|c|}
\hline Case & RCS.Pressure & Cavity & Vessel Hole stre & Core Fraction Ejected \\
\hline $\begin{array}{l}1 \\
2 \\
3 \\
4 \\
5 \\
6\end{array}$ & $\begin{array}{l}\text { Highe, } \\
\text { Highe.b } \\
\text { HIghe, } \\
\text { Highe, } \\
\text { HIghe, } \\
\text { Highe : }\end{array}$ & $\begin{array}{l}\text { Wet" } \\
\text { Wet* } \\
\text { Wet: } \\
\text { Wet* } \\
\text { Dry } \\
\text { Dry }\end{array}$ & $\begin{array}{l}\text { Largee } \\
\text { Large } \\
\text { Largek } \\
\text { Sagll } \\
\text { Small } \\
\text { Sagll }\end{array}$ & $\begin{array}{l}\text { Highd } \\
\text { Mediume } \\
\text { Low } \\
\text { High } \\
\text { Mediun } \\
\text { Low }\end{array}$ \\
\hline $\begin{array}{l}7 \\
8 \\
9 \\
10 \\
11 \\
12\end{array}$ & $\begin{array}{l}\text { H1gh } \\
\text { H1gh } \\
\text { H1gh } \\
\text { HIgh } \\
\text { HIgh } \\
\text { H1gh }\end{array}$ & $\begin{array}{l}\text { Dry } \\
\text { Dry } \\
\text { Dry } \\
\text { Dry } \\
\text { Dry } \\
\text { Dry }\end{array}$ & $\begin{array}{l}\text { Large } \\
\text { Large } \\
\text { Large } \\
\text { Sall } \\
\text { Small } \\
\text { Swall }\end{array}$ & $\begin{array}{l}\text { High } \\
\text { Mediun } \\
\text { Low } \\
\text { High } \\
\text { Medfun } \\
\text { Low }\end{array}$ \\
\hline $\begin{array}{l}13 \\
14 \\
15 \\
16 \\
17 \\
18\end{array}$ & $\begin{array}{l}\text { Intermediate } \\
\text { Intermediace } \\
\text { Intermediate } \\
\text { Intermedlate } \\
\text { Intermediate } \\
\text { Intermediate }\end{array}$ & $\begin{array}{l}\text { Wet } \\
\text { Wet } \\
\text { Wet } \\
\text { Wet } \\
\text { Wet } \\
\text { Wet }\end{array}$ & $\begin{array}{l}\text { Large } \\
\text { Large } \\
\text { Large } \\
\text { Snall } \\
\text { Saall } \\
\text { Saall }\end{array}$ & $\begin{array}{l}\text { High } \\
\text { Mediun } \\
\text { Low } \\
\text { High } \\
\text { Medium } \\
\text { Low }\end{array}$ \\
\hline 19 & Low' & Any & Any & Any \\
\hline 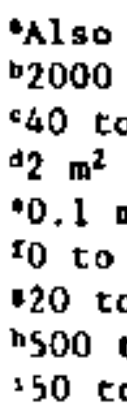 & $\begin{array}{l}\text { pplies to Intert } \\
02500 \text { psi } \\
600 \\
01 \\
402 \\
1000 \text { pst } \\
200 \text { psi }\end{array}$ & ate & & \\
\hline
\end{tabular}


Table 6-4

Agstegate Resulta Pressure Rise at

Vessel Brench for Surry (bars)

\begin{tabular}{|c|c|c|c|c|c|c|c|c|c|}
\hline \multirow[b]{2}{*}{ Case } & \multirow[b]{2}{*}{ Hole size } & \multirow[b]{2}{*}{ Amount_Ejected } & \multirow[b]{2}{*}{0.01} & \multirow[b]{2}{*}{0.05} & \multirow[b]{2}{*}{0.25} & \multicolumn{3}{|c|}{ Fractile } & \multirow[b]{2}{*}{0.99} \\
\hline & & & & & & 0.50 & 0,75 & 0.95 & \\
\hline 1 & Large & 40 to 600 & 1.3 & 2.0 & 3.3 & 5.0 & 6.9 & 9.5 & 21.8 \\
\hline 2 & Large & 20 to 40 s & 1.1 & 1.6 & 2.5 & 4.2 & 5.9 & 8.2 & 10.4 \\
\hline 3 & large & 0 to 20 & 0.7 & 1.0 & 1.6 & 2.6 & 3.7 & 5.6 & 7.7 \\
\hline 4 & Small & 40 to 608 & 0.9 & 1.7 & 3.0 & 4.4 & 5.8 & 8.2 & 10.3 \\
\hline 5 & Sma11 & 20 to 402 & 0.8 & 1.4 & 2.4 & 3.5 & 4.9 & 6.8 & 8.8 \\
\hline 6 & Sma1l & 0 to 208 & 0.5 & 0.9 & 1.6 & 2.3 & 3.2 & 5.0 & 6.9 \\
\hline 7 & Large & 40 to 604 & $\mathbf{1}, 5$ & 2.4 & 4.1 & 6.2 & 8.0 & 10.6 & 12.2 \\
\hline g & Large & 20 to $40 t$ & 1.3 & 1.9 & 3.3 & 5.0 & 6.6 & 9.3 & 10.8 \\
\hline 9 & Large & 0 to 20 & 0.8 & 1.2 & 2.0 & 3.0 & 4.1 & 6.2 & 7.9 \\
\hline 10 & Sma11 & 40 to $60 \mathrm{~s}$ & 1.1 & 2.0 & 3.5 & 4.9 & 6.7 & 8.8 & 10.4 \\
\hline 11 & Smo11 & 20 to 408 & 1.0 & 1.7 & 2.6 & 3.8 & 5.7 & 7.5 & 9.1 \\
\hline 12 & Smol1 & 0 to 200 & 0.6 & I. 1 & 1.7 & 2.4 & 3.6 & 5.3 & 7.1 \\
\hline 13 & Large & 40 to 601 & 0.9 & 1.5 & 2.7 & 4.4 & 6.0 & 8.8 & 10.8 \\
\hline 14 & Large & 20 to 404 & 0.7 & 1.1 & 2.0 & 4.0 & 5.2 & 7.7 & 9.3 \\
\hline 15 & Large & 0 to 20 & 0.5 & 0.8 & 1.4 & 2.5 & 3.4 & 5.4 & 7.2 \\
\hline 16 & Snal1 & 40 to 60 s & 0.8 & 1.4 & 2.6 & 3.8 & 5.1 & 8.1 & 10.2 \\
\hline 17 & Sagl1 & 20 to 40 t & 0.6 & 1.1 & 1.9 & 3.0 & 4.4 & 6.8 & 8.6 \\
\hline 18 & Snall & 0 to 208 & 0.4 & 0.8 & 2.3 & 2.0 & 3.0 & 5.0 & 6.8 \\
\hline 19 & Any & Any & 0.2 & 0.4 & 0.7 & 1.0 & 1.5 & 3.1 & 5.0 \\
\hline
\end{tabular}


Table 6.5

Aggregato Results Pressure R!se at

Vessol Breach for Surry (psig)

\begin{tabular}{|c|c|c|c|c|c|c|c|c|c|c|}
\hline \multirow[b]{2}{*}{ CEse } & \multirow[b]{2}{*}{$\begin{array}{l}\text { Hole } \\
\text { stze }\end{array}$} & \multirow{2}{*}{\multicolumn{2}{|c|}{$\begin{array}{l}\text { :mount } \\
\text { Elected }\end{array}$}} & \multicolumn{7}{|c|}{ Ereactle } \\
\hline & & & & 0.01 & $\underline{0.05}$ & 0.25 & 0.50 & 0.75 & 0.95 & 0,99 \\
\hline 1 & Large & 40 & to $60 \mathrm{t}$ & 18.1 & 28.3 & 47.9 & 72.5 & 99.4 & 137.1 & 171.1 \\
\hline 2 & Larga & 20 & to 401 & 16.0 & 23.2 & 36.3 & 60.9 & 85.6 & 118.9 & 150.8 \\
\hline 3 & Largo & 0 & to 201 & 9.4 & 14.5 & 23.2 & 37.7 & 53.7 & 81.9 & 111.7 \\
\hline 4 & Sna1l & 40 & to 60s & 13.1 & 23.9 & 43.5 & 63.1 & 84.1 & 118.9 & 148.7 \\
\hline 5 & Sanll & 20 & to $40 \%$ & 11.6 & 20.3 & 34.8 & 50.8 & 71.1 & 98.6 & 127.6 \\
\hline 6 & Small & 0 & to 203 & 7.3 & 13.1 & 22.5 & 32,6 & 46.4 & 71.8 & 100,1 \\
\hline 7 & Large & 40 & to 60t & 21.8 & 34.1 & 59.5 & 89.2 & 115.3 & 153.0 & 176.9 \\
\hline 8 & large & 20 & to 40 s & 18.9 & 27.6 & 47.9 & 72.5 & 95.7 & 134.9 & 156.6 \\
\hline 9 & Large & 0 & to 201 & 10.9 & 16.7 & 29.0 & 43.5 & 58.7 & 89.9 & 114.6 \\
\hline 10 & Sma11 & 40 & to 600 & 16.0 & 28.3 & 50.0 & 71.1 & 97.2 & 126.9 & 150.8 \\
\hline 11 & Small & 20 & to 401 & 14.5 & 24.7 & 37.7 & 55.1 & 82.7 & 108.8 & 132.0 \\
\hline 12 & Sma1l & 0 & to 204 & B. 7 & 15.2 & 239 & 34.6 & 52.2 & 76.9 & 102.3 \\
\hline 13 & Large & 40 & to 601 & 13.1 & 21.0 & 39.2 & 63.8 & 87.0 & 126.9 & 155.9 \\
\hline 14 & Large & 20 & to 401 & 10.2 & 16.0 & 29.0 & 58.0 & 75.4 & 111.7 & 134.9 \\
\hline 15 & Large & 0 & to 201 & 6,5 & 10.9 & 19.6 & 36.3 & 48.6 & 7 B. 3 & 103.7 \\
\hline 16 & Sm811 & 40 & to $60 \%$ & 20.9 & 19.6 & 37.0 & 54.4 & 74.0 & 217.5 & 147.2 \\
\hline 17 & Sinal1 & 20 & to 401 & 8.7 & 16.0 & 27.6 & 43,5 & 63.8 & 98.6 & 124.7 \\
\hline 18 & Small & 0 & to $20 k$ & $5 . B$ & 10.9 & 18.9 & 29.0 & 42.8 & $71 . \mathrm{B}$ & 98.6 \\
\hline 19 & Any & Any & & 2.9 & 5.8 & 10.2 & 14.5 & 21.8 & 45.0 & 72.5 \\
\hline
\end{tabular}


Individual Elicitations for Issue 6

$5.6 \cdot 11$ 


\section{Expert A's Ellc1tetion}

\section{Issuo 6: Prossure RIso at Vessel Breach for Surry}

\section{Descripcton of Experc A's Rationale/Methodolopy}

Expert A observed that there was less known about DCH than about the other causes of the pressute rise listed above. There have been four DCH experiments at Sandia using the surtsey factlity. The inttial CONTAIN predlctions natched the DCH-1 experiment folrly well, and matched the DCi2. DCH-3, and $\mathrm{DCH}+4$ tests fairly poorly, A much better match to the later chree DCH tests was obtained by changing the trapping parameter in CONTAIN f roa the value used for the DCH-1 cest.

The effects of full cavicy of water are hard to estimate; the wacer could make the pressure rise larger due to increased stean production, or the water could make the pressure rise smaller due to quenching. Expert A concluded that, for surry, the medlan pressure rise for the full cavity case would be sifghtly higher chan for the equivalent case with a dry cavity.

The hot gas resulting from vessel breach at any pressure atove a few hundred psia will resule in ignition th there is enough oxygen and hydrogen for combustion. The combustion should be complete. Expert A concluded that detonations were not $11 \mathrm{kely}$ at Surry. At the time of vessel breach, che pre-existing hydrogen would be cold and would deflagrate while the hydrogeti plume from the vessel vould be hot and would probably burn as a diffusion flame. At Surry, it is very unlikely that enough hydrogen could accutalate by the time of vessel breach to allow a global detonation. Expert A felt that local detonations could not be ruled our. however, and the possibility of detonations contributed to the spread In his distribu. cions. The detonation mechanlsw is the fallure of tgnicion or the diffusion flame for a few critical seconds as the hot gas flows out fron the lule in the vessel. If this occurs, then detonable concentrations could exist in a linted volume.

The case structure listed above accounts for varlations, in a coarse fashlon, due to water in the cavity. sprays, and RCS pressura at vessel failure. The subcase structure accounts for differences due to the amount of In-vessel zirconiua oxidation, the hole size, and the fraction of mass ejected. Other factors were accounted for by broadening the uncertainty bounds. In the course of this analysis. Expert A concluded that the pressure rise was fairly insersitive to the albount of in.vessel zirconium oxidation. The eight subcascs are defined by a chree-letcer code: 


\begin{tabular}{|c|c|c|c|c|c|}
\hline Postetion & Bescription & Letter & Werd & Norglat & Range \\
\hline First & In-Vessel 2r Oxidation & 0 & $\begin{array}{l}\text { High } \\
\text { Low }\end{array}$ & $\begin{array}{l}602 \\
258\end{array}$ & $\begin{array}{l}40 \text { to } 808 \\
10 \text { to } 408\end{array}$ \\
\hline Second & Vassel Hole stze & $\begin{array}{l}\mathbf{H} \\
\mathbf{h}\end{array}$ & $\begin{array}{l}\text { Large } \\
\text { Sag11 }\end{array}$ & $\begin{array}{l}2 \mathrm{~m}^{2} \\
0.1 \mathrm{~m}^{2}\end{array}$ & $\begin{array}{l}>0.5 \mathrm{~m}^{2} \\
<0.5 \mathrm{~m}^{2}\end{array}$ \\
\hline Third & Core Fraction Ejected & $\begin{array}{l}\text { C } \\
\text { c }\end{array}$ & $\begin{array}{l}\text { Large } \\
\text { Small }\end{array}$ & $\begin{array}{l}758 \\
338\end{array}$ & $\begin{array}{l}>50 \% \\
<50 \%\end{array}$ \\
\hline
\end{tabular}

Expert A denoted his Surry cases with the letter "R". Thus, Case R3b-OHc is Case $3 b$ as defined above, with high oxidation of zirconiun in-vessel, a large hole size, and a small fraction of the core ejected.

Expert A approached the problem by using the avallable CONTAIN, MAAP, and Surtsey results to carefully assess pressure rise distributions for three base cases. Using a PC spreadsheet program, he then adjusted these base cases to get values for all the other 61 subcases required.

The extremes of his ranges for the base cases were based on energy balance calculations which are relatively straightforward. The best estinate is based an code resules, primarily contalN results as reporced in Reference $A \cdot 1$, and some subsequent calculations, ${ }^{A-2}$ to ${ }^{\text {th }}$ Recent 18 -cell CONTAIN results suggest, for example, that some of the earlfer results nay be too hipll by about 1.0 bar. Expert A spent most of his time on the base cases ryiug to get the center of his distributions correct, since that is where the bulk of the probability lies. He took very little time with the low pressure rise end of the curves since the pressure rises in this region will not fall the containment. He spent conslderable time on the upper fids, however, even though contalnment fallure is assured for chese prossure rises, because the base case is often reduced in calculating the substifary cases. As the base cases tere picked to be about the nost severe expected for the chree RCS pressure levels, the base case is never increased enough in obtaining a derivative case that the low pressure ilse end of the curve becomes important.

For Surry, Expert A selected three bases cases, deroted 1R, 2R, and 3R. Tlu fill designation for each case and the reason it was selected are:

\begin{tabular}{|c|c|c|}
\hline Base & ldentifter & Reason for Selection. \\
\hline 1R & RLb-oltC & $\begin{array}{l}\text { Dry cavlty nore likely than full cavity at } \\
\text { Surry }\end{array}$ \\
\hline $2 \mathrm{R}$ & R3b-ollC & $\begin{array}{l}\text { Availabllity of restilts for compartson with } \\
\text { JR }\end{array}$ \\
\hline IR & $\mathrm{N} i_{6}-\mathrm{OHCC}$ & Parallel paratsatier choice \\
\hline
\end{tabular}


Base Case 1R: 2000 to 2500 psia in RCS, cavity dry, and no sprays, The subcase is low zircontum axidation in-vessel, a large hole, and large fraction of core ejected. For his median value, Experc A started from Surry Case 17 in Reference $A-1$, which has a pressure rise of 10.3 bars. He reduced this pressure by 0.8 bar because of the $18-c e l l$ resulcs. He made another adjustment to account for the fraction of the core partici. pacing in DCH from 750 because the Surtsey tests showed that not all the core participated.A.5 to A-B Expert A also relied on other recent CONTAIN calculations. After other adjustments for the zirconium oxidation fraction and trapping, Expert A arrived at a median value of 8.0 bars.

The following ts Expert A's complete pressure rise discribution for base case IR:

$\begin{array}{lllllllr}\text { Cum. Prob. } & 0.01 & 0.05 & 0.25 & 0.50 & 0.75 & 0.95 & 0.99 \\ \Delta p \text { (bars) } & 1.0 & 2.0 & 5.0 & 8.0 & 10.0 & 13.0 & 15.0\end{array}$

The range ts from 1 to 15 bars wth the nedian at 8.0 bars. Note that these are pressure rises, not total resultant pressure as reported in Reference A-1. The medlan value is based on cases 7,17 . and 26 in this work adjusted for the fraction ejected which participates in DCH. the fraction of zirconfun oxldized in-vessel. the Surtsey experiments, the fraction of unoxidized netal in the ejecta, and the 18 -cell results. Hore of these adjustments were negative than positive, so the pressure rise of 10.3 bars for Case 17 in Reference $A-1$ was, on the whole, adjusted downward more than two bars to get the midpolnt value for this case.

Expert A chose in upper and lower bounds based on the report of the Containgent Loads Working Group and several other calculations and

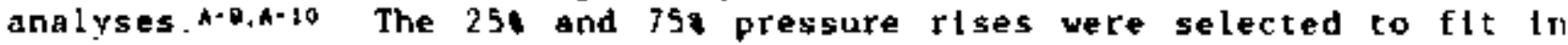
between the median value and the bounds on the basls of the code calculations already referenced. Speciftc reasoning. with detatled references, are avallable for each value given above in the notes of Expert $A$. Which are too voluminous to be included here.

Bese Cexe 2R: 500 to 1000 psin in RCS, cavity dry, and no sprays. The subcas is low zirconium oxidation. large hole, and large fraction of core ejecred. This ls also denoced case R3b.oHC. The pressure tise distrlbution for this base case is primartly based on recent CUNTAIN runs. For the median value, the adjustoents made to the intermediate pressure resule from this reference are ruch the same as those made for the medlan value in base case $1 R$. The median and upper bounds are somewhat lower than in base case $1 R$ because of the lower pressure in the RCS at the $t$ inde of vessel fallure.

Export A observed that, for Surry, the presence of water ln the cavity Increases the peak pressures when the RCs pressure is hlgh before visstel breach but for Intermediaze pressures. as lire, the presence of water decreases the resulting. contalnent pressures. Tlits is different from the whavtor expectrd for Sequoyah, and the reason is that the cavlty at surry holds considerably less water than the cuvity at Sequnyah. The presence of sprays and vater in the cavity inhlbit the prestira rise are 
effectively for intermediate pressure in the RCS (base case 2R) than they do when there is full system pressure in the RCS at breach (bose case 1R).

Expert A gave the following pressure rise distribution for base case 2R:

$\begin{array}{llllllll}\text { Cum. Prob. } & 0.01 & 0.05 & 0.25 & 0.50 & 0.75 & 0.95 & 0.99 \\ \Delta p \text { (bars) } & 0.8 & 2.0 & 4.5 & 6.7 & 8.7 & 11.0 & 14.0\end{array}$

The upper bound is 1.0 bar less that the upper bound in base case $1 R$, and the median value is 1.3 bars lower than the median in base case $1 R$.

Base Case 3R: less than 200 psia in RCS, full cavity, and sprays operat. ing. The subcase is low zircontum oxidation, large hole, and large fraction of core ejected. This is also denoted case R4-oHC. The pressure rise in this case is due to phenomena other than DCH: steam spike, HCCI. and hydrogen combustion. DCH is negligible at these low RCS pressures. The distribution for pressure $r$ ise is largely dertved from the various cases considered by the Containment Loads Working Group. The cases on winch the middle and high end of the distribution rely on CONTAIN results ${ }^{-7}$ while the low end reflects the pressure rise due to the steam spike alone.

Expert $A$ arrived at the followlng pressure rise distribution for tase case 3R:

$\begin{array}{llllllll}\text { Cum. Prob. } & 0.01 & 0.05 & 0.25 & 0.50 & 0.75 & 0.95 & 0.99 \\ \Delta \mathrm{p} \text { (bars) } & 0.2 & 0.5 & 1.2 & 1.8 & 2.5 & 5.0 & 6.5\end{array}$

Expert A detived the pressure rise distributions for all the other cases by means of adjustments to the three base cases described above. These adjustments and the reasoning behind them are described in Expert $A^{\prime} s$ notes which are not included here. As an example, in obtaining the small fraction of core ejected cases from the large fraction of core ejected cases, he reduced the median pressure rise since reducting the fraction of the co,e ejected in various CONTAIN runs showed such an effect.

\section{Results of Expert A's Elicjtation}

Expert A provided a table giving the $1,5,25,50,75,95$, and 99 values for 64 cases and subcases. For 1 isting here, only the 5,50 , and 958 values art shown. Furthermore, Expert A concluded that the effects of the amount of in-vessel zirconium oxidation could not be distinguished in the presence of other uncertainties for all cases except R4. (Case $R 4$ is discussed below.) Thus his results for Rl-OHC aie the same as for Rl-oHC. for example. Therefore, this variable has been eliminated and only four subcases ( $\mathrm{HC}$, hC, Hc, and he) are shown for each case in the following cable. The pressure rises in the following table are in bars. 


\begin{tabular}{|c|c|c|c|c|c|c|c|}
\hline Case & 51 & 508 & 958 & Case & 50 & 500 & 95 \\
\hline $\begin{array}{l}\mathrm{R} 1-\mathrm{HC} \\
\mathrm{Rl}-\mathrm{hC}\end{array}$ & $\begin{array}{l}1.6 \\
1.1\end{array}$ & $\begin{array}{l}6.4 \\
4.5\end{array}$ & $\begin{array}{r}11.7 \\
9.4\end{array}$ & $\begin{array}{ll}\text { R1 He } \\
\text { Rl the }\end{array}$ & $\begin{array}{l}1.3 \\
0.9\end{array}$ & $\begin{array}{l}5.1 \\
3.6\end{array}$ & $\begin{array}{l}9.4 \\
7.5\end{array}$ \\
\hline $\begin{array}{l}\text { Rla-kC } \\
\text { Rla-hC }\end{array}$ & $\begin{array}{l}2.0 \\
1.2\end{array}$ & $\begin{array}{l}8.0 \\
4.8\end{array}$ & $\begin{array}{l}13.0 \\
10.4\end{array}$ & $\begin{array}{l}\text { Rla-Hc } \\
\text { Rla-he }\end{array}$ & $\begin{array}{l}1.6 \\
1.0\end{array}$ & $\begin{array}{l}6.4 \\
3.8\end{array}$ & $\begin{array}{r}10.4 \\
8.3\end{array}$ \\
\hline $\begin{array}{l}\text { R1b-HC } \\
\text { RIb-hC }\end{array}$ & $\begin{array}{l}2.0 \\
1.4\end{array}$ & $\begin{array}{l}8.0 \\
5.6\end{array}$ & $\begin{array}{l}13.0 \\
10.4\end{array}$ & $\begin{array}{l}\text { Rlb-Hc } \\
\text { Rlb-he }\end{array}$ & $\begin{array}{l}1.6 \\
1.1\end{array}$ & $\begin{array}{l}6.4 \\
4.5\end{array}$ & $\begin{array}{r}10.4 \\
8.3\end{array}$ \\
\hline $\begin{array}{l}\text { Rlc-HC } \\
\text { Rlc-hC }\end{array}$ & $\begin{array}{l}2.2 \\
1.7\end{array}$ & $\begin{array}{l}8.8 \\
6.7\end{array}$ & $\begin{array}{l}13.0 \\
11.4\end{array}$ & $\begin{array}{l}\text { Rlc } \cdot \mathrm{Hc} \\
\text { Rlc-he }\end{array}$ & $\begin{array}{l}1.8 \\
1.3\end{array}$ & $\begin{array}{l}7.0 \\
5.4\end{array}$ & $\begin{array}{r}10.4 \\
9.2\end{array}$ \\
\hline $\begin{array}{l}\text { R3 }-\mathrm{HC} \\
\text { R3 }-\mathrm{hC}\end{array}$ & $\begin{array}{l}1.8 \\
1.5\end{array}$ & $\begin{array}{l}6.0 \\
5.1\end{array}$ & $\begin{array}{l}9.9 \\
9.4\end{array}$ & $\begin{array}{ll}\text { R3 } & -\mathrm{He} \\
\mathrm{R} 3 & -\mathrm{hc}\end{array}$ & $\begin{array}{l}1.4 \\
1.2\end{array}$ & $\begin{array}{l}4.8 \\
4.1\end{array}$ & $\begin{array}{l}7.9 \\
7.5\end{array}$ \\
\hline $\begin{array}{l}\text { R3a-HC } \\
\text { R3a-hC }\end{array}$ & $\begin{array}{l}2.0 \\
1.4\end{array}$ & $\begin{array}{l}6.7 \\
4.8\end{array}$ & $\begin{array}{r}11.0 \\
9.9\end{array}$ & $\begin{array}{l}R 3 a-H c \\
R 3 a-h c\end{array}$ & $\begin{array}{l}1.6 \\
1.2\end{array}$ & $\begin{array}{l}5.4 \\
3.9\end{array}$ & $\begin{array}{l}8.8 \\
7.9\end{array}$ \\
\hline $\begin{array}{l}R 3 b-H C \\
R 3 b-h C\end{array}$ & $\begin{array}{l}2.0 \\
1.7\end{array}$ & $\begin{array}{l}6.7 \\
5.7\end{array}$ & $\begin{array}{l}11.0 \\
10.4\end{array}$ & $\begin{array}{l}\mathrm{R} 3 \mathrm{~b} \cdot \mathrm{Hc} \\
\mathrm{R} 3 \mathrm{~b}-\mathrm{hc}\end{array}$ & $\begin{array}{l}1.6 \\
1.4\end{array}$ & $\begin{array}{l}5.4 \\
4.6\end{array}$ & $\begin{array}{l}8.8 \\
8.4\end{array}$ \\
\hline $\begin{array}{ll}\mathrm{R} 4 & -\mathrm{HC} \\
\mathrm{R} 4 & -\mathrm{hC}\end{array}$ & $\begin{array}{l}0.4 \\
0.5\end{array}$ & $\begin{array}{l}1.6 \\
1.8\end{array}$ & $\begin{array}{l}4.5 \\
5.0\end{array}$ & $\begin{array}{ll}\text { R4 } & -\mathrm{Hc} \\
\mathrm{R} 4 & -\mathrm{hc}\end{array}$ & $\begin{array}{l}0.2 \\
0.2\end{array}$ & $\begin{array}{l}0.9 \\
0.8\end{array}$ & $\begin{array}{l}2.5 \\
2.2\end{array}$ \\
\hline
\end{tabular}

For Case $R 4$, there were slight differences in the pressure rise that depended on the amount of in-vessel zirconitur oxidation for subcases hc, $\mathrm{Hc}$, and hc. For subcases, the Hc and hc subcases, the 999 pressure rises are less than 3.5 bars and the 0.0 differences are less than 0.5 bars, so the differences are not worth preserving since the surry containment will not be fafled by pressure rises of this magnitude even if the lowest failure pressure given by the structural panel is used. For the hc subcase, the 99 values are 6.5 bars (for ohc) and 5.85 (for onc). These values bring the load pressure into the lower portion of the range where failure of the containment is possible. The pressure rise aistribution for subcase with the higher values (OhC) are listed above. If the elicitations of the other experts show strong dependencies on the amount of $z$ irconitum axidation, the differences Expert a has given for case R4 will be utilized. In the table above, the differences between subcase $H C$ and subcase hC are small, and the differences between subcase Hc and subcasa he are even smaller. A good argument can be made Eor combining these subcases for Case H4 so that only $\mathrm{C}$ and $c$ subcases remain.

\section{Sources of Uncertainty}

Expert A emphasized that there were many uncertainties in estimating containment laads, especially containuent loads at vessel breach. Self. hesting of the molten materlal as it travels from the vessel throughout containment is not accounted for in the lumped-parameter codes. This phenomenon is not captured in the Brookhaven experiments. Entrainment and Weber break-up are not mechanistically treated in the detailed codes. 
A zirconitum oxide crust on the efected droplets may cause them to behave like solid particles rather than liquid particles. Internal gas generation may fragment the droplets, thus affecting the particle size distribution.

Nitrogen chemistry is not inclided in any of the models. If nitrogen conblnes with the metal oxides in the droplet the flow of nitrogen into the droplet may cause fragmentation if the nitrogen is subsequentiy relessed. The interactions of corium droplets with surfaces are not well understood; while it is known that moitell corlum does not wet concrete surfaces, and concrete spalis when covered with enough molten corium, exactly how the corium droplets w:11 interact with concrete surfaces in a DCH event is unknown. The DCH experiments have shown that there is considerable varlability in trapping rates. Finally, the flow paths in the containnent may change during the event as a resilt of the event itself. 


\section{REFERENCES}

A-1. D. C. Williams et a1, "Contalnment Loads Due to Direct Containment Heating and Asscciated Hydrogen Behavior: Analysis and Calculations

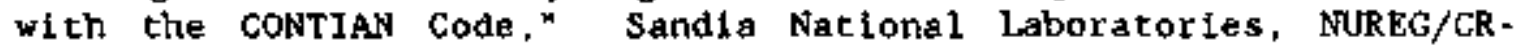
4896. SAND87-0133, May 1987.

A-2. D. C. Will1ans, "CONTAIN DCH Calculations fot PWRs," Viewgraphs for NUREG/CR-1150 Contalnwent Loads Panel (docunented in References A-3 and A-4), December 17, 1987

A-3. D. C. Williams, conTAIN Analyses of Direct Containuent Heating Events in the surry piant," ANs Thermalhydraulics Diviston Proceedings of the ANS/ENS International Negting, oct. $31-$ Nov 4. 1988, Washingtor, DC, 1988 .

A 4. D. C. Williams et al., *Integrated Phenomenological Analysis of Contalnment Response to Severe Core Damage Accidents," Progress, in Nuclear Energy, $19,69,1987$.

A-5. M. Pilch and $W$. W. Tarbell, "Preliminary Calculations on Direct Heating of a Containment Atmosphere by Airborne Debris," Sandia National Laboratories, NUREC/CR-4455, SANDB5-2439, July 1986.

A-6. W. W. Tarbell et al., "Results From the DCH-1 Experinent," Sandia Nat lonal Laboratorles, NUREG/CR-4871. SANDB6-24B3, June 1987.

A.7. M. Pilch and W. W. Tarbell, "High Pressure Ejection of Melt From a Reactor Pressure Vessel: The Discharge Phase," Sandia Nacional Laboratories, Albuquerque, NM, NUREG/CR-4383, SAND85-0012, Septenber 1985 .

A-8. W. W. Tarbe11, "Pressurized Melt Ejection Into Sealed Reactor Cavities." Sandia National laboratories, NUREG/CR-4512, SAND86-0153, October 1986 .

A.9. D. W. Stamps et al., Uncertainties in Hydrogen Combustion," SANDB7$2277 \mathrm{C}$, Sandia National Laboratories, 1987.

A-10. D, C. Williams and K. D. Bergeron, "CoNTAIN Calculations of Contairment Loadings of Dry PWRs," Nuclear Engineering and Desien. 90, 153. 1986 . 


\section{Issue 6: Prossure Rise at Vessel Breach for Surry}

\section{Description of Expert B's Rationale/Methodolocy}

The Expert provided a narrative description of the events he considered most likely to occur during pressurized melt ejection, based on experiments and calculaclons. When melt first enters the cavity, it spreads anto all the walls. The following gas entrains the liquid from the cavity. The flow would "dead end" at the seal table, then turn. The Expert does not belleve that the nelt will freeze on the walls. Approximately 808 of the melt will exit the cavity as droplets. The gas velocity will be several hundred $\mathrm{m} / \mathrm{s}$, and the droplet diameters must be in the range of tenths of nillideters. The droplets contain unreacted metallics, and zirconium would react in a fraction of a second. Therefore, if the droplets can be kept suspended for about one second, $1008 z$ irconfum reac. tion could occur, provided the atmosphere was not steam starved. The export does not beileve that the resction will be turned off by low temperature. The chemica? reaccions will be very efflcient and complete; all zirconfum and 50 of of the fron wlll be reacted, and all pre-existing hydrogen will be burned.

Expert B based his "best estimates" on CONTAIN calculations and on scaled experiments of the similar Zion containnent. The case for vessel failure with tha RCS at 500 to 1000 psia was taken as a base case, and the cunulative distribution function (CDF) for that case was modified for other cases. Gavity water could either enhance or reduce the pressure. The medlan was kept the same for wet cavity cases, but the distribution was 3tretched at both ends. On the low side, an overabundance of water might reduce pressure by two bars. On the high side, calculations indicate the possibility of increasing pressure by one bat.

He based the high side of his distributions on getting a stean blowdown which optimized entrainnent, and on burning the remaining 1ron. On the low side, he considered phenomena which might reduce pressure; larger drop diameter, or faster trapping. Calculations had indicated that pressure jaight be reduced by one bar for larger drops and one bar for better crapping. He thus considered that the base case pressure could be reduced by three bars for the 5 th percentile.

Dependence on extent of zirconium oxidation, vessel breach area, and fraction of melt ejected was also to be considered. CoNTaIN calculations had indicated that there was little dependence on previous zirconium oxidation. The reason for low dependence on previous zirconium oxidation might be oxidation starvation or steam starvation in the cavity: he considers that latter to be doubtful. The effect of greater hole area is to give higher pressute across the entire band, because the gas would exit with higher velocity. The effect of fraction of core ejected was handled by scaling the base case ratio of final to intilal pressure. If the fraction of melt is reduced from 75 to 258 , this would reduce pressure increment by a factor of 0.6 . 
Table B-1 contains the results of Expert B's elicitation. Expert B concluded that Cases 1 and $I C$ and Cases 3 and $3 A$ were indistinguishable.

Table B.I

Loads at Vessel Breach at surry for Expert B (bars)

\begin{tabular}{|c|c|c|c|c|c|c|c|c|c|}
\hline \multirow[b]{3}{*}{ Case } & \multicolumn{2}{|c|}{ Subcase } & & & & & & & \\
\hline & \multirow{2}{*}{$\begin{array}{l}\text { Hole } \\
\text { Size }\end{array}$} & \multirow{2}{*}{$\begin{array}{l}\text { Fraction } \\
\text { Ejected }\end{array}$} & \multicolumn{7}{|c|}{ Eractile } \\
\hline & & & 0.001 & 0.010 & $\underline{0.550}$ & 0.500 & 0.950 & $\underline{0,990}$ & $\underline{0,999}$ \\
\hline $1 / 1 C$ & High & High & 1.5 & 2.0 & 2.5 & 7.0 & 10.3 & 12.2 & 14.0 \\
\hline $1 / 10$ & H1gh & Low & 1.5 & 2.5 & 3.5 & 5.0 & 6.5 & 7.8 & 9.1 \\
\hline $1 / 10$ & Low & High & 1.0 & 1.2 & 1.5 & 6.0 & 10.3 & 12.2 & 14.0 \\
\hline $1 / 10$ & Low & Low & 1.5 & 2.0 & 2.5 & 4.0 & 5.5 & 6.8 & 9.1 \\
\hline $1 A$ & High & Hi gh & 1.5 & 4.0 & 5.0 & 8.0 & 9.3 & 11.2 & 14.0 \\
\hline IA & High & Low & 1.5 & 3.0 & 4.0 & 6.0 & 7.0 & 6. 3 & 9.1 \\
\hline $1 \mathrm{~A}$ & Low & High & 1.0 & 1.5 & 2.5 & 8.0 & 10.3 & 12.2 & 14.0 \\
\hline lA & Low & Low & 1.5 & 2.5 & 3.5 & 5.0 & 6.5 & 7.8 & 9.1 \\
\hline 18 & High & HLgh & 1.5 & 3.0 & 4.0 & 8.0 & 9.3 & 11.2 & 14.0 \\
\hline 1B & High & Low & 1.5 & 3.0 & 4.0 & 5.5 & 6.0 & 7.3 & 9.1 \\
\hline $1 \mathrm{~B}$ & Low & High & 1. 5 & 2.0 & 3.0 & 7.0 & 9.3 & 11.2 & 14.0 \\
\hline $1 \mathrm{~B}$ & Low & Low & 1.5 & 2.0 & 3.0 & 4.5 & 6.0 & 7.3 & 9.1 \\
\hline $3 / 3 \mathrm{~A}$ & High & High & 15 & 3.0 & 4.0 & 7.0 & 10.0 & 12.0 & 14.0 \\
\hline $3 / 3 A$ & $\mathrm{High}$ & Low & 1.5 & 3.5 & 4.0 & 5.0 & 7.5 & 8.8 & 9.1 \\
\hline $3 / 3 \mathrm{~A}$ & Low & High & 1.5 & 2.0 & 3.0 & 6.0 & 10.0 & 12.2 & 14.0 \\
\hline $3 / 3 \mathrm{~A}$ & Low & Low & 1.5 & 1.8 & 2.0 & 4.0 & 7.0 & 8.3 & 9.1 \\
\hline $3 \mathbf{B}$ & High & H: gh & 1.5 & 4.0 & 5.0 & 6.0 & 10.0 & 12.2 & 14.0 \\
\hline $3 B$ & High & Low & 1.5 & 3.0 & 3.5 & 4.0 & 7.0 & 8.3 & 9.1 \\
\hline $3 B$ & Low & High & 1.5 & 3.0 & 4.0 & 5.0 & 9.0 & 11.2 & 14,0 \\
\hline $3 B$ & Low & Low & 1.5 & 2.0 & 2.5 & 3.0 & 6.0 & 7.3 & 9.1 \\
\hline 4 & HLgh & HIgh & 0.2 & 0.5 & 1. 0 & 1.3 & 1.8 & 2.0 & 2.5 \\
\hline 4 & High & Low & 0.2 & 0.3 & 0.5 & 0.6 & 0.8 & 0.9 & 1.0 \\
\hline 4 & Low & High & 0.2 & 0.5 & 1.0 & 1.3 & 1.8 & 2.9 & 2.5 \\
\hline 4 & Low & Low & 0.2 & 0.3 & 0.5 & 0.6 & 0.8 & 0.9 & 1.0 \\
\hline
\end{tabular}

Sources of Uncertalnty

A najor source of uncertainty is the eftect of cavity water. This could either increase or decrease the pressure increment. Other sources of uncertainty are the effects of drop diameter, the extent of iron oxication, and the efficleacy of trapping.

As showti in Table B-1, uncertainty in the inttal conditions also leads to a jarge uncercaituty in the results. The mass ejected and chacacter of the blowdown could lead to large differences in the pressure increment. 
Expert C's Ellcitation

\section{Issue 6: Pregsure Rise at Vessel Bregch for Surry}

\section{Description of Expert C's Rationale/Methodoloxy}

Inicial condiltons for each case were subdivided by:

Fraction of zirconlum oxfdized before vessel breach-25 (low) and 60 s (high); size of hole in vessel-.0.1 $\mathrm{m}^{2}$ (jet) and $2 \mathrm{~m}^{2}$ ( $\mathrm{xip}$ ); fraction of melc ejected- 258 (small) and 758 (najor). For each case there are elght distinct sets of initlal conditions. For example LJM would represent 258 zixconium oxidation, a $0.1 \mathrm{~m}^{2}$ hole in the vessel, and 758 of the core promptly ejected.

As base cases, the HMC calculations by Corradini et al.. and CONTAIN calculations by $D$. C. Hillians were used. All the cases were tabulated; appilcable calculations vere then assigned to a spectfic case and set of inftial conditions as shown in Table c-1. The calculations by Corradini were Jone for 100 e elt ejection. The Expert reduced the pressure inctement from the calculation by the ratio of melt ejected in the initial conditinns: he was oware that the relation between pressure increment and fraction ejected was probably nonlinear, but had no other means of estimating the pressure increment corresponding to lowe: core fractions released. There were a large number of cases without a point eatimate. Also, a large body of calculations performed by industry were unavailable.

Some of the cases wer combined because of similarities, or because thera is no information svallable for distinguishing them. For example, he believed that biy water in the cavity would be dispersed slmost immediately, and there was no vay to distingulsh between full and half cavities. Gases 1 and $1 \mathrm{~A}$ were comblned, as were Cases 3 and $3 \mathrm{~A}$.

In order to get a distribution, he considered the upper bound as the highest pressure calculated by Corradini. As a lower bound, the pressure increment without direct hesting (i.e., a stean spike only) was used. For the high pressure cases, results calculated hy Corradini were weighted according to how close the initial and boundary condicions approximated che desir:d case, and calculated a median value. For Cases $1 B$ and $3 B$, he had access to both CONTAIN and MAPP calculations, CONTAIN calculations for unconditional hydrogen burn and default burn were averaged, and used for the upper part of the distribution. The MApp results were consistently lower than CoNTaIN results, and were used for the lower part of the distribution. The median was then selected between the two sets of calculations. A curve was then hand-fitted to the lower bound, gedian. and upper bound.

He believed the CONTAIN calculations to be consistently above the median, but that the reasons for the high values were rooted in the assumptions used. Given the assumptions, he constdered the CONTAIN results to be credible. He was thus able to use the CONTAIN sensitivity calculations to estimate the effects of changes in intlal conditions. 
Table C.I

Calculations Applicable to Issue 6

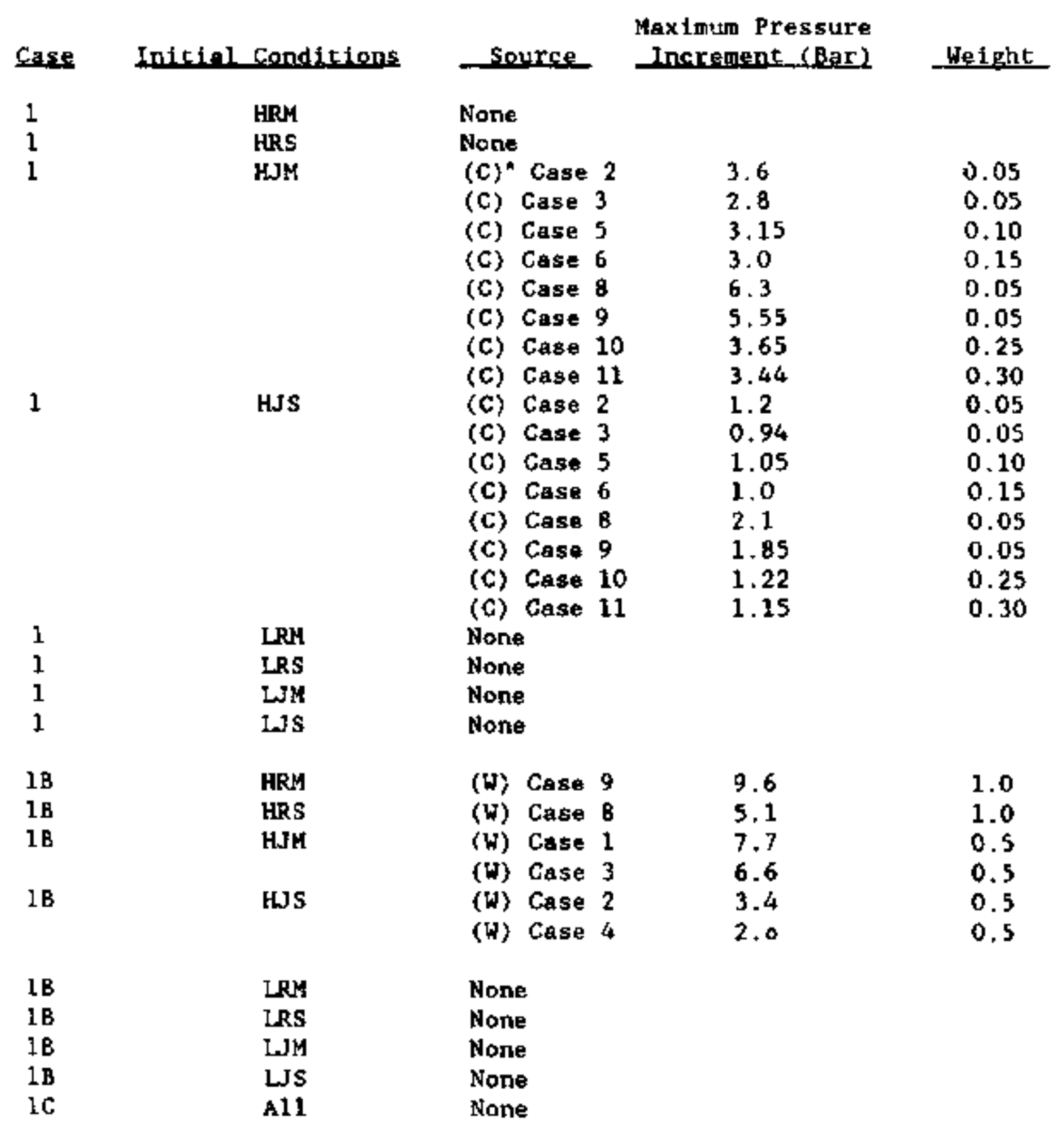


Table C-1 (continued)

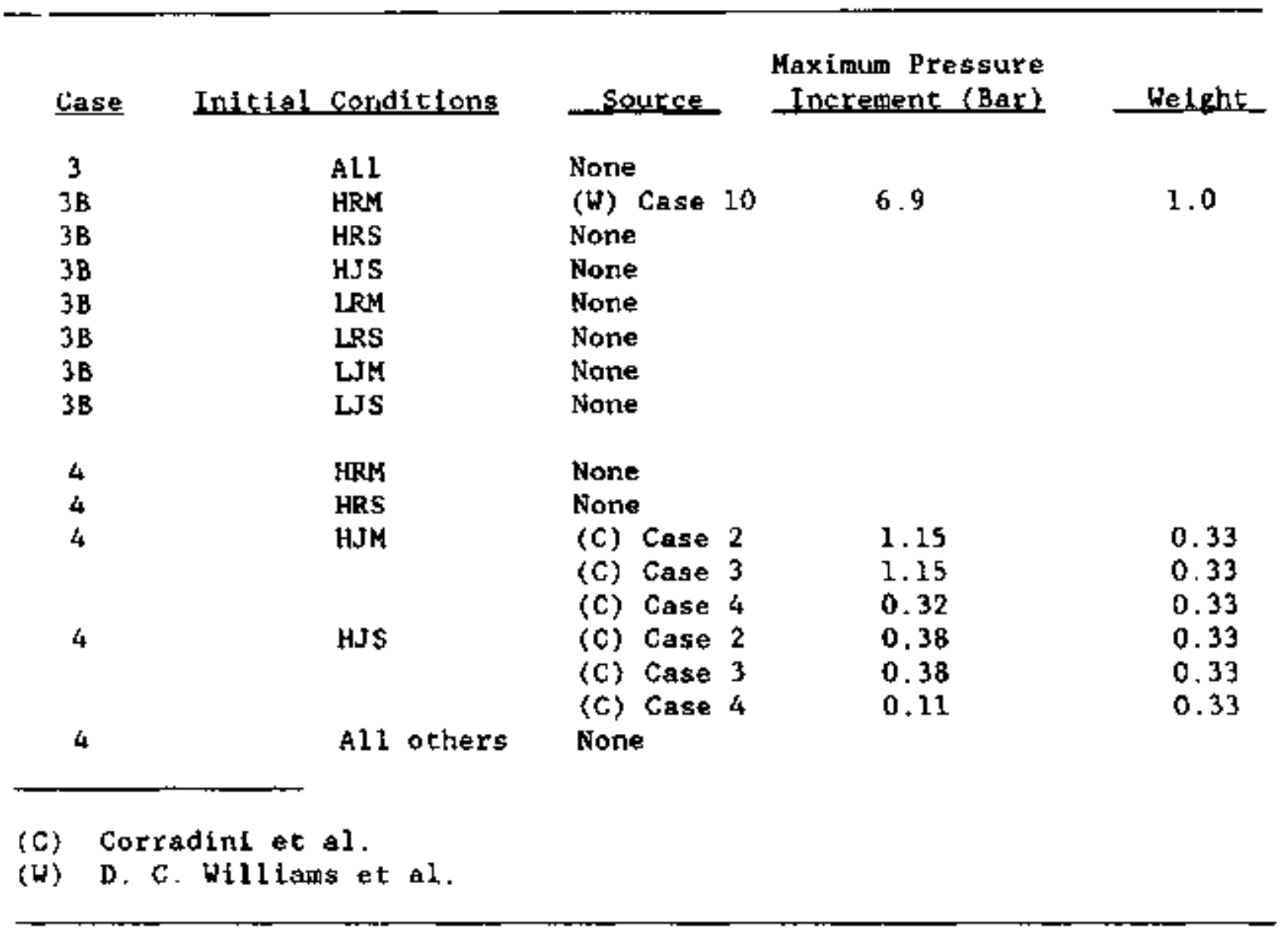

Table C.2 shows Expert C's distrfbutions for those cases for which code results are available.

Table C.2

Distributions for Pressure Increment (bars)

\begin{tabular}{llllllll}
\hline & & \multicolumn{7}{c}{ Fractiles } \\
\cline { 3 - 7 } Case & Initial Conditions & 01 & $\underline{0.1}$ & $\underline{0.5}$ & 0.9 & 0.99 \\
\hline 1 & HJM & 2 & 3 & 4 & 5 & 6 \\
1 & HJS & 1 & 1.5 & 2 & 2.5 & 3 \\
IB & HJM & 4 & 5 & 6 & 7 & 8 \\
3B & HRM & 4 & 5 & 6 & 7 & 8 \\
3B & HJM & 3 & 4.5 & 6 & 7.5 & 8.5 \\
4 & HJM & 0.5 & 1 & 1.5 & 2 & 3 \\
\hline
\end{tabular}


To aggregate the issues, the Information missing from Expert $C^{\prime} s$ elicitation was created from the data that Expert $C$ provided. This aggregation was revlewed by the experts and the results appear in the frilowing attachment.

\section{Besults of Expert C's Elitcitetion}

Ratios are used to estimire the pressure rise distributions for each case and subcase for which there is no information in Table $C-1$. The ratio of "S" to "M" is estimaced fron cases 1 and $1 \mathrm{E}$ :

\begin{tabular}{|c|c|c|c|c|c|c|}
\hline & & & & tile & & \\
\hline Case & Subcases & .01 & .10 & .50 & .90 & .99 \\
\hline 1 & HJS :HJM & .5 & .5 & .5 & .5 & .5 \\
\hline 18 & HRS:HRM & .444 & .5 & .5 & .5 & .5 \\
\hline 18 & H.JS:H.JM & .375 & .4 & .417 & .429 & .438 \\
\hline & Meatı & .440 & .467 & .472 & .476 & .479 \\
\hline
\end{tabular}

Similarly, the ratio of " $J$ " to " $R$ " 1 s estimated from cases $1 B$ and $3 B$ :

\begin{tabular}{lllllll} 
& \multicolumn{5}{c}{ Fractile } \\
\cline { 3 - 7 } Case & Subcases & .01 & .10 & .50 & .90 & .99 \\
1B & HJM:HRM & .889 & .833 & .750 & .700 & .667 \\
1B & HJS:HRS & .750 & .667 & .625 & .600 & .583 \\
3B & HJM:HRM & .750 & .900 & 1.000 & 1.071 & 1.062 \\
& Mean & .796 & .800 & .792 & .790 & .771
\end{tabular}

The ratios of cases for which there are data are as follows:

Fractile

$\begin{array}{llllll}\text { Cases } & .01 & .10 & .50 & .90 & .99 \\ 1 \mathrm{~B}: 1 & 1.75 & 1.5 & 1.375 & 1.3 & 1.25 \\ 3 \mathrm{~B}: 1 \mathrm{~B} & .75 & .9 & 1 . & 1.067 & 1.067 \\ 4: 1 & .25 & .333 & .375 & .5 & .5 \\ \text { 3B:1 } & 1.5 & 1.5 & 1.5 & 1.5 & 1.42\end{array}$

There are to calculations or estimates for case $1 \mathrm{C}$. If case $1 C$ is equal to case 1 , the following ratios between cases car to set up:

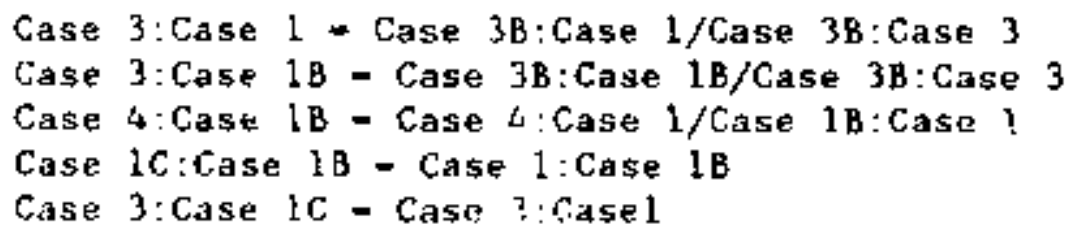

In this maner, ratios were set up between all cases. The ratios for each flictile were calculated, so that the ratios between cases are inintuplets. Table $C-3$ shows the results of these calculations for all lat ios betwren cases. 
Table $c-3$

Ratios for Louds at Vessel Breach at Surry for Expert $C$

\begin{tabular}{|c|c|c|c|c|c|c|}
\hline \multirow{2}{*}{\multicolumn{2}{|c|}{ Rat to of Case-to.Case }} & \multicolumn{5}{|c|}{ Fractile } \\
\hline & & \multirow{2}{*}{$\frac{.01}{1.000}$} & \multirow{2}{*}{$\frac{10}{1.000}$} & \multirow{2}{*}{$\frac{.50}{1.000}$} & \multirow{2}{*}{$\begin{array}{l}.90 \\
1.000\end{array}$} & \multirow{2}{*}{$\begin{array}{l}-99 \\
1.000\end{array}$} \\
\hline 1 & 1 & & & & & \\
\hline $1 \mathrm{~B}$ & 1 & 1.750 & 1.500 & 1.375 & 1.300 & 1.250 \\
\hline $1 C$ & 1 & 1.000 & 1.000 & 1.000 & 1.000 & 1.000 \\
\hline 3 & 1 & 0.429 & 0.600 & 0.727 & 0.821 & 0.854 \\
\hline $3 E$ & 1 & 0.750 & 0.900 & 1.000 & 1.067 & 1.067 \\
\hline 4 & 1 & 0.250 & 0.333 & 0.375 & 0.500 & 0.500 \\
\hline 1 & 1B & 0.571 & 0.667 & 0.727 & 0.769 & 0.800 \\
\hline 1B & IB & 1.0160 & 1000 & 1.000 & 1.000 & 1,000 \\
\hline $1 c$ & 1B & 0.571 & 0.667 & 0.727 & 0.769 & 0.800 \\
\hline 3 & IB & ก 245 & 0.400 & 0.529 & 0.631 & 0.683 \\
\hline 3B & $1 \mathrm{~B}$ & 0.750 & 0.900 & 1.000 & 1.067 & 1.067 \\
\hline 4 & $1 B$ & 0.143 & 0.222 & 0.273 & 0.385 & 0.400 \\
\hline 1 & $1 \mathrm{C}$ & 1.000 & 1.000 & 1.000 & 1.000 & 1.000 \\
\hline 1B & $1 \mathrm{C}$ & 1.750 & 1.500 & 1.375 & 1.300 & 1.250 \\
\hline $1 \mathrm{C}$ & $1 \mathrm{C}$ & 1.000 & 1.000 & 1.000 & 1.000 & 1.000 \\
\hline 3 & 10 & 0.429 & 0.600 & 0.727 & D.821 & 0.854 \\
\hline 3B & 10 & 0.750 & 0.900 & 1.000 & 1.067 & 1.067 \\
\hline 4 & $1 \mathrm{C}$ & 0.250 & 0.333 & 0.375 & 0.500 & 0.500 \\
\hline 1 & 3 & 2.333 & 1.667 & 1.375 & 1.218 & $1 .: 72$ \\
\hline $1 \mathrm{~B}$ & 3 & 4.083 & 2.500 & 1.891 & 1,584 & 1.464 \\
\hline IC & 3 & 2.333 & 1.667 & 1.375 & 1.21 .8 & 1.172 \\
\hline 3 & 3 & 1.000 & 1.000 & 1.000 & 1.000 & 1.000 \\
\hline $3 \mathrm{~B}$ & 3 & 1.750 & 1.500 & 3.375 & 1.300 & 1.250 \\
\hline 4 & 3 & 0.333 & 0.370 & 0.375 & 0.469 & 0.469 \\
\hline l & $3 \mathrm{~b}$ & 1.333 & 1.111 & 1.000 & 0.937 & 0.937 \\
\hline $1 \mathrm{~B}$ & $3 B$ & 1.333 & 1.111 & 1.000 & 0.937 & 0.937 \\
\hline 10 & $3 B$ & 1.333 & 1.111 & 1.200 & 0.937 & 0.937 \\
\hline 3 & 3B & $05 / 2$ & 0.667 & 0.727 & 0.769 & 0.800 \\
\hline 35 & 3B & 1.000 & 1.000 & 1.000 & 1.000 & 1,000 \\
\hline
\end{tabular}


Table $[-3$ (co.tinued)

\begin{tabular}{|c|c|c|c|c|c|c|}
\hline \multirow{2}{*}{\multicolumn{2}{|c|}{ Ratity of Casse-to-Case }} & \multicolumn{5}{|c|}{ Practile } \\
\hline & & .01 & .10 & 50 & 90 & .99 \\
\hline 4 & $3 \mathrm{~B}$ & 0.333 & 0.370 & 0.375 & 0.459 & 0.469 \\
\hline 1 & 4 & 4,000 & 3.003 & 2.667 & 2.000 & 2.000 \\
\hline 1B & 4 & 7.000 & 4.505 & 3.667 & 2.600 & 2.500 \\
\hline $1 \mathrm{C}$ & 4 & 4.000 & 3.003 & 2.667 & 2000 & 2.000 \\
\hline 3 & 4 & 3.000 & 2.703 & 2.667 & 2,134 & 2.134 \\
\hline 3B & 4 & 3.000 & 2.703 & 2.667 & 2.134 & 2.134 \\
\hline 4 & 4 & 1.000 & 1.000 & 1.000 & 1.000 & 1.000 \\
\hline
\end{tabular}

The next step to consider each of the cases and subcases for which there is no pressure rise distribution. If the case/subcase distribution is not available, frist look through all subcases of the same case. If any distributions are available, calculate each fractile as the mean of the subcase ratios times the fractile value for the distributions that ire available. If there are no distributions given within that case, calculate each fractile as the nean of the subcase ratios tines the case ratios for all case/subcase combinatien (chat 1s, for any case) for which distributions are available.

The advantage of this method is that the results are internally consistent. There is no differentiation between low and high 2 irconium oxidation as Expert $c$ believed the effect of zirconium oxidation would be small. The results of Expert $C$ ate shown in Table C.4.

Table C.4

Loads at Vessel Breach at Surcy

\begin{tabular}{|c|c|c|c|c|c|c|}
\hline \multirow[b]{2}{*}{ Case } & \multirow[b]{2}{*}{ Subcase } & \multicolumn{5}{|c|}{ Fractile } \\
\hline & & .01 & .10 & .50 & 90 & .99 \\
\hline $1 / 1 \mathrm{~A}$ & HRM & 2.8 & 3.5 & 4,1 & 4.8 & 5.7 \\
\hline $1 / 1 A$ & HRS & 1.3 & 1.6 & 1.9 & 2. 3 & 2.8 \\
\hline $1 / 1 \mathrm{~A}$ & H.JM & 2.0 & 3.0 & 4.0 & 5.0 & 6.0 \\
\hline $1 / 1$ in & H.JS & 1.0 & 1.5 & 20 & 2.5 & 3.0 \\
\hline $1 \mathrm{~B}$ & HRM & 4.5 & 6.0 & 8.0 & 10.0 & 12.0 \\
\hline $1 B$ & HRS & 2.0 & 3.0 & 4.0 & 5.0 & 6.0 \\
\hline 1B & HJM & 4.0 & 5,0 & 6.0 & 7.0 & 8.0 \\
\hline lB & HJS & 1.5 & 2.0 & 2.5 & 3.0 & 34 \\
\hline
\end{tabular}


Table C.4 (continued)

\begin{tabular}{|c|c|c|c|c|c|c|}
\hline \multirow[b]{2}{*}{ Case } & \multirow[b]{2}{*}{ Subcase } & \multicolumn{5}{|c|}{ Erectile } \\
\hline & & - & 10 & -50 & -90 & _.99 \\
\hline 1C & HRM & 3.2 & 3.9 & 4.8 & 5.6 & 6.8 \\
\hline $1 \mathrm{C}$ & HRS & 1.4 & 1.8 & 2.3 & 2.7 & 3.3 \\
\hline 16 & HJM & 2.4 & 3.6 & 4.8 & 6.0 & 7.2 \\
\hline $1 c$ & HJS & 1.1 & 1.7 & 2.3 & 2.8 & 3.5 \\
\hline $3 / 3 A$ & HRM & 1.4 & 2.4 & 3.6 & 4.6 & 5.9 \\
\hline $3 / 3 A$ & HRS & 0.6 & 1.1 & 1.7 & 2.2 & 2.8 \\
\hline $3 / 3 A$ & HJM & 1.1 & 2.2 & 3.6 & 5.0 & 6.3 \\
\hline $3 / 3 \mathrm{~A}$ & HJS & 0.5 & 1.0 & 1.7 & 2.4 & 3.0 \\
\hline $3 \mathrm{~B}$ & HRY & 4.0 & 5,0 & 6.0 & 7.0 & 8.0 \\
\hline $3 \mathrm{~B}$ & HRS & 1.8 & 2.3 & 2.8 & 3.3 & 3.8 \\
\hline 3B & HJM & 3.0 & 4.5 & 6.0 & 7.5 & 8.5 \\
\hline $3 B$ & HJS & 1.3 & 2.1 & 2.8 & 3.6 & 4.1 \\
\hline 4 & HRM & 0.7 & 1.1 & 1. 5 & 1.9 & 2.8 \\
\hline 4 & HRS & 0.3 & 0.5 & 0.7 & 0.9 & 1.3 \\
\hline 4 & $\mathrm{H} . \mathrm{M}$ & 0.5 & 1.0 & 1.5 & 2.0 & 3.0 \\
\hline 4 & HJS & 0.2 & 0.5 & 0.7 & 1.0 & 1.4 \\
\hline
\end{tabular}




\section{Expert D's Elicftation}

\section{Issue 6: Tresaure Rlse at Vessel Breach for Surry}

\section{Description of Expert D's kationale/Methodology}

Expert $D$ concluded that Case lc was very unlikely to occur because the only way to get a full cavity at Surry is for the sprays to operate in the recirculation mode. He grouped Case lc with Case 1b. Expert D did not want to group Case ic with Case 1 because he felt sprays are very important and that spray and no-spray cases should not be grouped together. The sprays can reduce the total resuitant pressure by 2.5 bars if the lower base pressure is considered. If the total pressure is close to the failure pressure, this may make an important difference.

Expert D did not consider Case 4 as he felt it was a straight hydrogen burn problem anc would produce a minimal threst to the containment. Expert D also grouped Case la with Case 1 , and Case 3 a with Case 3 , because he felt the differences between a full eavity and a partially full cavity were not significant. Thus Expert $D$ reduced the cases to faur:

\begin{tabular}{|c|c|c|c|}
\hline Case & $\begin{array}{l}\text { RCS Pressure } \\
\text { (psia) }\end{array}$ & Cayity Hater & Sprays operating \\
\hline 1 & 2000 to 2500 & Wet & Yes \\
\hline $1 b$ & 2000 to 2500 & Dry & No \\
\hline 3 & 500 te 1000 & Wet & Yes \\
\hline $3 \mathrm{~b}$ & 500 to 1000 & Dry & No \\
\hline
\end{tabular}

CONTAIN Is currently the only code which has a DCH model, and thus Expert $D$ used the CONTAIN results as the basis for his analysis. The magnitude of the DCH pressure rise depends upon the fraction of the core ejected thich is unaxidized metal, primarily zirconium. The initial portion of the ejected matertal could come from the oxide layer in the lower head of the reactor vessel. A likely scenario has the oxidic material coming out first, inwediately followed by steam, and then the metal-rich core debris coming out later. This would give little or no hydrogen production from the particles entrained in the high-velocity steam blowdown.

The heating in DCH comes about one third from the sensible heat in the particles and about two thitds from the chenical reaction (hydrogen production by metal-steam reaction). The effects of metal fraction varlation in the ejected materlal are hard to quantify: a metal-lean rixture could reduce the pressure to $60 \%$ of that calculated for the case where the ejected material is honogeneous based on the total core. There are no CONTAIN tuns with oxide-rich ejected material to check this.

For the small hole cases, Expert $D$ adjusted the ConTAIN pressures upwarc somewhat since there is the possibility that more than one penetration may fail ac or about the same time. 
Considering that the DGH model in CONTAIN is fairly recent. Expert D Eelt that the number of runs avallable was large. Variacions had been run for the effects of RCS pressure, presence of water in the cavity, amount of zirconium oxidized in the vessel, the melt fraction ejected, and the initial openirg size. There were no cases, however, that showed the effects of spray operation at the tine of vessel breach.

Expert $D$ defined his base case by starting from the 18 -node surry model with UCHB as defined In Reference D.1. The CONTAIN result, eppropriate for Case Ib, showed a peak pressure of $0.93 \mathrm{MPa}$. Expert D then made several adjustrents to this value:

$-0.03 \mathrm{MPa}$ The particle size should be $1 \mathrm{~nm}$ based on the SPIT and DCH tests. Agglomeration is neglected in CONTAIN.

- $0.03 \mathrm{Hpa}$ The CONTAIN nodel should Include enhanced trapping.

- $005 \mathrm{MPa}$ The effects of the thin steel in the contalinent will reduce the peak pressure.

Thus Expert $D$ arrived at $0.82 \mathrm{MPa}$ for iis base case, best estimate pressure rise. It applies to the subcase with the large fraction of melt ejected (75) and the sall initial hole.

Expert D concluded that the effects of co-dispersed water should not be included for the following reasons:

- For events likely to challenge containment, there will be no sprays operating and the cavity will contain little or no water at vessel breach.

- If there is not much water in the cavity, this water is likely to be blown out of the cavity ahead of the core debris as seen in the "l-s water expulsion cases." (Note: $20,000 \mathrm{~kg}$ of water results in about 1 ft of water on the cavicy floor.)

- If there is a large amount of water in the cavity, the effect of co-dispersed water, especiaily with UCHB, will be to reduce the naximu pressure rise observed.

Expert D observe-t that the fraction of the zirconftur oxidized In-vessel was not particularly important. In the ConTAIN run where the in-vessel oxidation was reduced from 50 to $30 \%$, the pressure rise was reduced by only about $0.02 \mathrm{MPa}$. Therefore, the effects of in-vessel zirconium oxidation will be ignored. The bese case has an in-vessel zirconium oxidation of $50 \%$, which is in the middle of the range. 
Expert D assumed the following inttal conditions:

\begin{tabular}{lcc} 
& With Sprays & Without Sprays \\
\cline { 2 - 3 } Partial Pressure of Alr (psia) & 11 & 12 \\
Partial Pressure of Steam (psia) & 4 & 12 \\
Partial Pressure of $\mathrm{H}_{2}$ (psia) & 1.7 & 1.8 \\
Gas Temperature (F) & 150 & 200
\end{tabular}

The hydrogen partial pressure corresponds to 600 zirconium oxidation, which gives about $950 \mathrm{lb}$. The hydrogen mole fraction in contaiment would be about 0.10 when the sprays are operating. As any additional hydrogen released would be accompanted by steam at a $2: 1$ or $3: 1$ nole ratio, detonation is not credible.

If the sprays are opersting, they condense about $5001 b_{p}$ of steat per second when the steam concentration is high. About $100 \mathrm{ft}^{3}$ of 1 lquid water will be airborne in the form of spray droplets at any given time. The droplet surface area wll be on the order of $1,000,000 \mathrm{ft}^{2}$. Taking into account that the sprays reduce the Initial contalnaent pressure by 0.5 to 1.0 bar relative to the no-spray case, the peak pressure with sprays operating $1 \mathrm{~s}$ expected to be about 1.5 to 2.5 bars lover than the equivalent case without the sprays operating.

There is considerable dependence on the particle stze in the upward direction. If the particle slze assuned in the CONYAIN runs $(1.0 \mathrm{~mm}$ is increased, the pressure fise will decrease because the material in the center of the particle will no: have reacted before the particle $1 s$ quenched. That 18, for the larger particles, the particle cools off before the zirconium in the center of it reacts with steam. On the other hand, if the particle size is decreased fron that assuned in ConTaIN, there is a negligible effect since all the metal in the particle 1.3 reacting already.

The SPIT tests showed that $10 \mathrm{~s}$ of the mass was in particles with an effective mean diameter of greater than $3 \mathrm{~mm}$. Thus there night be a 5 . chance that the particles could be large enough so that the hydrogen release is only 108 of what was assuned for the base case, which would reduce the pressure rise to half that of the base case. Note that there is a limic to the upper size of particles because they break up due to impaction or due to internal gas generation.

ConTaIN assumes that the core debris distributed throughout the containnent during the blowdown phase of the DCH process ts homogeneous. Expert D expects the entrained aaterlal to be richer in oxides than a homogenous mixture. That $1 s$, he thinks it likely that there will be segregation of the metals from the oxides in the botton head before vessel failure. The composition of the debris ejected should be correlated with the results of the In-Vessel Panel. At the extrene, 508 of the zircontun could be segregated so that it would exit the vessel after the high velocity gas flow phase of the high pressure melt efection event. Expert D did not consider it credible that the core debris ejected in the first phase could be $r^{i}$ ch in unoxidized metal. 
Expert $D$ also pointed out that, when DCH occurs, only a very snall portion of the hydrogen pre-existing in the contalnment or produced during the HPME can be expected to renain unburned after the event is over.

\section{Results of Experc D's Elicitation}

Base Case. Expert $D$ started with a best estimate of 0.82 MPa for the pressure $r$ tse for Case lb as described sbove. This value applites to the high fraction ejected and swall hole subcase. He multiplied this value by 0.90 since he considered it his best estimate that 208 of the $z$ ircontum would be segregaced and would not participate in the Dcr event. Finally. he multiplied his midpoint value by 0.97 to account for the fact that the hydrogen combustion might not be $100 \mathrm{~s}$ complete as assumed in CONTAIN. He thus got his 500 probable value of $0,72 \mathrm{MPs}$.

For the upper bound (958), he assuned that no zirconiun was segregated and that the hydrogen combustion was 1008 complete. Thus the zirconium segregation and coinpleteness factors are 1.00. However, for the upper bound case he considered tt likely that the particles would have an effective mesn dianeter of 0.5 mm instead of the 1.0 man assumed in CONTAIN. This introduces a factor of 1,03 . Thus his upper bound for the pressure tise is $0.86 \mathrm{MPa}$. For the lowet bound (58), he assumed that 508 of the zirconium was segregated and that the hydrogen combustion was $90 \mathrm{a}$ complete. The zirconium segregation factor is 0.75 and the completeness factor is 0.90 . For the lower bound case Expert D considered it likely that the particles would have an effective mesn diameter of $3.0 \mathrm{~mm}$. which Introduces a factor of 0.50 . Thus his lower bound for the pressure rise is $0.28 \mathrm{MPa}$. The results of these manipulations can be expressed in cabular form:

Case 1b, High RCS pressure, dry cavtcy, large fraction ejected, small hole.

\begin{tabular}{|c|c|c|}
\hline 58 & 508 & 95. \\
\hline 0.82 & 0.82 & 0.82 \\
\hline 1.0 & 1.0 & 1.0 \\
\hline 1.0 & 1.0 & 1.0 \\
\hline 0.75 & 0.90 & 1.0 \\
\hline 0.50 & 1.00 & 1.05 \\
\hline 0.90 & 0.97 & 1.00 \\
\hline .28 & .72 & .86 \\
\hline
\end{tabular}

As chere are two sizes of hole opening. and three fractions of melt ejected, there are six subcases for the base case, Case lb. The results are listed on attached Tabies D-l through D-6.

A longe part of the pressure $r$ ise comes fron the bydrogen burn so the pressure rise is not as dependent upon DCH as one wight think at first. 
Other Cases: Expert D took Case lb as his base case since that was the one for which the most CoNTAIN results were available, He initially put wider distributions on the other cases since he could not start from available CONTALN resilts. The factors used to obtain the starting values for pressure rise for the four cases are given on the next page.

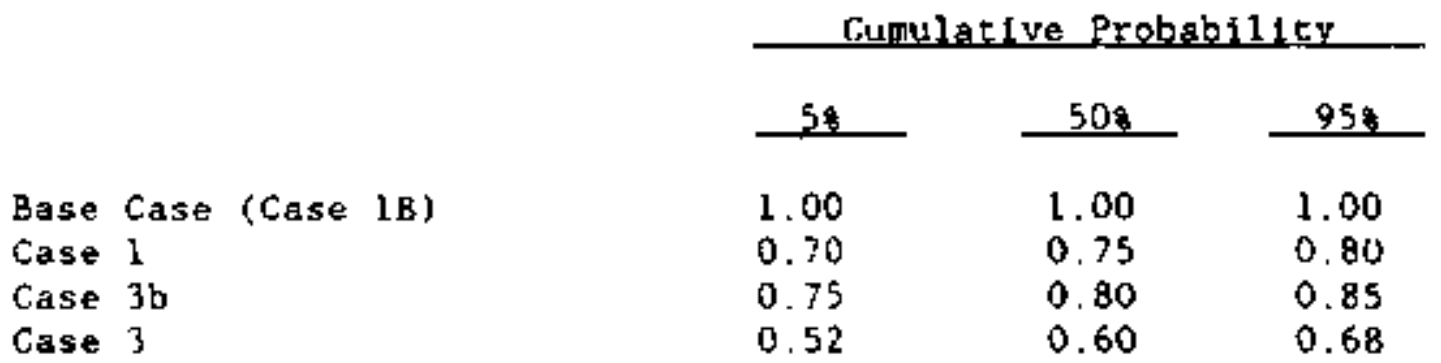

These factors are applied to the general base case pressure rise of $0.82 \mathrm{MPa}$, Case $1 \mathrm{~b}$ is the most severe since it has the highest RCS pressure and a dry cavity. Case 3 ls the lesst severe (of these four) since it has a lower RCS pressure and a wet cavity. Expert D figured that Case 3 was the most uncertaln because he had only to adjust for one factor in going from the base Case (lb) to Case 1 or Case $3 b$, while he had to adjust two factors (RCS pressure and cavity water) in going from Case $1 b$ to Gase 3 .

The six subcases for each of the other three cases are contained in Tables D-7 through D-24. The various adjustment factors are applied fust as they were for the base case above. The fraction ejected, zircontum segregation, particle size, and completeness factors are independent of case. The hole size factors depend upon the RCS pressure.

The fraction ejected factors are:

Fraction Ejected

25\%

508

758

\section{Eactor}

0.80

0,90

1.00

The small hole size factor is 1.00 for all points on the cunulative probability curve. The adjustment factors for the large hole ate:

\begin{tabular}{|c|c|c|c|}
\hline & \multicolumn{3}{|c|}{ Cumulative Probabllity } \\
\hline & $-S_{B}$ & 508 & 950 \\
\hline $\begin{array}{l}\text { High RCS Pressure } \\
\text { Low RCS Pressure }\end{array}$ & $\begin{array}{l}1.00 \\
1.00\end{array}$ & $\begin{array}{l}1.10 \\
1.03\end{array}$ & $\begin{array}{l}1.25 \\
1.10\end{array}$ \\
\hline
\end{tabular}


The zircontum segregation factors are:

Cumulative Probability.

\begin{tabular}{llll} 
& -58 & 508 & 953 \\
\cline { 3 - 4 } & & & \\
Fraction of 2r Segregated & 0.50 & 0.20 & 0.00 \\
Factor & 0.75 & 0.90 & 1.00
\end{tabular}

The particle size adjustment factors are:

\begin{tabular}{|c|c|c|}
\hline 58 & $50 \mathrm{~s}$ & 958 \\
\hline $\begin{array}{l}3.00 \\
0.50\end{array}$ & 1.00 & $\begin{array}{l}0.50 \\
1.05\end{array}$ \\
\hline
\end{tabular}

Effective Particle

Diameter (nn)

3.00
0.50

1.00

1.0S

Factor

The completeness factors are:

Cumulative Probability

$\begin{array}{cccc} & 58 & 508 & 958 \\ \text { Factor } & 0.90 & 0.97 & 1.00\end{array}$

These factors have all been applied in the manner described to obtained the resuitant pressure rises shown in Tables D-1 through 0-24. The pressure rises at vessel breach are sumnartzed in Table 0.25 .

\section{Sourses of Uncertainty}

Expert 0 felt the uncertalnty in rates was not so important since nost processes went to completion. The variabilicy in the fraction ejected and the hole size have partially been accounted for in the subcase structure. The major uncertainties that cause the broadness of the distributions are the amount of zirconiun segregation before breach (or the metal fraction ejected early) and the effective particle size. The effect of incomplete hydrogen combustion is small since 1 t is expected to be very nearly complete it. all cases.

\section{Correlations with ocher Varlables}

The anount of unoxidized zirconfum in the core debrts ejected before the gas blowdown should be correlated with the results of the In-Vessel panel. 
Table D.1

Case 1b: High RCS Pressure and Dry Cavity

Large Fraction Ejected

Snill Hole size

\begin{tabular}{|c|c|c|c|}
\hline & \multicolumn{3}{|c|}{ Cumplative Probability } \\
\hline & 5 용 & 50. & 958 \\
\hline $\begin{array}{l}\text { Base Pressure Rise (MPa) } \\
\text { Fraction Ejected Factor } \\
\text { Hole Size Factor } \\
\text { Zirconium Segregation Factor } \\
\text { Particle Size Factor } \\
\text { Completeness Factor }\end{array}$ & $\begin{array}{l}0.82 \\
1.00 \\
1.00 \\
0.75 \\
0.50 \\
0.90\end{array}$ & $\begin{array}{l}0.82 \\
1.00 \\
1.00 \\
0.90 \\
1.00 \\
0.97\end{array}$ & $\begin{array}{l}0.82 \\
1.00 \\
1.00 \\
1.00 \\
1.05 \\
1.00\end{array}$ \\
\hline Resultant Pressure Rise (MPa) & 0.28 & 0.72 & 0.86 \\
\hline
\end{tabular}

Table D-2

Case 1b: HIgh RCS Pressure and Dry Cavity

Hedlum Fraction Ejected

sma1l Hole size

\begin{tabular}{|c|c|c|c|}
\hline & \multicolumn{3}{|c|}{ Cumulat1ve Probability } \\
\hline & 5 로 & -501 & 95 \\
\hline $\begin{array}{l}\text { Base Pressure Rise (MPa) } \\
\text { Fraction Ejected Factor } \\
\text { Hole Size Factor } \\
\text { Zirconium Segregation Factor } \\
\text { Particle Size Factor } \\
\text { Completeness Factor }\end{array}$ & $\begin{array}{l}0.82 \\
0.90 \\
1.00 \\
0.75 \\
0.50 \\
0.90\end{array}$ & $\begin{array}{l}0.82 \\
0.90 \\
1.00 \\
0.90 \\
1.00 \\
0.97\end{array}$ & $\begin{array}{l}0.82 \\
0.90 \\
1.00 \\
1.00 \\
1.05 \\
1.00\end{array}$ \\
\hline Resultant Pressure Rise (HFa) & 0.25 & 0.64 & 0.77 \\
\hline
\end{tabular}


Table $0-3$

Case lb: High RCS Pressure and Dry Cavity

Srall Fraction Ejected

small tole size

\begin{tabular}{|c|c|c|c|}
\hline & \multicolumn{3}{|c|}{ Cumulative Probability } \\
\hline & 58 & $50 \%$ & 958 \\
\hline Base Pressure Rise (MPa) & 0.82 & 0.82 & 0.82 \\
\hline Fraccion Ejected Factor & 0.80 & 0.80 & 0.80 \\
\hline Hole Size Factor & 1.00 & 1.00 & 1,00 \\
\hline ZIrconium Segregation Factor & 0.75 & 0,90 & 1.00 \\
\hline Particle Size Factor & 0.50 & 1.00 & 1.05 \\
\hline Completuness Fascor & 0.90 & 0.97 & 1.00 \\
\hline Resultant Pressure Rise (MPa) & 0.22 & 0.57 & 0.69 \\
\hline
\end{tabular}

Table D-4

Case 1b: High RCS Pressure and Dry Cavity

Large Fraction Bjected

Large hole size

\begin{tabular}{|c|c|c|c|}
\hline & \multicolumn{3}{|c|}{ Cumulative Probabilicy } \\
\hline & 58 & 508 & 958 \\
\hline Base Pressure Rise (MPa) & 0.82 & 0.82 & 0.82 \\
\hline Fracticn Ejected Factor & 1.00 & 1.00 & 1.00 \\
\hline Hole size Factor & 1.00 & 1.10 & 1.25 \\
\hline Zirconium Segregation Factor & 0.75 & 0.90 & 1.00 \\
\hline Particle Size Factor & 0.50 & 1.00 & 1.05 \\
\hline Completeness Factor & 0.90 & 0.97 & 1.00 \\
\hline Resulrant Pressure Rise (MPa) & 0.28 & 0.79 & 1.08 \\
\hline
\end{tabular}


Table $D .5$

Case lb: HIgh RCS Pressure and Dry Cavity

Iedium Fraction Ejected

Large Hole size

\begin{tabular}{|c|c|c|c|}
\hline & \multicolumn{3}{|c|}{ Cumulative Probab11ity } \\
\hline & 5 鯜 & $\mathrm{SOS}$ & $95 \%$ \\
\hline $\begin{array}{l}\text { Base Pressure Rise (MPa) } \\
\text { Fraction Ejected Fector } \\
\text { Hole Size Factor } \\
\text { Zircontum Segregation Factor } \\
\text { Particle Size Factor } \\
\text { Completeness Factor }\end{array}$ & $\begin{array}{l}0.82 \\
0.90 \\
1.00 \\
0.75 \\
0.50 \\
0.90\end{array}$ & $\begin{array}{l}0.82 \\
0.90 \\
1.10 \\
0.90 \\
1.00 \\
0.97\end{array}$ & $\begin{array}{l}0.82 \\
0.90 \\
1.25 \\
1.00 \\
1.05 \\
1.00\end{array}$ \\
\hline Resultant Pressure Rise (MPa) & 0.25 & 0.71 & 0.97 \\
\hline
\end{tabular}

Table D-6

Case 1b: High RCS Pressure and Dry Cavity

Mediun Fraction Ejected

Large Hole S1ze

\begin{tabular}{|c|c|c|c|}
\hline & \multicolumn{3}{|c|}{ Cumulative Probabjilty } \\
\hline & 58 & $50 \%$ & $95 \%$ \\
\hline $\begin{array}{l}\text { Base Pressure Rise (MPa) } \\
\text { Fraction Ejected Factor }\end{array}$ & $\begin{array}{l}0.82 \\
0.80\end{array}$ & $\begin{array}{l}0.82 \\
0.80\end{array}$ & 0.82 \\
\hline $\begin{array}{l}\text { Hole Size Factor } \\
\text { Zirconium Segregation Factor } \\
\text { Particle Size Factor } \\
\text { Completeness Factor }\end{array}$ & $\begin{array}{l}1.00 \\
0.75 \\
0.50 \\
0.90\end{array}$ & $\begin{array}{l}1.10 \\
0.90 \\
1.00 \\
0.97\end{array}$ & $\begin{array}{l}1.25 \\
1.00 \\
1.05 \\
1.00\end{array}$ \\
\hline Resultant Pressure Rise (MPa) & 0.22 & 0.63 & 0.86 \\
\hline
\end{tabular}


Table 0.7

Case 1: HIgh RCS Pressure and wet Cavity

Large Fraction Efected

Small hole Size

\begin{tabular}{|c|c|c|c|}
\hline & Can & Dye $P x$ & Ltty \\
\hline & .58 & 508 & 958 \\
\hline Base Pressure Rise (MPa) & 0.57 & 0.62 & 0.66 \\
\hline Fraction Ejected Factor & 2.00 & 1.00 & 1.00 \\
\hline Hole size Factor & 1.00 & 1.00 & 1.00 \\
\hline Zirconium Segregation Factor & 0.75 & 0.90 & 1.00 \\
\hline Particle Size Factor & 0.50 & 1.00 & 1.05 \\
\hline Completeness Factor & 0.90 & 0.97 & 1.00 \\
\hline Resultant Pressure Rise (MPa) & 0.19 & 0.54 & 0.69 \\
\hline
\end{tabular}

Table D-8

Case 1: High RCS Pressure and Wet Cavity

Hedium Fraction EJected

Snall Hole Size

\begin{tabular}{|c|c|c|c|}
\hline & \multicolumn{3}{|c|}{ Cunulative Probabi 115y } \\
\hline & 58 & 508 & 958 \\
\hline $\begin{array}{l}\text { Base Pressure Rise (MPa) } \\
\text { Fraction Ejected Factor } \\
\text { Hole Size Factor } \\
\text { Zirconiun Segregation Factor } \\
\text { Particle Size Factor } \\
\text { Completeness Factor }\end{array}$ & $\begin{array}{l}0.57 \\
0.90 \\
1.00 \\
0.75 \\
0.50 \\
0.90\end{array}$ & $\begin{array}{l}0.62 \\
0.90 \\
1.00 \\
0.90 \\
1.00 \\
0.97\end{array}$ & $\begin{array}{l}0.66 \\
0.90 \\
1.00 \\
1.00 \\
1.05 \\
1.00\end{array}$ \\
\hline Resuliant Pressure Rise (MPa) & 0.17 & 0.48 & 0.62 \\
\hline
\end{tabular}


Table D-9

Case 1: High RCS Pressure and Wet Cavity

Small Fraction Ejected

Small Hole Size

\begin{tabular}{|c|c|c|c|}
\hline & \multicolumn{3}{|c|}{ Cumulative Probability } \\
\hline & 59. & $50 \%$ & 95\% \\
\hline $\begin{array}{l}\text { Bese Pressure Rise (MPa) } \\
\text { Fraction Ejected Factor } \\
\text { Hole Size Factor } \\
\text { Zirconium Segregation Factor } \\
\text { Particle Size Factor } \\
\text { Completeness Factor }\end{array}$ & $\begin{array}{l}0.57 \\
0.80 \\
1.00 \\
0.75 \\
0.50 \\
0.90\end{array}$ & $\begin{array}{l}0.62 \\
0.80 \\
1.00 \\
0.90 \\
1.00 \\
0.97\end{array}$ & $\begin{array}{l}0.66 \\
0.80 \\
1.00 \\
1.00 \\
1.05 \\
1.00\end{array}$ \\
\hline Resultant Pressure Rise (MPa) & 0.15 & 0.43 & 0.55 \\
\hline
\end{tabular}

Table $0-10$

Case 1: High RCS Pressure and Wet Cavity

Large Fraction Ejected

Lrge Hole size

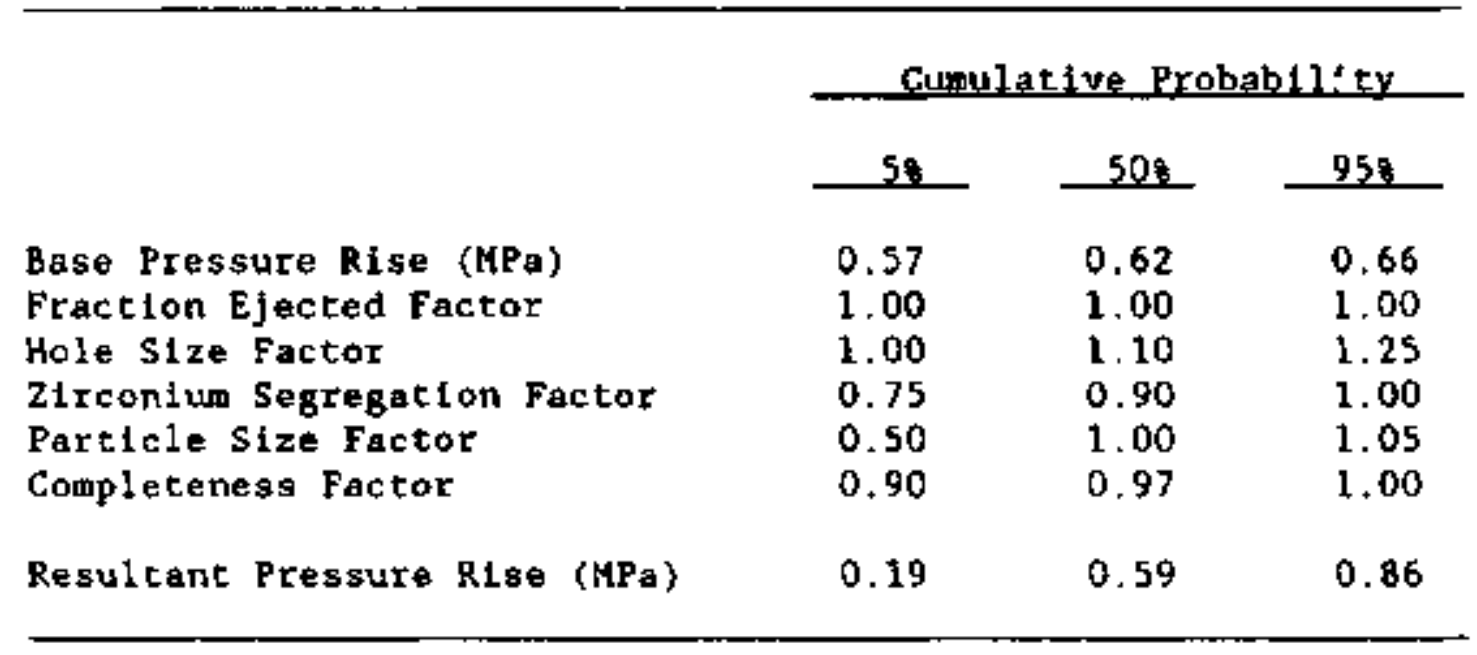


Table $0-11$

Case 1. High RCS Pressure and Wet Cavity

Medium Fraction Ejected

Large Hole size

\begin{tabular}{|c|c|c|c|}
\hline & \multicolumn{3}{|c|}{ Cumulative Probability } \\
\hline & 5. & 50 & 959 \\
\hline Base Pressure Rise (MPa) & 0.57 & 0.62 & 0.66 \\
\hline Fraction Ejacted Factor & 0.90 & 0.90 & 0.90 \\
\hline Hole Size Factor & 1.00 & 1.10 & 1.25 \\
\hline Zirconfum Segregation Factor & 0.75 & 0.90 & 1.00 \\
\hline Gatticle Size Factor & 0.50 & 1.00 & 1.05 \\
\hline Completeness Factor & 0.90 & 0.97 & 1.00 \\
\hline Resultant Pressure R1se (MPa) & 0.17 & 0.53 & 0.77 \\
\hline
\end{tabular}

Table D-12

Cose 1: High RCS Pressure and Wet Cavity

small Fraction Ejected

Large Hole size

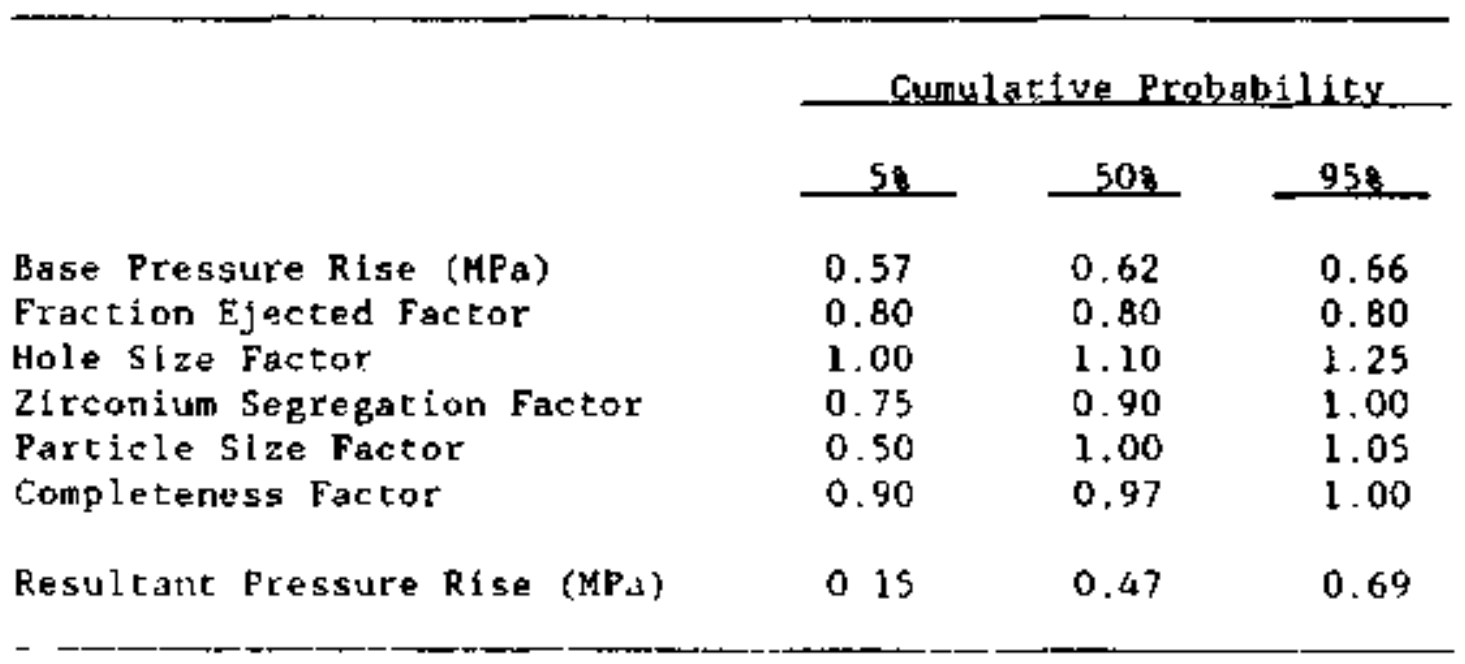


Table D.13

Case 3b: Maderate RCS Pressure and Dry Cavity

Large Fraction Ejected

Sall hole Size

\begin{tabular}{|c|c|c|c|}
\hline & \multicolumn{3}{|c|}{ Cumulative Probability } \\
\hline & 58 & 508 & 950 \\
\hline Base Pressure Rise (MPa) & 0.62 & 0.66 & 0.70 \\
\hline Fraction Ejected Factor & 1.00 & 1.00 & 1.00 \\
\hline Hole size Factor & 1.00 & 1.00 & 1.00 \\
\hline Zirconium Segregation Factor & 0.75 & 0.90 & 1.00 \\
\hline Particle Size Factor & 0.50 & 1.00 & 1.05 \\
\hline Completeness Factor & 0.90 & 0.97 & 1.00 \\
\hline Resultant Pressure Rise (MPa) & 0.21 & 0.57 & 0.73 \\
\hline
\end{tabular}

Table D-14

Case 3b: Noderate RCS Pressure and Dry Cavity

Medlum Fraction Ejected

soall hole Size

\begin{tabular}{|c|c|c|c|}
\hline & \multicolumn{3}{|c|}{ Cumuiative Probabilify. } \\
\hline & $5 \%$ & 509 & 958 \\
\hline Base Pressure Rise (MPa) & 0.62 & 0.66 & 0.70 \\
\hline Fraction Ejected Factor & 0.90 & 0.90 & 0.90 \\
\hline Hole Size Factor & 1.00 & 1.00 & 1.00 \\
\hline Zirconium Segregation Factor & 0.75 & 0.90 & 1.00 \\
\hline Particle Size Factor & 0.50 & 1.00 & 1.05 \\
\hline Completeness Factor & 0.90 & 0.97 & 1.00 \\
\hline Resultant Pressure Rise (MPa) & 0.19 & 0.52 & 0.66 \\
\hline
\end{tabular}


Table D.15

Case 3b: Moderate RCS Pressure and Dry Cavity

Small Praction Ejected

Sand1 Hole size

\begin{tabular}{|c|c|c|c|}
\hline & \multicolumn{3}{|c|}{ Cumulative Probabiflty } \\
\hline & 58 & $50 \%$ & 958 \\
\hline $\begin{array}{l}\text { Base Pressure Rise (MPa) } \\
\text { Fraction Ejected Factor } \\
\text { Hole Size Factor } \\
\text { Zirconiun Segregation Factor } \\
\text { Particle Size Factor } \\
\text { Completeness Factor }\end{array}$ & $\begin{array}{l}0.62 \\
0.80 \\
1.00 \\
0.75 \\
0.50 \\
0.90\end{array}$ & $\begin{array}{l}0.66 \\
0.80 \\
1.00 \\
0.90 \\
1.00 \\
0.97\end{array}$ & $\begin{array}{l}0.70 \\
0.80 \\
1.00 \\
1.00 \\
1.05 \\
1.00\end{array}$ \\
\hline Resultant Pressure Rise (MPa) & 0.17 & 0.46 & 0.59 \\
\hline
\end{tabular}

Table $0+16$

Case 3b: Moderate RCS Pressure and Dry Cavity

Large Praction Ejected

Lage fole size

\begin{tabular}{|c|c|c|c|}
\hline & \multicolumn{3}{|c|}{ Cumulative Probability } \\
\hline & 59 & 508 & 958 \\
\hline Base Pressure Rlse (HPa) & 0.62 & 0.66 & 0.70 \\
\hline Fraction Ejected Factor & 1.00 & 1.00 & 1.00 \\
\hline Hole Size Factor & 1.00 & 1.03 & 1.10 \\
\hline Zirconium Segregation Factor & 0.75 & 0.90 & 1.00 \\
\hline Particle Size Factor & 0.50 & 1.00 & 1.05 \\
\hline Completeness Factor & 0.90 & 0.97 & 1.00 \\
\hline Resultant Pressure Rlse (MPa) & 0.21 & 0.59 & 0.81 \\
\hline
\end{tabular}


Table $\mathrm{U}-17$

Case 3b: Moderate RCS Pressure and Dry Cavity

Hedium Fraction Ejected

Large Hole slze

\begin{tabular}{|c|c|c|c|}
\hline & \multicolumn{3}{|c|}{ Cunulative Probability } \\
\hline & 58 & 508 & 958 \\
\hline $\begin{array}{l}\text { Base Pressure Rise (MEa) } \\
\text { Fraction Ejected Factor } \\
\text { Hole Size Factor } \\
\text { 2irconiwr Segregation Factor } \\
\text { Particle Stze Factor } \\
\text { Completeness Factor }\end{array}$ & $\begin{array}{l}0.62 \\
0.90 \\
1.00 \\
0.75 \\
0.50 \\
0.90\end{array}$ & $\begin{array}{l}0.66 \\
0.90 \\
1.03 \\
0.90 \\
1.00 \\
0.97\end{array}$ & $\begin{array}{l}0.70 \\
0.90 \\
1.10 \\
1.00 \\
1.05 \\
1.00\end{array}$ \\
\hline Resultant Pressure Rise (MPa) & 0.19 & 0.53 & 0.72 \\
\hline
\end{tabular}

Table $D \cdot 18$

Case 3b: Moderate RCS Pressure and Dry Cavity

Small Fraction Ejected

Large Hole size

\begin{tabular}{|c|c|c|c|}
\hline & \multicolumn{3}{|c|}{ Cumulative Probability } \\
\hline & st. & son & 958 \\
\hline $\begin{array}{l}\text { Base Pressure Rise (KPa) } \\
\text { Fraction Ejected Factor } \\
\text { Hole Size Factor } \\
\text { zirconfum Segregation Factor } \\
\text { Particle Size Factor } \\
\text { Completeness Factor }\end{array}$ & $\begin{array}{l}0.62 \\
0.60 \\
1.00 \\
0.75 \\
0.50 \\
0.90\end{array}$ & $\begin{array}{l}0.66 \\
0.80 \\
1.03 \\
0.90 \\
1.00 \\
0.97\end{array}$ & $\begin{array}{l}0.70 \\
0.80 \\
1.10 \\
1.00 \\
1.05 \\
1.00\end{array}$ \\
\hline Resultant Pressure Rlse (MPs) & 0.17 & 0.47 & 0.64 \\
\hline
\end{tabular}


Table $0-19$

Case 3: Moderate RCS Pressure and Wet Cavity

Large Fraction Ejected

Smali bole Size

\begin{tabular}{|c|c|c|c|}
\hline & \multicolumn{3}{|c|}{ Sumulative Probabilicy } \\
\hline & 58 & 501 & 958 \\
\hline Base Pressure Rise (MPa) & 0.43 & 0.49 & 0.56 \\
\hline Fraction Ejected Factor & 1.00 & 1.00 & 1.00 \\
\hline Hole Size Factor & 1.00 & 1.00 & 1.00 \\
\hline Zirconfum Segregation Factor & 0.75 & 0.90 & 1.00 \\
\hline Particle Size Factor & 0.50 & 1.00 & 1.05 \\
\hline Completeness Factor & 0.90 & 0.97 & 1.00 \\
\hline Resultant Pressure Rise (MPa) & 0.14 & 0.43 & 0.59 \\
\hline
\end{tabular}

Table D. 20

Case 3: Moderate RCS Pressure and Wet Cavity

Mediun Fraction Ejected

Small Hole slze

\begin{tabular}{|c|c|c|c|}
\hline & \multicolumn{3}{|c|}{ Cumulat tue Probability } \\
\hline & 58 & $50 \%$ & 95. \\
\hline Base Pressure Rise (MPa) & 0.43 & 0.49 & 0.56 \\
\hline Eraction Ejected Factor & 0.90 & 0.90 & 0.90 \\
\hline Hole Size Factor & 1.00 & 1.00 & 1.00 \\
\hline Zirconitum Segregation Factor & 0.75 & 0.90 & 1.00 \\
\hline Particle size factor & 0.50 & 1.00 & 1.05 \\
\hline Completeness Factor & 0.90 & 0.97 & 1.00 \\
\hline Resultant Pressure Rise (MPa) & 0.13 & 0.39 & 0.53 \\
\hline
\end{tabular}


Table D-21

Case 3: Moderate RCS Pressure and Wet Cavity

Small Fraction Ejected

Small Hole size

\begin{tabular}{|c|c|c|c|}
\hline & \multicolumn{3}{|c|}{ Cumulative Probabilitsy } \\
\hline & 58 & 508 & 952 \\
\hline $\begin{array}{l}\text { Base Pressure Rise (MPa) } \\
\text { Eraction Ejected Factor } \\
\text { Hole Size Factor } \\
\text { Zirconium Segregation Factor } \\
\text { Particle Size Factor } \\
\text { Completeness Factor }\end{array}$ & $\begin{array}{l}0.43 \\
0.80 \\
1.00 \\
0.75 \\
0.50 \\
0.90\end{array}$ & $\begin{array}{l}0.49 \\
0.80 \\
1.00 \\
0.90 \\
1.00 \\
0.97\end{array}$ & $\begin{array}{l}0.56 \\
0.80 \\
1.00 \\
1.00 \\
1.05 \\
1.00\end{array}$ \\
\hline Resultant Pressure Rise ( $\mathrm{MPa}$ ) & 0.12 & 0.34 & 0.47 \\
\hline
\end{tabular}

Table $D \cdot 22$

Case 3: Moderate RCS Pressure and Wet Cavity

Large Fraction Ejocted

Large Hole Slze

\begin{tabular}{|c|c|c|c|}
\hline & \multicolumn{3}{|c|}{ Cunulative_Probab 11 ity. } \\
\hline & 58 & $50:$ & $95 \%$ \\
\hline Base Pressure Rise (MPa) & 0.43 & 0.49 & 0.56 \\
\hline Fraction Ejected Factor & 1.00 & 1. 00 & 1.00 \\
\hline Hole Size Factor & 1.00 & 1.03 & 1.10 \\
\hline Zirconiur Segregation Factur & 0.75 & 0.90 & 1.00 \\
\hline Particle size Factor & 0.50 & 1.00 & 1.05 \\
\hline Completeness Factor & 0.90 & 0.97 & 1.00 \\
\hline Resultant Pressure Rise (MPa) & 0,14 & 0.44 & 0.64 \\
\hline
\end{tabular}


Table D. 23

Case 3: Moderate RCS Pressure and Wet Cavity Hedium Praction Ejected

Large Hole Size

\begin{tabular}{|c|c|c|c|}
\hline & \multicolumn{3}{|c|}{ Cumulative Probabllity } \\
\hline & S8 & 500 & $95 \mathrm{~h}$ \\
\hline $\begin{array}{l}\text { Base Pressure Rise (MPa) } \\
\text { Fraction Ejected Factor } \\
\text { Hole Size Factor } \\
\text { zirconium Segregation Factor } \\
\text { Particle Size Factor } \\
\text { Completeness Factor }\end{array}$ & $\begin{array}{l}0.43 \\
0.90 \\
1.00 \\
0.75 \\
0.50 \\
0.90\end{array}$ & $\begin{array}{l}0.49 \\
0.90 \\
1.03 \\
0.90 \\
1.00 \\
0.97\end{array}$ & $\begin{array}{l}0.56 \\
0.90 \\
1.10 \\
1.00 \\
1.05 \\
1.00\end{array}$ \\
\hline Resultant Pressure Rise (MPa) & 0.13 & 0.40 & 0.58 \\
\hline
\end{tabular}

Table $D-24$

Case 3: Moderate RCS Pressure and Wet Cavity

Small Praction Ejected

Large Hole Size

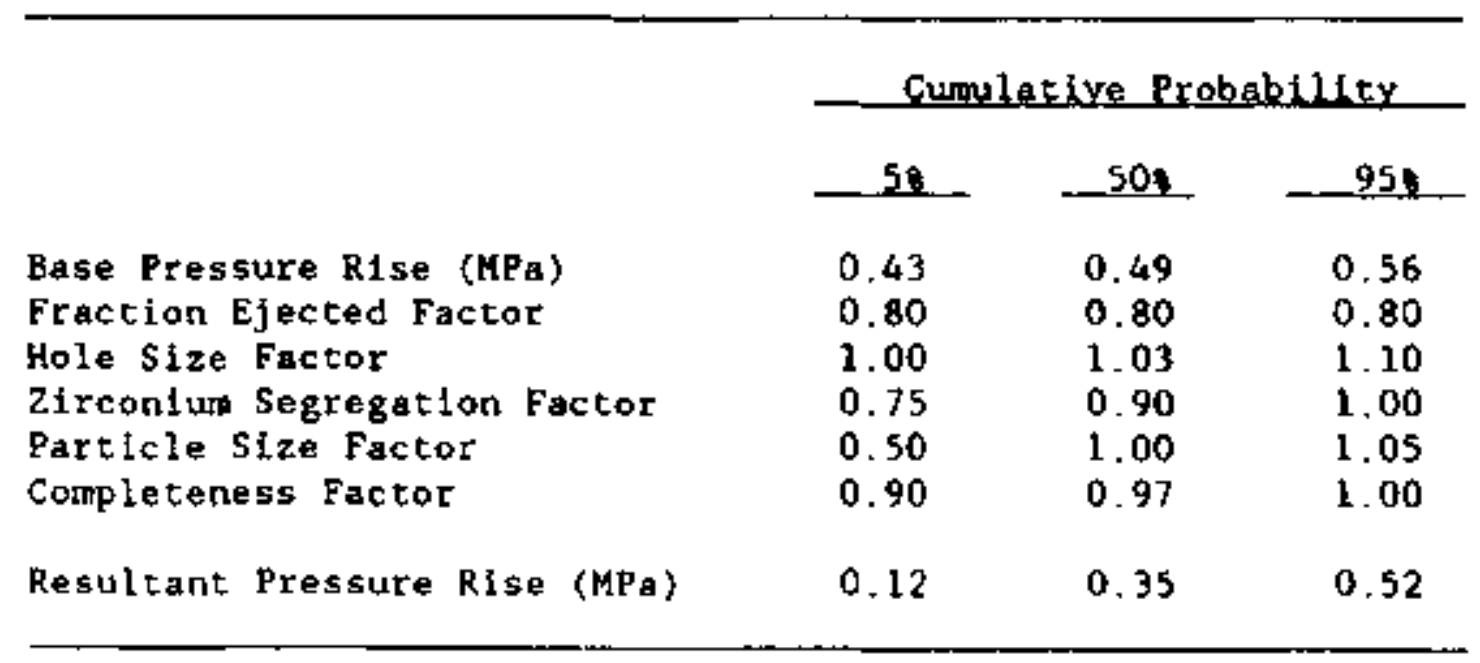


Table D-25

Loads at Vessel Breach at Surry for Expert D (bars)

\begin{tabular}{|c|c|c|c|c|c|c|c|}
\hline \multirow[b]{2}{*}{ Casse } & \multicolumn{2}{|c|}{ Subcase } & \multicolumn{5}{|c|}{ Frastile } \\
\hline & $\begin{array}{l}\text { Hole } \\
\text { Slze }\end{array}$ & $\begin{array}{l}\text { Fraction } \\
\text { Ejescted }\end{array}$ & $0.010^{*}$ & 0.050 & 0,500 & 0,950 & $0,990^{*}$ \\
\hline 1 & High & $\mathbf{H I}_{\mathbf{g h}}$ & 1.5 & 1.9 & 5.9 & 8.6 & 9.9 \\
\hline 1 & $\mathrm{H} \perp \mathrm{gh}$ & Low & 1.2 & 1.5 & 4.7 & 6.9 & 7.9 \\
\hline 1 & Low & HI gh & 1.6 & 1.9 & 5.4 & 6.9 & 8.0 \\
\hline 1 & Low & Low & 1.3 & 1.5 & 4.3 & 5.5 & 6.4 \\
\hline $1 \mathrm{~A}$ & High & High & 1.5 & 1.9 & 5.9 & 8.6 & 9.9 \\
\hline lA & High & Low & 1.2 & 1.5 & 4.7 & 6.9 & 7.9 \\
\hline $1 \mathrm{~A}$ & Low & High & 1.6 & 1.9 & 5.4 & 6.9 & 8.0 \\
\hline $1 \mathrm{~A}$ & Low & Low & 1.3 & 1.5 & 4.3 & 5.5 & 6.4 \\
\hline 1B & $\mathrm{HI} \mathbf{g h}$ & HIgh & 2.3 & 2.8 & 7.9 & $10 . B$ & 22.4 \\
\hline 1B & High & Low & 1.8 & 2.2 & 6.3 & 8.6 & 9.9 \\
\hline 1B & Low & High & 2.4 & 2.8 & 7.2 & 8.6 & 10.0 \\
\hline $1 \mathrm{~B}$ & Low & Low & 1.9 & 2.2 & 5.7 & 6.9 & 8.0 \\
\hline $1 \mathrm{c}$ & High & High & 2.3 & 2.6 & 7.9 & 10.8 & 12.4 \\
\hline $1 \mathrm{c}$ & High & Low & 1.8 & 2.2 & 6.3 & 8.6 & 9.9 \\
\hline $1 C$ & Low & HIgh & 2.4 & 2.8 & 7.2 & 8.6 & 10.0 \\
\hline $1 C$ & Low & Low & 1.9 & 2.2 & 5.7 & 6.9 & B. 0 \\
\hline 3 & HIgh & High & 1.1 & 1.4 & 4.4 & 6.4 & 7.4 \\
\hline 3 & Hegh & Low & 1.0 & 1.2 & 3.5 & 5.2 & 6.0 \\
\hline 3 & Low & $\mathbf{H I}_{\mathbf{B h}}$ & 1.1 & 1.4 & 4,3 & 5.9 & 6.8 \\
\hline 3 & Low & Low & 1.0 & 1.2 & 3.4 & 4.7 & 5,4 \\
\hline $3 \mathrm{~A}$ & High & High & 1.1 & 2.4 & 4.4 & 6.4 & 7.4 \\
\hline 3A & Hi gh & Low & 2.0 & 1.2 & 3.5 & 5.2 & 6.0 \\
\hline $3 \mathrm{~A}$ & Low & High & 1.1 & 1.4 & 4.3 & 5.9 & 6.8 \\
\hline $3 \mathrm{~A}$ & Low & Lov & 1.0 & 1.2 & 3.4 & 4.7 & 5.4 \\
\hline $3 \mathrm{~B}$ & High & High & 1.8 & 2.1 & 5.9 & 8.1 & 9.3 \\
\hline $3 \mathrm{~B}$ & High & Low & 1.4 & 1.7 & 4.7 & 6.4 & 7.9 \\
\hline 3B & Low & High & 1.8 & 2.1 & 5.7 & 7.3 & 8.5 \\
\hline $3 B$ & Low & Low & 1.4 & 1.7 & 4.6 & 5.9 & 6.8 \\
\hline 4 & High & High & 0.2 & 0.4 & 1.7 & 3.3 & 5.2 \\
\hline 4 & High & Lor & 0.1 & 0.3 & 0.7 & 1.7 & 2.6 \\
\hline 4 & Low & High & 0.3 & 0.6 & 1.5 & 3.8 & 5.8 \\
\hline 4 & Low & Low & 0.1 & 0.3 & 0.7 & 1.5 & 2.3 \\
\hline
\end{tabular}

- lst and 99 th percentiles have been estimated by extrapolation. 
REFERENCE

D-I. D. C. Williams et al., "Containnent Loads Due to Direct Containment Heating and Assaciated Hydrogen Behavior: Analysis and Calculat $t o n s$ with the CONTIAN Code." Sandia National Laboratorles, NUREG/CR-4896. SANDB7-0133, May 1987. 
5.7 Contafnment Loads Issue 7: Pressure Increment in the Zion Contalnment at Vessel Breach

\author{
Sumbary of Expert Panel's Assessment of Is 8ue 7 : \\ Pressure Increment in the Zion Containment at Vessel Breach
}

Experts consulted: Lou Baker, Argonne National Lsboratory; Ken Bergeron, Sandia National Laboratortes; Ted Ginsberg, Brookhaven National Laboratory: Marty Plys, Fauske of Assoclaces; Fred Torr1, Plekard, Lowe, \& Grrick.

\title{
Issue Description
}

What distributions characterize the uncertainty in the pressure increnent in the zion containment at vessel breach?

This 1ssue is concerned with the pressure increment in containment due to depressurizacion of the RCS, ex-vessel fuel coolant interactions, hydrogen combustion, and DCH. This issue applies to all neltdown scenarios in which the reactor vestel falls and a fraction of the core is ejected. RCS blowdown and DCH cause significant loads to the containment only if the RGS pressure is ten to twenty atmospheres or more above that of the containment at vessel breach. The inftial presentation of this issue delineated four RCS pressure ranges for consideration. This was reduced to three pressure ranges, and the case structure for 210 was redefined as follows:

\begin{tabular}{|c|c|c|c|}
\hline Case & RCS Pressure & $\begin{array}{c}\text { Cavity water } \\
\text { (psi) }\end{array}$ & Sprays Operating \\
\hline 1 & 2000 to 2500 & Full & Yes \\
\hline IA & 2000 to 2500 & Half & No \\
\hline 1B & 2000 to 2500 & Dry & No \\
\hline 3 & 500 to 1000 & Ful 1 & Yes \\
\hline $3 \mathrm{~A}$ & 500 to 1000 & Half & No \\
\hline 38 & 500 to 1000 & Dry & No \\
\hline $3 c$ & 500 to 1000 & Full & No \\
\hline 4 & 15 to 200 & Full & Yes \\
\hline
\end{tabular}

The panel of five experts collectively determined to provide information based on three additional variables. The variables were: anount of zirconiuro oxidation: high (f5s) and low (258), melt fraction ejected: high (75) and low (338), and initial hole size: large (2 $\mathrm{m}^{2}$ ) and small (.l $\mathrm{m}^{2}$ ). This weans there were elght subcases for each of the eight cases above.

\section{Sumnary of Experts' Rationale}

Expert A observed that there was less known about DCH than about the other causes of the pressure rise listed in the issue descriplion. Thete have been four DCH experiments at Sandia using the surtscy facllity. The initial CONTAIN predictions mached the DCH-l experiment fairly well, but matched the DCH-2, DCH.3. and DH:H tests fajrly paorly. A much better matcli to the bater three DCH tests was obtajted by chatging the trappling. parameter in CONTAIN from the value used for the DCl-1 test.

$$
5.7 \cdot 1
$$


The effects of full cavity of water are hard to estinate; the water could make the pressure rise larger due to increased steam production, or the water could make the pressure rise smaller due to quenching. Expert A concluded that the medien presgure rise for the full cavity case would be slightly bighet than for the equivalent case with a dry cavity. The hot gas resulting from vessel breach at any pressure above a fow hundred psi will result in ignition if there is enough oxygen and hydrogen for combustion. The combustion should be complete. Expert A concluded that detonations were not likely at zion. At the time of vessel breach, the pre-existing hydrogen would be cold and would deflagrate while the hydrogen plume from the vessel would be hot and would probably burn as a diffusion flame. At Zion, it is very unlikely that enough hydrogen could accumulate by the time of vessel breach to allow a global detonation. Expert A felt that local detonations could not be ruled out, however, and the possibility of detonations contributed to the spread in his distributions. The detonation mechanisa is the failure of lgnition or the diffusion flame for a few eritical seconds as the hot gas flows out from the hole in the vessel. If this occurs, then detonatable concentrations could exist in a limited volume.

The case structure listed above accounts for varlations due to wacer in the cavity, sprays, and RCS pressure at vessel fallure. The subcase structure accounts for differences due to the amount of in-vessel zirconium oxidation, the hole size, and the fractlon of alass ejected. other factors were accounted for by broadening the uncertainty bounds. In the course of this analysis, Expert A concluded that the pressure rise was fairly insensitive to the arount of in-vessel zirconiun oxidation. The eight subcases were defined by a three +letter code:

\begin{tabular}{|c|c|c|}
\hline Description & Letter & Word \\
\hline $\begin{array}{l}\text { In-Vessel zirconium } \\
\text { oxidation }\end{array}$ & $\begin{array}{l}0 \\
0\end{array}$ & $\begin{array}{l}\text { High } \\
\text { Low }\end{array}$ \\
\hline Vessel Hole stze & $\begin{array}{l}\mathrm{H} \\
\mathrm{h}\end{array}$ & $\begin{array}{l}\text { Large } \\
\text { Smal1 }\end{array}$ \\
\hline Core Fraction Ejected & $\begin{array}{l}c \\
c\end{array}$ & $\begin{array}{l}\text { Large } \\
\text { Sma1l }\end{array}$ \\
\hline
\end{tabular}

Thus, Case lB-OHc is Gase 13 as defined in Section 2 , wh thigh oxidation of zirconiur in.vessel, a large hole size, and a mall fraction of the core ejected.

Expert a approached the problem by using the available CONTAIN, MAAP, and surtsey results to carefully determine pressure rise distributions for three base cases. Using a PC spreadsheet progran, he then adjusted these base cases to get values for all the other 61 subcases required.

The extremes of his ranges for the base cases were based on energy bajance calculations, which are relatively stralghtforward. The best estimate is 
based on code results, primarily contaIN results for $z$ ion and other CONTAIN results in NUREG/CR-4896.A-1 Recent 1B-cell CONTAIN results show, for example. that sone of the earlfer results are too high by about one bar. Expert A spent most of his time on the base cases trying to get the center of his distributions correct. since that is where the bulk of the probability 1ies. He spent very litele time on the low pressure rise end of the curves since te felt that the pressure rises in this region would not fail the contalnment. He spent a fair amount of time on the upper ends, however, even though containeent failure is assured for these pressure rises, because the base case is often reduced in calculating the subsidisry cases. As the base cases were plcked to be about the most severe expected for the three RCS presgure levels. the base case is never increased enough in obtaining a derivative case that the low pressure end of the curve becomes important.

Expert B based this assessment on BNL ZIon CONTAIN calculations." The results of both the melt ejection visualization experiments executed at BNL, and the SNL Surtsey experinents were also considered. The BNL calculations utilize an SPl me1t, $22.000 \mathrm{~kg}$ of iron and a melt tenpersture of $2500 \mathrm{~K}$.

Expert B belleved that the direct contalnuent heating scenatio is typlfied by cartain phenomens. The molten core is expelled from the vessel into the reactor cavity. The blowdown gas then follows and entrains the melt which ther exits the cavity in the form of particles, rather than in waves or flims. The debris particia droplet size is on the order of tenchs of millimeters. The gas is heated as it passes through the melt, causing it to accelerate to velocities of several hundred meters per second. More than 80 of of the molten core exits the cavity; there is no freezing of the melt on the cavity walls because the snoll residence times in the cavity 1 imit crust formation. The $z$ irconium-stean reaction is complete, 11 mited only by steam starvation, and steam can react with up to as much as 50 a of the iron in the melt, after the unoxidized zirconiun has been consumed.

Expert B began his assessinent with a "base case" scenario for Case 1B. Sensitivity variations frow that case wore then considered with respect to zirconium content, break size, and aelt nass. Sensitivity to zirconiu content was not demonstrated from BNL CONTAIN calculations, so separate assessments for this parameter were eliminated, and the amount of zirconium unoxidized in the aelt was fixed at 50 a for the distributions. With the larger hole size, more steam escapes with the molten debris, thus increasing the distribution pressure increment values except for the upper bound, because maximum stean rates were already considered for this value.

Upper bounds were determined by adjusting the median value while cansidering three separate phenomens. The Elrst adjustment is to allow all the hydrogen generaced to be burned. The other two adjustaents include increasing the steam blowdown time ta equal the aelt ejection time and decreasing the trapping rate of the particles.

"T Ginsberg et a)., "CONTAIN Sensitivity studies of zion DCH Containment Loadings," Brookhaven National Laboratury, Letter Report, February 26, 1988.

$$
5.7-3
$$


The lower bounds were determined by adjusting the median value for two plenomena. The Elrst $1 s$ a decrease In the extent of the hydrogen generstion: this affects the burn pressure increase. The second is to increase the particle trapping rate to account for largef particles and shorter suspension times.

Expert $C$ concluded that it was impossible to duplicate the codes by hand, ot even genterate good approximations, so his epproach was to take the avallable code calculations, consider the assumptions made in each code and the assumptions made in the input for the runs avallable, and then adapt and adjust the results from the codes to get the values required here. He concluded that the code developers and analysts were knowledgeable in the complex physical issues and that they had exercised due diligence in the development and use of the codes. He belfeved that his role in the elicitation was best served by an incerpretation of the codes and avallable results for the cases at hand. It is impossible to account for all the nonlinearities and interactions in one's head for a problem as complex as this; we rely on the code to do this. A simple approach based on faw hand calculations too risky for such a complex problem.

Expert $C$ relied primarlly on MAAP-1 and CONTAIN* calculations. He also utilized the Argotne experiments, ${ }^{c-2}$

Experc $C$ provided pressure rises for elght subcases for each of the cases defined in Section 1 . These subcases are defined by a three-letter code:

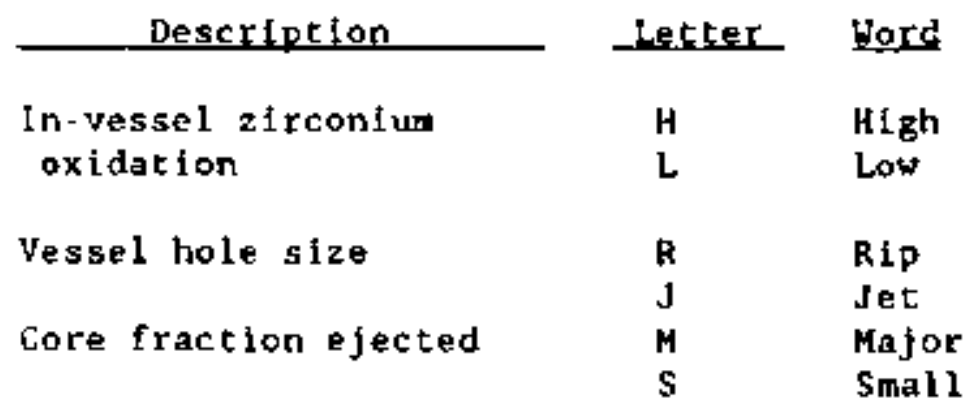

That is, Case 3B.HJM is Case 3B as defined, wh high oxidation of zirconium In-vessel, a small (Jet) hole slae, and a large (Major) fraction of the core ejected.

Expert $C$ tabulated the number of avallable code results for each case and subcase. There were about a dozen runs each for cases 1B-HJM and 3B-HJM, and two results (each) for cases 1B-HJS and 3B-HJS. The other cases had no code calculations at all. Case 1B is che worst case, 1... it gives the highest $\Delta p$ in the contatnoent, so Expert $C$ started with Case lH-HJM. Resules for the subcases for which there were no runs has to be obtained by shifting and scaling from the four cases for whtch the code results were avai lable.

Expert D performind thetmodynamle calculation tor the assessant. The calculatior was wexcuted by a short computer program that provided the

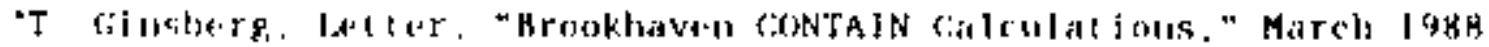

$$
5 \text { H.t. }
$$


values for the nedtans of the distributions, lnternal energy tables were employed in the code execution. An adiabatic energy balance was utilized and so the effect of hole size was not provided, although it was judged that the distribution ranges would incorporate the effect.

Various assumptions were made for the colculations. It was assumed that the core debris is at $2530 \mathrm{~K}: 0.257 \mathrm{MJ} / \mathrm{kg}$ latent heat and $0.943 \mathrm{~mJ} / \mathrm{kg}$ sensible heat. Between 0 and 20 (depending on the case being sssessed) of the efected core is quenched, producing steam. From results of surtsey Tests 2, 3, and 4 , It is assumed that at least 10 of the ejected core ts frozen on the cavity walls. Both zirconium and iron are reacted with steam in creating hydrogen. When hydrogen is produced. 90 t of the hydrogen is burned, and the resulting pressure tise is computed (108 is unavallable due to poor mixing in the lower part of the contalnment where alr has been purged by stean blowdown).

Expert $D$ belfeved that detonations would not occur because unconditional burning of hydrogen together th th the rate of hydrogen production and mode of mixing precludes detonatable mixtures. As an Informal check, the resulcs of the calculations were compared with Expert B's preliminary CONTAIN results for $z$ ion and it was noted that for the upper limits, the results were in general agreement.

Expert $D$ did bounding calculations for the upper and lower bounds of the distributions ( 1 and 99 percentiles), by setting credible limits on the metal-steam reactions. The extent of the reaction was then varied to complete the distributions. To establish the lower bound of the distribution, a 258 metal-steam reaction was assumed, and to establish the upper bound, a complete reaction was assumed. In all the distributions. Expert $D$ tended to $B$ ive a little pote weight to the lower values, because the calculation did not include the heat sinks in the contalnment, which, if included would resule in a smaller pressure increnent.

For shifting from Case 1 and 1 ts subcases to Case 3 and its subcases, Expert $D$ varied the amount of quenching depending on the anount of cavity water. In Case 3, it was assumed that there was less steam blowdown energy than in Case 1, becatse there is less water inventory and less energy in the primacy system at vessel bresch. For Case 4, a stean spike was calculated, negligible hydrogen was produced, and no pressure increnent from hydrogen burns was computed. The upper bound for case 4 was determined by assuming complete conversion of core melt energy to stean.

Expert $E$ concluded that the DCH following vessel failure with the vessel t 1000 psi would be signlficantly different fron the DCH following vessel breach at 500 psi. Therefore he split up Case 3 into Case 3 (1000 ps\$) and Case 5 ( $500 \mathrm{psi})$. He concluded that the pressure rise for Case 3C would not differ significantly from that for Case 3, so separate pressure rtse values were not given.

Expert E also decided that he could not make meaningful distinctions based on the metalic content of the ejected core materlal. so he el iminated the fraction of the zirconium oxidized in-vessel as a variable. His subcase structure is defined by a two-letter code: 


$\begin{array}{lll}\text { Vessel hole slze } & \text { H } & \text { Large } \\ & \text { h } & \text { Snall } \\ \text { Core fraction ejected } & \text { G } & \text { Large } \\ & \text { c } & \text { Snall }\end{array}$

That 1s, Case 3B-hC 1s vessel fallure at 1000 psi, dry cavity, no sprays, a snall intial hole size, and large fraction of the core ejected (penetration failure).

Expert E relied primarily on MAAPE-1 and CoNTALN calculations. Results of code calculations were avallable only for cases 1B-hC, 1B-hc, 3B-hC, and 3B-hc. Most of the results avallable were for the hC subcase for both Cases 1B and 3B. Therefore, Expert E considered his "base" subcase to be hC: a small hole and a large fraction of core ejected.

Expert E obtalned his aidpoint values for cases $1 \mathrm{~B}-\mathrm{hC}$ and $3 \mathrm{~B}-\mathrm{hC}$ by weighting the CONTAIN results more or less equally with the MAAP results with UCHB. To obtain bis upper bound, he considered the CONTAIN results and physical linitations. He noted that even with very conservative assumptions, the ConTAIN analyses rarely, if ever, got any pressure rises over 12 to 14 bars. The maximur found wth the MAAP code was around nine bars. These maxima would probably fall zlon as they started fron a base pressure of 2.4 to 2.8 bars, so he felt that the exact naximum pressure rise may not be very important. The lower bound of his distribution for pressure rise is fixed by a steam spike with no hydrogen burn, which results in a one to two bar pressure rlse "fioor" for all the distributions.

The pressure rise distributions for all the other cases and subcases were decermined from these cases by shifting the results of the base cases, scaling the results of the base cases, or both. In applying a shift to the base case, a value was added to the midpoint and upper bound values. In scaling the base case values, the difference between the midpoint value or the upper bound and the lawer bound was multiplied by a factor. The lower bound value was usually not affected by these operations since it was fixed by the pressure rige attributable to the stean spike alone. This pressure rise was not affected by the phenopena being accounted for in the shifting and scaling adjustments. If boch adfustments were applfed, the shifting adjustment was applied first.

In going from the dry cavity cases where there were code runs avallable to the wet cavity cases where there uere no code results, Expert $\mathbf{E}$ concluder that the upper bound would not be affected stnce it is possible that the water in the cavity might all be expelled from it before the DCH portion of the event conmenced. He considered tt more likely that some quenching would occur, however, and that the midpoint value for the wet cavity Case would be reduced one to two bars below the value for the equivalent dry cavity case. For the partially-full cavity cases. Expect E considered that water expulsion was nore likely than in the full cavity case. The mldpoint pressure rise values for these cases he set at 0.5 to 1.0 bars below the value for the equivalent ory cavity case.

'T, Ginsberg, Letter, "Brookhaven CONTAIN Calculatlons," March 1988. 
Hethod of ABsregation

The data were analyzed as a "block factorial" or "factorlal repeated measures" experiment, chat is, an experiment having more than one type of treatment. In which every combination of treatment levels is applied to each subject. Initially, the treatment types were considered to be "cases," with elght levels, and "subcases," with elght levels (corresponding to combinations of low and high fraction ejected with large and small hole areas, and with high and low zirconium oxidation levels). An analysis of varlance (ANOVA) was carried out on the date for the 1st. $50 \mathrm{th}$, and 99 th percentiles of the experts' distributions.A-1 An ANOVA compares two Independent estimates of the population variance: one conputed frow the treatment aeans ( $1, e .$, the "between treatments" variance), and the ather as the "within treatments" variance. This is equivalent to comparing the varlance in the dependent variable attributable to the treatments with the unexplained (tesldual) varlance.

The differences between experts are indeed significant. There are no significant case-by-subcase irtersctions, indicating that the experts applied the subcase vartations consistently to each case.

Main effects' contraste for cases were tested, "MaIn effects are the means of the dependent variable (the pressure increment) averaged over all subcases and experts for each case. The differences between nain effects means were tested by a Last Signiflcani Difference (LSD) test. The LSD is the smallest absolute value of the differences between two means which should be considered significant. In order to retaln as many cases as necessary, the signiflcance level for the ISD test was set quite blgh (208). The ANOVA showed that Cases 1A and 1B can be conbined, as can 3A. 3B, and $3 \mathrm{C}$.

To test the differences actributable to Individual subcases within a case. a simple main effects ANOVA was perforned. This ANOVA compares the variance actributable to the subcases evaluated at each of the cases to the residual variance. At least for the 50th and 99 th percentles, sone subcasps are signiflcantly different for Case 1 through Case 3C. For Case 4, hawever, there is no signiflcant difference at any level. All subcases can thus be combined for case 4, but only the high and low zirconium oxidation subcases can be combtned for the other cases.

There were ariginally 64 subcases. When zicconium oxidation levels are combined the nuber drops to 32. If Cases $1 \mathrm{~A}$ and $1 \mathrm{~B}$, and $3 \mathrm{~A}, 3 \mathrm{~B}$, and $3 \mathrm{C}$ are combined and subcase distinctions are dropped for Case 4, the total number of distinct subcases is 17 . Each expert's data for Cases la and 13. and $3 \mathrm{~A}, 3 \mathrm{~B}$, and $3 \mathrm{C}$ were averaged, as were subcases for Case 4 . Table $7-1$ gives a descrlption of the 17 new cages in terms of RCS pressure, anount of cavity water, whether the sprays are operating, the core fraction ejected, anil the vessel hole size. 
Table $7 \cdot 1$

Characteristics of Combined Cases

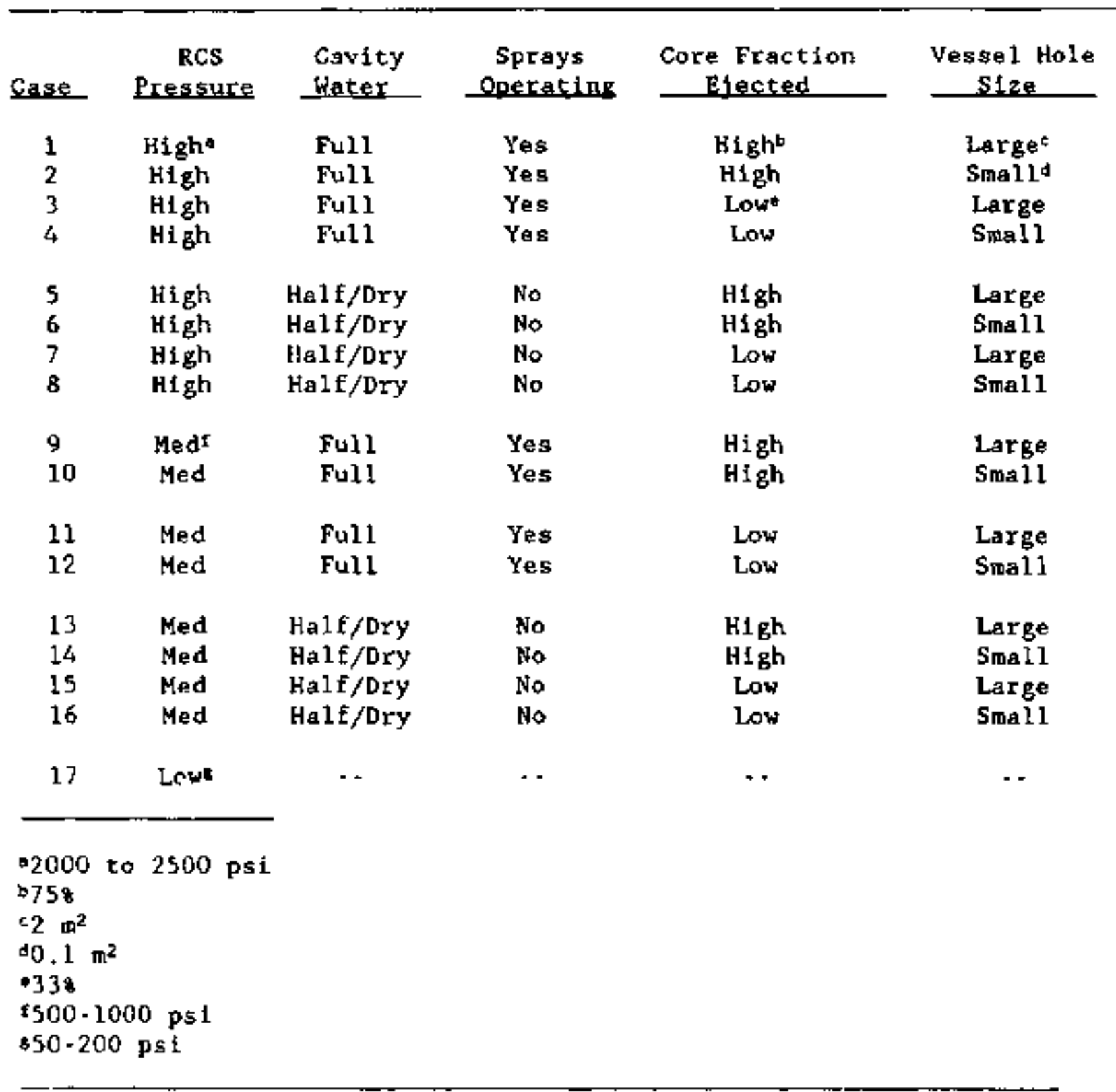

\section{Agtresated Results}

The final step was to obtain an aggregate set of values far each of the 17 cases; for each pressure increment value, probabilities were determined for each expert by interpolation, and the probabilities were then averaged, Interpolation was then used on the aggregated CDFs to find values for the lst, 5th, 25th, 50th, $75 \mathrm{th}$, 95th, and $99 \mathrm{th}$ pereficiles, for cach case. In view of the large differences between experts, it is unnecessary 10 use a finer suldivision of the CDF than this Table $7-7$ shows the results far the final CDF and Figure 1.1 shows the aggregate for Cass I (higle RCS pressure, full cavity water, sprays operatine, ligh fract bon of core ejecled, and large vessel hold). 
Table 7.2

Aggregate Results: Pressure Rise

at Vessel Breach at Zion (bars)

\begin{tabular}{|c|c|c|c|c|c|c|c|c|c|}
\hline \multirow[b]{2}{*}{ Case } & \multicolumn{8}{|c|}{ Fractile } & \multirow[b]{2}{*}{-0.99} \\
\hline & 0.01 & 0.05 & 0.10 & 0.25 & 0.50 & 0.75 & 0.90 & 0.95 & \\
\hline $\begin{array}{l}1 \\
2 \\
3 \\
4\end{array}$ & $\begin{array}{l}1.33 \\
1.24 \\
1.20 \\
1.11\end{array}$ & $\begin{array}{l}2.39 \\
2.09 \\
2.03 \\
1.82\end{array}$ & $\begin{array}{l}3.23 \\
2.69 \\
2.49 \\
2.20\end{array}$ & $\begin{array}{l}5.12 \\
4.05 \\
3.51 \\
2.94\end{array}$ & $\begin{array}{l}6.68 \\
6.03 \\
4.55 \\
4.05\end{array}$ & $\begin{array}{l}7.95 \\
7.10 \\
5.60 \\
4.86\end{array}$ & $\begin{array}{l}9.57 \\
8.25 \\
6.48 \\
5.63\end{array}$ & $\begin{array}{r}10.67 \\
9.67 \\
6.97 \\
6.43\end{array}$ & $\begin{array}{r}12.11 \\
11.17 \\
7.66 \\
7.62\end{array}$ \\
\hline $\begin{array}{l}5 \\
2 \\
7 \\
8\end{array}$ & $\begin{array}{l}1.91 \\
1.84 \\
1.85 \\
1.48\end{array}$ & $\begin{array}{l}2.85 \\
2.55 \\
2.43 \\
2.03\end{array}$ & $\begin{array}{l}3.77 \\
3.18 \\
2.94 \\
2.43\end{array}$ & $\begin{array}{l}5.83 \\
4.75 \\
4.02 \\
3.36\end{array}$ & $\begin{array}{l}7.38 \\
6.72 \\
4.97 \\
4.51\end{array}$ & $\begin{array}{l}\text { B. } 52 \\
7.80 \\
5.86 \\
5.40\end{array}$ & $\begin{array}{l}9.66 \\
8.60 \\
6.82 \\
6.14\end{array}$ & $\begin{array}{r}10.27 \\
9.26 \\
7.26 \\
6.52\end{array}$ & $\begin{array}{r}11.30 \\
10.64 \\
7.96 \\
7.30\end{array}$ \\
\hline $\begin{array}{l}9 \\
10 \\
11 \\
12\end{array}$ & $\begin{array}{l}1.19 \\
0.96 \\
1.04 \\
0.91\end{array}$ & $\begin{array}{l}1.97 \\
1.67 \\
1.63 \\
1.25\end{array}$ & $\begin{array}{l}2.54 \\
2.06 \\
1.99 \\
1.52\end{array}$ & $\begin{array}{l}3.66 \\
2.93 \\
2.70 \\
2.21\end{array}$ & $\begin{array}{l}5.32 \\
4.48 \\
3.65 \\
3.13\end{array}$ & $\begin{array}{l}6.45 \\
6.00 \\
4.49 \\
3.97\end{array}$ & $\begin{array}{l}7.34 \\
6.90 \\
5.14 \\
4.46\end{array}$ & $\begin{array}{l}8.14 \\
7.71 \\
5.48 \\
4.73\end{array}$ & $\begin{array}{l}9.60 \\
9.57 \\
5.92 \\
5.22\end{array}$ \\
\hline $\begin{array}{l}13 \\
14 \\
15 \\
16 \\
17\end{array}$ & $\begin{array}{l}2.00 \\
1.42 \\
1.67 \\
1.07 \\
0.45\end{array}$ & $\begin{array}{l}2.50 \\
2.08 \\
2.07 \\
1.67 \\
0.75\end{array}$ & $\begin{array}{l}3.00 \\
2.48 \\
2.31 \\
1.96 \\
0.92\end{array}$ & $\begin{array}{l}4.14 \\
3.36 \\
2.96 \\
2.46 \\
1.22\end{array}$ & $\begin{array}{l}5.99 \\
5.02 \\
4.02 \\
3.48 \\
1.75\end{array}$ & $\begin{array}{l}7.13 \\
6.59 \\
4.78 \\
4.34 \\
2.48\end{array}$ & $\begin{array}{l}7.92 \\
7.41 \\
3.26 \\
4.86 \\
3.02\end{array}$ & $\begin{array}{l}8.50 \\
7.79 \\
5.58 \\
5.16 \\
3.34\end{array}$ & $\begin{array}{l}9.62 \\
9.04 \\
5.99 \\
5.64 \\
4.28\end{array}$ \\
\hline
\end{tabular}

For use in the user function of the APET, the Eraction of melt ejected was divided into three groups: 0 to 20s, 20 to $40 \mathrm{~s}$, and 40 to $60 \mathrm{~s}$. The reason for doing this is that the dividing point between high and low fraction ejected (50s ejected) used by the Contalruent Loads Expert Panel turns out to be very near the high end of the aggregate distribution glven for the fraction of melt ejected by the In-Vessel Expert Panel. If the high-low division given by the Containnent Loads Expert Panel was used, over 80 of of the cases would fall in the low category.

Since it was not possible to get the Containment Loads Expert Panel to evaluate a new set of distributtans, the data are manipulated in the following way. For the 20 to 40 ejected group, the low-fraction-ejected results from the Containment Loads Expert Panel can be used difectly since the nominal value used by the contaiment loads experts was 338 ejected. For the 40 to bon ejected group. the loads low-fraction-ejected and highfraction-ejected can be averagid The average of the nominal fractions ejected is 54 , which is reasonably close to the center of this group. For the 0 to 20 ejected group. the average of the low fraction resilts and the Case 4 results (< 200 psia) cart be used. 


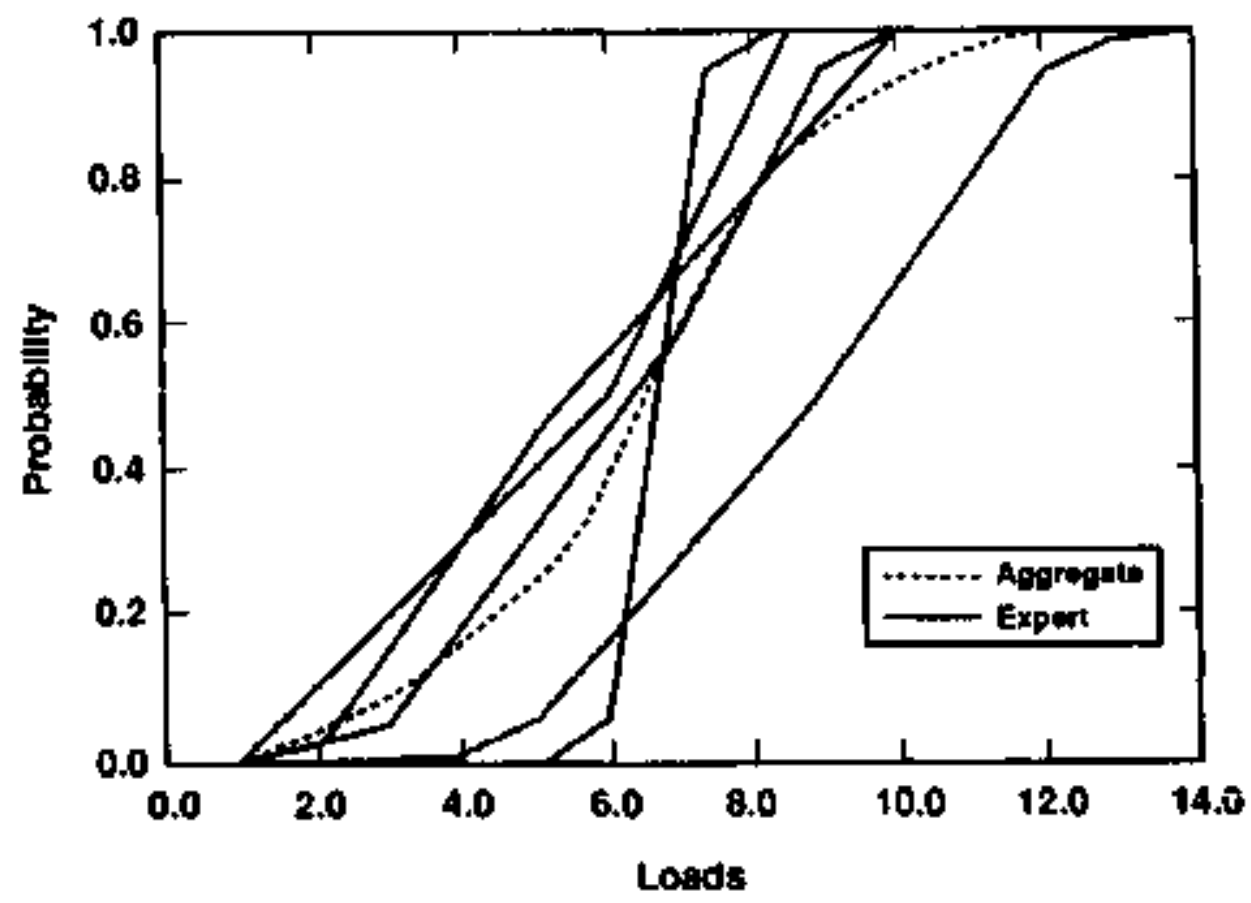

Figure 7-1. Aggregate of Zion Containrent Loading for Case 1.

Table 7-3 gives the new description of the, now, 25 cases in terws of RCS pressure, amount of cavity water, whether the sprays are operating, the core fraction ejected, and the vessel's hole slze. Table 7-4 shows the aggregate results for the pressure rise at zion (Table 7-2) expanded to three fraction-ejected groups by the method described above. Table 7-5 is Table 7-4, with the units converted from bars to psi for direct comarison with the results of the Structural Response Expert Panel. Figure $7-2$ is the same as Figure 7.1 but with the revised aggregate distribution used for the 40 to 608 ejected group also included. 
Table $7-3$

Characteristics of Combined Cases

Expanded from Table 7-1

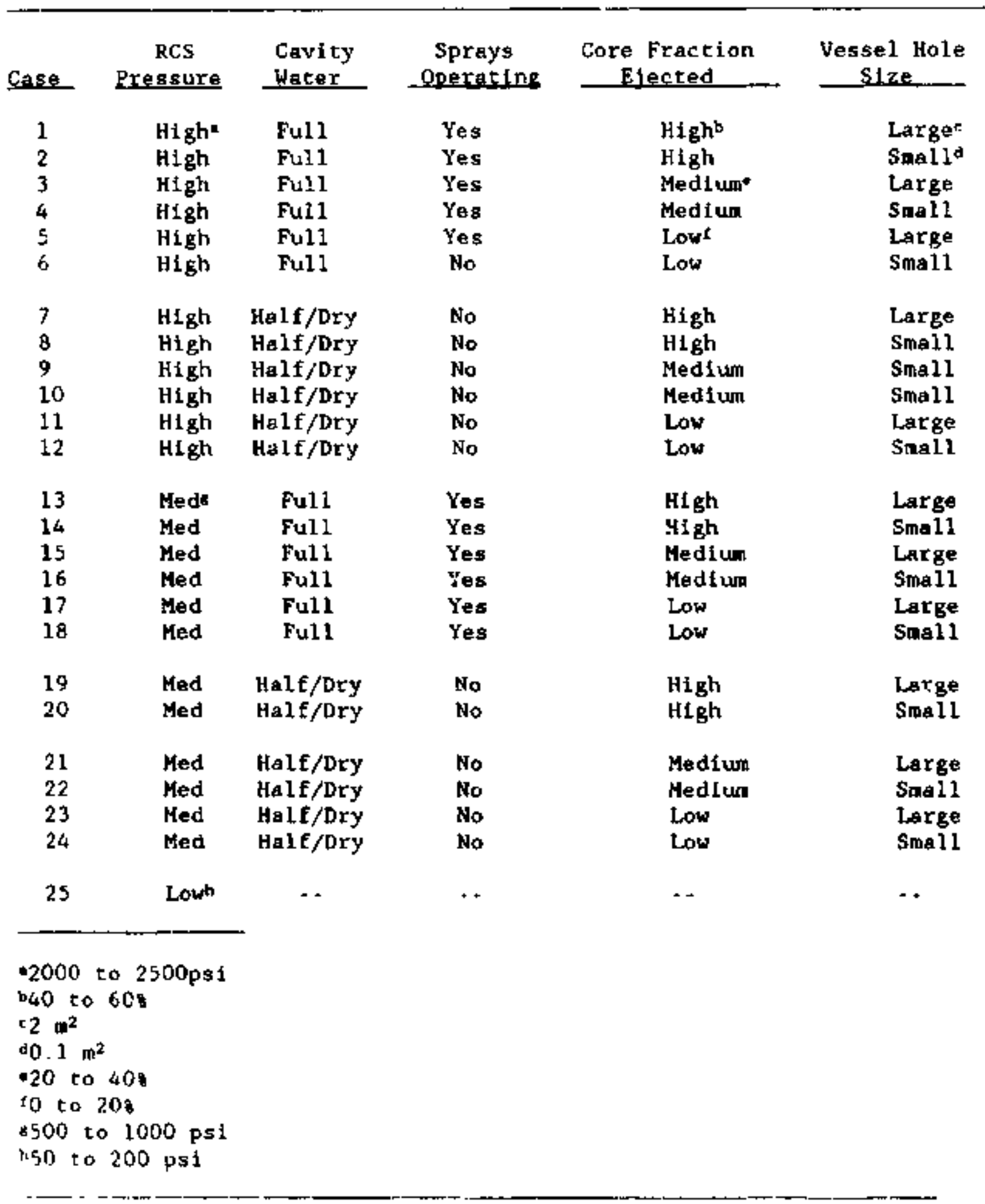


Table $7-4$

Aggregate Results; Pressure Rise

at Vesse1 Breach at Zion (bars)

\begin{tabular}{|c|c|c|c|c|c|c|c|c|c|}
\hline \multirow[b]{2}{*}{ Case } & \multicolumn{9}{|c|}{ Fractille } \\
\hline & $\underline{0.01}$ & 0,05 & 0.10 & $\underline{0.25}$ & $\underline{0.50}$ & 0.75 & $\underline{0.90}$ & 0.95 & -0.99 \\
\hline 1 & 1.27 & 2.21 & 2.86 & 4.32 & 5.62 & 6.78 & 8.02 & 8. 82 & 9.89 \\
\hline 2 & 1.18 & 1. 96 & 2.45 & 3.50 & 5.04 & 5.98 & 6.94 & B. 05 & 9.40 \\
\hline 3 & 1.20 & 2.03 & 2.49 & 3.51 & 4.55 & 5.60 & 6.48 & 6.97 & 7.66 \\
\hline 4 & 1.11 & 1.82 & 2.20 & 2.94 & 4,05 & 4.86 & 5.63 & 6.43 & 7.62 \\
\hline 5 & 0.83 & 1.39 & 1.71 & 2.37 & 3.15 & 4.04 & 4.75 & 5.15 & 5.97 \\
\hline 6 & 0.18 & 1.29 & 1. 56 & 2,08 & 2.90 & $3.6 ?$ & 4.33 & 4.88 & 5.95 \\
\hline 7 & 1.88 & 2.64 & 3.36 & 4.93 & 6.18 & 7.19 & 8. 24 & B. 77 & 9.63 \\
\hline 8 & 1.66 & 2.30 & 2.81 & 4.05 & 5.62 & 6.60 & 7.37 & 7.89 & 8.97 \\
\hline 9 & 1.85 & 2.43 & 2.94 & 4.02 & 4.97 & 5.86 & 6.82 & 7.26 & 7.96 \\
\hline 10 & 1.48 & 2.03 & 2.43 & 3.36 & 4.51 & 5.40 & 6.14 & 6.52 & 7.30 \\
\hline 11 & 1.15 & 1.59 & 1.93 & 2.62 & 3.36 & 4.17 & 4,92 & 5.30 & 6.12 \\
\hline 12 & 0.97 & 1.39 & 1.68 & 2.29 & 3.13 & 3.94 & 4.58 & 4.93 & 5.79 \\
\hline 13 & 1. 12 & 1. BO & 2.27 & 3.18 & 4.49 & 5.47 & E. 24 & 6.81 & 7.76 \\
\hline 14 & 0.94 & 1.46 & 1.79 & 2.57 & 3,81 & 4.99 & 5.68 & 6.22 & 7.39 \\
\hline 15 & 1.04 & 1.63 & 1.99 & 2.70 & 3.65 & 4.49 & 5.14 & 5.48 & 5.92 \\
\hline 16 & 0.91 & 1.25 & 1.52 & 2.21 & 3.13 & 3.97 & 4.46 & 4.73 & 5.22 \\
\hline 17 & 0.75 & 1.19 & 1.46 & 1.96 & 2.70 & 3.48 & 4.08 & 4.41 & 5.10 \\
\hline 18 & 0.68 & 1.00 & 1.22 & 1.72 & 2,44 & 3.23 & 3.74 & 4.03 & 4.75 \\
\hline 19 & 1.84 & 2.29 & 2.65 & 3.55 & 5.01 & 5.96 & 6.59 & 7.04 & 7.80 \\
\hline 20 & 1.25 & 1.88 & 2.22 & 2.91 & 4.25 & 5.47 & 6.14 & 6.47 & 7.34 \\
\hline 21 & 1.67 & 7.07 & 231 & 2.96 & 4.02 & 4.78 & 5.26 & 5.38 & $4.9+4$ \\
\hline 22 & 1.07 & 167 & 1.96 & 2.46 & $3.4,8$ & 4.34 & 4.88 & 5.16 & $5.6 \%$ \\
\hline 23 & 1.06 & 1,41 & 1.62 & 209 & 2.88 & 3.63 & $4.1 / 4$ & $\therefore .06$ & 3.14 \\
\hline 74 & 016 & 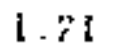 & 1.44 & ]. 84 & 7.62 & 3.41 & 3.95 & 4.73 & 4.96 \\
\hline 25 & 0.45 & 075 & 0.92 & 1.22 & 1.75 & 2.48 & 3.02 & 3.34 & 4.28 \\
\hline
\end{tabular}


Table 7.5

Aggregate Results; Pressure Rise

Vessel Breach at Zion (psig)

Fractile.

\begin{tabular}{rrrrrrrrrrr} 
Cese & $\underline{0.01}$ & $\underline{0.05}$ & $\underline{0.10}$ & $\underline{0.25}$ & $\underline{0.50}$ & $\underline{0.75}$ & $\underline{0.90}$ & $\underline{0.95}$ & -0.99 \\
1 & 18.34 & 32.05 & 41.47 & $2 . .57$ & $\mathbf{8 1 . 4 2}$ & 98.24 & 116.36 & 127.89 & 143.33 \\
2 & 17.04 & 28.35 & 35.45 & 50.68 & 73.08 & 86.71 & 100.63 & 116.73 & 136.23 \\
3 & 17.40 & 29.43 & 36.10 & 50.90 & 65.98 & 81.20 & 93.96 & 101.06 & 111.07 \\
4 & 16.09 & 26.39 & 31.90 & 42.63 & 58.73 & 70.47 & 81.64 & 93.24 & 110.49 \\
& & & & & & & & & \\
5 & 11.96 & 20.16 & 24.72 & 34.29 & 45.68 & 58.58 & 68.88 & 74.75 & 86.57 \\
6 & 11.31 & 18.63 & 22.62 & 30.16 & 42.05 & 53.22 & 62.71 & 70.83 & 86.28 \\
7 & 27.26 & 38.28 & 48.65 & 71.41 & 89.54 & 104.26 & 119.48 & 127.09 & 139.63 \\
8 & 24.07 & 33.28 & 40.67 & 58.80 & 81.42 & 95.70 & 106.87 & 114.41 & 130.07 \\
& & & & & & & & & \\
9 & 26.83 & 35.24 & 42.53 & 58.29 & 72.06 & 84.97 & 99.89 & 105.27 & 115.42 \\
10 & 21.46 & 29.43 & 35.24 & 48.72 & 65.40 & 78.30 & 89.03 & 94.54 & 105.85 \\
11 & 16.67 & 23.06 & 27.99 & 37.99 & 48.72 & 60.47 & 71.34 & 76.85 & 89.74 \\
12 & 13.99 & 20.16 & 24.29 & 33.20 & 45.39 & 57.13 & 66.41 & 71.49 & 83.96 \\
& & & & & & & & & \\
13 & 16.17 & 26.10 & 32.84 & 46.11 & 65.03 & 79.31 & 90.48 & 98.75 & 112.52 \\
14 & 13.56 & 21.17 & 25.95 & 37.27 & 55.17 & 72.28 & 82.36 & 90.19 & 107.23 \\
15 & 15.08 & 23.64 & 28.85 & 39.15 & 52.93 & 65.10 & 74.53 & 79.46 & 85.84 \\
16 & 13.20 & 18.13 & 22.04 & 32.05 & 45.39 & 57.56 & 64.67 & 68.58 & 75.69 \\
& & & & & & & & & \\
17 & 10.80 & 17.26 & 21.10 & 28.42 & 39.15 & 50.53 & 59.16 & 63.94 & 73.95 \\
18 & 9.86 & 14.50 & 17.69 & 24.87 & 35.38 & 46.76 & 54.23 & 58.51 & 68.88 \\
19 & 26.61 & 33.13 & 38.50 & 51.47 & 72.57 & 86.35 & 95.56 & 102.08 & 113.17 \\
20 & 18.05 & 27.19 & 32.19 & 42.19 & 61.63 & 79.24 & 89.10 & 93.89 & 106.43 \\
& & & & & & & & & \\
21 & 24.22 & 30.01 & 33.49 & 42.92 & 58.29 & 69.31 & 76.27 & 80.91 & 86.85 \\
22 & 15.52 & 24.22 & 28.42 & 35.67 & 50.46 & 62.93 & 70.76 & 74.82 & 81.78 \\
23 & 15.37 & 20.44 & 23.42 & 30.31 & 41.83 & 52.64 & 60.03 & 64.67 & 74.46 \\
24 & 11.02 & 17.55 & 20.88 & 26.68 & 37.92 & 49.44 & 57.28 & 61.63 & 71.92 \\
25 & 6.52 & 10.88 & 13.34 & 17.69 & 25.38 & 35.96 & 43.79 & 48.43 & 62.06 \\
& & & & & & & & & \\
\hline
\end{tabular}




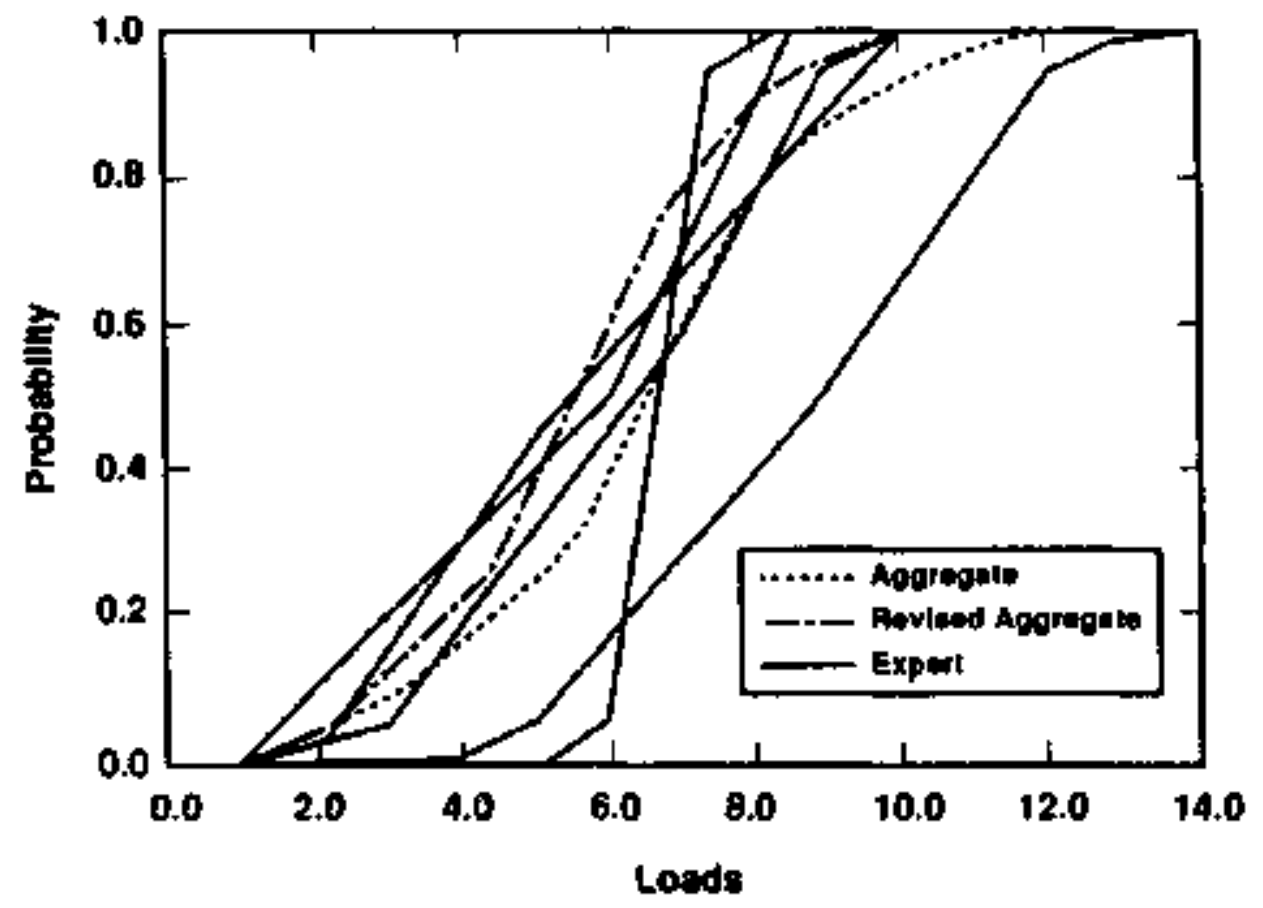

Figure 7.2. Revised Aggregate of Zion Containment Loading for Case 1 . 
Individual Elicitations of Jssue 7

$5.7 \cdot 15$ 
Expert A's Elfeltation

Issue 7: Pressure R1se At Vessel Bresch for zion

\section{Description of Expert A's Rationale Methodology}

Expert A observed that there was less known about DCH than about the other causes of the pressure rise listed above. There have been four DCH experiments at Sandis using the surtsey facility. The initial cONTAIN predictions matched the DCH-l experiment fairly well, and matched the DCH2. $\mathrm{DCH}-3$, and $\mathrm{DCH}-4$ tests poorly, A much better match to the later three DCH tests was obtained by changing the trapping parameter in conTAIN fron the value used for the DCH-1 test.

The effects of a full cavity of water are hard to estimate; the water could make the pressure rise larger due to incressed steam production, or the water could make the pressure rise smaller due to quenching. Expert $A$ concluded that, for Sequoyah, the median pressure rise for the full cavity case would be slightly higher than for the equivalent case with a dry cavity.

The hot gas resulting from vessel breach at any pressure above a few hundred psia will result in ignition if there is enough oxygen and hydrogen for combustion. The combustion should be complete. Expert A concluded that detonations were not likely at Zfon. At the time of vessef breach, the pre-existing hydrogen would be cold and would deflagrate while the hydrogen plume from the vessel would be hot and would probably burn as a diffusion flame. At Zion, it is very unlikely that enough hydrogen could accumulate by the time of vessel breach to allow a global deconation. Expert A felt that local detonations could not be ruled out, however, and the possibility of detonations contributed to the spread in hts distributions. The detonation mechanfsm is the failure of ignition or the diffusion flame for a few critical seconds as the hot gas flows out from the hole in the vessel. If this occurs, then detonable concentrations could exist in a limlted volume.

The case structure 1 isted above accounts for variations, in a coarse fashion. due to water in the cavity. sprays, and RCS pressure ac vessel fallure. The subcase structure accounts for differences due to the amount of $1 \mathrm{n}$-vessel zirconium oxidation, the hole size, and the fraction of mass ejected. Other factors wer accounted for by braadening the uncertainty bounds. In the course of this analys1s, Expert A concluded that the pressure rise was fatrly insensitive to the arount of in-vessel zirconium oxidation. The eight subcases are defined by a three-letter code: 


\begin{tabular}{|c|c|c|c|c|c|}
\hline Position & Descriotion & Letcter & Word & Nominal & Range \\
\hline First & In-Vessel Zr Oxidation & $\begin{array}{l}0 \\
0\end{array}$ & $\begin{array}{l}\text { High } \\
\text { Low }\end{array}$ & $\begin{array}{l}608 \\
258\end{array}$ & $\begin{array}{l}40-808 \\
10-408\end{array}$ \\
\hline second & Vessel Hole Size & $\begin{array}{l}\mathrm{H} \\
\mathrm{h}\end{array}$ & $\begin{array}{l}\text { Large } \\
\text { Smail }\end{array}$ & $\begin{array}{r}2 \mathrm{~m}^{2} \\
.1 \mathrm{~m}^{2}\end{array}$ & $\begin{array}{l}>0.5 \mathrm{~m}^{2} \\
<0.5 \mathrm{~m}^{2}\end{array}$ \\
\hline Third & Core Fraction Ejected & $\begin{array}{l}c \\
c\end{array}$ & $\begin{array}{l}\text { Large } \\
\text { Small }\end{array}$ & $\begin{array}{l}758 \\
337\end{array}$ & $\begin{array}{l}>508 \\
<508\end{array}$ \\
\hline
\end{tabular}

Expert A denoted his Zion cases with the letter " $Z^{n}$. Thus, Case $23 \mathrm{~b}-\mathrm{OHc}$ is Case $3 b$ as defined above, with high oxidation of zirconium in-vessel, a large hole slze, and a snall fraction of the core ejected.

Expert $A$ approached the problem by using the available CONTAIN, MAA. and surtsey results to carefully deteraine pressure rise distributions for three base cases. Using a PC spreadsheet program, he then adjusted these base cases to get values for all the other 6l subcases required.

The extremes of his ranges for the base cases were based on relatively straightforward energy balance calculations. The best estinate 1 s based on code results. primarily CONTAIN results for ZIon and other ConTAIN results in NUREG/CR-4896, A-1 Recent $18-\mathrm{cell}$ CONTAIN results show that sone of the earlier results are too high by about 1.0 bar. Expert A spent most of hls time on the base cases trying to get the center of his distributions correct, since that is where the bulk of the probability lies. He took very little time with the low pressure rise end of the curves since the pressure rises in this region will not fail the contalnment. He spent a fair amount of time on the upper ends, however, even though contalruent failure is assured for these pressure rises, because the base case is often reduced in calculating the substdiary cases. As the base cases were picked to be about the most severe expected for the three RCS pressure levals, the base case is never increased enough in obtaining a derivative case that the low pressure $r$ ise end of the curve becones tmportant.

For Zion, Expert A selected three base cases, denoted 12, 22, and 32 . The full deslgnation for each case and the reason $l$ was selected are:

\begin{tabular}{|c|c|c|}
\hline Base & Ident ifiti: & 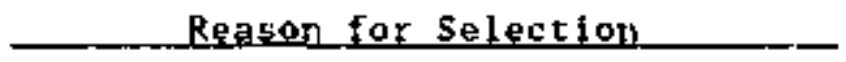 \\
\hline 12 & $\mathrm{Zl} \cdot \mathrm{oHC}$ & $\begin{array}{l}\text { Full cavity more likely than dry } \\
\text { cavity at zlon }\end{array}$ \\
\hline 27 & $\mathrm{Z3b}-\mathrm{OHC}$ & $\begin{array}{l}\text { Dry cavity case has highest pressure } \\
\text { rise }\end{array}$ \\
\hline 32 & $\mathrm{Z} / 4-\mathrm{oHC}$ & Parailel paramelet chojce \\
\hline
\end{tabular}

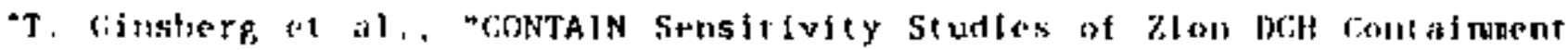

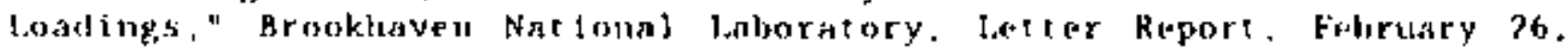
1488. 
Base Case 17: 2000 to 2500 psia tr RCS, cavity full, and sprays operating. The subcase is low zircontun oxidacion in vessel, a large hole, and large fraction of core ejected. The middle part of Expert A's pressure rise distribution for base Case 12 is based on the $A$ series of CONTAIN runs made at Brookhaven for 2 ion and Cases 17 and 19 in NUREG/CR-4896.A-1 The values from the Brookhaven runs were adjusted to account for the fraction of the core participating in DCH from 758 because the Surtsey tests showed that not all the core participated. ${ }^{A-2}$ to A-5 Other adjustments were made to account for the results of the 18 -cell runs, sprays, and the effects of codispersed water." After other adjustments for the zirconiur axidacion fraction and trapping, Expert A arrived at a median value of 6.5 bars.

The following is Expert A's complete pressure rise distribucion for base $\therefore$ ase 12:

$\begin{array}{lllllllr}\text { Curn. Prob. } & 0.01 & 0.05 & 0.25 & 0.50 & 0.75 & 0.95 & 0.99 \\ \text { AP (bars) } & 1.5 & 3.0 & 4.5 & 6.5 & 8.0 & 9.0 & 10.0\end{array}$

For his base Case 12, Expert A got a range from 1.5 to 10 bars with the inedian at 6.5 bars. Note that these are pressure rises, not total resultant pressure as reported in Reference $A-1$. Specific reasoning, with detafled references, are available for each value given above in the notes of Expert $A$, which are too voluminous to be lncluded here.

Expert $A$ chose his upper and lower bounds based on the report of the Containnent loads working Group and other calculations and analyses.

Base Case 2z: 500 to 2000 psia in RCS, cavity dry, and no sprays. The subcase is low zirconium oxidation, large hole, and large fraction of core ejected. This is also denoted case z3b.offC. The pressure rise distribution for this base case is primarily based on the $B$ series of CONTAIN runs made at Brookhaven for $Z i n^{*}$ and analogous conTAIN runs made for Zion for this ptoject." For the middle values, the adjustnents made to the intermediate pressure result from this reference are much the same as those made for the middle values in base Case 12. The median and upper bounds are somewhat lower chan In base Case 12 because of the lower pressure in the RCS at the tine of vessel failure.

Expert A observed that, for zion. the presence of water in the cavity increases the peak pressures when the RCS pressure is high before VB, but for intermediate pressures, as hete, the presence of water decreases the resulting containment pressures. This is different from the behavior expected far Sequoyah, but is sinilar to the situation at Surry. The

'Co-dispersed Water Case. Appendix to T. Ginsberg's Letler Report below.

“T Ginsberg et al. "CONTAlN Senstefuity studies of Zlon DCH Contalnment loadings," srookhaven National Laboratory, Lecter Repnrt, February 26, 1988 .

“D. C Whilisams, "Updale on CONTAIN DCH Calculatfons for Surry," fetter Report to NURFG.1150 Contadjunent Loads Panel. January 11. 1988. 
reason is that the cavities at Surry and Zion hold considerably less water than the cavity at Sequoyah. The presence of sprays and water in the cavity inhibit the pressure rise pore effectively for intermediate pressure in the RCS (base Case 22) than they do when there is full system pressure tn the RCS at breach (base Case 12).

Expert A arrived at the followlng pressure rise distribution for base Case 22:

$\begin{array}{llllllll}\text { Cum. Prob. } & 0.01 & 0.05 & 0.25 & 0.50 & 0.75 & 0.95 & 0.99 \\ \Delta p \text { (bars) } & 2.0 & 3.0 & 4.0 & 5.5 & 6.8 & 8.0 & 9.0\end{array}$

Both the median and the upper bound are 1.0 bar less than thejt counterpart pressure rises in base case 12. There are several threshold effects which are difficult to account for satistactorily. For example. elther the pre-existing hydrogen $1 \mathrm{~s}$ already burned or it is not. and el ther quenching occurs or it does not.

Base Case 32: less than 200 psia in RCS, full cavity, and sprays operating. The subcase is low zirconiun oxidation, large hole, and large fraction of core ejected. Thls 13 also denoted case z4-oHC. The pressure rise in this Case is due to phenomena other than DCH: steam spike, molten core-coolant interaction, and hydrogen cambustion. DCH is negligible at these low RCS pressures. The distribution for pressure rise is largely derived from the various cases considered by the Containment loads Working Group. The cases on which the middle and high end of the distribution rely on HECTR results while the low end is reflects the pressure rise due to the steam spike alone.

Expert A arrived at the following pressure rise distribution for base Case $3 z$ :

$\begin{array}{llllllll}\text { Cum. Prob. } & 0.01 & 0.05 & 0.25 & 0.50 & 0.75 & 0.95 & 0.99 \\ \Delta \text { (bars) } & 0.3 & 0.8 & 1.2 & 1.5 & 2.5 & 5.0 & 6.0\end{array}$

Expert A derived the pressure rise distributions for all the acher cases by means of adjustments to the three base cases descrlbed above. These adjustmetits and the reasoning behind ther are described in Expert $A$ 's notes which are not included here. As an example, in obtalning the small traction of core ejected cases from the large fraction of core ejected cases, he reduced the medial pressure risc since reducing the fraction of the core ejected in varlous CONTAlN runs showed such an effect.

\section{Resules of Expent 's Ellcikateal}

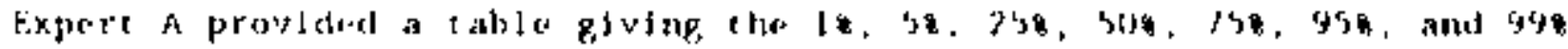

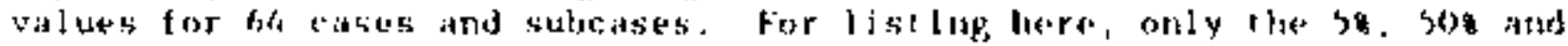

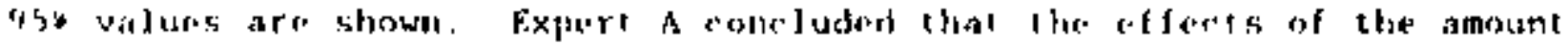

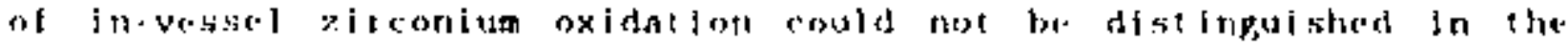

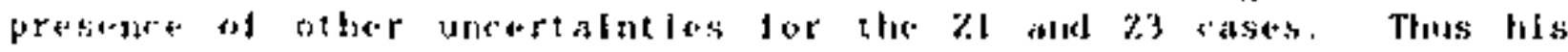

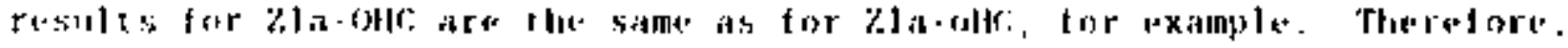

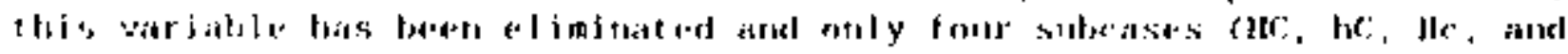

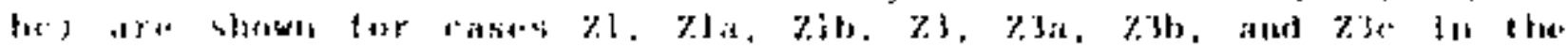


following table. He also concluded that only the effects of the anount of core ejected could be distingulshed in the presence of other uncertainties for Case 24 . Therefore, the other two vartables have been elininated and only two subcases ( $C$ and $C$ ) are shown for 24 in the following cable. The pressure rises in the following table are in bars.

\begin{tabular}{|c|c|c|c|c|c|c|c|}
\hline Cisse & 18 & $\underline{\text { SOs }}$ & 9旦牙 & Case & 13 & 500 & 998 \\
\hline $\begin{array}{ll}21 & -\mathrm{HC} \\
\mathrm{Zl} & -\mathrm{hC}\end{array}$ & $\begin{array}{l}3.0 \\
2.6\end{array}$ & $\begin{array}{l}6.5 \\
5.5\end{array}$ & $\begin{array}{l}9.0 \\
7.6\end{array}$ & $\begin{array}{ll}21 & -H c \\
\mathrm{zl} & -\mathrm{he}\end{array}$ & $\begin{array}{l}2.3 \\
1.9\end{array}$ & $\begin{array}{l}4.9 \\
4.1\end{array}$ & $\begin{array}{l}6.8 \\
5.7\end{array}$ \\
\hline $\begin{array}{l}21 a \cdot H C \\
21 a-h c\end{array}$ & $\begin{array}{l}3.6 \\
3.1\end{array}$ & $\begin{array}{l}7.8 \\
6.6\end{array}$ & $\begin{array}{l}9.9 \\
8.4\end{array}$ & $\begin{array}{l}21 \mathrm{a}-\mathrm{Hc} \\
21 \mathrm{a}-\mathrm{hc}\end{array}$ & $\begin{array}{l}2.7 \\
2.3\end{array}$ & $\begin{array}{l}5.9 \\
5.0\end{array}$ & $\begin{array}{l}7.4 \\
6.3\end{array}$ \\
\hline $\begin{array}{l}\mathrm{Z1b}-\mathrm{HC} \\
\mathrm{21b}-\mathrm{hC}\end{array}$ & $\begin{array}{l}3.6 \\
3.1\end{array}$ & $\begin{array}{l}6.5 \\
5.5\end{array}$ & $\begin{array}{l}10.8 \\
9.2\end{array}$ & $\begin{array}{l}\mathrm{Zlb}+\mathrm{Hc} \\
\mathrm{2lb}-\mathrm{hc}\end{array}$ & $\begin{array}{l}2.7 \\
2.3\end{array}$ & $\begin{array}{l}4.9 \\
4.1\end{array}$ & $\begin{array}{l}8.1 \\
6.9\end{array}$ \\
\hline $\begin{array}{ll}23 & -\mathrm{HC} \\
23 & -\mathrm{hC}\end{array}$ & $\begin{array}{l}2.4 \\
1.9\end{array}$ & $\begin{array}{l}4.4 \\
3.5\end{array}$ & $\begin{array}{l}7.2 \\
5.8\end{array}$ & $\begin{array}{l}23-\mathrm{Hc} \\
23-\mathrm{he}\end{array}$ & $\begin{array}{l}1.7 \\
1.3\end{array}$ & $\begin{array}{l}3.1 \\
2.5\end{array}$ & $\begin{array}{l}5.0 \\
4.0\end{array}$ \\
\hline $\begin{array}{l}\mathrm{Z3a} \cdot \mathrm{HC} \\
\mathrm{Z3a} \cdot \mathrm{hC}\end{array}$ & $\begin{array}{l}3.3 \\
2.6\end{array}$ & $\begin{array}{l}6.1 \\
4.8\end{array}$ & $\begin{array}{l}8.8 \\
7.0\end{array}$ & $\begin{array}{l}\mathrm{Z3a}-\mathrm{Hc} \\
23 a-\mathrm{hc}\end{array}$ & $\begin{array}{l}2.3 \\
1.8\end{array}$ & $\begin{array}{l}4.2 \\
3.4\end{array}$ & $\begin{array}{l}6.2 \\
4.9\end{array}$ \\
\hline $\begin{array}{l}23 \mathrm{~b}-\mathrm{HC} \\
\mathrm{z} 3 \mathrm{~b}-\mathrm{hC}\end{array}$ & $\begin{array}{l}3.0 \\
2.4\end{array}$ & $\begin{array}{l}5.5 \\
4.4\end{array}$ & $\begin{array}{l}8.0 \\
6.4\end{array}$ & $\begin{array}{l}23 \mathrm{~b}-\mathrm{Hc} \\
23 \mathrm{~b}-\mathrm{hc}\end{array}$ & $\begin{array}{l}2.1 \\
1.7\end{array}$ & $\begin{array}{l}3.8 \\
3.1\end{array}$ & $\begin{array}{l}5.6 \\
4.5\end{array}$ \\
\hline $\begin{array}{l}23 c \cdot \mathrm{HC} \\
\mathrm{Z3c} \cdot \mathrm{hC}\end{array}$ & $\begin{array}{l}2.6 \\
2.4\end{array}$ & $\begin{array}{l}4.7 \\
3.7\end{array}$ & $\begin{array}{l}7.6 \\
6.1\end{array}$ & $\begin{array}{l}23 \mathrm{c}-\mathrm{Hc} \\
23 \mathrm{c}-\mathrm{hc}\end{array}$ & $\begin{array}{l}1.8 \\
1.4\end{array}$ & $\begin{array}{l}3.3 \\
2.6\end{array}$ & $\begin{array}{l}5.3 \\
4.3\end{array}$ \\
\hline$z 4-C$ & 0.8 & 1.5 & 5.0 & $24 \cdot c$ & 0.6 & 1.1 & 3.5 \\
\hline
\end{tabular}

Expert A emphasized that there were inany uncertainties in estimating contalnment loads, especially containment loads at vessel breach. Selfheating of the molten material as it travels from the vessel throughout containment is not accounted for in the lumped-parameter codes. Thls phenomenon is not captured in the Brookhaven experiments. Entrainment and Weber break-up ace not mechanistically treated in the detailed codes, A zirconiun oxide crust on the ejected droplets may cause them to behave like solid particles rather than liquid particles. Internal gas generation may fragment the droplets, chus affecting the partiele size distribution.

Nitrogen chemistry is not lncluded in any of the madels. If nitrogen combines with the metal oxides in the droplet, the flow of nitroger into the droplet may rause fragmentat on tf the nitrogen is sulsequent ly relensed. The irligarciots of corium droplets with surfices are not well understond: while it is known that molten cotham stoes not wet conctele surfares, and concrete spalls when covered with enough molten corfum, axactly how the corfum diroglets will interact with concreta surfaces in a Drit event is unknown Tho Drit axporiments bave shown that there ls

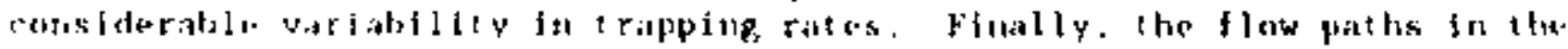

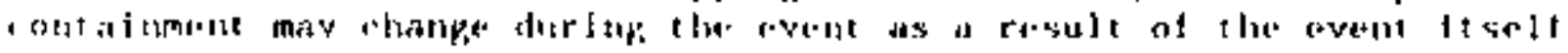


A-1. D. C. Williams et al., "Containnent Loads Due to Direct Containment Heating and Assoclated Hydrogen Behavior: Analysis and Calculatiors with the CONTAIN Code." Sandia National Laboratories, NUREG/CR-4B96, SAND87.0633, May 1987.

A.2. M. Pilch and A, W. Tarbe11, "Preliminary Calculations on Direct Heating of a Containment Atmosphere by Airborne Debris," Sandia National Laboratories, NUREG/CR-4455. SANDB5-2439, July 1986.

A-3. W. W. Tarbell et al., "Resules From the DCH-l Experiment, Sandia National Laboratories. NUREG/CR-4871, SAND86-2483, June 1987.

A-4. M. Pilch and $w$. W. Tarbell, "High Pressure Ejection of Melt From a Reactor Pressure Vessel." Sandia National Laboratories, NUREG/CR4383. SANDB5-0012, September 1965.

A.5.W. W. Tarbell. "Pressurized Melt Ejection Into Sealed Reactor Cavities," Sandia National Laboratories, NUREG/CR-4512, SAND86-0153, October 1986 . 
Expert B's Elfeltation

\section{Issue 7: Pressure RIa at Veasel Breach for zion}

\section{Description of Expert B's Rationale/Methodlogy}

Expert B based the assessment on BNL's CONTA3N calculations for 2ion. The results of both the melt ejection visualization experiments executed at BNL, and the Sandia Surtsey experiments were also considered. The BNI. calculations utflize an SP1 melt--22,000 kg of iron and a melt temperature of $2500 \mathrm{~K}$.

Expert B believes that the direct containnent heating scenario is typified by certain phenomena. The molten core is expelled from the vessel into the reactor cavity. The blowdown gas then follows and entrains the melt which then exits the cavity in the forn of particulate, rather than in waves or flims. The debris particulate droplet $\$$ ize is on the order of tenths of millimeters. The gas is heated as it passes through the melt, causing it to accelerate to velocities af several hundred meters per second. Mare than 80 of the molten core exits the cavity, there is no freezing of the melt on the cavity walls because the small residence times in the cavity limit crust formation. The zirconium-steam reaction is conplete, limited only by steam starvacion, and steam can react wich up to as much as 50 of of the Iron in the melt, after the unoxidized zirconium has been consuned.

Expert B approached the assessment with a "base case" scenario, Case lb. Sensitivity varlaclons from that case vere then considered with respect to zirconium content, break size and melt mass. From BNL CONTAIN calculations. sensitivity to zirconium cantent was not demonstrated, so separate assessments for this parameter were elininated, and the amount of zirconiur unoxidized $1 \pi$ the melt was fixed at 50 s for the distributions. For the larger hole size, more stesm escapes with the nolten debris, thus increas. ing the distribution pressure increment values except for the upper bound, because maximum steam ratps are already considered for this value.

Upper bounds were determined by adjusting the medtan value considering three separate phenomena. The first adjustment is to allow all the hydrogen generated to be burned. The other two adfustments include increasing the steam blowdown time to equal the nelt ejection the and decreasing the trapping rate of the particles.

The lower bounds vere determined by adjusting the redian value for two phenomena. The first is a decrease in the extent of the hydrogen generation-this affects the burn pressure increase. The second is to increase particle trapping rate to account for larger particles and shorter suspension times. 


\section{Results of Expert B's Eligitation}

The distribitions are provided in Table B-1 For Cases $1,1 a$, and $1 b$, fn Table B-2 for Cases 3, $3 a, 3 b$, and $3 c$, and in Table B-3 for Case 4.

Table B-1

Pressure Increment in the Zion Containment at Vessel Breach

Melt Hole

\begin{tabular}{|c|c|c|c|c|c|c|c|c|c|}
\hline \multicolumn{3}{|c|}{ Me1t Hole } & \multicolumn{7}{|c|}{ Cumbulative Probabllities. } \\
\hline Case & $\begin{array}{l}\text { Me1t } \\
\text { Mass } \\
\text { (욘) } \\
\end{array}$ & $\begin{array}{l}\text { Hole } \\
\text { Area } \\
\left(M^{\star} 2\right)\end{array}$ & .18 & $\underline{17}$ & $\underline{51}$ & 508 & $\underline{959}$ & -998 & 99.98 \\
\hline & & & \multicolumn{7}{|c|}{ Pressure Increment (bar) } \\
\hline 1 & 75 & 0.1 & 1.5 & 3.0 & 4.0 & B. 0 & 11.0 & 12.0 & 14.0 \\
\hline 1 & 75 & 2.0 & 1.5 & 4.0 & 5.0 & 9.0 & 12.0 & 13.0 & 14.0 \\
\hline 1 & 25 & 0.1 & 1.0 & 1.5 & 2.5 & 5.0 & 7.5 & 8,3 & 8.5 \\
\hline 1 & $2=$ & 2.0 & 1.0 & 2.0 & 3.5 & 6.0 & 7.5 & 8.3 & B. 5 \\
\hline la & 75 & 0.1 & 1.5 & 3.0 & 4.0 & 8.0 & 11.0 & 12.0 & 14.0 \\
\hline $1 a$ & 75 & 2.0 & 1.5 & 4.0 & 5.0 & 9.0 & 12.0 & 13.0 & 14.0 \\
\hline $1 a$ & 25 & 0.1 & 1.0 & 1.5 & 2.5 & 5.0 & 7.5 & 8.3 & 8.5 \\
\hline 1 a & 25 & 2.0 & 1.0 & 2.0 & 3.5 & 6.0 & 7.5 & 8.3 & 8. 5 \\
\hline $1 b$ & 75 & 0.1 & 2.5 & 4.0 & 6.0 & 7.0 & 10.0 & 12.0 & 14.0 \\
\hline lb & 75 & 2.0 & 1.5 & 5.0 & 7.0 & 8.0 & 10.0 & 12.0 & 14.0 \\
\hline Ib & 25 & 0.1 & 1.0 & 2.0 & 3.5 & 4.5 & 7.0 & 7.8 & 8. 5 \\
\hline lh & 25 & 2.0 & 1.0 & 2.0 & 3.5 & 4.5 & 7.0 & 7.8 & 8.5 \\
\hline
\end{tabular}

Table B. 2

Pressure lncrement in the Zion Containment at Vessel Breach
Melt Hole

Melt Hole

Mass Area

Case (1) (42)
Cumulative Probabilities

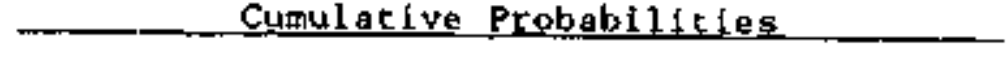

18 18 58 50\% 958 998 990 Pressure. Inerement (bar)

\begin{tabular}{|c|c|c|c|c|c|c|c|c|c|}
\hline 3 & 75 & (1) 1 & 03 & 0,8 & 15 & 15 & 9,3 & 11.4 & 13.0 \\
\hline 3 & 75 & $\lambda 11$ & 113 & 1.5 & $\gamma 4$ & 6.5 & 9 3 & 11,4 & 13.0 \\
\hline 3 & 25 & () i & (1) 5 & 0.8 & 1.0 & 35 & 48 & 60 & $1 \mathrm{5}$ \\
\hline 3 & $P S$ & 70 & (f) 5 & 1.8 & 28 & & ; & 601 & \\
\hline
\end{tabular}


Table B-2 (continued)

\begin{tabular}{|c|c|c|c|c|c|c|c|c|c|}
\hline \multicolumn{3}{|c|}{ Melt Hole } & \multicolumn{7}{|c|}{ Cumulative Probabtlities } \\
\hline$\underline{\text { Case }}$ & $\begin{array}{l}\text { Melt } \\
\text { Mass } \\
\text { (8) } \\
\end{array}$ & $\begin{array}{l}\text { Hole } \\
\text { Area } \\
\left(M^{2} 2\right)\end{array}$ & 18 & 18 & sq & 508 & $\underline{958}$ & 99\% & 99.98 \\
\hline & & & \multicolumn{7}{|c|}{ Pressure Increment (bar) } \\
\hline $\begin{array}{l}3 a \\
3 a \\
3 a \\
3 a\end{array}$ & $\begin{array}{l}75 \\
75 \\
25 \\
25\end{array}$ & $\begin{array}{l}0.1 \\
2.0 \\
0.1 \\
2.0\end{array}$ & $\begin{array}{l}0.5 \\
0.5 \\
0.5 \\
0.5\end{array}$ & $\begin{array}{l}0.8 \\
1.5 \\
0.8 \\
1.8\end{array}$ & $\begin{array}{l}1.5 \\
2.5 \\
1.0 \\
2.0\end{array}$ & $\begin{array}{l}5.5 \\
6.5 \\
3.5 \\
4.5\end{array}$ & $\begin{array}{l}9.3 \\
9.3 \\
4.8 \\
5.5\end{array}$ & $\begin{array}{l}11.4 \\
11.4 \\
6.0 \\
6.0\end{array}$ & $\begin{array}{l}13.0 \\
13.0 \\
7.5 \\
7.5\end{array}$ \\
\hline $\begin{array}{l}3 b \\
3 b \\
3 b \\
3 b\end{array}$ & $\begin{array}{l}75 \\
75 \\
25 \\
25\end{array}$ & $\begin{array}{l}0.1 \\
2.0 \\
0.1 \\
2.0\end{array}$ & $\begin{array}{l}0.5 \\
1.5 \\
0.5 \\
0.5\end{array}$ & $\begin{array}{l}1.0 \\
4.0 \\
1.0 \\
2.0\end{array}$ & $\begin{array}{l}2.0 \\
5.0 \\
1.5 \\
2.5\end{array}$ & $\begin{array}{l}4.5 \\
7.0 \\
2.5 \\
3.5\end{array}$ & $\begin{array}{l}9.3 \\
10.0 \\
4.8 \\
4.8\end{array}$ & $\begin{array}{l}10.4 \\
12.0 \\
6.0 \\
6.0\end{array}$ & $\begin{array}{l}13.0 \\
14.0 \\
7.5 \\
7.5\end{array}$ \\
\hline $\begin{array}{l}3 c \\
3 c \\
3 c \\
3 c\end{array}$ & $\begin{array}{l}75 \\
75 \\
25 \\
25\end{array}$ & $\begin{array}{l}0.1 \\
2.0 \\
0.1 \\
2.0\end{array}$ & $\begin{array}{l}0.5 \\
0.5 \\
0.5 \\
0.5\end{array}$ & $\begin{array}{l}0.8 \\
1.5 \\
0.8 \\
1.8\end{array}$ & $\begin{array}{l}1.5 \\
2.5 \\
1.0 \\
2.0\end{array}$ & $\begin{array}{l}5.5 \\
6.5 \\
3.5 \\
4.5\end{array}$ & $\begin{array}{l}9.3 \\
9.3 \\
4.8 \\
5.5\end{array}$ & $\begin{array}{l}11.4 \\
11.4 \\
6.0 \\
6.0\end{array}$ & $\begin{array}{l}13.0 \\
13.0 \\
7.5 \\
7.5\end{array}$ \\
\hline
\end{tabular}

Table B+ 3

Pressure Increment in the Zlon Contafnment at Vessel Breach

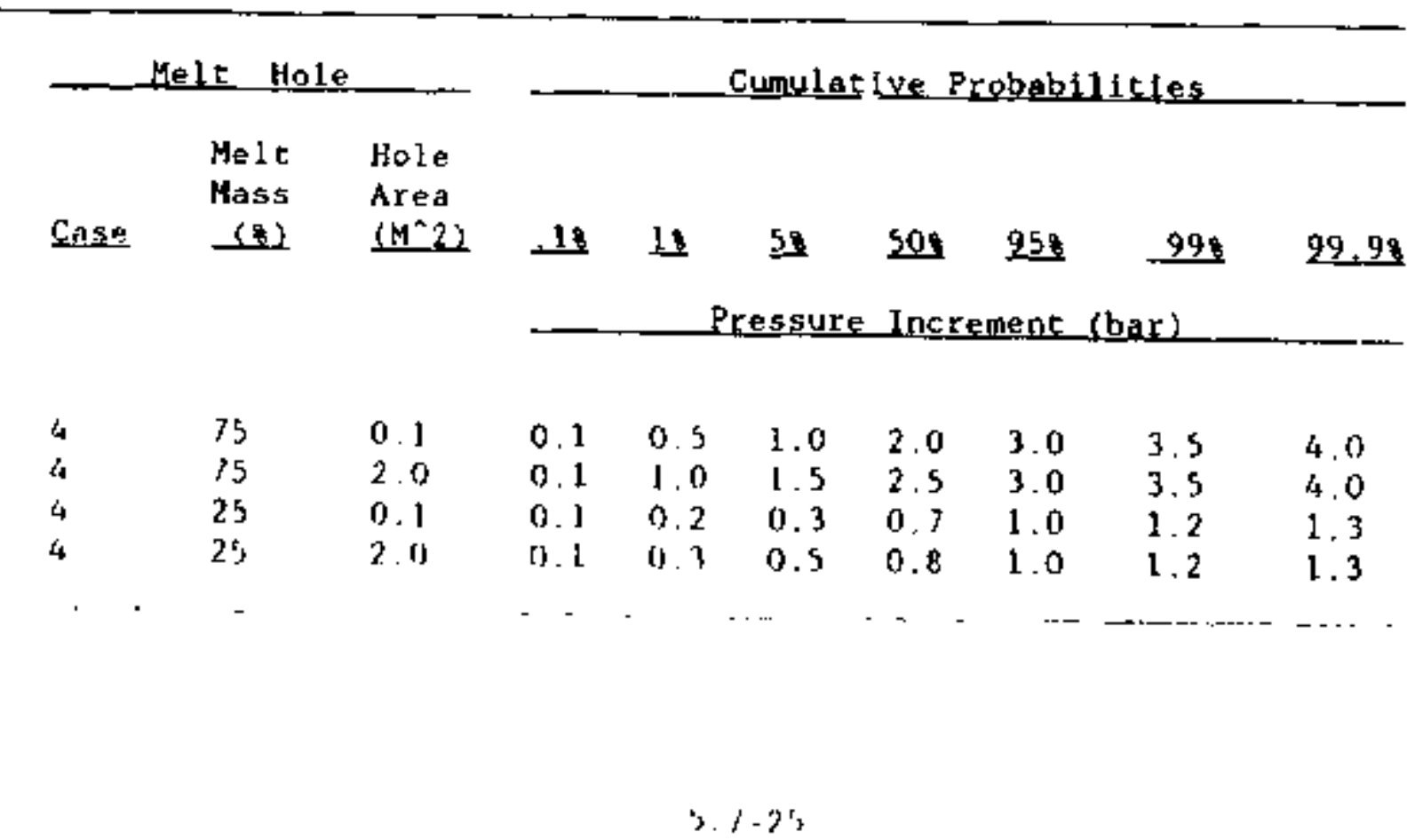




\section{Sources of Uncertalnty}

Expert B was certain that the molten debris is expelled from the cavity as particles or droplets, not as waves or films. Particle size and residence time in the contalnment atmosphere are uncertain, and were considered; however, in the 1000 to 2000 psi RCS pressure cases, the particle size will probably be of the order of a half of a ajllineter, and even for short residence times, the chemical reation rate is high. Freezing of melt on the reactor cavity walls is highly unlikely, but consideration of such affects the assessment distribution. The rates of mixing, entrairment, and the extent of steam starvation are uncertain and affect the extent of hydrogen production. 


\section{Expert C"s Elic1tation}

\section{Issue 7: Pressure R1se at Vessel Breach for zion}

\section{Description of Expert C's_Rationale/Methodology}

Expert $C$ concluded that it was inpossible to duplicate the codes by hand. or even generate good approximations, so his approach was to take the avallable code calculations, cansider the assumptions made in the code itself and the assumptions made In the input for the avallable code calculations, and then adapt and adjust the resulcs from the codes to get the values required here. He concluded that the code developers and analysts were knowledgeable $1 \pi$ the complex physical 1 ssues and that they had exercfsed due diligence in the development and use of the codes. He belleved that his role in the elictiation was best served by an interpretation of the codes and avallable results for the cases at hand. It is imposible to account for all the nonlinearitles and interactions in one's head for a problem as complex as this; we rely on the code to do this. A simple approach based on a few hand calculations is too risky for such a complex problen.

Expert $C$ relied primarily on MAAC-J and CONTAINC-2 calculations. He also utilized the Argonne experiments. ${ }^{c-3}$

Expert $C$ provided pressure rises for eight subcases for each of the cases defined above. These subcases are defined by a three-latter code:

\begin{tabular}{|c|c|c|c|c|c|}
\hline Posicion & Descrintion & Letter & Werd & Nominal & Bange \\
\hline First & $\begin{array}{l}\text { In-vessel zircontum } \\
\text { oxidation }\end{array}$ & $\begin{array}{l}\mathrm{H} \\
\mathbf{L}\end{array}$ & $\begin{array}{l}\text { High } \\
\text { Low }\end{array}$ & $\begin{array}{l}608 \\
258\end{array}$ & $\begin{array}{l}40.808 \\
10-408\end{array}$ \\
\hline Second & Vessel hole size & $\begin{array}{l}\mathrm{R} \\
\mathrm{J}\end{array}$ & $\begin{array}{l}\text { RLp } \\
\text { Jet }\end{array}$ & $\begin{array}{r}2 \mathrm{~m}^{2} \\
.1 \mathrm{~m}^{2}\end{array}$ & $\begin{array}{l}>0.5 \mathrm{~m}^{2} \\
<0.5 \mathrm{~m}^{2}\end{array}$ \\
\hline Third & Core fraction ejected & $\begin{array}{l}M \\
\mathbf{S}\end{array}$ & $\begin{array}{l}\text { Major } \\
\text { Small }\end{array}$ & $\begin{array}{l}758 \\
338\end{array}$ & $\begin{array}{l}>508 \\
<508\end{array}$ \\
\hline
\end{tabular}

Case 23b-HJM is Case 23b as defined above, with High oxfdation of 2 irconium in-vessel, a small (Jet) hole size, and a large (Major) Eraction of the core ejected.

Expert $c$ tabulated the number of available code results for each case and subease. There were avaitable about a dozen calculations each for Zlb-HJM and $23 \mathrm{~b}$-HJM. and two results (each) for Zlb-HJS and 23b-HJS. The other cases have no cods calculations avallabi. 2lb is the worst case. I.e., it gives the highe'st $A p$ in contalntent, bo Expert $C$ started wt th $21 \mathrm{~b}$-itsm. kesults for thr adt subcases fat whjch there are no runs at all have to bu obtained by shitifing and scallug from the four cases for which code results are avajlable 
Expert $C$ thought that the uncertainty in the models in the codes and the Input In the codes is adequately represented by the differences between CONTAIN and MAAP. CONTAIN is pessimistic in that all the debris ejected comes out early and then is entrained by the very high velocity gas jet that follows. Furthermore, the trapplng assumed in CONTA1N is less efficient than that in MAAP and that shown in the Argonne experiments. Expert $C$ believed that the CONTAIN calculations represent the pessinistic extreme because the pressure rises. He concluded that the code developers and analysts were knowledgeable in the complex physical issues and that they had exercised due diligence in the development and use of the codes. He believed that his role in the elicitation was best served by an interpretation of the codes and avallable results for the cases at hand. CONTAIN models DCH much better chan MAAP does, but sone of the assumptions like 100 entrainment are not realistic and not suitable for a best estitnate.

\section{Resulfs of Expert $C^{\prime}$ s Elicitation}

Expert $C$ provided the following table whtch contains his conclusians about the pressure $r i s e$ at vessel breach for 2 ion. The nonenclature for the yarious cases has been defined above. All pressure rises are in bars. The three values given are the 1,50 and 998 values for a cumulative probability curve.

\begin{tabular}{|c|c|c|c|c|c|c|c|}
\hline C모도e & 18 & 502 & 998 & Gas토 & 18 & 500 & 298 \\
\hline ZI - HEH & 1.0 & 6.5 & 9.0 & ZI - LRH & 1.0 & 5.5 & B. 0 \\
\hline 21 - HRS & 1.0 & 5.0 & 7.0 & 21 - LRS & 1.0 & 4.0 & 6.0 \\
\hline $21-H J M$ & 1.0 & 5.5 & 8.0 & $21-5 M$ & 1.0 & 4,5 & 7.0 \\
\hline $21-$ H.J & 1.0 & 4.0 & 6.0 & Zl - Lls & 1.0 & 3.0 & 5.0 \\
\hline Z1h-1 HRM & 2.0 & 7.0 & 10. & Z1b-LRM & 2.0 & 6.0 & 9.0 \\
\hline $\mathrm{Zlb} \cdot \mathrm{HRS}$ & 2.0 & 5.5 & 8.0 & $21 b \cdot$ LRS & 2.0 & 4.5 & 7.0 \\
\hline $2 ! \mathrm{b} \cdot \mathrm{HJM}$ & 2.0 & 6.0 & 9,0 & 2lb-ISH & 2.0 & 5.0 & 8.0 \\
\hline Zlb-HJS & 2.0 & 4.5 & 7.0 & $21 b \cdot 215$ & 2.0 & 3.5 & 6.0 \\
\hline 23 - HRM & 2.0 & 4.5 & 70 & 23 - LRM & 1.0 & 3.5 & 6.0 \\
\hline 23 -HRS & 1.0 & 3.0 & 3.5 & Z3 - LRS & 1.0 & 2.5 & 4.5 \\
\hline $23-\mathrm{HJM}$ & 1.0 & 4.0 & 6.5 & 23 - LJH & 1.0 & 3.0 & 5.5 \\
\hline $23 \cdot$ KJS & 1.0 & 2.5 & 5.0 & $23 \cdot$ LIS & 1.0 & 2.0 & 4.0 \\
\hline Z3b-HRH & 2.0 & 5,0 & 8.0 & $Z$ 'bh-I.RM & 2.0 & 4.0 & 7.0 \\
\hline $23 k \cdot 1 ! R S$ & . n & 3.5 & 6. 1 & 23b-LRS & 2.9 & 3,9 & 3.5 \\
\hline $2,3,4.0 H$ & 7.0 & 4.5 & t. & $23 !-5$ LM & 2.0 & 3.5 & 6.5 \\
\hline$\because 91) \cdot 4.15$ & 3.0 & $3.1)$ & 60 & $23 \mathrm{~b} \cdot \mathrm{lds}$ & 2.0 & 2.5 & 5.0 \\
\hline $2 / \cdot I S p$ & 7.0 & 3.0 & 4 41 & $2 d_{t} \cdot I . S_{\mathrm{p}}$ & 1.0 & 1.5 & 7.0 \\
\hline$Z u_{1} \cdot \cdot H$ & 7.1 & ג' & 30 & $2 / 4-1$. & 1.0 & 1.3 & 2.0 \\
\hline
\end{tabular}


Expert $C$ concluded that the $21 b$ values applled to Case 21 a, so a separate set of values for 2 la is not provlded. Expert $C$ also decided that the Z3b values applied to Cases $23 a$ and $23 \mathrm{c}$ as well, so separate values for these cases are not provided. For Case 24, Expert $C$ thought that the pressure $r$ Ise would be so snall that the zion containment would not be challenged, He thought that only the amount of zitconium oxldation In-vessel and whether the sprays were operating were important. The Efrst line for the 24 case abo is with the sprays operating (24-HSp and Z4-Lsp) and the second line is without the sprays operating.

Expert $C$ provided detailed reasoning for his values for the HJM and HJS subcases for Cases $21 \mathrm{~b}$ and $\mathrm{Z3b}$. The other subcases and other cases were treated by analogy and his reasoning is nat presented in as much detail. The subcases are discussed in the order in which Expert $C$ considered them since he reasoned from the best known cases and subcases to the less well known.

Case Zlb-HJM: 2500 psia in the RCS at vessel failure, a dry cavicy, and no sprays. The HJM subcase 15 high zirconium oxidation, small $\left(0.5 \mathrm{~m}^{2}\right)$ hole (Jet), and Major (75) fraction of the core ejected. This is the worst of the eight subcases except for HRM ( $R=R i p=$ large $\left(2 \mathrm{~m}^{2}\right)$ hole). Expert $C$ thought MAAP Cases 2 and 3 , and CONTA1N cases $A \cdot E$ and $A-7$, had the most reasonable assumptions. Sone of the CONTAIN cases were considered less reasonable because they used an ejection model other than Model $A$ or $C$. Weighting the two MAAP results equally with the two conTAIN results, Expert $C$ got six bars for his median or best estimate value for the pressure $\mathrm{rise}$ at vessel breach for Zion for subcase Zlb-HJM.

Expert $C$ got the upper bound fron CONTAIN runs $s$ ince he thought they were more pessimistic than the MAAP runs. The worst combination would be the co-entrained water assumption from CONTAIN Case Al2 combined with ejection podel B from Case A-2. This unlikely combination should give the highest possible Ap; it is unlikely because co-entrained water implies the steam comes out simultaneously with the debris while ejectlon nodel B assumes the debris comes out before the steam, There was no CONTAIN run with this combination, but Expert $C$ estimated chat, if run, it would have glven a pressure $r$ ise of about 9 bars. This gives hir the 99 value for this subcase.

The lower hound on the $\Delta p$ distribution is flxed by the steam splke. For the lower hound. Expers $C$ assuned that there was no hydrogen burn (elther never igrited or all pre-existing hydrogen consuned in small burns before breach) and the pressure tise is due to the steam spike alone. This gives 1 or 2 bars: the exact numbet Isn't jmportant glven the failure pressure of the zion containment. There is no need to accurately detine the lown tall of the curve since ic has mo risk stgilfjcatice.

Case 2lb-HJS 2505 psia in the RCS at vessel tallure, a diy cavity. and

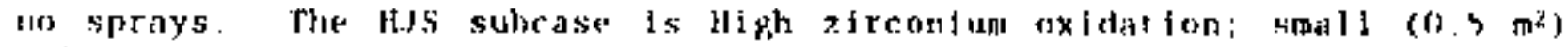
hole f.let): and Small (3) fraction of the corte ejected. This stabease is $\pi$ it as savert as $H$ IM berause a small riather thits a latge fraction of rhe

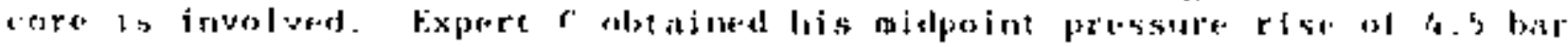

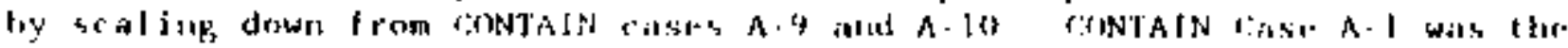


sinilar case for Zlb-HJM, and $1 \mathrm{t}$ was about 1 bar above the Expert $C^{\prime} s$ midpoint value. He thus reasoned that the midpoint for zlb-HJS should be 4. 3 bar. Expert $C$ would expect MAP runs to give about 3 bars. As 0.5 bar increments are as 5 mall as is reasonable to use, Expert $G$ rounded up to 4.5 bars. The upper bound was obtalned by scaling down fron 2lb-HJM. The lower bound is fixed by the stesm spike.

Case Z3b-hJM: S00 to 1000 psia in the RCS at vessel fallure, dry cavity, and no sprays. The hlM subcase is High zircontum oxtdacion; small (0.5 $\mathrm{m}^{2}$ ) hole (Jet); and Major (75) fraction of the core ejected. There are no MAAP results avallable. Expert $C$ assumed they would be about 2 bars below the pressure rises shown for CONTAIN cases B-6 and B-7, so he subtracted a bar from these resulcs, rounded up, and got 4.5 bat for his best estimate or midpoint. He scaled the 99 value down by 1.5 bars fron $21 \mathrm{~b}$-HJM since the widpoint dropped by that much. The lower bound is not adjusted since it represents the pressure rlse from the steam splke only.

Case z3b-HJS: 500 to 1000 psia in the RCS at vessel failure, dry cavity, and no sprays. The HJS subcase is High zirconfum oxidation; small $\left(0.5 \mathrm{~m}^{2}\right)$ hole (Jet); and Small (758) traction of the core ejected. There are no MAAP results available, but Expert $C$ assumed they would be about 2 bars below the pressure rlses shown for CoNTAIN cases B.9 and B-10, So he subtracted a bar from the CONTAIN results, rounded down, and got 3.0 bar for his best estimate or midpoint. He scaled the 998 value down by 1.5 bars fron Z3b-H.M since the midpoint dropped by that much. The lower bound remains fixed.

24 Cases: Less than 200 psia in the RCS at vessel failure. Expert $C$ concluded that for these low pressures in the RCS at failure, the effects of hole size and fraction of the core involved were negliglble. Hovever, he felt that effects of the sprays were important since they deterwined the effectiveness of the steam spike. He thus ptovided pressure rises for the four cases in the table above. Even the highest credible pressure rise for low RCS pressure at breach is 50 low that the 2 ion contalnment is not threatened, so the values shown are not worth spending any more time on even though they are fairly approximate. Expert $C$ estimated the Case $Z_{4}$ pressure rises frow hydrogen burn results for the Seabrook PRA.C-3 Seabrook and $Z$ ton are enough alike that this is well within the bounds of accuracy needed here. For the worst subcase, high in-vessel zlrconium oxidation with sprays. Expert c obtalned hls upper bound by assuning that there would be 802 zirconium oxidation and he got a resultant pressure of 80 psia. which gives pressure rise of about 4 bars. The other subcases were scaled fron this result with the ald of the Seabrook results. The arjor uncertainty was whether the stean concentration in the containment with no sprays operating would be so high as to preclude hydrogen coinbustion.

Cases 2lb-HRy and 21b-HRs: 2500 psia in the RCS at vessel faflure. dry cavily, and no sprays. The tIRS subcase is High zirconium oxidation; large $\left(2.0 \mathrm{~m}^{2}\right.$ ) hale (RLP): and small (33t) fraction of the core ejected. The HRM subcase is similar but has a Major portion of the core ejected. The larger hole will Increase the pressure rise at vessel breach sonewhat, but not by great amounts in the opinion of Expert $C$. He scaled the nidpoint values and the 99 values up 1 bar frod the $\mathrm{Zlb}$.HJM and Zlb-HJS subcase values. 
The 1 values stay the same since the steam spike is unaffected by the hole size.

Cases 21b-IRM, 21b-LRS, Z1b-LJM and Z1b-LJS: 2500 psia in the RCS at vessel fallure, dry cavity, and no sprays. The subcases all have low fraction of the zitcontum oxidized in-vessel. The zirconiun not oxidized in-vessel will oxidize during the HPME if the particle size is small and steam is available. However, the particles may be large enough so that not all the zirconium in them will oxidize, and some particles are bound to be rhis large even if the bulk of them are not.

Furthermore, sufficient steam may not be avallable, so the net effect is that the Lxx subcases will have lower pressure rises than the Hxx subcases. Considering the effects of hole size snd fraction ejected ta the Hxx set of subcases, Expert $C$ reduced both the ridpoint and 998 values of the $k \times x$ subcase pressure rises 1.0 bar to obtain the Lxx subcase values. The lower bound stays the same as the stearp spike is not affected.

Cases 23b-LRM, 23b-LRS, 23b-LJM and 23b-l.Js: 500 to $1000 \mathrm{psia}$ in the RCS at vessel failure, dry cavity, and no sprays. The subcases all have s low fraction of the zirconium oxidized in-vessel. These cases were treated by analogy with the $21 b-\mathrm{Lxx}$ cases. Expert $\mathrm{C}$ first subtracted 1.0 bar from all the 23b-fxx midpoint and 99 values to get the $23 \mathrm{~b}-\mathrm{Lxx}$ nidpoint and 998 values. Stnce hole size doesn't make as big a difference at these lower pressures, he then added 0.5 bar to the midpoint pressures for subcases LRS and LJS so that the differences between LRM and LJM, and between LRS and 1.tS would only be 0.5 bar.

2la and 23a Cases: Expert $C$ concluded that the pressure rise for a partially full cavity would be close to that for a dry cavity. He felt they were very unlikely to occur in any event, and that they were more Iikely to result in pressure rises similar to the dry cases (21b and 23b) than to the full cavity cases ( 21 and $\mathrm{z} 3$ ).

21 Cases: 2500 psia in the RCS at vessel failure, full cavity, and sprays. The problem here is to go from the dry cavity-no sprays coses (21b) where we have code results, to the full cavity..sprays cases (Z1) where there are no code results at all. Expert $C$ thought that the water in the cavity was likely to be pushed out of the cavity altogether by the initial fet of debris penetrating the water and Implnging on the cavity floor. This water pushed out into the cavity could reduce the pressure rise. FT sees three possible additional effects:

1. The stean produced by the initial jet impingement could efficiently sweep the debris out of the cavity:

2. The stean could enhance the metal-water reaction: and

3 The water droplets in the containment resulting from the sweep-out could quench the small particles entrained in the gas jet which follows the debris ejection. 
Expert $C$ saw competing effects from the cavity water and sprays together: the cavity water alone could increase the pressure rise by as much as 1.5 bars, but the sprays alone could reduce the pressure rise by a greater amount. Taking both effects into account, Expert $C$ obtafned his 21 pressure rise values by reducting the $21 b$ midpotnc pressure for each subcase by 0.5 bars, and reducing the $99 \%$ pressures by 1.0 bars. The lower bound was reduced to 1.0 bar since the sprays w1ll be very effective is reducing the stear spike.

23 Cases: 500 to 1000 psia in the RCS at vessel fallure, full cavity, and sprays. Expert $C$ applied the same reasoning to the 23 cases as he did to the 21 cases fust discussed. He obtained the 23 subcase values for the raidpolnts by subtracting 0.5 bars from the equivalent $23 \mathrm{~b}$ subcase, and he got the 998 values by subtracting 1.0 bar from the equivalent $23 b$ subcase.

23c Cases: S00 to 1000 psia in the RCS at vessel failure, full cavity, and no sprays. Expert $C$ thought that the incceased hydrogen production due to the steam from the full cavlcy would just about cancel out the cooling effects of the dispersed water at these temperatures. Thus he felt the 23b pressure rises should apply to all the 23 subcases.

\section{Scurces of Uncertalinty}

Expert $C$ felt the uncertainty in rates was not particularly important since nost processes went to completion. The variability in the fraction ejected and the hole size have partally been accounted for in the subcase structure. The major uncertainties that cause the braadness of the distributions are the amount of zircentum segregation before breach for the metal fraction ejected early) and the effectlve particle slze. The effect of incomplete hydrogen combustion is small since it is expected to be very nearly complete in all cases.

\section{Corctations with Other Variables}

The amount of unoxidized zirconiur in the core debris ejected before the gas blowdown should be correlated with the results of the In-Vessel fanel.

\section{Suggested Nethods Eor Rtducing Uncertainty}

Expert $C$ noted that there were code calculations for only 4 of the 48 cases and subcases. The obvious way to reduce uncertainty is co provide code calculations for the other 44 cases and subcases. This would considerably reduce the error introduced by shifting and scaling the results from the four cases with calculations to cover the other 44 cases. CONTAIN Tesults with the A.6 assumptions for cases $21,21 \mathrm{l} .23$, etc would have beet, particularly helptul. 


\section{References}

C-l. K. Fleming et al., "Risk Management Actions ... Seabrook," Plckard. Lowe, and Garrick, PLG-0550, July 1987.

C.2. B. W. Spenser et a1.. "Hydrodynamics and Heat Transfer Aspects of Corium Water Interactions," Electric Power Research Instltute, EPRI NP.5127, March 1987.

C.3 Plckard, Lowe and Garrick. Inc., "Seabrook Station Probabllistic Safety Analysis," prepared for the Public Service Company of New Happshire and the Yanke Atomic Electric Company, PLG-0300, December 1983. 
Expert D's Elfcitation

\section{Issue 7: Prossura Aise at Vossel Breach}

\section{Description of Expert R's Rationale/Methodology}

Expert D performed a thermodynamic calculation for the assessment. The calculation was executed by a computer program that provided the values for the distribution extremes ( 1 and 99 percentiles). Internal energy tables were employed in the code execution. An adlabatic energy balance was urilized so the effect of hole size was not provided, although it was judged that the distribution ranges would incorporate the effect.

Various assumptions were made for the calculation. It was assumed that the core debrts is ar $2530 \mathrm{~K}: 0.257 \mathrm{MJ} / \mathrm{kg}$ latent heat and $0.943 \mathrm{~mJ} / \mathrm{kg}$ senslble heat. Becween 0 to 20 (depending on the case beting assessed) of the ejected core is quenched, producing steam. From results of surtsey Tests 2.3 , and 4 , it was assumed that at least 10 of the ejected core is frozen on the cavity walls. Both zirconius and iron sre reacted with steam in creating hydrogen. When hydrogen is produced, 908 of the hydrogen is burned, and the resulting pressure $r$ ise computed (10s is unavallable due to poor mixing in the lower part of containment where alr has been purged by steam blowdown).

Expert $D$ believes that detonations will not occur because unconditional burning of hydrogen together with the rate of hydrogen production and mode of mixlng precludes detonable mixtures. As an informal check, the results of the calculations were compared with Expert C's preliminary CoNJAIN results for 2 ton and noted that for the upfir $11 \mathrm{~m} 1 \mathrm{ts}$, the results were in general agreement.

Expert $D$ did bounding calculations for the upper and loter bounds of the distributions ( 1 and 99 percentlles) by seteing credible lintes on the metal-steam reactions. The extent of the ex-vessel reaction was then varfed to complete the distribution. To establish the lower bound of the distribution, 25 metal/stean reaction was assumed, and to establish the upper bound, complete reaction was assumed. In all the distributions, Expert $D$ tended to give a little more welgh: to the lower values, because the calculation did not include the heat sinks in contalnment. which. If fincluded would result in a smaller pressure increment.

For shifting from Case $l$ and its subcases to Case $j$ and $t$ ts subcases, Expert $D$ varied the amount of quenching depending an the amount of cavity water tn Case 3 . It was assuned that thete was less gtean blowdown energy chan case l. because there is less water inventory and less energy in the primary system at vessel breach. For Case 4. a stean splke was calculated, regliglble hylrogen was produced, and no pressure increment from hydrogen lurfus was computed The upper bound tot Case 4 was determlned by nssuring complete conversion of cure melt energy to stras 


\section{Results of Expert Dis Elictiation}

Expert $D$ provided information based on the sensitivity variables of fraction of core ejected (33) and 758). and extent of In.vessel zircontum rapction (250 and 60\%). The distributions for the pressure increment in the 2 ion contalnment at vasel breach for case 1 are provided in Table $\mathrm{D}-\mathrm{l}$. for Case 3 in Table D-2, and for Case 4 in Table D-3.

Table D-1

Pressure Increment in the Zion Contalnnent at Vessel Breach

\section{Cumulat tve Probabilities}

\begin{tabular}{|c|c|c|c|c|c|c|c|}
\hline \multirow[t]{2}{*}{ Cise } & $\begin{array}{l}\text { Melt } \\
\text { Mass } \\
(1) \\
\end{array}$ & $\begin{array}{l}\text { In-Vessel } \\
\mathrm{Zr-reacted} \\
\text { (8) }\end{array}$ & 18 & 58 & 508 & 958 & 998 \\
\hline & & & \multicolumn{5}{|c|}{ Pressure Increment (bar) } \\
\hline 1 & 33 & 25 & 3.0 & 3.7 & 4.5 & 5.3 & 6.0 \\
\hline l & 33 & 60 & 3.0 & 3.6 & 4.3 & 4.9 & 5.5 \\
\hline 1 & 75 & 25 & 5.5 & 6.2 & 7.0 & 7.7 & 8.5 \\
\hline 1 & 75 & 60 & 5.0 & 5.7 & 6.5 & 7.2 & 6.0 \\
\hline la & 33 & 25 & 3.5 & 4.2 & 5.0 & 5.8 & 6.5 \\
\hline 1 a & 33 & 60 & 3.0 & 3.6 & 4.5 & 5.2 & 6.0 \\
\hline la & 75 & 25 & 5.8 & 6.7 & 7.5 & 8.4 & 9.2 \\
\hline $1 a$ & 75 & 60 & 6.0 & 6.6 & 7.2 & 7.8 & 8.4 \\
\hline 10 & 33 & 25 & 4.0 & 4.8 & 5.5 & 6.2 & 7.0 \\
\hline lb & 33 & 60 & 3.5 & 4.2 & 5.0 & 5.8 & 6.5 \\
\hline $1 b$ & 75 & 25 & 6.1 & 7.0 & 7.9 & 8. 8 & 9.7 \\
\hline Ib & 75 & 60 & 6.4 & 7.1 & 7.1 & 8.3 & 8. 9 \\
\hline
\end{tabular}


Table 0.2

Pressure Increment in the Zion Containment at Vessel Breach

Cumulat Ive Probab1liches

\begin{tabular}{|c|c|c|c|c|c|c|c|}
\hline Case & $\begin{array}{r}\text { Melt } \\
\text { Mass } \\
(0) \\
\end{array}$ & $\begin{array}{l}\text { In-Vessel } \\
2 r-r e a c t e d \\
(\$)\end{array}$ & 18 & 5 흘 & 508 & 958 & 998 \\
\hline & & & \multicolumn{5}{|c|}{ Presssure Increment (bar) } \\
\hline 3 & 33 & 25 & 2.5 & 3.2 & 4.0 & 4.8 & 5.5 \\
\hline 3 & 33 & 60 & 2.5 & 3.1 & 3. 8 & 4.4 & 5.0 \\
\hline 3 & 75 & 25 & ᄃ. 0 & 5.7 & 6.5 & 7.2 & 8.0 \\
\hline 3 & 75 & 60 & 4.5 & 5.2 & 6.0 & 6.7 & 7.5 \\
\hline $3 a$ & 33 & 25 & 3.0 & 3.7 & 4.5 & 5.3 & 6.0 \\
\hline $3 a$ & 33 & 60 & 2.5 & 3.1 & 4.0 & 4.7 & 5.5 \\
\hline $3 a$ & 75 & 25 & 5.3 & 6.2 & 7.0 & 7.9 & 8. 7 \\
\hline $3 a$ & 75 & 60 & 5.5 & 6.1 & 6.7 & 7.3 & 7.9 \\
\hline $3 b$ & 33 & 25 & 3.5 & 4,3 & 5.0 & 5.7 & 6.5 \\
\hline $3 b$ & 33 & 60 & 3.0 & 3.7 & 4.5 & 5.3 & 6.0 \\
\hline $3 b$ & 75 & 25 & 5.6 & 6.5 & 7.4 & 8.3 & 9.2 \\
\hline $3 \mathrm{~b}$ & 75 & 60 & 5.9 & 6.6 & 7.2 & 7.8 & B. 4 \\
\hline $3 c$ & 33 & 25 & 3.0 & 3.7 & 4.2 & 5.3 & 6.0 \\
\hline $3 c$ & 33 & 60 & 3.0 & 3.6 & 4.3 & 4.9 & 5.5 \\
\hline $3 c$ & 75 & 25 & 5.5 & 6.2 & 7.0 & 7.7 & 9.5 \\
\hline${ }^{3} \mathrm{c}$ & 75 & 60 & 5,0 & 5.7 & 6.5 & 7.2 & 8.0 \\
\hline
\end{tabular}

Table $D \cdot 3$

Pressure Ircrenent in the ZIon Containment at Vessel Breach

Cinlutative Probahllities

\begin{tabular}{|c|c|c|c|c|c|c|c|}
\hline ings: & $\begin{array}{l}\text { Melt } \\
\text { Mass } \\
\text {-112 } \\
\end{array}$ & $\begin{array}{l}\text { In-Vessel } \\
Z_{T} \text { teacted } \\
\text { (a) }\end{array}$ & 18 & 58 & 20 & 958 & 998 \\
\hline & & & \multicolumn{5}{|c|}{ Pressure lincrement (bar) } \\
\hline$i_{4}$ & $3 ?$ & $\because 5$ & $0, \mathrm{~b}$ & 0.8 & 1.7 & 1.6 & 2.0 \\
\hline$\therefore$ & 33 & $6, t)$ & 0). 5 & ?. 8 & 1.2 & 1.6 & 2.0 \\
\hline$\therefore$ & is & 25 & 0.1 & 9. 8 & 1.2 & 1.6 & 2.0 \\
\hline$\cdot$ & $/ 1$ & $f, t)$ & 1). & (1) 8 & 1. . & 16 & 7.0 \\
\hline
\end{tabular}


The distributions for the amount of hydrogen produced at vessel breach are provided in Table $\mathrm{D}-4$ for Cases 1 and $3\left(\mathrm{H}_{2}\right.$ in Case 4 is negligible).

Table D-4

Pressure Increment in the ZIon Contalnment at Vesse 1 Breach

Cumulative Probabilitiles

\begin{tabular}{|c|c|c|c|c|c|c|c|}
\hline Case & \multirow[t]{2}{*}{$\begin{array}{l}\text { Melt } \\
\text { Mass } \\
\text { (B) }\end{array}$} & \multirow[t]{2}{*}{$\begin{array}{l}\text { In-Vegsel } \\
\mathrm{Zr} \text {-reacted } \\
\quad(\mathrm{B}) \\
\end{array}$} & 18 & 58 & 508 & 958 & 998 \\
\hline & & & \multicolumn{5}{|c|}{ Hydrogen Produced (Mg-moles) } \\
\hline $1,3,3 e$ & 33 & 25 & 0.03 & 0.05 & 0.08 & 0.11 & 0.14 \\
\hline $1,3,3 \mathrm{c}$ & 33 & 60 & 0.03 & 0.05 & 0.07 & 0.09 & 0.11 \\
\hline $1,3,3 \mathrm{c}$ & 75 & 25 & 0.07 & 0.14 & 9.20 & 0.27 & 0.33 \\
\hline $1,3,3 c$ & 75 & 60 & 0.06 & 0.11 & 0.16 & 0.21 & 0.26 \\
\hline la, Ja & 33 & 25 & 0.04 & 0.08 & 0.11 & 0.14 & 0.17 \\
\hline La1, 3a & 33 & 60 & 0.07 & 0.08 & 0.10 & 0.12 & 0.13 \\
\hline 1a, 3a & 75 & 25 & 0.09 & 0.16 & 0.24 & 0.31 & 0.38 \\
\hline $1 \mathrm{a}, \mathrm{ka}$ & 75 & 60 & 0.06 & 0.11 & 0.16 & 0.21 & 0.26 \\
\hline lb, 3b & 33 & 25 & 0.05 & 0,08 & 0.12 & 0.16 & 0.19 \\
\hline $1 b, 3 b$ & 33 & 60 & 0.04 & 0.06 & 0.09 & 0.12 & 0.14 \\
\hline $1 b, 3 b$ & 75 & 25 & 0.11 & 0.19 & 0.26 & 0.34 & 0.42 \\
\hline 1b. 3b & 75 & 60 & 0.08 & 0.15 & 0.21 & 0.27 & 0.33 \\
\hline
\end{tabular}

\section{Sources of Uncertainty}

The maln uncertainty ident lf led by Expert $D$ is che extent of gas/dehris co. entrainment during debris quenching in the cavity and thus, the extent of the metol-stean ratartion: uncertainty tn particle size and dispersal is alse related. Whar uncertaincies include the amount of debris quenching. the extent of debris hold-up in the cavity, effects of sprays, mixing in contajnment. extent of bydiogen burn, and the reactor vessel hole size and morte of steam-debris blowdown. It was judged that the distribution linits providred erreompatss al: these uncertalnty elfects

\section{Sugeestod Methods tor keducing Uncertaduty}

Sinere. 
Expert E'B Elicitation

\section{Issue 7: Pressure Rise at Vessel Breach for zion}

\section{Descrtiption of Expert F's Rationale/Methodglony}

Expert E concluded that the DCH following vessel failure with the vessel at 1000 psia would be signiflcantly different from the DCH following breach at 500 psia Therefore he broke up the 23 cases Into 23 cases ( 1000 psia) and 25 ( 500 psia) cases Expert E concluded that the presaure rise for Case Z3c would not differ significantly from that for Gase 23 , so separate pressurt rise values for Case $23 c$ are not given.

Expert E also decided that he could not wake meaningful distinctions based on the metallic content of the ejected core naterlal, so he eliminated the fraction of the zirconium oxidized in-vessel as a variable. His subcase structure is deftned by a two-letter code:

\begin{tabular}{|c|c|c|c|c|c|}
\hline Position & Descriptien & Letcter & Word & Nomfnal & Range \\
\hline First & Core Fraction Ejecced & $\begin{array}{l}\mathrm{C} \\
\mathrm{c}\end{array}$ & $\begin{array}{l}\text { Large } \\
\text { Snall }\end{array}$ & $\begin{array}{l}758 \\
338\end{array}$ & $\begin{array}{l}>508 \\
<508\end{array}$ \\
\hline Second & Vessel Hole Size & $\begin{array}{l}\text { H } \\
\mathrm{h}\end{array}$ & $\begin{array}{l}\text { Large } \\
\text { Small }\end{array}$ & $\begin{array}{l}7^{2} \\
\mathrm{n}^{2}\end{array}$ & $\begin{array}{l}>0.5 \mathrm{~m}^{2} \\
<0.5 \mathrm{~m}^{2}\end{array}$ \\
\hline
\end{tabular}

That 15 , Case $23 b-C h$ is vessel fallure at 1000 psia, dry cavity, no sprays, a latge fraction of the core ejected, and a small infelal hole stze (penetration fallure).

Expert E relied prinarily on MAAPE-1 and CONTAIN* calculations. Results of code calculations are avallable only for Zlb-Ch, Zlb-ch, Z3b-Ch, and Z3b-ch. Most of the results avallable are fr: the $C h$ subcase for both Case 21 b and 23b Therefore. Expert $E$ considered his "base" subcase to be Ch: large fraction of the core ejected and small hole.

Expert $E$ also considered calculations performed by nember of the Source Term Panel concerning fission product release during DCH. In that Expert's wodel, orly about 20 of the core debris could be finely fragmented and thus contribute to DCh upan dispersal from the reactor cavity. This is in contrast to the avallable MAAP and CONTAlN calculations which assurpe that 75 to 100 of the core may be fragmented and dispersed. Hence, the maximum pressure attainable in a DCH event is substantially lower in this new model than in the MAAP and CONTAIN calculations There is uncercalnty in the fraction of debrls which can participate in DCH, but the available code calcilations for 7.1 on we performed with latge fractlons rather than with a range of values

"T Ginsherg, tetcer, "Broskhaven CONTAjn Calculations," March 1986 
Expert E obtalned his midpoint values for $21 \mathrm{~b}-\mathrm{Ch}$ and $23 \mathrm{~b}$-Ch by welghting the CONTAIN results more or less equally with the MAAP results with UCHB, To abtain his upper bound, he consldered the CONTAIN results and physical linttations. He noted thet only with very conservative assumptions did the CONTAIN analyses attain maximup pressures over 10 bars. The maximum found w1th the MAP code wag around 7 bars. The lower bound of his distribution for pressure rlse is fixed by a stealn spike with no hydrogen burn, which results in a 1.0 to 2.0 bar pressure rise "floor" Eor all the distributions. Expert $E$ chose his midpoint pressute $r$ ise to be closer to the lower bound than to the upper bound. This reflects his bellef that, while there may be broad uncercainty, the probsbility of appraaching the upper bound is small.

The pressure rise distributions for all the other cases and subcases were determined fron these base cases by shifting the results of the base cases, scaling the results of the base cases, or both. In applying a shift to the base case, a value was added to the midpoint and upper bound values. In scaling the base case values, the dffference between the midpoint value or the upper bound and che lower bound was multiplied by a factor. The lower bound value is usually not affected by these operacions since it is fixed by the pressure rise attributable to the stear spike alone. This pressure rise is not affected by the phenonena being accounted for in the shifting and scaling adjustments. If both adjustnents are applied, the shifting adjustment is applied first.

In going from the dry cavicy cases where there were code runs avallable ta the wet cavity cases where there were no code results. Expert $E$ concluded that the upper bound was not affected since it is possible that the vater in the cavity might all be expelled from it before the DCH portion of the event compenced. Based an Spenser's expertments, E-z he considered 1t more likely that some quenching would occur, however, and the thdpolnt value for the wet cavity case was reduced 1.0 to 2.0 bars below the value for the equivalent dry cavicy case. For the partially-tull cavity cases, Expert E considered that water expulsion was nore likely than in the full cavity case. The midpoint pressure rise values for these cases are 0.5 to 1.0 bars below the value for the equivalent dry cavity case.

Expert E slso considered the co-entrainuent of water and debris which is part of the DCH model in CONTAIN, e $^{-3}$ He discounted this effect for two reasons. First, the co-entrainment caused a slight increasp in pressure in the Surry results and a slight decrease in pressure in the Bellefonte results. Second, the increased pressure rise tn the Surry results was noted for cavity water masses less than $70 \mathrm{MT}$ and actained 1 ts maximum when the cavity tater mass was $30 \mathrm{MT}$. However, when half full the zion cavity holds about 100 HT of water, so $i \hat{f}$ even half that amount of water were co. entralned, the hypothetical pressure riss would be small. 


\section{Besults of Expert E's Elicteation}

Experc E provided the following table which contalns his conclusions about the pressure rise at vessel breach for zion. The nomenclature for the various cases has been defined ebove. All pressure rises are in bars. The three values given are the 1,50 and 998 values for cumulave probability curve.

\begin{tabular}{|c|c|c|c|c|c|c|c|}
\hline Casse & 18 & 503 & 998 & Case & 18 & 509 & 998 \\
\hline $21+C h$ & 2.0 & 4.0 & 8.0 & 21 -ch & 2.0 & 3.0 & 5.0 \\
\hline $\mathrm{Zl} \cdot \mathrm{CH}$ & 2.0 & 5.5 & 10.0 & $\mathrm{Zl} \mathrm{- \textrm {cH }}$ & 2.0 & 3.5 & 6.0 \\
\hline zla Ch & 2.0 & 4.0 & 8.0 & Zla-ch & 2.0 & 3.0 & 5.0 \\
\hline $\mathrm{Zla} \cdot \mathrm{CH}$ & 2.0 & 6.0 & 10.0 & Zla-cH & 2.0 & 4.0 & 6.0 \\
\hline Z1b-Ch & 2.0 & 5.0 & 8.0 & zlb-ch & 1.0 & 3.0 & 5.5 \\
\hline $\mathrm{Zlb} \cdot \mathrm{CH}$ & 2.0 & 7.5 & 10.0 & $\mathrm{Zlb}-\mathrm{cH}$ & 2.0 & 4.5 & 6.5 \\
\hline $23-\mathrm{Ch}$ & 2.0 & 3.5 & 6.0 & $23 \cdot \mathrm{ch}$ & 2.0 & 3.0 & 5.0 \\
\hline $\mathrm{Z3}-\mathrm{CH}$ & 2.0 & 4.0 & 7.5 & $\mathrm{Z3} \cdot \mathrm{cH}$ & 2.0 & 3.5 & 5.5 \\
\hline $\mathrm{Z3a} \cdot \mathrm{Ch}$ & 2.0 & 3.5 & 6.0 & $23 a-c h$ & 2.0 & 3.0 & 5.0 \\
\hline $\mathrm{Z3a}-\mathrm{CH}$ & 2.0 & 4.5 & 7.5 & $23 \mathrm{a} \cdot \mathrm{cH}$ & 2.0 & 3.5 & 5.5 \\
\hline $23 b \cdot C h$ & 2.0 & 4.5 & 6.0 & $23 b-c h$ & 1.0 & 3.5 & 5.0 \\
\hline $236 \cdot \mathrm{CH}$ & 2.0 & 6.0 & 8.0 & $23 b-c H$ & 1.0 & 4.0 & 6.0 \\
\hline $24-\mathrm{Ch}$ & 2.0 & 3.0 & 4.0 & $24-\mathrm{ch}$ & 2.0 & 2.5 & 3.0 \\
\hline $\mathrm{Z} 4 \cdot \mathrm{CH}$ & 2.0 & 3.0 & 4.0 & $24 \cdot \mathrm{cH}$ & 2.0 & 2.5 & 3.0 \\
\hline zsb-ch & 2.0 & 3.5 & 5.0 & $\mathrm{zSb} \cdot \mathrm{ch}$ & 1.0 & 3.0 & 5.0 \\
\hline $25 b-c H$ & 2.0 & 5.0 & 7.0 & $\mathrm{Z} 5 \mathrm{~b}-\mathrm{cH}$ & 2.0 & 4.0 & 6.0 \\
\hline
\end{tabular}

Expert $E$ concluded that the $25 b$ values applied to Cases 25 and $25 a$, sa no distributions are slown for Cases 25 and $Z 5 a$.

A rase-ty-case discussion follows. The cases and subcases are presented in the order Expert $E$ considered them as he reasoned from the cases for which the rost information was avatlable to the cases for which the lpast information was available.

Case zlb: 2500 psia la the RCS at vessel fallure, ary cavity, and no sprays for subuase Ch. Expert f based his midpoint value on CONTAin Caste A.' (Ap . 6.6 bats) and MAAP with UCHB (Ap - 4,0 bars). Tla MAAP resule

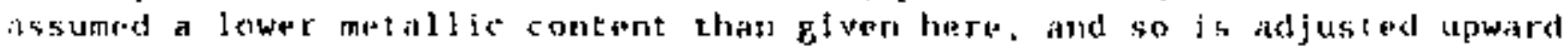
atowit l.t biar. The upper bound for zlb-ch is based on coNTAIN Catsits A.7

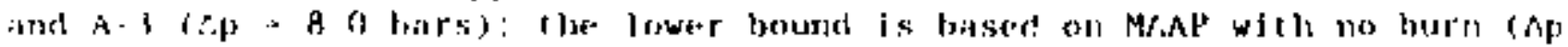

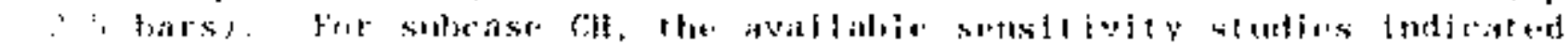

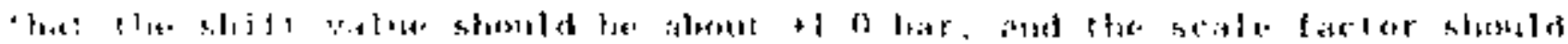

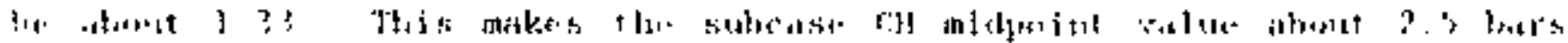

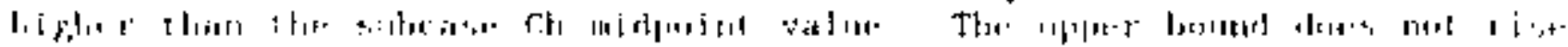


quite this much because of physical limitations on the possible pressure rise. In going from the $C x$ subcases to the $c x$ subcases, the shift value was -1.0 bar and the scale factor vas 0.75 , based on CONTAIN Case A.10. The midpoint value for subcase ch ts thus 2.0 bars below that for subcase $\mathrm{Ch}$. The reduction in the amount of the core involved in DCH does not reduce the pressure $r$ ise proportionately since a large portion of the pressure rise is due to hydrogen combustion, which does not depend on the fraction of the core ejected.

Case zi: 2500 psia in the RCS at vessel fallure, a full cavity, and sprays. For subcase Ch, Expert E used the results of spencer's experfments to reduce the $21 b$. Ch midpoint value 1.0 bar to get the midpoint value for $\mathrm{Zl}-\mathrm{Ch}$. This accounts for quenching. The CONTAIN sensitivity analyses for Surry and sequoyah support this effect of a full cavity. The upper bound for $\mathrm{zl}-\mathrm{Ch}$ remaIns the same as for $\mathrm{zlb}-\mathrm{Ch}$ since the water in the cavity may be expelled early in the event and there will be no net lowering of the pressure rise. The lower bound is fixed by the stean spike alone. For subcase $\mathrm{CH}$, the 21 -Ch values are adjusted with a scale factor of 1.33. In going from the $C x$ subcases to the cx subcases, a scale factor of 0,5 was used.

Case 21a: 2500 psia in the RCS at vessel failure, a partially full cavity. and no sprays. Expert $E$ thought that the Eour subcases for Case 21 a would be similar to those for Case Zl. Pressure rise for the ch and $C h$ cases were taken to be the same as in the full cavity (2.1) cases, while the median pressure rises for the $\mathrm{cH}$ and $\mathrm{Cll}$ cases were adjutted upward frum the 21 cases to account for less quenching or water expulsion.

Case 23b: 1000 psia in the RCS at vessel failute, dry cavtty, and no irays. For subcase Ch, Expert E based his nidpotnt value on CONTAIN Case B. $)(\Delta \mathrm{P}+\mathrm{S}$.$\} bars) and MAAP with UCHR ( \mathrm{AP}=4.0$ bars). The MAAP mechanistic sweepouc model predicts conplete sweepout which the RCS pressure about 1000 psia before breach, and Expert $E$ agrees with this prediction. The upper bound for $23 \mathrm{~b}-\mathrm{Ch}$ is based on CONTAIN cases 8.2 and B.3 (Ap = 6. 3 bars); the lower bound is hased on MAap with no burn ( $\Delta \mathrm{p}=$ 2.5 bars) but was reduced to 2.0 bars for reasons not glven. For subcase $\mathrm{CH}$, the avalable sensitivity studles tndicated that the shift value should be about +1.0 bar. and the scale factor should be shout 1.33. This saakes the subcase CH midpoint value about 1.5 bars higher than the subease $C h$ midpoint value. The upper bound rlses by the same arount. In going fron the cix stubcases to the cx subcases. the shift value was o. 5 bar and the seale factor was 9.15 , based on CONTAJN case 8.10 . The midpoilut value for suluease ell is thus 1.0 bars below that for subcaso Ch. The reduction in

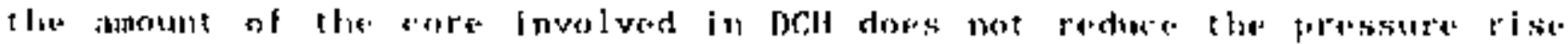

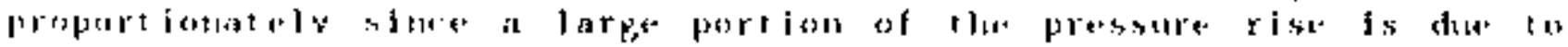

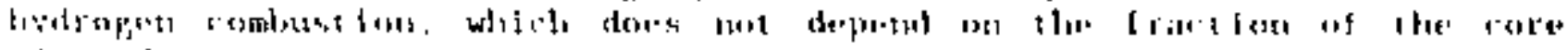
- juctud

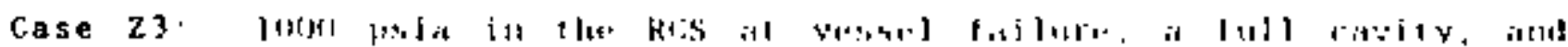

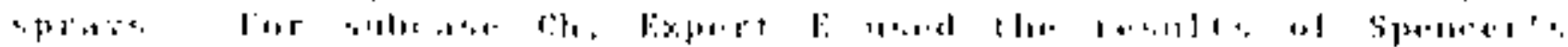

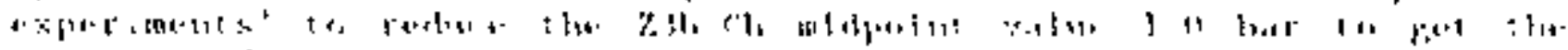

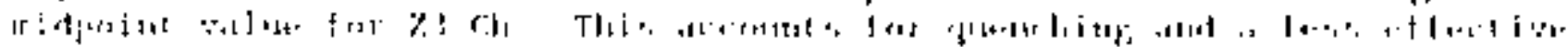

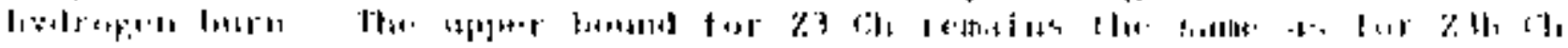


The lower bound is flxed by the stean splke alone. For subcase $\mathrm{CH}_{1}$ the 23$\mathrm{Ch}$ values are adjusted with a scale Eactor of 1.33. In going from the $\mathrm{Cx}$ subcases to the cx subcases, a scale factor of 0.5 was used.

Case 23e: 1000 psia in the RCS at vessel failure, a partially full cavity, and no sprays. Expert $E$ thought that the four subcases for Case 23a would be similar to those for Case 23 . Pressure rises for these cases were taken to be the same as in the full cavity (23) cases, except that the median for the $\mathrm{CH}$ case was judged to be higher to account for less quenching or water expulsion.

Case 24: Less than 200 psia in the RCS at vessel failure. The midpoint values are typical for pressure rises resulting from effective quenching. As very little hydrogen is generated, there is little pressure rise atcributable to hydrogen combustion.

Cases 25, 25a, and 25b: 500 psia in the RCS at vessel failure. Expert E separated these cases from the 23 (1000 psia) cases because 500 psia is so close to the threshold of entraintent that the disfersal mechanism may be predominantly wavelike. In the table above, results are shown only for Case $2 \mathrm{Sb}$, and these apply to eases 25 and $25 \mathrm{a}$. Expert $\mathrm{E}$ used CoNTAIN Case C.I $(\Delta P \approx 4.0$ bars) as a basis: he adjusted this result upward somewhat to get his upper bound and downosard to get his midpoint value, at this low driving pressure, particle quench in the lower compartment is possible even though there is no water in the cavity. Spencer's experiments indicate that very $11 t$ te difference becween full cavity and dry cavity can be expected at these pressures.

\section{Sources of Uncertainty}

Expert $E$ had litele to say about the sources of uncertainty. The variability in the fraction ejected and the hole size have partially been accounted for in the subcase structure. Incertalnties that cause the breadth of the distributions are the amount of $z$ irconlum oxidation before breach (or the metal fraction ejected) and the extent of wavelike vs. particle-like debris form in the lower compartment.

\section{Correlations with or her Variables}

Since Expert E did not give separate results for the high and low cases for the araunt of unoxidized 21 rconitum in the core debris ejected before the gas blowdown. it will not be possible to corlelate his pressure rlse values with this factor in the results of the In.Vessel Expert Panel.

\section{Sugpested Methods for geduc ing Uncertainty}

Expert F noted that there were code calculations for very few of the many cases and subcases The obvlous way to reduce uncertatnty is to provide code ralculations for the cases and subcases for which there are presently ro resulas. Thls would considerably reduce the erors jatroduced by shif:tre, atrit scalling, the results fron the cases and subcases with code

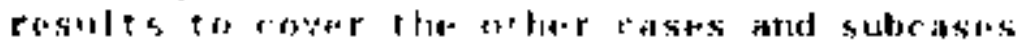




\section{REFERENCES}

E-1. K. Fleming et al., "Risk Managenent Actions ... Seabrook," Pickard, Lowe, and Garrick, Inc., PLG-0550, July $198 \%$.

E.2. B. W. Spenser et al., "Hydrodynanics and Heat Transfer Aspects of Corfum Water Interactions," Electric Power Research Institute, EPR 1 NP-5127, March 1987.

E.3. D. C. Wllliams et al. "Contairment Loads Due to Ditect Containwent Heating and Assoclated Hydrogen Behavior: Analysis and Calculations with the CONTAIN Code." Sandia National Laboratorles, NUREg/CR-4896. SAND87.0633, May 1987 . 
6. MOLTEN CORE/CONTAINMENT INTERACTION ISSUES RESULTS - - Part 2

The results in this section deal with Molten Core Containment 1nteraction Issues (MCCI) issues.

6.1 MCCI Issue 1: Peach Botcom Drywell Shell Meltthrough

Summary and Aggregation of MCCI Issue 1: Peach Botton Dryoll Shell Meltthrough

Experts consulted: Dave Brodley, Sandia National Laboratories; Mike Corradini, University of Wisconsin; Georpe Greene, Brookhaven National Laboratory; Mike Hazzan, Stone \& Webster: Mujid Kazini. Massachusetes Institute of Technology: Raj Sehgal, Electric Power Research Institute.

\section{Issup Description}

This issue relates to whether containment failute occurs as a result of core debris contacting the steel drywell shell at the drywell floor level. The reviewers were asked to provide subjective probabilities for dryvell failure tn this mode for several different bolling water reactor (sWR) vessel breach scenarios. The suggested scenarios vere characterized by six parameters. These $5 i x$ parameters and the various levels associated with each parameter are presented in the table below.

The variable ellcited was the probability of drywell failure as a function of time.

Suggested Scenar 10 Parameters

Scenario Parameters

l. Failure Mode

7. RPV Pressure

3 Dowb is Supethat
Levels

a. Plop (> 408 of core released at vessel breach)

b. Penctration tafluge of vessel

a. High (1000 psia)

b. Low (200 pisia)

a. Wighh (> 100 K)

b. Low (c) 100 V.) 
Scenarto Parameters

4. Debris Unoxidized Hecal Upon Egress Fron Vessel

5. Water on Drywell Floor

6. Decay Power Level
Levels

a. High metal - 65 o 2 tronlum equivaleat initially in debris on concrete (meant to encompass a range of 50\% $-80 \%$ )

b. Low Metal - 35 zirconium equivalent intelally in debris on concrete (meant to encompass a range of 20 to $50 \mathrm{t}$ )

a. Yes (replenished)

b. No (not roplenished)

a. High (soon after scram--2 h)

b. Low (well after scram--10 h)

Afcer the discussion the experts decided to consider debrts flow rate fron the vessel rather than failure mode, and declded that the decay power level did not impact the scenario enough to consider as an additonal paraneter. The flow rates considered were $<50 \mathrm{~kg} / \mathrm{s}, 50$ to $100 \mathrm{~kg} / \mathrm{s}$, and $>100 \mathrm{~kg} / \mathrm{s}$.

\section{Summary of Expercs'Baclonale/Methodlogy}

There seened to be two schools of thought on this lssue. Some experts felt that debris spreading is hydrodynamically limbed and that the drywell shell will fall alnost every time that the vessel is breached. other experts felt that the movenent of the debris is thermodynamically 11mited and will be impeded by crust formation and the presence of water; these experts felt that the dicywell shell will not fail every time the vessel ts breached.

All experts agreed that the drywell shell will fatl in the range of 1000 to $1300 \mathrm{~K}$. They $\mathrm{als}$. Tgreed that superhed in the early phases of the accident 1 s extremely important and that there always will be enough unoxldized metsl in the debrls to fuel a viporous core concrete Interaction. The areas of disagreement were the debris spreading Itmitaclons (as mentloned In the previous paragraph), the effect of water. and the effect of the CRD materials underneath the reactor pressure vessel.

Expert based his assessment on a simple heat conduction model. The model accounied for bolling heat transfer in the cases In which water was present and for radlation heat transfer frow the shell to the atmosphere above the drywell floor. The expert felt ihat the debris flow rate trom the vesse] was txtremely important because the flow raze determincs clie depth of debrls wn the drywell fjoor and the heat content of the debris when it

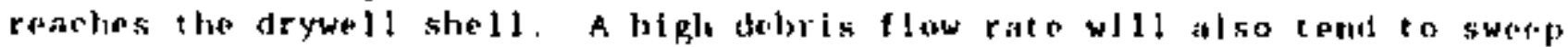

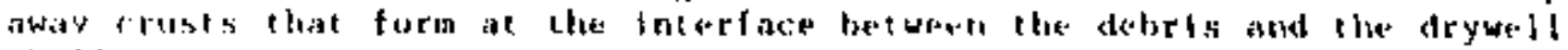
slit. II 
The Expert felt that either the condition of low percentage of unoxidized metal in the debrts or the condition of low lnitial superheat in the debris will favor stable crust formation. Whenever a crust is formed at the she11, the crust will insulate the shell and the probability of shell failure will dimintsh.

He felt that if water ts present on top of the debris, that it will be in the bolling heat transfer regime and will reduce the probabllity of shell fallure. He also felt that the CRD structure underneath the vessel would disperse the flow and remove energy from the debris in high debris flow cases.

Expert based his assessment on a two-dimensional heat-conduction nodel of the drywell shell (the model included convection fron the debris) and several coRCoN calculations. He felt that debris spreading will be controlled by the metallte phase since a small fraction of the initial core debris is oxidlc. There will therefore be a rapld iniclal ablation of the concrete, a high gas release and a high heat source from chemical reactions. (This is consistent with experimental results.) Debris spresding is expected to be hydrodynamically limited, not thermodynamically limited.

The Expert felt that quenching of core debris 18 unlikely. Water reduces the flow of nolten wetal as a result of the cooling of the leading edge of the flowing welt. Water vill have a significant inpact only when the nelt superheat is quite low. Expert B felt that crust formation is unlikely in the presence of a flowing core melt under nost conditions.

The Expert concluded that drywell shell fallute was likely except for cases with shallow debris layers cooled by water and for cases with inefficlent heat transfer.

Expert $c$. from expariaental observation, felt melt spreading to be a hydrodynamically ifmited phenomenon (not limited by heat transfer). He predicted that there will be minimum sump retention due to inertial effects and no floor-mounted obstacles to debris flow. He felt that the melt will contact the steel shell within seconds of RPV fallure.

The Expert fele that water will present minlmal oppostction to melt spreading (melts have been observed to flow under water experimentally). The thelt water thermal interactions will be in the film boiling regime. retarding heat transfer; attenuation of core flow will be a secondary effect The Expert felt that crusts are not expected to appear early.

The Experl concluded that there is a high probability of drywell shell fallure.

Expert 0 fielt that in most scenarlos, heat removal from the CRD structure underneath the RPV or hent removal fron overlaying water pools would allow crusts to form. The Expert felt that the drywel] shell faflure probability would be lor in most cases.

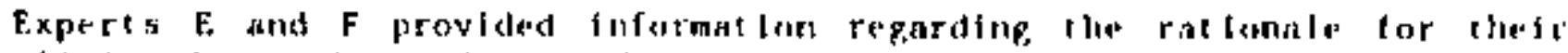
ellcteations after the complotion at thelr flicltation whluep. That informat lall is suamarlzed In thls sectlon. 
Expert 8 assumed that the entire drywell floor is avallable for spreading. He assuned that the melt spreads across the drywell floor in an even. quasi-steady manner, without dynamlc effects, above its salldus point. As the melt fills the sunp region, the activity is high, no crusts are formed (prevented by gas sparging frod the core concrete interaction), wixing is expected, and the ealt flows quickly. The nelt cools quickly as the melt spreads to che drywell wall (from spreading over such a large area.) crusts begin to forn and the radial heat flux $1 \mathrm{~s}$ reduced by factor of 3 to 4.

The Expert felt that the CRD aaterials underneath the RPV will prevent the lower plenum wall frok unzipping. It can act as a dechenical breakup rechanisn and as a heat sink. The first two effects could be laportant. the third may be a second order effect.

The Expert falt that water enhances cruseing behavior and potentially prevents melt from spreading. He also stated that crusting occurs when melt is spread out over an extremely wide area.

Expert $F$ assumed sesi.circular progression of the welt into the ennular reglon of the drywell. He perforded a heac balance for the seat-circular leading edge to calculate hov far the aelt reaches before reaching the freezing point. He neglected upward radiation losies bechuse they are smaller than the downward heat loss to concrete. He assumed that the waximun heat generation rate over the height of the melt is linited by the concrete decomposition rate uhich is litited by the downward heat flux. The heat flux to the deconposing concrete is given by:

$$
q^{*}=20\left(T-T_{D}\right)^{2} w / a^{2}
$$

where

$T$ - relt temperature and $T_{0}$ - deconpasition tempersture.

The Expert assured thet stable crust ulll fotm at the leading edge. He nodeled the dryvell shell as an ennular fin conducting the heat upward ond radiating the heat to the atmosphere above the melt.

\section{Methed of Aegrepation}

Severel things vere done to che individual eltcitations in order to aggregate them: interpolation to complete all of the quentiles necessary to average the elicttations; If no informetion vas given for a variable, it was assured that $1 \mathrm{t}$ did not lapact the scenarlo; sone of the scenarios provided by the experta vere averaged rogether to avold exponding the table into further dimensions (e.g., FCI, no FCI); and in one case the CDF was created froa from best estimates of fallure times.

forty-elght cases vere sveragad 
Complete Sec of sconarlos for consideretion

In Aggregation of Peach botron Drywell shell Fa1lure Issue

\section{a) low flow rase $(<50 \mathrm{~kg} / \mathrm{s})$}

Al) High Pressure, High Metal, High Superheat, Water

A2) Htgh Pressure, High Metal, High Superheat, No Water

A3) High Pressure, High Hetal, Low Superheat, Water

n4) High Pressure, HIgh Hetal, Low Superheat, No Water

A5) High Pressure. Low Metal, High Superheat, Hater

A6) High Pressure, Low Metal, High Superheat, No Water

A7) High Pressure, Low Metal, Low Superheat, Water

A8) High Pressuce, Low Metal, Low Superheat, No Water

A9) Low Pressure, High Metal, High Superheat, Water

A10) Low Pressure, High Hetal, High Superheat, No Water

Al1) Low Pressure, High Metal, Low Superheat, Water

Al2) Low Pressure, H1gh Metal, Low Superheat, No Water

Al3) Low Pressure, Low Metal, High Superheat, Water

A14) Low Pressure, Low \& Metal, H1gh Superheat, No Water

Als) Low Presgure, Low Metal, Low Superheat, Water

A16) Low Pressure, Low Metal, Low Superheat, No Water

\section{B) Hedlui flow rate $(50 \mathrm{~kg} / \mathrm{s}<$ flow rate $<100 \mathrm{~kg} / \mathrm{s})$}

BI) High Pressure, High Metal,

B2) H1gh Pressure, High Mecal,

B3) High Pressure, H1 gh Metal,

B4) High Pressure, HIgh Metal.

B5) High Pressure, Low Metal.

B6) High Pressure, Low Metal,

B7) High Pressure, Low Hetal,

B8) High Pressure, Low \& Metal,

B9) Low Pressure. HIgh Metal.

Blo) Low Pressure, High ketal,

B11) Low Pressure, High Metal.

B12) Low Pressure, HIgh Metal,

B13) Low Pressure.

Bl4) Low Pressure.

B15) Low Pressure.

Low Metal.

Low Hetal,

Low Hecal,

High Superheat.

Water

High Superheat, No Water

low Superheat. Wacer

Low Superbeat, No Water

High Superheat, Water

HIgh Superbeat, No Water

Low Superheat.

Low Superheat.

Water

High Superheat. Water

High superheat.

Low Superhert,

No Water

Low Superheat.

Water

High Superbeat,

No Water

High Superheat.

Low Superbeat.

Hater

No Water

Water

Low Superheat.

No Water

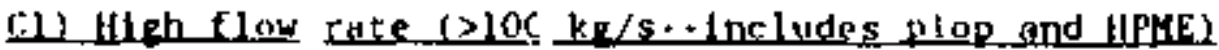

C1)

c?)

(3)

(t)

(.5)

(.).

r.)

(.6)
High Pressure, High thetal. High Pressure, High Hetal. High Pressure. High i Yetal. High Pressure. H[gh - Metal. High Pressure, low thetal. Hiph Pressure, Jow g Metal. Higli l'ressure, Low Mecal. Hi pli Pressure. low Metel.
High Superheat, HIgh Superhear, low Superheat, low Superheat, Itight superleat, Hl gh Superlicat. jow Superlieal. Lsw Susperlient .
Water

No Water

Wacer

No Water

Water

No Witer

Water

No Hat a.r 


\begin{tabular}{|c|c|c|c|c|c|c|c|}
\hline ) & $\begin{array}{l}\text { Low } \\
\text { Low } \\
\text { Low } \\
\text { Low } \\
\text { Low } \\
\text { Low } \\
\text { Low } \\
\text { Low }\end{array}$ & $\begin{array}{l}\text { Pres } \\
\text { Pres } \\
\text { Pres } \\
\text { Pres } \\
\text { Pres } \\
\text { Pres } \\
\text { Pres } \\
\text { Pres }\end{array}$ & $\begin{array}{l}\text { High } \\
\text { High } \\
\text { High } \\
\text { H1 gh } \\
\text { Low } \\
\text { Low } \\
\text { Low } \\
\text { Low }\end{array}$ & $\begin{array}{l}\text { - Metal } \\
\text { - Metal } \\
\text { - Metal } \\
\text { - Mecal }\end{array}$ & $\begin{array}{l}\text { H1gh } \\
\text { High } \\
\text { Low } \\
\text { Low } \\
\text { High } \\
\text { High } \\
\text { Low } \\
\text { Low }\end{array}$ & $\begin{array}{l}\text { Superheat, } \\
\text { Supertheat, } \\
\text { Superheat, } \\
\text { Superheat, } \\
\text { Superheat, } \\
\text { Superheat, } \\
\text { Superheat, } \\
\text { Superheat. }\end{array}$ & $\begin{array}{l}\text { Water } \\
\text { No Water } \\
\text { Water } \\
\text { No Water } \\
\text { Water } \\
\text { No Water } \\
\text { Water } \\
\text { No Water }\end{array}$ \\
\hline
\end{tabular}

Many of the distributions that resulted fror averaging the experts' results were very similar to simplify the APET, an ANOVA analysis (see description of ANOVA In Section $S$ 6): was perforaed to reduce the number of cases Distributions for the following five cases were implemented into the event tree

a) Low and aediun flow with water

b) Low ond medium flow whout water

c) High flow with water

d) High flow whthout water and two out of three other parameters high (pressure, percentage of netal, and superheat)

e) High flow without tater and two out of three other paraneters low (pressure, percentage of metal, and superheat)

\section{Agereqated Results}

Values in tables are probabilities of drywell shell fallure for given case (e g, All and given time Desertption of cases are found in the previous section

Tahle 6.1

Average of 48 cases

(Average of all six experts-drywell shell fallure 1ssue)

\begin{tabular}{|c|c|c|c|c|c|c|c|c|c|}
\hline Casse & $2 \mathrm{~min}$ & ملهـ 5 & ת19 & bـلـ & $2 h$ & I. & 1.5.5. & $10 \mathrm{~h}$ & CCI_ne? \\
\hline Al & $\begin{array}{ll}0 & 01\end{array}$ & 010 & 023 & 033 & 034 & 034 & 034 & 034 & 034 \\
\hline A? & 017 & 026 & 039 & 051 & 053 & 055 & 053 & 055 & 055 \\
\hline A) & $\begin{array}{lll}0 & 01\end{array}$ & 010 & 023 & 033 & 034 & 034 & 034 & 034 & $0 \quad 3 / 4$ \\
\hline $\mathrm{A}_{4}$ & 017 & 026 & 036 & 049 & $0 \quad 51$ & 051 & 051 & 051 & 051 \\
\hline A5 & 001 & 008 & ก 22 & 037 & 033 & $\begin{array}{ll}0 & 33\end{array}$ & 034 & 034 & 034 \\
\hline$A 6$ & 017 & 024 & $\begin{array}{lll}0 & 38\end{array}$ & 049 & 01 & 053 & $\begin{array}{lll}0 & 53\end{array}$ & $\begin{array}{ll}0 & 53\end{array}$ & 053 \\
\hline A 7 & $00 !$ & $00 B$ & () 22 & $0 \quad 32$ & 033 & 033 & D 3/4 & $0 \quad 34$ & 034 \\
\hline$A B$ & 011 & 024 & 038 & 048 & 050 & $0 \mathrm{~s}]$ & 051 & 051 & 051 \\
\hline A9 & 000 & 006 & 018 & 031 & () 33 & 033 & 033 & 033 & 033 \\
\hline A 10 & $\|$ in? & 015 & 1) 35 & $\left.\begin{array}{lll}0 & 5\end{array}\right]$ & 053 & 035 & 055 & 055 & ניל (1) \\
\hline$A^{\prime} l$ & 000 & 007 & 011 & 028 & $\begin{array}{lll}0 & 30\end{array}$ & 03 & (1) 33 & 033 & 031 \\
\hline A) ? & 010 & (1) 11 & (9) 78 & 0160 & o bo & ניל & 1) & $\begin{array}{lll}0 & 51\end{array}$ & $0 \$ 1$ \\
\hline
\end{tabular}


Table 6.1 (continued)

\begin{tabular}{|c|c|c|c|c|c|c|c|c|c|}
\hline case & 2 min & 5 ـIn & $10 \mathrm{mtn}$ & $1 \mathrm{~h}$ & $2 h$ & 3h & . & $10 \mathrm{~h}$ & CCI_neg \\
\hline A. 3 & 0.00 & 0.06 & 0.18 & 0.31 & 0.33 & 0.33 & 0.33 & 0.33 & 0.33 \\
\hline A14 & 0.02 & 0.14 & 0.35 & 0.50 & 0.52 & 0.53 & 0.53 & 0.53 & 0.53 \\
\hline Als & 0,00 & 0.02 & 0.12 & 0.28 & 0.30 & 0.31 & 0.32 & 0.32 & 0.33 \\
\hline Al6 & 0.02 & 0.11 & 0.28 & 0.46 & 0.49 & 0.50 & 0.51 & 0.51 & 0.51 \\
\hline B) & 0.01 & 0.10 & 0.30 & 0.35 & 0.36 & 0.36 & 0.36 & 0.36 & 0.36 \\
\hline B2 & 0.17 & 0.26 & 0.51 & 0.60 & 0.61 & 0.61 & 0.62 & 0.62 & 0.62 \\
\hline B3 & 0.01 & 0.10 & 0.30 & 0.34 & 0.35 & 0.35 & 0.35 & 0.35 & 0.35 \\
\hline B4 & 0.17 & 0.26 & 0.47 & 0.52 & 0.53 & 0.53 & 0.53 & 0.53 & 0.53 \\
\hline B5 & 0.01 & 0.09 & 0.29 & 0.36 & 0.36 & 0.37 & 0.38 & $0.3 \mathrm{~B}$ & 0.38 \\
\hline B6 & 0.17 & 0.25 & 0.45 & 0.54 & 0.56 & 0.56 & 0.57 & 0.57 & 0.57 \\
\hline B7 & 0.01 & 0.08 & 0.28 & 0.32 & 0.33 & 0,34 & 0.34 & 0.34 & 0.35 \\
\hline B8 & 0.17 & 0.25 & 0.45 & 0.50 & 0.51 & 0.52 & 0.52 & 0.52 & 0.52 \\
\hline B9 & 0.00 & 0.07 & 0.25 & 0.33 & 0.34 & 0.35 & 0.35 & 0.35 & 0.35 \\
\hline B10 & 0.02 & 0.15 & 0.47 & 0.60 & 0.61 & 0.61 & 0.62 & 0.62 & 0.62 \\
\hline B11 & 0.00 & 0.03 & 0.19 & 0.29 & 0.31 & 0.33 & 0.34 & 0.34 & 0.35 \\
\hline B12. & 0.02 & 0.11 & 0.37 & 0.49 & 0.52 & 0.53 & 0.53 & 0.53 & 0.53 \\
\hline BI 3 & 0.00 & 0.07 & 0.25 & 0.35 & 0.36 & 0.37 & 0.37 & 0.37 & 0.37 \\
\hline B14 & 0.02 & 0.15 & 0.42 & 0.55 & 0.56 & 0.56 & 0.57 & 0.57 & 0.57 \\
\hline B15 & 0.00 & 0.03 & 0.18 & 0.28 & 0.30 & 0.31 & 0.32 & 0.33 & 0.33 \\
\hline B16 & 0.02 & 0.11 & 0.36 & 0.48 & 0.50 & 0.51 & 0.52 & 0.52 & 0.52 \\
\hline $\mathrm{Cl}$ & 0.02 & 0.18 & 0.35 & 0.41 & 0.41 & 0.41 & 0.41 & 041 & 0.41 \\
\hline$C 2$ & 0.21 & 0.59 & 0.77 & 0.84 & 0.85 & 0.85 & 0.85 & 0.85 & 0.85 \\
\hline C3 & 0.02 & 0.15 & 0.29 & 0.35 & 0.36 & 0.36 & 0.36 & 0.36 & 0.36 \\
\hline $\mathrm{C4}$ & 0.21 & 0.52 & 0.63 & 0.78 & 0.79 & 0.79 & 0.79 & 0.79 & 0.80 \\
\hline C5 & 0.02 & 0.15 & 0.30 & 0.36 & 0.36 & 0.37 & 0.37 & 0.37 & 0.37 \\
\hline C6 & 0.21 & 0.43 & 0.65 & 0.71 & 0.72 & 0.72 & 0.73 & 0.73 & 0.73 \\
\hline C7 & 0.02 & 0.14 & 0.29 & 0.35 & 0.35 & 0.35 & 0.35 & 0.35 & 0.35 \\
\hline C8 & 0.21 & 0.36 & 0.49 & 0.56 & 0.57 & 0.58 & 0.58 & 0.58 & 0.58 \\
\hline$C 9$ & 0.05 & 0.22 & 0.38 & 0.44 & 0.44 & 0.45 & 0.46 & 0.46 & 0.46 \\
\hline C10 & 0.21 & 0.59 & 0.78 & 0.85 & 0.86 & 0.87 & 0.87 & 0.87 & 0.87 \\
\hline C11 & 0.05 & 0.10 & 0.33 & 0.39 & 0.39 & 0.39 & 0.39 & 0.39 & 0.39 \\
\hline C12 & 0.21 & 0.41 & 0.53 & 0.66 & 0.67 & 0.67 & 0.68 & 0.68 & 0.68 \\
\hline$C \leqslant 3$ & 0.05 & 0.18 & 0,33 & 0.39 & 0.40 & 0.40 & 0.40 & 0.40 & 0.40 \\
\hline $\mathrm{Cl4}$ & $0.2 \mathrm{l}$ & 0.39 & 0.57 & 0.63 & 0.64 & 0.65 & 0.65 & 0.65 & 0.65 \\
\hline C15 & 0.05 & 0.18 & 0.32 & 0.38 & 0.38 & 0.38 & 0.38 & 0.39 & 0.39 \\
\hline C16 & 0.21 & 0.35 & 0.47 & 0.53 & 0.54 & 0.54 & 0.54 & 0.54 & 0.54 \\
\hline
\end{tabular}


Tabl 6 6.2

Avarege of Five Collapsed Cases After ANOVA

[Valuen In tablen are probabilities of

drywall shell fallure and given time]

\section{Average of toy and Medtun Flox Canea Uth Water}

$\begin{array}{lllllllll}2 \text { min } & 5 \mathrm{gin} & 10 \mathrm{aln} & 1 \mathrm{~h} & 2 \mathrm{~h} & 3 \mathrm{~h} & 5 \mathrm{~h} & 10 \mathrm{~h} & \text { CcI neg } \\ 0.00 & 0.07 & 0.22 & 0.32 & 0.33 & 0.34 & 0.34 & 0.34 & 0.35\end{array}$

ayerach of hoy and Wedfun Elon Ganes without Water

$\begin{array}{lllllllll}2 \text { min } & 5 \text { min } & 10 \text { aln } & 1 h & 2 h & 3 h & 5 h & 10 h & \text { CcI neg } \\ 0.09 & 0.19 & 0.39 & 0.51 & 0.53 & 0.54 & 0.54 & 0.54 & 0.54\end{array}$

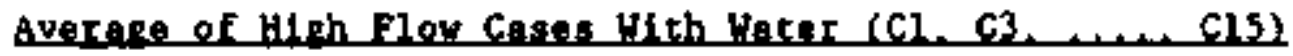

$\begin{array}{lllllllll}2 \text { oin } & 5 \text { nin } & 10 \text { in } & 1 \mathrm{~h} & 2 \mathrm{~h} & 3 \mathrm{~h} & 5 \mathrm{~h} & 10 \mathrm{~h} & \text { CcI neg } \\ 0.04 & 0.17 & 0.32 & 0.38 & 0.39 & 0.39 & 0.39 & 0.39 & 0.39\end{array}$

Avarace of Hith Flow Garine. No Hiter.

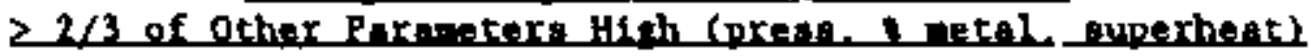

$\begin{array}{lllrrrrrr}2=1 B & 5 \text { min } & 10 \text { fin } & 1 \mathrm{~h} & 2 \mathrm{~h} & 3 \mathrm{~h} & 5 \mathrm{~h} & 10 \mathrm{~h} & \text { CCI neg } \\ 0.21 & 0.53 & 0.71 & 0.79 & 0.80 & 0.81 & 0.81 & 0.81 & 0.81\end{array}$

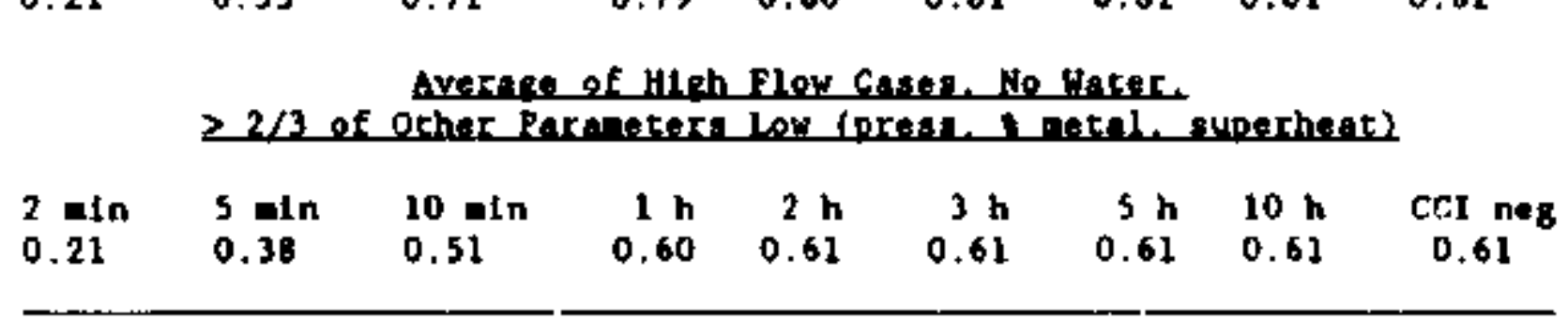




\section{Individuel Elicitations for MCCI Isoue I}

6. 1.9 


\section{Isuve 1: Paech Dotton Drywell Sholl Meltthrough}

\section{Description of Expert A's Ration le Mechodology}

Expert $A$ comblned the fallure oode paraneter with the RPV prossure parameter and expressed the result as a debris flou rate. The Expert consldered three debris flow rates: high or "plop" (greater than $100 \mathrm{~kg} / \mathrm{s}$ ); mediun (between $50 \mathrm{~kg} / \mathrm{s}$ and $200 \mathrm{~kg} / \mathrm{s}$ ): and low (1ess then $50 \mathrm{~kg} / \mathrm{s}$ ). For the "plop" case the Expert assuned the majority of the core was released from the vessel. The Expert belleved that the flow rate was foportant because it deternines the debris depth on the drywell floor and the heat content of the debris when it reaches the drywell shell. For cases with a high flow rate the debris will reoch the shell wore quickly and with higher heat content than for cases with a low flou rate. In addition, the high flow rate cases vill tend to "sweep away" crusts that forn on the sheil, thus increasing the heat transfer to the shell. Also, higher heat transfer coefficients are generally associated with high debris flow rates than with lou debris flow rates.

For the unoxidized wetal content in the debris, the Expert considered that the high level corresponded to more than 70 unoxidlzed aetal. The effects of this paraneter are that metal-rich debrls conposition has the potential to relesse a lot of cheolcal energy, and an oxide-rich compositlon favors a stable crust foration.

A high superheat level was assumed to range froo 100 to $1000 \mathrm{~K}$. A lou superheat level corresponds to a superheat of less than $100 \mathrm{~K}$. The amount If superhest in the debrig "gets" the initial energy content of the debris. Irlves the heat transfer, and affects the formation of a crust. A low supetheat level favors the foration of a stable crust.

The Experc felt that the presence of vater in the drywell would coul the shell via bolling hear cransfer and, thus, redure the probability of shell failure.

The Experc belleved thet the difference between the decay power at 2 h and $10 \mathrm{~h}$ would have only a negligible effect. And therefore it was not included as a parameter in his assegsant.

The Expert also belleved that the presence of a mechantial barriar (o.) che "Rat's Hest" of ateel under the RPV) was inportant for the high flowrate case ("plop") because it would tend to rewove energy from the debris. disperse the debris jet. and cause the debris to rain into the pool, lncreselng the likellhood that the dobrla would bo quenched.

The Expert fele that the formstion of a gtable crust at the shell vas very Inportant because the cruat would Insulate the ohell and, thus, reduce the probability of thell fallure. Debria waterial with a low anount of superheat and a hlgh oxide content favored the tormetion of a crust, whe reas cacos with a high flow rate discouraged cruct foraction (swept crust away). 
The Expert based hls estimates on a slople hest-conduction nodel. The heat-conduction oodel accounted for bolling heat transfer (far cases where water was present) and for radiation heat cransfer fron the thell to the atnophere bove the drywell floor (radiation frou the debris to the shell vad not modeled, however). This afople model allowed the Expert to vary varlous nodel paranters to se* their offects on the shell teaperature. The Expert's fallure criterla were based on an "offlce" survey he conducted of structural experts which Indicated that the drywell shell would lose its strength in the range of $1100 \mathrm{~K}$ to $1500 \mathrm{~K}$. In addition, he sesumed the melting temperature of the shell was epproxinacely $1750 \mathrm{~K}$. The uncertainty in the teoperature et which the drywell shell will fall has been Included in his assessinent.

\section{Results of Expert A's EMc1tation}

The Expert assessed the cumulntive probability of drywell shell fallure for Four different tlaes: 10 win, $1 \mathrm{~h}, 3 \mathrm{~h}$, and when CCI releases are negligible (approxinstely $10 \mathrm{~h}$ ). The Expert belleved, hovever, if the dryvell is going to fall, it will fafl within $3 \mathrm{~h}$. Thus, the probabllities at $3 \mathrm{~h}$ and when CCI releases are negligible are the same. The results are presented in Table A-l.

Table $A \cdot 1$

Cunulative Probability of Drywell Shell fallure

\begin{tabular}{|c|c|c|c|c|c|c|c|}
\hline \multicolumn{4}{|c|}{ Scenaris Paraneters } & \multicolumn{4}{|c|}{ Iine: } \\
\hline $\begin{array}{l}\text { Pour } \\
\text { Race }\end{array}$ & Wtetal & Syperhest & Water & $10 \mathrm{mln}$ & $1 \mathrm{~h}$ & $3 h$ & CCI Nies \\
\hline HLgh & Low & Low & Yes & 0.002 & 0.01 & 0.01 & 0.01 \\
\hline High & Lay & Low & No & 0.02 & 0.1 & 0.1 & 0.1 \\
\hline High & Low & HIgh & Yes & 0.05 & 0.05 & 0.05 & 0.05 \\
\hline H[gh & Low & HIgh & No & 0.2 & 0.2 & 0.2 & 0.2 \\
\hline High & $H ! g h$ & Lov & Yes & $0.0 \mathrm{~s}$ & 0.02 & 0.02 & 0.02 \\
\hline H1 gh & Hlgh & Low & No & 0.12 & 0.6 & 0.6 & 0.6 \\
\hline High & HLgh & H1Eh & YeI & 0.3 & 0.3 & 0.3 & 0.3 \\
\hline $\mathrm{HI}_{\mathrm{gh}}$ & H1gh & HIgh & No & 0.95 & 0.95 & 0.95 & 0.95 \\
\hline Mediun & Low & Low & Yes & 0.0 & 0.0 & 0.01 & 0.01 \\
\hline Nedium & Low & Low & No & 0.03 & 0.1 & 0.1 & 0.1 \\
\hline Mediun & Lor & H1gh & Yes & 0.03 & 0.2 & 0.2 & 0.2 \\
\hline Mediun & Low & HIgh & No & 0.03 & 0.3 & 0.3 & 0.3 \\
\hline
\end{tabular}


Table $n-1$ (continued)

\begin{tabular}{llllllll}
\hline Mediug & High & Low & Yee & 0.01 & 0.05 & 0.05 & 0.05 \\
Kediun & HIgh & Lov & No & 0.03 & 0.1 & 0.1 & 0.1 \\
Mediun & High & High & Yos & 0.03 & 0.1 & 0.1 & 0.1 \\
Medius & High & High & No & 0.03 & 0.3 & 0.3 & 0.3 \\
& & & & & & & \\
Low & Low & Low & Yes & 0.0 & 0.0 & 0.001 & 0.00 \\
Low & Low & Low & No & 0.001 & 0.005 & 0.05 & 0.05 \\
Low & Low & High & Yos & 0.0 & 0.0 & 0.001 & 0.001 \\
Low & Low & High & No & 0.01 & 0.03 & 0.1 & 0.1 \\
Low & High & Low & Yos & 0.0 & 0.0 & 0.001 & 0.001 \\
Low & High & Low & No & 0.001 & 0.005 & 0.05 & 0.05 \\
Low & High & High & Yes & 0.0 & 0.0 & 0.005 & 0.005 \\
Low & High & High & No & 0.02 & 0.05 & 0.2 & 0.2
\end{tabular}

"T - 0.0 corresponds to when the debris hita the Arywell floor.

\section{Sources of Uncertainty}

Sources of uncertainty included the rather coacse degctiption of the Initial conditions (a.g.. high and low for the various paranter levelg); the temperature which the drywell shell will fall; the ability for the debris to form a sable cruat; and the heat-trangfer coefficlent between the crust and the debris.

\section{Correlactons with Other Vartables}

No correlations were discussed between other variables in the event trees and the variables discussed as part of this isaue.

\section{Surgested Hethod: for Reducine Uncertilnty}

The Expert Indlcoted that nore preclse Initiol conditions would have allowed hin to "get hts hands around the problen" more oafly but would not have totally reduced the uncertalnty associated with this isgue. To significancly reduce the uncertainty associated with this lssue, the Expert thought that an Integrated experinent of this issue should be perforaed with oceled madel of t Mark I conteinment. Fros this uxperient, anenligful Inforation bout debria-flou charactoriatlca, cruat formetion, and heat-tranafer eecheniad could be obtalned. The Expert folt that enough analyelcal work and aeparated exfect: experimenta hed already been done and additionel work along these lines would not be as benefictel as an integrated experloent. 


\section{Expert B': Elicltetion}

\section{Issue 1: Peech Bacton Drywell Shell Neltthrough}

\section{Descriotion of Expert B's Rationale/Methodology}

The Expert based his assessment on a two-dimensional heat-conduction model of the drywell she11. The model Included convection from the debris: heat transfer from the debris surface by elther radiation or boillng heat transfer (for cases with water); radlation and convection from the back side of the shell; and heat transfer to the concrete. The nodel also allowed the Expert to vary both the debris temperature and the debris-shell heat-transfer coefficlent as a function of time. The Expert varied the vaclous paraneters in his model to assess their eftects on the shell temperature. In addition, he calculated the shell temperature when CORCON results for Peach Botton were used as Input to his model. Based on these calculations, he was able to assess the effects of the various parameters on the drywell shell terperature. The Expert concluded that drywell shell fallure was likely except for cases with shallow debris layers cooled by water, and with ineflicient heat transter. With very effictent heat iransfer, coolant adition was not effectlve, and, except for when the shell fails rapidly, back side heat losses were small.

In his assessment, the Expert consldered faflure of the drywell shell by both melting and creep rupture. He assuned that the fallure remperature (by creep rupture) was $1300 \mathrm{~K}$. He stated that the failure temperature was uncertain because if only a small area of the shell was heated the fallure temperature might be quite different than if the shell was heated sircuaferentially.

Several factors thac the Expert did not feel were important were the decay power level and the addicion of vater to the debrls after the debris has been deposited on the dryuell floor. The Expert belleved that the difference between the decay power ac 2 h and $10 \mathrm{~h}$ would have only a negligible effect and, thetefore, was not included as a parameter 1n hls assessment

The Expert tharacterized the accldenc by two major $t$ ime regines: before 10 min, and after 10 min. During the first tima regine the debris flous across the dryvell floor to the shell and piles up against the shell in localized area. Durlng the second tlme reglne the debris spreads out across the drywell floot. Durligg the ftrst time reglme the thell heats up quite rapidly but only in a localized area, whertas during the second tine reglae more shell are is exposed to the debris but the heatup process 13 much s lower.

thie Experc Indjated that che amount of superheat assoctated with the debris was mainly important for early times. Conversely, che amount of unoxidized netal in the debris was malniy lmportant during the late tape regline. For cases with a higit unaxidized metal content in the debris. the result would be rapld tnitial ablation of the concrete, hlgh gas release. and a hlgh heat source from the chemical reactions. The water on the 
drywell floor affects the debris temperature during both the early and late time regimes. During the early tine regime the water in the cavity has the potential to quench the debris. During the late time regime the maln effect of water was to transfer heat away from the debris by bolling heat transfer. The effect of water, however, was more important during the early time regime. The Expert gave little credit for vater because he felt that it was unlikely the debris would be quenched in the pool of water under the vessel. To quench the debris, slgnificant debris fragmentation (fragments less than $1 \mathrm{~cm}$ ) must occur and sufficlent water must be present. The Expert believed that fine fragmentation was unlikely. Also, the Expert belleved much of the "rat's nest" of structure below the vessel would be melted by the flowing debris and a larger opening would be created, naking fine fragmentation even less likely. Because the water pool in Peach Botton has a raximu depth of less than $3 \mathrm{ft}$, the Expert concluded that debris quenching appeared unlikely. The presence of water could also reduce the flow of molten debris primarily as a result of cooling of the leading edge of the flowing debris. The expert suspected, however, that water would have a sightficant impact only for scenarios in which the melt superheat was quite low.

\section{Results of Expers B's Elicitarion}

The Experc divided the various scenarios into three baslc cases: "plop" type fallure, low-pressure penetration fallure, and high-pressure penetration fallure. For each case, various parameters were chosen from the table in the Issue Description and a series of scenarlos vas assessed. For each scenarlo, the Expert assessed the probability of drywell shell Eallure for flve different times: $5 \mathrm{~min}, 10 \mathrm{~min}, 3 \mathrm{~h}, \mathrm{~s} h$, and when ccl releases are negligible (approxinately 7 to $B \mathrm{~h}$ ). The cuaulative probabilicles of drywell shell fallure for the various scenarios are presented In Table B.l.

\section{"Plop" Type Falluie. No tater}

For this case, the Expert comblned the high-and low-pressure parameters. In addition, he essumed the amount of superheat agsoclated with the debris must be high. He based his assessment on a debris flow rate of at least $1000 \mathrm{~kg} / \mathrm{s}$ ( 120 metrlc tons of debris deposited in the cavt ty in $2 \mathrm{~min}$ ), and he assumed the debrls had ac least $290 \mathrm{~K}$ of superheat. Based on his calculations. fatlure of the drywell shell appe ared likely within minutes of vessel fallure, and the amount of metallfe material in the debrla had essentially no effect.

\section{"Plop" Irpe Fallure, Water}

Since high superheat had been assumed for thls case and yuenching of the melt appeated unlikely. the probabilities of shell fallure were not greaty different frod the previous case values. The Expert had given sone credit for cooling of the melt by the water, whlch shlted sone of the probability to later times, however. fallure still appeared likely within 1 h. 


\section{Lou-Preasure Penetration_Fatlure, Loy Superheat. No Watex}

Although the Expert's calculations indlcated that shell failure was assured within $1 \mathrm{~h}$, he gave a gignificant probability of fallure to the 1 . to $3-\mathrm{h}$ tine interval. This reflects uncertalnty in the nature of the flow and crusting behavior for the low superheat cases. There was a slight reduction in the probabilities of fallure for the low unoxidized netal case since the fallure tiots were long enough that the chemical reaction energy source nay have given out if the metal becane fully oxidized. This would occur only for very high in-veasel oxldation.

\section{low-Pressure_Penthation Faldure. Low stperheat. Water}

The Expert felt this case offered the greatest potential for delaying or perhaps even preventing shell fallure since it involved slow flow, low superhest, lov unoxidized metal content, and additional cooling of the melt and the shell due to water. The probabilities of early fallure were reduced due to the effect of water on the flow of low superheat aaterial (water, hovever, would not have prevented contact with the drywell shell). Water also made crust formation more likely under low superheatconditions, thereby reducing the rate of heat flow to the shell, and extending the tifie required for fallure. Agatn, the effect of the unoxidized metal content was only significant for faflure tiwes greater than $l \mathrm{~h}$. In arriving at the fallure probabilities, the Expert has tried to filter in his uncertainty regarding coolant effectiveness and debris-to-iner heat trensfer.

\section{Lov-Pressure Penetraclon Fallure. Hith superheat, lo tater}

The Expert believes the foration of a crust upan contact wich the shell was unlikely because of the high debris superheat. As result, drywell shell fallure within anutes of intifal debris contact seemed assured. The arount of unoxidized metal in the debris was concluded to have no effect on the shell fallure probabilitles because of the rapid failure thes.

\section{tow-Pressure Penetration Fallure. Hiph Superheat, Wacer}

The Expert belleved the presence of vater vould have only a small effect on shell heatup. Because crusting is unlikely for hlgh superheats, the shell falled quite early and the coolant had lttele effect on the fallure probabilities. The amount of unoxidized netal in the debris also had little effect because fallure occurted before betal oxidation approached conpletion.

\section{Hiph-Pressure Penetration Fellure. No Hater}

Based on results fron direct contalnnent heating (DCH) experinents conducted at Sandia Hational Laboratorles, the Expert felt that the debris ejected under high pressure would lmpact the drywell shell as a rapidiy flowing jet. Because the heat-transfer rate during the iaptingement of the jet would be even higher thall for the floding oelt, early fallure of the shell was even nore likely than for the low-pressure cases. The initiel adount of debris superheat was not laportant because the chenfeal energy 
Table $B-1$

Cunulative Probability of Drywall Shell Fallur*

\begin{tabular}{|c|c|c|c|c|c|c|c|c|c|c|}
\hline \multicolumn{5}{|c|}{ Scenario Par meters } & \multicolumn{6}{|c|}{ Thme: } \\
\hline $\begin{array}{l}\text { Faflure } \\
\text { Tyes }\end{array}$ & Rressures & Letal & Suporhent & Wntex & nans & 10 nin & Lh & B_ & Sh & CCI Nos \\
\hline $\begin{array}{l}\text { Large } \\
\text { Lrge }\end{array}$ & : & - & - & $\begin{array}{l}\text { No } \\
\text { Yes }\end{array}$ & $\begin{array}{l}0.6 \\
0.4\end{array}$ & $\begin{array}{l}0.9 \\
0.7\end{array}$ & $\begin{array}{l}1.0 \\
0.98\end{array}$ & $\begin{array}{l}1.0 \\
1.0\end{array}$ & $\begin{array}{l}1.0 \\
1.0\end{array}$ & $\begin{array}{l}1.0 \\
1.0\end{array}$ \\
\hline $\begin{array}{l}\text { Suall } \\
\text { Suall }\end{array}$ & $\begin{array}{l}\text { Low } \\
\text { Low }\end{array}$ & $\begin{array}{l}\text { Low } \\
\text { HIgh }\end{array}$ & $\begin{array}{l}\text { Low } \\
\text { Low }\end{array}$ & $\begin{array}{l}\text { No } \\
\text { No }\end{array}$ & $\begin{array}{l}0.2 \\
0.2\end{array}$ & $\begin{array}{l}0.4 \\
0.4\end{array}$ & $\begin{array}{l}0.85 \\
0.85\end{array}$ & $\begin{array}{l}0.95 \\
1.0\end{array}$ & $\begin{array}{l}1.0 \\
1.0\end{array}$ & $\begin{array}{l}1.0 \\
1.0\end{array}$ \\
\hline $\begin{array}{l}\text { San11 } \\
\text { Sanl1 }\end{array}$ & $\begin{array}{l}\text { Lov } \\
\text { Lov }\end{array}$ & $\begin{array}{l}\text { Low } \\
\text { High }\end{array}$ & $\begin{array}{l}\text { Low } \\
\text { Low }\end{array}$ & $\begin{array}{l}\text { Yes } \\
\text { Yes }\end{array}$ & $\begin{array}{l}0.1 \\
0.1\end{array}$ & $\begin{array}{l}0.3 \\
0.3\end{array}$ & $\begin{array}{l}0.7 \\
0.7\end{array}$ & $\begin{array}{l}0.85 \\
0.9\end{array}$ & $\begin{array}{l}0.93 \\
0.98\end{array}$ & $\begin{array}{l}0.95 \\
1.0\end{array}$ \\
\hline Suall & Low & - & HIgh & No & 0.5 & 0.85 & 1.0 & 1.0 & 1.0 & 1.0 \\
\hline $\operatorname{sen} 11$ & Low & - & High & Yes & 0.33 & 0.67 & 0.9 & 1.0 & 1.0 & 1.0 \\
\hline $\begin{array}{l}\operatorname{san} 11 \\
\operatorname{san} 11\end{array}$ & $\begin{array}{l}\text { H1gh } \\
\text { H1gh }\end{array}$ & $\begin{array}{l}\text { Low } \\
\text { High }\end{array}$ & - & $\begin{array}{l}\text { No } \\
\text { No }\end{array}$ & $\begin{array}{l}0.5 \\
0.6\end{array}$ & $\begin{array}{l}0.9 \\
0.95\end{array}$ & $\begin{array}{l}0.95 \\
1.0\end{array}$ & $\begin{array}{l}1.0 \\
1.0\end{array}$ & $\begin{array}{l}1.0 \\
1.0\end{array}$ & $\begin{array}{l}1.0 \\
1.0\end{array}$ \\
\hline $\begin{array}{l}\text { Sanll } \\
\text { Saall }\end{array}$ & $\begin{array}{l}\text { High } \\
\text { High }\end{array}$ & $\begin{array}{l}\text { Low } \\
\text { High }\end{array}$ & - & $\begin{array}{l}\text { Yes } \\
\text { Yes }\end{array}$ & $\begin{array}{l}0.4 \\
0.5\end{array}$ & $\begin{array}{l}0.85 \\
0.9\end{array}$ & $\begin{array}{l}0.9 \\
0.95\end{array}$ & $\begin{array}{l}0.95 \\
1.0\end{array}$ & $\begin{array}{l}1.0 \\
1.0\end{array}$ & $\begin{array}{l}1.0 \\
1.0\end{array}$ \\
\hline
\end{tabular}

t I - 0.0 corresponds to when the debris hits the drywell floor. 
release during metal oxidetion controls the temperature of the jet. After the blowdown, the Expert belleved the probability distribution would approach those of the low-pressure cases.

\section{Hah-Pressure Penecrasion Fallure. Waker}

The Expert referenced experinentg st Sandia National Laboratories as basis for his conclusion that tater is not a slgnificant benefit in a highpressure accldent, at least for early times. In these experlinents in which melt was injected Into a water. Fllled cavity at high pressure, the water was observed to remove heat effectively only froe the leading edge of the jet. The rapid pressure rise in the cavity then displaced the water ahead of the jec and the remaining portion of the jet was essentially unaffected by the water

\section{Source of Uncertainty}

The major sources of uncertalncy were the rather coarse description of the initial conditions (f.e., high and low for the varlous paraneter levels). and the effec: of water on the drywell shell teaperature.

\section{Correlations vith other Variables}

No correlations were thscussed between other variables in the event trees and the varlables discussed as part of this issue

\section{Sugres sed Hethods for Reductor Uncertainty}

The Expert indicated that if inltial conditions were defined pore precisely (1.e., actual values for the varlous paraneters) the uncertainty associated wh the inftial conditlons could be reduced. However. this would requtre an enormous increase in the nuber of cases that vould have to be analyzed. 
Expert C* Eliclketion

Ineue 1: Pouch Bottoe Dryvall Maltehrough

\section{Description of Experc C's_Rationale/Mechodology}

\section{Scenartos Considered by Expert}

Expert $C$ considered three general scenarlos-each with and without water:

1. Vessel fallure by penetracton fallure: low pressure in the vessel at the time the debris is released from the vessel; low debris superheat at the time of debris egress; and a high percentage of unoxidized metal avallable in the debris after vessel breach.

2. Vessel faflure in the plop mode (plop sas the phrase that was used at the elicitation meeting to designate a large coberent drop of debris into the cavtty: this Expert defined the plop as about 70 metric cons of debris); high pressure at vessel breach; high superheat in the debrls upon egress frou the vessel; and an intermediate anount of unoxidized aetal avallable in the debris after vessel breach (the Expert defined interaediate as about 500 of the orfigal amount of unoxidtzed aetal).

3. Vessel fatbure by penetration fallure: high pressure at vessel breach ( 1000 psia) causing a fet expulsion of the debris; low superheat in the debris; and a high percentage of unoxidized betal avallable In the debris after vessel breach.

The Expert felt that, for the current level of resolution, the phenomenology would be sintlar for all percentages of unoxidized aetal available in the debris after vessel bresch greater than 25 (he did not feel that it was credible to predict percentages less than 25:), He also felt that the leval of decay heat power in the debris vas inconsequential - tha: the zirconiun oxidation provtded enough energy to drive the CCI.

All ather varlables are taken into account in the curves that bound the fnitial or central curve.

Predicted Phenonenological Progression of Eyents and Rationale in Each Srenario

Scenar to A

1. The Expert assuned that a penetration fallure will result in a nolten core tlow rate of about $100 \mathrm{~kg} / \mathrm{s}$. The range of this value could be from $: 00$ to $200 \mathrm{~kg} / \mathrm{s}$.

2. The flow continues uninpeded through the materlals directly below the resctor vessel (the CRD and In-core instrumentation aaterlal-the "rat's nest"). The rationale for thls uniapeded flow is that the flow widh hinld be relatively narrow and would have alrect line of olght throught the "rat's nest." 
3. The molten core qulckly melts through the steel sump pit cover directly beneath the reactor vessel and begina an agresaive CCI in the sump pit. The sump pit fille up by the time the collapsed lovel of nolcen debris reacheo one half of the sump pit depth. The time elapsed from vessel fallure to this point 1s obout $4 \mathrm{~min}$.

4. In the next $6 \mathrm{~min}$, about $5 \mathrm{~m}^{3}$ of debria will fill the cavity, fall the door in the cavity, aproad out in an area outaldo the cavity that will cover a 90-degreo section of the dryvell floor, and will contact the drywell shall. The depth of the debris w11l be around $10 \mathrm{cn}$. (The inclination of the floor-about $1 \mathrm{cu-will}$ not have a large inpact on the progression.)

5. If the debris was covered with $15 \mathrm{~cm}$ of water it vould take about 15 win to boll off. Th1s assumes a heat flux fron the debris to the water of about $0.1 \mathrm{w} / \mathrm{cm}^{2}$. The ffect of the water is to delay the spread, it does not have an order-of-angnitude of fect. A crust could fore. but would reheat and nelt in this scenario.

6. The Expert's bast agtiwate of the tine for the debris to reach the steel shell with $15 \mathrm{cs}$ of water on the floor Is therefore in the vicintey of 10 aln-this includes the coupeting eftects of the cooling by the water and the hoating by the CCI. The Expert belleves that the flow of the debris is hydrodynanically liatted-it is not liated by he at transfer aechanisms.

7. Once the debris contects the drywell bhell, the Expert relled on the ablation ansiysis in Reference C-l. The Expert folt that even if it took aletively lang tive to ablate $(50$ of $)$, that the tenstle strength of the shol: would be lost within ninutes, resulting in follure of the shell.

\section{Sconer10}

1. In this ecenarto, the Expert considered a coherent drop of obout 70 metric cons of debris-thit is equivalent to about 10 a $^{3}$ of debris.

2 He felt that the debria would spresd over che pedestal ragion and half of the drysell floor (about $70 a^{2}$ ), and would be bout 15 ea deap.

3. Any woter in the drywell at the time of vessel fallure would be pushed out of the way. The Expert assuned that thete vas 10 ch of water, but assuned that it would end up in the region of the drywell thst the debris did not occupy. Consequently, he did not glve any credit for the water. He also atated that any effect of the vater will be quickly lost; there is not enough water to negate the large amount of zirconiun available.

4. The Expert steted that the debrls could freeze at the debris/concrete interface and that the concrete vill itlll outgas. The water in the concrate w111 evaporate into the ifebrlo and the stean will oxidize the zirconlua. The efrconlud oxidation will create the energy necessary to drive the endothermtc CCI. The stear conlng out of the concrete 111 
equilibrate both thermally and chemically withln a few centimeters of the debris/concrete boundary.

5. The Expert does not belleve that any crusts will fors; data show that, when superheated, matallic molta do not support crusts. It does not atter if crusts fore on the periphery of the spread. Any cruete that do form w111 be nelted by the energy fron the vigorous zirconius oxidation.

6. Shell contect wil occur within minutes. The Expert folt that the heat-tranefer coafficlent between the debris and the shell would be on the order of $2000 \mathrm{~W} /\left(\mathrm{a}^{2} \mathrm{~K}\right)$, not 1000 . He felt that fallure would occur rapldly.

7. The Expert felt that the large anount of zirconiun avallable in the BuR debris is the aost important paraneter in this problea. The effect of the decay heat power is negligible.

Scanar 10 G

1. The Expert consldered this high-pressure welt ejection scenario.

2. The Expert aspined that the debris flaw rater would bo about a factor of two greater than the flov rates in Scenario $A(200 \mathrm{~kg} / \mathrm{s}$ in this: scenario.)

3. The Expert felt that the first part of the nelt (about 50) way lose heat neleing a hole through the rat'. nast, but that the reat of the nale (95) wil go through the sare hole without losing a signtficant amount of energy.

4. The Expert felt that the debris vould plobably hit the pedestal floor in o coherent jet.

5. If there was water in the aup, It vould probably be displeced by an FCI.

6. Eather the molten gtrean $\mathbf{1 1 1} \mathrm{h} 1 \mathrm{t}$ the pedestal and be deflected, or the welt wlll be atodized by the gases produced. Etther way thate w111 be - spray of highly netallic zirconiun out the dryell door. There vill be an area of high heat transfer dfrectly outside the podegtal doorvay.

7. The 21 rconiue will react with stean in flight and will heat up-it will not be cooled. All indications are that chis will behave like a plasag jet .

8. In this scenario, it is alwost lopossible to prevent an instantaneous faflure of the dryvell shell. The debris translt tine would be on lie order of seconds, the ablation tlae about $l$ ain. 


\section{Results of Expert C's Ellcteation}

The results of this Expert's elfcitations are presented in Figures C-1 through C-3. Figure $C-1$ presents the results of the elicitation of Scenario A, Figure C.2 presents the results of the elicitation of Scenario $B$, and Figure C-3 prasents the results of the elfcitation of scenario $C$. The curves on FIgures $C \cdot 1$ through $C \cdot 3$ are CFPDs-the $y$ axis represents the probability of dryoll shell failure and the $x$ axis represents the tine to failure.

Three curves are shown in Figure $\mathrm{C}+1$. The center curve is the Expert's best estinate-the rationale is provided in the previous section. The curve to the left is the upper ind CFPC for the scenario and the curve to the right is the lower bound $c r i b$.

The upper bound CFPD for Scenario a specifically includes the following considerations: (1) little or no water on the drywell and pedestal floor: (2) high debris flow rate from the vessel $(200$ to $300 \mathrm{~kg} / \mathrm{s})$ : (3) a low restatance to debris spreading; and (4) a higher superheet. The lower bound CFPD for Scenario A considers (1) a lot of water avallable in the drywell: (2) a low debris flow rate from the vessel (< $100 \mathrm{~kg}$ ); and (3) nore material retardation of the debris flow.

Figure C.2 includes two CFPDs representat Ive of Scenarlo $B$; the difference between the two is due to the presence of water. The CFPD on the left reptesents a scenario in which there is little or no water avallable for debris quenching. If there is water avallable. the events are shifted in time by a few minutes, resulting in the CFPD on the right.

Figure C-3 Includes one CFPD; the Expert feels that the dryuell shell will fail vith little uncercainty in less than $30 \mathrm{~min}$ in Scenarjo $\mathrm{C}$.

\section{Sources sf Uncertainty}

\section{Scenex 10 A}

The Expert felt that most of the uncertaluty in this scenarlo is in ine tite that it takes for the debris to spread. A fuel-coolant interaction (FCI) In the sump pit could blow the vater out and alter the spreading scenario. Inertial effects in the sump could cause the sunp to overflaw earller. Expert $C$ felt that a coolable debrls bed would result fros any scenarlo in which the debris taok over $2 \mathrm{~h}$ to reach the shell.

The Expert felt that the effect of high superheat in the debris vauld only worsen the situation and did not provlde a separate case. This and other uncertainties are considered in the uncertainty ranges given.

\section{Scenarto}

Factors that could modify the progression of this scenarlo are an extremely low unoxidized wetal concent in the debris: low flow fron the vessel; low superheat: and a substantial water barter roupled with a substantial physical barrier. 


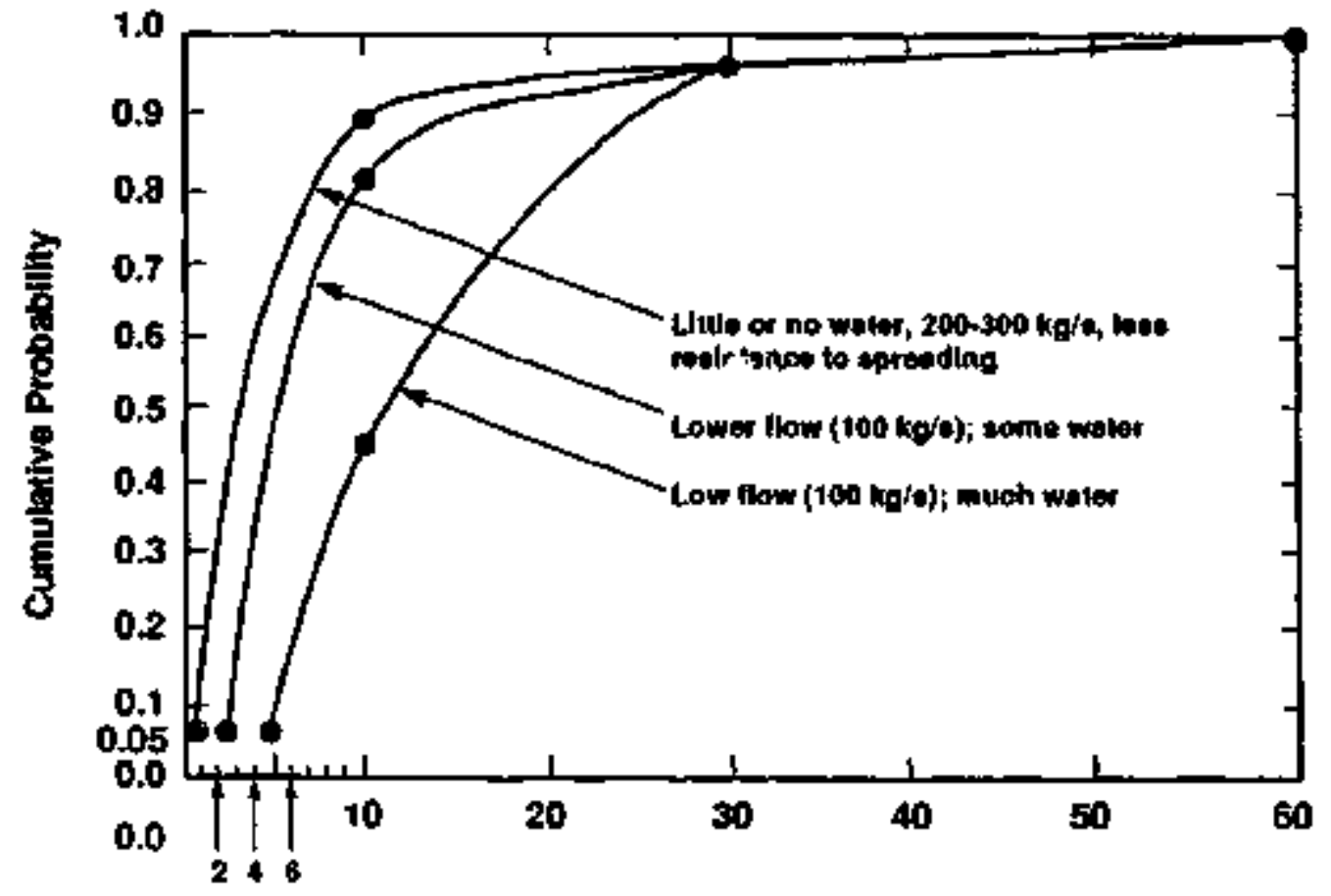

Figure C-1, Cumulative Failure Probability of Drywell vs. Tine for Scenarto A.

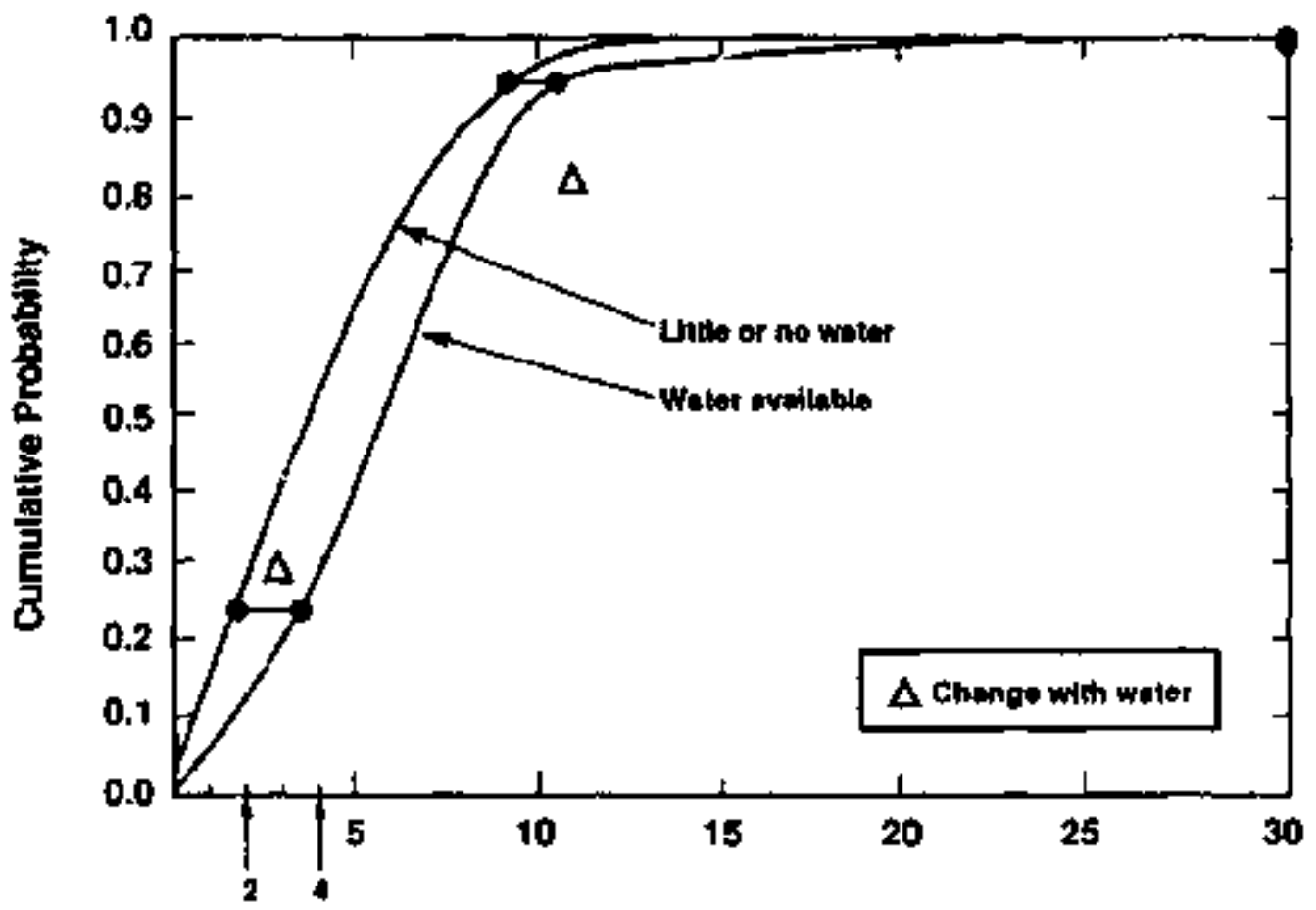

Figure C.2. Cumulative Fallure Probability of Drywell vs. Tine for Scenario B. 


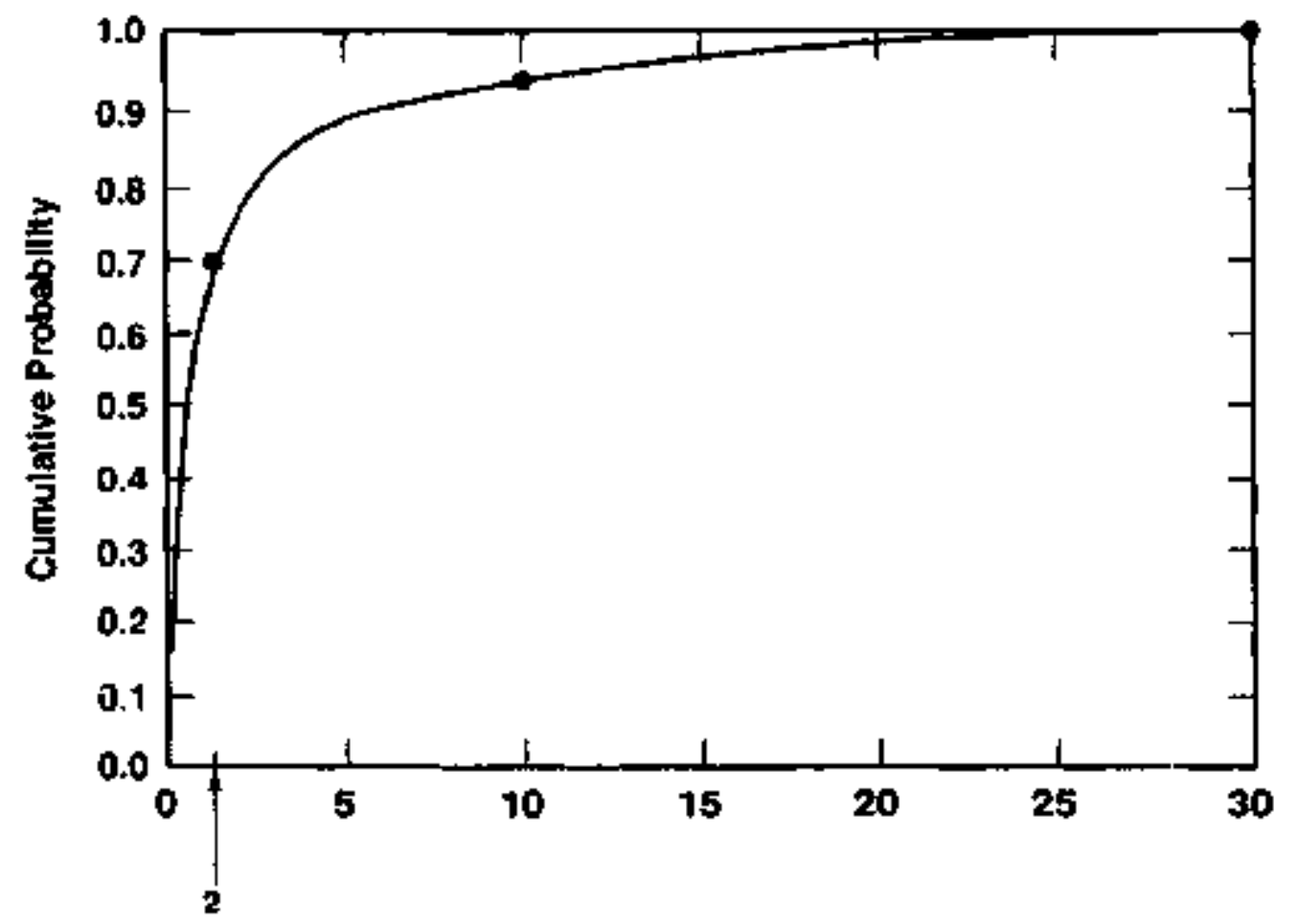

Figure C-3. Cumulative Fallure Probability of Drywell vs. Time for Scenario C. 
There are some phenomena that could limit the effect of the plasma torch. If the hole in the reactor pressure vessel opened up more, it could stop this plasme torch. If there was enough water to interact with the entire debris, the scenario would be impacted; however, the Expert felt that there wotald be a low probsbility that there would be that wuch water.

The Expert fett that the unoxidized zfrconium renaining in the debris would have to be lower than any plausible value (< 158) to impact the scenarlo. He also felt chat the rat's nest would not have nore than a 58 effect, and that the amount of superheat would not impact this scenario. 


\section{REFERENCE}

C-1. G, A, Greene, K, R, Perkins, and $S$, A. Hodge, "Hark I Containnent Drywell, Impact of Core/Conctete Interactions on Contalnment Integrity and Fatlure of the Drywell Liner." In Source Term Evaluation for Accident Conditions, IAEA, Vlenna, Austria, IAEA-SH$281, p, 429,1985$. 
Expert D's Elicitation

Is aue 1: Peach Botton Dryell Heltthrough

\section{Description of Expert D's Rationale/Methodology}

Scenarios Considered by Expert

The following scenarios were constdered by the Expert:

A. Scenarios with debris flow $>100 \mathrm{~kg} / \mathrm{s}$ and low pressure upon debris egress

Al--Netalle debris," low superheat, "water avallable

A2--Metallie debris, high superheat, "** water avallahle

A3--Oxidtc ${ }^{* * *}$ debris, low superheat, water avallable

A4--Oxidic debris, high superheat, water available

A5- Metollic debris, Low superheat, no water avaflable

A6--lietallic debris, high superheat, no water avallable

A7-Oxidic debris, low superheat, no water available

A8-Oxidic debris, high superhear, no water available.

B. Scenartos with debris flow $>50 \mathrm{~kg} / \mathrm{a}$ and $<100 \mathrm{~kg} / \mathrm{s}$, and low pressure upon debris egress

B1++Metallic debris, low superheat, water avallable

B2--Metallic debris, high superheat, water available

83-Oxidic debris, law superheat, vater avallable

B4--Oxidic debris, high superheat, water avallable

B5.-Metallic debris, low superheat, no water avallable

B6-- Metallic debris, high superheat, no vater avallable

B7-Oxidic debris, low supetheac, to water available

B8--Oxidic debris, high superheat, no water available

C. Scenarios with debris flot $<50 \mathrm{~kg} / \mathrm{s}$ and low pressure upon debris egress

C1--Metallic debris, low superhest, sater avallable

C2-Metallic debris, high superhest, water avallablo

C3--Oxidie debris, low superheat, water avallable

C4--Oxidic debris, high superheat, water avallable

C5--Metallic debris, low superheat, no water avajlable

C6--Metallic debris, high superheat, no water avallable

c7--Oxide debr1s, low superheat, no vater avallable

C8--Oxidic debris, high superheat, no water available

"Metallic - mix of steel, B4c, Zr

"Low superheat $=<100 \mathrm{~K}$

***igh superheat $->100 \mathrm{~K}$

${ }^{* * *} \mathrm{Oxidic}=\mathrm{UO}_{2}, 2 \mathrm{rO}_{2}$, steel, B4C, $\mathrm{Zr}$ 
D. Scenarios with debris flow $>100 \mathrm{~kg} / \mathrm{s}$ and high pressure upon debris egress

D1 - Low superheat, water svailable

D2--High superhest, water avallable

D3--Low superheat, no water available

04--High superheat, no water available

Each of the scenarios is represented by an event tree; the 24 low-pressure scenarlos are represented by a comion logfc structure. and the four high. pressure scenarios are represented by a conmon logic structure. The top events on the event trees represent the parameters that define the scenarios presented in Section $\mathrm{I}$. The probability of drywell shell fatlure and the best estimate of the time of that fallure are given for each branch on the individual event trees.

The entice elicitation was spent evaluating the probsbilities for each of the branches.

Resules of Expert D's Ellicitation

The results of the Expert's ellcitation are presented in the following event trees. 
CASE: A1

EFFECT LOSS OF GRUST FROB TIYE OF

OF SUPER - STABLE OF FAILURE

BARRIER HEAT FATURE

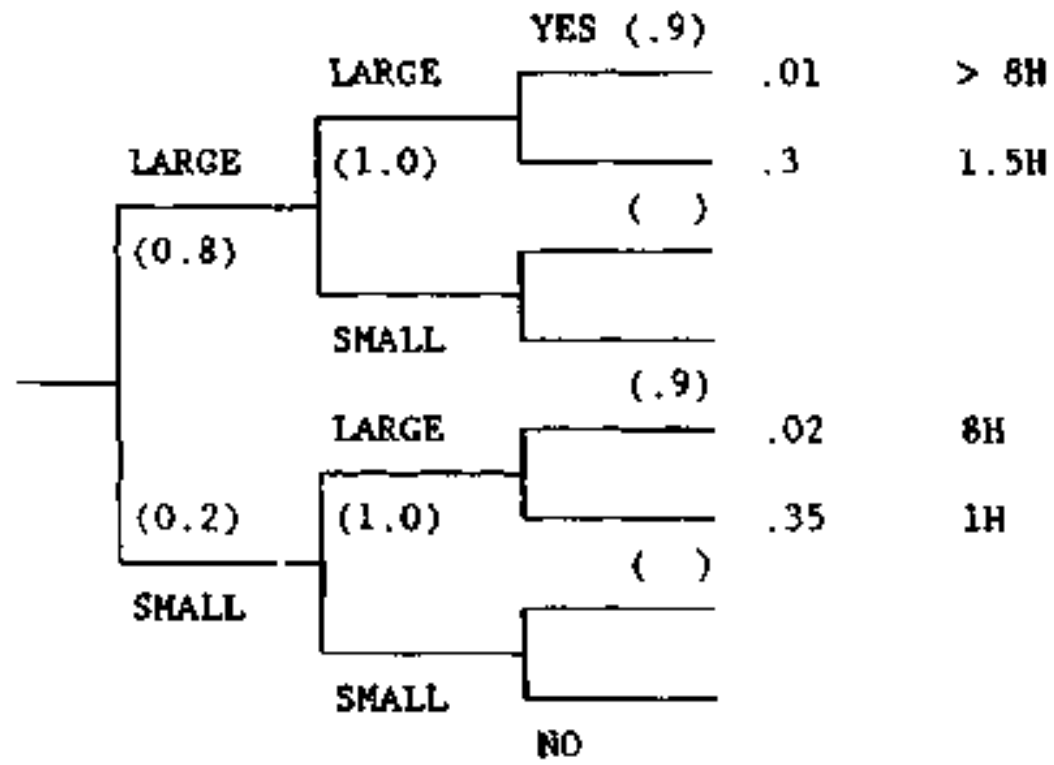

CASE: A2

$\begin{array}{lllll}\text { EFFECT } & \text { LOSS OF } & \text { CRUST } & \text { PROB } & \text { TIME OF } \\ \text { OF } & \text { SUPER - } & \text { STABLE } & \text { OF } & \text { FAILURE } \\ \text { BARRIER } & \text { HEAT } & & \text { FAILIRE } & \end{array}$

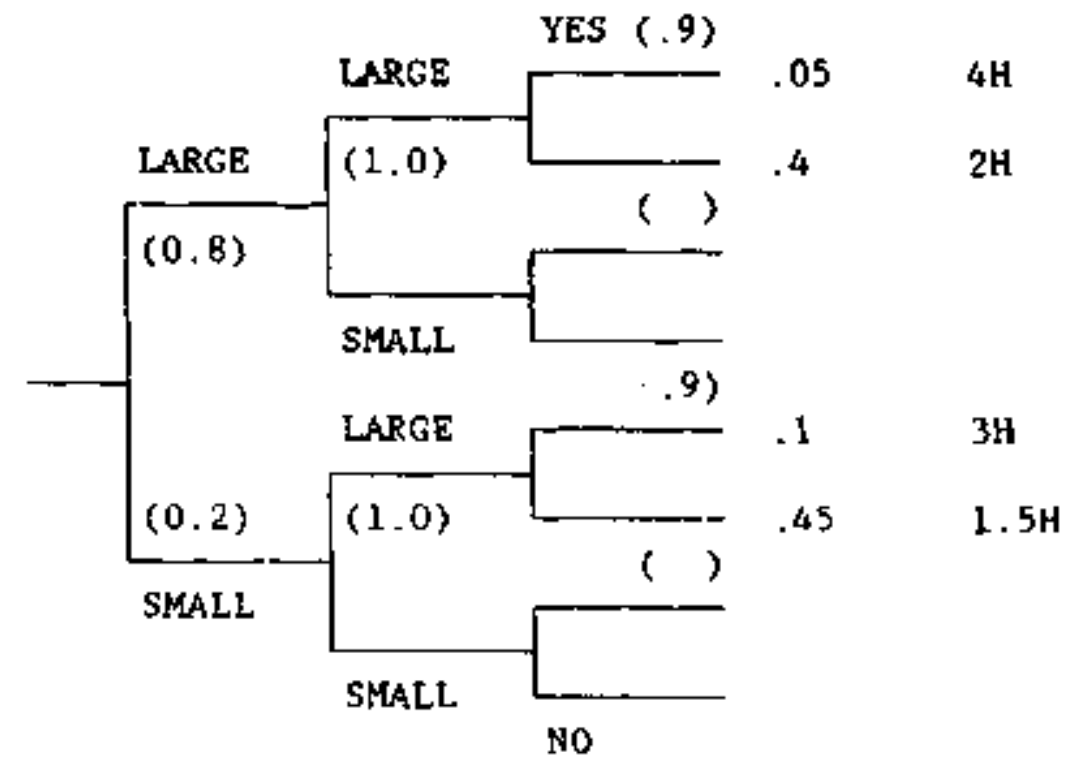


CASE: A3

$\begin{array}{lllll}\text { EFFECT } & \text { LOSS OF } & \text { CRUST } & \text { PROB } & \text { TIME OF } \\ \text { OF } & \text { SUPER- } & \text { STABLE } & \text { OF } & \text { FAILURE } \\ \text { BARRIER } & \text { HEAT } & & \text { FAILURE } & \end{array}$

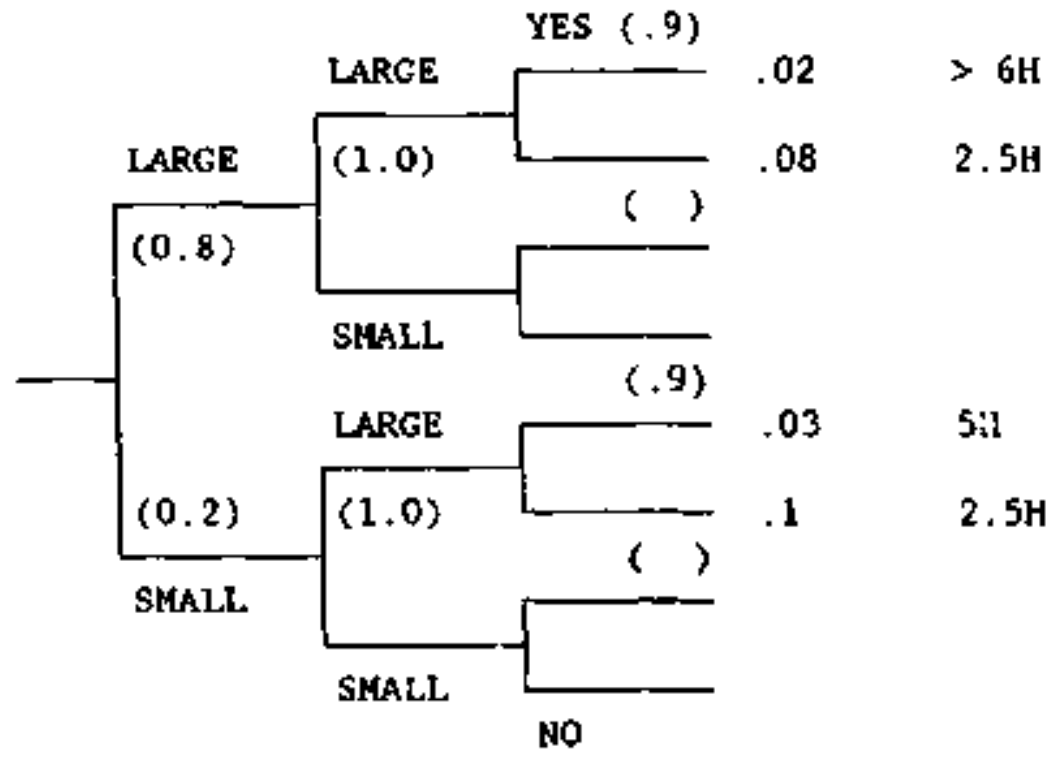

CASE: A4

$\begin{array}{lllll}\text { EFFECT } & \text { LOSS OF } & \text { CRUST } & \text { PROB } & \text { TIME OF } \\ \text { OE } & \text { SUPER } & \text { STABLE } & \text { OF } & \text { FAILARE } \\ \text { BARRIER } & \text { HFAT } & & \text { FAILURE } & \end{array}$

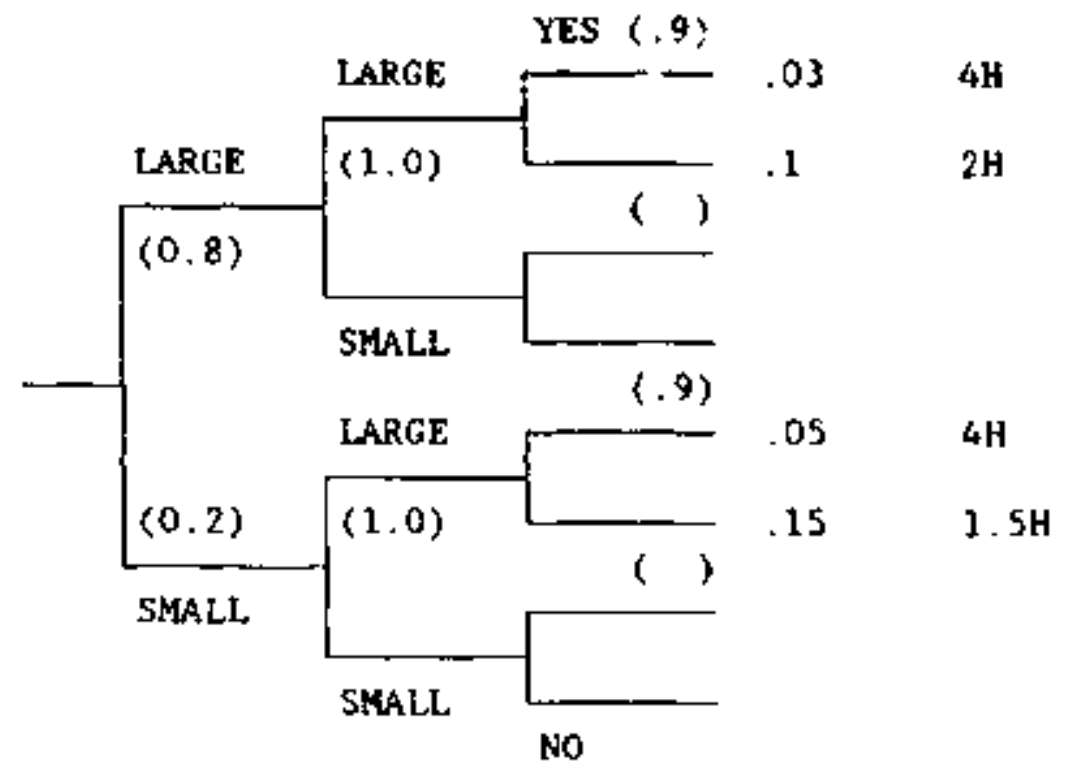


CASE: A5

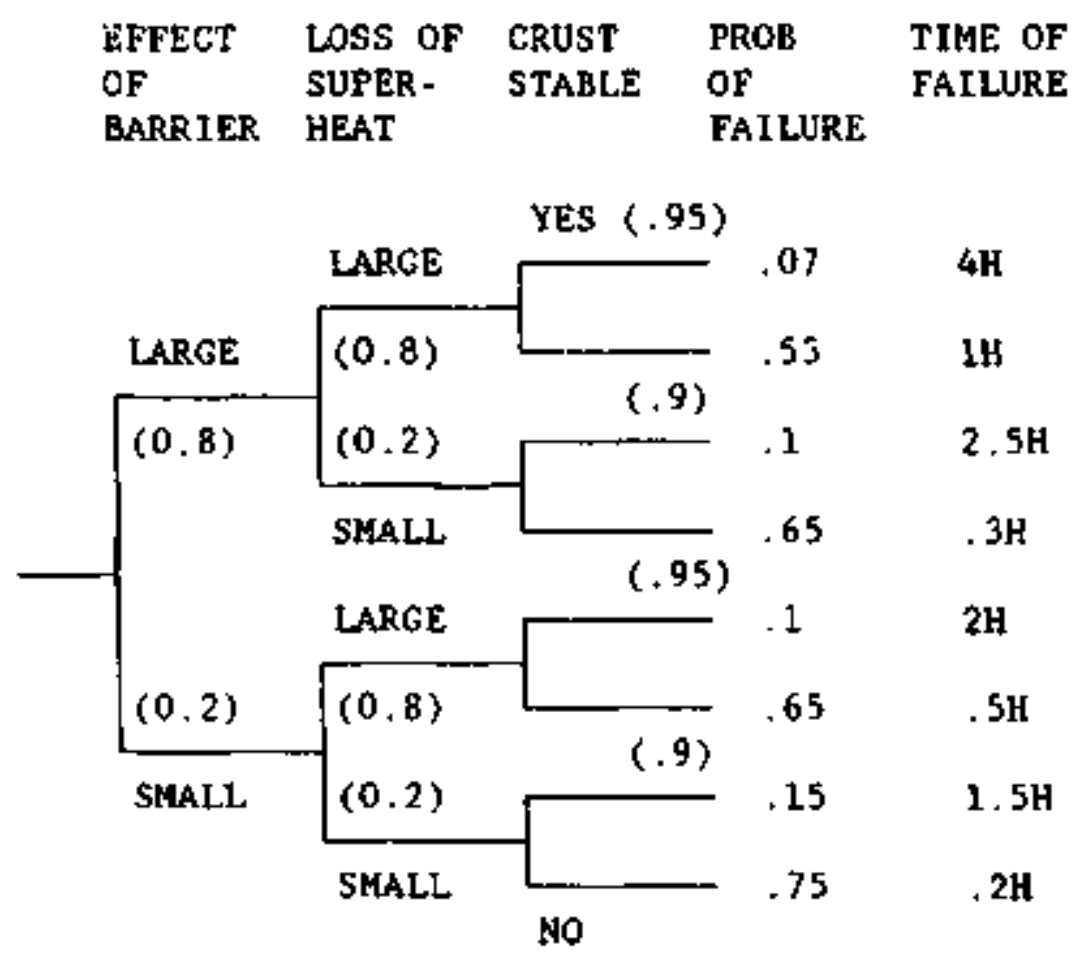

CASE: A6

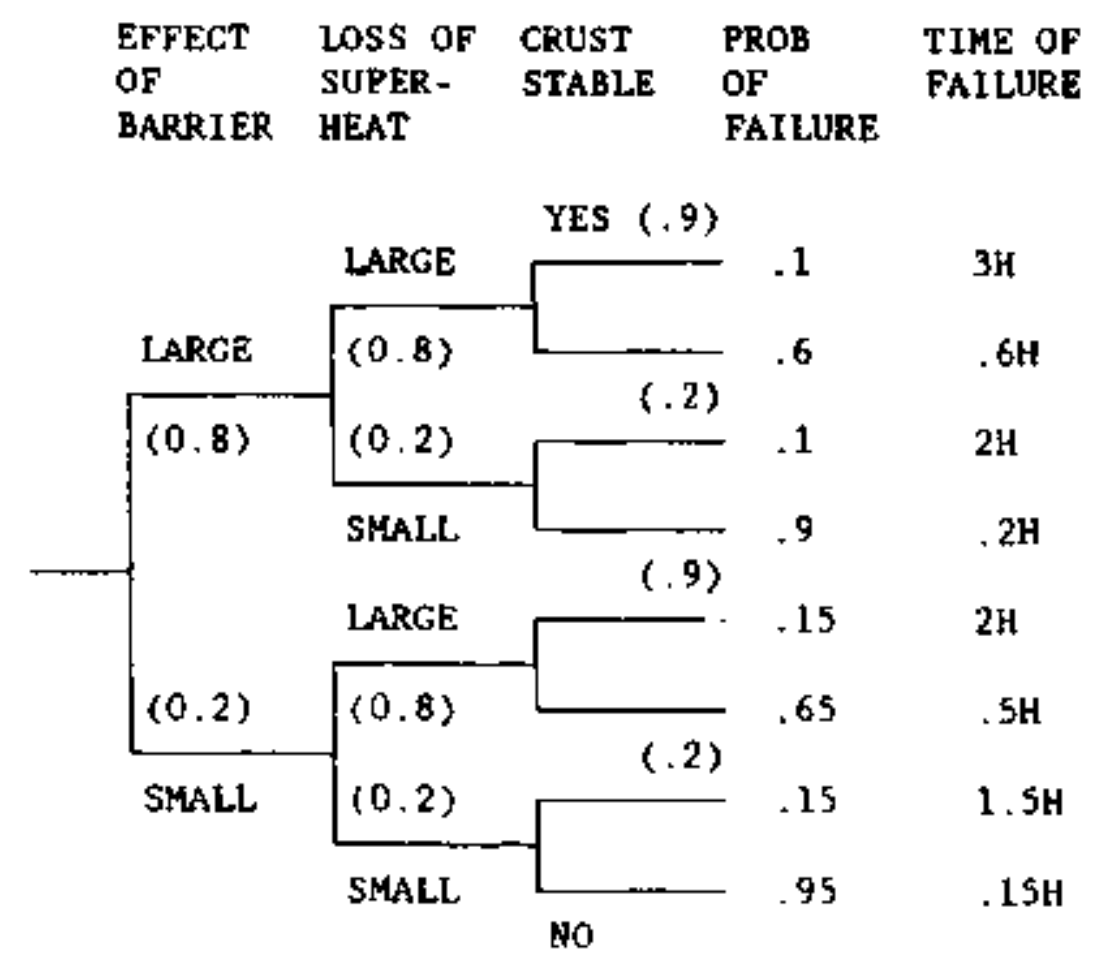


CASE: A7

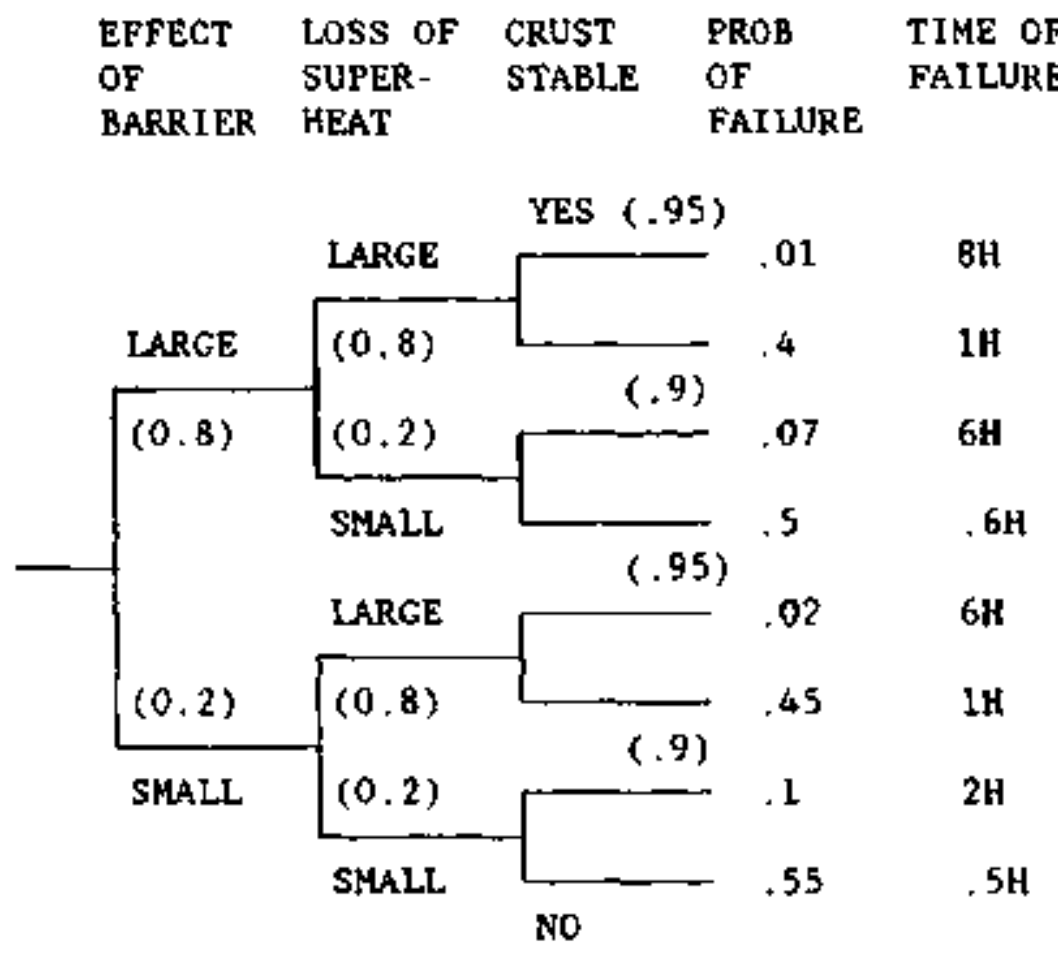

CASE: A8

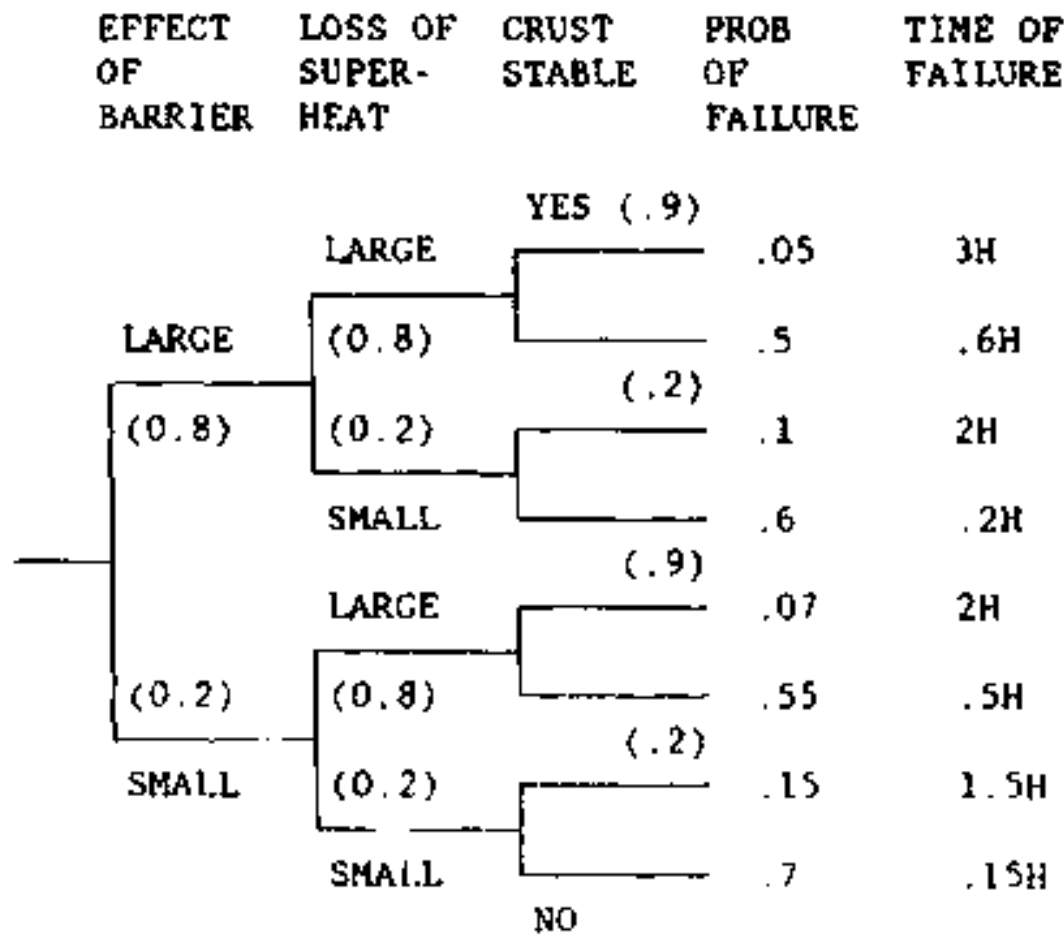


CASE: $\mathrm{Bl} / \mathrm{B} 3$

$\begin{array}{lllll}\text { EFFECT } & \text { LOSS OF } & \text { CRUST } & \text { PROB } & \text { TIME OF } \\ \text { OF } & \text { SUPER- } & \text { STABLE } & \text { OF } & \text { FAILURE } \\ \text { BARRIER } & \text { HEAT } & & \text { FAILURE } & \end{array}$

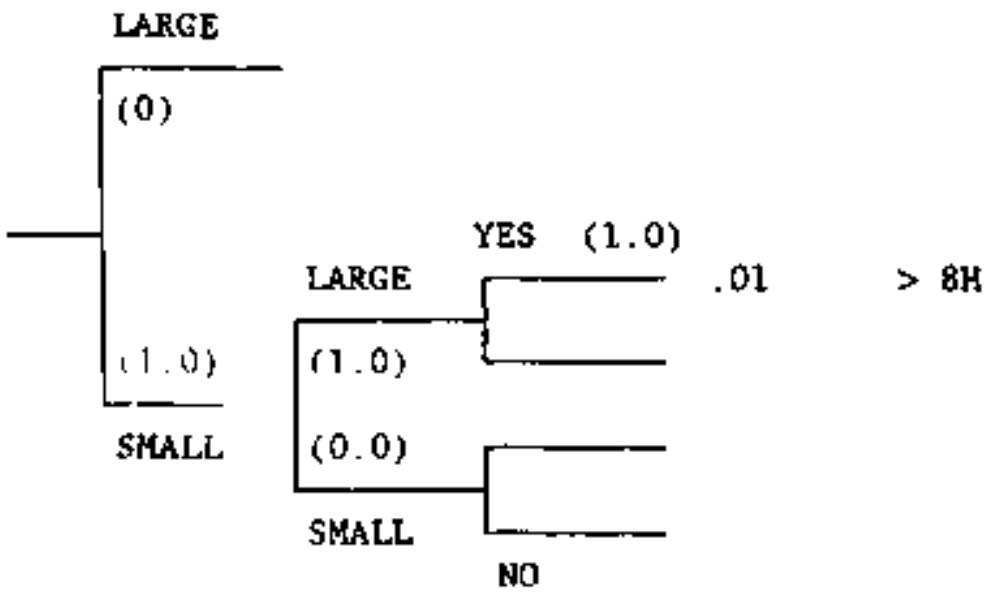

CASE: B2/B4

$\begin{array}{lllll}\text { EFFECT } & \text { LOSS OF } & \text { CRUST } & \text { PROB } & \text { TIME OF } \\ \text { OF } & \text { SUPER- } & \text { STABLE } & \text { OF } & \text { FAILURE } \\ \text { BARRIER } & \text { HEAT } & & \text { FAILURE } & \end{array}$

LARGE

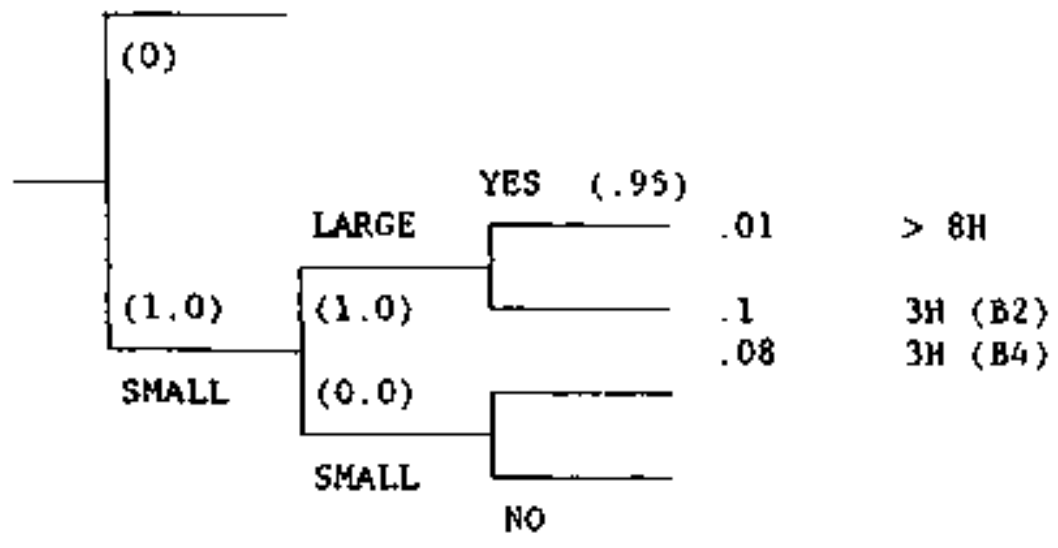

6. $1 \cdot 33$ 
CASE: B5/B7

$\begin{array}{lllll}\text { EFFECT } & \text { LOSS OF } & \text { CRUST } & \text { PROB } & \text { TIME OF } \\ \text { OF } & \text { SUPER } & \text { STABLE } & \text { OF } & \text { FAILURE } \\ \text { BARRIER } & \text { HEAT } & & \text { FAILURE } & \end{array}$

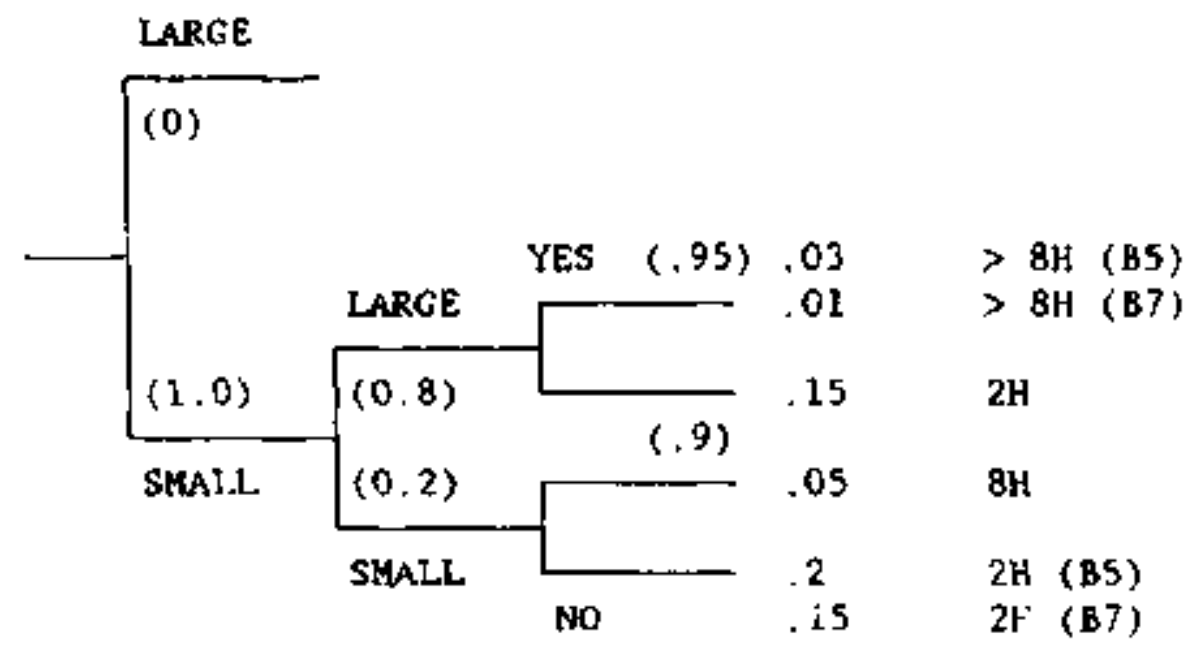

CASE: $\quad$ B6/B8

$\begin{array}{lllll}\text { EFFECT } & \text { LOSS OF } & \text { CRUET } & \text { PROB } & \text { TIME OF } \\ \text { OF } & \text { SUPER- } & \text { STABLE } & \text { OF } & \text { FAILURE } \\ \text { BARRIER } & \text { HEAT } & & \text { FAIUURE } & \end{array}$

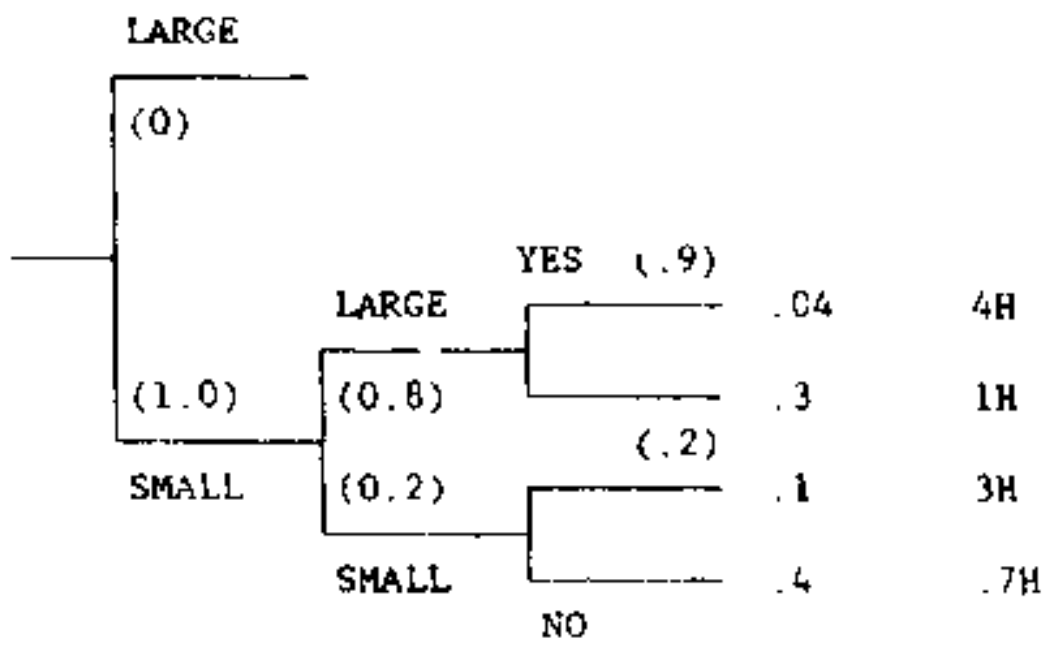


CASE: $\quad \mathrm{Cl} / \mathrm{G3}$

$\begin{array}{lllll}\text { EFFECT } & \text { LOSS OF } & \text { CRUST } & \text { PROB } & \text { TIME OF } \\ \text { OF } & \text { SUPER- } & \text { STABLE } & \text { OF } & \text { FAILURE } \\ \text { BARRIER } & \text { HEAT } & & \text { FAILURE } & \end{array}$

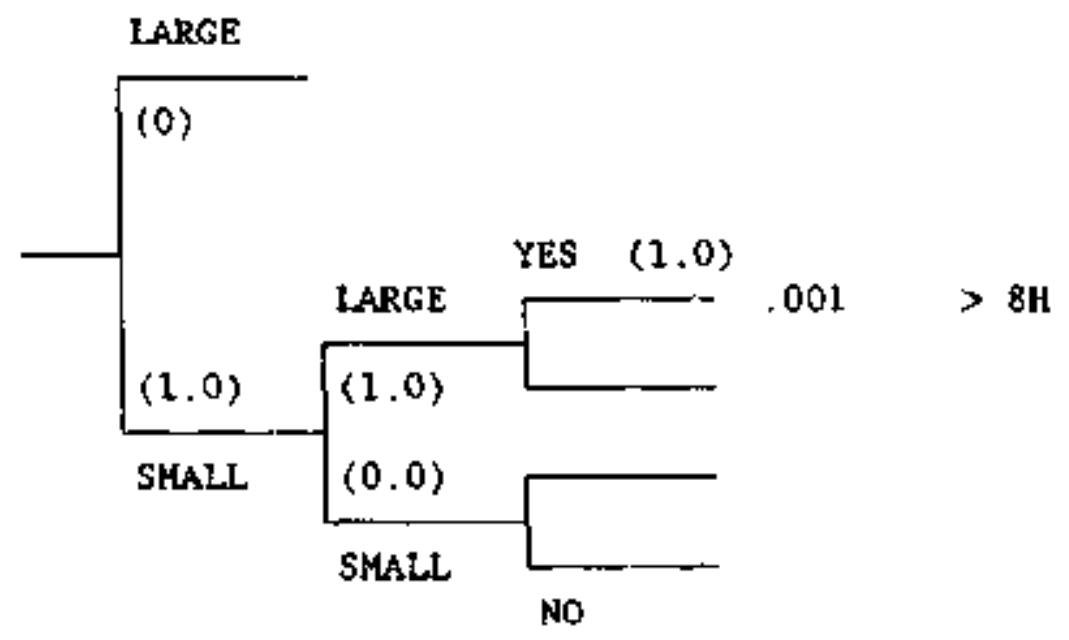

CASE: $\quad \mathrm{C} 2 / \mathrm{C} 4$

$\begin{array}{lllll}\text { EFFECT } & \text { LOSS OF } & \text { CRUST } & \text { PROB } & \text { TIME OF } \\ \text { OF } & \text { SUPER- } & \text { STABLE } & \text { OF } & \text { FAILIURE } \\ \text { BARRIER } & \text { HEAT } & & \text { FAILURE } & \end{array}$

LARGE

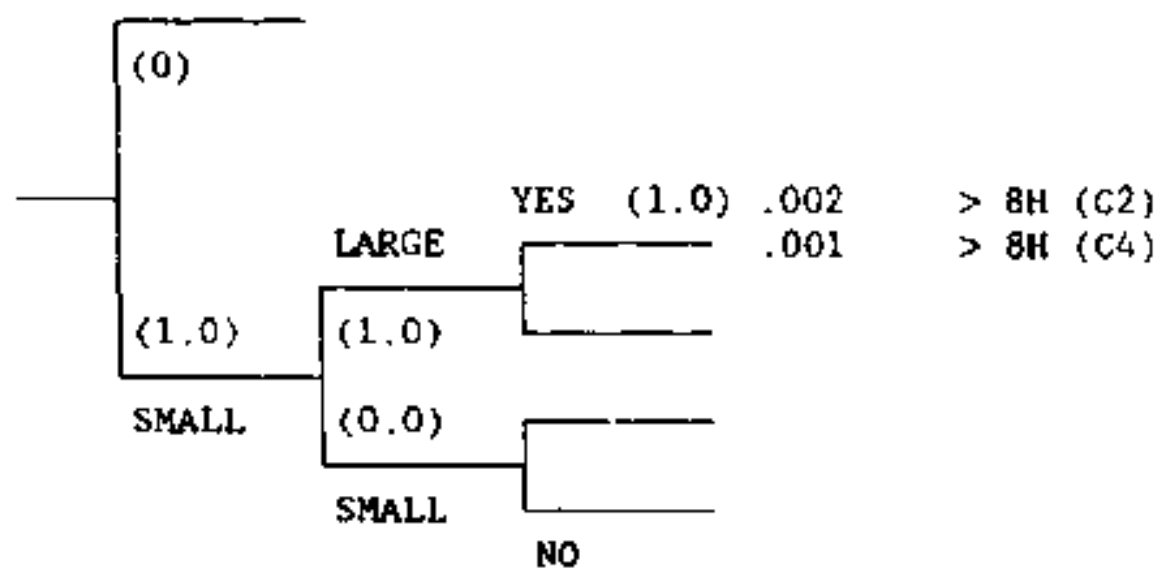


CASE: $\quad$ C5/C7

$\begin{array}{lllll}\text { EFFECT } & \text { LOSS OF } & \text { CRUST } & \text { PROB } & \text { TIKE OF } \\ \text { OF } & \text { SUPER. } & \text { STABLE } & \text { OF } & \text { FAILURE } \\ \text { BARRIER } & \text { HEAT } & & \text { FAILURE } & \end{array}$

LARGE

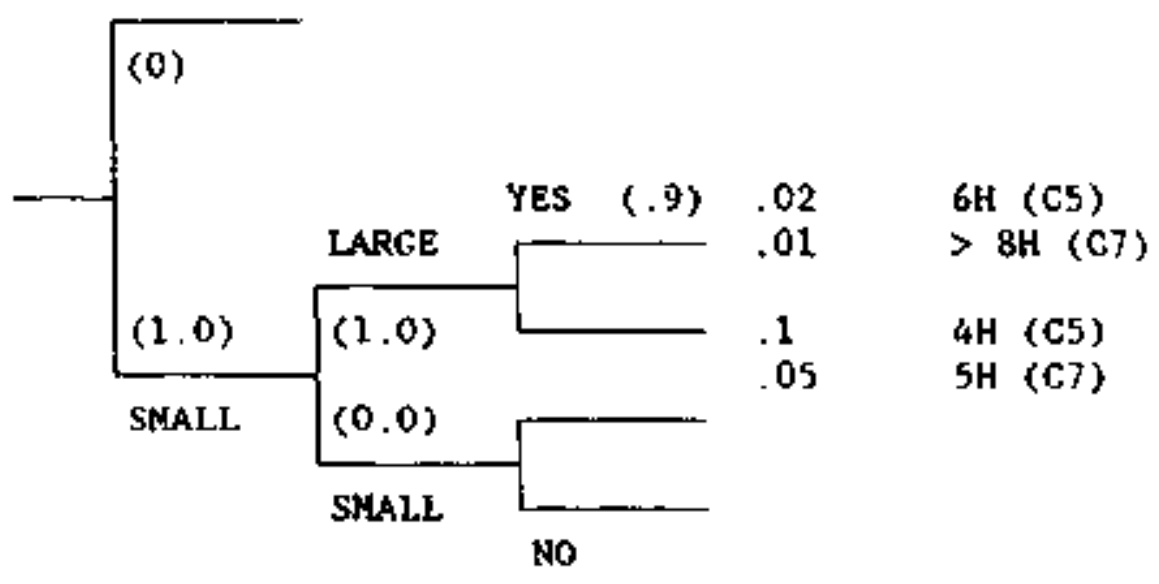

CASE: $\quad 66 / \mathrm{C} 8$

$\begin{array}{lllll}\text { EFFECT } & \text { LOSS OF } & \text { CRUST } & \text { PROB } & \text { TIME OF } \\ \text { OF } & \text { SUPER. } & \text { STABLE } & \text { OF } & \text { FAILURE } \\ \text { BARRIER } & \text { HEAT } & & \text { FAILURE } & \end{array}$

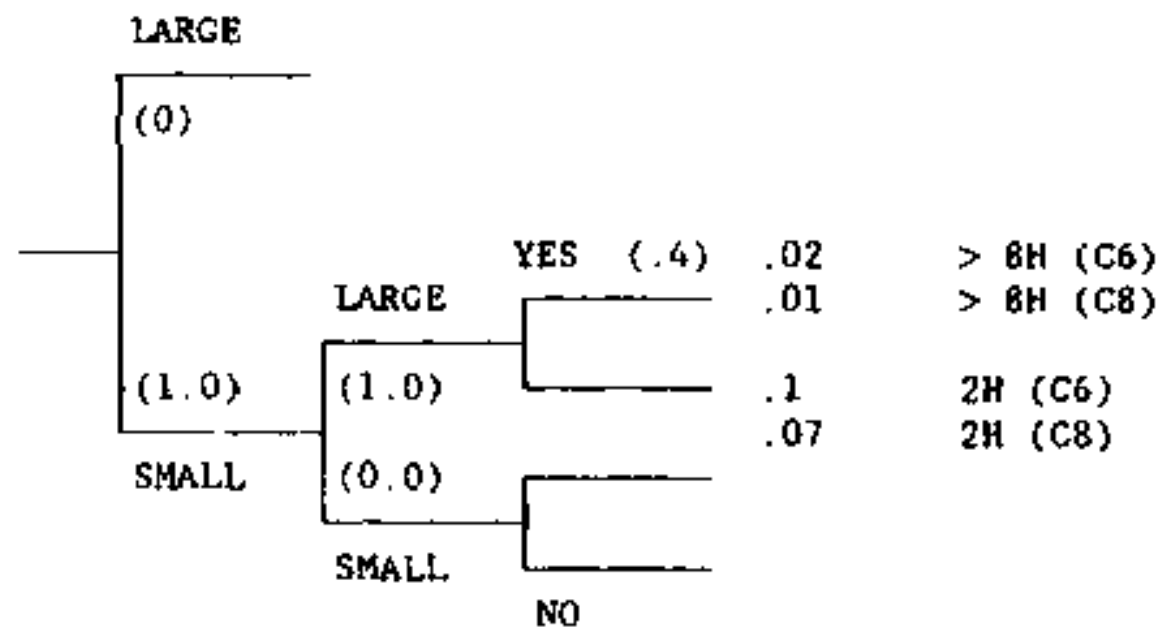


GASE: D1/D2

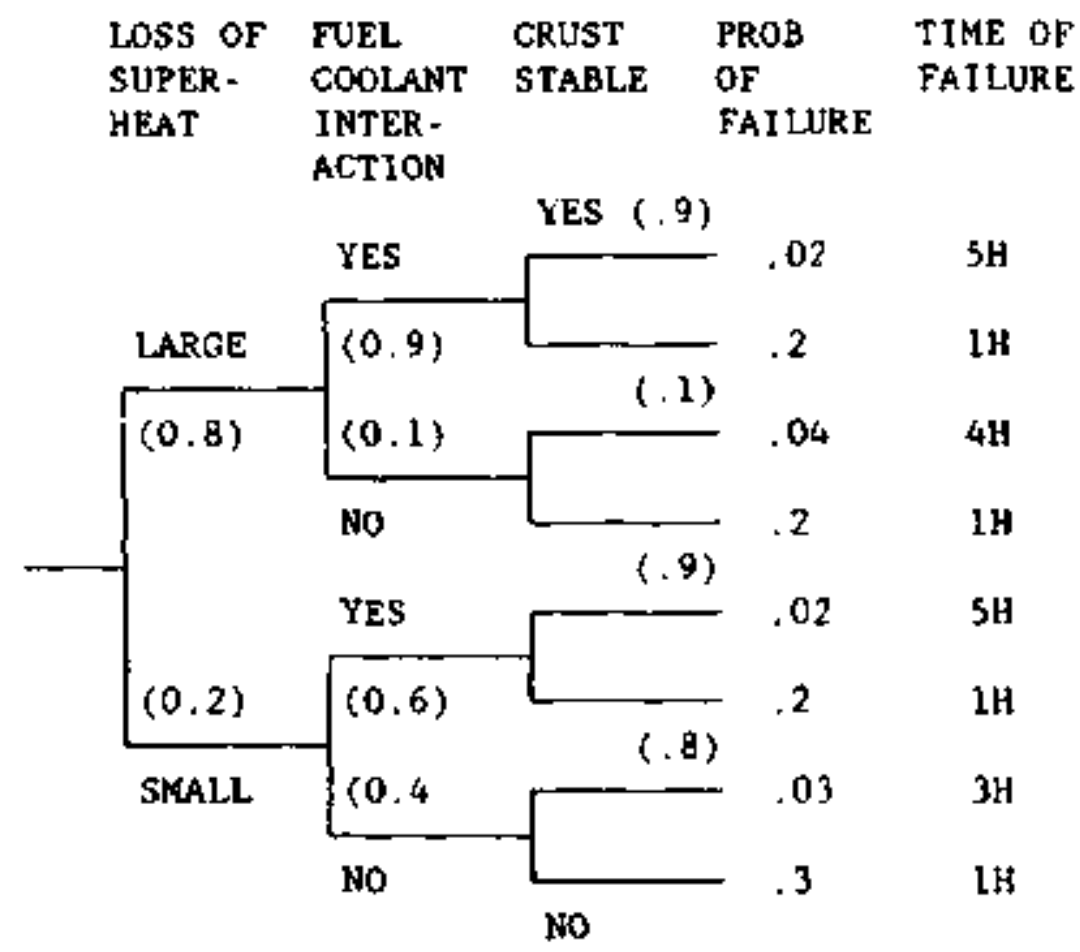

CASE: $D 3 / D 4$

$\begin{array}{lllll}\text { LOSS OF } & \text { FUEL } & \text { CRUST } & \text { PROB } & \text { TIME OF } \\ \text { SUPER- } & \text { COOLANT } & \text { STABIE } & \text { OF } & \text { FAILURE } \\ \text { HEAT } & \text { INTER- } & & \text { FAILURE } & \\ & \text { ACTIDN } & & & \end{array}$

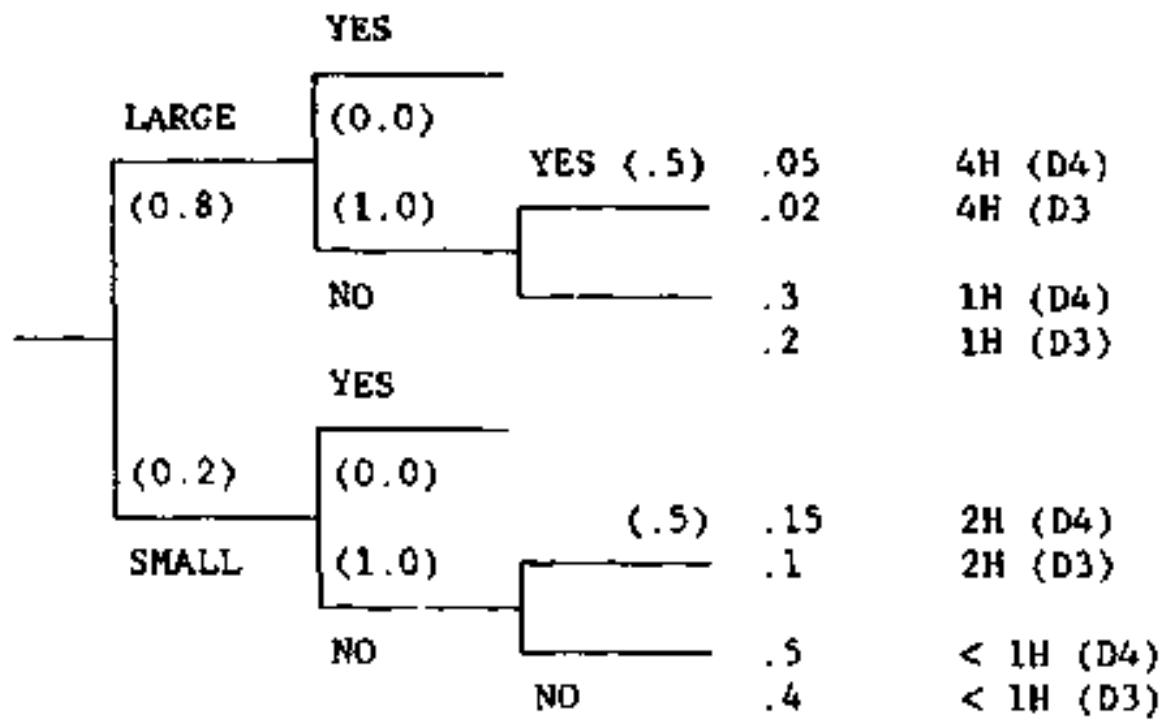


Expert E' Elleitation

\section{Is sue 1: Peech Botton Drywe 11 Heltthrough}

\section{Description of Experc_E's Rationale/Methodology}

The Expert developed an event tree containing the conditions which he felt, after his review of extant analysis and his own parametcle calculations, would be the dominant phystcal conditions that would influence the progression of the drywell liner atcack. The major analyses wete (1) MELCOR - showed low enthalpy, stratified debris, 13 oxidation, metals then metals + oxides then oxides; and (2) IDCOR MAAP-homogenized, high temperature, no cooiability, large pour (l nt/s), nostly molten, low zirconium, If no water was present, both pradictad quick fallure. With water present. MELCOR predicted no failure but MAPP predicted failure.

The primary factor affating the probabllity of failure was the conditicn of the melt wass: (a) continuous nass approaching the 1fner; or (b) dispersed mass approaching the liner. Parameters affecting this condition were (1) vessel pressure: (2) rate of pour from vessel; (3) presence of water in the reactor cavity; and (4) posslbility of FCls. The first three parameters are determined by the accident progression and the results of the in-vessel expert elicitation. The Expert defined two ranges for each parameter and then assessed a probability distrlbution or drywel1 liner thelcthrough for each of the seven resulting cases, caking into account the uncertainties within each range and other underlying parameter uncertalinties.

\section{Continuous Melt}

For a continuous mass of mat approaching the liner, the basic problem is: For what depth of naterfal and wat heat.transfer rate will drywell 1 iner temperatures exceed the inner failure temperature? The Expert performed a sensitfvity calculation using a model of the drywell liner and varying both the depth of the aelt and the heat-transfer rate. The Expert then o-sessed the effect of varlous intital conditions such as pour rate, composition, enthalpy (implies molten and temperature), and zitconium content (1mplies energy relesse due to $C C I$ ). The variables are connected by the melc sequence (1.e., a large pour of $1 \mathrm{mt} / \mathrm{s}$ will have high temperatures and be homogeneously mixed with very low zirconfum axidation; a small pour of 1 at/s will have a low tenperature and be stratified with a low zircanium oxidation).

\section{Quspersed Melt}

The Expert consfdered two nechanisns for dispersal of the melt direct contalnment heating (DCH) and FCIs. For OCH, two subconditions were consldered: (1) no water, and (2) water, like an FCI. For FCI, water must be present either in+vessel or in-pedestal. A review of FCI analyses was performed and it was determined that FCI vas fovored for large pours, and either was quencted and dispersed immediately with subsequent heatup to MCCl or only partially quenched whth irasediate MCCI. 


\section{Results of Expert E's Elleitation}

First the relatlve likelihood of the liner fallure was assessed to get an overall ranking and then the probability distrfbution for each of the seven scenatios was assessed.

The seven scenarlos are:

1. High pressure (1000 psi), water;

2. High pressure (1000 ps1), no water;

3. Low pressure ( $<200 \mathrm{ps}$ ), high pour (1 wt/s), water, FCI;

4. Low pressure $(<200 \mathrm{pst})$, high pour $(1 \mathrm{mc} / \mathrm{s})$, water, no FCI;

5. Low pressure (< $200 \mathrm{ps} 1$ ), high pour ( $1 \mathrm{mt} / 5)$, no water:

6. Low pressure (< $200 \mathrm{psi}), 10 \mathrm{w}$ pour $(.1 \mathrm{mt} / \mathrm{s})$, water; and

7. Low pressure ( $<200 \mathrm{psi})$, low pour $(.1 \mathrm{mt} / \mathrm{s})$, no water.

The relative likelihood of faflure was estimated as such: scenarios 2 and 5 were most likely, then $7,4,1$, and 3 were equally likely, followed by 6 . The total likelihood of liner fallure for each scenario was then assessed : $P_{f}(2)=P_{f}(5)=1, P_{f}(7)-1, P_{f}(4)=.5, P_{f}(1)=.05, P_{g}(3)=.04$, and $P_{E}(6)$ - $0 . P_{1}(7)$ was gregter than $P_{t}(4)$ at $1 h$ or more, equal at 10 min, and less at $2 \mathrm{~min}$. The fallure for scenarios 1 and 3 was judged to be slightly different.

The probability distributions are:

Time

$\begin{array}{cllllll}\text { Scenario } & 0 & 2 \min & 10 \mathrm{~min} & 1 \mathrm{~h} & 2 \mathrm{~h} & 10 \mathrm{~h} \\ 1 & 0 & 0.05 & 0.05 & 0.05 & 0.05 & 0.05 \\ 2 & 0 & 1.0 & 1.0 & 1.0 & 1.0 & 1.0 \\ 3 & 0 & 0.04 & 0.04 & 0.04 & 0.04 & 0.04 \\ 4 & 0 & 0.5 & 0.5 & 0.5 & 0.5 & 0.5 \\ 5 & 0 & 1.0 & 1.0 & 1.0 & 1.0 & 1.0 \\ 6 & 0 & 0.0 & 0.0 & 0.0 & 0.0 & 0.0 \\ 7 & 0 & 0.1 & 0.5 & 1.0 & 1.0 & 1.0\end{array}$

Sources of Uncertalinty

The major source of uncertainty was the rather coarse description of the Initial conditions and the effect of water on the drywell shell temperature. 


\section{Correlations with other variables}

The correlations with variables to be supplied by the $1 \pi$-vessel group or the accident sequence were consldered in che event tree decomposition. All othex variables vere considered in the uncertainty for each case.

\section{Suggested Methods for Reducing Uncertainties}

The Expert indicated that if the Initial conditions could be specified more precisely, then sone of the uncertainties could be reduced. However, as a result of the in-vessel graup resuits, the largest uncertainties come from difficulties in understanding the core-selt progreasior. in-vessel which would require an exorbitant effort to resolve for this project. 


\section{Issue 1: Peach Bottom Dryvell Meltthrough}

\section{Description of Expert F's Rationale Methodology}

Expert $F$ constructed an event cree based on the various conditions and parameters that he judged to have the most signiflcant effects based on his own and extant analysis. He then assessed ranges for these parameters based on the magnitude of the possible effects. T:e parameters are (1) pour rate-three ranges were selected (< $50 \mathrm{~kg} / \mathrm{s}, 50 \cdot 100 \mathrm{~kg} / \mathrm{s},>100 \mathrm{~kg} / \mathrm{s}$ ); (2) pressure--two ranges were selected (HI. LOW); (3) presence of water in cavicy (YES, No): (4) rype of melt--three values were selected: (oxtde, mixture, and metallic); (S) melt superheat--two values were selected (HI, LOW); and (6) 21 rconitur values wete selected (HI, LOW). In addition, the possibllity of FCI was assessed for one sase.

\section{Assumptions}

1. The pour was assured to come out fast intially and then slow down.

2. The mel: was always coolable when water was present, even with FCI, since good crusts are formed.

3. Low zirconium was 30 of total metalilc content of melt.

4. Decay heat was not Inportant.

5. Pours separated by more than 20 min should be treated as separate.

6. The total mass ejected frow vestel that begins to threaten che liner (necassary to get 5-ca depth) is 100 tons (45 metric tons).

7. With water present the total mass is not important; without water It's not important if the oelt is oxidic.

\section{Resulte of Expert_E's Elicitation}

The Expert's results are glven on the next page. 


\begin{tabular}{|c|c|c|c|c|c|c|c|c|}
\hline \multirow[b]{2}{*}{ Scenaris } & \multicolumn{2}{|c|}{ Pour } & \multirow[b]{2}{*}{ Water } & \multirow[b]{2}{*}{ Type } & \multicolumn{3}{|l|}{ Super } & \multirow{3}{*}{$\frac{\text { Prob. }}{.001}$} \\
\hline & Rate & Press & & & Heat & $2 x$ & FCI & \\
\hline 1 & $<\$ 0$ & $\mathrm{H}, \mathrm{L}$ & $Y$ & - & - & - & . & \\
\hline 2 & $<50$ & $\mathrm{H}, \mathrm{L}$ & $n$ & OX & - & - & - & .001 \\
\hline 3 & $<50$ & $\mathrm{H}, \mathrm{L}$ & $\mathbf{N}$ & MIX & $L$ & $=$ & - & .001 \\
\hline 4 & $<50$ & H, L & $\mathbf{N}$ & $\operatorname{MIX}$ & H & $\cdot$ & $\cdot$ & .01 \\
\hline 5 & $<50$ & $\mathrm{H}, \mathrm{L}$ & $\mathbf{N}$ & MET & L & 1 & . & .001 \\
\hline 6 & $<50$ & $H, 1$ & N & NET & L & H & + & .05 \\
\hline 7 & $<50$ & $H_{t} \mathbf{L}$ & $\mathbf{N}$ & MET & H & $\mathbf{L}$ & - & .05 \\
\hline 8 & $<50$ & H, L & $\mathbb{N}$ & MET & H & $\mathbf{H}$ & - & .1 \\
\hline 9 & $50-100$ & $H, L$ & $\mathbf{Y}$ & $\mathrm{OX}$ & - & . & - & .001 \\
\hline 10 & $50-100$ & $\mathrm{H}, \mathrm{L}$ & $\mathbf{Y}$ & MET & - & - & - & .01 \\
\hline 11 & $\$ 0.100$ & $\mathrm{H}, \mathrm{L}$ & N & $\mathrm{ox}$ & - & $\cdot$ & $\cdot$ & .001 \\
\hline 12 & $50-100$ & H. L & $\mathbf{H}$ & MIX & I. & $\cdot$ & $\cdot$ & .001 \\
\hline 13 & $50 \cdot 100$ & $\mathrm{H}, \mathrm{L}$ & $\mathbf{N}$ & $\operatorname{mrx}$ & $\mathrm{H}$ & - & - & .1 \\
\hline 14 & $50 \cdot 100$ & $\mathrm{H}, \mathrm{L}$ & $N$ & MET & L & L & . & .1 \\
\hline 15 & $50-100$ & H.L & $\mathrm{N}$ & MET & $\mathbf{L}$ & $\mathbf{H}$ & - & .2 \\
\hline 16 & $50 \cdot 100$ & H, L & $\mathbf{N}$ & MET & H & $\cdot$ & $\cdot$ & .5 \\
\hline 17 & $>100$ & H, L & $\mathbf{Y}$ & $o x$ & L & - & - & .01 \\
\hline 18 & $>100$ & H, L & $\mathrm{Y}$ & ox & H & - & . & .05 \\
\hline 19 & $>100$ & $\mathrm{H}, \mathrm{L}$ & $\mathbf{Y}$ & MIX & $\mathbf{L}$ & - & - & .02 \\
\hline 20 & $>100$ & H, L & $\mathbf{Y}$ & MIX & $\mathbf{H}$ & $\cdot$ & - & .1 \\
\hline 21 & $>100$ & $H_{+} \mathrm{L}$ & $\mathbf{Y}$ & MET & $\mathbf{L}$ & $\cdot$ & - & .05 \\
\hline 22 & $>100$ & H, L & $\mathbf{Y}$ & MET & H & - & .95 & .05 \\
\hline 23 & $>100$ & $\mathrm{H}, \mathrm{L}$ & $\mathbf{Y}$ & MET & H & - & .05 & .3 \\
\hline 24 & $>100$ & L & $\mathbf{N}$ & $o x$ & L & - & - & .1 \\
\hline 25 & $>100$ & L & $\mathrm{N}$ & ox & H & - & - & .5 \\
\hline 26 & $>100$ & I. & $\mathrm{N}$ & $M$ & I & L & - & .2 \\
\hline 27 & $>100$ & L & $\mathrm{N}$ & M & $\mathbf{L}$ & $\mathbf{H}$ & - & .5 \\
\hline $2 B$ & $>100$ & $\mathrm{~L}$ & N & $M$ & $\mathbf{H}$ & - & $=$ & .999 \\
\hline 29 & $>100$ & $\mathbf{H}$ & $\mathrm{N}$ & $0 x$ & $L$ & - & . & .2 \\
\hline 30 & $>100$ & $\mathbf{H}$ & $N$ & $0 x$ & H & - & - & .999 \\
\hline 31 & $>100$ & H & $\mathrm{N}$ & M & - & - & - & .999 \\
\hline
\end{tabular}

The Expert judged that the probability of fallure for high zirconiun pours was twice that of low zirconlurn pours except for the high pour case where it was 2,5 times.

The tlae of fallure was assessed independently and depended on whether the melt was oxidic or metallic, and whether water was present. The start cime was from the point of $S \mathrm{co}$ of cortum (sbout 100 tons of corfur). 


\begin{tabular}{|c|c|c|}
\hline Case & 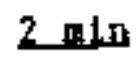 & 10 min \\
\hline OxIdIc, no water & 0.1 & 1.0 \\
\hline Metallic, no water & 1.0 & 1.0 \\
\hline Oxidic, water & 0.03 & 0.3 \\
\hline Metallic, wator & 0.3 & 1.0 \\
\hline
\end{tabular}

\section{Sourcess of Uncertainty}

The major source of uncertainty was the rather coarse description of the intelal condictons and the effect of water on the drywell shell cemperature.

\section{Correlations with Other Variables}

The correlations with variables to be supplied by the in-vessel group or the accident sequence were considered in the event tree decomposition. All other variables were considered in the uncertainty for each case.

\section{Sugrested Hethods for Reducing Uncertaincy}

The Expert indicated that if the initial conditions could be specified more precisely, then some of the uncertainties could be reduced. However, as a result of the in-vessel group results, the largest uncertainties cone from difficulties in understanding the core+melt progression in-vessel which would require an exorbitant effort to resolve for this project. 
6.2 MCCI Issue 2: Grand Gulf Pedestal Erosion

\section{Summary and Aggregation of MCCI Is sue 2 Grand Gulf Pedestal Erosion}

Experts consulted; Dave Bradley, Sandia National Laboratories; Mike Corradini, University of Wisconsin; George Greene, Brookhaven National Laboratory; Mike Hazzan, Stone \& Webster; Mujid Kazimi. Massachussetts Institute of Technology; Raj Sehgal. Electric Power Research Institute.

\section{Issue Description}

The exparts were asked to characterize the uncertainty in the radial erosion of concrete in the Grand Gulf reactor vessel pedestal due to the interaction of core debris with the concrete. In addition, they were asked to quantify the depth of thermal penetration ahead of the erosion front and the probability that radial erosion occurs above the drywell floor.

The suggested scenarios were characterized by six parameters. These six parameters and the varlous levels associated with each parameter are presented in the tablo below

\section{Suggested Scenario Parameters}

\section{Scenario Parameters}

1. Fallure Hode

2. Reactor Pressure Vessel (RPV) Pressure

3. Debris Superheat

4. Debris Unoxidized Metal Upon Egress From Vessel

5. Water on Drywell Floor

\section{Levels}

a. Plop ( $>40$ of core released at vessel breach)

b Penetration failure of vessel

a. High (1000 psia),

b. Low (200 psia)

a. High (> $100 \mathrm{~K})$

b. Low $(<100 \mathrm{~K})$

a. High metal - 65 zirconjum equivalent initially in debris on concrete (50 to 80 )

b. Low metal - 35 zirconium equivalent initialiy in debris on concrete $(20$ to SOr)

a. Yes (replenished)

b. No (not replenished) 
The experts were encouraged to select only those scenario parameters which they felt were important to the issue.

After discussion, the experts cectded to consider debris flow rate from the vessel rather than fallure mode (the flow rates considered were $<50 \mathrm{~kg} / \mathrm{s}$, 50 to $100 \mathrm{~kg} / \mathrm{s}$, and $>100 \mathrm{~kg} / \mathrm{s}$ ). They also dectded that the decay power level and the RPS pressure did nor impact the scenario enough to consider as additional parameters.

\section{Sumpary of Experts' Bationsle/Methodology}

This 1ssue is coupled with the Grand Gulf pedestal failure issue. considered by the Structural Response Experc Panel. The structural response experts characterlzed the pedestal fullure probability in terns of the thermal front that precedes the debris/concrete erosion front. All six MCCl experts agreed that the theral front would penetrate the conctete a few centimeters ahead of the erosion front. For practical purposes, the erosion front and the thermal front were considered as the same front.

Expert A considered varlation in the following parameters while addressing the Grand Gulf pedestal erosion 1ssue: amount of 21 rconlum, amount of superheat, and amount of cavity water. Expert A based his rationale on CORCON calculations that he performed and on a review of pertinent experimental results. He felt that the parameter that was most 1mportant to this lssue vas the amount of unoxidized metal in the debris. He explained that the effects of zirconitur oxidation, the amount of superheat, and the presence of water would be Important primarily during the early stages of the pedestal erosion (during the first several hours). Expert $A$ felt that the zirconium would be depleted in 2 to $2.5 \mathrm{~h}$.

Expert A indicated that the effect of pour rate on pedestal erosion was important shortly after vessel breach. He felt that erosion during this time regime was governed by zircontum oxidation. which was a slower process than the release of debrts from the RPV. He concluded that the effect of different pour rates would not be very important to the longer term erosion results. He thought that the effect of decay heat on pedestal erosfon was minor and he did not consider variations of that parameter.

Expert B assessed the cases in which the vessel failed while at low pressure. Sle folt that the high pressure ejection scenarios would result In direct containment heating (DCH) and should be considered elsewhere. fxptr: persidered the effeet on pedestal erosfon of large and small pours frote the prossure vessel and the effect of water in the pedestal cavily for 
the low pressure cases. The $\mathrm{size}$ of the pour defines the propertes of t'e core debris. Expert B described a large pour as a homogenous pour witt $s$ high enthalpy, a high temperature and a very low amount of zirconi 1 oxidation. He described a small pour as a stratffied port ( $f_{\text {e }}$. net 1 cones out first followed by the oxides) with an enthaipy lower than that for the high pour, a temperature just above the liquidus temperature, and a low amount of zirconiun oxidation (although higher than that for the high pour). For the large pour cases the only effect cavity water had was that it made fuel coolant interactions (FCls) possibla. The Expert thought the FCI case would eventually degenerate into the case without the FCI with an additional sime $1 \mathrm{ag}$ of about $1 \mathrm{~h}$. The effect of water in the small pour cases the was to partially quench the debris.

Experc $B$ performed bounding calculations based on a hand calculation scheme presented at the introductory neeting by Marty Plys of Fal. He assuned the sideward and downward erosion rates were equal and that the power fraction 1 toto the concrete was 0.5 (e.g., 503 of the energy released from the debris enters che concrete and the other SOr is released from the top of the debris pool). He based his calcuiations on a limestone/common sand concrete. He felt the rebar in the concrete would have a minor effect on erosion rate and was not modeled in his calculations. For the lower bound the Expert used the IDCOR assumption that the core debris is initially quenched and then is reheated by decay heat.

Expert B indicated that there were two rime regimes important with regard to the erosion rate. During the first tape regine the zirconium is oxidized and the concrete erodes rapidly. After the zirconilum has oxidized. the erostion rate is governed by the decay heat and the oxidacion of iron. During this time regime the smount of concrete sblated is essentially proportional to the decay heat. The erosion rate during this second time regime is slow compared to the first time reglae erosion rate.

Expert $C$ based his distributions on a review of pertinent experimental and analyctical results. He felt that no erosion would occur above the drywell floor since the amount of debris would not reach that belekt. Radiation would spall off a little concrete ab. 'e that height, but would quickly hit rebar and spallation would cease.

MCCI was judged to cease at approximately $10 \mathrm{~h}$. The volune of the eroded material was judged to be a function of the amount of unoxidized metals available in the debris. Water was assuned to delay the erosion process. but not to otherwise alter the erosion process.

Expert D based his treatment of the issue on experimental and analytical results which he had performed or reviewed in the past. Expert $D$ judged the volume of the eroded material to be a function of the amount of unoxidized metals ava!lable in the debris. The concrete was assessed to erode at a $1: 1$ rate fit the radial and vertical directions. Expert D felt that the presstice of zirconium enhaticed radial erosion relative to irticis after the zlrconium has burned off, the rate of erosion will detcense to about $1 / 4$ th of the original rate. The presence of rebar will difute the melt and kesp it liquid louger. Water will not queneh the febris and, therefore, will not affect the results much. 
Expart E stated that about 45 MW of energy will be generated by the oxidation of zirconiun. About $20 \mathrm{~kW}$ will be generated after the zirconium oxidation ceases. After the zirconius oxidation ceases, the debris vill behave $11 \mathrm{ke}$ hot solid; it will continue to orode through the concrete in the dowtyard direction, but not in the radial direction.

Expert E felt that the zirconium oxidation would cease at 6 h for a limestone concrete/debris interaction. This would increase to 8 h for limestone/common sand concrete. Oxidation of chromiun and Iron has a minor impact on the scenario. The Expert felt that there could be major uncertainties in the time to zirconium burnout, but that the total concrete eroded would not be altered significantly by changes in zirconlun oxidation timing. He also felt that the volumetric ecosion rate is conserved; if the radial erosion was underestimated, the axial erosion would have been overestinated. He felt that nost of the effects of superbeat, water, and zitconiun could be represented by simple shifts in the timing of the CCI.

Expert. F thought that the volune of concrete eroded at the point that radioactive aerosol release due to CCI ceases vas a function of the amount of unoxidtzed metal in the debris. The presence of water and the flow rate of the debris fron the vessel were judged to Impact the penetration by changing the duration of CCI. The anount of zirconiur left in the debris was felt to be directly proportional to the final valume of concrete eroded. The initial superheat In the debris and the inteial level of decay heat in the debris vere considered to be unimportant to the final volune eroded. Expert $F$ felt that the perlod of 1nterest of the CCI would last for $8 \mathrm{~h}$.

\section{Hethod of Aerregation}

In order to acconmodate all of the intornation recelved in the six elicitations, we had to consider 24 scenarios (Table 6-1). For each scenarto we interpolaced or extrapolated the information that each Individual expert gave us to fill out a COF for each of the 24 scenarios; tables of curulative probablltties for radial erosion depths for different times wer then produced. There are tables representing the probability of different radial erosion depths at $1,3,6$, and $10 \mathrm{~h}$.

Table 6-1

Complete Set of Scenarios for Constderation in AgBregacion

A) Low flow rate $(<50 \mathrm{~kg} / \mathrm{s})$

AI) High Mecal, High Superheat, Water

A2) High Metal, High Superheat, No Water

A3) High Metal, Low Superheat, Water

A4) High Heta1, Low Superheat, No Wacer

A5) Law Metal, High Superheat, Water

A6) Low Metal, High Superheat, No Water

A7) Low Metal, Low Superheat, Water

AB) Low Metal. Low Superheat, No Water 
Table 6.1 (continued)

Medium flow race $150 \mathrm{~kg} / \mathrm{s}<\mathrm{flow}$ rate $<100 \mathrm{~kg} / \mathrm{s})$

B1) High Metal, High Superheat, Water

B2) Hlgh Metal, High Superheat, No Water

B3) H1gh Metal, Low Superheat, Water

B4) High Metal, Low Superheat, No Water

B5) Low Metal, High Superheat, Water

B6) Low Meta1, High Superheat, No Water

B7) Low Hetal. Low Superheat, Later

B8) Low Metal, Low Superheat, No Water

High flow rate ( $>100$ kris--includes plop and HPME)

C1) High Metal, High Superheat, Hacer

C2) High Metal, High Superheat, No Water

C3) H1gh Metal, Low Superheat, Water

c4) High Metal, Low Superheat, No Water

C5) Low Metal, High Superheat, Water

c6) Low Metal, Htgh Superheat, No Wacer

C7) Low Meta1, Low Superheat, Water

c8) Low Metal, Low Superheat, No Water

The rationale for considering the radial erosion depth and not the axial erosion depth is as follows: the structural experts stated that axial erosion depths were not ixportant for this issue. The radial eroston depths ald the temperature of the outer rebar group were considered by the structural expert. to be the critical factors in evaluating pedestal fallure. The HCil group staced unanimously that the temperature front would precede the erosion face by only a few centimeters.

The observation times were chosen on the basis of CCI source term releases: at $1 \mathrm{~h}$ the aerosol generation from the CCI 19 most vigorous-a suppression pool bypass at this point would be extrenely important to risk; at $3 \mathrm{~h}$ large fraction of most radionuclides (except tellurlun) have been already been released to the suppression pool ( $1 \mathrm{f}$ no suppression pool bypass has occurred): at $6 \mathrm{~h}$ and $10 \mathrm{~h}$, most of the radionuclides have been released to the suppression pool, but tellurium releases may still be occurring.

Many of the distributions that resulted from averaging the experts' results were very similar. To simplizy the accldent progression event tree (APET), an ANOVA analysis (see description of ANOVA in Section 5.6) was performed to reduce the number of cases. Distributions for the following seven groups were inplewented into the event tree:

Group 1 .. Water, high metal, high superheat (all flow rates)

Group 2 . Water. high metal, low superheat and water, low metal, high superheat (all flow rates) 
Group 3 -. Water, low metal, low superheat (all flow rates)

Group 4 -. No water, low flow and

no water, mediun flow, low metal

Group 5 -. No water, medium flow, high metal

Group 6 -. No water, high flow, high metal

Group 7 -- No water, high flow, low metal

Speciflc Assumptions Made to Aggcegate Regults

\section{Expert A:}

The results given in the elicitation were applied to all pour rates.

\section{Expert B:}

1. Case 3 was used to represent all scenarlos in which a replenishing water supply was ptesent.

2. Case 1 was used for $a 11$ of the $B$ and $C$ scenarios defined in Table 6-1 (the medtum and bigh flow rate scenarios) in which a replenishing water supply was not present.

3. Case 2 was used for all of the A scenarios defined in Table 6-1 (the low flow rate scenarios) in which a replenishing water supply was not present.

4. The uncertainty ranges were obtained through inspection of the figure provided in the raw elicitation notes. Before the change in slope in all three curves, the uncertainty range (from the .01 quantile to the .99 quantile) was assumed to be $\pm 10 \mathrm{~cm} \mathrm{-.} \mathrm{after} \mathrm{the} \mathrm{change} \mathrm{in} \mathrm{slope,}$ the uncertainty range was assumed to be $\pm 5 \mathrm{~cm}$.

5. The magnttude of the cadial erosion depths wece assumed to be equal to the magnitude of the axial erosion depths.

\section{Expert C:}

1. Used the redian and the bounds given by the Expert to represent the median and the , 01 and .99 quantiles for all scenarios.

2. Interpolated for values at $3 \mathrm{~h}$.

Expert D:

I. The values provided by the expert [or the large four and small pour cases were used to represent the $A$ and 13 scenarios defined in At tachent 1 (the low flow race and the medium flow ratc sconartos.) The values provided by the Expert for the plop cases wore used to represent the $C$ scenartos defined in Attachene 1 (Lhe high flow rate cases, ) 
2. An uncertainty interval (.01 and .99 quantiles) of $\pm 5 \mathrm{~cm}$ for radial erosion values of less than $100 \mathrm{cto}$ and an interval of $\pm 10 \mathrm{ch}$ for radial erosion values of greater than or equal to $100 \mathrm{~cm}$ was assumed.

Expert E:

All assunations are explained $i n$ the elicitation writeup.

Expert F :

All assunptions are explained in the ellcitation writeup.

\section{Angregated Results}

Table 6-2

Average of 24 Cases

Cumulative Probabflity of Different Radial Erosion

Depths at Different Times

(Radial Erosion Depths are in cn)

\begin{tabular}{|c|c|c|c|c|c|c|c|c|c|c|c|c|}
\hline \multirow[b]{2}{*}{ Sconeriso } & \multicolumn{6}{|c|}{1 Hour } & \multicolumn{6}{|c|}{3 Howres } \\
\hline & 11 & 251 & 301 & $73 x$ & g97 & & 12 & 251 & 1 & sal & 74: & e9x \\
\hline Al & 00 & 50 & 166 & 235 & ath 7 & & 0.0 & 16.5 & & 31.4 & $5+.6$ & 69.5 \\
\hline *2 & 35 & 122 & 21.3 & 284 & 583 & & 110 & 332 & & 533 & 632 & 105 \\
\hline 13 & 00 & +1 & 134 & 217 & 406 & 6 & 30 & 11.2 & & 30.2 & 545 & 605 \\
\hline A4 & 2 & 10.5 & 202 & 283 & 552 & 2 & 82 & 207 & & 52.0 & 521 & 783 \\
\hline AS & 0.0 & 53 & 111 & 195 & 345 & 5 & 0.0 & 238 & & $2+2$ & 459 & 6) \\
\hline A6 & 35 & 111 & 18 & 239 & 30.1 & & 11.0 & 265 & 5 & 413 & 506 & 602 \\
\hline A 7 & 00 & 35 & 47 & 195 & 34: & 5 & 0.0 & 100 & 0 & 200 & 450 & 67.7 \\
\hline AB & 2 & 00 & 170 & 22 & 301 & 1 & 8.2 & 231 & 1 & 37.6 & 580 & 602 \\
\hline 31 & 00 & 50 & 167 & 23.7 & 50.2 & & 0.0 & 16 & $\$$ & 31 B & ss 3 & 715 \\
\hline$B 2$ & 33 & 146 & 225 & 905 & 592 & $z$ & 11.9 & 33 & 6 & 57.2 & 67.1 & Bt 4 \\
\hline $\mathbf{B 3}$ & 00 & 41 & 13.4 & 219 & 302 & 2 & 00 & 112 & $z$ & 30.3 & 352 & 115 \\
\hline Bt & 24 & 110 & 213 & 281 & 575 & 5 & e 2 & 302 & 2 & 54.1 & 657 & ot \\
\hline B5 & 00 & $\$ 3$ & 111 & 106 & 35: & 5 & 0.0 & 13 & 1 & 245 & 467 & 677 \\
\hline 86 & 35 & 113 & 195 & $2+6$ & 407 & 7 & 119 & 26 & 9 & 1. B & $83 \mathrm{~B}$ & 84: \\
\hline By & 00 & 36 & 7 & 105 & 35 & 5 & 0.0 & 10 & 0 & 211 & 467 & 67.7 \\
\hline B8 & 24 & 60 & 179 & 237 & 407 & 7 & 82 & 23 & + & 370 & 63 & 84.0 \\
\hline c1 & 00 & 80 & 178 & 208 & so & 2 & 00 & 16 & 5 & 34.8 & 537 & 2000 \\
\hline C2 & 35 & 14.8 & 260 & $3+3$ & 592 & 2 & $11 \%$ & 33 & 6 & 573 & 780 & 2000 \\
\hline$c 3$ & 00 & 43 & 13 & 20 & 502 & 2 & 00 & 112 & 2 & 30.3 & 55,3 & 1000 \\
\hline$c 4$ & 24 & 110 & 240 & 322 & 5): & 3 & 2 & 302 & 2 & 341 & 72 & 1000 \\
\hline c5 & 00 & 53 & 11 & 23 & $37:$ & 3 & 00 & 138 & 9 & 245 & 167 & 1000 \\
\hline$C 6$ & 35 & 113 & 213 & 20 & 403 & 7 & 11.0 & 24 & 9 & 410 & 750 & 1000 \\
\hline c) & 00 & 36 & B 7 & 25 & 375 & 5 & 00 & 10 & 0 & 21.1 & $46=$ & 1000 \\
\hline 68 & 24 & 00 & 108 & $2 \theta$ & 407 & 7 & 62 & 23 & 4 & 370 & Is 0 & 1000 \\
\hline
\end{tabular}


Table 6-2 (continued)

\begin{tabular}{|c|c|c|c|c|c|c|c|c|c|c|c|c|c|c|c|}
\hline \multirow[b]{2}{*}{ sempristo } & \multicolumn{7}{|c|}{5 Houre } & \multicolumn{8}{|c|}{ 10 Honst. } \\
\hline & $1 \mathbf{1}$ & $25 x$ & sont & $25 \pi$ & & 091 & & 11 & & 252 & & 502 & 73 & & 991 \\
\hline A1 & 160 & 351 & 537 & 816 & & 1340 & 0 & 361 & & 658 & & 987 & $1 \mathrm{Lt}:$ & 5 & 1900 \\
\hline$A 2$ & 327 & 551 & es & 106 & & $13+0$ & 0 & 100 & & 730 & & 1092 & 128 & 8 & 1580 \\
\hline$A 3$ & 160 & 343 & 524 & 91 & & 1340 & 0 & 361 & & 64 & & 975 & 112 & 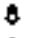 & 1300 \\
\hline An & 306 & 546 & 820 & 106 & & 134 & 0 & 400 & & 721 & & 1082 & 127 & 3 & 1580 \\
\hline AS & 160 & 28 & 432 & 150 & & 134 & 0 & 26 & & $50 \div$ & & 816 & 108 & 3 & 1550 \\
\hline $\mathrm{A \theta}$ & 24 & 439 & 665 & 106 & & 134 & 0 & 30 & & 586 & & 696 & 122 & 6 & 1500 \\
\hline A) & 160 & 283 & 422 & 750 & 0 & 134 & 0 & 250 & & 40 & 8 & 507 & 109 & 3 & 1590 \\
\hline$A B$ & 240 & 435 & $65 s$ & 106 & & 134 & 0 & 303 & & 502 & & a8 0 & 122 & 8 & 1580 \\
\hline B1 & 160 & 354 & 561 & 62 & & 134 & 0 & 300 & & 663 & & 008 & 114 & 5 & 159.0 \\
\hline B2 & 32 & $\$ 55$ & 842 & 100 & 0 & $13+$ & 0 & 400 & & 730 & 0 & 1002 & 120 & $\mathrm{~s}$ & 1300 \\
\hline B3 & 160 & 345 & 527 & 82 & 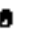 & 134 & 0 & 30 & & 65? & 3 & at. 7 & 112 & 8 & 1300 \\
\hline$B 4$ & 306 & 567 & B2 & 1088 & a & $13+$ & 0 & 40 & & 72 & 1 & 1082 & 125 & 3 & 1500 \\
\hline 13 & 160 & 291 & 435 & 750 & 0 & $13 *$ & 0 & 200 & & 510 & 0 & 32,6 & 108 & 3 & 150.0 \\
\hline BS & 248 & it 2 & 672 & 108 & 9 & 134 & 0 & 315 & & 5日: & 5 & DQ 6 & 126 & 3 & 1590 \\
\hline B3 & 160 & 285 & 125 & 750 & 0 & 134 & 0 & 28.0 & & $30:$ & 5 & 007 & 100 & a & 1500 \\
\hline Bs & 243 & 439 & Bs 3 & 208 & $\theta$ & 134 & 0 & 31 & & Se & 0 & ab $\mathrm{B}$ & 126 & 5 & 1580 \\
\hline C1 & 160 & 35 & 541 & $8 \mathbf{2}$ & $\mathbf{g}$ & 134 & 0 & 30 & & 66 & 3 & D9 8 & 114 & 5 & 1590 \\
\hline $\mathrm{c} 2$ & 326 & $5 \$ 5$ & 由 & 209 & 9 & 134 & 0 & 100 & & 73 & 0 & 1092 & 129 & 8 & 1500 \\
\hline $\mathrm{C} 3$ & 160 & 345 & 527 & 02 & 8 & 134 & 0 & 39 & 4 & $69 ?$ & 3 & 虾 7 & 122 & 8 & 1500 \\
\hline C4 & 306 & 547 & 826 & 108 & $\boldsymbol{\theta}$ & 134 & 0 & 400 & 0 & 72 & 1 & 2082 & 129 & 5 & 1590 \\
\hline Cs & 180 & 201 & 435 & 75 & 0 & 134 & 0 & 2B 0 & 0 & 51 & a & 816 & 108 & $\$$ & 1590 \\
\hline$C 6$ & 240 & 142 & 672 & 100 & $\mathbf{s}$ & 134 & 0 & $31=$ & 5 & sg & 3 & 10 6 & 126 & 5 & 1500 \\
\hline C) & 160 & 205 & 425 & 75 & 0 & 194 & 0 & 20 & 0 & 30 & 5 & 807 & 108 & 3 & 1500 \\
\hline $\mathrm{Ce}$ & $2+3$ & 439 & 665 & 100 & 8 & 134 & 0 & 31 & 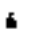 & 50 & 0 & Be 8 & 126 & 5 & 1300 \\
\hline
\end{tabular}

Table 6-3

Average of 7 Gases

Cumulative Probability of Different Radial Erosion Depths at Different Times

(Redial Erosion Depths are in $\mathrm{cm}$ )

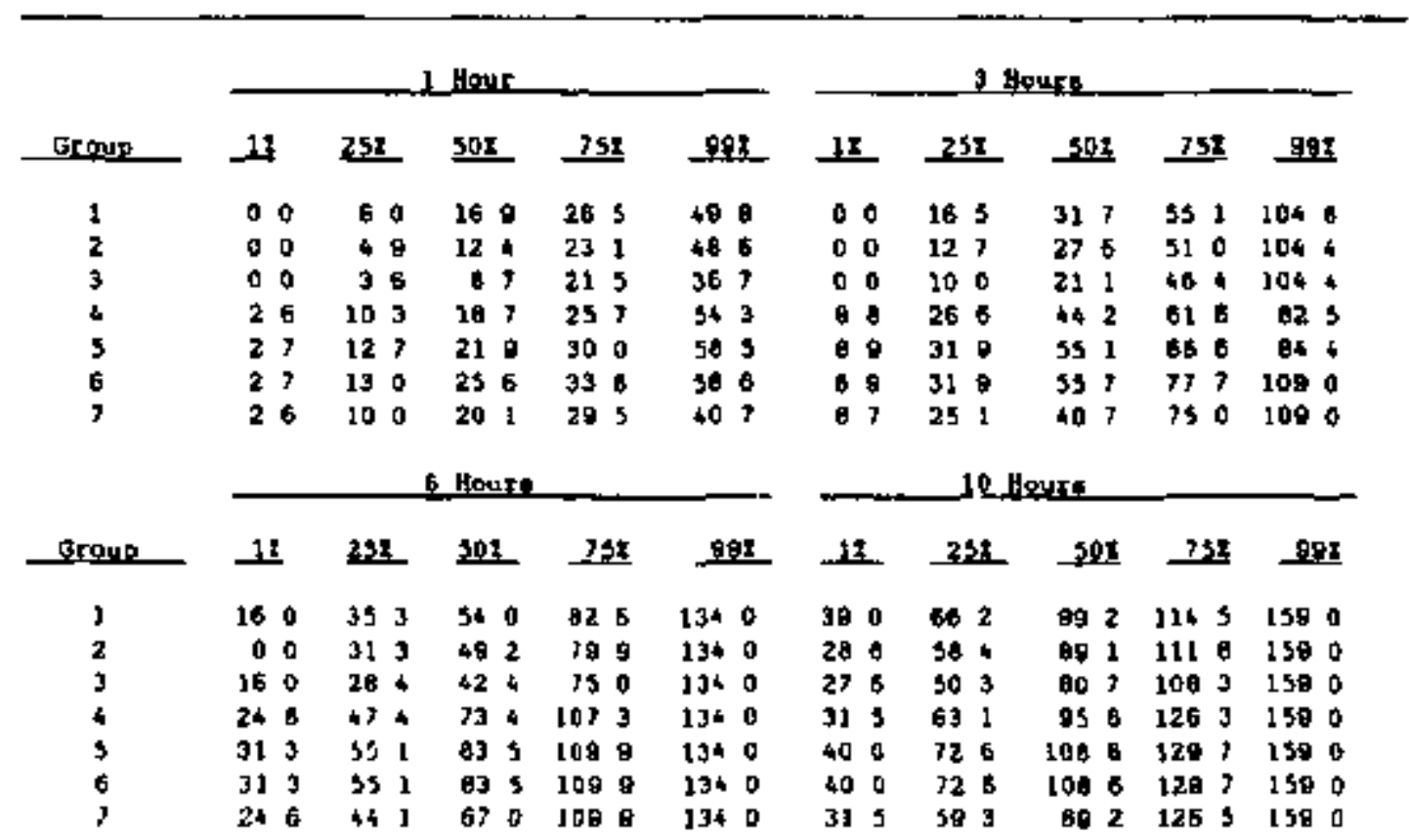



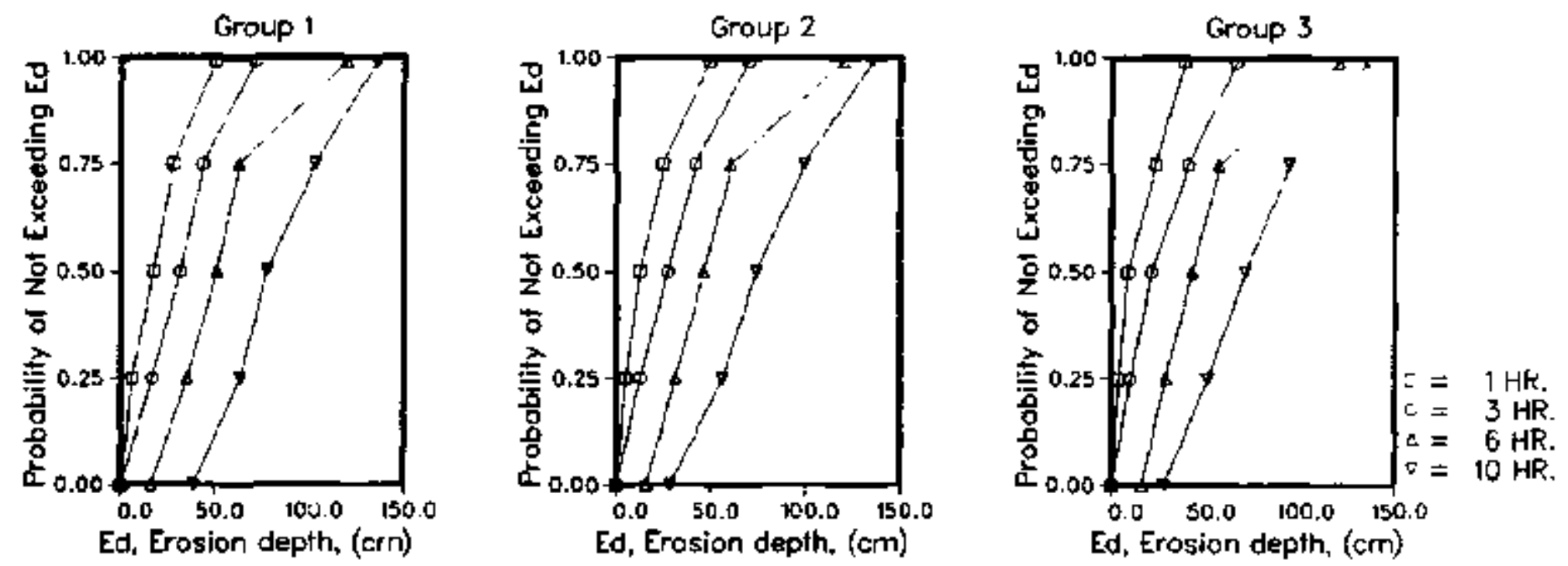

$\stackrel{0}{i}$
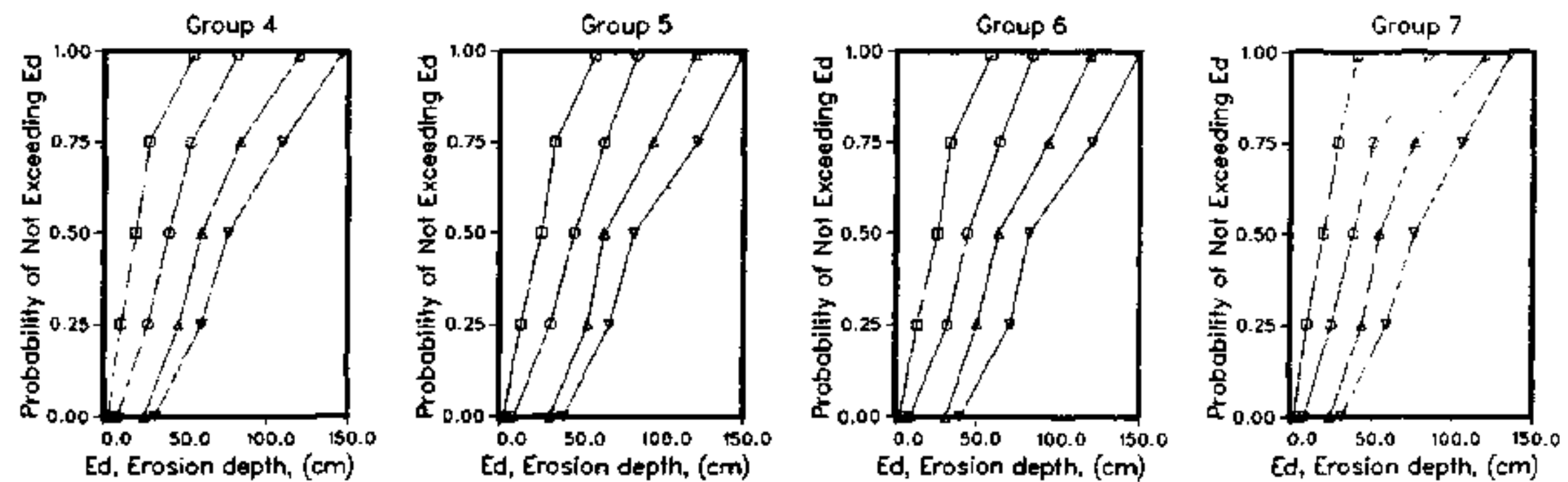

Eigure 6.1. Aggregation of MCCI Issue 2. Cumulative Probabilty of Different Radial Erosion Depths at Different Tímes. 
Individual Elicitations for MCCI Issue 2 


\section{Expert A's Elicitetion}

\section{Isave 2: Padestal Erosion at Grand Gulf}

\section{Description of Expert A's Rationaledyethodology}

The scenario parameters that the Expert considered were amount of zirconfun, amount of superheat, and cavity water. The Expert based his numbers on the CORCON calculations that he performed and on the review of pertinent experimental results. The Expert felt that the most important parameter was the amount of unoxidized metal in the debris. A high level of unoxidized metal corresponds to approxinately 80 t unoxidized zirconium, and a low level corresponds to 20 unoxidized zirconiun. He indicated that the effects of zirconium oxidation, the amount of superheat, and the presence of water would be primarily inportant during the early stages of the pedestal erosion (first several hours). The Expert estimated that the $z$ frconfun would be depleted in 2 to $2.5 \mathrm{~h}$. The low zirconiun cases will have early and late erosion depths which are 50 and 20 of the high zirconium ceses, respectively. The Expert thought that the presence of watez would have a 50 effect in the early stages and would have an overall effect of 10 to 20 .

The Expert 1ndicated that the effect of pour rate on pedestal erosion is only important shortly after vessel breach. However, he felt erosion during this tine regiwe was governed by zirconium oxidacion which occurs more slowly than the pour rate. Thus, the Expert concluded that effects of pour rate would not be very laportant. In addition, he thought that the effect of decay heat on pedestal erosion was minor and, thus, did not consider it as a parameter.

The Expert stated that the location of naxime radial erosion would occur 1 to 1.5 above the pedestal floor. The drywell floor is approxinately 1.9 in above the pedestal floor. Thus, the Expert concluded that signiflcant radial exosion would not occur above the drywell floor.

It was also the opinion of the Expert that the thetwal front would only penetrate into the conctete a few centlmeters ahead of the erosion front. The thickness of the pedestal wall 1s approximately $1.75 \mathrm{a}$ and, therefore. in the context of this issue, the thermal front can be characterized by the erosion front.

\section{Results_of Expent A's Elification}

The Expert provided cumulative probabilities for various pedestal erosion depths at $1,3,6$, and $10 \mathrm{~h}$ for the high unoxidized petal case with high and low superhest. These two distributions will be referred to as the base distributions. The erosion depth accounts for both ablation and thermal penetration (the theraal penetration is only a couple of centimeters ahead of the ablation front). To get the rewaining distributions (low zirconfum cases and water cases) the base distributions are reduced to sccount for the effects the parameters have on the erosion depth. A low level of $z$ irconicum reduces the bage distribution erosion depths by $50,40,25$, and 
20, at $1,3,6$, and $10 \mathrm{~h}$, respectively. Stallarly, the presence of water reduces the base distribution erosion depths by $50,40,25$, and 20 at 1 , 3. 6, and $10 \mathrm{~h}$, ranpectively. There are elght cases sssociated with the three scenario paraneters. These cases are dencribed in Table A-l. The base distribution: (Cases 1 and 3 ) are presented in Table A.2. The distributions for the ight caves ar presented in Table A-3.

Table A-1

Cane Descriptions

\begin{tabular}{|c|c|c|c|}
\hline Cane & Unoxidized $f \in t a l$ & Superheat & Water \\
\hline 1 & High & H1gh & No \\
\hline 2 & HIgh & High & Yes \\
\hline 3 & H1 gh & Low & Mo \\
\hline 4 & H1 gh & Los & Yes \\
\hline 5 & Low & High & No \\
\hline 6 & Lov & H1gh & Yes \\
\hline 7 & Low & Lov & No \\
\hline 8 & Lov & Low & Yes \\
\hline
\end{tabular}

Table A-2

Base Distributions - Erosion Depth Probebilities for High Level of Unoxidlzed Metal

\begin{tabular}{lcc} 
& \multicolumn{2}{c}{ Erogion Depth (n) } \\
\cline { 2 - 3 } Probability & Low Superheat & High_Superheat \\
& $1 h^{*}$ & \\
0.01 & & \\
0.25 & 0.05 & 0.15 \\
0.50 & 0.15 & 0.30 \\
0.75 & 0.25 & 0.40 \\
0.99 & 0.35 & 0.50 \\
& 0.40 & 0.60
\end{tabular}

$\begin{array}{lll}0.01 & 0.20 & 0.30 \\ 0.20 & 0.35 & 0.40 \\ 0.50 & 0.50 & 0.55 \\ 0.75 & 0.55 & 0.65 \\ 0.99 & 0.65 & 0.80\end{array}$


Table A-2 (continued)

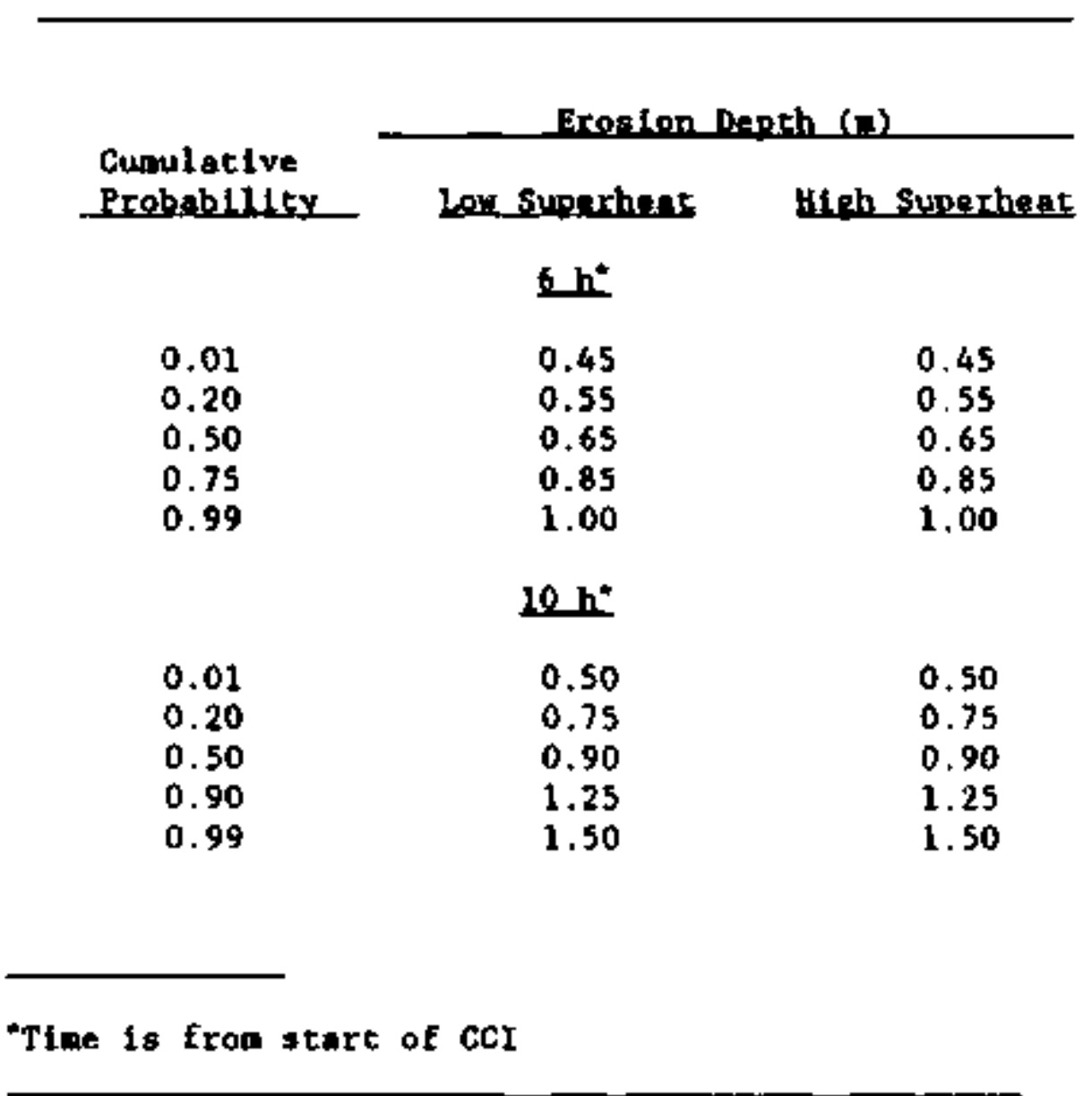

Table A-3

Pedestal Radial Erosion Depths (w)

\begin{tabular}{|c|c|c|c|c|c|}
\hline \multirow[b]{2}{*}{ Case } & \multicolumn{5}{|c|}{ Curulative Prababulities } \\
\hline & 0.01 & 0.25 & 0.50 & 0.75 & 2.99 \\
\hline \multicolumn{6}{|c|}{1 h } \\
\hline 1 & 0.150 & 0.300 & 0.4000 & o. 500 & 0.600 \\
\hline 2 & 0.075 & 0.150 & 0.200 & 0.250 & 0.300 \\
\hline 3 & 0.050 & 0.150 & 0.250 & 0.350 & 0.400 \\
\hline 4 & 0.025 & 0.075 & 0.125 & 0.175 & 0.200 \\
\hline 5 & 0.075 & 0.150 & 0.200 & 0.250 & 0.300 \\
\hline 6 & 0.038 & 0.075 & 0.100 & 0.125 & 0.150 \\
\hline 7 & 0.025 & 0.075 & 0.125 & 0.175 & 0.200 \\
\hline 8 & 0.013 & 0.038 & 0.063 & 0.098 & 0,100 \\
\hline
\end{tabular}


Toble A-3 (continued)

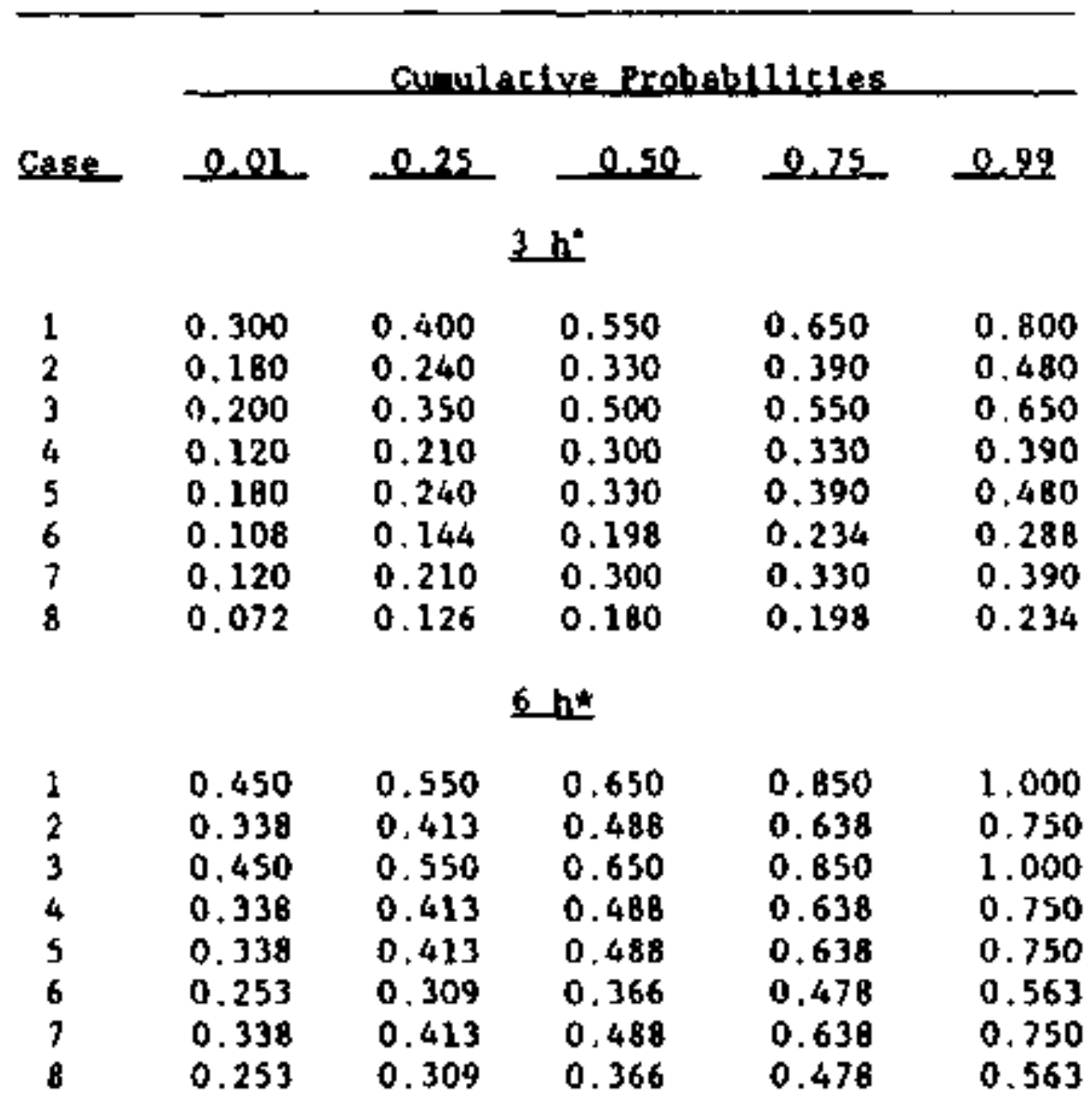

$10 \mathrm{~h}^{*}$

$\begin{array}{llllll}1 & 0.500 & 0.750 & 0.900 & 1.250 & 1.500 \\ 2 & 0.400 & 0.600 & 0.720 & 1.000 & 1.200 \\ 3 & 0.500 & 0.750 & 0.900 & 1.250 & 1.500 \\ 4 & 0.400 & 0.600 & 0.720 & 1.000 & 1.200 \\ 5 & 0.400 & 0.600 & 0.720 & 1.000 & 1.200 \\ 6 & 0.320 & 0.480 & 0.576 & 0.800 & 0.960 \\ 7 & 0.400 & 0.600 & 0.720 & 1.000 & 1.200 \\ 8 & 0.320 & 0.480 & 0.576 & 0.800 & 0.960\end{array}$

"Times are frow start af $\mathrm{CCI}$

\section{Sources of uncertainty}

The Expert Indicated that some of the uncertainty stens from the coarse description of the Inltial conditions. Hovever, the Expert stated that there is still a significant anount of uncercaincy assoctated with this issue that does not sten from the description of the initial conditions. lie has reviewed results from a variety of enalytical adels as well as from varicus experimental progxans, and thece 18 not a general agreement among thein. 
Expert B's Elficitation

Issue 2: Padestal Erosion at Grand Gulf

\section{Description of Expert B's Rationale/rechodolocy}

The scenario parameters that the Expezt considered were pressure, debris pour rate, and cavicy water. The Expert thought that core debris ejected at high pressure would be dispersed and the scenatio would follow a DCH path. The effects of DCH were not to be addressed by this panel. Therefore, the Expert only assessed the low-pressure cases. For the lowpressure cases, the Expert considered the effects on pedestal erosion of large and small pours and the effect of water In the pedestal cavity. The size of the pour defines the properties of the core debris. The Expert described a large pour as being a homogenous pour with a high enthalpy, a high cemperature and a very low amount of zirconium oxidation, On the other hand, a small pour was described as being a stratified pour (i,e, metal comes out first followed by the oxides) with an enthalpy lower than that for the high pour, a temperature just above the liquidus temperature. and a Iow amount of zircontum oxidation (although higher than that for the high pour). For the large pour cases the only effect cavity water had was that it made FCIs posstble. Although the panel was not asked to assess the effects of FCIs, the Expert thought the FCI case would degenerate into the case without the FCI. However, there would be a time lag assoctated ot th the FCI case. The Expert estimated this time lag would be approximately 1 h. For the small pour cases the water's effect was that it partially quenched the debris. The Expert stated that the effects of an FCI for this case would be negligible. The case structure is shown in Figure B-l.

Fressure Pour Water FCI /DCH

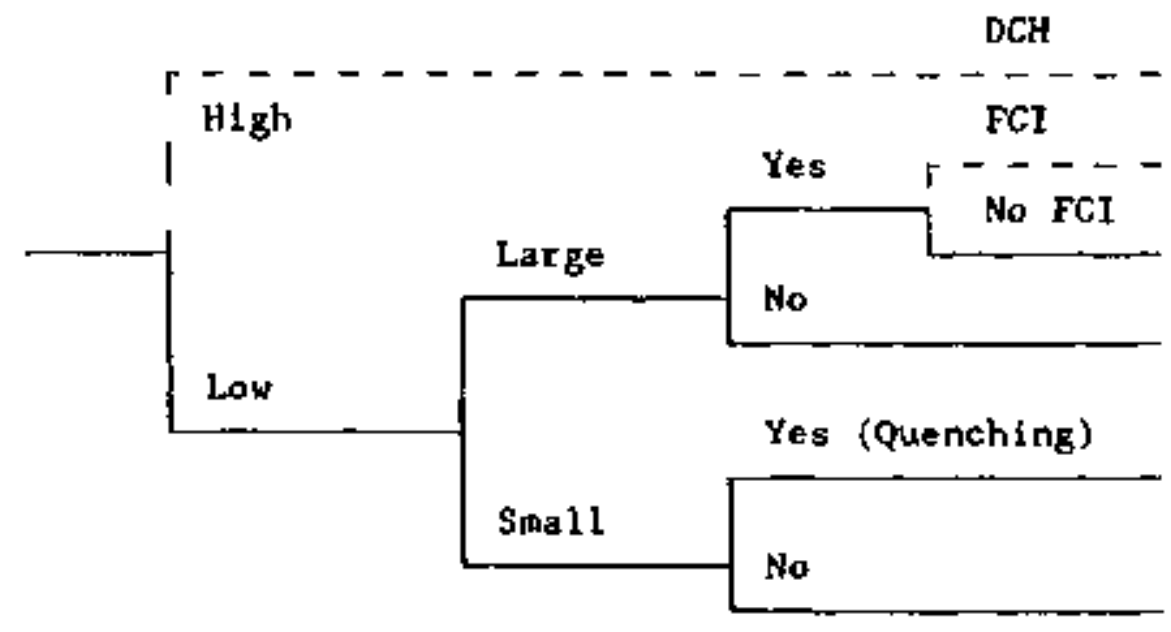

Figure B-1. Case Structure for Grand Gulf Pedestal Erostion 
To estimate the concrece erosion depth as a function of time, the Expert performed some bounding calculations. The Expert based his calculations on a hand calculation scheme presented by Harty Plys of FAI ${ }^{-1}$ As an upper bound (fast eroston), the Expert assumed the Eull core was instantaneously deposited in the cavity at high temperature. He assumed 15t of the zirconium had been oxidized. and used a decay heat level of to (short-terti station blackout). In addition, he assumed the sideward and downard erosion rates were equal and that the power fraction into the concrete vas 0.5 (e.g. 50s of the energy released from the debris enters the concrete and the other $50 \mathrm{~s}$ is released $f$ rom the top of the debris pool). Ho based his calculations on a limestone/common sand concrete, He felt that the rebar in the concrete would have a minor effect on erosion rate and was not modeled in his calculations. Although these are relatively siople hand calculations which do not take into account coking, the Expert felt that these results would be similar to results one would expect from CORCON. Furthermore, because of assumptions he made, the Expert felt his calculations would have faster erosion rates than eroston rates predicted by CORCON. For the lower bound the Expert used the IDCOR assumption that the core debris is intefally quenched and then is reheated by decay heat. The shape of this curve is the saae as the shape for the upper bound except that it is shifted in time. The Expert estimated that this time shift would be approximately $5 \mathrm{~h}$ (i.e., the CCl would begin $5 \mathrm{~h}$ after the core was depost ted in the cavity).

The Expert Indicated that there were two $t$ ime regimes that were important with regard to the etosion rate. During the first time regime the zircanium is oxidized and the erosion rate is faftly fast. After the zirconium is oxidized, the erosion rate is governed by the decay heat and the oxidation of iton. During this time reglme the amount of concrete ablated is essentially propottionsl to the decay heat. The erosion rate durfing this second time regime is slow compared to the first time regime erosion rate. The Expert estimated that it would take $4 \mathrm{~h}$ to deplece the $z$ ircontum.

\section{Results of Expert B's Ellctitation}

The Expert expressed the pedestal concrete erosion depth in terms of 2max and ardax. The term $Z_{\max }$ corresponds to the maxtmum downward erosion depth, measured from the pedestal cavity floor. Similarly, the term $\Delta$ rmax corresponds to the maximum radial erosion depth, measured from the cavity wall. At each time increment the eroded georetry of the cavity will be a right cylinder. This is illustrated in Figure B-2. The erosion depths, as a function of time, for the upper bound and the lower bound are presented in Table B.1. The Expert expressed the uncertainty in the erosian depth as a time shift. For both curves, the uncertaincies at the 1 and 2-petosion dopths are $30 \mathrm{~min}$ and $60 \mathrm{~min}$. respectively. 


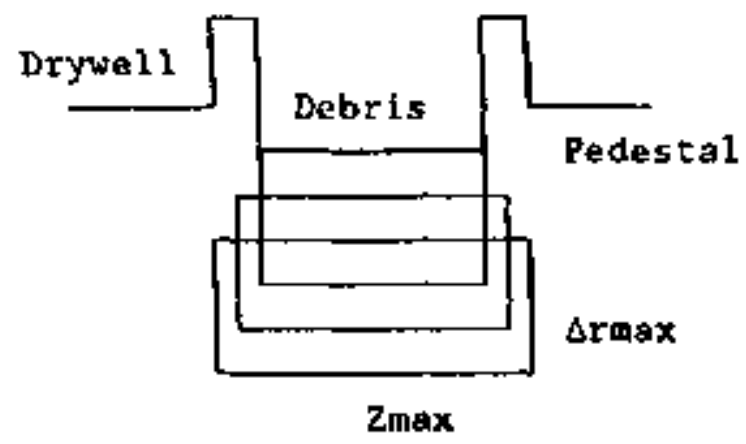

Figure B-2. Eroded Pedestal Geometry

Table B.l

Bounding Calculations for Grand Culf Pedestal Erosion Depths

Erosion Depth (n)

215ax Armax
Tine (h,s)

Upper Bound

$$
\begin{aligned}
& 0.0 \\
& 4.0
\end{aligned}
$$$$
28.0
$$

Lower Bound

5.0

9,0

33.

The Expert defined three cases: Case 1 corresponds to a large pour with no FCI: Case 2 corresponds to small pour with no water in the cavity; and Case 3 corresponds to a small pour with water in the cavity. The Expert felt the large pour case corresponded to the upper bound analysis. Because core debris is added to the pedestal cavity at a slower rate for the small pour case than for the large pour case, the Expert thought the erosion for the small pour would still start at time zero but progress at a slower race. However, the same amount of mat rial is deposited in the cavity for both the large pour and the small pour, and, therefore, the erosion rate for the small pour will eventually catch up to the large pour. The Expert estimated that $1 \mathrm{t}$ would take $1 \mathrm{~h}$ longer for the small pour to erode $l$ to of concrete than it would for the large pour. After that point, however, the erosion rate would be the same. The difference between case 2 and Case 3 stems from the water in the cavity. The Expert thought the water in the cavity would initially cool the debris which would result in an intelally slower erosion rate. He estimated it would take $1 \mathrm{~h}$ longer for $1 \mathrm{~m}$ of cancrete to be eroded in Case 3 than it would In Case 2. After that point. however, the erosion rate would be the sane. These results are sumnarlzed in Table B-2. 
Table B-2

Grand Gulf Pedestal Erosion Depths for Cases 1, 2, and 3

\begin{tabular}{|c|c|c|c|}
\hline \multirow[b]{2}{*}{$\begin{array}{c}\text { Erosion Depth (a) } \\
2 \text { 2na Armax }\end{array}$} & \multicolumn{3}{|c|}{ Itme $(h, s)$} \\
\hline & Gase 1 & Casc 2 & Case 3 \\
\hline $\begin{array}{l}0.0 \\
1.0 \\
2.0\end{array}$ & $\begin{array}{r}0.0 \\
4.0 \\
28.0\end{array}$ & $\begin{array}{r}0.0 \\
5.0 \\
29.0\end{array}$ & $\begin{array}{r}0.0 \\
6.0 \\
30.0\end{array}$ \\
\hline
\end{tabular}

The Expert was certain that signiflcant radial erosion would anly occur below the drywell floor elevation.

It was also the opinton of the Expert that the theraal front would anly penetrate into the concrete a few centimeters ahead of the ecosion front. The Expert stated that the temperature profile through the concrete pedestal wall can be approximated by an exponential decay function.

\section{Sources of Uncerteinty}

The major source of uncercainty was the rather coarse description of the initial conditions. However, the Expert felt most cases would fall somewhere between his upper and lower bound cases. 
REFERENCE

B-1. M. G. Piys, "Hand Calculations for Core-Concrete Attack and Pedestal Failure Timing with Applications to Lasalle and Grand Gulf," MUREG. 1150 Molten Core Containment Interaction Expert Review Group Meeting. Albuquerque, NM, December, 1987 (reproduced in NUREG, GR. 4551, Part 6). 
Expert C's Elicitation

\section{Issue 2: Pedestal Exosion at Grend Gulf}

\section{Description of Expert C's Rationale/Hechodolocky}

The Expert considered all of the scenario parapeters described in the lssue desctipeion and based his numbers on a review of pertinent experimental and apalytical regults. This allowed hí to get tines for distances penetrated vs. tIme for various codes and models. He then reevaluated these results based on considerations of the uncertain paraneters and models.

\section{Regults of Expert $\mathrm{C}^{\prime}$ s. Elicitation}

The Expert thought that the thermal penetration front would be only a few centimeters ahead of the exosion front. Since the thickness of the pedestal wall is approximately l.75 m, the thermal front can be characterized by the erosion front for this issue.

The Expert thought that no erosion was posstble sbove the drywell floor since the amount of debris would not reach that helght. The drywell floor is approximately 1.9 ab above the pedestal floor and the Expert assessed that even if some melt was at that elevation the location of maximal erosion would be below the pedestal floor. Radiation would spall off a lictle concrete but immediately it would hit rebar and little nore would occur.

The Expert gave a distribution for radial (dr) and vertical ( $z$ ) erosian at a specified "critical point," defined to be the point of maximal radial erosion, except in certain cases where another point with only slightly less maximal erosion could be identffied with substantially less vertical erosion than that at the maximur point. MCCl was judged to cease for all practical purposes at approximately $10 \mathrm{~h}$. The volume of the eroded material was fudged to be strictly a function of the amount of unoxidized intals avallable from the care. Water was assumed to only delay the erosion process, but not alter the total erosion volune or erosion directions.

Uncertainty about the radial and vertical erosion distances was fudged to be a direct function of the erosion direction, expressed as a ratio of $d r / z$, whlch was estimated to be between $2: 1$ and $1: 2$. For times of 1,6 , and $10 \mathrm{~h}$, a median dr was estimated, as well as a lower and upper bound. vertical erosion depths were also estimated.

\begin{tabular}{|c|c|c|c|}
\hline \multirow{2}{*}{$\begin{array}{l}\text { Paramecer } \\
\text { (cm) }\end{array}$} & \multicolumn{3}{|c|}{ Ifre (h) } \\
\hline & 1 & 6 & 10 \\
\hline$d r_{05}$ & 2.5 & 43 & 60 \\
\hline $\mathrm{dr} .90$ & 15 & 75 & 90 \\
\hline dr as & 30 & 125 & 140 \\
\hline 205 & 22 & 87 & 112 \\
\hline$z 90$ & 18 & 75 & 105 \\
\hline$z$ ys & 12 & 50 & 87 \\
\hline
\end{tabular}

6. 7.22 
The condition of melt was assessed as metal rich with 75 of the core, 30 s of the zirconium, and no water. The melt was sald to proceed almost vertically after $10 \mathrm{~h}$ with no further radial erosion.

\section{Sources of Uncertainty}

The main uncertainty is in the models. The uncertainty in the physical paraneters or initisl canditions does not affect the long term erosion distance significantly. 
Expert D's Elfeitation

\section{Issue 2: Pedestal Erosion at Grand Gulf}

\section{Descriotion of Bxpert D's. Rat lonele/Hechodelogy}

The expert considered all of the scenario parameters described in the 1ssue description and based his numbers on a review of pertinent experimental and analyctical results which he had performed or reviewed in the past. The Expert gave tentative results based on Linestone concrete and did three simple calculations for radial, vertical, and both vertical and radial erosion. The concrete at Grand Gulf may be limestone/comon sand and the Expert did not consider the effect of the large amount of rebar that is present; he was planning to review these considerations and see $1 \mathrm{f}$ they affected his results. No changes were recelved so the original elicitation was used.

\section{Results of Expert D's Elicitation}

The Expert thought that the theraal penetration fror.t would be only a few centimeters $(5 \mathrm{~cm})$ ahead of the erosion front. Sirce the thickness of the pedestal wall is approximately $1.75 \mathrm{~m}$, the theraal front can be charasterized by the erosion front for this issue.

The Expert thought that no eroston was possible above the drywell floor since the anount of debris would not reach that height. The drywell floor is approximately 1.9 above the pedestal floor and the Expert assessed that even if some melt was at that elevation the location of maximal erosion would be below the pedestal floot. Radiative orosion ts not possible if vater is present; otherwise, a few centimeters of spallation may be possible. but not a significant amount.

The Expert gave values for radial (dx) and vertical ( $z$ ) erosion at a specifled "critical point," defined to be the point of maximal radial erosion. MCCI was judged to cease for all practical purposes at approxinately $10 \mathrm{~h}$. The volune of the eroded material was judged to be strictly a function of the anount of unoxidized metals avallable from the core. The limestone was assessed to erode at a $1: 1$ rate for the radial and vertical directions. The presence of $z$ ircontum was asgessed to enhance radial erosion relative to vertical. With no zirconium present (i.e., after it has burned of $f$ ), the rate of erosion $\mathbf{1} 11$ decrease to about $1 / 4 \mathrm{th}$ of the original rate. The presence of rebar vill dilute the melt and keep it liquid longer. Water will not quench the debris and, therefore, will not affect the results much.

Three scenarios were defined: (1) large pour, (2) small pour, and (3) plop. The plop was assessed at $.5 \mathrm{~h}$, then assuned linear until $3 \mathrm{~h}$, after which $z$ trconium depletes and the rate drops to $1 / 4 \mathrm{th}$ of that in the first $3 \mathrm{~h}$, and finally the rate drops to $3 / 4 \mathrm{ch}$ of the 3 - to $6 \cdot \mathrm{h}$ rate to give the $10 . \mathrm{h}$ result. For the pours, the 6 - and $10-\mathrm{h}$ results will be the same as the plop cases: however, the earlter rate will be slower and constant up to the 
6-h point. The tate of erosion is different initially due to the initial conditions, but, after several hours, the effects of the initial conditions are washed out and the final erosion distances and rates all approach the sane values.

\section{Time (h.)}

$\begin{array}{lrrrrr}\text { Variable }(c m) & 5 & 1 & 3 & 6 & 10 \\ \text { Pour } r_{\max } & 10 & 21 & 63 & 125 & 150 \\ \text { Pour } z\left(r_{\max }\right) & 7 & 16 & 47 & 94 & 113 \\ \text { Plop } r_{\max } & 16 & 33 & 100 & 125 & 150 \\ \text { Plop } z\left(r_{\max }\right) & 13 & 25 & 75 & 94 & 113\end{array}$

\section{Sourcss of Uncertainty}

The major contributors to the uncertainty are (1) the lack of defintte identification of concrete cype; (2) the uncertainty on the amount of rebar; and (3) the effects of the amount of zirconiun present. 
Expert E': Elicitation

\section{Istue 2: Pedestal Erosion at Grand Gulf}

\section{Depcriotion of Expert E's Racionale/Mathodplogr}

The Expert stated that about 45 wh of energy w11l be generated by the oxidation of zirconium. About 10 wW wll be generated after the zirconium oxidation ceastes. After the zirconium oxidation ceases, the debris will behave like a hot solid; it will continue to erode through the conctete in the downward direction, but not in the radial direction.

The Expert stated that for a lfwestone concrete/debris interaction, the zirconiun oxidation would stop at $6 \mathrm{~h}$. If the concrete was 1 inestone/ comon sand, the zirconium oxidation would go on for $8 \mathrm{~h}$. The oxidation of chroniun and iron have a rinor tropact on the scenarlo. The Expert felt that there could be major uncertaintles in the tiue to zirconim burnout, but that the total concrete eroded would not be altered significantly by changes in zirconiun oxfdation timing. He also felt that the volumetric erosion rats is conserved; if the radial erosion was underestiated, the axial erosion would have been overestimated.

\section{Besults of Expert's E's_Elfestation}

The Expert veriffed that the therael penetration front preceded the eroston front by no ure than a few centimeters.

The Expert defined a base case in which the debris contained low superbeat, high zirconium content, and no water. The radial erosion depths for 1,3 , 6 . and $10 \mathrm{~h}$ for this case are given below:

$1 \mathrm{~h}: 13.33 \mathrm{~cm}$

$3 \mathrm{~h}: 40 \mathrm{cn}$

$6 \mathrm{~h}: 70 \mathrm{~cm}$

$10 \mathrm{~h}: 90 \mathrm{cn}$.

The uncertalnty on the base case value at six hours were extrapolated for the .01 and .99 quantiles and are presented below:

.01 quanclle: $40 \mathrm{~cm}$

.50 quantile: $70 \mathrm{~cm}$

.99 guantile: $130 \mathrm{~cm}$.

The Expert felt that most $O$ ' ine effects of superheat, water, and zirconium could be represented by sinple shifts in the timing of the CcI. The Expert felt that the effect of high superheat would be to speed the erosion up by $1 / 2 \mathrm{~h}$. He felt that the effect of water would be to slow the ecoston down by a factor of 0.85 (multiply the tine values by a factor of $1.0 \% .85$ ). The effect of lower zirconiun content would be to cause the CCI to burn aut in half the time-the erosion depths would be the same as the high zirconlur case up unt 11 that poine. 
The values gfven in the elleltation were for 1 imestane concrete. To account for the fact that Grand Gulf has limestone/conmon sand concrete, the Expert suggerted that we add $2 \mathrm{~h}$ to the duration of CCI. (In the limestone base case, the CCI duration is $6 \mathrm{~h}$.)

The nedian of the base case was modifled to represent the effects described above (the process and the medians resulting frow the process axe presented below). To calculate the .01 and .99 quantiles, the median was multiplled by a the sane factor used for the base case, 6-h example--the median was cultiplied by $40 / 70$ to get the .01 quantile; the median was multiplied by $130 / 70$ to get the .99 quantile.

Modification of Base Case Mediana to Obtain Medians for Other Cases (Radial Erosion Depth [cal]

1. Base case:

$\begin{array}{llll}1 \mathrm{~h} & 3 \mathrm{~h} & 6 \mathrm{~h} & 10 \mathrm{~h} \\ 13.33 \mathrm{~cm} & 40 \mathrm{~cm} & 70 \mathrm{~cm} & 90 \mathrm{~cm}\end{array}$

2. Bste cate with linestone/comon wand (lg/cs) --ahift tining by $2 \mathrm{~h}$

$$
\begin{array}{llll}
3 \mathrm{~h} & 5 \mathrm{~h} & 8 \mathrm{~h} & 12 \mathrm{~h} \\
13.33 \mathrm{~cm} & 40 \mathrm{~cm} & 70 \mathrm{~cm} & 90 \mathrm{~cm}
\end{array}
$$

Interpolate and extrapolate for necessery tiaes:
$1 \mathbf{h}$
$3 \mathrm{~h}$
$6 \mathrm{~h}$
$10 \mathrm{~h}$
4 ca
$13.33 \mathrm{~cm} 50 \mathrm{~cm}$
$80 \mathrm{ca}$

3. No water, high zirconful high euperheat, $18 /$ cs - -ohfft case 2 by $1 / 2 \mathrm{~h}$

$$
\begin{array}{llll}
5 \mathrm{~h} & 2.5 \mathrm{~h} & 5.5 \mathrm{~h} & 9.5 \mathrm{~h} \\
4 \mathrm{~cd} & 13.33 \mathrm{~cm} & 50 \mathrm{~cm} & 80 \mathrm{~cm}
\end{array}
$$

Interpolate and extrapolate for necensary times:

$$
\begin{array}{llll}
1 \mathrm{~h} & 3 \mathrm{~h} & 6 \mathrm{~h} & 10 \mathrm{~h} \\
6.33 \mathrm{~cm} & 19.44 \mathrm{~cm} & 53.75 \mathrm{~cm} & 83.75 \mathrm{~cm}
\end{array}
$$

4. No water, low zirconlus low tuperthest, la/cs-.ccI burns out at $4 \mathrm{~h}$ rather than 8 ; curve stays the sabe as case 2 unt1l that point
$1 \mathrm{~h}$
$3 \mathrm{~h}$
$6 \mathrm{~h}$
$10 \mathrm{~h}$
4 co
13.33
$40 \mathrm{~cm}$
55 ce

5. No water, low zirconfus high duperheat, $1 \mathrm{~g} / \mathrm{cs} \cdot \operatorname{sh}$ ffe case 4 by $1 / 2 \mathrm{~h}$

$\begin{array}{llll}5 \mathrm{~h} & 2.5 \mathrm{~h} & 5.5 \mathrm{~h} & 9.5 \mathrm{~h} \\ 4 \mathrm{~cm} & 13.33 & 40 \mathrm{~cm} & 55 \mathrm{~cd}\end{array}$


Interpolate and extrapolate for necessary tines:
$1 \mathrm{~h}$
$3 \mathrm{~h}$
$6 \mathrm{~h}$
$10 \mathrm{~h}$
$6.33 \mathrm{~cm}$
$19.44 \mathrm{~cm} 41.88 \mathrm{~cm} 56.88 \mathrm{~cm}$

6. Water, high zirconiun low super heat, ls/cs*stretch timing on case 2 out by factor of .85

$$
\begin{array}{llll}
1.17 \mathrm{~h} & 3.53 \mathrm{~h} & 7.05 \mathrm{~h} & 11.76 \mathrm{~h} \\
4 \mathrm{~cm} & 13.33 \mathrm{~cm} & 50 \mathrm{~cm} & 80 \mathrm{cn}
\end{array}
$$

Interpolate and extrapolate for necessary times:
$1 \mathrm{~h}$
$3 \mathrm{~h}$
$6 \mathrm{~h}$
$10 \mathrm{~h}$
$3.3 \mathrm{cr}$
$11.23 \mathrm{~cm} 38.99 \mathrm{~cm}$
$68.75 \mathrm{~cm}$

7. Water, high zirconfun high superheat, 1s/cs--stretch timing on case 3 out by a factor of .85

$$
\begin{array}{llll}
1.17 \mathrm{~h} & 3.53 \mathrm{~h} & 7.05 \mathrm{~h} & 11.76 \mathrm{~h} \\
6.33 \mathrm{~cm} & 19.44 \mathrm{~cm} & 53.75 \mathrm{~cm} & 83.75 \mathrm{~cm}
\end{array}
$$

Interpolate and extrapolate for necessary times:
$1 \mathrm{~h}$
$3 \mathrm{~h}$
$6 \mathrm{~h}$
$10 \mathrm{~h}$
$5.35 \mathrm{~cm}$
$16.49 \mathrm{~cm} \quad 43.46 \mathrm{~cm}$
$72.5 \mathrm{~cm}$

8. Water, low zireonlum low superheat, ls/cs-stretch tiaing on case 4 out by a factor of .85

$$
\begin{array}{llll}
1.27 \mathrm{~h} & 3.53 \mathrm{~h} & 7.05 \mathrm{~h} & 11.76 \mathrm{~h} \\
4 \mathrm{co} & 13.33 & 40 \mathrm{~cm} & 55 \mathrm{~cm}
\end{array}
$$

Interpolate and extrapolate for necessary tines:
$1 \mathrm{~h}$
$3 \mathrm{~h}$
$6 \mathrm{~h}$
$10 \mathrm{~h}$
$3.3 \mathrm{~cm} \quad 11.23 \mathrm{~cm} 31.99 \mathrm{~cm} 49.37 \mathrm{co}$

9. Water, low zirconlum high superheat, 2s/cs--stretch timing on case 5 out by a factor of .85

$$
\begin{array}{llll}
1.17 \mathrm{~h} & 3.53 \mathrm{~h} & 7.05 \mathrm{~h} & 11.76 \mathrm{~h} \\
6.33 \mathrm{~cm} & 19.44 \mathrm{~cm} & 41.80 \mathrm{~cm} & 56.68 \mathrm{~cm}
\end{array}
$$

Interpolate and extrapolate for necessary tines:

$$
\begin{array}{llll}
1 \mathrm{~h} & 3 \mathrm{~h} & 6 \mathrm{~h} & 10 \mathrm{~h} \\
5.35 \mathrm{~cm} & 16.49 \mathrm{~cm} & 35.14 \mathrm{~cm} & 51.25 \mathrm{~cm}
\end{array}
$$

The values for above cases 2 through 9 were used for bath low pour and high pour scenarios in the sggregated results of this issue. 


\section{Sources of Uncercalinty}

Th1s Expert felt that a large part of the uncertainty in this scenario was in the tiaing of zirconiur oxidation. 
Expert $F^{\prime}$ : E1icitation

Insue 2: Pedental Eroslon at Grand Gulf

\section{Description of Expert F's Rationale/ Methodelogy}

The volune of concrete eroded at the point that radioactive aerosol telease due to $\mathrm{CCI}$ ceases was thought by this Expert to be essentially a function of the amount of unoxidized metal in the debris. The presence of water and the flow rate of the debris fron the vessel were judged to 1mpact the penetration by changing the duration of $\mathrm{CCl}$. The anount of $21 \mathrm{rconi}$. Th left In the debris was felt to be directly proportional to the final volume of concrete eroded. The Inttial auperheat in the debris and the infial level of decay heat in the debris were considered to be unimportant to the final volume eroded.

\section{Resulys of Expert Fis Silcteation}

The Expert verified that the thermal penetration front preceded the erosion front by no more than $5 \mathrm{~cm}$. He also stated that most of the erosion that occurred above the drywell floor was due to radiation--this would not be more than $20 \mathrm{ca}$.

This Expert gave the results for erosion depth 1n terms of volume of concrete exoded and direction of erosion. (Maximun radial erosion would correspond to ninimum exial erosion.)

The Expert defined a base case consisting of a high debris flow rate fron the vessel, no water on the debris, and a large smount of zirconium avallable In the debris. For the base case, the Expert stated that for the purpose of source term assessment, the period of interest of the CCI would last for $8 \mathrm{~h}$. At $1 \mathrm{~h}, 30$ of the final eroston volume has been eroded, At $3 \mathrm{~h}, 608$ of the final volume has been eroded. The Expert stated that the error in these values is $\pm 5 t$.

The Expert defined a cumulative distribution on the aximum radial erosion depth associated with the naximun volune eroded for the base case-the results are presented belou:

\begin{tabular}{|c|c|}
\hline$\Delta r(c)$ & $E\left(A_{L}\right)$ \\
\hline $\begin{array}{l}40 \\
50 \\
75 \\
110 \\
130\end{array}$ & $\begin{array}{l}.05 \\
.25 \\
.95 \\
.99 \\
1.0\end{array}$ \\
\hline $\begin{array}{l}\Delta r: \text { maxtmum } \\
F(\Delta r): \quad C D F\end{array}$ & radial erosion \\
\hline
\end{tabular}


Values were also given for axial erosion rates, but for this issue we are not concerned with erosion in the axlal direction (the structural Response Panel fudged the axial erosion to be unimportant to the pedestal fallure issue.)

The effect of water, debris pour rate fron the vessel, the anount of zirconiun renaining in the debris on the CCI was described by the Expert in terms of changes in the duration of the CCI or changes in the total volume erodec:

1. Effect of water-add $2.5 \mathrm{~h}$ to the duration of $\operatorname{CCI}$ (e.g., $8 \mathrm{~h}+2.5 \mathrm{~h}-$ $10.5 \mathrm{~h}) \cdot+$ total volume eroded stays constant.

2. Effect of low pour--add 40 minutes to the duration of CCI--total volume eroded stays constant

3. Effect of low 2 irconiur--divide final erosion volune by 2 - duration of CCI stays constant

\section{Converston of Expert's values to tabular form for squregation}

Given the naxinum radial erosion depth and the percentage of volumetric eroston. the radial erosion depth was ealculated using the following equation:

Equation 1:

$$
\begin{aligned}
& \Delta r=\left(\left(\mathrm{V} / \mathrm{v}_{\max }\right)^{\left.\star \Delta \mathrm{r}_{\operatorname{mx}}\right)^{2}}\right)^{0.5} \\
& \text { Ar - - radial erosion depth } \\
& \checkmark \text {.. valune eroded at the of interest } \\
& v_{m x} \text {... volume eroded at end of CCI } \\
& v / N_{\text {max }} \text { - - percentage of volunetric erosion at the of interest } \\
& \Delta x_{\text {anx }} \text { - radial erosion depth for } v_{\text {war }}
\end{aligned}
$$

All of the operations defined by the expert to modify the base case

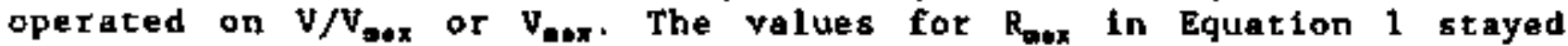
constant. The $B_{\text {bax }}$ values for the .01, .5, and .99 quantiles are given below:

$\Delta r_{\max }$ for .01 quantile - $38 \mathrm{~cm}$ (extrapolated fron values given by expert) $\Delta r_{\text {awx }}$ for .5 quantile - $58.9 \mathrm{~cm}$ (1nterpolated frow values given by expert) $\Delta \mathrm{r}_{\text {nex }}$ for .99 quantile - $110 \mathrm{~cm}$

Values for $V / V_{\text {ax }}$ for the base case were modifled using the Expert's instructions on how to manipulate $v_{\text {man. }} v / v_{\text {max }}$ and the tiaing of CCl. $V / V_{\text {ex }}$ values for all cases defined by the Expert are presented in the table below. 
Table F-1

Interpolated Values of $v / N_{\text {bux }}$ Enr Cases Defined by Expert

(top value: .01 quantile, mfddle value: .5 quenctle bottork value: .99 quantile in centimeters)

\begin{tabular}{|c|c|c|c|c|}
\hline Case & l.h & $3 \mathrm{~h}$ & $6 \mathrm{~h}$ & $10 \mathrm{~h}$ \\
\hline $\begin{array}{l}\text { Large pour. } \\
\text { High zireoniun } \\
\text { No water }\end{array}$ & $\begin{array}{l}20.8 \\
32.3 \\
60.3\end{array}$ & $\begin{array}{l}29.4 \\
45.6 \\
85.2\end{array}$ & $\begin{array}{l}34.8 \\
54.0 \\
100.8\end{array}$ & $\begin{array}{l}38.0 \\
58.9 \\
110.0\end{array}$ \\
\hline $\begin{array}{l}\text { Large pour, } \\
\text { Low zirconium } \\
\text { No water }\end{array}$ & $\begin{array}{l}14.7 \\
22.8 \\
42.6\end{array}$ & $\begin{array}{l}20.8 \\
32.3 \\
60.3\end{array}$ & $\begin{array}{l}24.6 \\
38.2 \\
71.3\end{array}$ & $\begin{array}{l}30.0 \\
46.6 \\
87.0\end{array}$ \\
\hline $\begin{array}{l}\text { Large pour, } \\
\text { H1gh zirconfum } \\
\text { Water }\end{array}$ & $\begin{array}{l}18.2 \\
28.2 \\
52.6\end{array}$ & $\begin{array}{l}25.7 \\
39.8 \\
74.4\end{array}$ & $\begin{array}{l}30.4 \\
47.1 \\
88.0\end{array}$ & $\begin{array}{l}37.8 \\
58.6 \\
109.5\end{array}$ \\
\hline $\begin{array}{l}\text { Large pour, } \\
\text { Low zirconium } \\
\text { Water }\end{array}$ & $\begin{array}{l}12.9 \\
19.9 \\
37.2\end{array}$ & $\begin{array}{l}18.2 \\
28.2 \\
52.6\end{array}$ & $\begin{array}{l}21.5 \\
33.3 \\
62.2\end{array}$ & $\begin{array}{l}26.7 \\
41.4 \\
77.4\end{array}$ \\
\hline $\begin{array}{l}\text { Low pour, } \\
\text { High zirconiun } \\
\text { No Water }\end{array}$ & $\begin{array}{l}20.0 \\
31.0 \\
57.9\end{array}$ & $\begin{array}{l}28.3 \\
43.8 \\
81.9\end{array}$ & $\begin{array}{l}33.5 \\
51.9 \\
96.8\end{array}$ & $\begin{array}{l}38.0 \\
58.9 \\
110.0\end{array}$ \\
\hline $\begin{array}{l}\text { Low pour, } \\
\text { Low zfreontum } \\
\text { No weter }\end{array}$ & $\begin{array}{l}14.1 \\
21.9 \\
40.9\end{array}$ & $\begin{array}{l}20.0 \\
31.0 \\
57.9\end{array}$ & $\begin{array}{l}23.7 \\
36.7 \\
68.5\end{array}$ & $\begin{array}{l}28.9 \\
44.7 \\
83.6\end{array}$ \\
\hline $\begin{array}{l}\text { Low pour, } \\
\text { High zircontur } \\
\text { Water }\end{array}$ & $\begin{array}{l}17.6 \\
27.3 \\
51.0\end{array}$ & $\begin{array}{l}24.9 \\
38.6 \\
72.1\end{array}$ & $\begin{array}{l}29.5 \\
45.7 \\
65.4\end{array}$ & $\begin{array}{l}36.3 \\
56.2 \\
104.9\end{array}$ \\
\hline $\begin{array}{l}\text { Low pour, } \\
\text { Lov Z1rcontum } \\
\text { Water }\end{array}$ & $\begin{array}{l}12.5 \\
19.3 \\
36.1\end{array}$ & $\begin{array}{l}17.6 \\
27.3 \\
51.0\end{array}$ & $\begin{array}{l}20.9 \\
32.3 \\
60.4\end{array}$ & $\begin{array}{l}25.6 \\
39.7 \\
74.2\end{array}$ \\
\hline
\end{tabular}

The values in the above toble and the values for $R_{\text {ar }}$ for the .01 , . 30 , and .99 quantiles were used as input to Equation 1 to calculate the radial eroufon depth values for all thes necessary to fIIl out the cables presented in aggregated results.

\section{Sourcer of Uncertalnty}

The uncertalnty in the radial erosion depth is largely due to the uncertainty in the direction of concrete erosion. This uncertainty overwhelms the uncertalnty in the volune that 18 eroded. The Expart chose hit values wth only zirconius in wind. Taking other unoxidized netals Into eccount could nodlfy the results by 200 . 
APPENDIX A 
APPENDIX A

This Appendix contalns lists of references provided to the Contalnnert Loads Panel and Holten Core/Containnent Interaction Panel. 
SUPPLTED AT CONTAINMENT LOADS PANEL MEETING, December 15-17, 1987

1. Aelcome and Introduction, $N$. R. ortiz, SNL. COPIES OF VIEWGRAPHS.

2. Elicitation of Expert opinion, steve Hora, University of Hawail at Hilo. COPIES OF VIEWGRAPHS.

3. Overview of NUREG-1250 backend methodology, fred Harper, sNL. COPIES OF VIEWGRAPHS.

4. Introduction to NUREG-1150 containment Loading and MCCI Isgues, Eric Haskin, SNL. COPIES OF VIEWGRAPHS.

5. Hydrogen Phenomena at Grand Gulf (Issue 11), Chris Amos, SAIC. COPIES OF VIEWGRAPHS.

6. Presentation of hydrogen research results, Marty Sherman, SNL. COPIES OF VIEHGRAPHS.

7. Containuent Loads at Sequoyah due to Hydrogen Phenomena prior to vessel Breach (Issue 12 ), J. J. Gregory, SNL. COPIES of VIEHGRAPHS.

a. BWR REactor Building Failure Due to Hydrogen Burns (Issues \$34), arthur C. Payne, Jr., SNL, COPIES OF VIEWGRAPHS.

9. Pressure Rise at Vessel Breach at Grand Gulf (Issue \#5), C. N. Amos, SAIC. COPIES OF VIENGRAPHS.

10. Fuel-Coolant Interactions, Marshall Berman, SNL. COPIES OF VIEWGRAPHS.

11. An Experimental study of Isothermal and Boiling Liquid Jets, B. W. Marshall, Jr. and N. Berman, 14th water Reactor safety Research Information Neeting, Gaithersburg, Maryland, october 27-31, 1986. COPIES OF VIEWGRAPHS.

12. Ex-Vessel FCIs for Grand Gulf Risk Analysis, Marshall Berman (Memo to Allan Benjamin, December 19, 1986.)

13. Melt-Coolant Interactions Sandia/NRC Bibliography, July 8 , 1987.

14. Pressure Rise at Vessel Breach for PWRs (Issues $\$ B-10$ ), Walter B. Murfin, Technadyne. COPIES of VIEWGRAPHS.

15. Letter to Elaine D. Bergeron from Chang $K$. Park, Decenber 14, 1987. This letter outlines the differences between 2 ion and other plants that wight be important to Issue $\$ 10$.

16. "Pressure-Temperature Response in an Ice-condenser Containment for selected Accidents", S. E. Dingman and $A$. $L$. Camp, SAND85-1824C (Sandia National Laboratories, Albuguerque, NM),

17. "Pressurized Melt Ejection into scaled Reactor Cavities", $W$. Tarbell, M. Pllch, J. Brockaann, J. Ross, D. Gilbert, NUREG/CR4512, SNAD86-0153, October 1986.

18. "High Pressure Ejection of Helt from a Reactor Pressure Vessel: The Discharge Phasen, W. Pilch and $W$. Tarbell, NUREG/CR* 4383, SNidB5-0012, September 1985.

19. "Surry S2D Severe Accident containment Loads calculations Using HMC", L. Pong, M. Corradini, G. Moses, UWRsR-34 (University of Wisconsin, Madison, WI), March 1986.

20. "High-Pressure Helt Ejection", T. M. Lee (from uncertainty Rapers on. Severe Accident source Terms, NUREG-1265, Chapter 4).

21. Combustion-Induced Loads in Large-OrY PWR Containments, F. E. Haskin, V. Behr and L. Soith (In proceedings of the_second 
Workshop on Containment Integrity", T, Molina and R. Cochrell, *ds., NUREG/CP-0056, SAND84-1514, pages 129-162.

22. "Preliminary Calculations on Direct Heating of a Containment. Atmosphere by Airborne Core Debris", H. Pilch and w. Tarbell, NUKEG/CR-4455, SANDB5-2439, July 1986.

23. "Hydrodynamics Aspects of Ex-Veseel Debris Dispersal in Zion-type Containment Design", B. Spencer, D. Kilsdonk and $J$. Sienicki, ANL/LWR/SAF 83-1, January 1983.

24. "Corfum Droplet size in Direct Containment Heating", J. sienicki and B. spencer, in Seyere-Accident Therpan Hydraulics,

Pp. 557-564.

25. "Results trom the DCH-1 Experiment", W. Tarbell, J. Brockmann, M. Pilch, J. Ross, M. Oliver, D. Lucero, T, Kerley, F. Areilano, R. Gomez, NUREG/CR-4871, SANDB6-2483, June 1987.

26. "steas Explosion Experiments at Intermediate scale: FITSB Series", D. Mitchell and N. Evans, NUREG/CR-3983, SANDE3-1057, February 1986 .

27. "Kigh Pressure Melt Ejection and Direct Containment Heating in Ice Condenser Containments", M. Pilch, W. Tarbell, D. Carroll and $J$. Tills, Presented at the International ANS/ENS Topical Heeting on operability of Nuclear Power systems in Normal and Adverse Environments, Octuber 1, 2986.

28. DCH Experiments and Analyses at sandia National Laboratories, W. Tarbell, M. Pilch, J. Brockmann, SNL. COPIES OF VIEWGRAPHS.

29. Aspects of Zion-specific DCH Loading Phenomenology, $T$. Ginsberg, BNL. COPIES OF VIEWGRAPHS.

30. CONTAIN DCH Calculations for PWRs, D. Williams, K. Bergeron, D. Carroll, D. Louie, K. Murata, J. Tills, K. Washington, SNL. COPIES OF VIEWGRAPHS.

31. "Containment Loads due to Direct containment Heating and Associated Hydrogen Behavior: Anelysis and Celculations with the CoNTAIN Code", D. Williams, K. Bergeron, D. Carroll, R. Gasser, $J$. Tills and $K$. Washington, NUREG/CR-4896, SAND87-0633, May 1987 . 32. Statements on containment Loading and Hydrogen Issues at Sequoyah, W. Lau, TVA.

33. "MARCH-HECTR Analysjs of Lelected Accidents in an IceCondenser Containment", A. Camp, V. Behr and F. Haskin, MUREG/CR3912, SANDB 3-0501, December 1984.

34. Draft of "Technical Report 23.1, Sequoyah Nuelear Plant, Integrated containment Analysis" (Tennessee valley authority, Knoxville, Tennessee), July 1984.

\section{LIST OF DOCUMENTS MAILED TO COMTAINMENT LOADS PANEL AFTER DECEMBER IEETING}

35. "Hydrogen" (List of references compiled by the USNRC for use by expert panels\}.

36. "Direct Heating" (List of references compiled by the USNRC for use by expert panels).

37. DCH in Integrated Accident Analysis UBing MAAP 3B, Marc Kenton, FAI . COPIES OF VIEWGRAPHS.

38. Direct containment Heating, F. Torri, PLF, copIEs of VIEWGRAPHS. 
39. "Update on conTaIN DCH calculations for surry", D. C. Willame (Miemo to NUREg-1150 Containment Loads Panel, January 11, 1988 .

40. "Parametric CONTAIN Calculations of the Containment Response of the Grand Gulf Plant Due to Reactor Pressure Vessel Fallure at High Pressure", K. K. Nurata and D. I. Y. Louie, SNL (Attachment to a Memo from $K$. Nurata to the NUREG-1150 Expert Panel Mombers, February 15, 1986).

41. "Possibility of Ignition of H2", J. H. $S$. Lee (Memo to containment Leads panel members, Februtry 16, 1988) .

42. "Elicitation Meeting Warch 7-11", Roger Breeding (Kemo to Contadneent Loade Panel, March 1, 1985).

43. "Transient Therman Hydroulic Analyais of Reactor coolant Syste. During station Blackout Sequences" (From PLG-0550, Pp. 6-1 to 6-57), July 1987 .

44. "Phenomenological Uncertaintles", (From PLG-0550, Pp. 8-29 to $8-99$ ), July 1987 .

45. "Explosions of Holten Aluminum in water- Cause and Prevention", George Long, Metal Progress, 71,107 (1957).

46. "Summary Report, Information for Consideration with Mark III Detonation Isstue" (Letter report mailed to $E$. Bergeron by J. $R$. Langley, January 5, 198B).

47. Draft of "Report Arseseing the Ability of Mark III containments to support Detonations" (Iatter report mailed to $\mathrm{E}$. Bergeron by $J$. R. Langley, January 5 , 1988).

\section{MAILED ONLY TO MEMBERS OF PANEL CONSIDERING ISSUES $3: 4$}

4B. Reactor Building Burn Calculations, s. Dingman, SNL. COPIES OF VIEWGRAPHS.

49. MMELCOR and HECTR Calculations for Peach Bottom Reactor Building", S. Dingman and $\mathrm{F}$. Haskin, COPIES OF VIEWGRAPHS of prese.itation at Silver Springs, HD, April 29, 1986.

50. Latter report to Tom Walker, usNRC from $\mathrm{E}$. Haskin, sNL, May 21, 1986.

51. "Analyais of Peach Bottom station Blackout with MELcoR", $\mathbf{s}$. Dingman, R. Cole, F. E. Haskin, SAND86-2129C.

52. Wrodel Description for ORWL NIne Cell Peach Bottom secondary Containent Model - PB.9.sc.1", sherrell Greene (Letter Report tent to Jeremy L. Sprung, skt by Sherrell Greene, Novenber 10 , 1986).

53. Whe Role of BHR IRK I secondary containuenta in sqvere Accident uitigation", sherrell R. Greene, proceedinge of the leth Water Rector safety Information Heeting, Gaitheraburg, Maryland, Oetober 27-31, 1986.

54. Whe Impact of BWR IIK I Primary Containment Fallure Dynamics on secondary containment Integrity", sherrell Greene, Proceedings of the 15th water Reactor safety informetion Meting. Galtheroburg, Maryland, October 29, 1967.

55. Uncertaintiea in Hydrogen combuetion, 0 . stamps, $c$. Wong and $L$. Nelson, SAND87-2277C, October 1987.

56. "HEcTR Analyaes of the Nevada Test site (NTS) premlxed Combustion Experiments", C. Wong, To be publiehed, 1987.

57. Resulte of Lasalle blowdown calculations. 
58. "Rige and Fall of the sequoyah ABwBY Plant Damage state", D. C. williams (Memo to Distribution, December 11, 1987).

59. "CONTAIN Calculations for some DCH scenarior in the seguoyah plant", D. C. Williams (Letter Report to the NUREG-1150 source Term and Lotds panels, April 5, 1988)

60. "An Updete on Direct Containment Heating for Ice Condenser Plants", J. Tills (Informal Transmition to NUREG-1150 Containoent Loads Expert Panel, January 12, 1988).

61. "Pogeibility of Detonation and üther contalnment toads for Sequoyah", M. Sherman, February 23, 1988.

62. "Grand Gulf Hydrogen Deflagration and Detonation Loads Prior to Vessel Breach", M. Sherman, March 1, 1988.

63. "Vapor Explosions in the BWR Mark II Wetwe11", M. Corradini (Attachment to Letter to E. Bergeron, Jenuary 20, 1988).

64. "Stratified Vapor Explosion Experinents", $K$. Bang and $M$. Corradini (Conference paper to be presented at the national heat. Transfer Conference, Houston, Texas, August 1988) .

65. "Ex-Vesel FCI in a Mark-III Drywell", M. Corradini (Attachment to Letter to E. Bergeron, January 2, 1988).

MAILED TO PANEL BY T. GINSBERG

66. "Contain sensttivity calculations of zion DCH Containment Loadings", T. Ginsberg, C. Grimshaw, C. Park, W. Tutu (Letter report, February 26, 1908)

\# SUPPLIED AT CONThINMENT LOADS PANEL ELICITATION MEETING, MARCH $8-11,2988$

67. QUASAR results (Attachment to Letter to Dr. Patricia Worthington, USNRC from Min Lee, BNL, March 7, 1986)

68. Hydroger Phenomena at Grand Gulf (Issue 11), C. Amos, SAIC. COPIES OF VIENGRAPHS.

69. Grand Gulf Hydrogen Burn Calculations, Tom Brown, copIEs of VI EWGRAPHS.

70. HECTR Grand Gulf calculations, T. Brown, SNL, COPIES OF VIEWGRAPHS.

71. Perspective on Isgue 1 , J. Metcalfe, Ssw. NOTES. B3. Perspective on Ineue \$1, I. Baker, Nu. NOTES.

72. Grand Gulf Hydrogen Deflagration and Detonation Loads Prfor to Vessel Breach, March 1, 1988, M. Sherman, ANL.

73. Containment Loeds at sequoyah due to Hydrogen phenomena prior to vebeel breach (Itaue (2), J. J. Gregory, SNL. copIEs of VIEWGRAPHS.

74. Perepective on Iesue $\mathbf{2 ,} \mathrm{J}$, Helcalfe, Skw, Notes.

75. Perspective on Issue 12, P. Worthington, NRC. NOTEs.

76. Lasalie MELCOR hydrogen calculations, Arthur Payne, SNL. COPIES OF VIEWGRAPHS.

77. Perspective on Issues 344, Narty Plys, FAI. NOTES.

78. Perspective on Issues 344, Fred TOrri, PLEG. NOTES.

79. Pressure Rite at Vessel Breach at Grand Gult (Igsue \$5), c. Amos, SAIC. COPIES OF VIEWGRAPHS.

\$80. Description of recent contarn calculations for Grand Gulf, K. Murata, SNL. COPIES OF VIEWGRAPHS. 
81. Perspective on Issue 45, K, Bergeron, SNL. NOTES.

82. Perspective on Issue 45, T, Ginsberg, BNI. NOTES.

a3. Perspective on Issue 15 , L. Baker, ANL. NOTES.

84. Perspective on Issue 18, Marty Plye, FAI. NOTES.

85. Perspective on Issue 18, K. Bergeron, SNL. NOTES.

B6. Perspective on Issue 18, T. Ginbberg, SNL. NoTEs.

87. Pressure Increment at Vessel Breach for Surry, walt Murfin,. COPIES OF VIEWGRAPHS.

88. Pressure Increment at Vessel Breach for zion (Istue 110 ), w. Murfin, Technadyne, COPIES OF VIEWGRAPHS.

89. Perspect1ve on Iseue 110, Marty Plys, FAI. NoTEs.

90. Ferepective on Issue 110 , Fred Torri, PLs. NOTES.

91. Perspective on Issue 10?????, Ted Ginsberg, BNL. NOTEs. 
LIST OF HANDOUIS GIVEN TO MOLTEN-CORE CONTAINMENT EXPERT PANEL $(6-21-8 B)$

1. Welcome and Introduction, N. R, ortiz, SNL, copIEs op VIEWGRAPHS.

2. Elicitation of Expert opinion, steve Hara, University of Hawaii at Hilo. COPIES OF VIEWGRAPHS.

3. Overview of NUREG-1150 backend methodology, Fred Harper, SNL. COPIES OF VIENGRAPHS.

4. Introduction to NUREG-1150 containment Loading and MCCI Isgues, Eric Haskin, SNL. COPIES OF VIEWGRAPHS.

5. Pedestal Erosion at Grand Gulf, Thomag D. Brown, SNL. CopIEs OF VIEWGRAPHS.

6. Core-conerete Interactions, E. R. copus, copIEs OF VI EWGRAPHS.

7. Reactor Cavity Floor Failure at Lasalle, Arthur C. Payne, Jr. COPIES OF VIENGRAPHS.

8. "Miscellaneous Calculations", Arthur C. Payne Jr. and Clint J. Shaffer, SNL. HANDOUT.

9. Hand Calculations for Concrete Attack and Pedestal Faliure Timing Applications to Lasalle and Grand Gulf, Martin G. Plys. COPIES OF VIENGRAPHS.

10. Peach Bottom Drywell Heltthrough Issue, Fred T, Harper. COPIES OF VIEHGRAPHS.

11. Review of the Status of the Mark I BWR steel containment Shell helt-Through Analyses, G. A. Greene. CopIEs of VIEWGRAPHS. 12. Mark I Liner Temperature Response Calculations, Mike EpBtien. COPIES OF VIEWGRAPHS.

13. BWR Mork I containment shell Helt Through Analyses, T. Halker. COPIES OF VIEWGRAPHS.

REFERENCE MATERIAL HANDED OUT AT THE INTRODUCTORY MEETING

14. "The Jet Impingement Phase of Molten core-concrete Interactions", J. J. sienick1 and B. W. Spencer, Proceedings of the Committee on the safety of Nuclear Inetallations (CSNI) specialista" Heeting on Core Debris-Conerete Interactions, February 1987.

15. "Concrete Data for Primbry containment", George Crane, attachment to letter to Arthur Payne, 11 February 1987.

16. "Large-seale, Transient Tests of the Interection of Nolten steel with Concret", Dana Poware and Fronk Arellano, NUREG/CR2202, SANbE1-1753.

17. Hydrodynamics and Heat Transfor nspects of Corlum-Water Interactions", Interis Report, B. Spencer, J. sienicki and $L$. MeUnber, EPRI NP-5127, Mareh 1987 (Electric Power Research Inetitute

19. Instde kRC, Vol 9, No. 25, Dec 7, 1987.

19. D. A. Powers, and F. E. Arellano, Erosion of sted structures by fligh Temparature Nelts NUREG/CR-2284, SAND81-1755, Sandia National Laboratories, Albuquerque, NM, June, 1983.

20. D. A. Powers, Erosion of steel structures by High Temperature Welts, Nuclear science and Enginering_88 (1984) 357 
21. D. A. Powers and F. E. Arellano, High.Temperature Melt Attack on Steq and Uranis-Coated steel, NUREG/CR-3366, SANDB3-1350, Sandia Hational Laboratories, Albuquerque, Ny, April, 1984. 22, G. A. Greene, K. R. Perkins, and $\$$. A. Hodge, Mark I Contalnment Drywell, Impact of core/Concrete Interactions on containment Intogrity and Failure of the Drywell Iiner" in source Term Evaluation, for Acsident conditions IAEA, vienna, Austria, paper IAEA-SM-281/36 page 429, Oct. 26-Nov, 1, 1985.

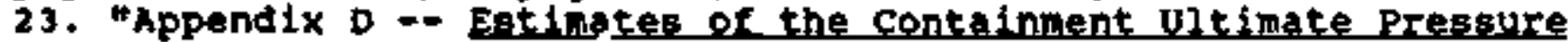
capacity and the Fallure Modes, IDCOR 85.3-B2, FAI-86-1 (document numbers may not be correct -- I only have copy of the appendix.) 24. Letter from A, R. Buhl, IT to Eric S. Beckjord, NRC, July 9, 1997, Response to Brookheven National Laboratory's (BNL) Compents on IDCOR's Hodel of the Mark I Containfent Response to Direct Contact with Molten Core Debris.

25. S. Levy, Inc. Analysis, Presentation, Concepts for Mitigation and stabilization.

26. Ott, L.J., Boiling water Rector severe Accident Response (BWRSAR) Hodel Development Activities, Presentation, Program Review Heeting, Sep. 15, 1987.

27. Letter from D. A. Powers to R. 0 . Meyer (NRC), Melt spreading in Test SURC 4, Sep 22, 1987.

28. R. E. Henry, "FAI, "IDCOR (MAAP) Modeling of core Melt Progression, Reactor Vessel Failure and Containment Response," Presented to the Browns Ferry Containment capability study, sep. $30,1987$.

29. Letter from Brian $w$. Sheron, NRC to $A$. $R$, Buhl, IT, oct 2 , 1987 , Response to Reference 7.

30. C. R. Hyman," Multicell ConTarn Analysis of BwR MK I Drywell Response to Time- Vessel Release of Core Debris," Bolling water Reactor severe Accident Technology (BkRSAT) Program, presented at Severe Fuel Damage, Containment Loads, and Source Term Research Program Reviow Metting, silver spring, Maryland, oct, 19-23, 1987.

31. "BWr Bottom Head Fallure Mode," SARRP Background paper handed out to NUREG-1150 In-Vesse1 Review Group, Nov. 21-13, 1987.

\section{MAILED TO EXPERTS AFTER FIRST MEETING:}

32. "Report on Mark I Drywell shell Melt-through", $K$. D. Bergeron, SNI. Memo to Members of MUREG-1150 Expert Panel on Wolten Core Concrete Interactions, February 18, 1986.

33. "Core-Conerete Interaction" reference 1 ist.

34. Proposed Mark I Performance Program, copies of viewgraphs presented at December 4, 1987 ACRs Meeting.

35. "References from Martin Plys' Presentation".

36. TURC1: Lorge scale Metallic Melt-Concrete Interaction Experiments and Analysio, J, E. Gronager, A. J. Suo-Anttila, D. R. Bradley, J. E. Brockmann, NUREG/CR-4420, SAND85-0707.

37. TURC2 and 3: Large scale $\mathrm{UO}_{2} / 2 \mathrm{RO}_{2} / 2 \mathrm{r}$ Helt-concrete Interaction Experiments and Analysis, J. E. Gronager, A. J. SuoAnttila, J. E. Brockmann, NJPEG/CR-4521, SAND86-0318.

38. SWISs: Sustoined Heated Metallic Melt/Concrete Interactions With overlying water Pools, R. E. Blose, J. E. Gronager, $\boldsymbol{\lambda}$. J. Suo-Anttila, J. E. Brockmann, MUREG/CR-4727, SANDB5-1546. 
39. Sustained Concrete Attack by Low-Temperature, Fragmented Core Debris, W. W. Tarbell, D. R. BRadley, R. E. Blose, J. W. Ross, D. H. Gilbert, NUREG/CR-3024, SANDB 2-2476.

MAILED TO EXPERTS AFTER ELICITATION MEETING:

40. "Grand Gulf RPV Pedestal Concrete Type", T. D. Brown, SNL. Nemo to The NuREG-1150 MCCI Panel, April 7, 1988 